\title{
Statistical compilation of NAPAP chemical erosion observations
}

by Victor G. Mossotti, ${ }^{1}$ A. Raouf Eldeeb, ${ }^{2}$ Michael M. Reddy, ${ }^{3}$ Terry L. Fries, ${ }^{4}$ Mary Jane Coombs, ${ }^{1}$ Ron L. Schmiermund, ${ }^{5}$ and Susan I. Sherwood ${ }^{6}$

Open-File Report 98-755

2001

This report is preliminary and has not been reviewed for conformity with U.S. Geological Survey editorial standards. Any use of trade, product, or firm names is for descriptive purposes only and does not imply endorsement by the U.S. Government.

\section{U.S. DEPARTMENT OF THE INTERIOR U.S. GEOLOGICAL SURVEY}

${ }^{1} 345$ Middlefield Road, MS 901, Menlo Park, CA 94025

${ }^{2} 508$ Cheyenne Drive, Sunnyvale, CA 94087

${ }^{3}$ USGS WRD, 3215 Marine Street, Boulder, CO 80303

4345 Middlefield Road, MS 225, Menlo Park, CA 94025

${ }^{5} 655$ Dudley Street, Denver, CO 80215-5406

${ }^{6} 12$ East 97th Street, New York, NY 10029

This report is available online at http://geopubs.wr.usgs.gov/open-file/of98-755/. 


\section{Abstract}

In the mid 1980s, the National Acid Precipitation Assessment Program (NAPAP), in cooperation with the National Park Service (NPS) and the U.S. Geological Survey (USGS), initiated a Materials Research Program (MRP) that included a series of field and laboratory studies with the broad objective of providing scientific information on acid rain effects on calcareous building stone. Among the several effects investigated, the chemical dissolution of limestone and marble by rainfall was given particular attention because of the pervasive appearance of erosion effects on cultural materials situated outdoors.

In order to track the chemical erosion of stone objects in the field and in the laboratory, the $\mathrm{Ca}^{2+}$ ion concentration was monitored in the runoff solution from a variety of test objects located both outdoors and under more controlled conditions in the laboratory. This report provides a graphical and statistical overview of the $\mathrm{Ca}^{2+}$ chemistry in the runoff solutions from (1) five urban and rural sites (DC, NY, NJ, NC, and $\mathrm{OH}$ ) established by the MRP for materials studies over the period 1984 to 1989, (2) subevent study at the New York MRP site, (3) in situ study of limestone and marble monuments at Gettysburg, (4) laboratory experiments on calcite dissolution conducted by Baedecker, (5) laboratory simulations by Schmiermund, and (6) laboratory investigation of the surface reactivity of calcareous stone conducted by Fries and Mossotti.

The graphical representations provided a means for identifying erroneous data that can randomly appear in a database when field operations are semi-automated; a purged database suitable for the evaluation of quantitative models of stone erosion is appended to this report. An analysis of the sources of statistical variability in the data revealed that the rate of stone erosion is weakly dependent on the type of calcareous stone, the ambient temperature, and the $\mathrm{H}^{+}$concentration delivered in the incident rain. The analysis also showed that the rate of stone erosion is strongly dependent on the rain-delivery conditions and on the surface morphology and orientation. 


\section{CONTENTS}

\section{Page}

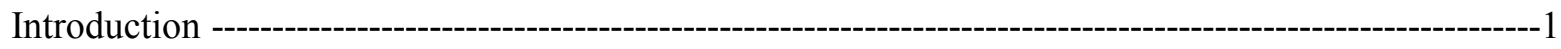

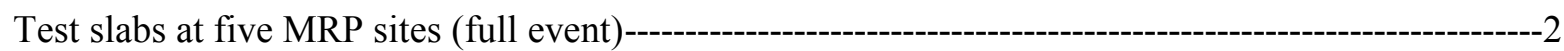

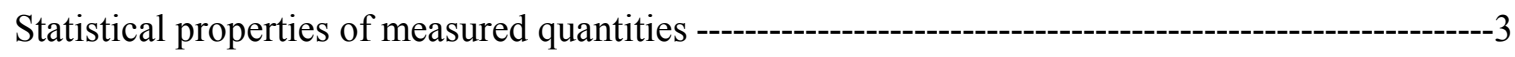

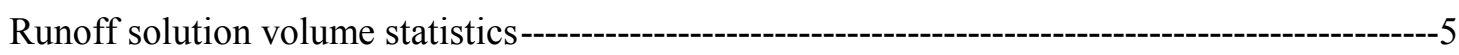

Statistics of $\mathrm{H}^{+}$concentration in incident rain ---

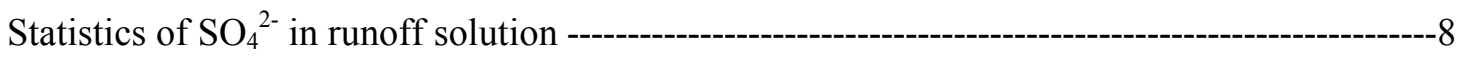

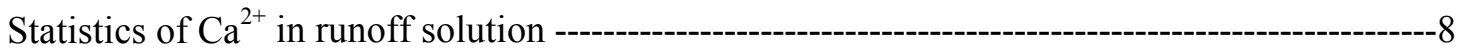

Reproducibility of measured quantities ---_-

Scatter in erosion effects across events---10

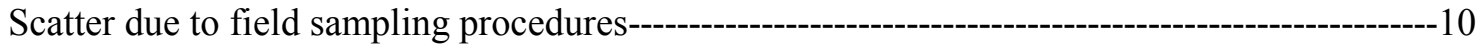

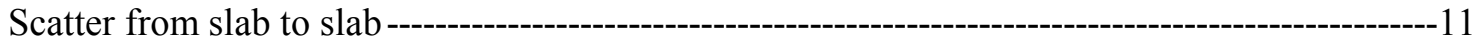

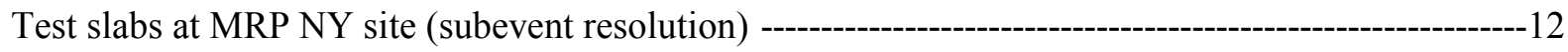

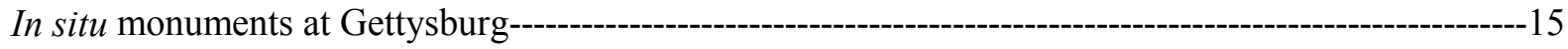

Baedecker laboratory simulations --o-16

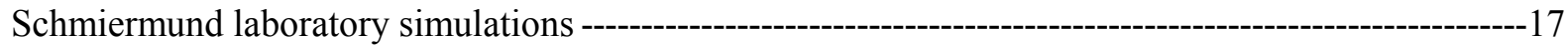

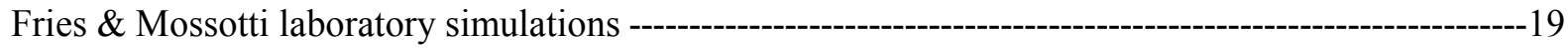

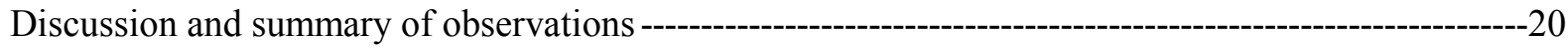

Corrupted field data ---

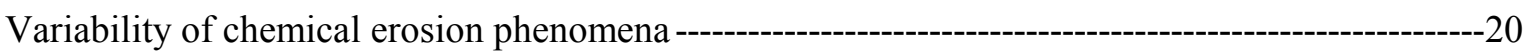

Incremental acid effect----

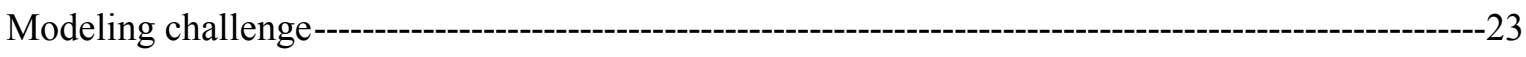

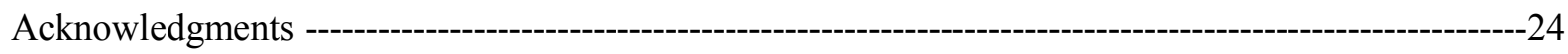

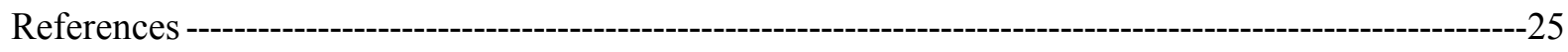

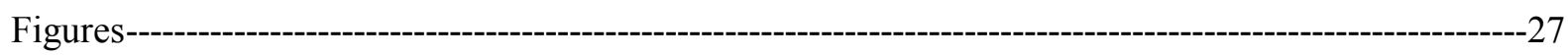

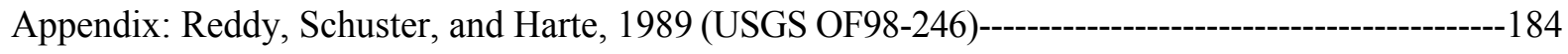




\section{Introduction}

In 1982, the National Acid Precipitation Assessment Program ${ }^{7}$ (NAPAP) was established with the broad objective of providing scientific information on acid rain effects that would be useful to the U.S. Congress for policy development. Pursuant to this objective, the efforts of the National Park Service (NPS) and the U.S. Geological Survey (USGS) were coordinated by NAPAP to explore the effects of acid deposition on the weathering of materials, especially calcareous stone. The NPS/USGS Materials Research Program (MRP) continued throughout the 1980s and into the 1990s. The main interest of the MRP was the erosion and chemical alteration of calcareous stone surfaces; this report is centered exclusively on erosion resulting from the chemical dissolution of calcareous stone.

Among the methods available for the measurement of calcareous stone erosion, the most expedient field method is based on the appearance of $\mathrm{Ca}^{2+}$ ions in the runoff solution from rainwashed stone. In order to observe deterioration effects under a variety of ambient environmental conditions, the MRP established field sites in May 1984 at Washington, DC; Newcomb, New York; Chester, New Jersey; and Raleigh (Research Triangle Park), North Carolina; in 1986, the NJ site was discontinued and a new site was established at Steubenville, Ohio. The MRP field exposure program, site management plans, and operational protocols have been described in detail elsewhere (Reddy and Werner, 1985; See and Reddy, 1987; Reddy and others, 1989). Although the observations were made in the field, considerable effort was made to monitor and control as many variables as possible. Standard protocols were established to explore the effects of acid deposition on erosion and alteration of carbonate stone across the five MRP field sites. Air quality, meteorology, chemical speciation in rain, and the chemical composition of particulate material were monitored at all field sites. Precipitation samples, with data on volume and $\mathrm{pH}$, were collected monthly.

In addition to the field exposure program on standard limestone and marble slabs, in situ experiments were conducted at Gettysburg on 100-year-old Carrara and Pennsylvania Blue marble monuments over the period 1986 to 1988 (Sherwood and Dolske, 1991; 1992). The observations at Gettysburg were made on objects of non-standard morphology and surface orientation. The preliminary interpretations of the field observations suggest that surface hydrodynamics is probably a critical factor in the erosion rate of calcareous stone. In order to isolate the hydrodynamic and chemical factors controlling the dissolution of carbonate stone, the MRP also established a program of laboratory experiments in which the surface hydrodynamics were tightly controlled (Schmiermund, 1991). Of the stone deterioration observations made by the MRP, Schmiermund's laboratory experiments provided the greatest degree of internal validity with regard to the observed effects.

The purpose of this report is to characterize the key variables controlling stone erosion and to identify the issues, effects, and phenomena that need to be addressed and evaluated. The statistical properties and correlations from five systematic studies are surveyed below. These include the:

\footnotetext{
${ }^{7}$ Authorized by Title VII of the Energy Security Act, Public Law 96-294.
} 
(1) MRP five-site study conducted over the period 1984 to1989 (Reddy and others, 1989);

(2) MRP subevent study at the New York MRP site (Reddy and others, 1989);

(3) In situ study of limestone and marble monuments at Gettysburg (Sherwood and Dolske, 1992);

(4) Baedecker (Reddy and Baedecker, 1990; sec. 3.3.2.2., p. 19-111 to 19-112) laboratory simulations of acid deposition on limestone and marble test slabs;

(5) Schmiermund (1991) laboratory simulations; and the

(6) Fries and Mossotti 1999 laboratory investigation of surface reactivity of calcareous stone.

For each of these studies, the salient features of the observations are graphically represented and the statistical properties are used to purge erroneous entries from the database; edited data files are appended to this report.

\section{Test slabs at five MRP sites (full event)}

At each of the exposure sites, runoff solution from standard $30 \times 60 \times 5-\mathrm{cm}$ Salem limestone and Shelburne marble test slabs and runoff solution from a blank test rack were collected at the end of each rain event for 2 to 6 months during each year the program operated; collections at all sites were discontinued during the winter months. The test slabs faced south and inclined $30^{\circ}$ to the horizon. Measurements at the exposure sites included the total runoff-solution volume, the specific conductance, the $\mathrm{pH}$ of the blank solution, and the $\mathrm{pH}$ of the runoff solution from the stone slabs; these measurements were usually made within a few hours of the rain event. The samples, collected in 1-liter containers, were filtered with a $0.45-\mu \mathrm{m}$ pack before being sent to the USGS for analysis, as described by Reddy and others, 1987.

Each sample was analyzed in the laboratory for calcium, magnesium, sodium, chloride, sulfate, and nitrate. Sample preparation, analytical procedures, and laboratory QC protocols are described by Skougstad and others (1979; Book 5, Chapter A1). Because the runoff solutions were filtered at the time of collection, the physical erosion due to undissolved fragments dislodged from the stone were not included in the $\mathrm{Ca}^{2+}$ signal.

In a series of reports, Reddy and others progressively updated statistical summaries on the variables measured in connection with the erosion experiments at the MRP field sites. In 1985, Reddy and Werner provided a preliminary report for the period June to October 1984 on the runoff-solution chemistry at the North Carolina exposure site. The 1985 report showed that the mass of $\mathrm{Ca}^{2+}$ loss at this site was strongly correlated with the rainfall volume and that the computed recession per inch of rain was weakly coupled to the $\mathrm{pH}$ of the rain. The $\mathrm{H}^{+}$ concentration in the incident rain at the North Carolina site ranged from $10^{-3.8}$ to $10^{-5.6} \mathrm{M}$ and averaged $\approx 10^{-4.4} \mathrm{M}$. The net sulfate concentration in the stone runoff from both marble and limestone was significantly greater than the sulfate concentration in the rain. Reddy and Werner noted that the blank-runoff solutions possibly could be biased relative to the runoff solutions from the test slabs because of the differential adherence of particulate matter to the stone test 
surfaces as compared to the polypropylene (blank) surfaces. The authors also cautioned that the data collected in the field were not verified at the collection site. Detailed meteorological and airpollution data were not available at the time of the 1985 report.

The runoff-solution-chemistry database was later expanded, first in a report by See and Reddy, 1987, and then in a report by Reddy, Schuster, and Harte, 1989 (RSH). The period covered by these two reports began in June 1984, and both reports covered all five MRP sites (DC, NY, NJ, $\mathrm{NC}$, and $\mathrm{OH}$ ). The RSH report extended the See and Reddy report from September 1986 to November 1987. Five types of samples were collected from 318 rain events during this period. To evaluate on-site sampling variability, replicate samples were collected from adjacent test slabs of the same type. The duplicate samples were submitted to the laboratory to identify variability caused by sample processing and handling. Additional distilled-water reference samples and standard reference water samples were submitted to the laboratory with the on-site samples. During the indicated period, 1,973 samples were processed; analytical results on 15 chemistry variables are available in the data files described in the RSH report attached as an appendix to this paper.

\section{Statistical properties of measured quantities}

One of our goals in this overview is to flag filled-in numbers and errors in the data sets. In this pursuit, we assume that the runoff variables are random and that the statistical nature of the runoff variables is site-independent. Figures 1 to 65 show histograms, distribution statistics, bestfit distribution models, and additional diagnostic plots of the MRP five-site runoff variables; the figures in the set are identified as follows: 
TABLE 1.- - Index to figures 1 to 65 (B: blank, L: limestone, M: marble).

\begin{tabular}{|c|c|c|c|c|c|c|}
\hline Variable/plot & & DC & NY & NJ & $\mathrm{NC}$ & $\mathbf{O H}$ \\
\hline Volume attributes & & BLM & BLM & BLM & BLM & BLM \\
\hline Volume & Average & 1 (avg) & 1 (avg) & 1(avg) & $1(\operatorname{avg})$ & (avg) \\
\hline Volume & Histogram & $1-3$ & $4-6$ & $7-9$ & $10-12$ & $13-15$ \\
\hline e: L vs. M & catter & 16(a) & 17(a) & $18(\mathrm{a})$ & 19(a) & 20(a) \\
\hline M, B & brted & $16(\mathrm{~b})$ & $17(\mathrm{~b})$ & $18(\mathrm{~b})$ & 19 (b) & $20(\mathrm{~b})$ \\
\hline Volur & Sorted & $16(\mathrm{c})$ & $17(\mathrm{c})$ & $18(\mathrm{c})$ & 19(c) & $20(\mathrm{c})$ \\
\hline Volume: L minus M & & 21 & 22 & 23 & 24 & 25 \\
\hline Aci & & B & B & B & B & B \\
\hline Concer & Average & 26(avg) & 26(avg) & 26(avg) & $26(\mathrm{avg})$ & 26(avg) \\
\hline Concentration: $\left[\mathrm{H}^{+}\right]$ & Histogram & 26 & 27 & 28 & 29 & 30 \\
\hline Load: $\mathrm{H}^{+}$ & Average & 31 (avg) & 31 (avg) & $31($ avg) & 31(avg) & 31 (avg) \\
\hline Load: $\mathrm{H}^{+}$ & Histogram & 31 & 32 & 33 & 34 & $\mathrm{n} / \mathrm{a}$ \\
\hline Runoff solution $\mathrm{SO}_{4}{ }^{2-}$ & & $\mathrm{LI}$ & LI & $\mathrm{LI}$ & LI & LM \\
\hline Concentration: $\left[\mathrm{SO}_{4}{ }^{2-}\right]$ & Average & 36 (avg) & 36(avg) & $36($ avg) & $36(\mathrm{avg})$ & 36(avg) \\
\hline Concentration: $\left[\mathrm{SO}_{4}{ }^{2-}\right]$ & Histogram & $36(a)$ & $37(a)$ & $38(a)$ & 39 (a) & $40(a)$ \\
\hline on: $\left[\mathrm{SO}_{4}{ }^{2-}\right]$ & listogram & $36(\mathrm{~b})$ & $37(\mathrm{~b})$ & $38(\mathrm{~b})$ & 39 (b) & $40(\mathrm{~b})$ \\
\hline Mass: $\mathrm{SO}_{4}^{2-}$ & Average & 41 (avg) & 41 (avg) & 41 (avg) & 41 (avg) & 41 (avg) \\
\hline Mass: $\mathrm{SO}_{4}{ }^{2-}$ & Histogram & $41(\mathrm{a})$ & $42(a)$ & $43(\mathrm{a})$ & $44(a)$ & $45(\mathrm{a})$ \\
\hline Mass: $\mathrm{SO}_{4}{ }^{2-}$ & Histogram & $41(\mathrm{~b})$ & $42(\mathrm{~b})$ & $43(\mathrm{~b})$ & 44(b) & $45(b)$ \\
\hline Runo & & $\mathrm{Ll}$ & LI & LI & LM & LM \\
\hline Concentr & Histogram & $46(a)$ & $47(\mathrm{a}$ & $48(a)$ & 49(a) & $50(a)$ \\
\hline Concentration: $\left[\mathrm{Ca}^{2+}\right]_{\text {uncor }}$ & Histogram & $46(\mathrm{~b})$ & $47(\mathrm{~b})$ & $48(\mathrm{~b})$ & 49(b) & $50(\mathrm{~b})$ \\
\hline Concentration: $\left[\mathrm{Ca}^{2+}\right]_{\mathrm{xs}}$ & Histogram & $51(\mathrm{a})$ & $52(\mathrm{a})$ & $53(\mathrm{a})$ & $54(a)$ & $55(\mathrm{a})$ \\
\hline Concentration: $\left[\mathrm{Ca}^{2+}\right]_{\mathrm{xs}}$ & Histogram & 51(b) & 52(b) & $53(\mathrm{~b})$ & $54(\mathrm{~b})$ & $55(\mathrm{~b})$ \\
\hline Mass: $\mathrm{Ca}^{2+}$ uncor & Histogram & $56(a)$ & $57(a)$ & $58(a)$ & 59 (a) & 60 (a) \\
\hline Mass: $\mathrm{Ca}^{2+}{ }_{\text {uncor }}$ & Histogram & $56(\mathrm{~b})$ & $57(\mathrm{~b})$ & $58(\mathrm{~b})$ & $59(\mathrm{~b})$ & $60(\mathrm{~b})$ \\
\hline Mass: $\mathrm{Ca}^{2+}{ }_{\mathrm{xs}}$ & Histogram & 61(a) & 62(a) & $63(\mathrm{a})$ & $64(a)$ & $65(a)$ \\
\hline Mass: $\mathrm{Ca}^{2+{ }_{\mathrm{xs}}}$ & Histogram & 61(b) & 62(b) & $63(\mathrm{~b})$ & 64(b) & $65(\mathrm{~b})$ \\
\hline
\end{tabular}

The original data for the field erosion experiments are provided in three files, all in ASCII format, which may be downloaded from the web page for this report [http://geopubs.wr.usgs.gov/open-file/of98-755]. The first file, DATAT.A, contains descriptive information and on-site measurements of $\mathrm{pH}$ and specific conductance. The second file, DATAT.B, contains laboratory measurements of $\mathrm{pH}$, specific conductance, alkalinity, and major anion concentrations. The third file, DATAT.C, provides laboratory measurements on major cation concentrations. Samples that showed extreme values for any of the measured variables were reanalyzed to validate the entries. The statistical analysis provided in this paper provides an additional means for the identification of erroneous data that otherwise would have gone undetected. Edited data files, designated DC Runoff data (Crrctd).TXT, NC Runoff data (Crrctd).TXT, NJ Runoff data (Crrctd).TXT, and NY Runoff data (Crrctd).TXT, are appended to this report along with the original data files. 
concentration variables in terms of "excess" concentrations over that collected in the blankrunoff solutions. For example, the blank-corrected $\mathrm{Ca}^{2+}$ and $\mathrm{SO}_{4}{ }^{2-}$ concentrations represent the $\mathrm{Ca}^{2+}$ and $\mathrm{SO}_{4}{ }^{2-}$ in the runoff solution in excess of the contributions from calcium- and sulfatebearing particulate material in the rain.

If the $\mathrm{Ca}^{2+}$ in the runoff solution from the test slabs only reflects weathering due to wet deposition, the excess $\mathrm{Ca}^{2+}$ signal may also have to be corrected for the dry deposition of $\mathrm{SO}_{2}$ to the test slab in between rain events. This correction is made by subtracting the excess $\mathrm{SO}_{4}{ }^{2-}$

simplicity, unless the subscripted notation, $\left[\mathrm{Ca}^{2+}\right]_{\mathrm{cor}}$, is explicitly used, $\left[\mathrm{Ca}^{2+}\right]$ will indicate that the $\mathrm{Ca}^{2+}$ concentration has been blank-corrected and corrected for the dry deposition of particulate $\mathrm{Ca}^{2+}$. The notation $\left[\mathrm{H}^{+}\right]^{0}$ designates the concentration of free $\mathrm{H}^{+}$in the incident rain.

\section{Runoff solution volume statistics}

Volume, averages (figure 1(avg)). The runoff volume is the key variable linking the observed concentrations to mass loss. Figure 1(avg) shows a comparison of the blank-runoff volume averaged over all observed events for each MRP site. Detailed statistics, including the range, mean values, standard deviation, and number of samples for the runoff-solution volumes for the blank, limestone, and marble slabs are provided in tables 5,6, and 7 in the appendix to this report.

Volume, histograms and chi-square test (figures 1 to 15). With the exception of figures 7 to 9 (NJ site), a general characteristic of the volume histograms is that their distributions somewhat conform to a gamma distribution. The statistical deviation of the runoff-volume data collected for the limestone, marble and blank slabs at the $\mathrm{NJ}$ site from the distributions of runoff-volume data from the $\mathrm{DC}, \mathrm{NY}, \mathrm{NC}$, and $\mathrm{OH}$ sites is evidence of the corruption of the $\mathrm{NJ}$ data set by a significant number of entries. ${ }^{8}$ In addition, there is a consistent statistical disparity among the limestone, marble, and blank distributions at all of the field sites. In general, the gamma distributions for the limestone volume data are more exponential-like ${ }^{9}$ than are the distributions for marble-volume or blank-volume data. Note that the ranges and the mean values for the limestone volume measurements are significantly less than the ranges and means for the marble or blank volume measurements. These findings are consistent with the imbibition of about $1.5 \mathrm{~L}$ of rain by the limestone slabs.

Volume (figures 16 to 20):(a) limestone vs. marble; (b) limestone, marble, and blank (sorted on blank); and (c) marble (sorted on marble volume). The plots in figures 16 to 20 reveal the degree of correlation and the extent of statistical consistency among the runoff volumes from the

${ }^{8}$ The significance level reported in figures 1 to 15 measures the probability that chisquare is due to random fluctuations around the assumed distribution. Thus, the closer the value of the significance to zero, the more unlikely it is that chi-square occurred by chance and that the sample does not fit the assumed distribution.

${ }^{9}$ An exponential distribution is a special case of the gamma distribution. 
limestone, marble, and blank slabs. The volume data in figures 16(a), 17(a), and 20(a) from the $\mathrm{DC}, \mathrm{NY}$, and $\mathrm{OH}$ sites, respectively, appear to be highly correlated. The limestone pattern is generally offset from the blank and marble plots by approximately $1.5 \mathrm{~L}$-no doubt a consequence of imbibition. The volume correlations are much weaker at the NJ and the NC sites, as seen in figures 18(a) and 19(a). Further, the offset between the limestone-volume curves and the marble/blank-volume curves apparent at the $\mathrm{DC}, \mathrm{NY}$, and $\mathrm{OH}$ sites is not evident at the NJ and NC sites. This suggests that there are a number of faults in the NJ and NC databases. The specific inaccuracies in the volume data from the NJ site are apparent by comparison of figure 16(b) to figure 20(b), which plots the runoff-solution volume from the limestone, marble, and blank slabs against the event index sorted on blank volume. Since imbibition is not expected on the marble test slabs, the runoff volume from the marble slabs, sorted on marble volume and shown in figures 16(c), 17(c), 18(c), 19(c), and 20(c), confirms suspicions regarding the inclusion of fill values for the volume data at the $\mathrm{NJ}$ and $\mathrm{NC}$ sites. It is apparent from figures 16(c), 17(c), 18(c), 19(c), and 20(c) that the volume increases continuously across the data sets at the DC, NY, and $\mathrm{OH}$ sites, but erratically at the NC and NJ sites. This pattern is most noticeable in the NC volume data by the plateaus at the 1-, 2-, and 4-L levels, and near the 4-L level in the NJ volume data. Unfortunately, the absence of accurate volume data diminishes the usefulness of the remaining runoff data from the $\mathrm{NJ}$ and $\mathrm{NC}$ sites for a given rain event and reduces the size of the data set available for quantitative testing of erosion models.

Differences in limestone and marble volumes from blank volume (figures 21 to 25). The figures in this set show the basis for a set of software tools for automatic identification and purging of corrupted volume data from the runoff-solution database. The figures show the volume difference patterns $\Delta_{\mathrm{L}}$ and $\Delta_{\mathrm{M}}$ as a line plot against event index for all five MRP sites, where

$$
\begin{aligned}
& \Delta_{\mathrm{L}}=U_{\text {blank }}-U_{\text {limestone }}, \text { and } \\
& \Delta_{\mathrm{M}}=U_{\text {blank }}-U_{\text {marble }} .
\end{aligned}
$$

In the above expressions, $U\left(\mathrm{~cm}^{3}\right)$ represents the volume of the runoff solution. In figures 21 to 25 , the events are sorted by increasing volume. The following criteria were used to validate the field observations:

Test 1: $\Delta_{\mathrm{L}}>0$ (applied to each event).

Test 2: Average $\left[\Delta_{\mathrm{L}}\right] \neq 0$ (applied to each site). Tests 1 and 2 acknowledge the effect of limestone imbibition such that the runoff volume from the limestone should always be less than that from the blank; the condition $\Delta_{\mathrm{L}} \leq 0$ is assumed to signal faulty volume data.

Test 3: Average $\left[\Delta_{\mathrm{M}}\right]=0$ (applied to each site). In test 3 we assume that marble imbibition is negligible and expect the difference variable, $\Delta_{\mathrm{M}}$, to vary randomly around the zero difference line.

Test 4: $\Delta_{\mathrm{L}} \neq 0$. (applied to each event).

Test 5: $\Delta_{M} \neq 0$. (applied to each event). 
Test 6: $\left(\Delta_{\mathrm{L}}-\Delta_{\mathrm{M}}\right) \neq 0$ (applied to each event). Tests 4,5 , and 6 are based on the assumption that the probability of exact coincidence in runoff volumes from the limestone, marble, and blank slabs is vanishingly small. Exact coincidence among any of these volumes for a given event would signal contrived volume-data.

Test 7: Random number test (applied to each event). Test 7 requires the volume values to be other than round numbers $\left(1,000 \mathrm{~cm}^{3}\right.$, for example).

The most ideal difference patterns are those from the $\mathrm{DC}$ and $\mathrm{OH}$ sites. With the exception of two points at the $\mathrm{OH}$ site and five points at the DC site, the difference patterns satisfy the first six criteria defined above. Although a computer program was used to identify the erroneous data, the bad data can be identified graphically in figures 21 to 25 for the points where the difference patterns equal zero.

Note that $\Delta_{\mathrm{L}}$ continuously increases with increasing volume at the $\mathrm{DC}$ and $\mathrm{OH}$ sites. This suggests that the limestone pore space does not become saturated, even during extended rain events.

Figure 22 (NY site) shows that a small group of rain events with high rain volumes have corrupted volume values based on test 1 . The most serious pathologies in the volume data, based on test 2, appear in the NJ and NC data sets. We suggest that the pathologies in the volume data are due to a data-filling procedure whereby incomplete data sets are augmented with contrived, integer-valued fill numbers when field observations were not available.

\section{Statistics of $\mathrm{H}^{+}$concentration in incident rain}

Average $\mathrm{H}^{+}$concentration at each site (figure 26(avg)). The bar graph in figure 26(avg) indicates that the $\mathrm{H}^{+}$concentration in the rain falling on the test slabs, $\left[\mathrm{H}^{+}\right]^{0}$, averaged over events at each site and unweighted for volume, was distinctly greater at the NJ site than at the other sites. However, in view of the statistical irregularity in the $\mathrm{H}^{+}$concentration histogram shown in figure 28 , the reader is cautioned not to over-interpret the significance of the average $\mathrm{H}^{+}$concentration at the $\mathrm{NJ}$ site. The mean $\left[\mathrm{H}^{+}\right]$at the $\mathrm{DC}, \mathrm{NC}, \mathrm{NJ}, \mathrm{NY}$, and $\mathrm{OH}$ sites correspond to $\mathrm{pH}$ values of $\approx 4.5,4.4,4.0,4.3$, and 4.8 , respectively. The standard deviation in the field measurements of $\left[\mathrm{H}^{+}\right]^{\mathrm{o}}$ was computed to be $\approx 0.03 \mathrm{mM}$.

$\mathrm{H}^{+}$concentration, histograms (figures 26 to 30 ). The most commanding feature in the $\left[\mathrm{H}^{+}\right]$ histograms is the radical, asymmetric gamma distribution at all of the MRP sites. With the exception of the $\mathrm{OH}$ site, the mean $\left[\mathrm{H}^{+}\right]$corresponds to a $\mathrm{pH}$ value in the range 4.5 to 5.1 , with the standard deviation at a given site less than $0.3 \mathrm{pH}$ units. The incident rain acidity at the $\mathrm{OH}$ site is systematically higher than that at the other sites, with a mean $\left[\mathrm{H}^{+}\right]$corresponding to a $\mathrm{pH}$ of 3.6.

$\mathrm{H}^{+}$load, histograms (figures 31 (avg) and 31 to 34). In the computation of the $\mathrm{H}^{+}$load, we assumed that the $\mathrm{H}^{+}$concentration in the rain was constant throughout the duration of the rain event. We also assumed that the same load was delivered to the marble and limestone slabs, regardless of limestone imbibition. The $\mathrm{H}^{+}$load, computed as the product $\left[\mathrm{H}^{+}\right] \times U_{\text {blank }}$, appears to be distributed exponentially at the DC, NY, and $\mathrm{OH}$ sites. This is not surprising, as the $\mathrm{H}^{+}$load 
is computed as the product of two gamma-distributed variables. The mean values of the $\mathrm{H}^{+}$loads at the exposure sites are shown in figure $31(\mathrm{avg})$. Although the occurrence of an $\mathrm{H}^{+}$load exceeding $1 / 2$ standard deviation exponentially above the mean value is unlikely at a given site, the $\mathrm{H}^{+}$loads at the NY site were found to be 30 to 40 percent greater than the $\mathrm{H}^{+}$load at the DC site; the histogram of the $\mathrm{H}^{+}$load at the $\mathrm{OH}$ site was not computed. Comparison of figure 1(a) with figure $31(\mathrm{avg})$ suggests that the disparity in average $\mathrm{H}^{+}$loads between exposure sites may be a consequence of differences in average rain $\mathrm{pH}$ rather than differences in rain volume.

\section{Statistics of $\mathrm{SO}_{4}{ }^{2-}$ in runoff solution}

$\underline{\text { Average } \mathrm{SO}_{4}}{ }_{4}{ }^{2-}$ concentration at each site (figure $36(\mathrm{avg})$ ). The average $\mathrm{SO}_{4}{ }^{2-}$ concentrations are consistently higher in the runoff solution from limestone relative to marble at all MRP sites, and there is considerable variability in $\mathrm{SO}_{4}{ }^{2-}$ concentration from site to site. Most notably, the average $\mathrm{SO}_{4}{ }^{2-}$ concentrations at the $\mathrm{OH}$ site are about 100 percent greater than those at the other sites.

$\underline{\mathrm{SO}}_{4}{ }^{2-}$ concentration, histograms (figures 36 to 40 ). $\mathrm{The}^{2} \mathrm{SO}_{4}{ }^{2-}$ concentrations in the runoff solution from limestone (figures 36(a), 37(a), 38(a), 39(a), and 40(a)) and marble (figures 36(b), 37(b), 38(b), 39(b), and 40(b)) appear to be gamma-distributed at all sites.

Average mass of dissolved $\mathrm{SO}_{4}{ }_{4}^{2-}$ at each site (figure 41(avg)). The average mass of dissolved gypsum at the MRP sites is given by the expression

$$
M_{\mathrm{CaCO}_{3}}=\frac{1}{N} \sum_{i=1}^{N}\left[\mathrm{SO}_{4}{ }^{2-}\right]_{\mathrm{corr}} \cdot U_{\mathrm{L}, \mathrm{M}} \cdot
$$

where the index $i$ is over the set of runoff-solution samples collected at a given site. The NY site shows the lowest gypsum off-load, while the $\mathrm{OH}$ site shows the highest.

Mass of dissolved $\mathrm{SO}_{4}{ }_{2-}$, histograms (figures 41 to 45 ). The dissolved $\mathrm{SO}_{4}{ }^{2-}$ off-load is computed as the product $\left[\mathrm{SO}_{4}{ }^{2-}\right.$ corr $\cdot U_{\mathrm{L}, \mathrm{M}}$. Although the mass of dissolved $\mathrm{SO}_{4}{ }^{2-}$ varies over a wide range from site to site, the $\mathrm{SO}_{4}{ }^{2-}$ is distributed exponentially at all sites. However, the histograms for the $\mathrm{SO}_{4}{ }^{2-}$ mass loss from limestone are slightly steeper on the low side than are the corresponding marble histograms. If we assume that the runoff solution is unsaturated in $\mathrm{Ca}^{2+}$ and $\mathrm{SO}_{4}{ }^{2-}$ with respect to $\mathrm{CaSO}_{4} \cdot 2 \mathrm{H}_{2} \mathrm{O}$, the relative steepness on the low side suggests that $\mathrm{SO}_{4}{ }^{2-}$ is transported into the pore space of the limestone with the imbibed surface solution.

\section{Statistics of $\mathrm{Ca}^{2+}$ in runoff solution}

$\mathrm{Ca}^{2+}$ uncor concentration, histograms (figures 46 to 50). The $\mathrm{Ca}^{2+}$ concentrations represented in figures 46 to 50 are uncorrected for $\mathrm{Ca}^{2+}$ in the incident rain, in particulate matter delivered in between rain events, and for $\mathrm{Ca}^{2+}$ released by dry deposition of $\mathrm{SO}_{2}$. The use of uncorrected concentrations provides information on the dissolution capacity of the runoff solutions and on the state of saturation of the solution in contact with the stone.

The $\mathrm{Ca}^{2+}$ concentrations represented in figures 46 to 50 generally are distributed over the range from 0.2 to $1.2 \mathrm{mM}$, with certain exceptions at some sites extending as high as $2.5 \mathrm{mM}$. 
Evidently, there are conditions in the catchment solution that promote the solubility of $\mathrm{CaCO}_{3}$ to levels that exceed the reported solubility $(\approx 0.14 \mathrm{mM})$ of calcite in pure water equilibrated with air. Even full conversion of the free $\mathrm{H}^{+}$ions delivered in the rain (reported in figures 26 to 30 ), which are less than $0.05 \mathrm{mM}$ with the exception of the NJ site, would fall short of being able to account for the extended solubility of calcite in the catchment solution. This suggests that, for many of the rain events, the runoff solution is undersaturated in $\mathrm{Ca}^{2+}$ with respect to the calcite surface. However, this does not preclude the occurrence of $\mathrm{Ca}^{2+}$ saturation with respect to $\mathrm{CaCO}_{3}$ on local areas of the stone. The question of equilibrium among chemical species in the catchment solution is a critical issue in the modeling of the runoff-solution chemistry.

$\underline{\mathrm{Ca}^{2+}} \times \underline{x s}$ concentration, histograms (figures 51 to 55 ). Similar to the uncorrected $\mathrm{Ca}^{2+}$ concentration distributions, the histograms for the excess $\mathrm{Ca}^{2+}$ concentrations are gamma-distributed at all sites. These distributions more closely approximate a normal distribution than do any of the other variables examined in this study. This is a consequence of the blank correction that is based on a variable whose distribution is weighted on the low-concentration side. Although each of the distributions is gamma, the central limit theorem predicts that the contour of the leading edge of the excess distribution will be normal-like. Interestingly, excess $\mathrm{Ca}^{2+}$ concentrations extending to $1.6 \mathrm{mM}$ are observed in these data sets, even after the blank correction has been applied. (MRP sites for these figures are indexed 51 to 55 with (a) limestone, and (b) marble.)

Mass of $\mathrm{Ca}^{2+}$ uncor, histograms (figures 56 to 60 ). The uncorrected mass-loss variable is computed as the product of the uncorrected $\mathrm{Ca}^{2+}$ concentration times the volume of the runoff from the test surface. The variable appears to be gamma-distributed at all MRP sites. The gamma distribution for limestone is generally more exponential-like than is the distribution for marble. This is expected if a fixed volume of solution is differentially imbibed by the limestone relative to the marble.

Mass of $\mathrm{Ca}^{2+}{ }_{x s}$, histograms (figures 61 to 65 ). The excess mass-loss variable is computed as the product of the excess $\mathrm{Ca}^{2+}$ concentration times the volume of the runoff from the test surface. Not surprisingly, the excess variable appears to be gamma-distributed at all MRP sites. These distributions reflect the variations in the factors controlling the runoff-solution chemistry from season to season.

\section{Reproducibility of measured quantities}

Figures 66 to 72, as indexed below, provide reference data on variations in runoff-solution chemistry at the MRP field sites. 
TABLE 2.- - Index to figures 66 to 72.

\begin{tabular}{|l|c|c|}
\hline Variable/plot & Limestone & Marble \\
\hline $\left.\mathrm{Ca}^{2+}\right]_{\mathrm{xs}}$ Vs. $\left[\mathrm{H}^{+}\right]^{\circ}$ & $\mathrm{DC}, \mathrm{NY}, \mathrm{NJ}, \mathrm{NC}, \mathrm{OH}$ & $\mathrm{DC}, \mathrm{NY}, \mathrm{NJ}, \mathrm{NC}, \mathrm{OH}$ \\
& 66 & 66 \\
$\Delta\left[\mathrm{Ca}^{2+}\right]_{\text {uncor Vs. }} \Delta U$ & $\mathrm{DC}$ & $\mathrm{DC}$ \\
$\Delta\left[\mathrm{Ca}^{2+}\right]_{\text {uncor }}$ Vs. $\Delta U$ & --- & 68 \\
$\Delta M_{t}$ uncor Vs. $\Delta U$ & 69 & --- \\
$\Delta M_{t}$ uncor vs. $\Delta U$ & -- & 70 \\
$\Delta\left[\mathrm{SO}_{4}{ }^{2-}\right]$ vs. $\Delta U$ & 71 & --- \\
$\Delta M_{\text {SO42- Vs. } \Delta U}$ & 72 & 72 \\
\hline
\end{tabular}

\section{Scatter in erosion effects across events}

Figure 66 provides an overall graphical view of the $\mathrm{Ca}^{2+}$ and $\mathrm{SO}_{4}{ }^{2-}$ chemistry in the runoff solution from the limestone and marble test slabs at all five MRP sites. Figure 66 shows back-toback scatter plots of the excess $\mathrm{Ca}^{2+}$ and $\mathrm{SO}_{4}{ }^{2-}$ concentrations versus the incident $\mathrm{H}^{+}$ concentrations for all rain events in the MRP database. Because figure 66 is a side-by-side comparison of the limestone and marble response to $\mathrm{H}^{+}$, both lateral scales from the origin toward the right and left represent positive abscissa scales for the $\mathrm{H}^{+}$concentration. The total solubility line in figure 66 represents the solubility of calcite as a function of the initial $\mathrm{H}^{+}$ concentration in the rain under free-drift equilibrium conditions. Also plotted in the figure are lines indicating the solubility of calcite in pure water and in water equilibrated with air. In addition, figure 66 shows the incremental solubility due to free $\mathrm{H}^{+}$delivered by the rain.

\section{Scatter due to field sampling procedures}

The error introduced into the measured quantities by the field sampling procedures was determined by comparison of the chemistry of the runoff solution from samples that were split at the DC field site. The mean values and the root-mean-square values of the differences in the uncorrected $\mathrm{H}^{+}, \mathrm{Ca}^{2+}$, and $\mathrm{SO}_{4}{ }^{2-}$ concentrations between ensembles of split-sample pairs are summarized in table 3 .

TABLE 3.-Variability of chemistry measurements on split samples retrieved from the MRP DC field site. $(n=$ number of split samples; $\mu=$ mean of differences between splits $(\mathrm{mmoles} / \mathrm{L}) ; \sigma=$ root mean square of difference (mmoles/L).)

\begin{tabular}{|c|c|c|c|c|c|c|c|c|c|c|}
\hline \multirow{2}{*}{\multicolumn{2}{|c|}{ Variable }} & \multicolumn{3}{|c|}{ Limestone } & \multicolumn{3}{|c|}{ Marble } & \multicolumn{3}{|c|}{ Blank } \\
\hline & & $n$ & $\mu$ & $\sigma$ & $n$ & $\mu$ & $\sigma$ & $n$ & $\mu$ & $\sigma$ \\
\hline Concentration & {$\left[\mathrm{Ca}^{2}\right.$} & 7 & -0.010 & 0.016 & 9 & -0.002 & 0.014 & 8 & -0.001 & 0.002 \\
\hline Load & {$\left[\mathrm{Ca}^{2+}\right] U_{\text {(umole) }}$} & 7 & -24.0 & 53.7 & 8 & -9.1 & 24.8 & 5 & 0.4 & 4.8 \\
\hline Concentration & {$\left[\mathrm{H}^{+}\right]_{(\mathrm{mmo} / \mathrm{L})}$} & 0 & --- & --- & 0 & --- & -- & 6 & -0.005 & 0.02 \\
\hline Load & {$\left[\mathrm{H}^{+}\right] U_{(\mu \mathrm{mole})}$} & 0 & --- & --- & 0 & --- & --- & 6 & -24.6 & 63.9 \\
\hline Concentration & {$\left[\mathrm{SO}_{4}{ }^{2-}\right]_{(\mathrm{mmo} / \mathrm{L})}$} & 3 & 0.010 & 0.01 & 1 & -0.11 & 0.11 & 0 & --- & --- \\
\hline Load & {$\left[\mathrm{SO}_{4}{ }^{2-}\right] U_{(\mu \mathrm{mole})}$} & 3 & -38.0 & 38.2 & 0 & -- & --- & 0 & --- & --- \\
\hline
\end{tabular}




\section{Scatter from slab to slab}

The slab-to-slab reproducibility in the field was established from the runoff-solution chemistry from duplicate limestone and marble slabs placed side by side in the exposure racks at the DC site. The mean and root-mean-square values of the differences between ensembles of sample pairs from the side-by-side test slabs in the uncorrected $\mathrm{H}^{+}, \mathrm{Ca}^{2+}$, and $\mathrm{SO}_{4}{ }^{2-}$ concentrations are detailed in table 4.

TABLE 4.- Variability of chemistry measurements collected from duplicate slabs at the MRP DC field site. $(n=$ number of samples from duplicate slabs; $\mu=$ mean of differences between duplicate slabs (mmoles/L); $\sigma=$ root mean square of difference (mmoles/L).)

\begin{tabular}{|l|l|c|c|c|c|c|c|c|c|c|}
\hline \multicolumn{2}{|c|}{ Variable } & \multicolumn{3}{|c|}{ Limestone } & \multicolumn{3}{c|}{ Marble } & \multicolumn{3}{c|}{ Blank } \\
\cline { 2 - 10 } \multicolumn{2}{l|}{} & $n$ & $\mu$ & $\sigma$ & $n$ & $\mu$ & $\sigma$ & $n$ & $\mu$ & $\sigma$ \\
\hline Concentration & {$\left[\mathrm{Ca}^{2+}\right]_{(\mathrm{mmol} / \mathrm{L})}$} & 74 & -0.103 & 0.196 & 59 & -0.037 & 0.121 & 76 & -0.002 & 0.066 \\
Load & {$\left[\mathrm{Ca}^{2+}\right] U_{(\mu \mathrm{mole})}$} & 58 & 55.4 & 499.1 & 75 & -122.8 & 289.4 & 73 & 1.8 & 42.9 \\
Concentration & {$\left[\mathrm{H}^{+}\right]_{(\mathrm{mmol} / \mathrm{L})}$} & 61 & 0.0 & 0.0 & 69 & 0.0 & 0.0 & 74 & -0.005 & 0.015 \\
Load & {$\left[\mathrm{H}^{+}\right] U_{(\mu \mathrm{mole})}$} & 0 & --- & --- & 0 & --- & --- & 6 & -24.6 & 63.9 \\
Concentration & {$\left[\mathrm{SO}_{4}{ }^{2-}\right]_{(\mathrm{mmol} / \mathrm{L})}$} & 52 & -0.041 & 0.091 & 58 & -0.011 & 0.050 & 24 & -0.006 & 0.022 \\
Load & {$\left[\mathrm{SO}_{4}{ }^{2-}\right] U_{(\mu \mathrm{mole})}$} & 57 & -15.7 & 236.9 & 75 & 36.3 & 114.6 & 70 & 3.8 & 16.9 \\
\hline
\end{tabular}

Table 5 provides the statistics on the variability in runoff-solution volume from duplicate slabs at the MRP DC field site. Additional observations of the slab-to-slab variabilities are shown in figures 67 to 72 .

TABLE 5.- Variability of runoff-solution volume, $U\left(\mathrm{~cm}^{3}\right)$, from duplicate slabs at the MRP DC field site. ( $n=$ number of samples from duplicate slabs; $\mu=$ mean of differences between duplicate slabs $\left(\mathrm{cm}^{3}\right) ; \sigma=$ root mean square of difference $\left(\mathrm{cm}^{3}\right)$.)

\begin{tabular}{|l|l|c|c|c|c|c|c|c|c|c|}
\hline \multicolumn{2}{|l|}{ Variable } & \multicolumn{3}{|c|}{ Limestone } & \multicolumn{3}{c|}{ Marble } & \multicolumn{3}{c|}{ Blank } \\
\cline { 3 - 10 } \multicolumn{2}{l|}{} & $n$ & $\mu$ & $\sigma$ & $n$ & $\mu$ & $\sigma$ & $n$ & $\mu$ & $\sigma$ \\
\hline Volume & $U_{(\mathrm{cm} 3)}$ & 66 & 363 & 682 & 74 & -126 & 556 & 73 & -8 & 116 \\
\hline
\end{tabular}

$\Delta\left[\mathrm{Ca}^{2+}\right]_{\text {uncor }}$ off limestone vs. $\Delta U$ for all DC-site observations (figure 67 ). The concentrationvariability maps for limestone and marble (figures 67 and 68, respectively) show plots of the difference between two $\left[\mathrm{Ca}^{2+}\right]_{\text {uncor }}$ readings versus the difference between two corresponding volume readings for duplicate measurements on the same event. In figure 67, most of the points fall in the fourth quadrant. The scatter in the $\left[\mathrm{Ca}^{2+}\right]$-difference variable is biased in the negative direction and the scatter in the volume-difference variable is biased in the positive direction. The positive bias in the volume-difference variable can be understood in terms of differential imbibition between the two limestone test slabs. The negative bias in the concentrationdifference variable, in the light of a positive bias in the volume-difference variable, is suggestive of a dilution effect.

$\Delta\left[\mathrm{Ca}^{2+}\right]_{\text {uncor }}$ off marble vs. $\Delta U$ for all DC-site observations (figure 68 ). In contrast to the corresponding plot for limestone (figure 67), most of the points in the plot for marble (figure 68) either fall in the second or fourth quadrants. The distributions of the difference variables along the ordinate and the abscissa are centered near zero. Although there is no evidence of differential 
imbibition between the two marble test slabs, the pattern shows that positive differences in volume correspond to negative differences in $\mathrm{Ca}^{2+}$ concentration, and vice versa. As in figure 67, this pattern is evidence of dilution of a runoff solution $\mathrm{Ca}^{2+}$ load that nominally appears to be the same for a given event for each of the test slabs.

$\underline{\Delta M} t$ uncor $\left(\mathrm{Ca}^{2+}\right.$ mass loss $)$ off limestone vs. $\Delta U$ for all DC-site observations (figure 69). The limestone and marble mass-loss plots (figures 69 and 70, respectively) show the difference between two mass-loss readings versus the difference between two corresponding volume readings for duplicate measurements on the same event. The mass loss is calculated as the product of the $\mathrm{Ca}^{2+}$ concentration and the runoff volume. Most of the points in the figure fall in either the first or second quadrant. Note that the mass-loss difference variable scatters along the ordinate around zero while the scatter in the volume-difference variable is biased in the positive direction. As in figure 67, this positive bias can be understood in terms of a systematic difference in imbibition between the two limestone test slabs.

$\underline{\Delta} \underline{t}_{\text {uncor }}\left(\mathrm{Ca}^{2+}\right.$ mass loss $)$ off marble vs. $\Delta U$ for all DC-site observations (figure 70$)$. Unlike the corresponding plot for limestone (figure 69), both difference variables for marble scatter around zero. In addition, most of the points fall in either the first or third quadrant, a pattern showing that positive differences in volume correspond to positive differences in marble mass loss, and vice versa. The broad distribution in the $\left[\mathrm{Ca}^{2+}\right]$ variable, as is evident in figures 46 to 51 , would rule out the pattern seen in figure 70 unless the variables $\left[\mathrm{Ca}^{2+}\right]$ and $U$ are significantly correlated. This apparent positive correlation not only requires explanation, but the observation can also serve as a test of proposed models for dissolution by wet deposition.

$\Delta\left[\mathrm{SO}_{4}{ }_{4}^{2-}\right]$ vs. $\Delta U$ for all DC-site observations (figure 71 ). The variability map for the $\mathrm{SO}_{4}{ }^{2-}$ concentration is a plot of the difference between duplicate $\left[\mathrm{SO}_{4}{ }^{2-}\right]$ measurements versus the difference between two corresponding duplicate volume readings for parallel measurements on the same event. Most of the points in this plot fall in the second and fourth quadrants, a pattern suggesting a dilution process.

$\underline{\Delta M}$ SO42-(mass of gypsum) vs. $\Delta U$ for all DC-site observations (figure 72 ). The mass of gypsum is calculated as the product of the $\mathrm{SO}_{4}{ }^{2-}$ concentration and the runoff volume. Figure 72 shows a plot of the difference between duplicate mass-loss readings versus the difference between corresponding duplicate volume readings for parallel measurements on the same event. Most of the points in this figure fall in either the second or forth quadrant. The variability patterns in figures 71 and 72 can provide a test of proposed cross-models for wet and dry deposition; these patterns will not be discussed further in this study.

\section{Test slabs at MRP NY site (subevent resolution)}

For the purposes of this study, a subevent is defined in terms of a fixed volume of rain rather than in terms of a fixed passage of time. This definition is based on the use of tipping-bucket rain-gauge technology at the field sites. Subevent runoff data from marble were provided for seven rain events, designated E-14, E-15, E-16, E-17, E-21, E-23, and E-25. Figures 73 through 102 , as outlined below in table 6 , show the dependence of a set of variables on subevent index, 
on the $\mathrm{H}^{+}$concentration, $\left[\mathrm{H}^{+}\right]^{0}$, in the incident rain, and on the cumulative time into the event.

TABLE 6.-Index to figures 73 to 102.

\begin{tabular}{|l|l|c|}
\hline \multicolumn{2}{|l|}{ Variable/plot } & Figure number \\
\hline Volume & $U_{\text {subevent }}$ Vs. index & 73 to 79 \\
Flow rate & $\mu_{<\Phi T>} / \mu_{\Phi-\text { event }}$ Vs. $T_{\text {max }}$ & 80 \\
Volume & $U_{\text {marble, subevent }}$ Vs. $U_{\text {blank }}$ & 81 \\
Concentration & $\mathrm{Ca}^{2+}$ cor, $\left[\mathrm{H}^{+}\right]^{\circ}, \Phi$ vs. $T_{\text {cum }}$ & 82 to 88 \\
Concentration & $\mathrm{Ca}^{2+}{ }_{\text {cor }}$ Vs. $\Phi$ & 89 to 95 \\
Concentration & $\mathrm{Ca}^{2+}$ cor Vs. $\left[\mathrm{H}^{+}\right]^{\circ}$ & 96 to 102 \\
\hline
\end{tabular}

Subevent runoff volume, $\mathrm{U}_{\text {subevent }}$, vs. subevent index (figures 73 to 79 ). In actual practice, each rain event is partitioned in accordance with a quasi-uniform volume-sampling protocol because the flow rate of the rain into the collection vessel does not precisely track the flow rate of the rain into the rain gauge. Accordingly, the runoff volume is a random variable with statistical properties defined over a quasi-uniform volume-sampling space. Figures 73 to 79 show the subevent runoff volume plotted against the corresponding subevent index for each rain event. With the exception of events 16 and $25, U_{\text {subevent }}$ is random across the event space. We assume that the volume data for E-16 and E-25 are contrived fill-data based on the rain-gauge volume. The lack of precise volume data for these events precludes quantitative analysis of the data with a model based on mass loss.

Subevent flow-rate observations (figure 80). If we let $T(\mathrm{sec})$ represent the period of a given subevent, the average flow-rate over the period $T$, denoted $<\Phi_{T}>\left(\mathrm{cm}^{3} / \mathrm{sec}\right)$, is computed by the ratio $U_{\text {subevent }} / T$. If $T_{\text {dry }}(\mathrm{sec})$ represents the time of dryness during a given subevent, and if $\Phi$ represents the average flow-rate when water is actually flowing over the test slab, then

$$
\begin{aligned}
& T=(U / \Phi)+T_{\mathrm{dry}} \cdot \text { Since } \\
& <\Phi_{T}>=U / T, \text { then } \\
& <\Phi_{T}>=\frac{U}{(U / \Phi)+T_{\mathrm{dry}}} \\
& =\frac{\Phi}{1+\left(T_{\mathrm{dry}} / T\right)} .
\end{aligned}
$$

If $T_{\mathrm{dry}}>0$, the measure $<\Phi_{T}>$ will understate the actual flow-rate. And if $T_{\mathrm{dry}}=0,<\Phi_{T}>$ will equal the actual flow-rate.

The average flow-rate over the full event, $\mu_{\Phi-\text {-event }}$, is given by the cumulative volume divided by the cumulative time of the event. The fixed-volume mean flow-rate, $\mu_{<\Phi T>}$, the mean value of the distribution, will be equal to the average flow-rate across the event if the actual flow-rate is constant throughout the entire rain event or if the distribution of $\left\langle\Phi_{T}\right\rangle$ is suitably asymmetric. Both of these measures will understate the actual flow-rate if the stone becomes dry at any time during a subevent period. 
In order to discover the subevents during which the stone may have become dry, we tracked $\mu_{<\Phi T>}$ and $\mu_{\Phi \text {-event }}$ as shown in figure 80 , while we systematically rejected subevent data associated with $T$ values greater than an arbitrarily selected value $T_{\max }$. As expected, the computed flow-rates increased and their ratio stabilized as $T_{\max }$ was decreased. The ratio $\mu_{<\Phi T>} / \mu_{\Phi \text {-event }}$ decreased from a value of $\approx 18$ at $T_{\max }=100$ minutes to 2.8 at $T_{\max }=40$ minutes; the ratio appears to remain unchanged as $T_{\max }$ is reduced to 15 minutes. The evidence in figure 15 indicates that subevent time values exceeding $\approx 40$ minutes may be corrupted because the stone may become dry. This analysis revealed that E-17, E-21, and E-23 each include two separate rain events separated by several hours of stone dryness (see figures 85, 86, and 87, respectively).

Subevent marble-runoff volume vs. subevent blank-runoff volume (figure 81). Figure 81, which shows the subevent marble-runoff volume plotted against the subevent blank-runoff volume, reveals contrived fill-data imbedded in the data sets for E-14, E-21, and E-23. The corrupted data are flagged by the appearance of constant-volume values from one subevent to the next. These fill data should be disregarded in the quantitative interpretation of the subevent observations.

$\left[\mathrm{Ca}^{2+}\right]_{\text {cor }}\left[\mathrm{H}^{+}\right]^{0}, \Phi$ vs. cumulative event time (figures 82 to 88 ). The figures in this set show the variation of $\left[\mathrm{Ca}^{2+}\right]_{\text {cor }}$ (purple), $\left[\mathrm{H}^{+}\right]^{\circ}$ (red), and $\Phi$ (green) with cumulative event time into a given event. The variables are not interpolated across the event; they are extended for the duration of the subevent time. Because of the conversion from a uniform-volume sampling space to cumulative event time, there is considerable granularity in the plot, and the patterns should not be over-interpreted.

With the exception of E-14, all three variables - $\left[\mathrm{Ca}^{2+}\right]_{\text {cor }},\left[\mathrm{H}^{+}\right]^{\circ}$, and $\Phi$-in figures 82 to 88 appear to vary randomly across the rain event. In E-14 (figure 82), the $\mathrm{Ca}^{2+}$ concentration seems to decrease regularly with increasing time, a pattern that may be in concert with a decrease in the $\mathrm{H}^{+}$concentration with time. E-14 is unique in that the $\left[\mathrm{H}^{+}\right]^{\mathrm{o}}$ is unusually high relative to $\left[\mathrm{H}^{+}\right]^{\mathrm{o}}$ in the other events, and the flow rate is unusually low.

In E-21 and E-23 (figures 86 and 87, respectively), it is of particular interest that $\left[\mathrm{Ca}^{2+}\right]$ and $\left[\mathrm{H}^{+}\right]^{\circ}$ consistently appear to be in phase with each other and out of phase with $\Phi$. This pattern is further explored in figures 89 through 95 below.

$\left[\mathrm{Ca}^{2+}\right]_{\text {cor }}$ vs. subevent flow-rate (figures 89 to 95 ). In this set of figures, we explore the relationship between the excess $\mathrm{Ca}^{2+}$ concentration in the subevent runoff solution and the flow rate of the rain over the slab during the subevent. In all of the events, the concentration offset represents 50 to 100 percent of the concentration signal. Throughout E-14 (figure 89), the flow rate is uncommonly low relative to the flow rate during the other events, and the $\mathrm{Ca}^{2+}$ concentration varies randomly with wide excursions. In E-15, E-16, E-17, E-21, and E-23 (figures 90, 91, 92, 93, and 94, respectively), the $\mathrm{Ca}^{2+}$ concentration is somewhat less than in E14 and appears to decrease slightly with increasing flow-rate.

$\left[\mathrm{Ca}^{2+}\right]_{\text {cor }}$ vs. subevent $\left[\mathrm{H}^{+}\right]^{\text {o }}$ (figures 96 to 102). In this set of figures, we examine the response of the $\mathrm{Ca}^{2+}$ concentration in the subevent-runoff solution to the $\left[\mathrm{H}^{+}\right]^{\mathrm{o}}$ in the incident rain for each 
subevent. In E-14, E-17, E-21, and E-23 (figures 96, 99, 100, and 101, respectively), the Ca ${ }^{2+}$ concentration shows a discernable response to $\left[\mathrm{H}^{+}\right]^{\mathrm{o}}$, while in E-15, E-16, and E-25 (figures 97 , 98 , and 102 , respectively), $\left[\mathrm{H}^{+}\right]^{\circ}$ appears to be too low to solicit a $\left[\mathrm{Ca}^{2+}\right]$ response. In all of the events, the $\mathrm{Ca}^{2+}$ concentration is about a factor of five too high to be accounted for by $100-$ percent conversion of $\left[\mathrm{H}^{+}\right]^{\circ}$ with a stoichiometric factor of 1 .

\section{In situ monuments at Gettysburg}

Over the period extending from mid 1986 to late autumn 1988, Sherwood and Dolske (1992), with the assistance of C. Platt and R. Platt, ${ }^{10}$ studied the impact of wet acid deposition on marble monuments at the Gettysburg National Military Park (NMP) in rural southeastern Pennsylvania. Runoff solutions were collected from two morphologically similar obelisks and two morphologically similar statues, as identified below:

\section{Obelisks}

General Zook Monument (Zook)(Pennsylvania Blue marble)

68th Pennsylvania Volunteers Monument (68PV)(Carrara marble)

\section{Statues}

Soldiers National Monument: War (Carrara marble)

Soldiers National Monument: History (Carrara marble)

Runoff solutions were collected from the obelisks for 32 rain events and from the statues for 21 rain events. Figures 103 through 107, as outlined below in table 7, show the dependence of $\mathrm{Ca}^{2+}$ concentration and mass in the runoff solutions on event index, on $\mathrm{H}^{+}$concentration in the incident rain, and on event duration.

TABLE 7.--Index to figures 103 to 107.

\begin{tabular}{|l|l|c|c|}
\hline \multicolumn{2}{|l|}{ Variable/plot } & Statues & Obelisks \\
\hline Concentration & $\mathrm{Ca}^{2+}{ }^{\text {cor Vs. index }}{ }_{\text {event }}$ & 103 & 103 \\
Concentration & $\mathrm{Ca}^{2+}{ }^{\text {cor Vs. }[\mathrm{H}+]^{\circ}}$ & 104 & 105 \\
Mass & $\mathrm{Ca}^{2+}{ }^{\text {cor Vs. event duration }}$ & 106 & 107 \\
\hline
\end{tabular}

Figure 103 shows scatter plots of $\mathrm{Ca}^{2+}$ concentration, corrected for dry deposition of sulfate against the event index for the obelisks and the statues; the averages of the chemistry variables associated with the Gettysburg monuments are given in table 8 . The most apparent aspect of the runoff-solution chemistry is the conspicuous difference between the general $\mathrm{Ca}^{2+}$-concentration levels in the runoff solution from the statues and the obelisks. The average $\mathrm{Ca}^{2+}$ concentration in the runoff solution from the statues $(0.94 \mathrm{mmol} / \mathrm{L})$ is nearly a factor of ten greater than the $\mathrm{Ca}^{2+}$ concentration in the runoff from the obelisks $(0.10 \mathrm{mmol} / \mathrm{L})$. Also of interest is the large difference between the blank-corrected $\mathrm{SO}_{4}{ }^{2-}$ concentrations in the runoff solution from the

\footnotetext{
${ }^{10}$ C. Platt and R. Platt, 905 Belmont Road, Gettysburg, PA 17325
} 
statues and the obelisks. The average $\mathrm{SO}_{4}{ }^{2-}$ concentration in the runoff solution from the statues $(0.26 \mathrm{mmol} / \mathrm{L})$ is 26 times greater than the $\mathrm{Ca}^{2+}$ concentration in the runoff from the obelisks $(0.01 \mathrm{mmol} / \mathrm{L})$. The concentration of $\mathrm{H}^{+}$in the incident rain varies by about a factor of 2 between the obelisks and the statues, but is in the same order of magnitude $(68 \mathrm{PV} \&$ Zook: $0.05 \mathrm{mmol} / \mathrm{L}$; War \& History: $0.22 \mathrm{mmol} / \mathrm{L}$ ). There appears to be no correlation between the $\mathrm{Ca}^{2+}$ concentration in the runoff solutions from the obelisks and the statues.

TABLE 8.-Average runoff-solution chemistry variables associated with the Gettysburg monuments studied by Sherwood and Dolske (1992).

\begin{tabular}{|c|c|c|c|c|c|c|}
\hline Object & $\begin{array}{c}\text { Incident }\left[\mathbf{H}^{+}\right]^{\mathbf{o}} \\
\mathrm{mmol} / \mathrm{L}\end{array}$ & $\begin{array}{c}{\left[\mathrm{SO}_{4}{ }^{2-}\right]} \\
\mathrm{mmol} / \mathrm{L}\end{array}$ & $\begin{array}{c}{\left[\mathrm{Ca}^{2+}\right]} \\
\mathrm{mmol} / \mathrm{L}\end{array}$ & $\begin{array}{l}{\left[\mathrm{Ca}^{2+}\right]_{\text {cor }}} \\
\mathrm{mmol} / \mathrm{L}\end{array}$ & $\begin{array}{l}\text { Mass loss per } \\
500 \mathrm{~cm}^{3} \mathrm{mmol}\end{array}$ & $\begin{array}{c}{\left[\mathrm{H}^{+}\right]^{0} \text { load }} \\
\text { per } 500 \mathrm{~cm}^{3} \\
\text { mmol }\end{array}$ \\
\hline $68 \mathrm{PV}$ & 0.050 & 0.011 & 0.125 & 0.114 & 43 & 16.7 \\
\hline ZOOK & 0.050 & 0.009 & 0.083 & 0.075 & 25 & 18.2 \\
\hline WAR & 0.021 & 0.237 & 1.088 & 0.792 & 518 & 15.5 \\
\hline HIST & 0.021 & 0.288 & 0.785 & 0.483 & 311 & 17.6 \\
\hline
\end{tabular}

Figures 104 and 105 show xy plots of $\left[\mathrm{Ca}^{2+}\right]_{\text {cor }}$ vs. $\mathrm{H}^{+}$concentration in the incident rain for the statues and the obelisks, respectively. In figure 105 (obelisks), the $\mathrm{Ca}^{2+}$ concentration appears to be weakly correlated with $\left[\mathrm{H}^{+}\right]^{\circ}$. However, most of the points for both monuments fall above the $\left[\mathrm{H}^{+}\right]^{\mathrm{o}} 1: 1$ line. In figure 104 (statues), virtually all of the points fall far above the $\left[\mathrm{H}^{+}\right]^{\mathrm{o}} 1: 1$ line, an observation that mirrors the data in the last two columns in table 8 and precludes the $\mathrm{H}^{+}$load as an important factor for the explanation of statue erosion.

Figures 106 and 107 show xy plots of the mass of $\mathrm{Ca}^{2+}$ lost during a rain event against the reported duration of the event for the statues and the obelisks, respectively. From the scatter of points in the figures, apparently there is almost no correlation between erosion and the reported event time; the average event time is around 11 hours. The disparity in mass loss from the statues (average $=415 \mathrm{~mol}$ ) relative to the obelisks (average $=34 \mu \mathrm{mol}$ ), a factor of 12, is more than twice the concentrational disparity seen in figure 103.

\section{Baedecker laboratory simulations}

In order to test the linearity of the $\left[\mathrm{Ca}^{2+}\right]$ response to incremental $\mathrm{H}^{+}$, and in order to determine the effective stoichiometric relationship between $\mathrm{H}^{+}$and $\mathrm{Ca}^{2+}$ in the dissolution of calcite by free $\mathrm{H}^{+}$, Baedecker and others (1992) explored the correlation between the excess $\mathrm{Ca}^{2+}$ concentration in the runoff from marble at the Newcomb, NY site; the excess $\mathrm{Ca}^{2+}$ signal was corrected for temperature. Figure 108 (Baedecker and others, 1992, figure 19-50, p. 19-112) shows a plot of the temperature-corrected excess $\mathrm{Ca}^{2+}$ concentration in runoff solution from marble at the NY site versus the $\mathrm{H}^{+}$concentration in the rain. The plot indicates a random response for $\mathrm{pH}$ values above $\approx 4.3$ and a slightly positive response for $\mathrm{pH}$ values less than $\approx 4.3$. Because of the wide relative variability in the $\mathrm{Ca}^{2+}$ concentrations for a given $\mathrm{pH}$ of the incident rain, information on the reaction stoichiometry from the plot was inconclusive. 
In a set of laboratory experiments conducted under more controlled conditions, Baedecker collected the runoff solution from limestone and marble test slabs to which a fixed volume of standard $\mathrm{H}_{2} \mathrm{SO}_{4}$ was systematically sprayed over the upper half of the slabs; these results are reproduced in figure 109 (Baedecker and others, 1992, figure 19-51, p. 19-112; full slab curves: marble "+", limestone "x"). In these experiments, Baedecker demonstrated a definitive monotonic $\mathrm{Ca}^{2+}$ response to $\left[\mathrm{H}^{+}\right]$at concentrations greater than $\approx 0.25 \mathrm{mM}$. Baedecker noted that the slope of the response curve in figure 109 indicated a $1 / 2: 1:: \mathrm{Ca}^{2+}: \mathrm{H}^{+}$stoichiometry in the attack of $\mathrm{H}^{+}$on $\mathrm{CaCO}_{3}$. Although not explicitly defined, the implicit model behind Baedecker's assumption of linearity in the $\mathrm{Ca}^{2+}$-versus $-\mathrm{H}^{+}$response was that the calcite dissolution is kinetically controlled and dominated by the reaction of $\mathrm{CaCO}_{3}$ with $\mathrm{H}^{+}$. In the dissolution of $\mathrm{CaCO}_{3}$ by free $\mathrm{H}^{+}$, a stoichiometry of $1 / 2: 1:: \mathrm{Ca}^{2+}: \mathrm{H}^{+}$indicates that one molecule of $\mathrm{CO}_{2}$ is produced for each molecule of $\mathrm{Ca}^{2+}$ released into the runoff solution. Because of the potential non-linearity of the response curves in figure 109, the $1 / 2: 1$ stoichiometry may apply only over the $\mathrm{pH}$ range 3 to 3.6. For experiments conducted with the $\left[\mathrm{H}^{+}\right]$in the test solution less than $0.1 \mathrm{mM}$, Baedecker's results are insufficiently resolved to determine the nature of the $\mathrm{Ca}^{2+}$ response to $\mathrm{H}^{+}$. Unfortunately, the original laboratory observations were not available for graphing the observations on the expanded scale from 0 to $0.1 \mathrm{mM}$.

Interestingly, Baedecker's results in figure 109 show that the $\left[\mathrm{Ca}^{2+}\right]$ intercept for limestone is about twice the value of that of a marble surface with the same nominal Euclidian area, and that the incremental response to $\mathrm{H}^{+}$is about the same for limestone and marble. This finding, which is consistent with field observations, suggests that the larger effective surface area of the limestone slab relative to the smoother marble is a critical factor controlling the magnitude of the $\mathrm{Ca}^{2+}$ response. However, this conclusion seems to be challenged by what are perhaps the most intriguing results of Baedecker's last set of experiments. In this set, which was designed to test the effect of droplet resident time on the $\mathrm{Ca}^{2+}$ response to a fixed $\mathrm{H}^{+}$load, Baedecker applied the same $\mathrm{H}^{+}$load to the upper and lower halves of the limestone and marble test slabs; the results of these experiments are also shown in figure 109 (half slab curves: marble " $\triangle$ ", limestone " $\square$ "). The puzzle presented by these results is the apparent insensitivity of the $\left[\mathrm{Ca}^{2+}\right]$ signal to the stone area washed by acidified solution.

\section{Schmiermund laboratory simulations}

In a set of carefully-executed laboratory experiments on 15-cm long polished Indiana limestone and Vermont marble test slabs, Schmiermund (1991) monitored the $\mathrm{Ca}^{2+}$ concentration in the runoff solution as a function of flow rate for different conditions of solution $\mathrm{pH}$, system temperature, and slab inclination. In all of Schmiermund's work, the acidified solution was applied at a fixed point at the top of the inclined stone slab, and runoff-solution observations were not started until the chemistry of the dynamic system reached a steady-state condition; steady-state conditioning typically required about two hours. Figures 110 to 115 show the effects of $\mathrm{pH}$, temperature, and slab inclination on the steady-state concentration of $\mathrm{Ca}^{2+}(\mu \mathrm{mol} / \mathrm{L})$ in the runoff solutions and on the steady-state rate of mass loss, $\dot{M}$, from the stone $\left(\mu \mathrm{mol} / \mathrm{s} / \mathrm{cm}_{\text {width }}\right)$, with the dependent variables plotted as a function of the volumetric flow-rate $\left(\mathrm{cm}^{3} / \mathrm{s} / \mathrm{cm}_{\text {width }}\right)$ of the solution over the slab. 
TABLE 9.- Index to figures 110 to 115.

\begin{tabular}{|l|c|c|c|c|}
\hline \multicolumn{2}{|c|}{ y-variable } & \multirow{2}{*}{ Plot } & \multicolumn{2}{c|}{ Figure number } \\
\cline { 4 - 5 } & & Limestone & Marble \\
\cline { 4 - 5 } Concentration & {$\left[\mathrm{Ca}^{2+}\right]$} & Flow rate and variable $\mathrm{pH}$ & 110 & 110 \\
Loss rate & $\dot{M}_{\mathrm{Ca}^{2+}}$ & Flow rate and variable $\mathrm{pH}$ & 111 & 111 \\
Concentration & {$\left[\mathrm{Ca}^{2+}\right]$} & Flow rate and variable temperature & $112(\mathrm{a})$ & $112(\mathrm{~b})$ \\
Loss rate & $\dot{M}_{\mathrm{Ca}^{2+}}$ & Flow rate and variable temperature & $113(\mathrm{a})$ & $113(\mathrm{~b})$ \\
Concentration & {$\left[\mathrm{Ca}^{2+}\right]$} & Flow rate and variable inclination & 114 & --- \\
Loss rate & $\dot{M}_{\mathrm{Ca}^{2+}}$ & Flow rate and variable inclination & 115 & --- \\
\hline
\end{tabular}

The reproducibility $(2 \sigma)$ of the flow rate and concentration measured in the Schmiermund laboratory simulations was generally from 1 to 3 percent, with only a few worst-case measurements extending to $\approx 5$ percent. Since the nominal $\mathrm{Ca}^{2+}$ concentration in the runoff solutions from the laboratory simulations was $\approx 0.1 \mathrm{mmol} / \mathrm{L}$, the expected variability of the measured erosion effect under controlled environmental conditions is expected to $b e \approx 0.003$ $\mathrm{mmol} / \mathrm{L}$. Because the analytical uncertainty is also $\approx 0.003 \mathrm{mmol} / \mathrm{L}$, the detection of excursions in the erosion phenomena under Schmiermund's simulation conditions is limited by the analytical precision in the measurement. Given the high internal validity of the Schmiermund simulations, the laboratory experiments are remarkable for information they revealed on the chemical erosion of calcareous stone. The effects that are of particular interest include:

- Dependence of $\left[\mathrm{Ca}^{2+}\right]$ on flow rate. Figures $110,112(a), 112(b)$, and 114 show that the $\mathrm{Ca}^{2+}$ concentration generally exhibits an inverse nonlinear dependence on the flow rate of solution over both limestone and marble surfaces.

- Dependence of $\dot{M}$ on flow rate over marble. Figures $111(\mathrm{pH}=3.5)$ and 113(b) show that the steady-state rate of mass loss from the marble test slab exhibits a linear dependence with a positive slope on the flow rate. The linearity of the effect suggests that the transfer rate of $\mathrm{Ca}^{2+}$ from the stone surface into the wash solution is limited by the transport rate of $\mathrm{H}^{+}$to the stone surface.

- Dependence of $\dot{M}$ on flow rate over limestone. Comparison of the limestone plots in figures $111,113(a)$, and 115 show that the steady-state rate of mass loss from the limestone test slab is a nonlinear function of the flow rate; the plots in all three figures exhibit a diminishing positive slope with increasing flow-rate. These observations indicate that there is a decrease in the net release rate of $\mathrm{Ca}^{2+}$ from the stone surface at the lower range of flow rates. Since the independent variable in figures 111, 113(a), and 115 is the solution flow-rate, the plots suggest that the release of $\mathrm{Ca}^{2+}$ may be limited by surface processes. Such mechanisms may include the reprecipitation of $\mathrm{CaCO}_{3}$ that would reduce the observed rate of mass loss. Note in figure 111 that the $\dot{M}$ response to flow rate becomes more linear as the initial $\mathrm{pH}$ is increased. 
- Dependence of $\left[\mathrm{Ca}^{2+}\right]$ on initial pH. Figure 110 shows that the steady-state $\mathrm{Ca}^{2+}$ concentration exhibits a nonlinear sensitivity to changes in the initial $\mathrm{H}^{+}$concentration of the test solution. For example, for a volumetric flow-rate of $0.04 \mathrm{~cm}^{3} / \mathrm{s} / \mathrm{cm}$-width, a change in the initial $\left[\mathrm{H}^{+}\right]$from $10^{-4}$ to $10^{-3.5}$ produces a ten-fold greater difference in $\left[\mathrm{Ca}^{2+}\right]$ response than that resulting from a change in the initial $\left[\mathrm{H}^{+}\right]$from $10^{-5}$ to $10^{-4.5}$.

- Dependence of $\dot{M}$ on initial pH. Figure 111 shows that the steady-state rate of mass loss exhibits a nonlinear sensitivity to changes in the initial $\mathrm{pH}$ of the test solution. Note in figure 111 that, for a volumetric flow-rate of $0.08 \mathrm{~cm}^{3} / \mathrm{s} / \mathrm{cm}$-width over limestone, a decrease in initial $\mathrm{pH}$ from 5 to 4.5 results in a five-fold greater $\mathrm{Ca}^{2+}$ mass-loss rate than that observed for a $\mathrm{pH}$ change from 4.5 to 4.0 .

Also note in figure 111 that, as the volumetric flow-rate is decreased, the rate curves appear to converge for both limestone and marble under all conditions. The conditions in the flow rate regime below $\approx 0.02 \mathrm{~cm}^{3} / \mathrm{s} / \mathrm{cm}$-width, simulations analogous to light rain events, correspond to a stagnant system that may approach chemical equilibrium.

- Dependence of $\left[\mathrm{Ca}^{2+}\right]$ and $\dot{M}$ on temperature. Figures 112 to 113 show a general positive dependence of $\mathrm{Ca}^{2+}$ concentration and $\mathrm{Ca}^{2+}$ mass-loss rate on temperature. This observation is especially notable in view of the retrograde effect of temperature on the solubility of calcite (Parkhurst and others, 1980; Baedecker and others, 1992, p. 19-121).

- Dependence of $\left[\mathbf{C a}^{2+}\right]$ and $\dot{M}$ on the angle of inclination. Figures 114 and 115 show that, at any given flow rate, the $\mathrm{Ca}^{2+}$ concentration and the rate of mass loss increases nonlinearly with the angle of inclination, at least up to a limit. This effect indicates that the detailed flow-pattern of the test solution over the limestone depends on the angle of inclination, even for a given solution flow-rate. It also suggests that hydrodynamics can be a significant factor in the chemical erosion of the stone surface vis-à-vis its influence on transport-limited processes taking place on the stone surface.

\section{Fries \& Mossotti laboratory simulations}

In an effort to assess the surface reactivity of stone over the nanoscale to microscale, Mossotti and others (2000) explored the dependence of the steady-state rate of mass loss from the weathered surfaces of $1.75-\mathrm{cm}$ diameter Berkshire Lee marble cores and from 30-cm long Vermont marble test slabs under turbulent flow conditions. Phenomenologically, the surface reactivity test is a measure of effective surface area available for dissolution by $\mathrm{H}_{2} \mathrm{O}$. The test is based on the reaction for the dissolution of calcite by pure water as described by Plummer and others (1978):

$$
\mathrm{CaCO}_{3}+\mathrm{H}_{2} \mathrm{O} \rightarrow \mathrm{Ca}^{2+}+\mathrm{HCO}_{3}^{-}+\mathrm{OH}^{-} \quad\left(k_{3}=10^{-6.92} \mathrm{~cm} / \mathrm{sec}\right)
$$

The rate constant for equation $4, k_{3}$, was measured by Plummer and others under conditions in which vigorously stirred solution reacted with crystals of fixed Euclidean area. If the reaction solution is not stirred vigorously, the effective area available for this reaction may be decreased 
by a variety of mechanisms, all of which probably involve the adsorption of ionic species on the calcite surface. Therefore, the effective reaction rate, $k_{3}$, will generally be less than the rate constant reported by Plummer and others.

In order to evaluate the general form of the effective rate-response curve for equation 4 experimentally, Fries and Mossotti measured the $\mathrm{Ca}^{2+}$ release rate as a function of solution flowrate for the $\mathrm{H}_{2} \mathrm{O}$ /marble system; the Fries and Mossotti data are reported here for the first time. Laboratory implementation of the surface reactivity test involves measurement of the susceptibility of the cleaned stone to dissolution by flowing water with an initial $\mathrm{pH}$ of 7.0. Figure 116 shows the dependence of the reaction rate on the flow rate of the test solution; note that increasing values along the ordinate represent a slower $\mathrm{Ca}^{2+}$ release rate. The conditions represented in figure 116 were different experimentally from the Schmiermund simulations in a number of critical parameters: (1) the test solution was confined to a 1-cm-wide flow channel down the marble test unit, (2) the test solution flow was turbulent at the point of introduction at the top of the flow channel, (3) the $\mathrm{Ca}^{2+}$ release rate was tested at flow rates that extended the Schmiermund test range by about 50 percent, and (4) the initial $\mathrm{pH}$ of the test solution was 7.0 for all tests. Figure 116 shows that, as the flow rate of the test solution is increased, the reaction rate asymptotically approaches the value of $10^{-6.92} \mathrm{~cm} / \mathrm{sec}$ found by Plummer and others (1978). Otherwise stated, at flow rates exceeding $0.01 \mathrm{~cm}^{3} / \mathrm{sec} / \mathrm{cm}$-of-contour, the sensitivity of the $\mathrm{Ca}^{2+}$ release rate to the solution flow rate continually decreases. The effect shown in figure 116 is of critical significance in the modeling of hydrodynamic effects on the stone surface.

\section{Discussion and summary of observations}

\section{Corrupted field data}

An important goal of the MRP in the design of the field and laboratory experiments was the development of a database that would provide information on the effects of atmospheric agents on the chemical erosion of calcareous stone. In our review of the MRP five-site database, we recognized that the uncertainties associated with the management of automated field measurements could result in erroneous entries in the database. Such errors, which frequently result from the overflow of the range limit of electronic and mechanical devices, were differentiated from uncorrupted data by the application of statistical and data-pattern tests as discussed in connection with figures 16 to 146. Edited data files reporting the runoff-solution chemistry for the five MRP sites are appended to this report along with the original data files. ${ }^{11}$ We assumed that no such problems occurred in the laboratory experiments.

\section{Variability of chemical erosion phenomena}

An important purpose of this overview is to document the statistical variability in the field data as related to stone erosion phenomena. An understanding of the variability of the system is critical because the informational content of the database is accommodated by the freedom of the

${ }^{11}$ Original data files: DATAT.A, DATAT.B, and DATAT.C; edited data files: DC Runoff data (Crrctd).TXT, NC Runoff data (Crrctd).TXT, NJ Runoff data (Crrctd).TXT, and NY Runoff data (Crrctd).TXT. 
system to exhibit excursions (Mossotti, 1984). In such an analysis, it is critical to identify the noise in the system as distinct from the intrinsic variability of the erosion phenomenon. The excursions in $\left[\mathrm{Ca}^{2+}\right]_{\mathrm{xs}}$ can be resolved into at least six components identified here as types I through VI; these include the reproducibility of the:

I analytical chemistry measurements,

II erosion effects from event to event on

- standard test objects (slabs) under

- controlled environmental conditions in the laboratory,

III field sampling procedures,

IV erosion effects from event to event across an ensemble of

- standard test objects (side-by-side duplicates) under

- variable environmental conditions in the field,

$\mathbf{V}$ erosion effects from event to event on a

- standard test object (standard slab) under

- variable environmental conditions in the field, and

VI erosion effects from event to event on an ensemble of

- irregular test objects (Gettysburg) under

- variable environmental conditions in the field.

The total variability is given by the root mean square (RMS) of the component variabilities. In the following paragraphs we will estimate the absolute variability of each of the above contributions to excursions in the runoff-solution chemistry.

\section{Type-I variability: analytical precision}

The precision-limited analytical detection limits, as reported by Reddy and others (1987), are given in table 10 . Because the corrected $\mathrm{Ca}^{2+}$ concentration, $\left[\mathrm{Ca}^{2+}\right]_{\text {cor }}$, is computed as the difference between $\left[\mathrm{Ca}^{2+}\right]_{\mathrm{xs}}$ and $\left[\mathrm{SO}_{4}{ }^{2-}\right]_{\mathrm{xs}}$, the error in the measurement of $\mathrm{Ca}^{2+}$ from erosion is given by the RMS of two $\left[\mathrm{Ca}^{2+}\right]$ and two $\left[\mathrm{SO}_{4}{ }^{2-}\right]$ measurements. Thus, from table 10 , the estimated analytical error in $\left[\mathrm{Ca}^{2+}\right]_{\text {cor }}$ is $\approx 0.003 \mathrm{mmol} / \mathrm{L}$.

TABLE 10.- Analytical detection limits and methods used for quantitative analysis of runoffsolution chemistry.

\begin{tabular}{|c|c|l|}
\hline Species in solution & $\begin{array}{c}\text { Analytical detection limit } \\
\text { (mmol/L) }\end{array}$ & \multicolumn{1}{|c|}{ Method of analysis } \\
\hline $\mathrm{Ca}^{2+}$ & 0.0004 & Induction-coupled plasma \\
$\mathrm{Mg}^{2+}$ & 0.0002 & Induction-coupled plasma \\
$\mathrm{Na}^{+}$ & 0.0034 & Induction-coupled plasma \\
$\mathrm{K}^{+}$ & 0.0001 & Atomic absorption \\
$\mathrm{Cl}^{-}$ & 0.0007 & Ion chromatography \\
$\mathrm{SO}_{4}{ }^{2-}$ & 0.002 & Ion chromatography \\
$\mathrm{NO}_{3}{ }^{+}$ & 0.0026 & Ion chromatography \\
$\mathrm{NH}_{4}^{+}$ & 0.00003 & Colorimetric \\
\hline
\end{tabular}


Type-II variability: reproducibility of erosion effects across controlled events (standard slab/controlled laboratory environment)

The reproducibility of erosion effects from event to event on standard test objects (slabs) under controlled environmental conditions has been reported by Schmiermund (1991) as determined in laboratory simulations. As discussed above in the section entitled "Schmiermund laboratory simulations", the reproducibility $(2 \sigma)$ of the $\mathrm{Ca}^{2+}$ concentration in the runoff solution from limestone and marble slabs under replicated controlled environmental conditions was generally from 1 to 3 percent of the $\mathrm{Ca}^{2+}$ concentration in the runoff solution. Based on the scatter in Schmiermund's findings, we can hypothetically project the reproducibility of the MRP field observations under fixed environmental conditions. Since the mean $\mathrm{Ca}^{2+}$ concentration in the runoff solutions at the MRP sites is $\approx 0.5 \mathrm{mmol} / \mathrm{L}$, the type-II variability in the measured erosion effect at the MRP sites would be $\approx 0.015 \mathrm{mmol} / \mathrm{L}$ for flat $30 \times 60-\mathrm{cm}$ flat limestone and marble slabs facing south and inclined $30^{\circ}$ to the horizon.

\section{Type-III variability: reproducibility of field sampling procedures (split sample)}

The reproducibility of the field sampling procedures was established on the basis of split samples collected at the DC field site. The root mean square of the differences in the uncorrected $\mathrm{Ca}^{2+}$ concentrations between ensembles of split-sample pairs was reported to be 0.016 and 0.014 $\mathrm{mmol} / \mathrm{L}$ for limestone and marble, respectively; these values already incorporate the analytical uncertainties but do not incorporate the type-II experimental noise discussed above.

\section{Type-IV variability: reproducibility of erosion effects across slabs (duplicate slabs, side by} side, variable field environment)

The slab-to-slab reproducibility in the field was determined from duplicate limestone and marble slabs placed side by side at the DC site. From table 4 of this report, the reproducibility of $\left[\mathrm{Ca}^{2+}\right]_{\text {uncor }}$ in the runoff solution was found to be $\approx \pm 0.1 \mathrm{mmol} / \mathrm{L}$ and $\approx \pm 0.06 \mathrm{mmol} / \mathrm{L}$ for limestone and marble, respectively. Since the $\mathrm{SO}_{4}{ }^{2-}$ concentration is generally a small fraction of the $\mathrm{Ca}^{2+}$ concentration in the runoff solution, the propagation of the uncertainties associated with the $\mathrm{SO}_{4}{ }^{2-}$ into the $\mathrm{SO}_{4}{ }^{2-}$-corrected $\mathrm{Ca}^{2+}$ concentration computation is minimal. Similarly, noise introduced as types I, II, or III also are relatively insignificant in comparison to the type-IV scatter in the runoff-solution-chemistry observations. It follows that the $2 \sigma$ noise in the measurement of chemical erosion at the MRP field sites, given by the RMS of types-I, II, III, and IV noise, are approximately:

$$
\begin{aligned}
& 2 \sigma^{L}{ }_{\left[\mathrm{Ca}^{2+}\right]} \approx 0.20 \mathrm{mmole} / \mathrm{L} \text { (limestone), and } \\
& 2 \sigma^{M}{ }_{\left[\mathrm{Ca}^{2+}\right]} \approx 0.12 \mathrm{mmole} / \mathrm{L} \text { (marble). }
\end{aligned}
$$

Type-V variability: reproducibility of erosion effects across events (standard slab, variable field environment)

Figure 66 shows that the excess $\mathrm{Ca}^{2+}$ concentration varies over the range from $\approx 0.1$ to $\approx 1.0$ $\mathrm{mmol} / \mathrm{L}$ in the runoff solution for all rain events for which data were collected. The variability in the $\left[\mathrm{Ca}^{2+}\right]$ signal exceeds the type-IV system noise by a factor of $\approx 5$ for tests on limestone and by a factor of $\approx 10$ for tests on marble. Since the tests at the MRP field sites were conducted on stone stabs with standardized morphology and orientation, the variability in the $\left[\mathrm{Ca}^{2+}\right]$ signal is 
evidence of a strong dependence of chemical erosion on the environmental variables.

\section{Type-VI variability: reproducibility of erosion effects across objects and rain events (irregular morphology, variable field environment at Gettysburg)}

Figure 103 shows that the $\mathrm{Ca}^{2+}$-concentration signal in the runoff solution from surfaces of complex morphology and orientation (statues: war and history) at the Gettysburg NMP are distributed over the range $\approx 0.3$ to $\approx 1.3 \mathrm{mmol} / \mathrm{L}$ while, for the same events, the $\mathrm{Ca}^{2+}$ signal from the flat, vertical surfaces (obelisks: $68 \mathrm{PV}$, Zook) cover the range $\approx 0.0$ to $\approx 0.3 \mathrm{mmol} / \mathrm{L}$. Since, for most of the recorded events at the Gettysburg site, the $\mathrm{Ca}^{2+}$ signal from the obelisks was obscured by type-IV noise in the measurement, chemical erosion was not quantitatively detectable by measurement of the $\mathrm{Ca}^{2+}$ chemistry in the runoff solution. In contrast, the $\mathrm{Ca}^{2+}$ signal from the statues exceeded the noise-in-signal by a factor which varied from $\approx 1.5$ to $\approx 7$. The disparity in $\mathrm{Ca}^{2+}$ signal between the obelisks and the statues, coupled with the findings from the Schmiermund simulations shown in figures 114 and 115 and the Fries and Mossotti experiments shown in figure 116, are evidence of the strong dependence of chemical erosion on the surface flow pattern over the stone.

\section{Incremental acid effect}

One of the foremost issues of interest to the MRP, especially in the mid 1980s, concerned the effect of anthropogenic $\mathrm{H}^{+}$on the chemical erosion rate of limestone and marble. The relative importance of the incremental acid effect (IAE) can be judged by contrasting the variability of the $\mathrm{H}^{+}$concentration in the incident rain with the variability in the observed chemical erosion at the field sites. Figures 26 to 30 show that the $\mathrm{H}^{+}$concentration in the incident rain generally varies to a maximum of $\approx 0.15 \mathrm{mmol} / \mathrm{L}$ across all events at all of the MRP field sites and with an average of $\approx 0.04 \mathrm{mmol} / \mathrm{L}$. By comparison, figure 66 shows that the excess $\mathrm{Ca}^{2+}$ concentration extends to $\approx 1.0 \mathrm{mmol} / \mathrm{L}$ in the runoff solution with an average $\left[\mathrm{Ca}^{2+}\right]$ of $\approx 0.4 \mathrm{mmol} / \mathrm{L}$ for marble and $\approx 0.5 \mathrm{mmol} / \mathrm{L}$ for limestone. If we assume that 100 percent of the free $\mathrm{H}^{+}$delivered in the rain stoichiometrically releases $\mathrm{Ca}^{2+}$ ions with a 1:1 efficiency, it is evident that the IAE cannot account for more that $\approx 10$ percent of the $\mathrm{Ca}^{2+}$ released into the runoff solution, and this occurs only in extreme acid rain events.

\section{Modeling challenge}

There are many distinctive characteristics of field and laboratory observations that require qualitative explanation and quantitative modeling. The most general of these characteristics is that the $\mathrm{Ca}^{2+}$ signal in the runoff solution is:

- weakly dependent on the type of calcareous stone,

- weakly dependent on the ambient temperature,

- weakly dependent on the incremental acid in the rain,

- strongly dependent on the environmental conditions, and

- strongly dependent on the surface morphology and orientation.

Given that the IAE can account for only $\approx 10$ percent of the $\mathrm{Ca}^{2+}$ in the runoff solution, the most demanding questions relate to the fundamental phenomenology of stone dissolution. What are 
the dominant chemical processes controlling the dissolution of calcareous stone, and how do such processes functionally depend on the environmental and morphological parameters? How do the hydrodynamic conditions on the catchment mechanistically influence the rate of stone dissolution, and how do the hydrodynamic variables depend on the rain delivery conditions and on the catchment morphology and orientation? In view of the temporally erratic nature of the rain delivery variables and of the random morphology of stone structures, a statistical framework with stochastic variables may be the most suitable approach for modeling the runoff-solution chemistry for calcareous stone objects.

\section{Acknowledgments}

The authors thank the National Park Service for their financial support of the laboratory and fieldwork reported here, and the NPS National Center for Preservation Technology and Training for their support of report preparation. We also wish to thank Terry Reedy and Mary Striegel for their reviews of this report. 


\section{References}

Baedecker, P.A., Reddy, M.M., Reimann, K.J., and Sciammarella, C.A., 1992, Effects of acidic deposition on the erosion of carbonate stone-Experimental results from the U.S. National Acid Precipitation Assessment Program (NAPAP): Atmospheric Environment, v. 26B, no. 2, p. 147-158.

Mossotti, V.G., 1984, The informational structure of analytical chemistry, chap. 1 of Treatise on Analytical Chemistry, Kolthoff, I.M., Elving, P., and Mossotti, V.G, eds.: John Wiley \& Sons, New York, p. 1-55.

Mossotti, V.G., Eldeeb, A.R., Fries, T.L., Coombs, Mary Jane, Naudé, V.N., Soderberg, Lisa, and Wheeler, G.S., 2001, The effect of selected cleaning techniques on Berkshire Lee marblea scientific study at Philadelphia City Hall: U.S. Geological Survey Professional Paper 163, (CD-ROM), (URL http://geopubs.wr.usgs.gov/prof-paper/pp1635).

Parkhurst, D.L., Thorstenson, D.C., and Plummer, L.N., 1980, PHREEQE - a computer program for geochemical calculations: U.S. Geological Survey Water-Resources Investigations Report 80-96, 195 p.

Plummer, L.N., Wigley, T.M.L., and Parkhurst, D.L., 1978, The kinetics of calcite dissolution in $\mathrm{CO}_{2}$-water systems at 5 to $60 \mathrm{C}$ and 0.0 to $1.0 \mathrm{~atm} \mathrm{CO}_{2}$ : American Journal of Science, v. 278, p. 179-216.

Reddy, M.M. and Baedecker, P.A., 1991, Field experiments - Run-off measurements - Results and discussion in Acidic deposition: State of science and technology, v. III, report 19: Washington, D.C., U.S. Government Printing Office, p. 19-110 to 19-121.

Reddy, M.M., Schuster, P.F., and Harte, J.J., 1989, Summary of data for on-site and laboratory analyses of precipitation runoff from carbonate rock surfaces, National Acid Precipitation Program, June 1984 to November 1987: U.S. Geological Survey Open-File Report 89246, $19 \mathrm{p}$.

Reddy, M.M., See, R.B., and Liebermann, T.D., 1987, Protocol for collecting, processing and shipping precipitation samples: U.S. Geological Survey Open-File Report 87-405A, 13 p.

Reddy, M.M. and Werner, M., 1985, Composition of rainfall-runoff from limestone and marble at Research Triangle Park, NC: U.S. Geological Survey Open-File Report 85-630, 6 p.

See, R.B. and Reddy, M.M., 1987, Summary of data for on-site and laboratory analyses of precipitation runoff from carbonate rock surfaces, National Acid Precipitation Program, June 1984 to September 1986: U.S. Geological Survey Open-File Report 87-461, 14 p. (For further information about the availability of the original field data, contact the Chief, Branch of Regional Research, Water Resources Division, Box 25046, mail stop 418, Denver Federal Center, Denver, Co. 80225-0046.)

Schmiermund, R.L., 1991, Steady-state weathering of limestone and marble by acidic precipitation - a quantitative laboratory simulation: Golden, CO, Colorado School of Mines, Ph.D. dissertation, 245 p.

Sherwood, S.I. and Dolske, D.A., 1991, Acidic deposition impacts on marble monuments at Gettysburg National Military Park: The Journal of Preservation Technology, v. 23, no. 4, p. 52-57.

Sherwood, S.I and Dolske, D.A., 1992, Acid deposition impacts on marble monuments at Gettysburg in International Congress on Deterioration and Conservation of Stone, 7th, 
Lisbon, Portugal, 1992 [Proceedings], p. 247-255.

Skougstad, M.W., Fishman, M.J., Friedman, L.J., Erdman, D.E., and Duncan, S.S., 1979, Methods for determination of inorganic substances in water and fluvial sediments: U.S. Geological Survey Techniques of Water-Resources Investigations, 626 p. 


\section{Figures}

\section{Average Runoff Blank Volume}

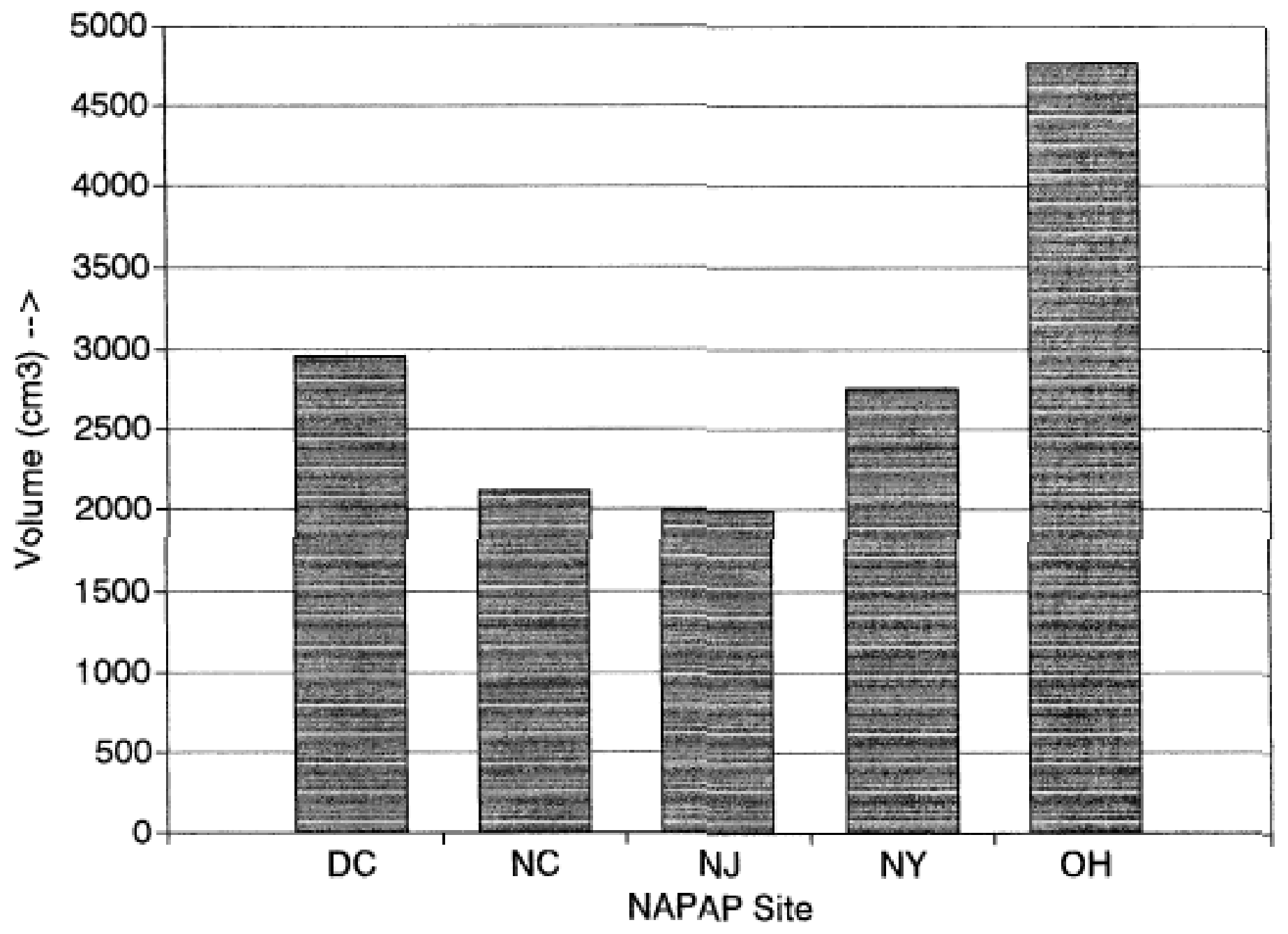

FIGURE 1(avg).-Average runoff volume . (Variable: volume $\left(\mathrm{cm}^{3}\right)$; material: blank; site: NAPAP-all sites.) 


\section{Blank Volume - NAPAP : DC}

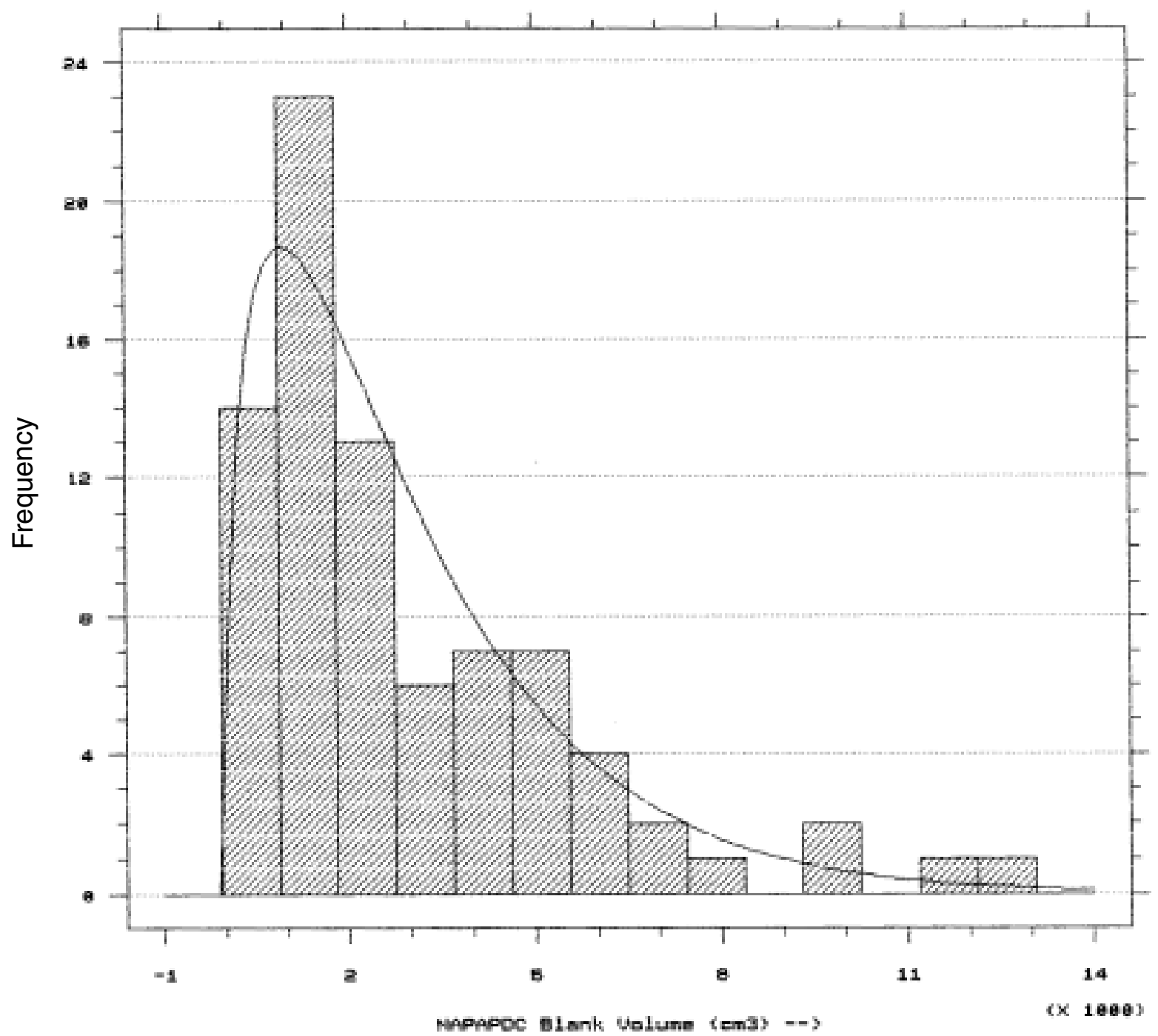

Chisquare Test

\begin{tabular}{|c|c|c|c|c|c|}
\hline & $\begin{array}{l}\text { Lower } \\
\text { Limit }\end{array}$ & $\begin{array}{l}\text { Upper } \\
\text { Limit }\end{array}$ & $\begin{array}{l}\text { Observed } \\
\text { Frequency }\end{array}$ & $\begin{array}{l}\text { Expected } \\
\text { Frequency }\end{array}$ & Chisquare \\
\hline & $\begin{array}{r}\text { at or below } \\
875.00 \\
1812.50 \\
2750.00 \\
3687.50 \\
4525.00 \\
5562.50\end{array}$ & $\begin{array}{r}875.00 \\
1812.50 \\
2750.00 \\
3687.50 \\
4625.00 \\
5562.50\end{array}$ & $\begin{array}{r}14 \\
23 \\
13 \\
6 \\
7 \\
7 \\
7 \\
11\end{array}$ & $\begin{array}{r}14.2 \\
17.9 \\
14.5 \\
10.8 \\
7.6 \\
5.3 \\
10.7\end{array}$ & $\begin{array}{r}.00344 \\
1.45511 \\
.15135 \\
2.10397 \\
.05174 \\
.56383 \\
.00901\end{array}$ \\
\hline
\end{tabular}

Chisquare $=4.34845$ with 4 d.f. Sig. level $=0.360898$

FIGURE 1.-Histograms and model with goodness-of-fit statistics. (Variable: volume $\left(\mathrm{cm}^{3}\right)$; material: blank; site: NAPAP-DC.) 


\section{Limestone Volume - NAPAP : DC}

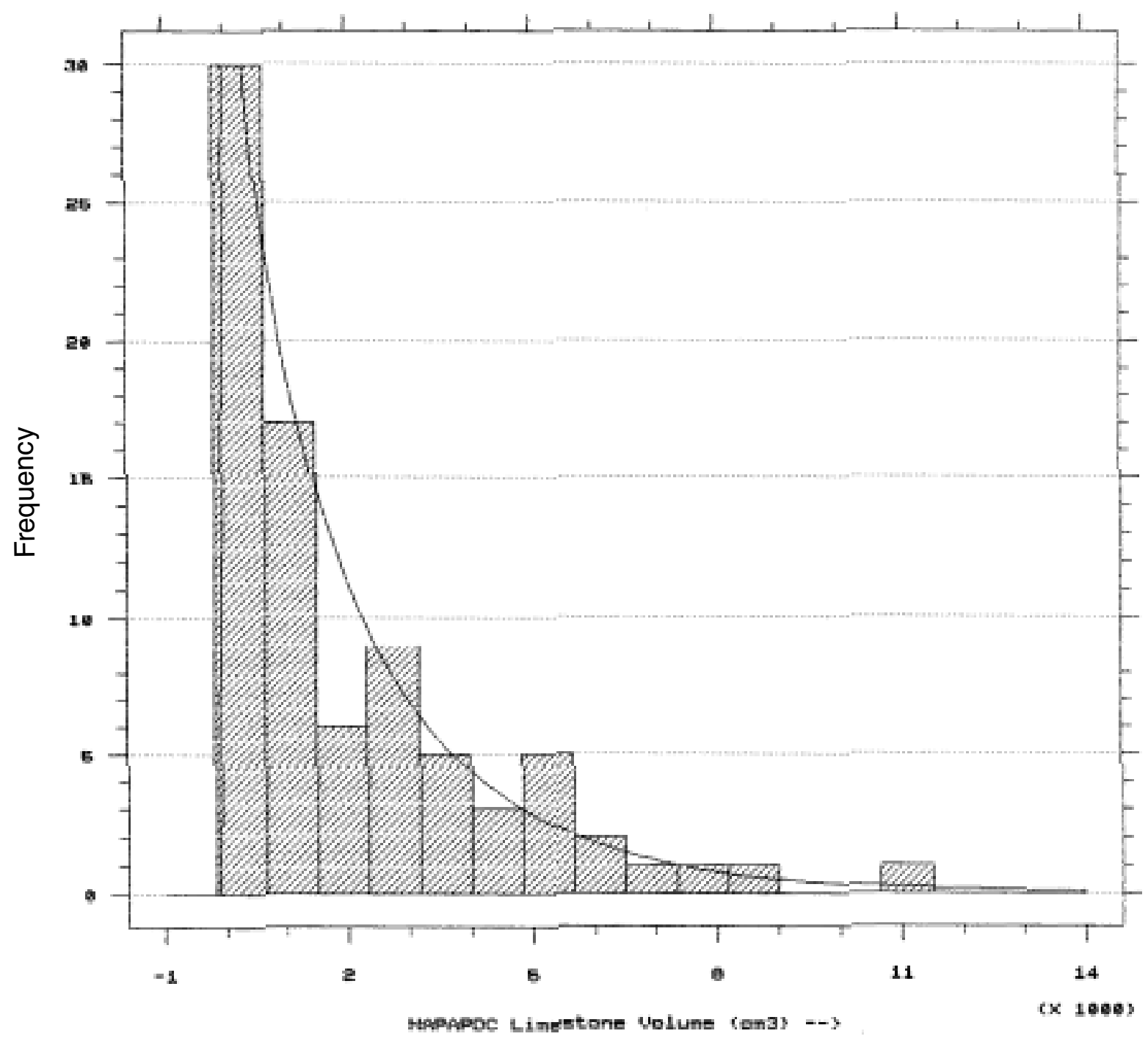

Chisquare Test

\begin{tabular}{|c|c|c|c|c|c|}
\hline & $\begin{array}{l}\text { Lower } \\
\text { Limit }\end{array}$ & $\begin{array}{l}\text { Upper } \\
\text { Limit }\end{array}$ & $\begin{array}{l}\text { Observed } \\
\text { Frequency }\end{array}$ & $\begin{array}{l}\text { Expected } \\
\text { Frequency }\end{array}$ & Chisquare \\
\hline above & 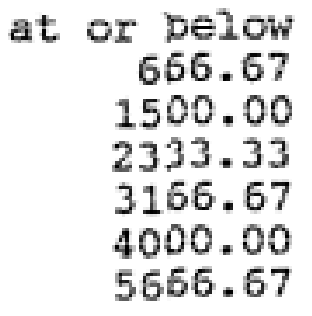 & $\begin{array}{r}565.67 \\
1500.00 \\
2333.33 \\
3166.67 \\
4000.00 \\
5656.67\end{array}$ & $\begin{array}{r}30 \\
17 \\
6 \\
9 \\
5 \\
8 \\
6\end{array}$ & $\begin{array}{r}25.7 \\
18.4 \\
11.8 \\
7.9 \\
5.3 \\
5.1 \\
5.7\end{array}$ & $\begin{array}{r}.7244 \\
.1075 \\
2.8793 \\
.1567 \\
.0213 \\
.5621 \\
.0157\end{array}$ \\
\hline
\end{tabular}

FIGURE 2.-Histograms and model with goodness-of-fit statistics. (Variable: volume $\left(\mathrm{cm}^{3}\right)$; material: limestone; site: NAPAP-DC.) 


\section{Marble Volume - NAPAP : DC}

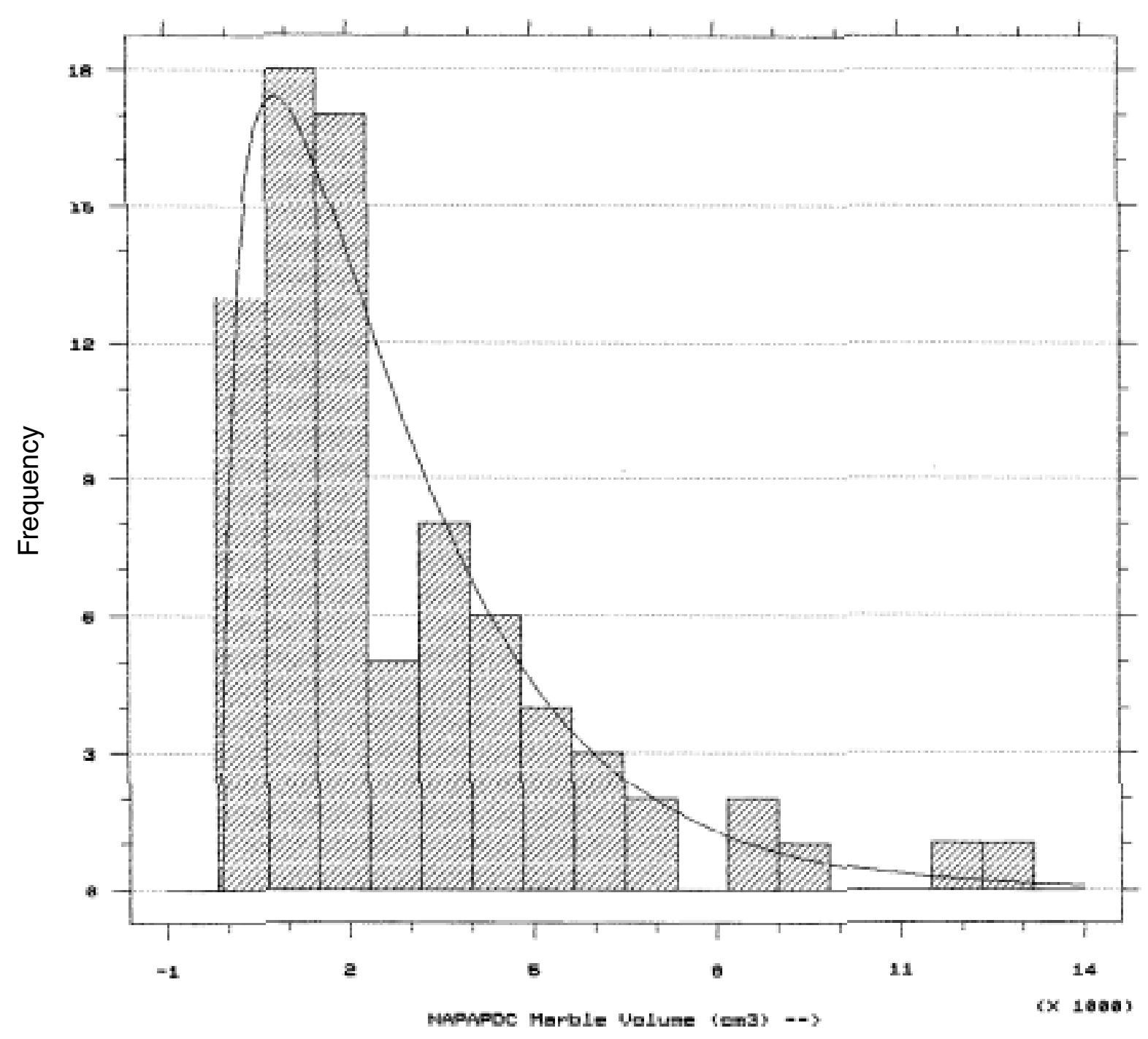

Chisquare Tiest

\begin{tabular}{|c|c|c|c|c|c|}
\hline & $\begin{array}{l}\text { Lower } \\
\text { jimit }\end{array}$ & $\begin{array}{l}\text { Upper } \\
\text { Limit }\end{array}$ & $\begin{array}{l}\text { Observed } \\
\text { Frequency }\end{array}$ & $\begin{array}{l}\text { Expected } \\
\text { Frequency }\end{array}$ & Chisquare \\
\hline bove & $\begin{array}{r}\text { at or pelow } \\
666.67 \\
1500.00 \\
2333.33 \\
3156.67 \\
4000.00 \\
4833.33 \\
6500.00\end{array}$ & $\begin{array}{r}666.67 \\
1500.00 \\
2333.33 \\
3166.67 \\
4000.00 \\
4833.33 \\
6500.00\end{array}$ & $\begin{array}{r}13 \\
18 \\
17 \\
5 \\
8 \\
5 \\
7 \\
7\end{array}$ & $\begin{array}{r}11.4 \\
16.9 \\
14.2 \\
10.9 \\
8.1 \\
5.8 \\
7.1 \\
6.6\end{array}$ & $\begin{array}{r}.223465 \\
.068090 \\
.543059 \\
3.214771 \\
.000590 \\
.005238 \\
.000557 \\
.028822\end{array}$ \\
\hline
\end{tabular}

Chisquare $=4.08459$ with 5 d.f. Sig. level $=0.537302$

FIGURE 3.-Histograms and model with goodness-of-fit statistics. (Variable: volume $\left(\mathrm{cm}^{3}\right)$; material: marble; site: NAPAP-DC.) 


\section{Blank Uolume - NAPAP : NY}

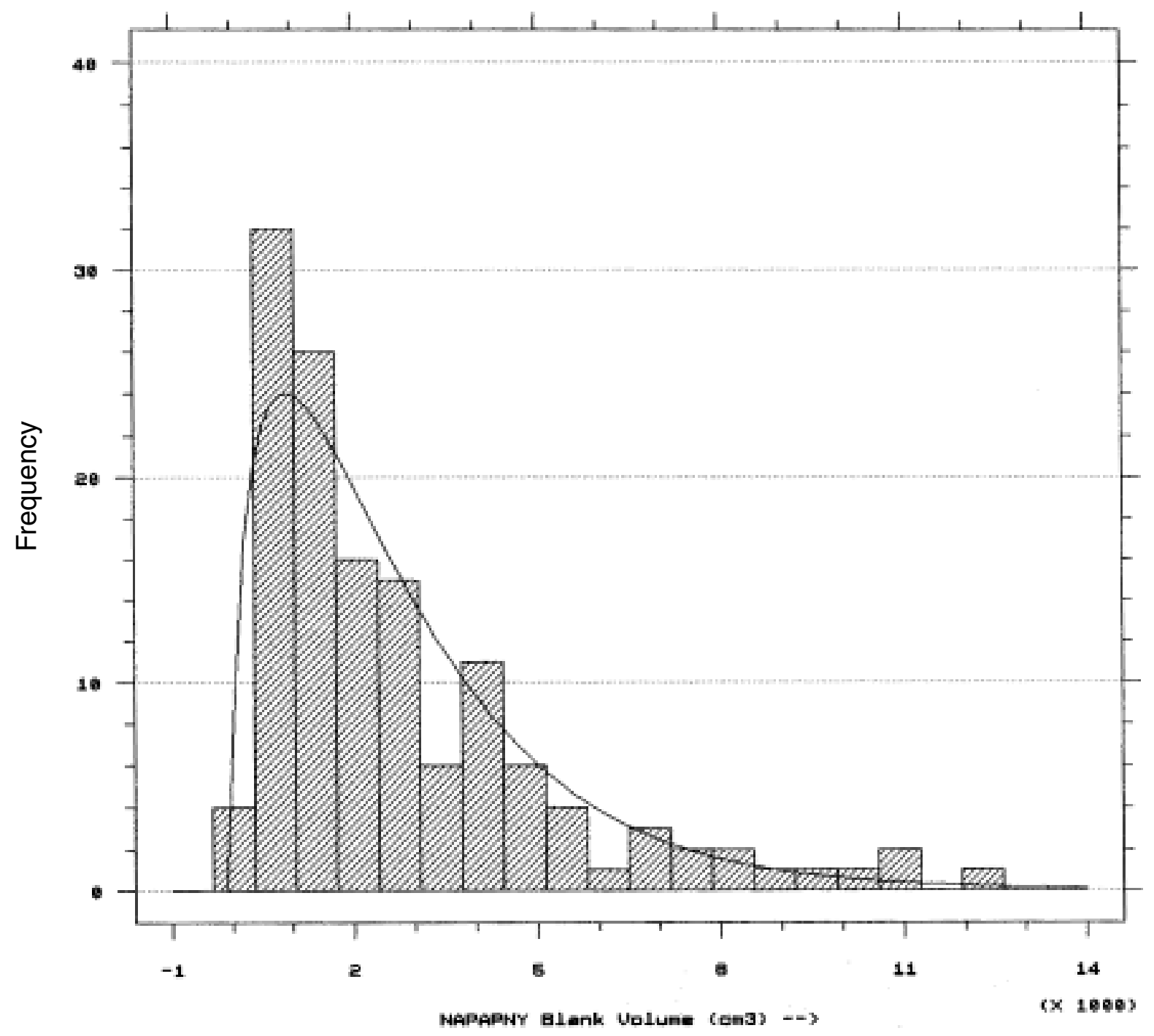

Chisquare Test

\begin{tabular}{|c|c|c|c|c|c|}
\hline & $\begin{array}{l}\text { Lower } \\
\text { Limit }\end{array}$ & $\begin{array}{l}\text { Upper } \\
\text { Limit }\end{array}$ & $\begin{array}{l}\text { Observed } \\
\text { Frequency }\end{array}$ & $\begin{array}{l}\text { Expected } \\
\text { Frequency }\end{array}$ & Chisquare \\
\hline above & $\begin{array}{r}\text { at below } \\
363.64 \\
1045.45 \\
1727.27 \\
2409.09 \\
3090.91 \\
3772.73 \\
4454.55 \\
5136.36 \\
6500.00\end{array}$ & $\begin{array}{r}363.64 \\
1045.45 \\
1727.27 \\
2409.09 \\
3090.91 \\
3772.73 \\
4454.55 \\
5136.36 \\
6500.00\end{array}$ & $\begin{array}{r}4 \\
32 \\
26 \\
16 \\
15 \\
6 \\
11 \\
6 \\
5 \\
13\end{array}$ & $\begin{array}{r}8.0 \\
23.2 \\
22.7 \\
19.2 \\
15.3 \\
11.8 \\
9.0 \\
6.7 \\
8.6 \\
9.5\end{array}$ & $\begin{array}{r}2.01490 \\
3.30962 \\
.47360 \\
.53318 \\
.00623 \\
2.87071 \\
.46629 \\
.07120 \\
1.49262 \\
1.31673\end{array}$ \\
\hline
\end{tabular}

Chisquare $=12.5551$ with 7 d.f. Sig. level $=0.0837202$

FIGURE 4.-Histograms and model with goodness-of-fit statistics. (Variable: volume $\left(\mathrm{cm}^{3}\right)$; material: blank; site: NAPAP-NY.) 


\section{Limestone Volume - NAPAP : NY}

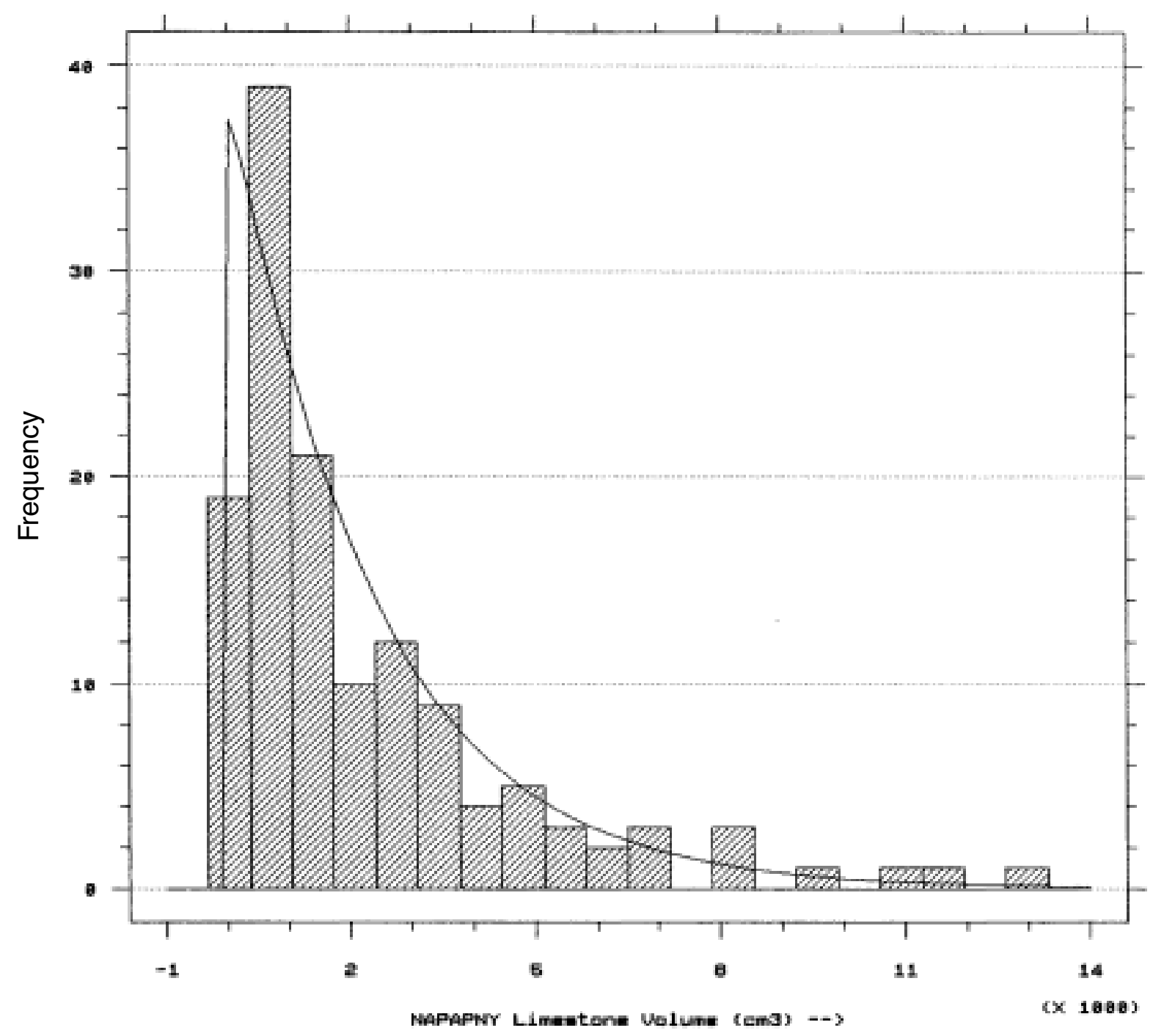

\section{Chisquare Test}

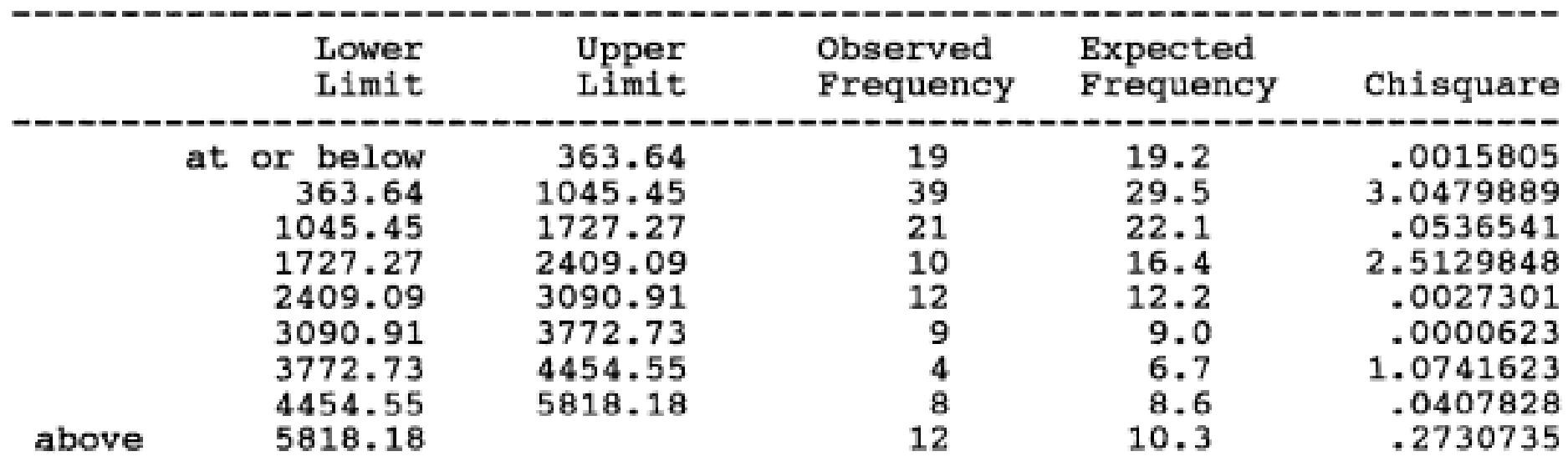

Chisquare $=7.00702$ with 6 d.f. Sig. level $=0.320199$

FIGURE 5.-Histograms and model with goodness-of-fit statistics. (Variable: volume $\left(\mathrm{cm}^{3}\right)$; material: limestone; site: NAPAP-NY.) 


\section{Marble Volume - NAPAP : NY}

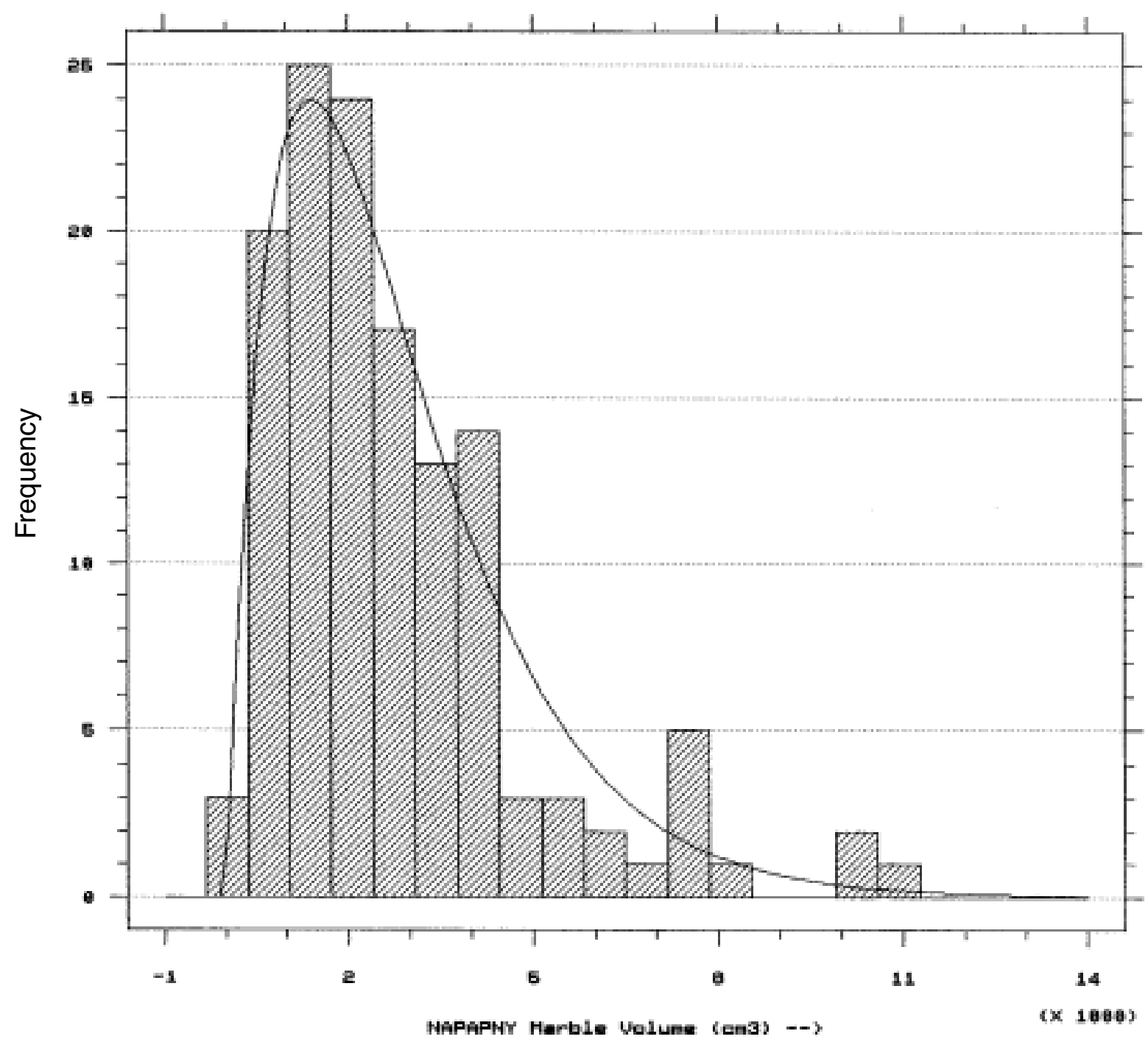

Chisquare Test

\begin{tabular}{|c|c|c|c|c|c|}
\hline & $\begin{array}{l}\text { Lower } \\
\text { Limit }\end{array}$ & $\begin{array}{l}\text { Upper } \\
\text { Limit }\end{array}$ & $\begin{array}{l}\text { Observed } \\
\text { Frequency }\end{array}$ & $\begin{array}{l}\text { Expected } \\
\text { Frequency }\end{array}$ & Chisquare \\
\hline bove & $\begin{array}{r}\text { at or below } \\
1045.45 \\
1727.27 \\
2409.09 \\
3090.91 \\
3772.73 \\
4454.55 \\
5136.36 \\
5818.18\end{array}$ & $\begin{array}{l}1045.45 \\
1727.27 \\
2409.09 \\
3090.91 \\
3772.73 \\
4454.55 \\
5136.36 \\
5818.18\end{array}$ & $\begin{array}{r}23 \\
25 \\
24 \\
17 \\
13 \\
14 \\
3 \\
3 \\
12\end{array}$ & $\begin{array}{r}23.0 \\
23.8 \\
21.9 \\
18.0 \\
13.8 \\
10.2 \\
7.3 \\
5.1 \\
10.8\end{array}$ & $\begin{array}{r}.00000695 \\
.06565220 \\
.19285543 \\
.05541143 \\
.05016556 \\
1.41306571 \\
2.54530241 \\
.88874881 \\
.12588236\end{array}$ \\
\hline
\end{tabular}

Chisquare $=5.33709$ with 6 d.f. Sig. level $=0.501361$

FIGURE 6.-Histograms and model with goodness-of-fit statistics. (Variable: volume $\left(\mathrm{cm}^{3}\right)$; material: marble; site: NAPAP-NY.) 


\section{Blank Volume - NAPAP : NJ}

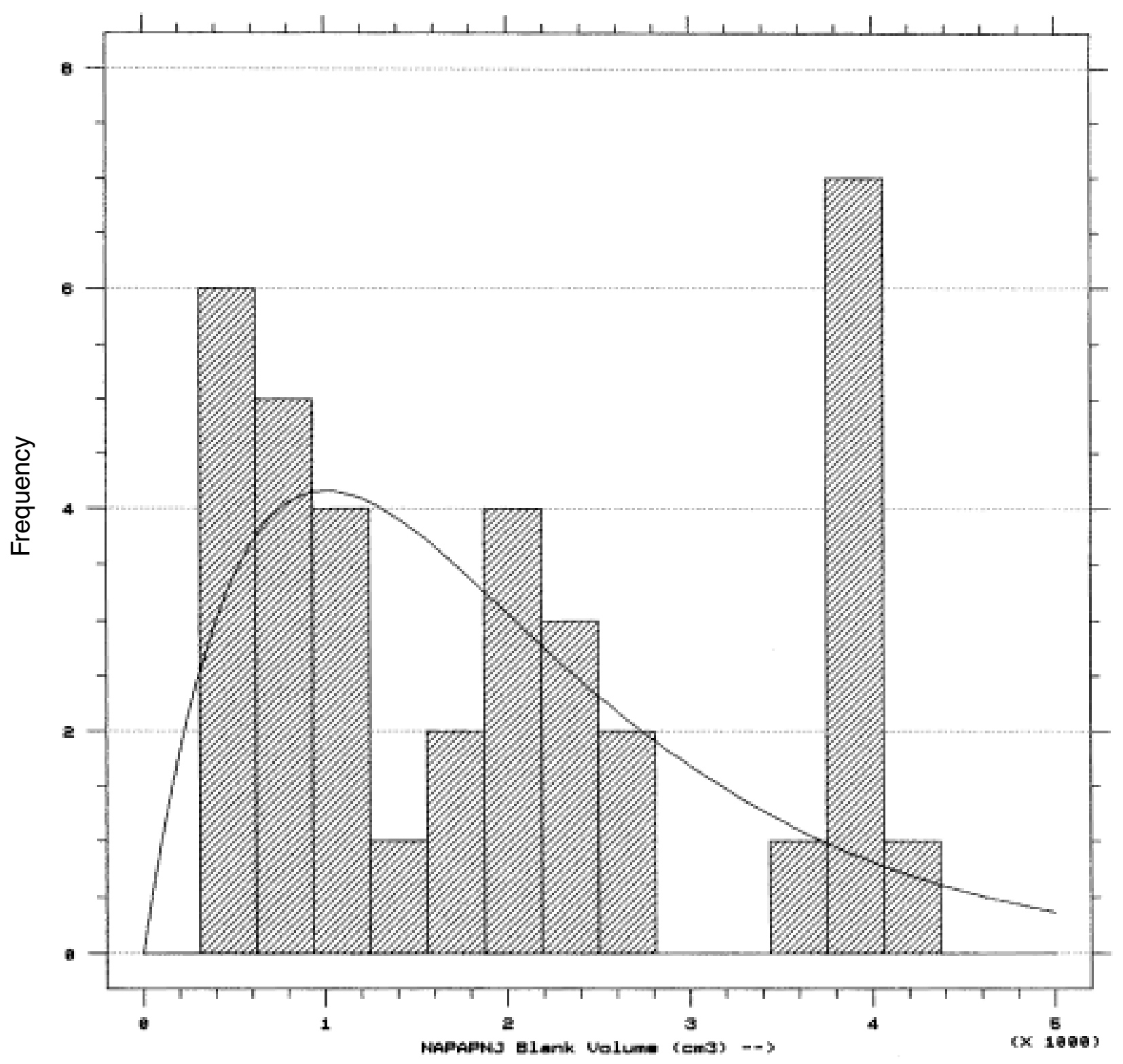

Tabulation Input Panel

Primary Variable

\section{- - - -}

Type

Lower limit

Upper limit

Continuous

No. of classes 16

Length $=36$

Minimum $=136.5$

Maximum $=4393.5$
Secondary Variable

Type

Lower limit

Upper limit

No. of classes

Length $=$

Minimum =

Maximum $=$

FIGURE 7.-Histograms and model with goodness-of-fit statistics. (Variable: volume $\left(\mathrm{cm}^{3}\right)$; material: blank; site: NAPAP-NJ) 


\section{Limestone Uolume - NAPAP : NJ}

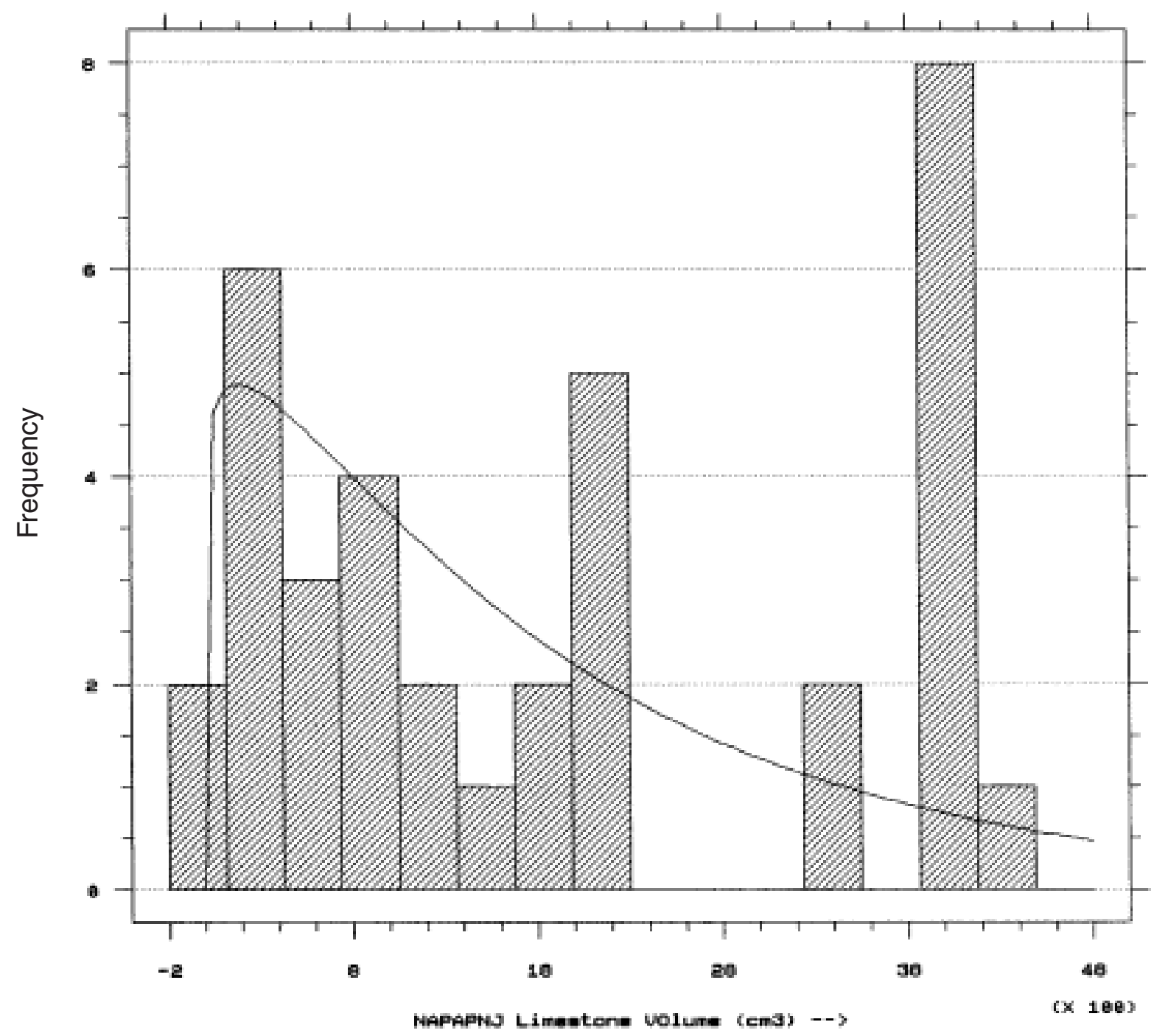

Chisquare Test

\begin{tabular}{|c|c|c|c|c|c|}
\hline & $\begin{array}{l}\text { Lower } \\
\text { Limit }\end{array}$ & $\begin{array}{l}\text { Upper } \\
\text { Limit }\end{array}$ & $\begin{array}{l}\text { Observed } \\
\text { Frequency }\end{array}$ & $\begin{array}{l}\text { Expected } \\
\text { Frequency }\end{array}$ & Chisqua \\
\hline 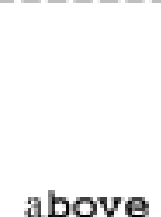 & $\begin{array}{r}\text { at or below } \\
425.00 \\
1050.00 \\
1675.00 \\
2612.50\end{array}$ & $\begin{array}{r}425.00 \\
1050.00 \\
1675.00 \\
2612.50\end{array}$ & $\begin{array}{r}8 \\
7 \\
3 \\
7 \\
11\end{array}$ & $\begin{array}{l}6.5 \\
8.2 \\
6.1 \\
6.1 \\
9.0\end{array}$ & $\begin{array}{r}.3 \\
.1 \\
1.5 \\
.1 \\
.4\end{array}$ \\
\hline
\end{tabular}

Chisquare $=2.68742$ with 2 d.f. Sig. level $=0.260876$

FIGURE 8.-Histograms and model with goodness-of-fit statistics. (Variable: volume $\left(\mathrm{cm}^{3}\right)$; material: limestone; site: NAPAP-NJ.) 


\section{Marble Volume - NAPAP : NJ}

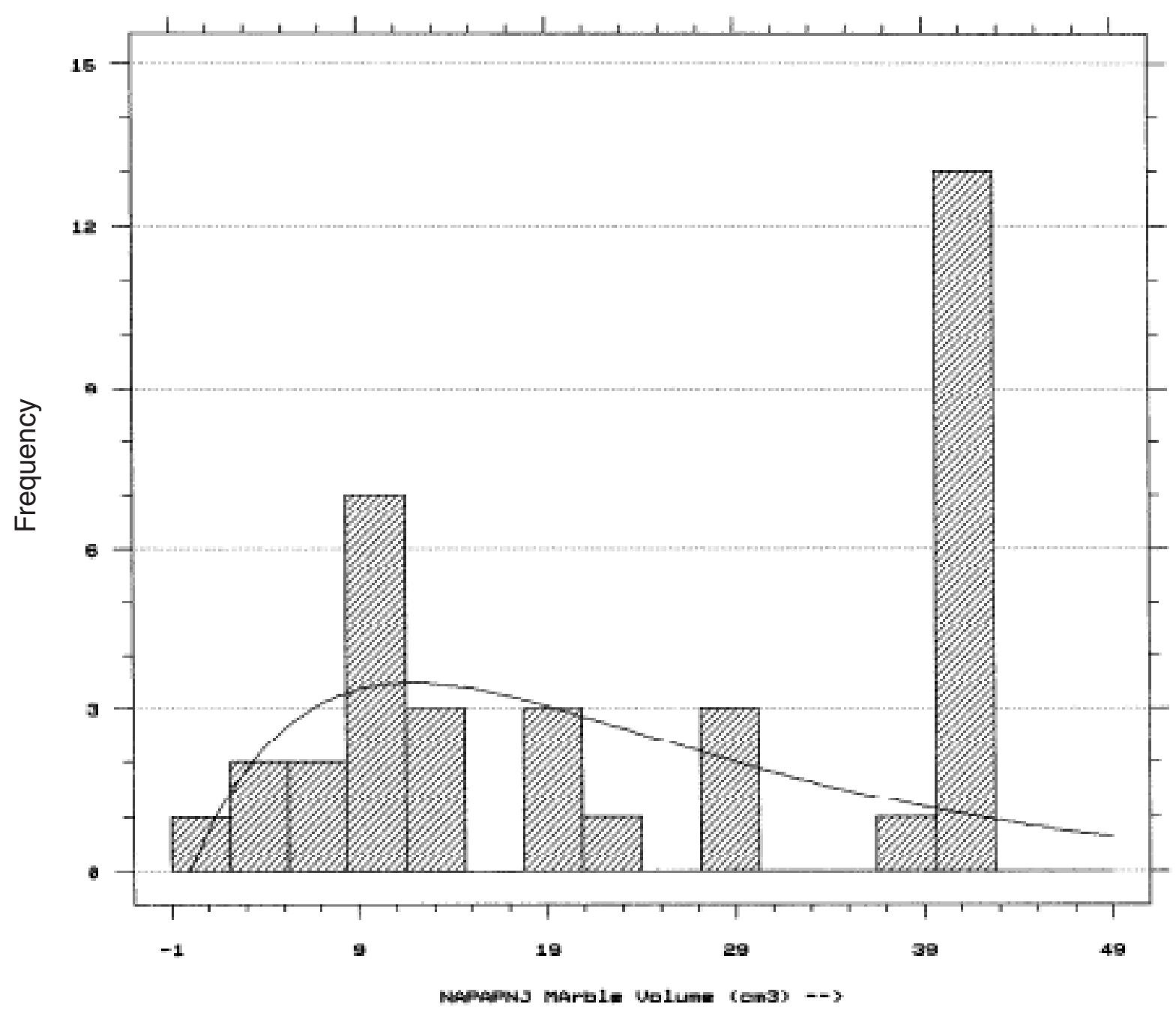

Chisquare Test

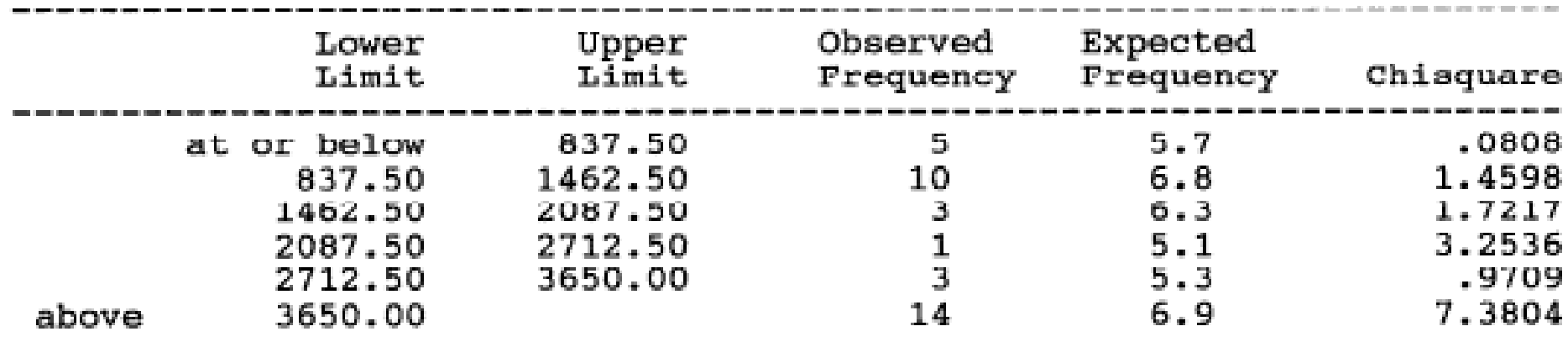

Chisquare $=14.867$ with 3 d.f. Sig. level $=1.93391 \mathrm{E}-3$

FIGURE 9.-Histograms and model with goodness-of-fit statistics. (Variable: volume $\left(\mathrm{cm}^{3}\right)$; material: marble; site: NAPAP-NJ.) 


\section{Blank Volume - NAPAP : NC}

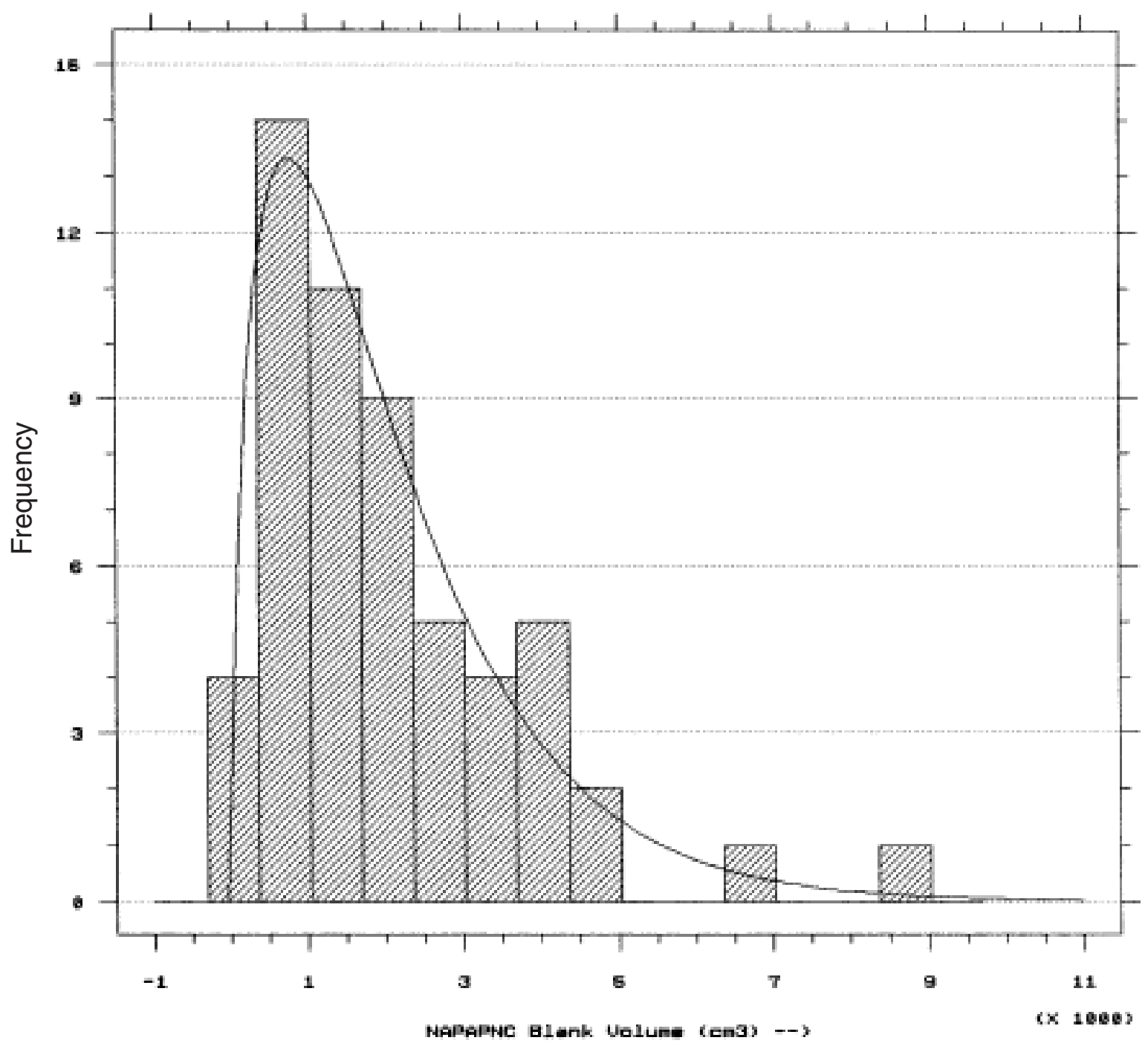

Chisquare Test

\begin{tabular}{|c|c|c|c|c|c|}
\hline & $\begin{array}{l}\text { Lower } \\
\text { Limit }\end{array}$ & $\begin{array}{l}\text { Upper } \\
\text { Limit }\end{array}$ & $\begin{array}{l}\text { Observed } \\
\text { Frequency }\end{array}$ & $\begin{array}{l}\text { Expected } \\
\text { Frequency }\end{array}$ & Chisquare \\
\hline bove & $\begin{array}{r}\text { at or below } \\
1033.33 \\
1700.00 \\
2366.67 \\
3033.33\end{array}$ & $\begin{array}{l}1033.33 \\
1700.00 \\
2366.67 \\
3033.33\end{array}$ & $\begin{array}{r}18 \\
11 \\
9 \\
5 \\
13\end{array}$ & $\begin{array}{r}17.5 \\
11.7 \\
8.8 \\
6.2 \\
11.8\end{array}$ & $\begin{array}{l}.01663 \\
.04477 \\
.00276 \\
.23415 \\
.12960\end{array}$ \\
\hline
\end{tabular}

Chisquare $=0.427913$ with 2 d.f. Sig. level $=0.807384$

FIGURE 10.-Histograms and model with goodness-of-fit statistics. (Variable: volume $\left(\mathrm{cm}^{3}\right)$; material: blank; site: NAPAP-NC.) 


\section{Limestone Volume - NAPAP : NC}

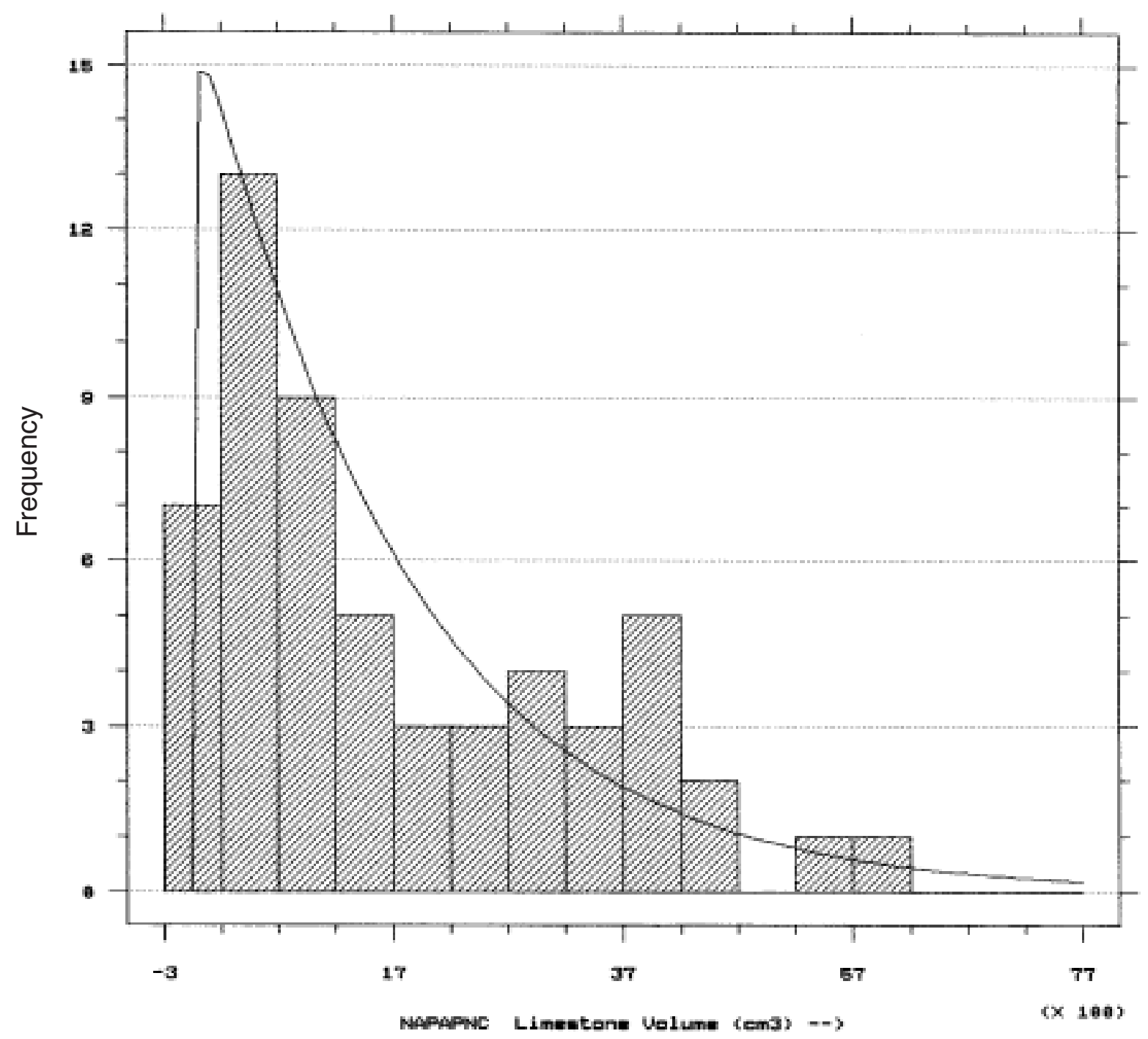

Chisquare Test

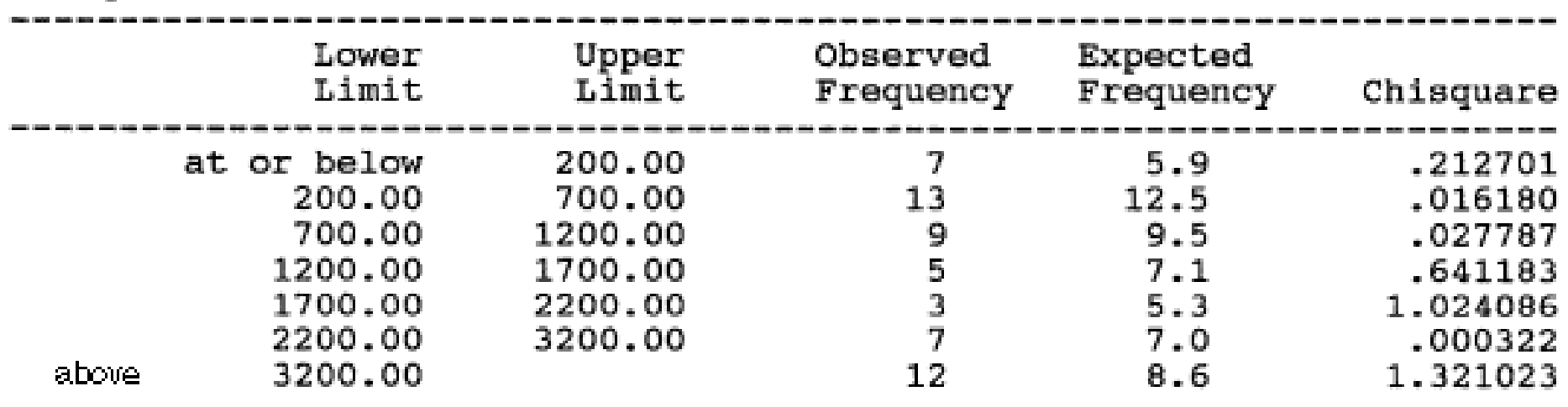

Chisquare $=3.24328$ with 4 d.f. Sig. level $=0.517969$

FIGURE 11.-Histograms and model with goodness-of-fit statistics. (Variable: volume $\left(\mathrm{cm}^{3}\right)$; material: limestone; site: NAPAP-NC.) 


\section{Marble Volume - NAPAP :NC}

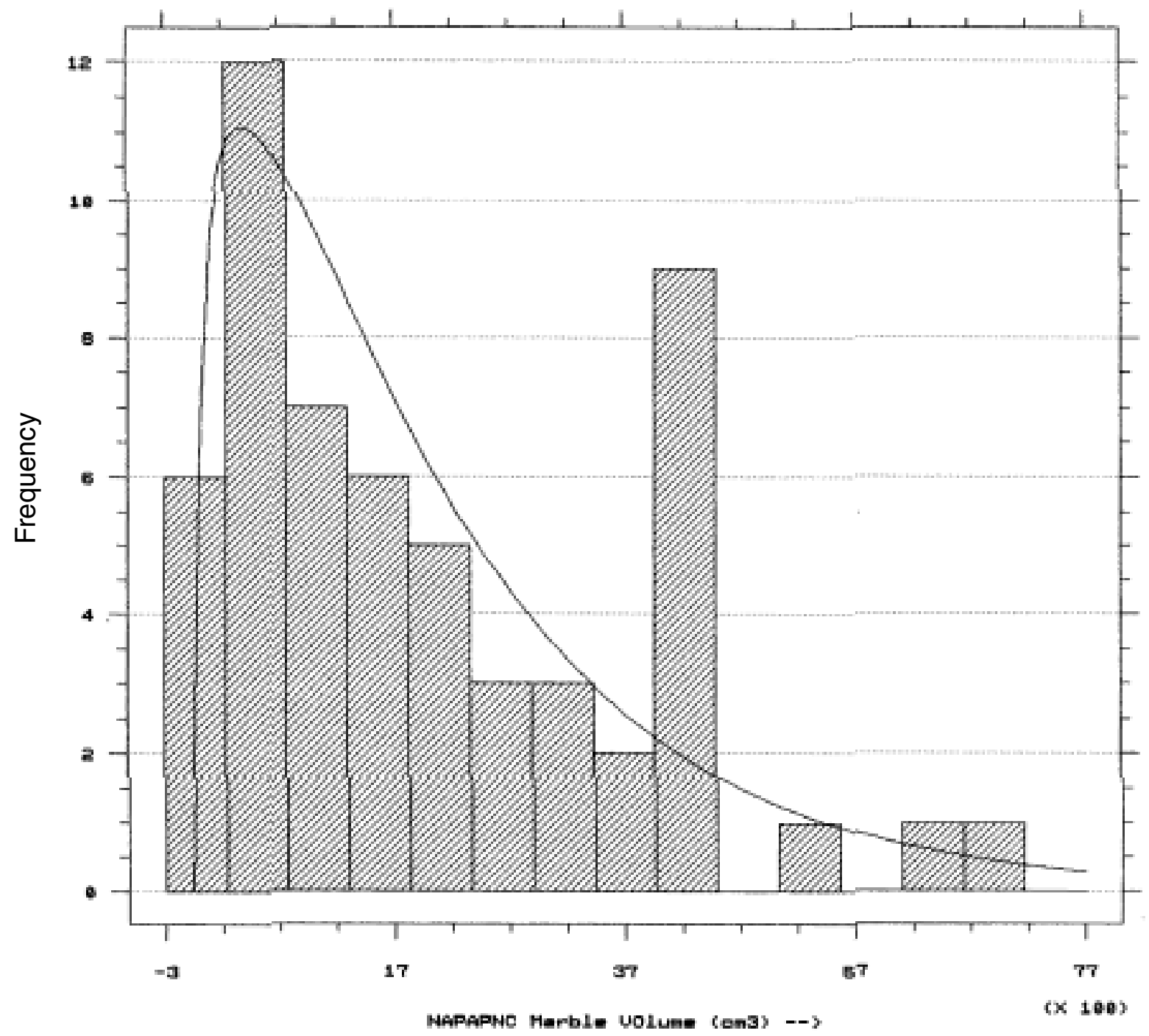

\section{Chisquare Test}

\begin{tabular}{|c|c|c|c|c|c|}
\hline & $\begin{array}{l}\text { Lower } \\
\text { Limit }\end{array}$ & $\begin{array}{l}\text { Upper } \\
\text { Limit }\end{array}$ & $\begin{array}{l}\text { Observed } \\
\text { Frequency }\end{array}$ & $\begin{array}{l}\text { Expected } \\
\text { Frequency }\end{array}$ & Chisquare \\
\hline & $\begin{array}{r}\text { at or below } \\
766.67 \\
1300.00 \\
1833.33 \\
2366.67 \\
3433.33\end{array}$ & $\begin{array}{r}766.67 \\
1300.00 \\
1833.33 \\
2366.67 \\
3433.33\end{array}$ & $\begin{array}{r}18 \\
7 \\
6 \\
5 \\
6 \\
14\end{array}$ & $\begin{array}{r}14.9 \\
9.5 \\
7.6 \\
5.9 \\
8.0 \\
10.1\end{array}$ & $\begin{array}{r}.633 \\
.640 \\
.335 \\
.142 \\
.488 \\
1.479\end{array}$ \\
\hline
\end{tabular}

Chisquare $=3.71713$ with 3 d.f. Sig. level $=0.293674$

FIGURE 12.-Histograms and model with goodness-of-fit statistics. (Variable: volume $\left(\mathrm{cm}^{3}\right)$; material: marble; site: NAPAP-NC.) 


\section{Blank Volume - NAPAP : OH}

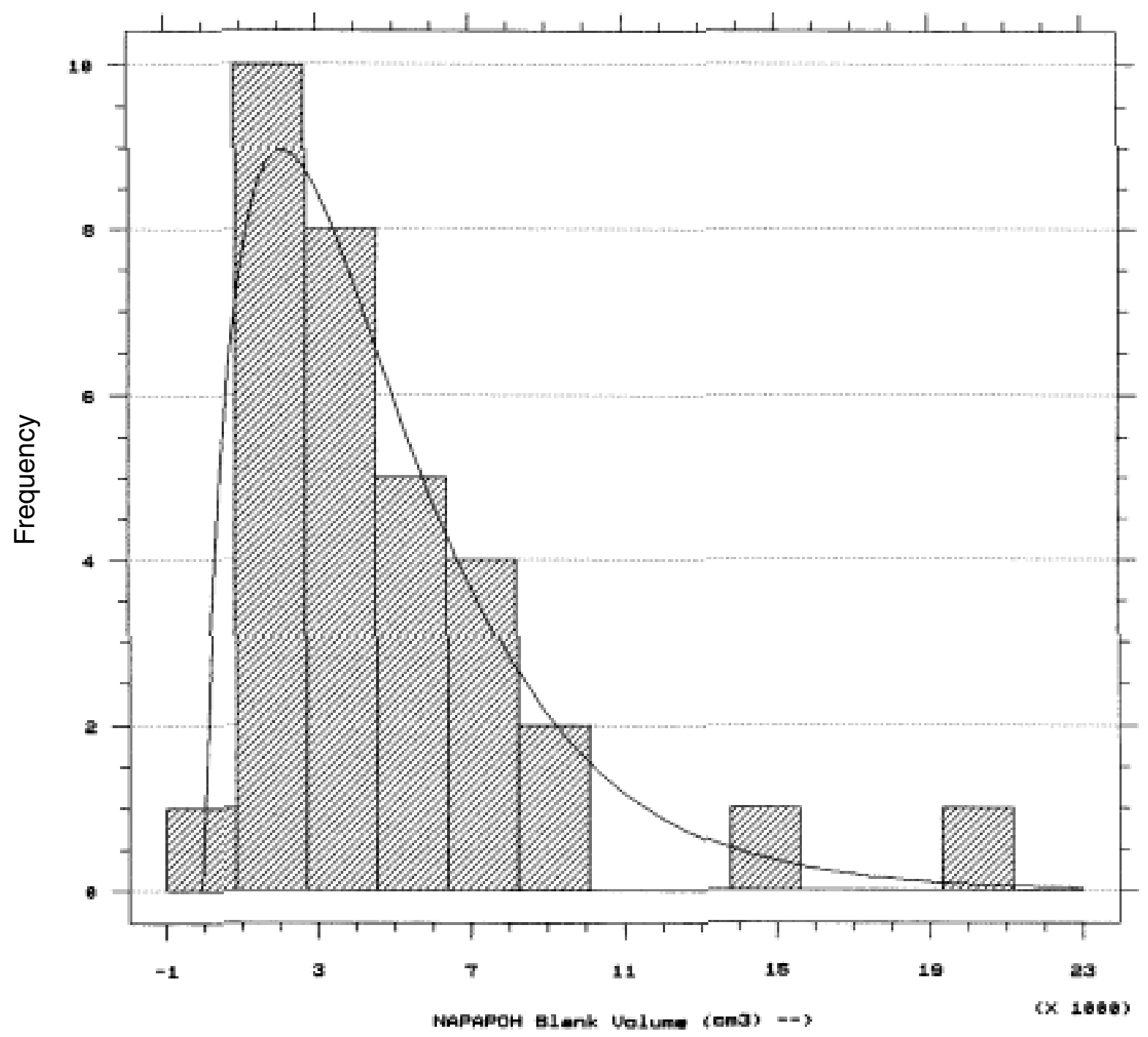

Chisquare Test

\begin{tabular}{|c|c|c|c|c|c|}
\hline & $\begin{array}{l}\text { Lower } \\
\text { Limit }\end{array}$ & $\begin{array}{l}\text { Upper } \\
\text { Limit }\end{array}$ & $\begin{array}{l}\text { Observed } \\
\text { Prequency }\end{array}$ & $\begin{array}{l}\text { Expected } \\
\text { Frequency }\end{array}$ & Chisquare \\
\hline & $\begin{array}{r}\text { at or below } \\
2692.31 \\
4538.46 \\
6384.62\end{array}$ & $\begin{array}{l}2692.31 \\
4538.46 \\
6384.62\end{array}$ & $\begin{array}{r}11 \\
8 \\
5 \\
8\end{array}$ & $\begin{array}{r}10.7 \\
7.7 \\
5.4 \\
8.2\end{array}$ & $\begin{array}{l}.00987 \\
.01037 \\
.02848 \\
.00566\end{array}$ \\
\hline
\end{tabular}

FIGURE 13.-Histograms and model with goodness-of-fit statistics. (Variable: volume $\left(\mathrm{cm}^{3}\right)$; material: blank; site: NAPAP-OH.) 


\section{Limestane Volume - NAPAP : OH}

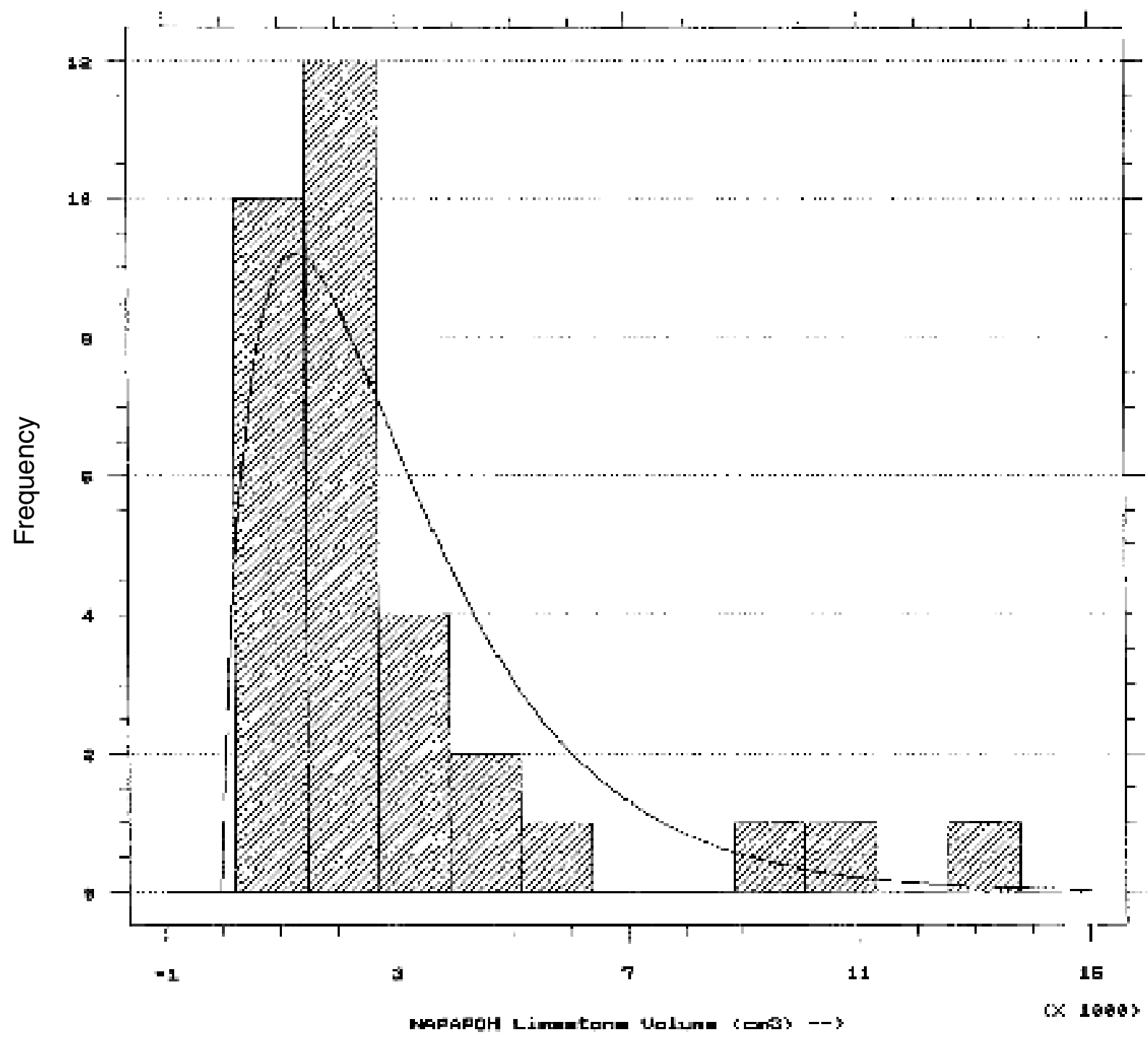

Chitquare Test

\begin{tabular}{|c|c|c|c|c|c|}
\hline & $\begin{array}{l}\text { Lower } \\
\text { Lim1t }\end{array}$ & $\begin{array}{l}\text { Upper } \\
\text { IImit }\end{array}$ & $\begin{array}{l}\text { Observed } \\
\text { Frequency }\end{array}$ & $\begin{array}{l}\text { Expected } \\
\text { Frequency }\end{array}$ & Chisquare \\
\hline above & $\begin{array}{r}\text { at or bejow } \\
1461.54 \\
2692.31 \\
3923.08\end{array}$ & $\begin{array}{l}1461.54 \\
2692.31 \\
3923.08\end{array}$ & $\begin{array}{r}10 \\
12 \\
4 \\
6\end{array}$ & $\begin{array}{l}8.8 \\
8.3 \\
5.9 \\
9.1\end{array}$ & $\begin{array}{r}.178 \\
1.669 \\
.615 \\
1.034\end{array}$ \\
\hline
\end{tabular}

Chisquare $=3.49662$ with 1 d.f. Sig. level $=0.0614942$

FIGURE 14.-Histograms and model with goodness-of-fit statistics. (Variable: volume $\left(\mathrm{cm}^{3}\right)$; material: limestone; site: NAPAP-OH.) 


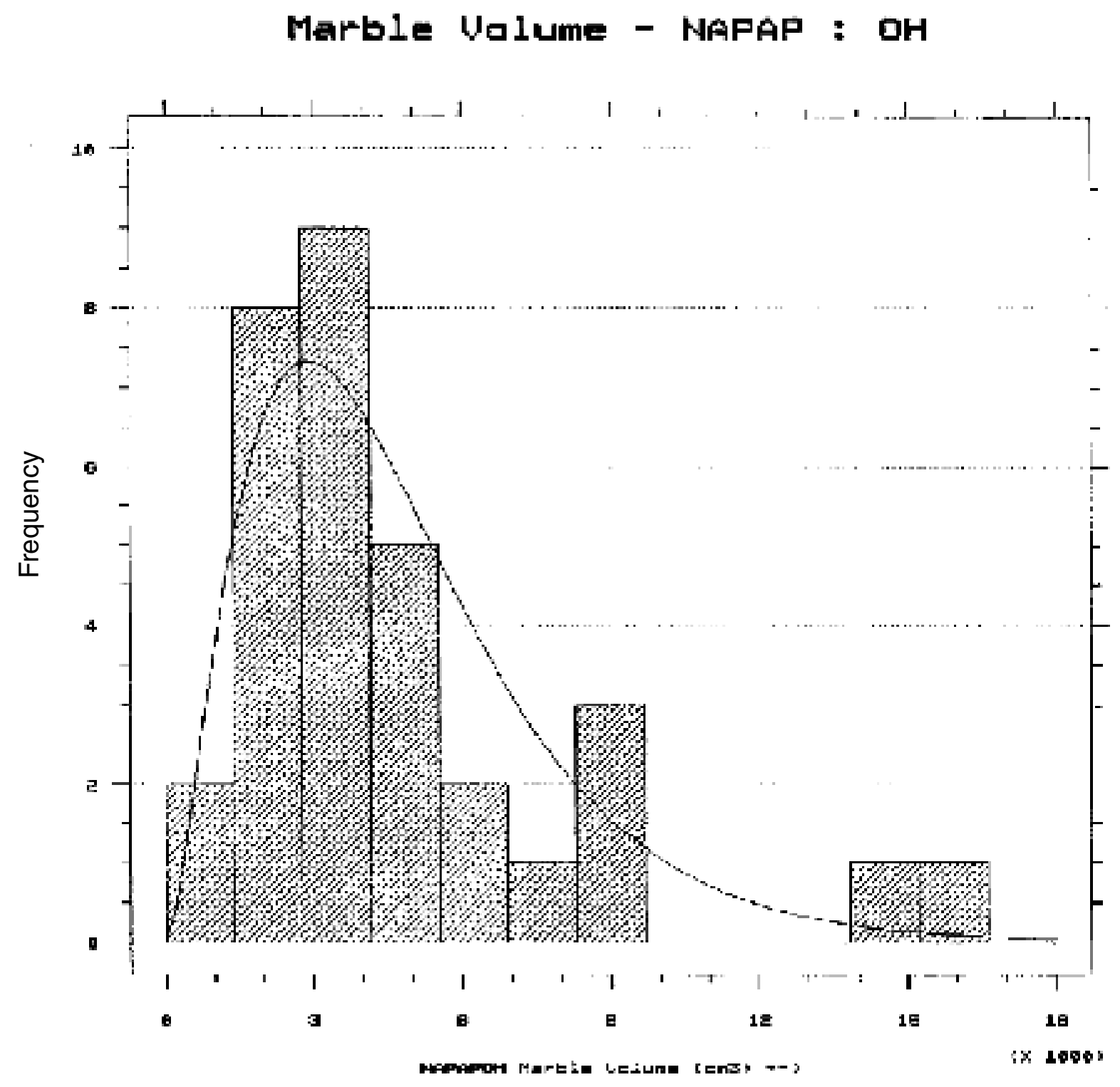

Chisquare Test

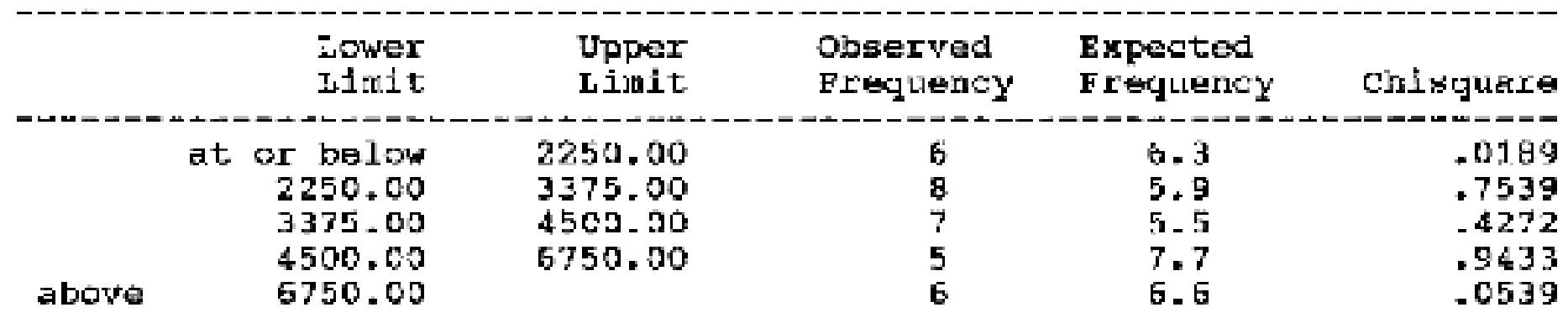

Ch: aquare $=2.19727$ with 2 d. f. sig. level $=0.333326$

FIGURE 15.-Histograms and model with goodness-of-fit statistics. (Variable: volume $\left(\mathrm{cm}^{3}\right)$; material: marble; site: NAPAP-OH.) 
FIGURE 16.-A, Limestone versus marble volumes. (Variable: volume $\left(\mathrm{cm}^{3}\right)$; material: limestone and marble; site: NAPAP-DC.) B, Limestone, marble, and blank volumes sorted on blank volume. (Variable: volume $\left(\mathrm{cm}^{3}\right)$; material: limestone, marble, and blank; site: NAPAP-DC.) C, Marble volume sorted on volume. (Variable: volume $\left(\mathrm{cm}^{3}\right)$; material: marble; site: NAPAP-DC.)

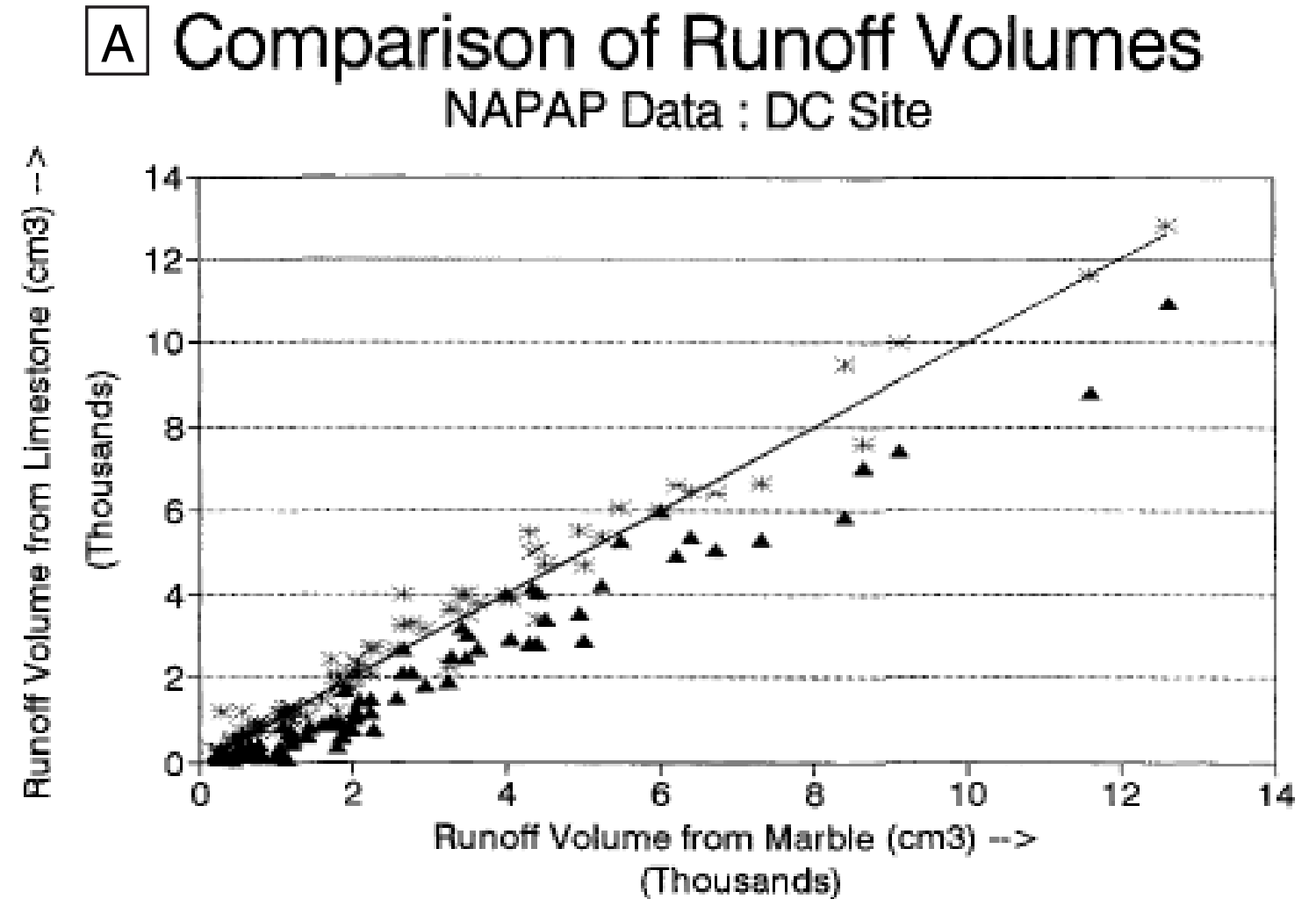

\section{A Limestone - Marble * Blank \\ B Comparison of Runoff Volumes NAPAP Data : DC Site}

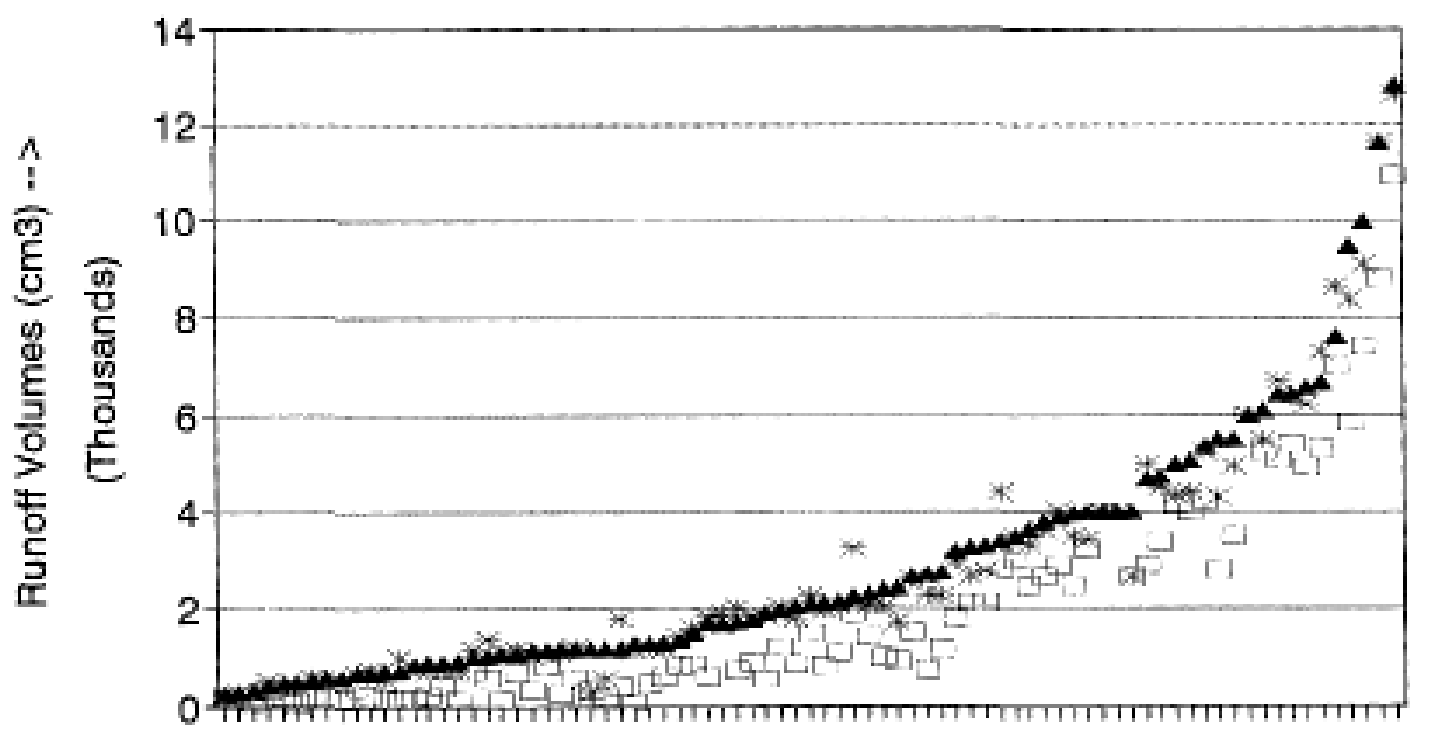

Event Index - Sorted on Blank Volume

$\sqcup$ Limestone $*$ Marble $\Delta$ Blank 


\section{Marble Volume NAPAP Data : DC Site}

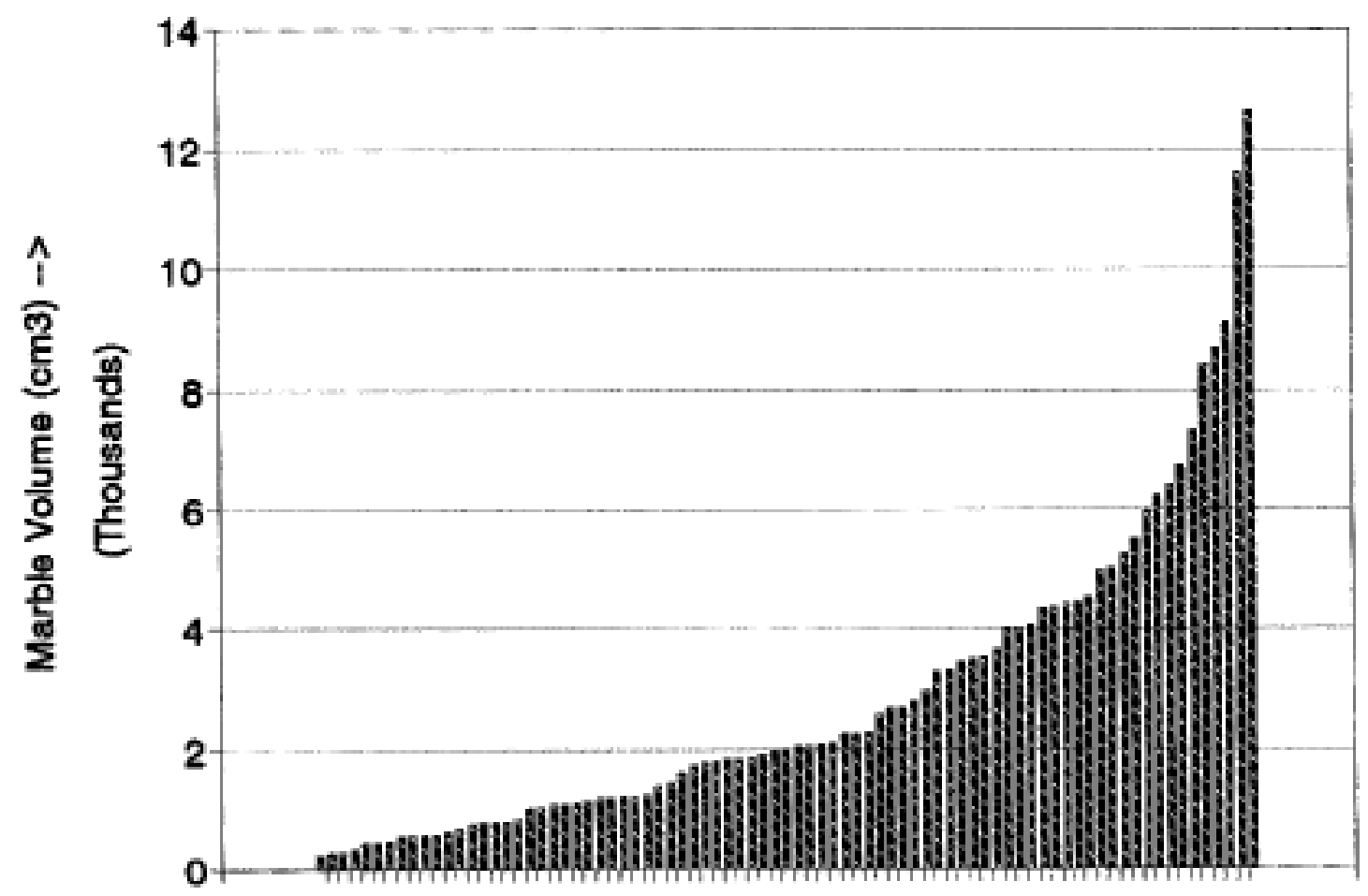


FIGURE 17.-A, Limestone versus marble volumes. (Variable: volume $\left(\mathrm{cm}^{3}\right)$; material: limestone and marble; site: NAPAP-NY.) B, Limestone, marble, and blank volumes sorted on blank volume. (Variable: volume $\left(\mathrm{cm}^{3}\right)$; material: limestone, marble, and blank; site: NAPAP-NY.) C, Marble volume sorted on volume. (Variable: volume $\left(\mathrm{cm}^{3}\right)$; material: marble; site: NAPAP-NY.)

\section{A Comparison of Runoff Volumes NAPAP Data : NY Site}

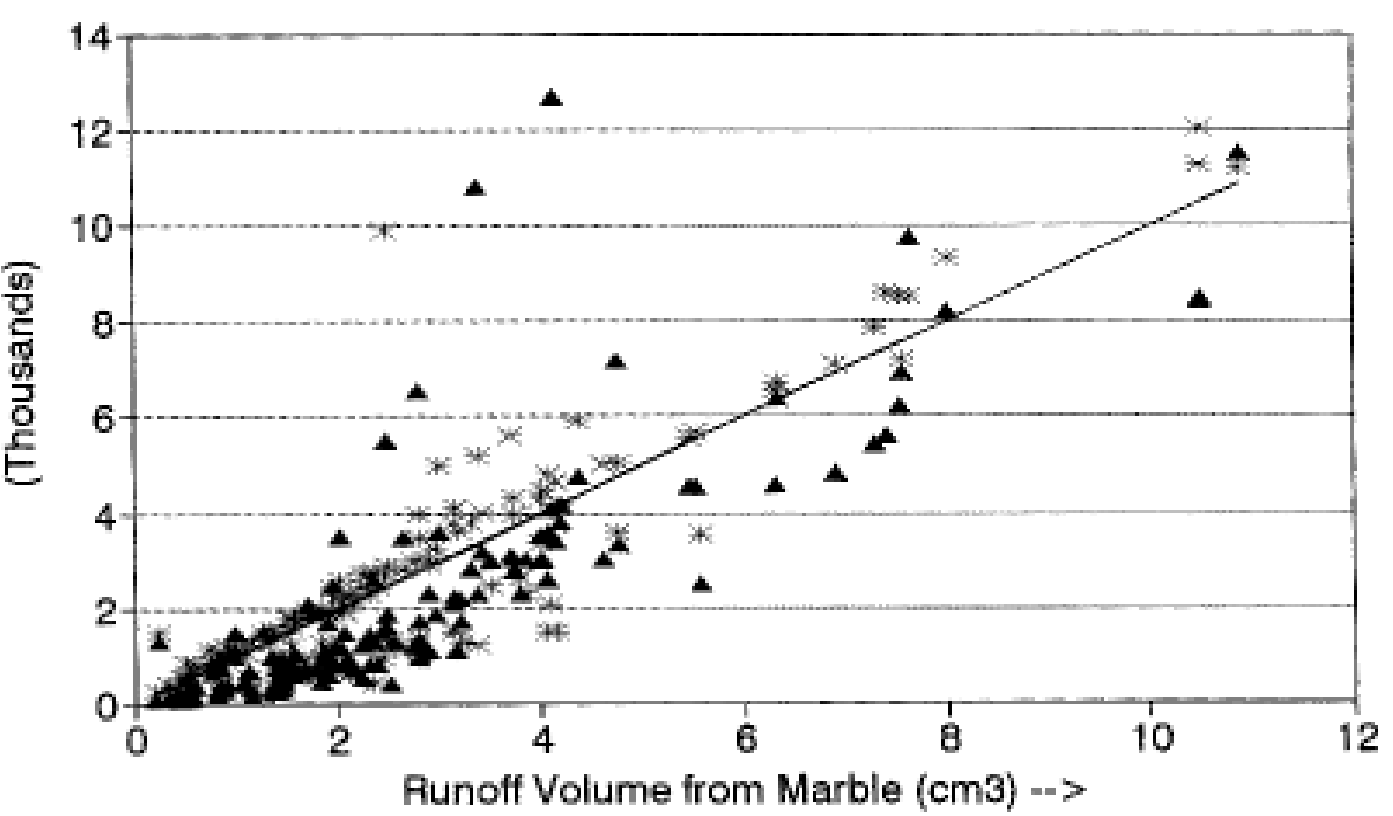

(Thousands)

\section{A Limestone - Marble * Blank \\ B Comparison of Runoff Volumes NAPAP Data : NY Site}

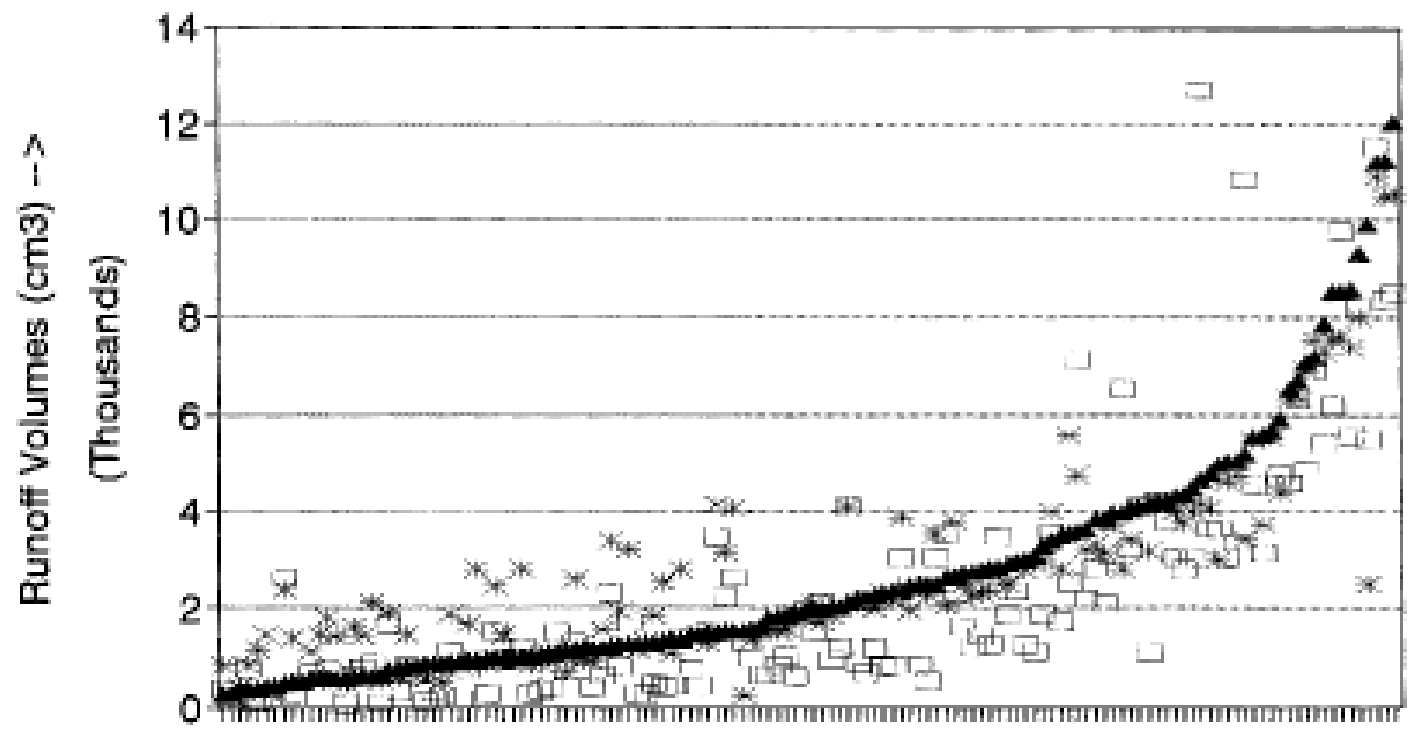

Event Index - Sorted on Blank Volume

\section{$\square$ Limestone * Marble A Blank}




\section{Marble Volume NAPAP Data : NY Site}

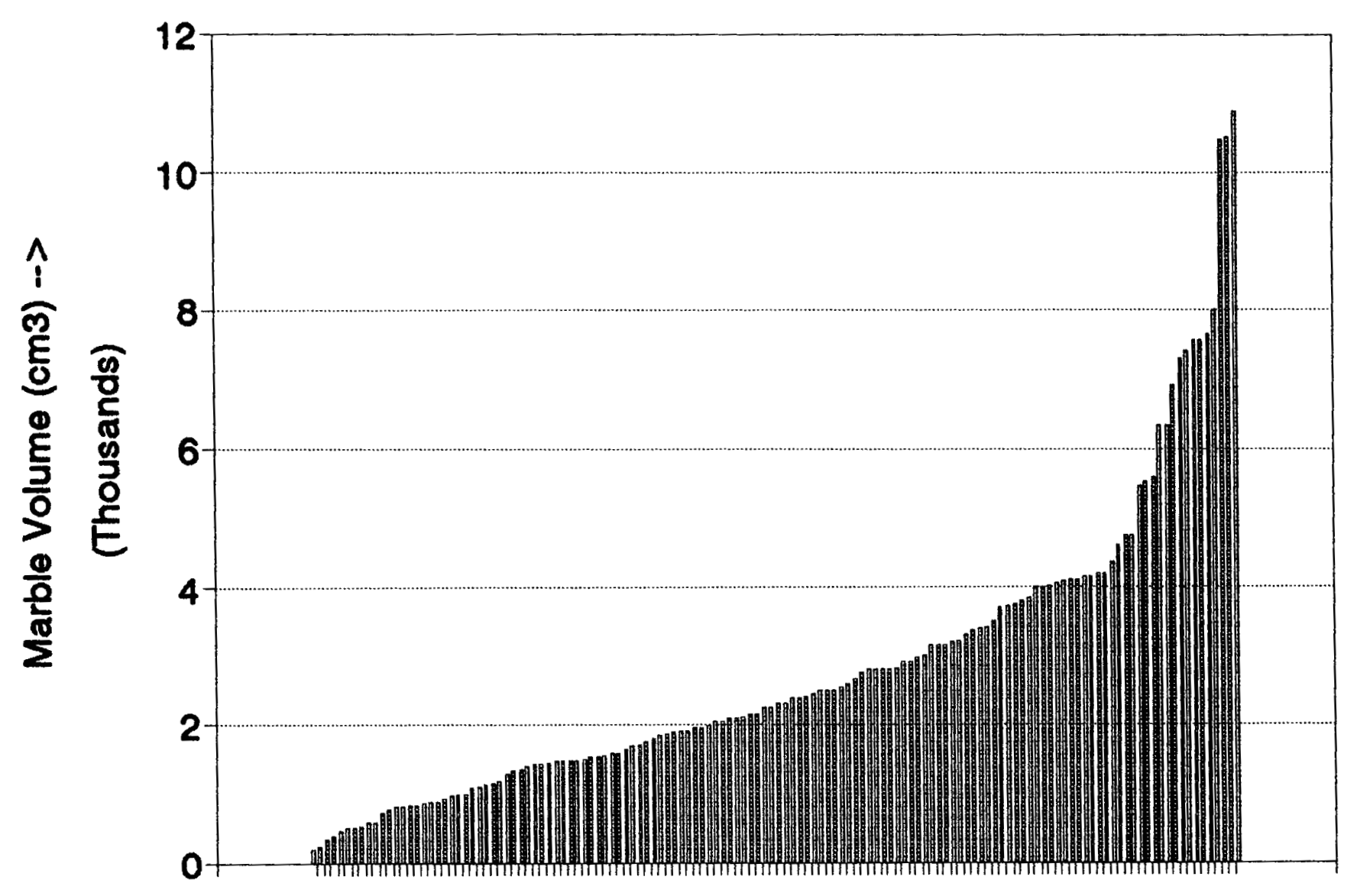


FIGURE 18.-A, Limestone versus marble volumes. (Variable: volume $\left(\mathrm{cm}^{3}\right)$; material: limestone and marble; site: NAPAP-NJ.) B, Limestone, marble, and blank volumes sorted on blank volume. (Variable: volume ( $\left.\mathrm{cm}^{3}\right)$; material: limestone, marble, and blank; site: NAPAP-NJ.) C, Marble volume sorted on volume. (Variable: volume $\left(\mathrm{cm}^{3}\right)$; material: marble; site: NAPAP-NJ.)

\section{A Comparison of Runoff Volumes} NAPAP Data : NJ Site

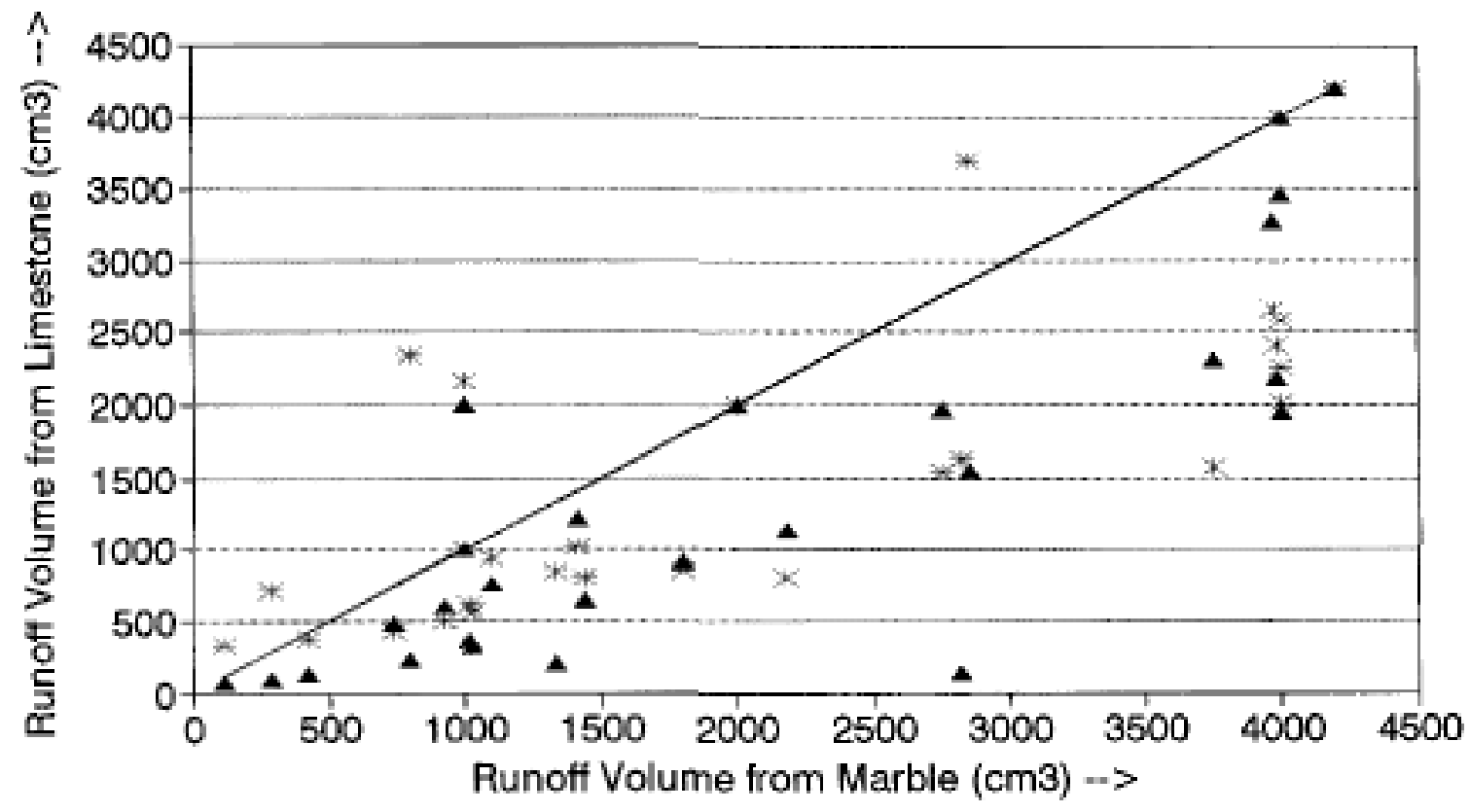

\section{A Limestone - Marble $*$ Blank \\ B Comparison of Runoff Volumes NAPAP Data : NJ Site}

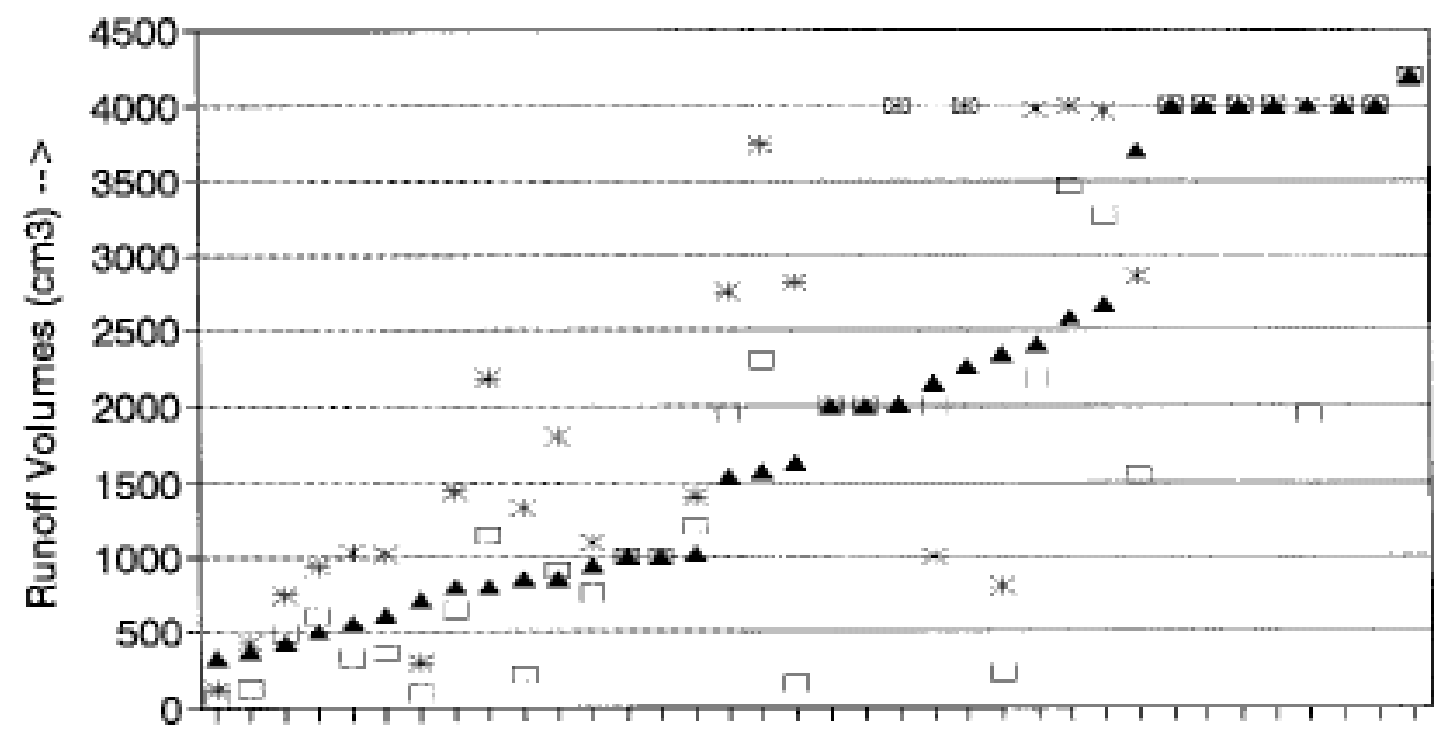

Event Index - Sorted on Blank Volume

L. Limestone * Marble $\Delta$ Blank




\section{Marble Volume NAPAP Data : NJ Site}

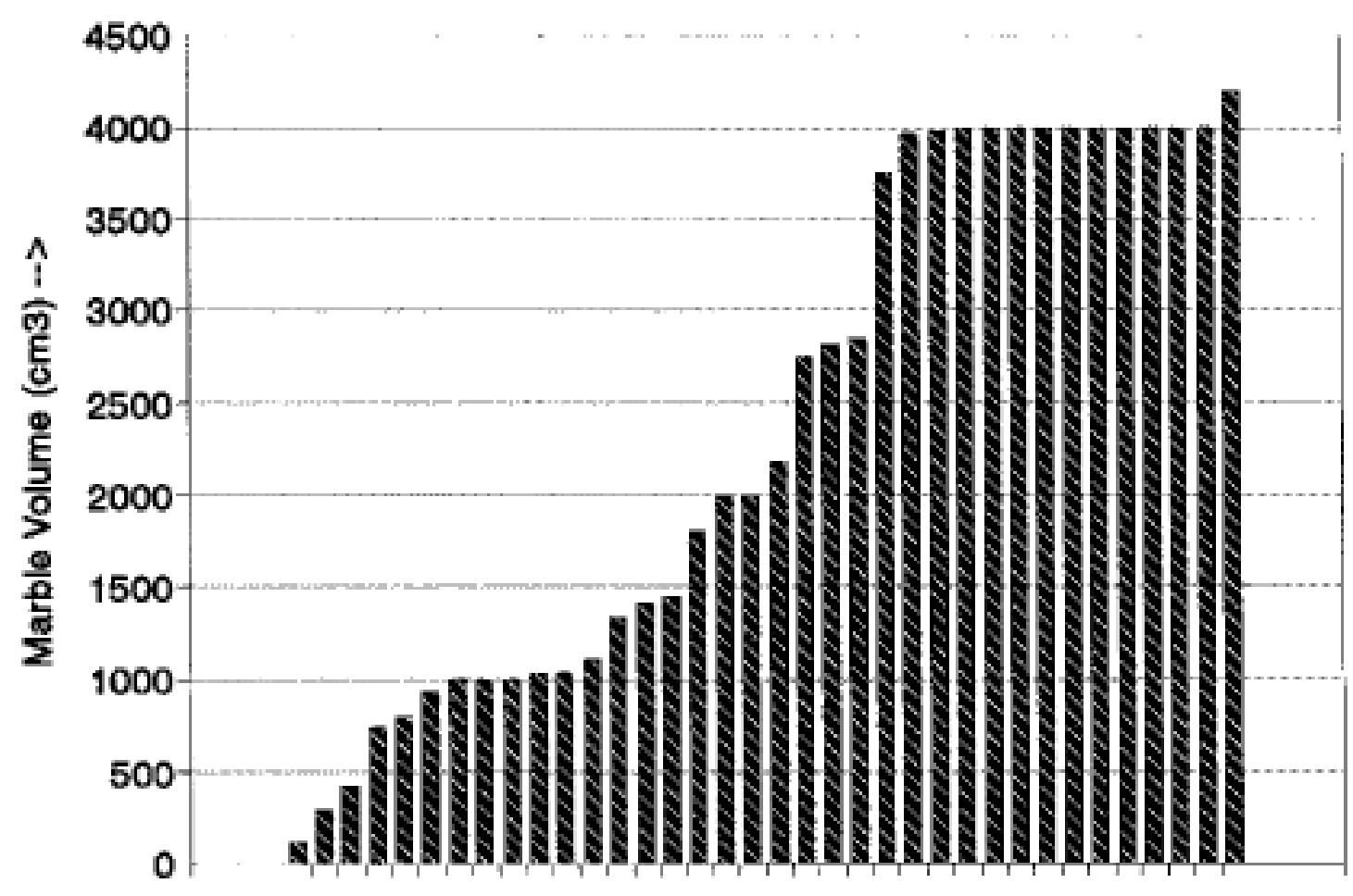


FIGURE 19.-A, Limestone versus marble volumes. (Variable: volume $\left(\mathrm{cm}^{3}\right)$; material: limestone and marble; site: NAPAP-NC.) B, Limestone, marble, and blank volumes sorted on blank volume. (Variable: volume $\left(\mathrm{cm}^{3}\right)$; material: limestone, marble, and blank; site: NAPAP-NC.) C, Marble volume sorted on volume. (Variable: volume $\left(\mathrm{cm}^{3}\right)$; material: marble; site: NAPAP-NC.)

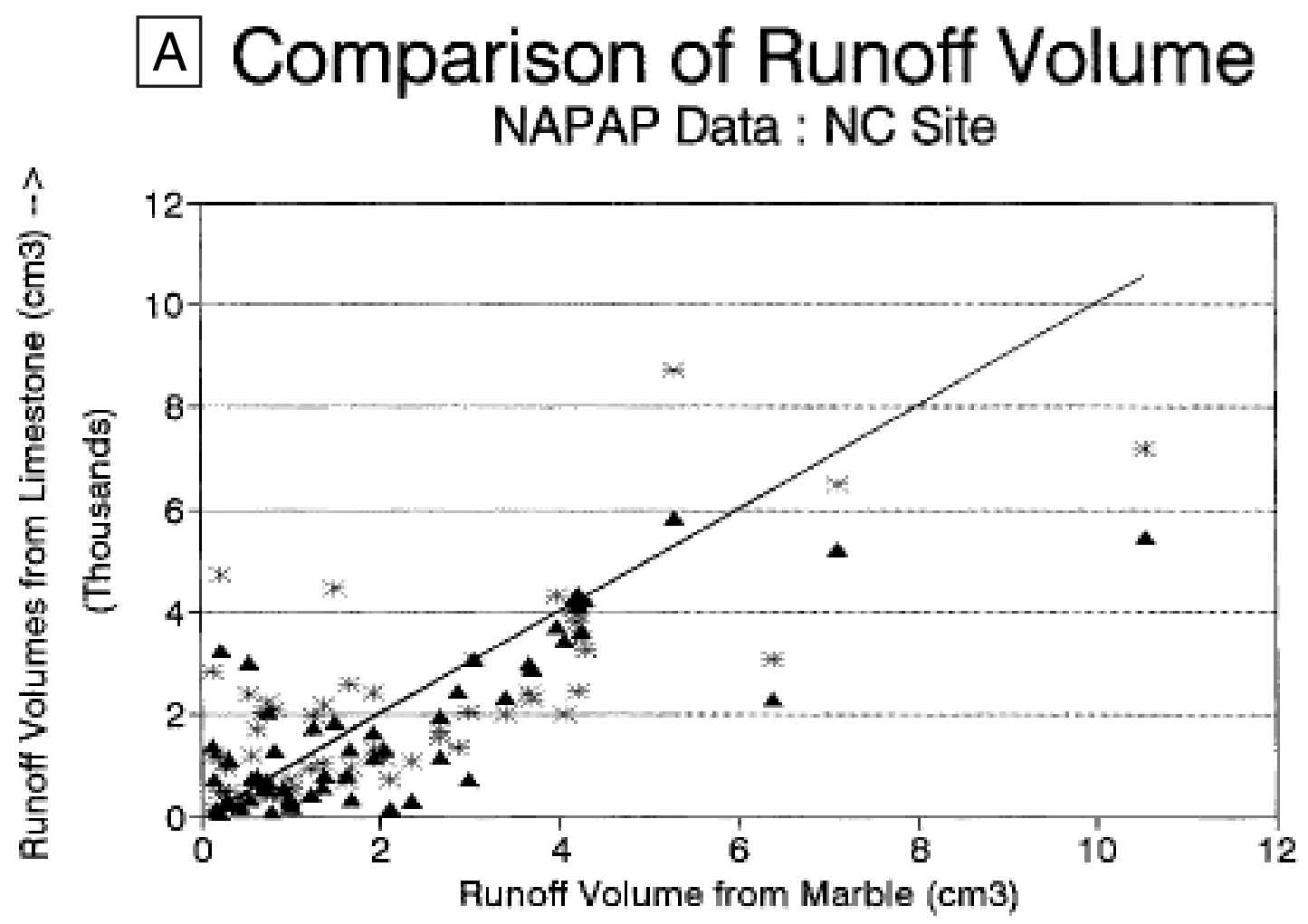

(Thousands)

\section{A Limestone - Marble * Blank \\ B Comparison of Runoff Volume NAPAP Data : NC Site}

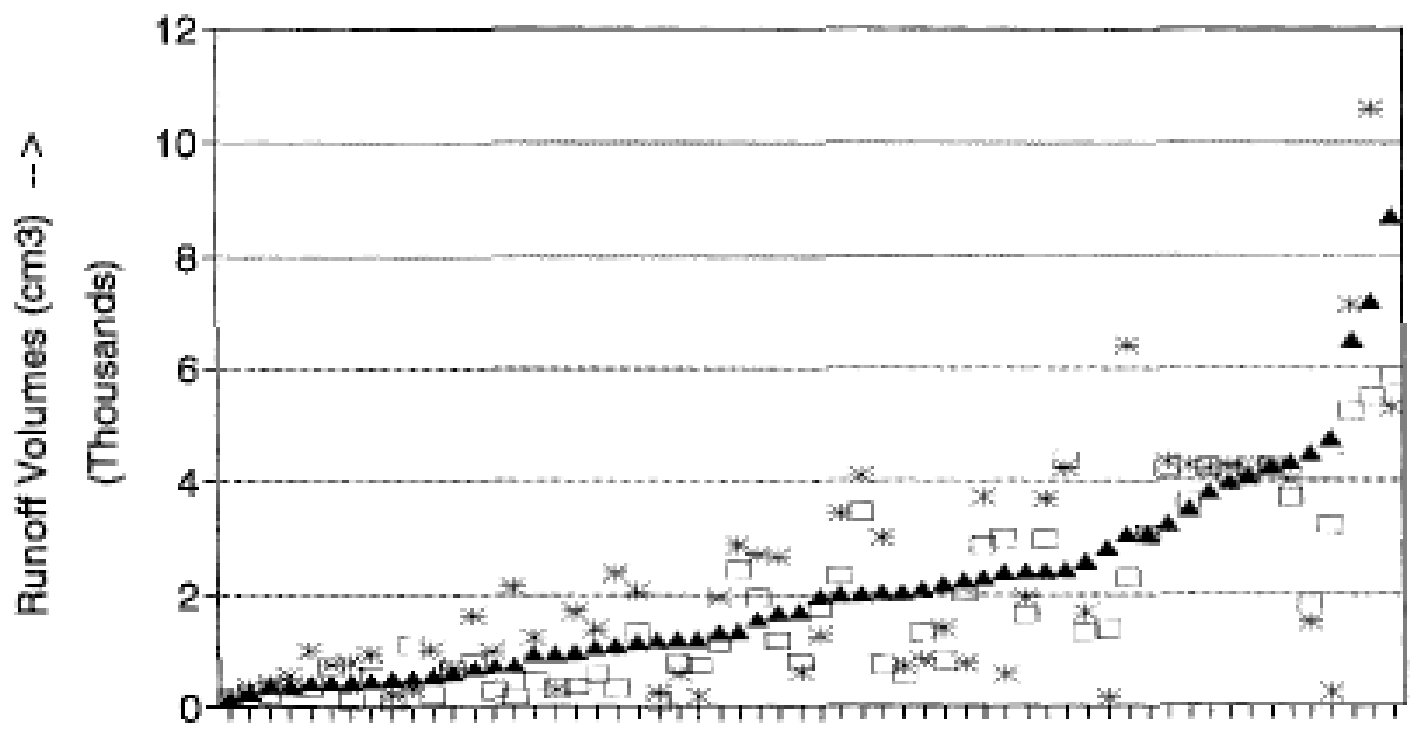

Event Index - Sorted on Blank Volume

L Limestone * Marble A Blank




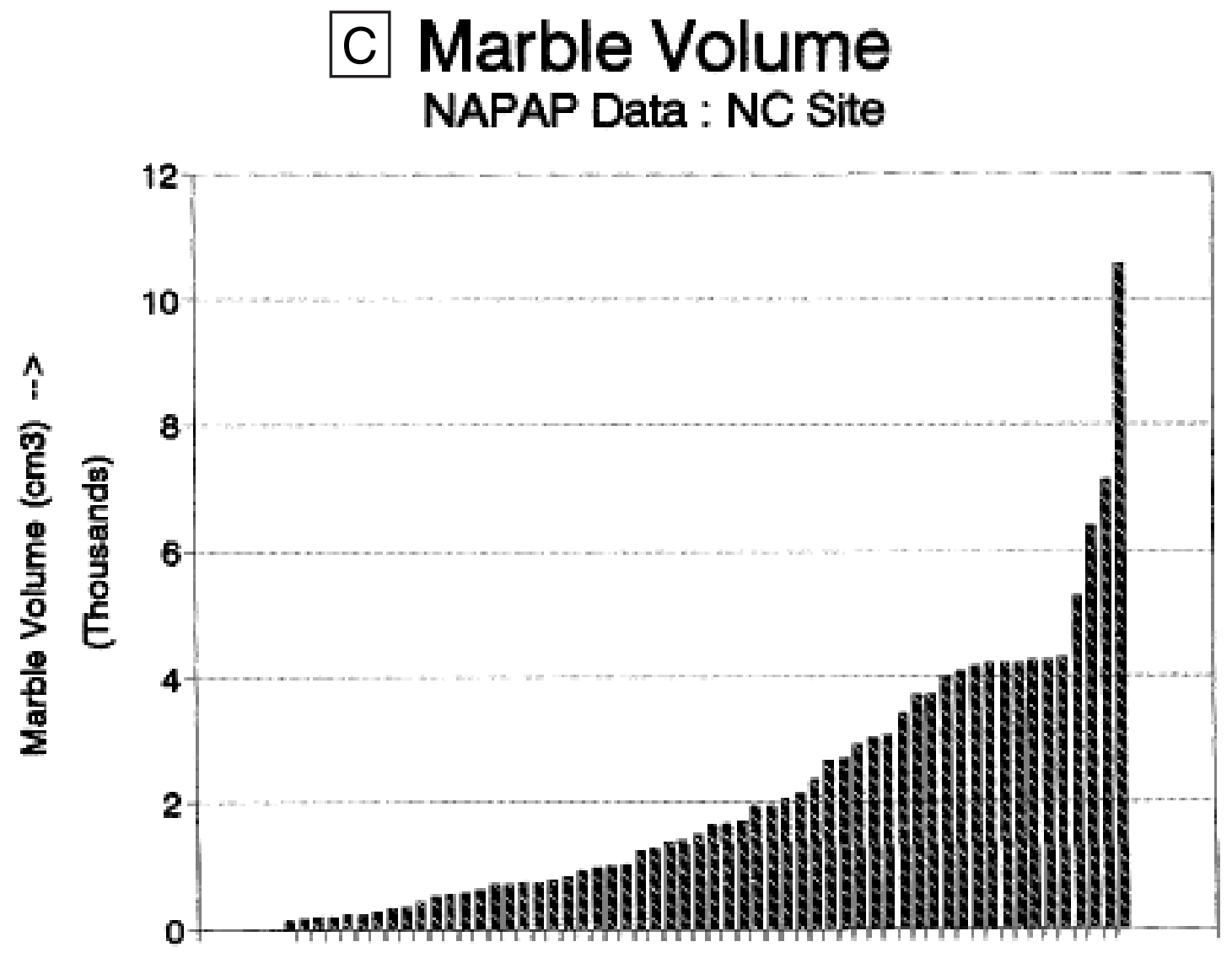


FIGURE 20.-A, Limestone versus marble volumes. (Variable: volume $\left(\mathrm{cm}^{3}\right)$; material: limestone and marble; site: NAPAP-OH.) B, Limestone, marble, and blank volumes sorted on blank volume. (Variable: volume $\left(\mathrm{cm}^{3}\right)$; material: limestone, marble, and blank; site: NAPAP-OH.) C, Marble volume sorted on volume. (Variable: volume $\left(\mathrm{cm}^{3}\right)$; material: marble; site: NAPAP-OH.)

A Comparison of Runoff Volumes NAPAP Data : OH Site

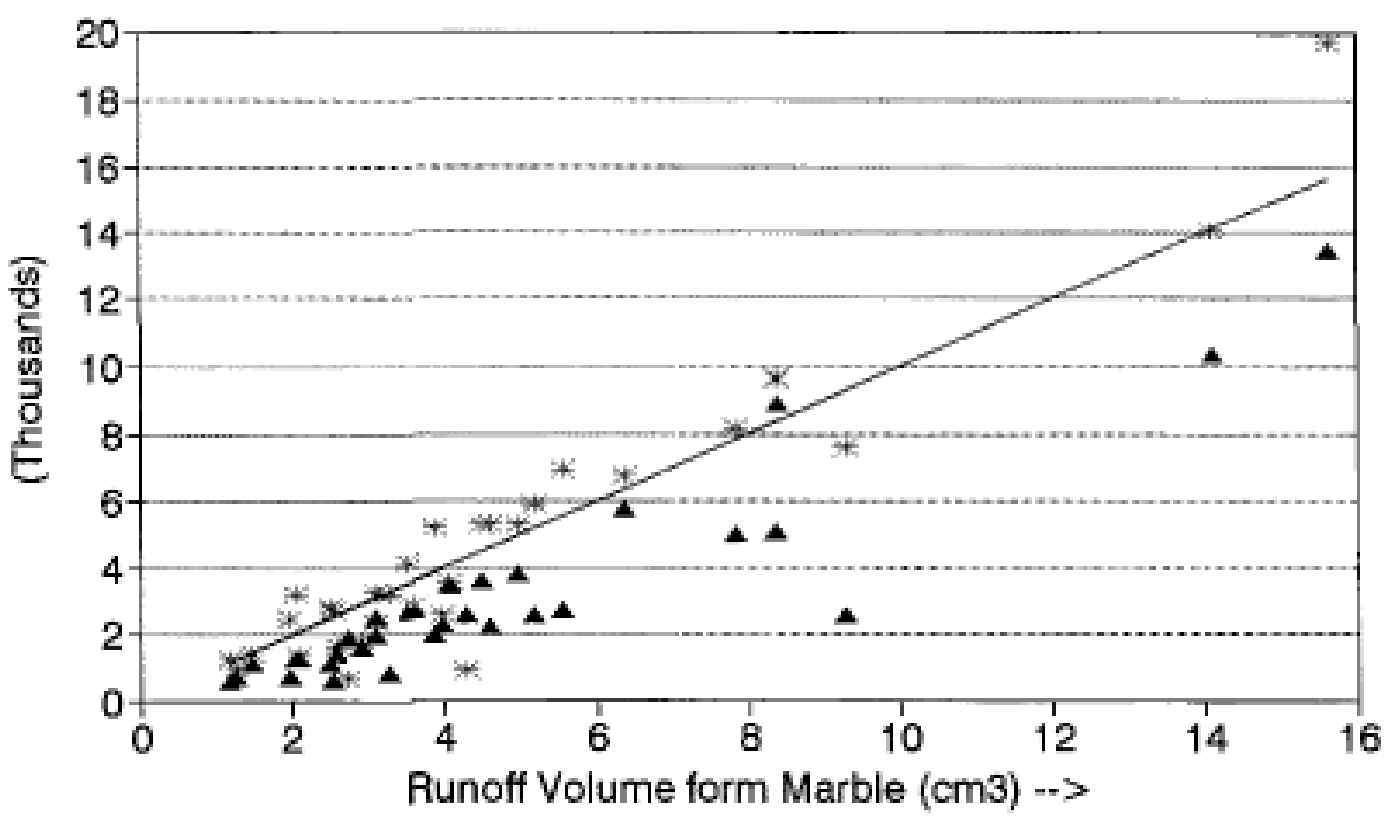
(Thousands)

\section{A Limestone - Marble * Blank \\ B Comparison of Runoff Volumes NAPAP Data : OH Site}

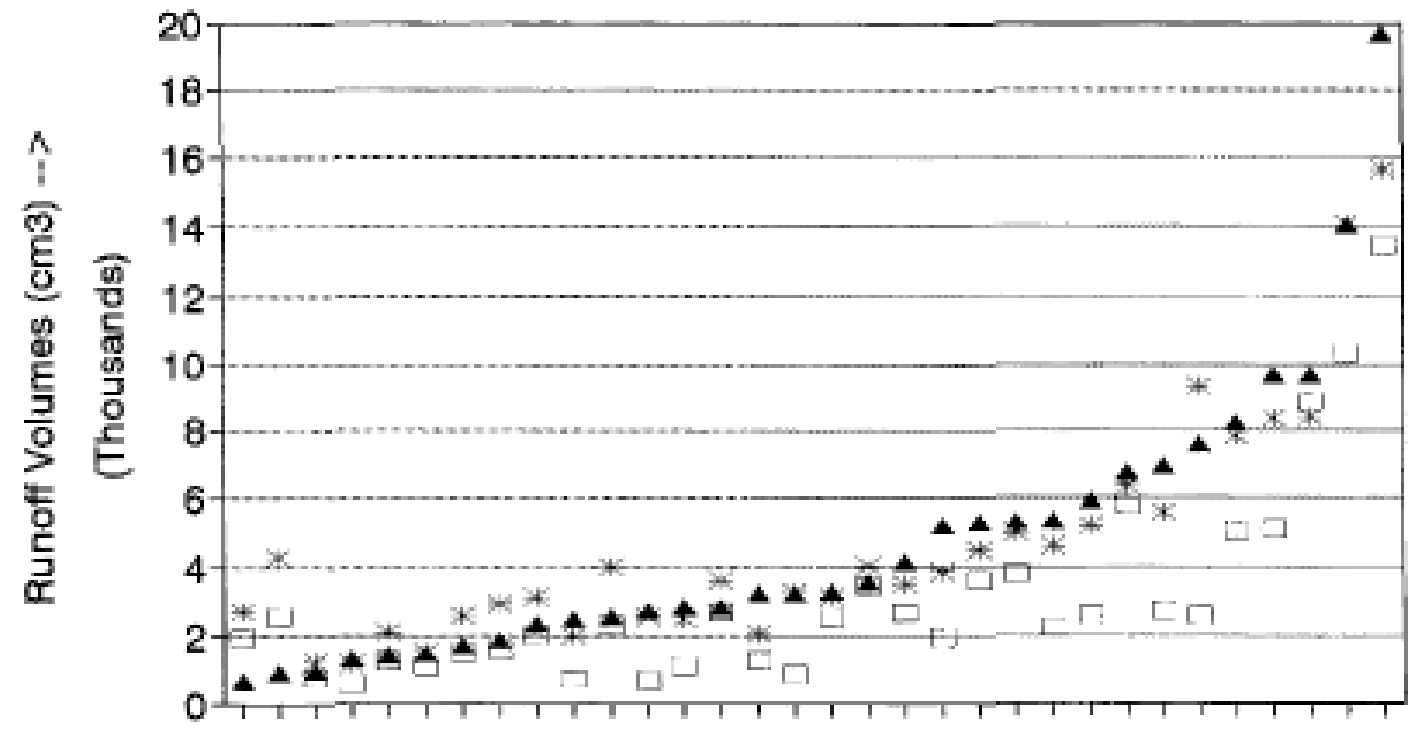

Event Index - Sorted on Blank Volume 


\section{Marble Volume NAPAP Data : OH Site}

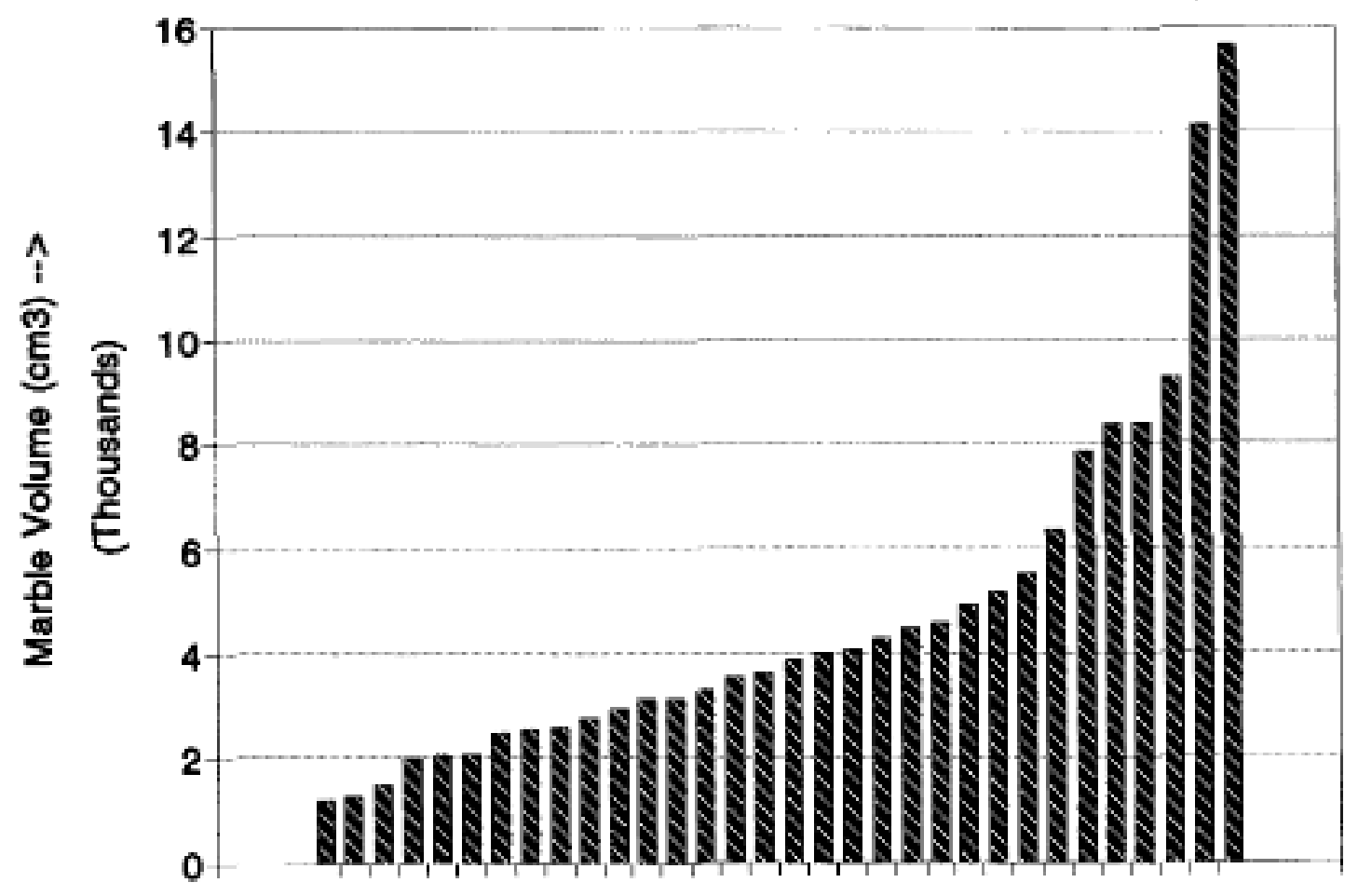




\section{Differences from Blank Volume \\ NAPAP Data : DC Site}

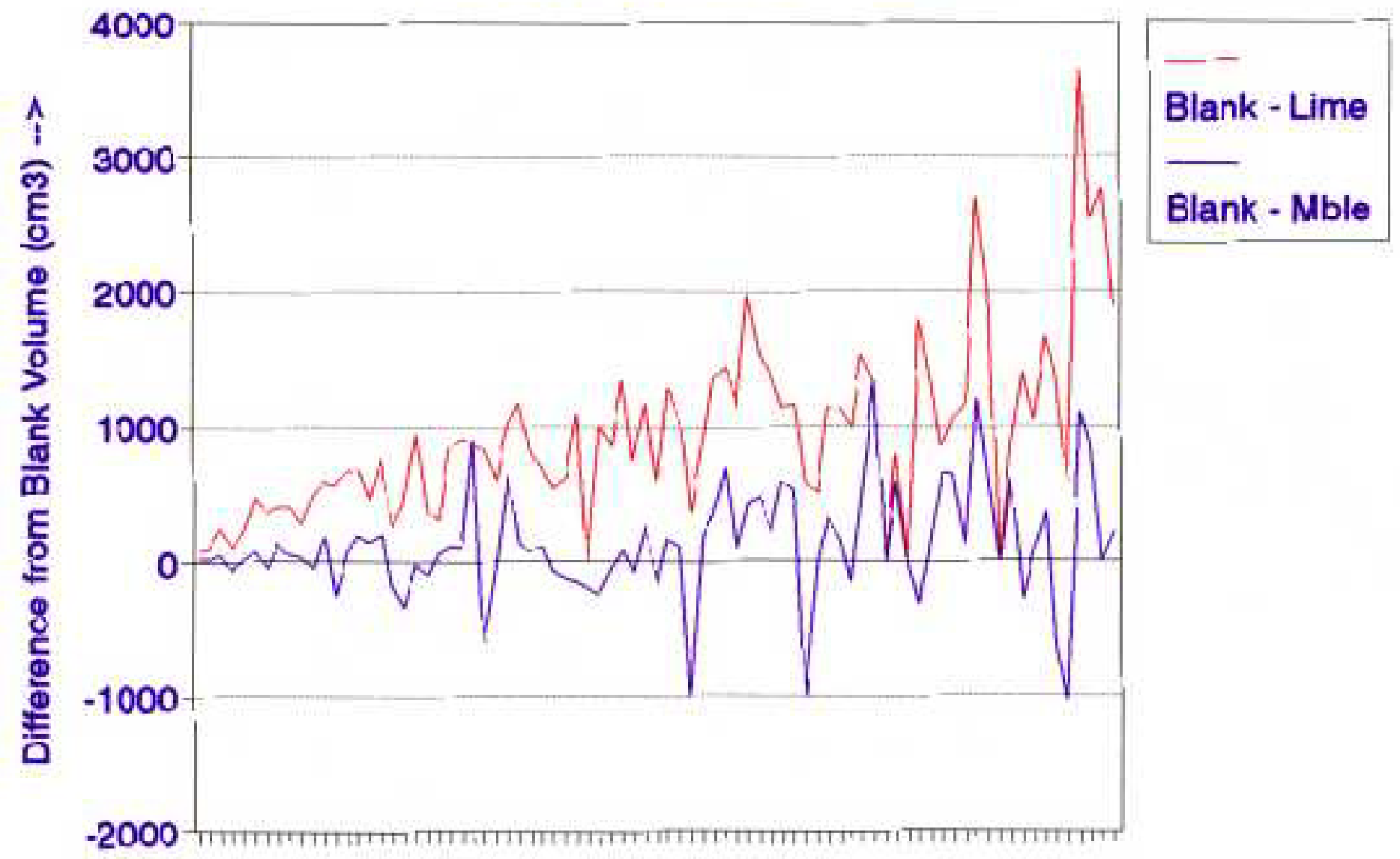

FIGURE 21.-Limestone-marble volume difference. (Variable: volume $\left(\mathrm{cm}^{3}\right)$; material: limestone and marble; site: NAPAP-DC.) 


\section{Difference from Blank Volume NAPAP Data : NY Site}

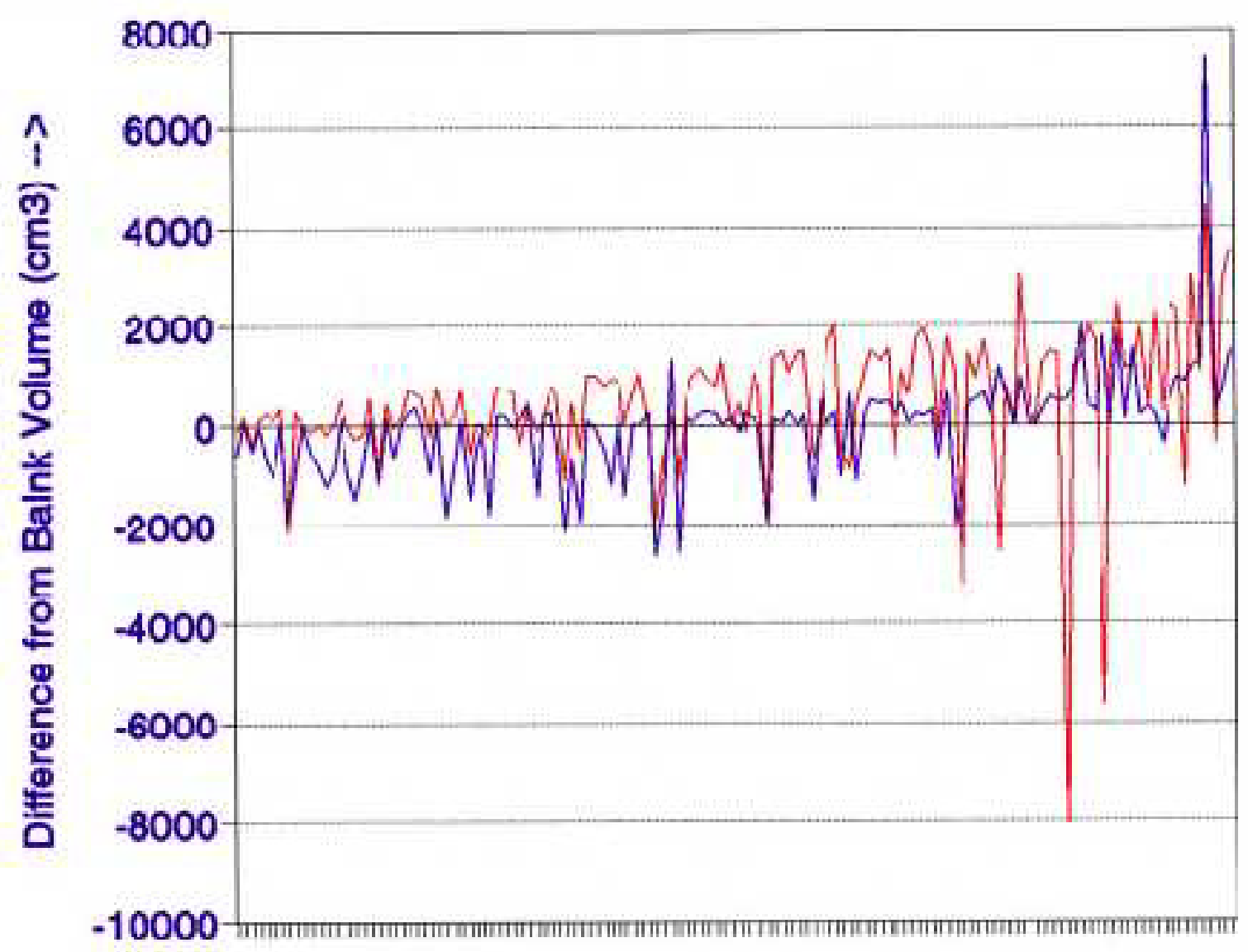

Blank - Lime

Blank - Mble

FIGURE 22.-Limestone-marble volume difference. (Variable: volume $\left(\mathrm{cm}^{3}\right)$; material: limestone and marble; site: NAPAP-NY.) 


\section{Differences from Blank Volume NAPAP Data : NJ Site}

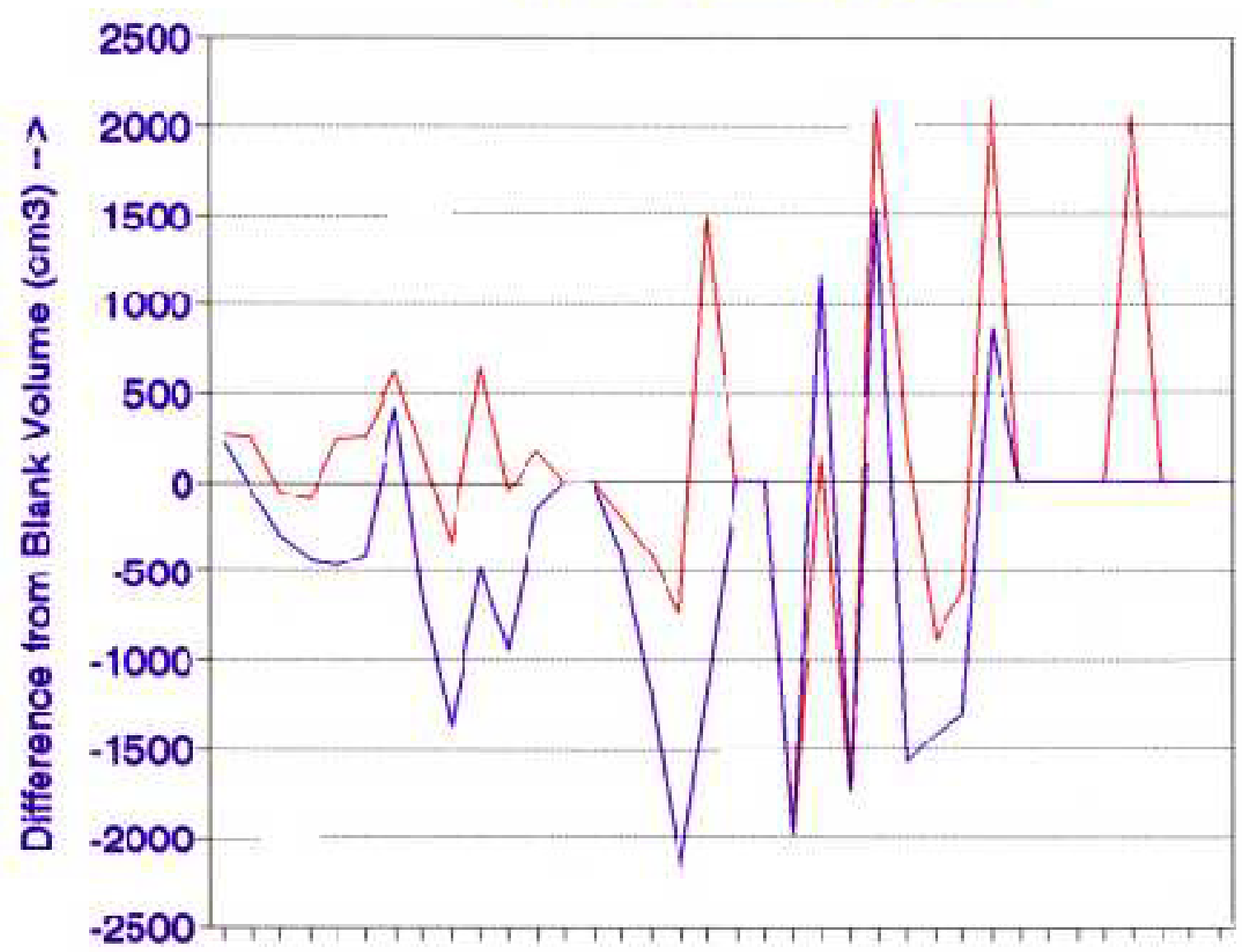

Blank - Lime

Blank - Mble

FIGURE 23.-Limestone-marble volume difference. (Variable: volume $\left(\mathrm{cm}^{3}\right)$; material: limestone and marble; site: NAPAP-NJ.) 


\section{Differences from Blank Volume NAPAP Data : NC Site}

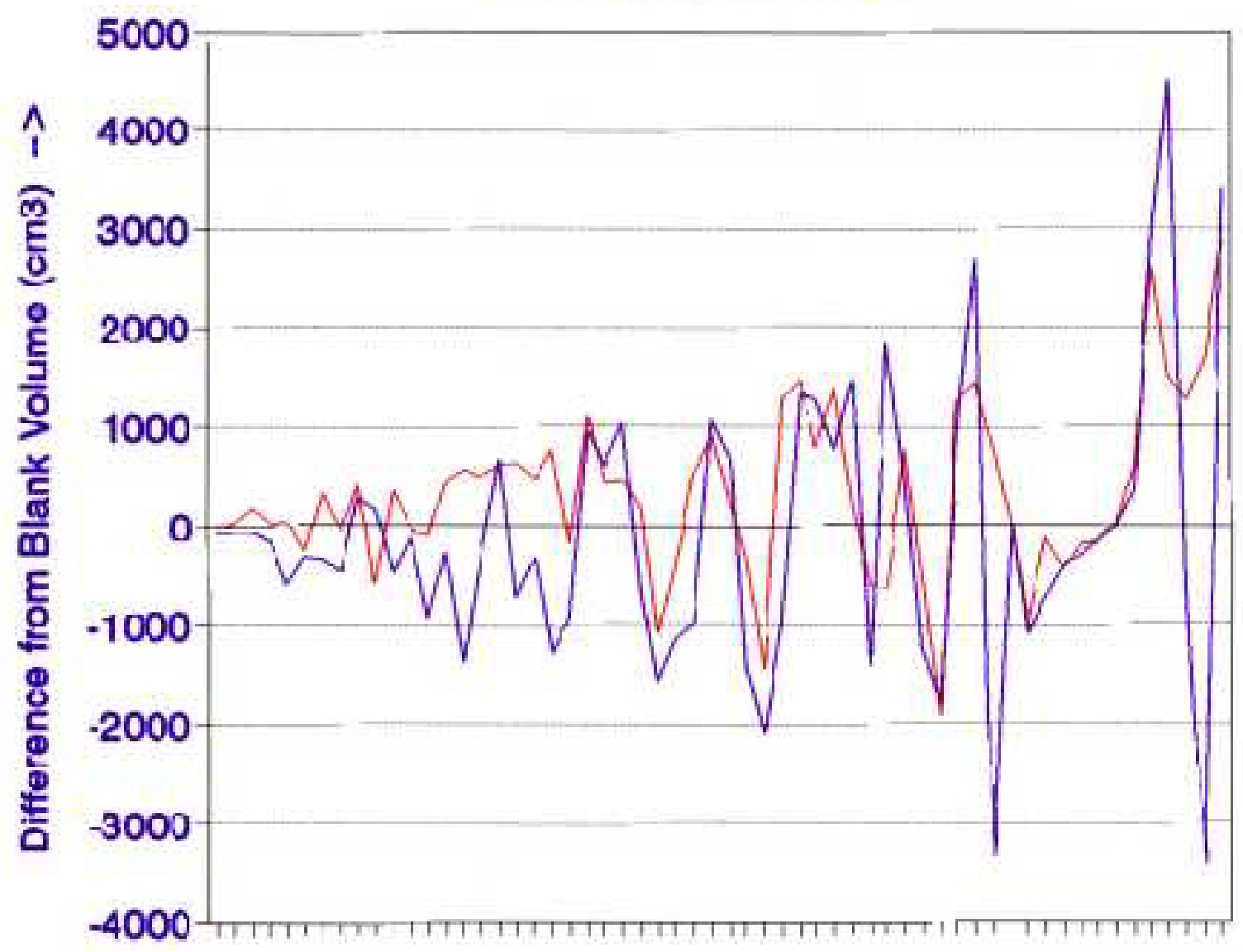

Blank - Lime

Blank - Mble

FIGURE 24.-Limestone-marble volume difference. (Variable: volume $\left(\mathrm{cm}^{3}\right)$; material: limestone and marble; site: NAPAP-NC.) 


\section{Volume Differences \\ NAPAP Data : OH Site}

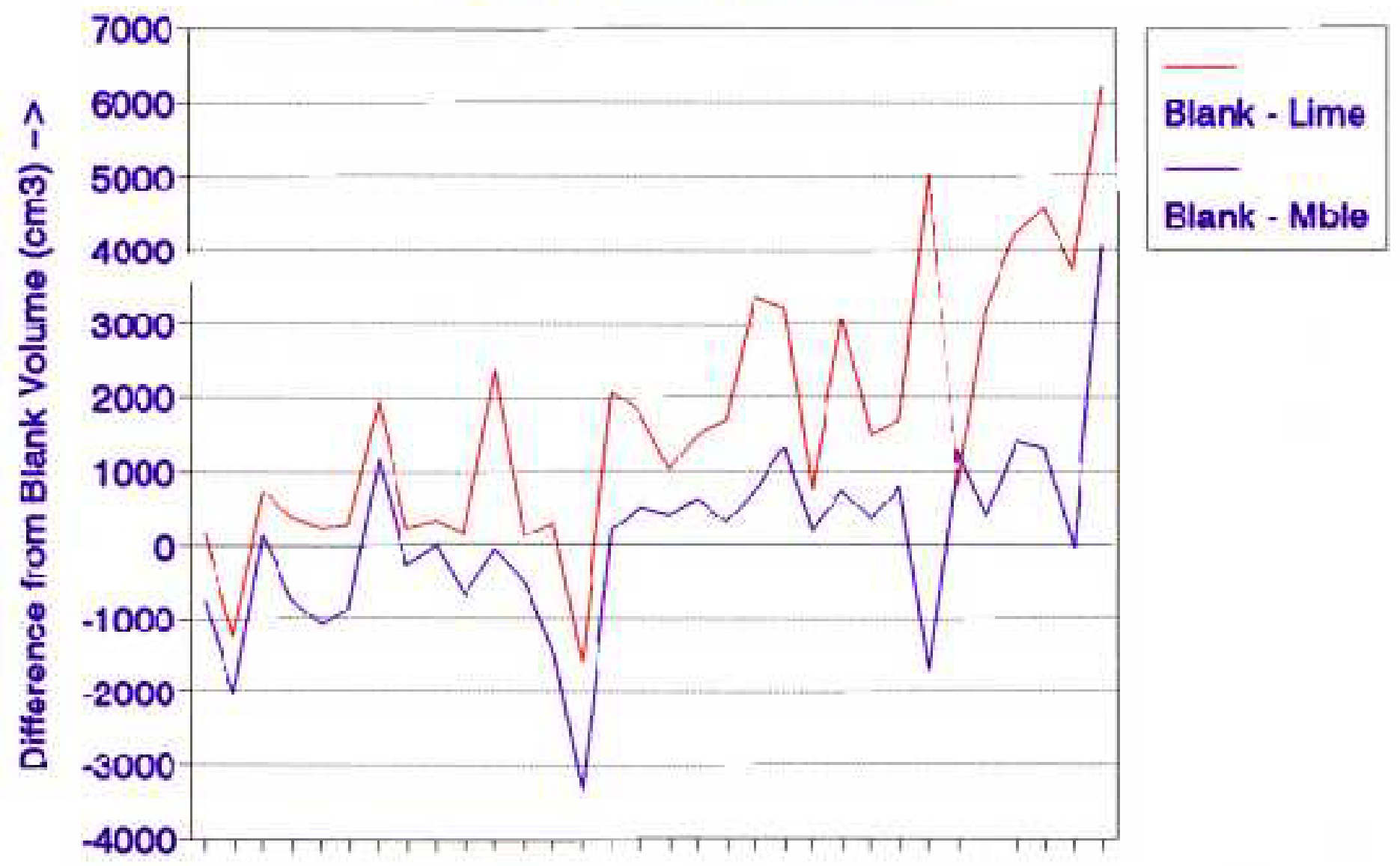

FIGURE 25.-Limestone-marble volume difference. (Variable: volume $\left(\mathrm{cm}^{3}\right)$; material: limestone and marble; site: NAPAP-OH.) 
[Ho] Averages

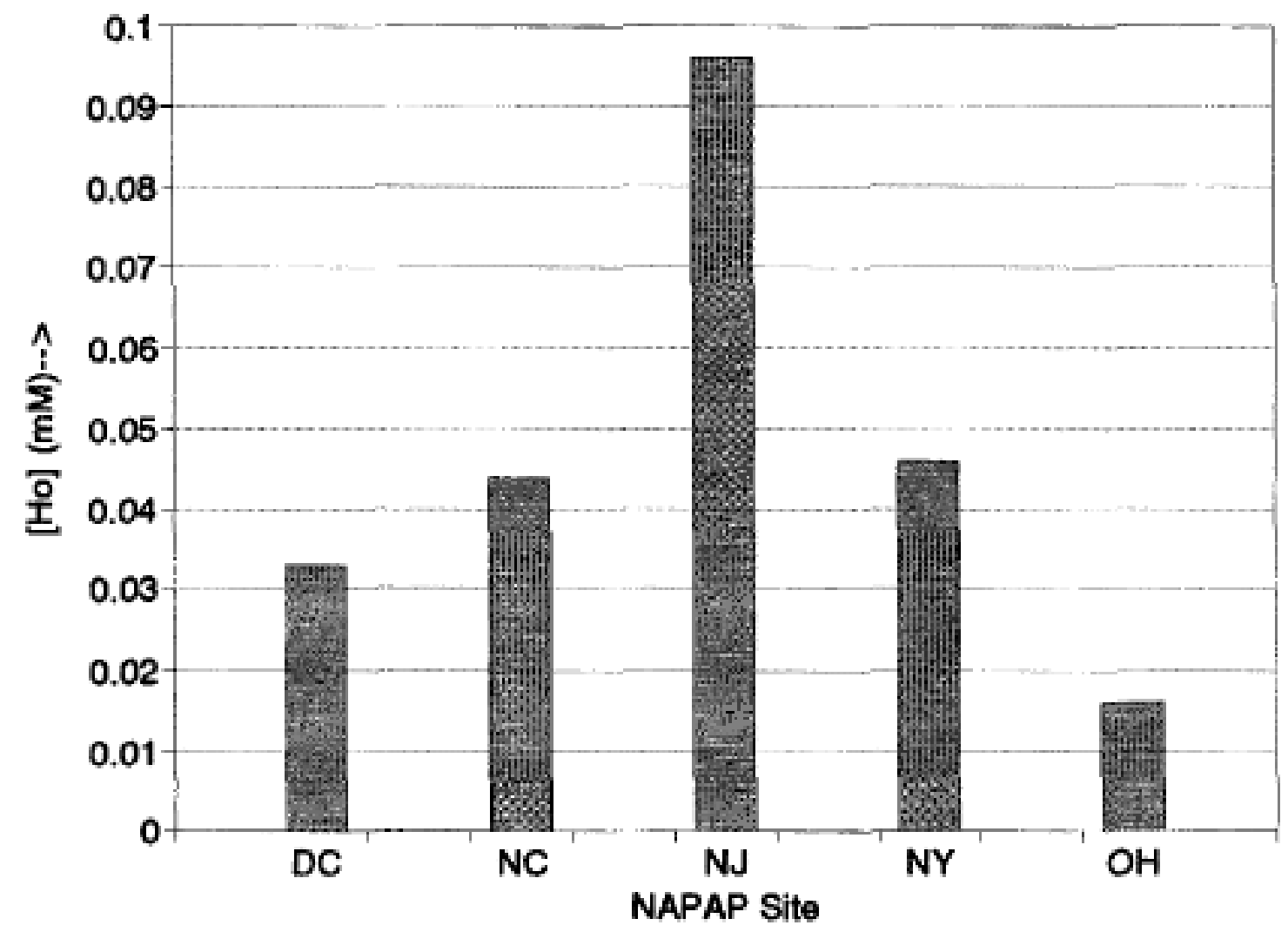

FIGURE 26(avg).-Average $\left[\mathrm{H}^{+}\right]^{\circ}$ concentration. (Variable: $\left\langle\left[\mathrm{H}^{+}\right]^{\circ}\right\rangle$; material: blank; site: NAPAP-all sites.) 
[Ho] Distribution - NAPAP : DC

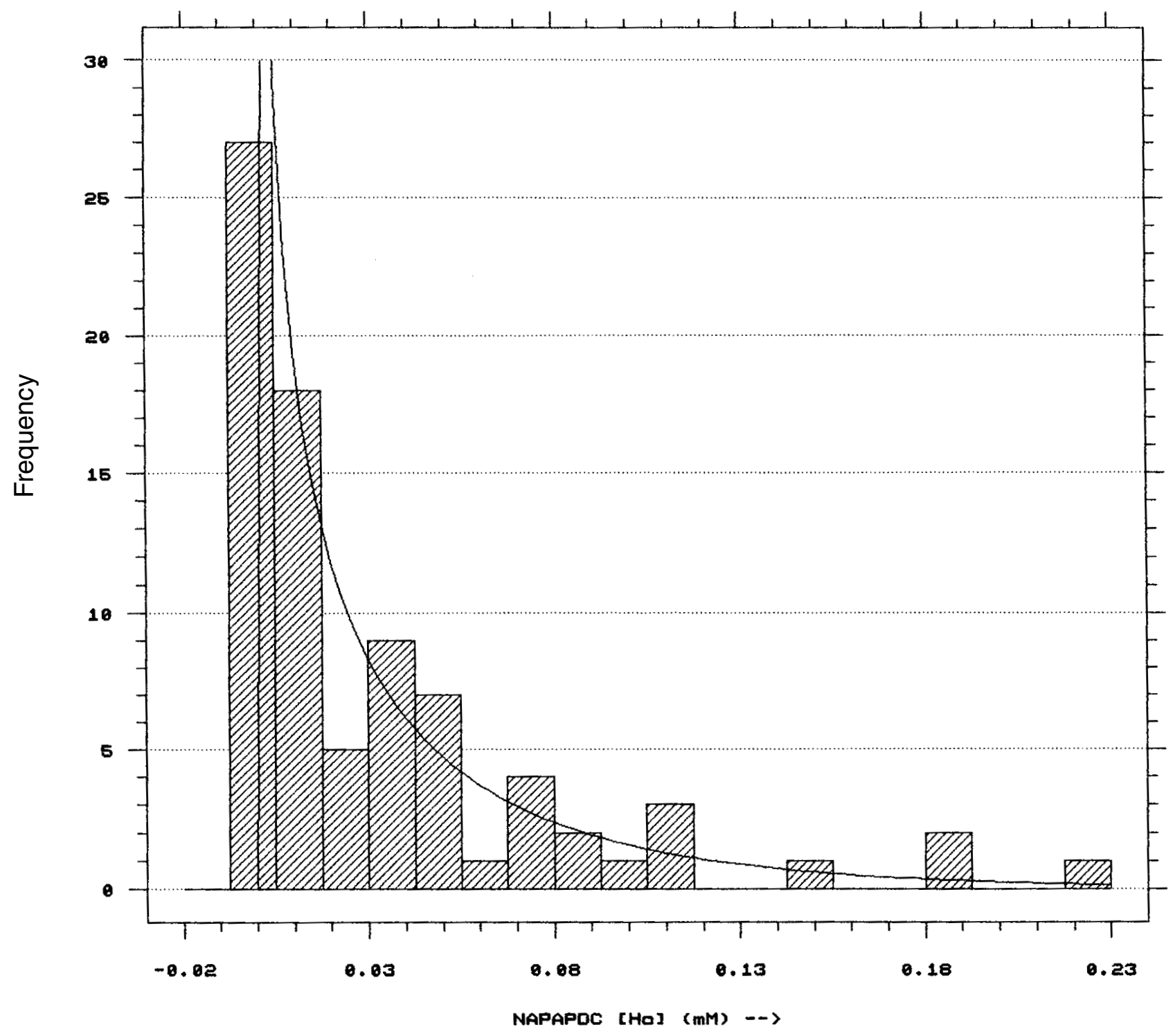

FIGURE 26.-Histograms and model with goodness-of-fit statistics. (Variable: $\mathrm{H}^{+}$concentration; material: blank; site: NAPAP-DC.) 
[Ho] Distribution - NAPAP Data: NY

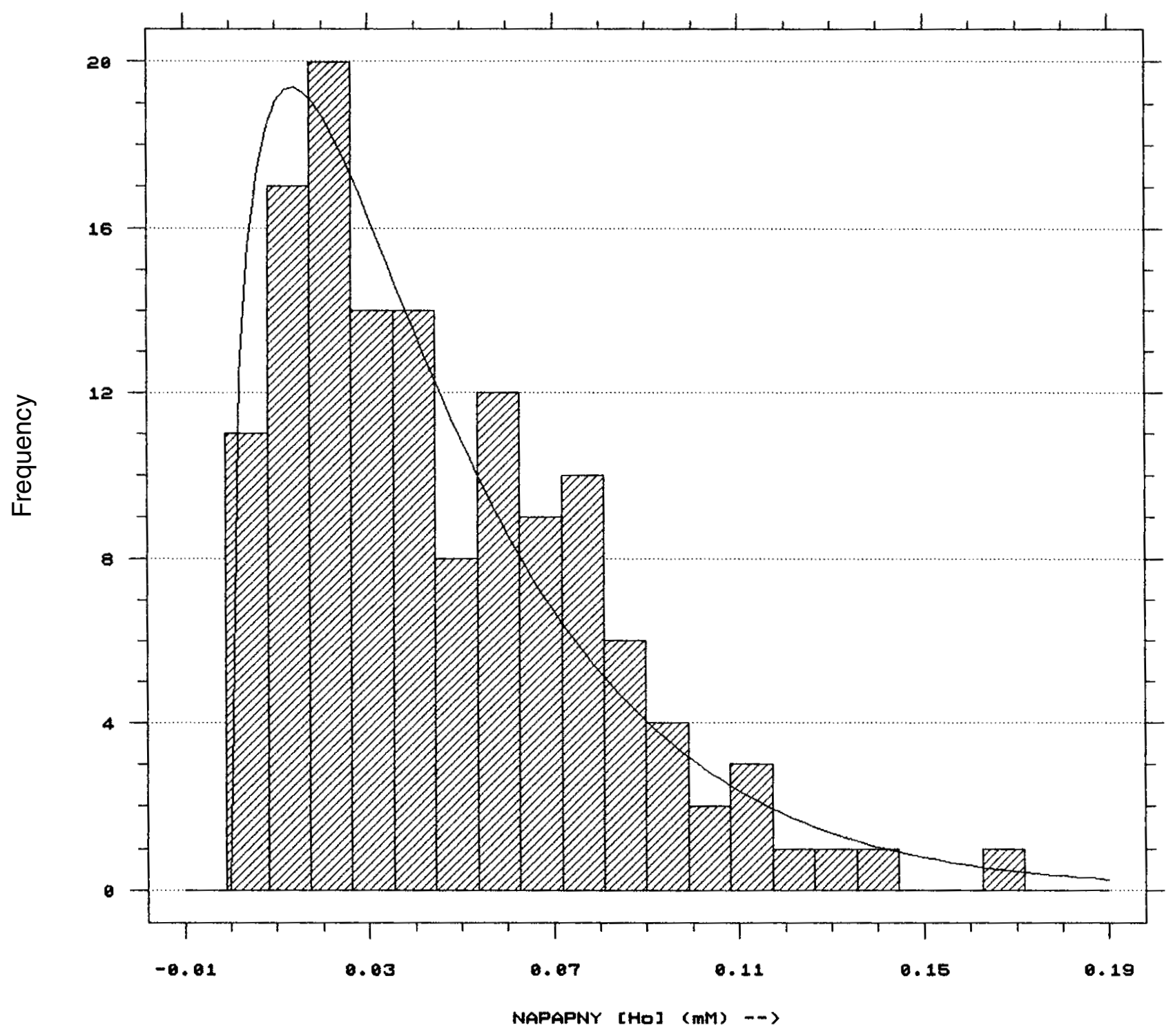

FIGURE 27.-Histograms and model with goodness-of-fit statistics. (Variable: $\mathrm{H}^{+}$concentration; material: blank; site: NAPAP-NY.) 


\section{[Ho] Distribution - NAPAP : NJ}

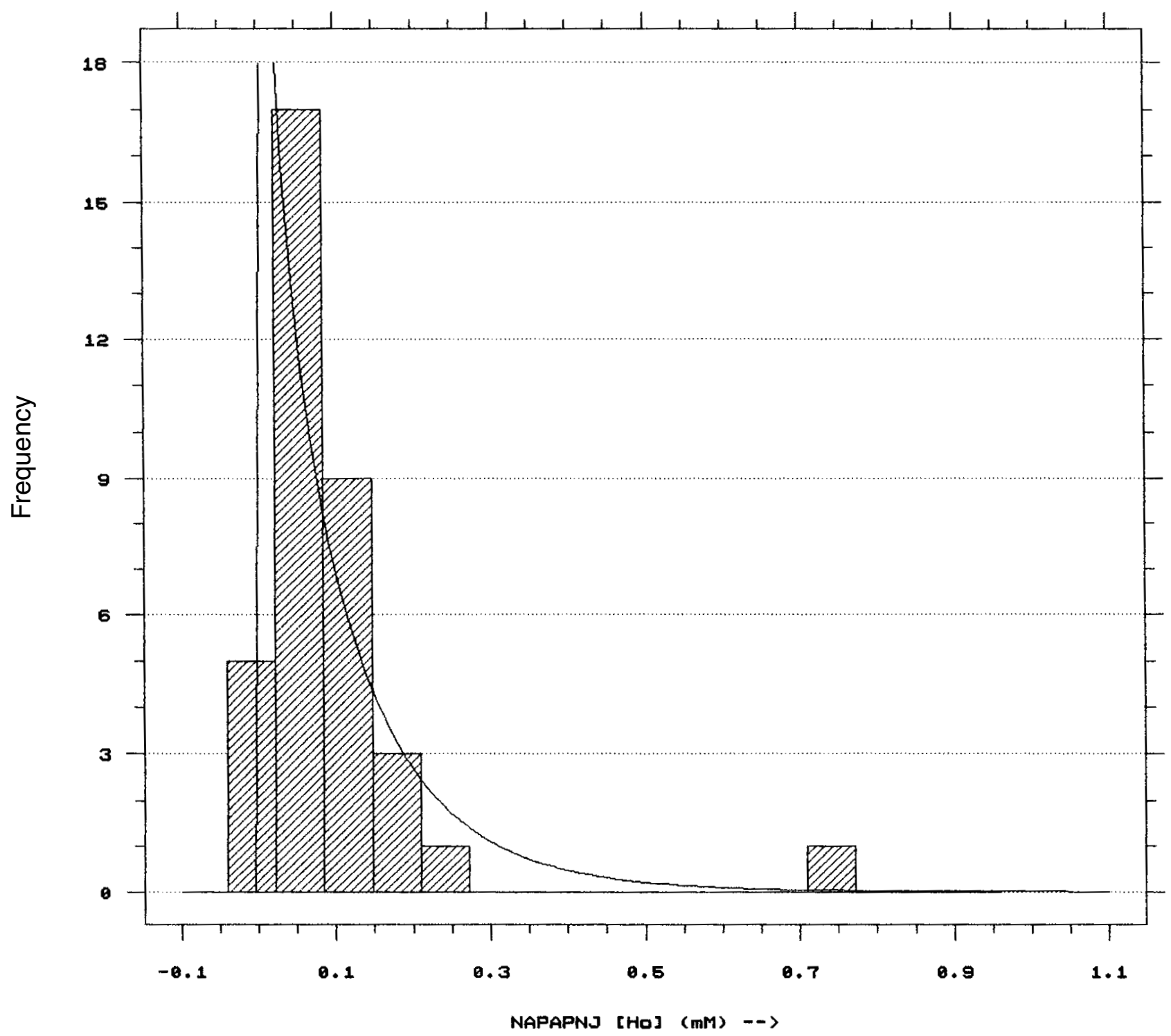

FIGURE 28.-Histograms and model with goodness-of-fit statistics. (Variable: $\mathrm{H}^{+}$concentration; material: blank; site: NAPAP-NJ.) 


\section{[Ho] Distribution - NAPAP : NC}

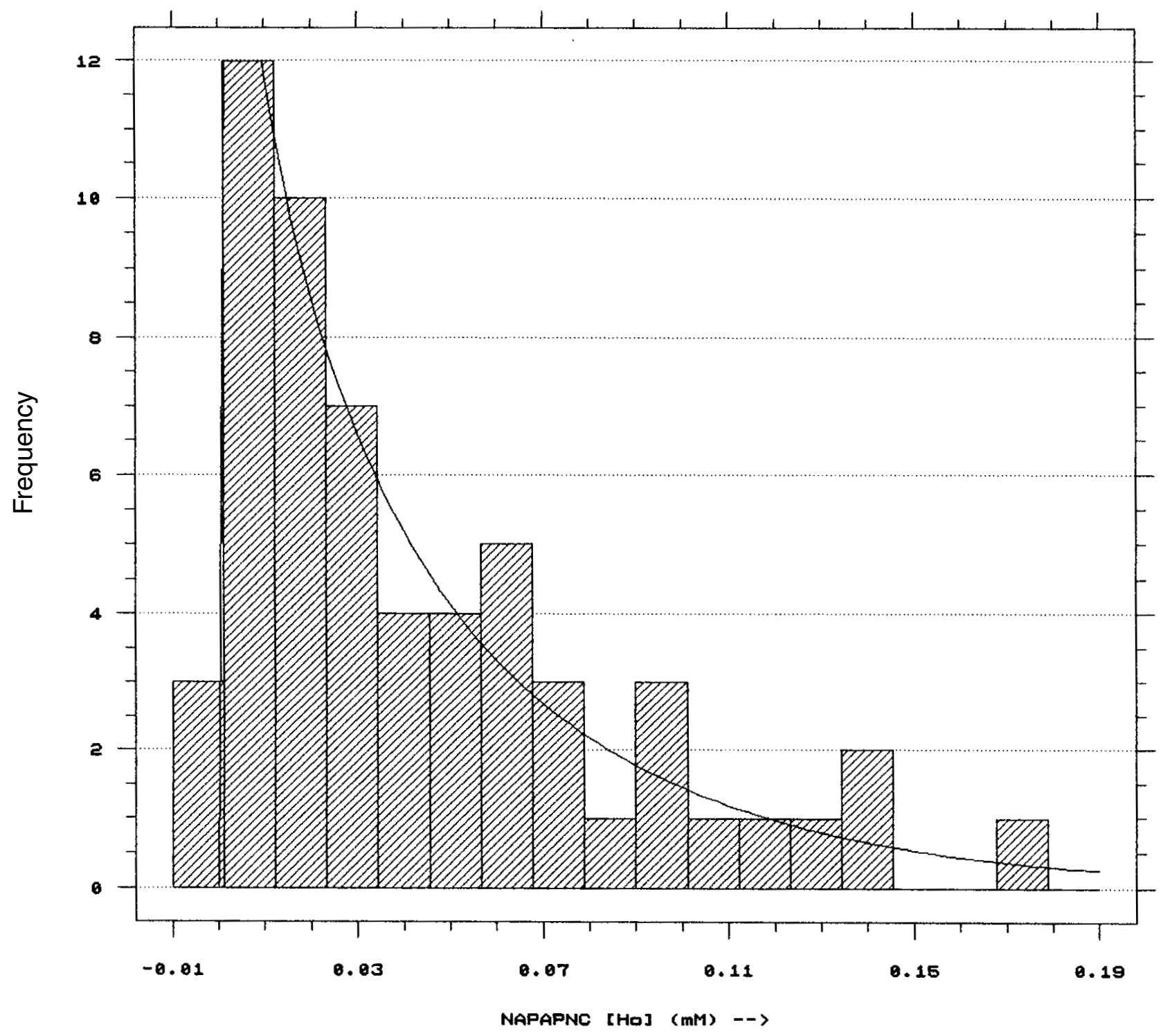

FIGURE 29.-Histograms and model with goodness-of-fit statistics. (Variable: $\mathrm{H}^{+}$concentration; material: blank; site: NAPAP-NC.) 


\section{[Ho] Distribution - NAPAP : OH}

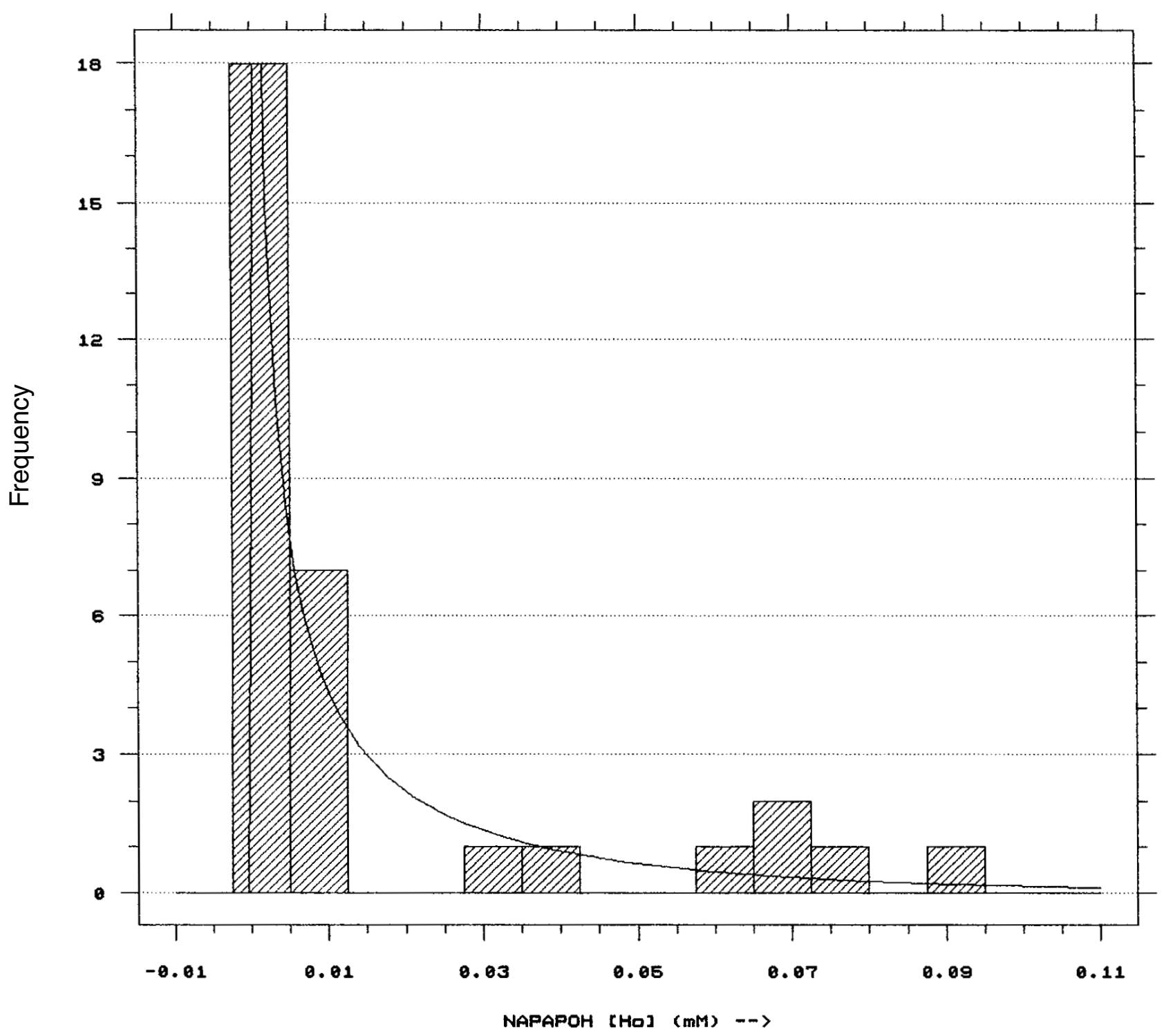

FIGURE 30.-Histograms and model with goodness-of-fit statistics. (Variable: $\mathrm{H}^{+}$concentration; material: blank; site: NAPAP-OH.) 


\section{Average Ho Load}

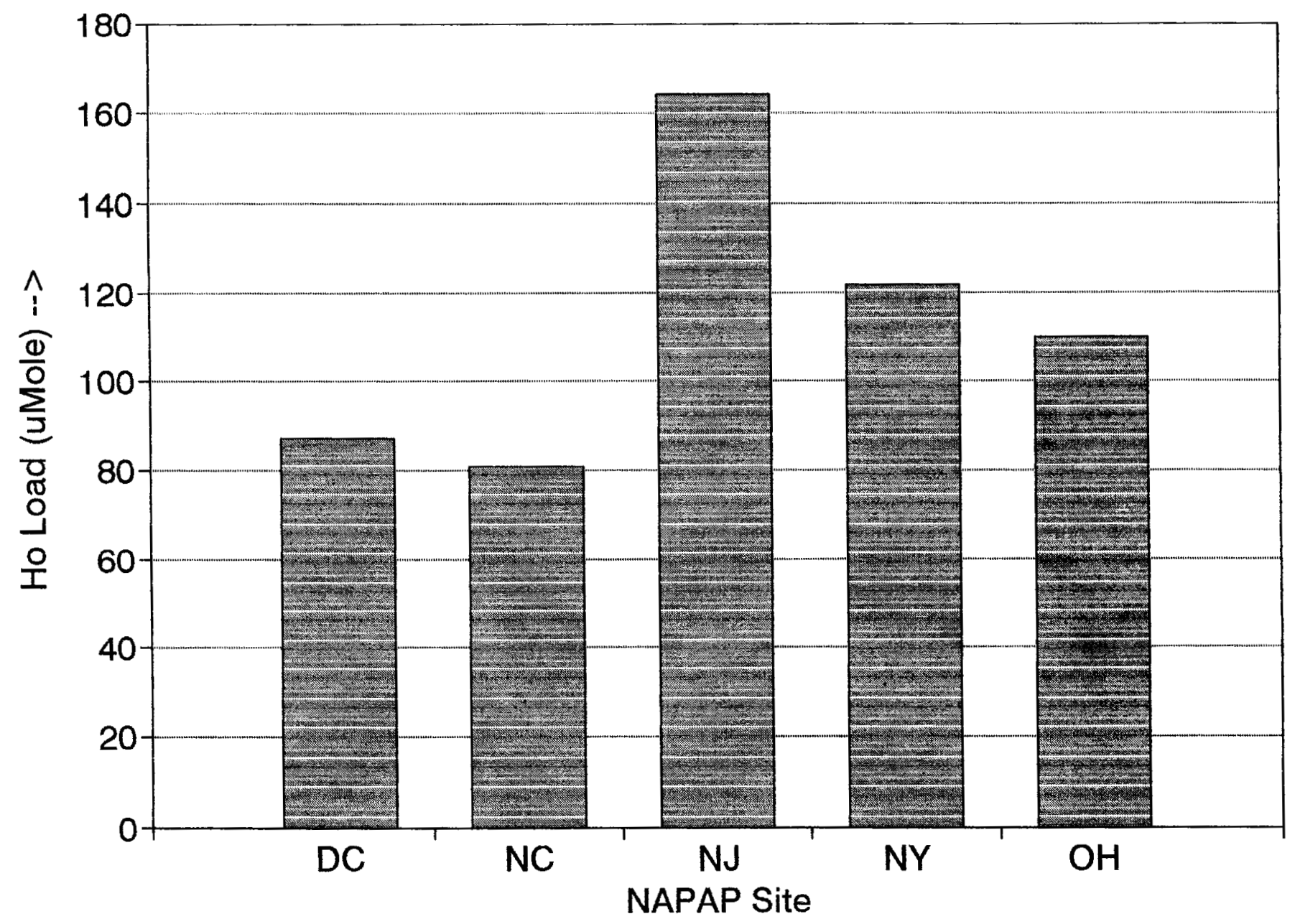

FIGURE 31(avg).-Average $\left[\mathrm{H}^{+}\right]^{\circ}$ load. (Variable: $<\left[\mathrm{H}^{+}\right]^{\circ}$ load $>$; material: blank; site: NAPAP-all sites.) 
HO Load - NAPAP : DC

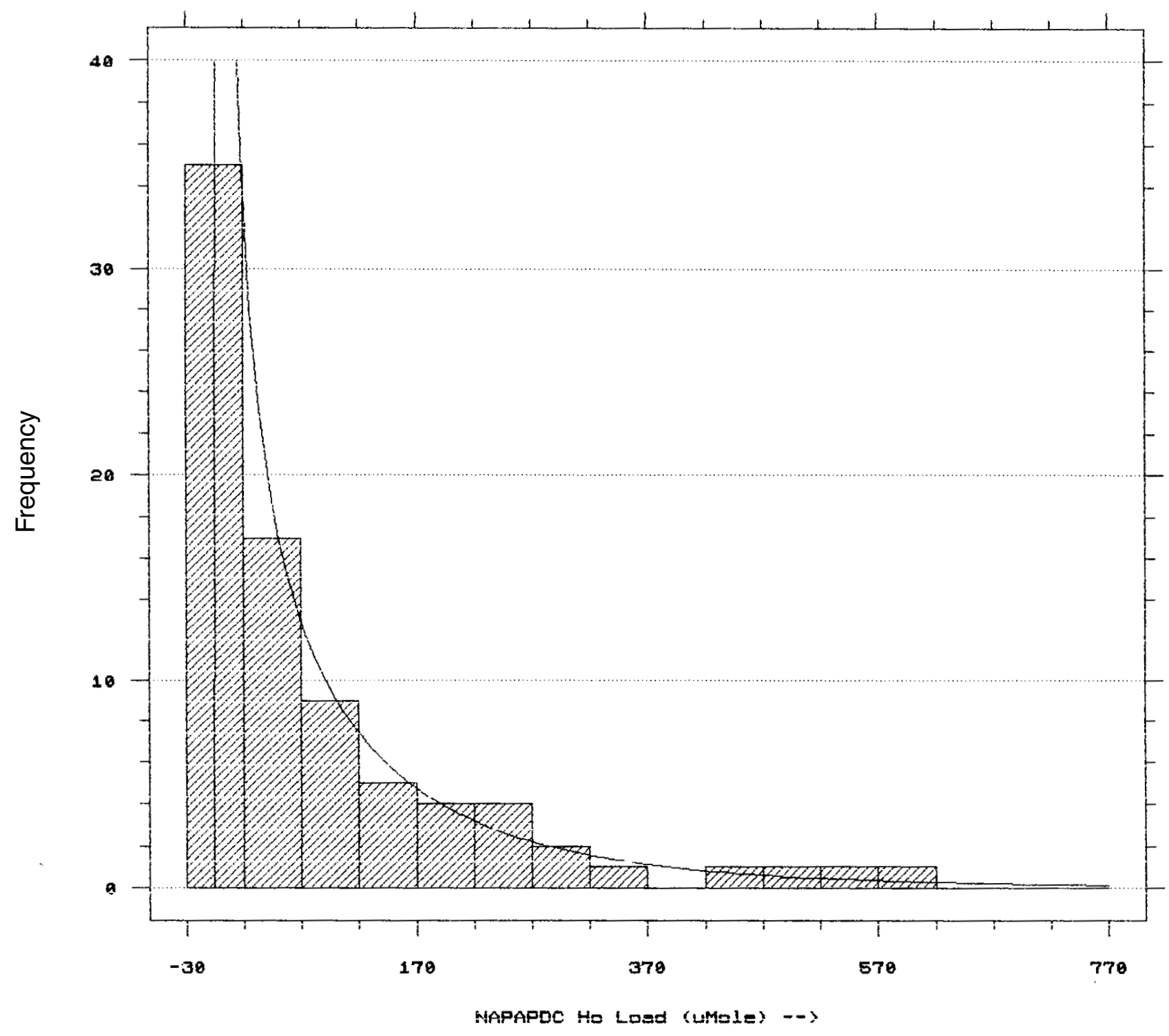

Chisquare Test:

\begin{tabular}{|c|c|c|c|c|c|}
\hline & $\begin{array}{l}\text { Lower } \\
\text { Limit }\end{array}$ & $\begin{array}{l}\text { Upper } \\
\text { Limit }\end{array}$ & $\begin{array}{l}\text { Observed } \\
\text { Frequency }\end{array}$ & $\begin{array}{l}\text { Expected } \\
\text { Frequency }\end{array}$ & Chisquare \\
\hline above & $\begin{array}{r}\text { below } \\
20.00 \\
70.00 \\
120.00 \\
170.00 \\
270.00\end{array}$ & $\begin{array}{r}20.00 \\
70.00 \\
120.00 \\
170.00 \\
270.00\end{array}$ & $\begin{array}{r}35 \\
17 \\
9 \\
5 \\
8 \\
7\end{array}$ & $\begin{array}{r}31.2 \\
19.5 \\
9.4 \\
5.7 \\
6.1 \\
9.0\end{array}$ & $\begin{array}{l}.4582 \\
.3172 \\
.0204 \\
.0813 \\
.5706 \\
.4635\end{array}$ \\
\hline
\end{tabular}

Chisquare $=1.91115$ with 3 a.f. Sig. level $=0.59105$ A

FIGURE 31.-Histograms and model with goodness-of-fit statistics. (Variable: $\mathrm{H}^{+}$load; material: blank; site: NAPAP-DC.) 
Ho Load - NAPAP : NY

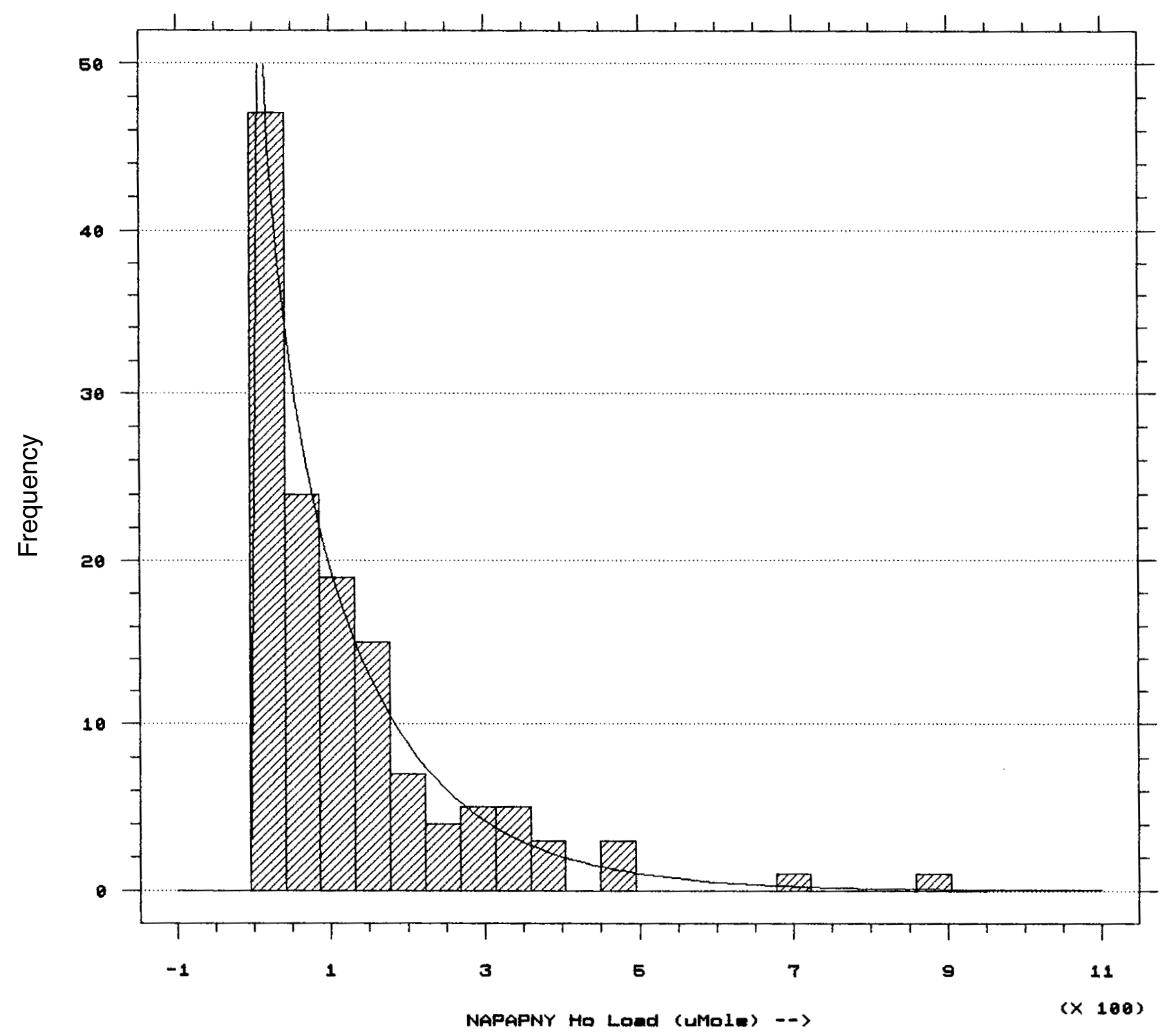

Chisquare Test

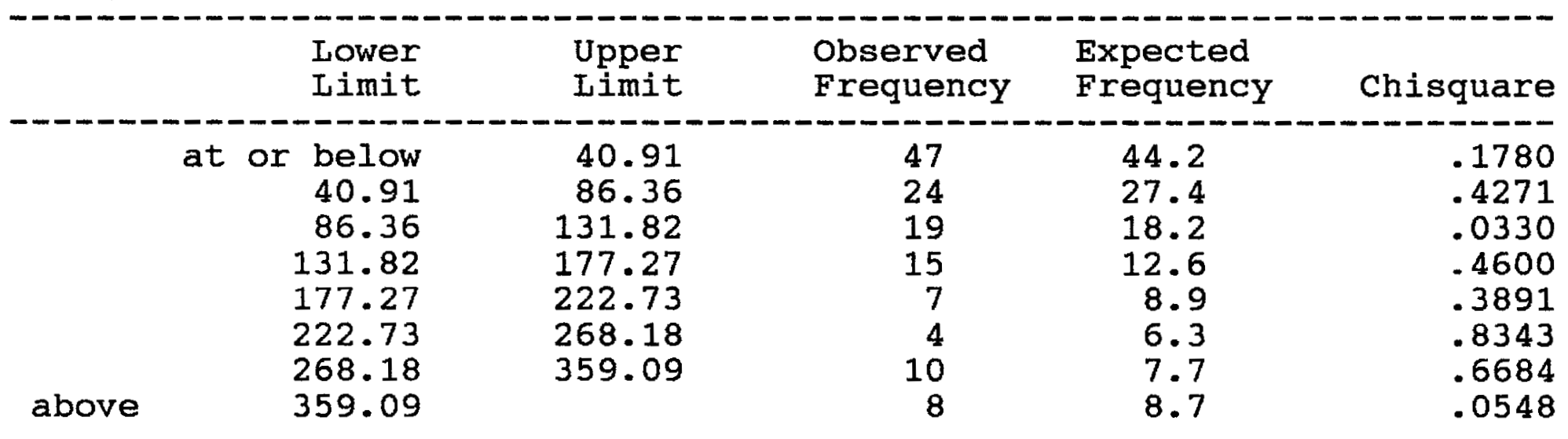

Chisquare $=3.04462$ with 5 d.f. Sig. level $=0.693107$

FIGURE 32.-Histograms and model with goodness-of-fit statistics. (Variable: $\mathrm{H}^{+}$load; material: blank; site: NAPAP-NY.) 


\section{Ho Load - NAPAP : NJ}

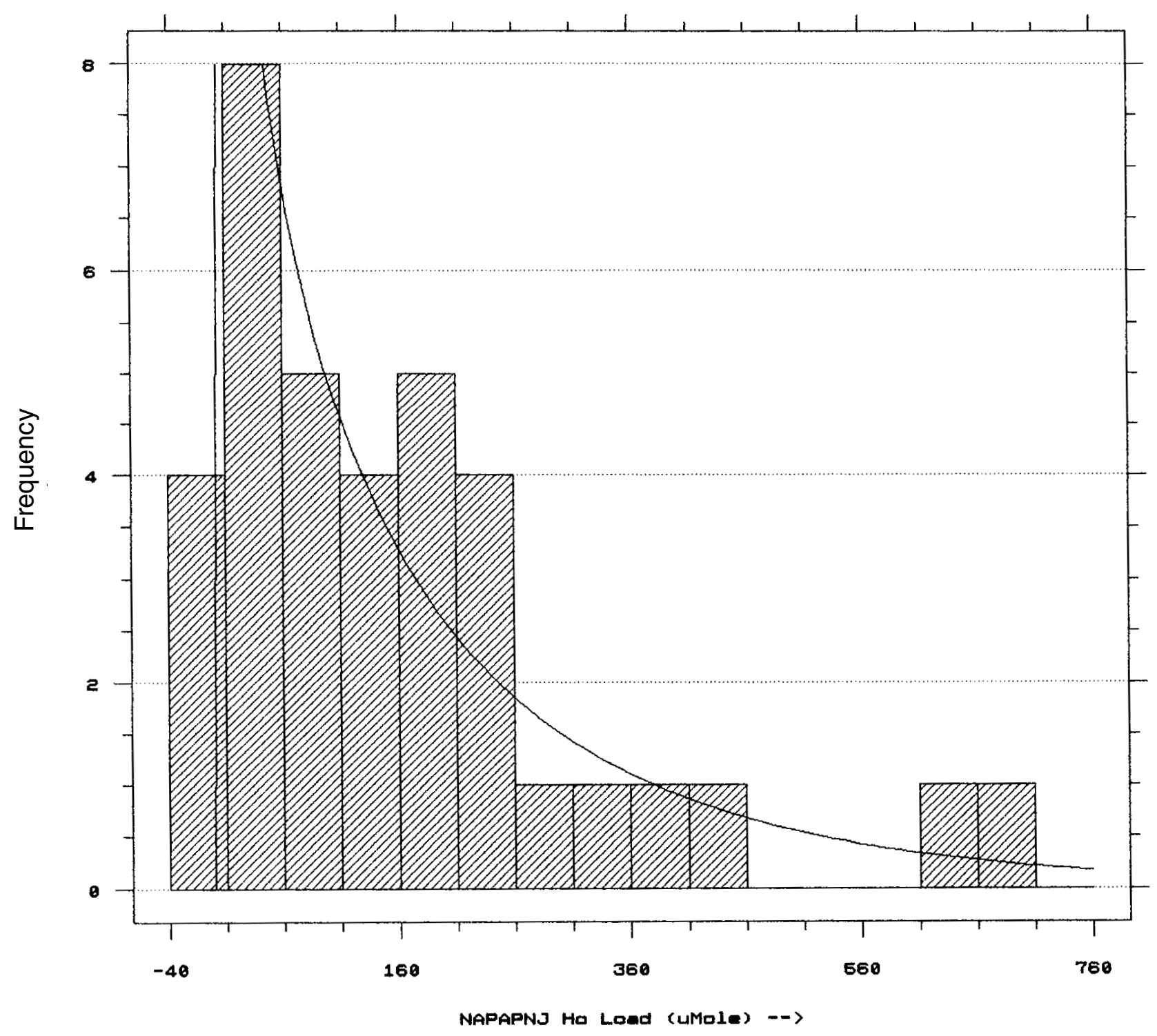

Chisquare Test

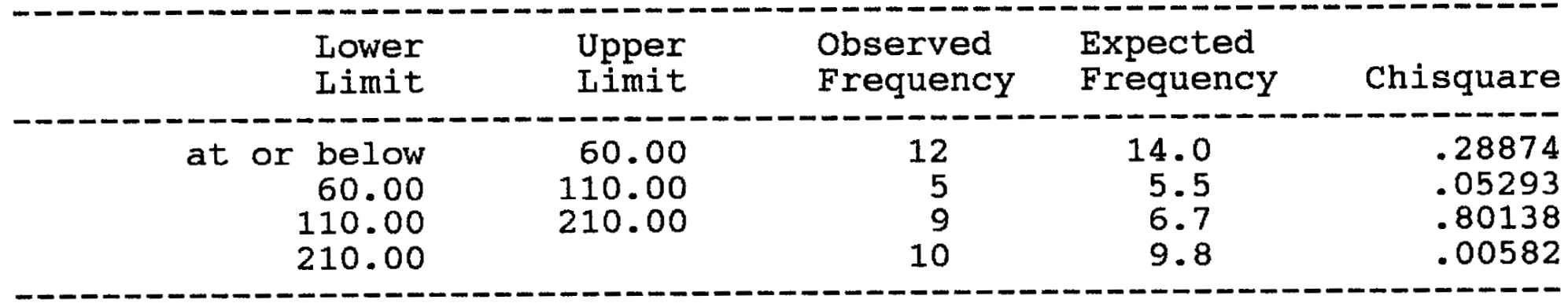

Chisquare $=1.14887$ with 1 d.f. Sig. level $=0.283785$

FIGURE 33.-Histograms and model with goodness-of-fit statistics. (Variable: $\mathrm{H}^{+}$load; material: blank; site: NAPAP-NJ.) 


\section{Ho Load - NAPAP : NC}

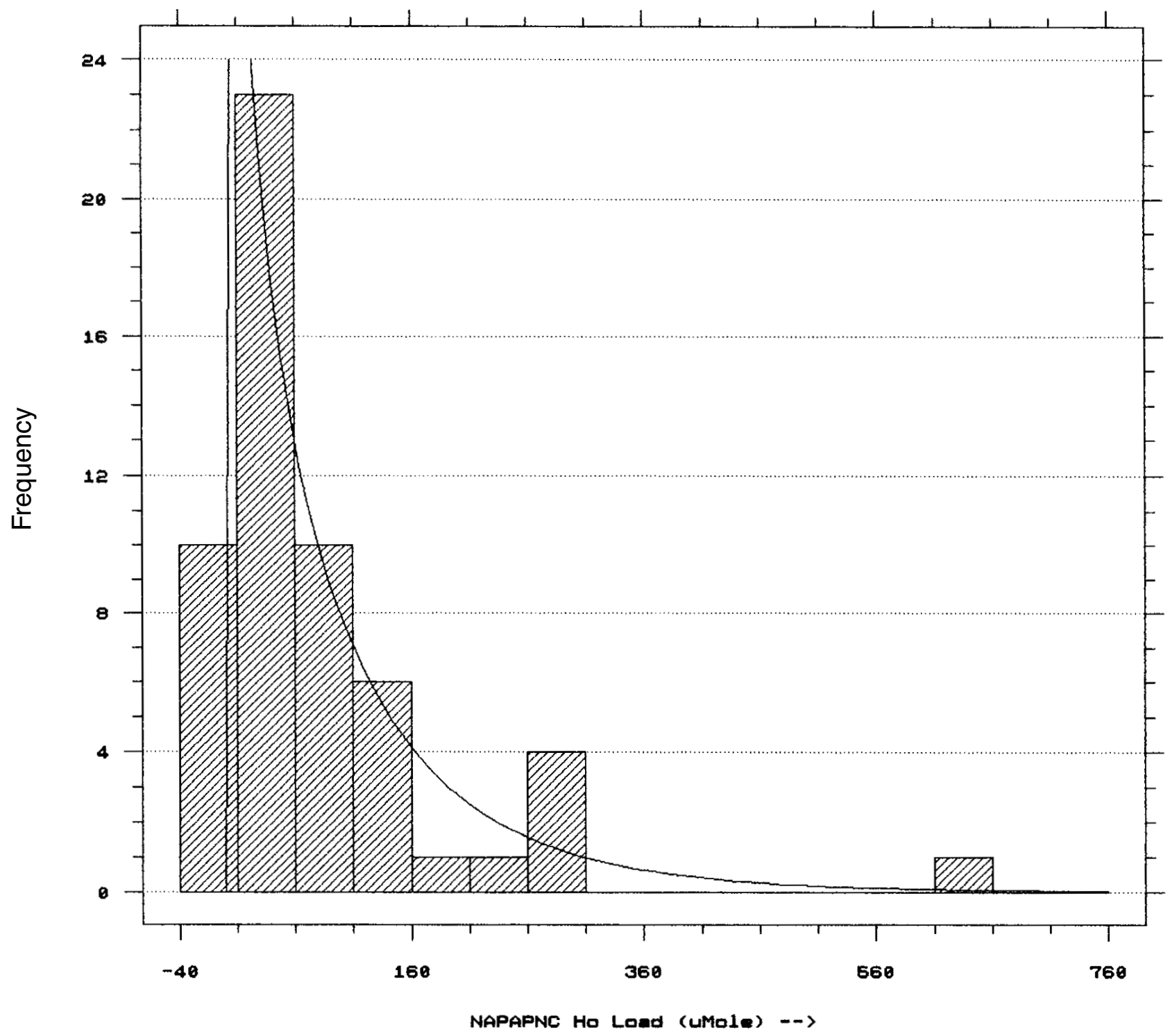

Chisquare Test

\begin{tabular}{|c|c|c|c|c|c|}
\hline & $\begin{array}{l}\text { Lower } \\
\text { Limit }\end{array}$ & $\begin{array}{l}\text { Upper } \\
\text { Limit }\end{array}$ & $\begin{array}{l}\text { Observed } \\
\text { Frequency }\end{array}$ & $\begin{array}{l}\text { Expected } \\
\text { Frequency }\end{array}$ & Chisquare \\
\hline at or & $\begin{array}{r}\text { below } \\
10.00 \\
60.00 \\
110.00 \\
160.00\end{array}$ & $\begin{array}{r}10.00 \\
60.00 \\
110.00 \\
160.00\end{array}$ & $\begin{array}{r}10 \\
23 \\
10 \\
6 \\
7\end{array}$ & $\begin{array}{r}11.5 \\
20.5 \\
9.6 \\
5.4 \\
9.0\end{array}$ & $\begin{array}{l}.2057 \\
.2973 \\
.0211 \\
.0671 \\
.4368\end{array}$ \\
\hline
\end{tabular}

Chisquare $=1.02803$ with 2 d.f. Sig. level $=0.598089$

FIGURE 34.-Histograms and model with goodness-of-fit statistics. (Variable: $\mathrm{H}^{+}$load; material: blank; site: NAPAP-NC.) 


\section{Averages of NAPAP [SO4] \\ Marble and Limestone}

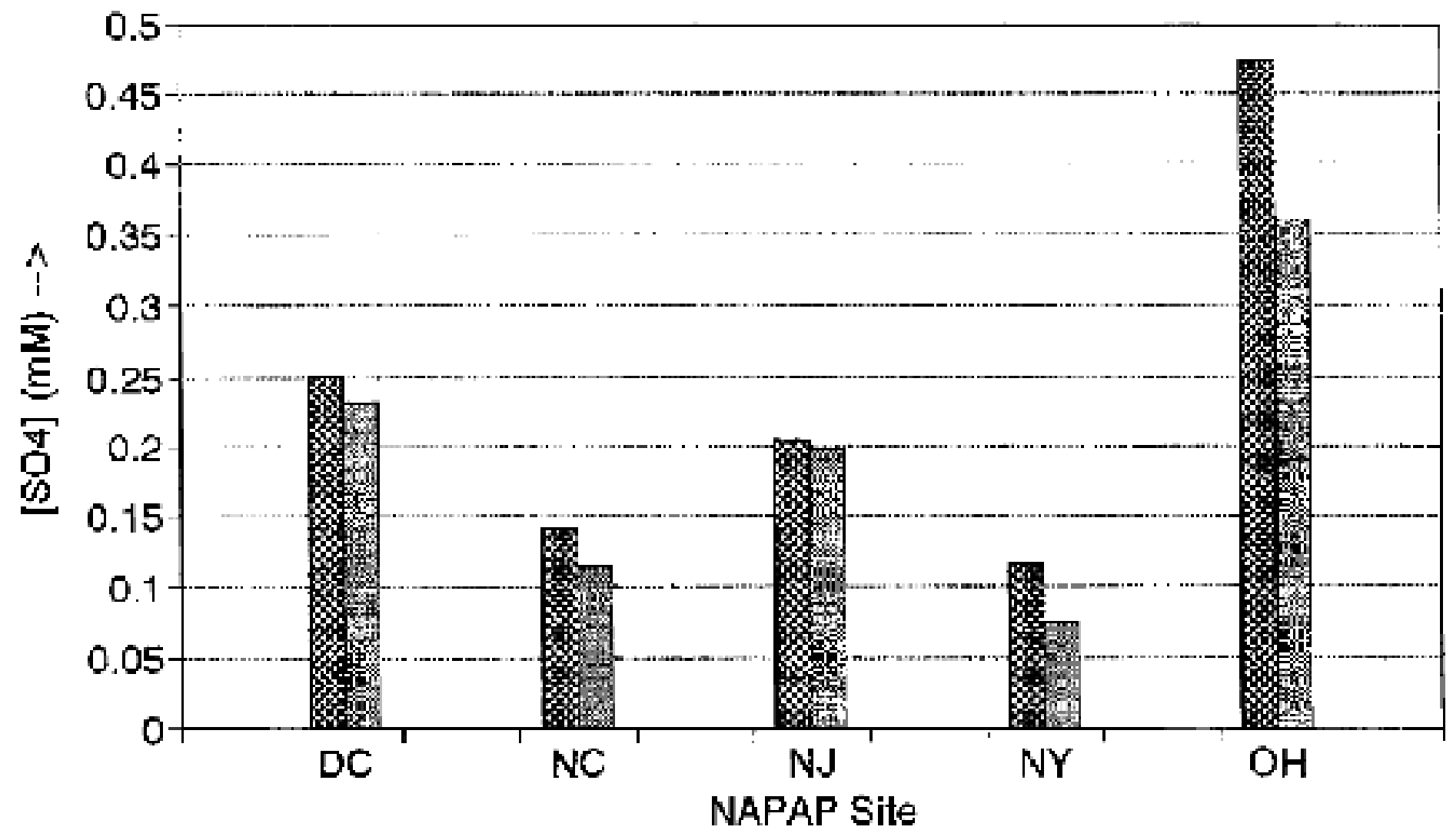

\section{Limestone [exis Marble}

FIGURE 36(avg).-Average $\mathrm{SO}_{4}{ }^{2-}$ concentration. (Variable: $<\left[\mathrm{SO}_{4}{ }^{2-}\right]>$; material: limestone and marble; site: NAPAP-all sites.) 
A [504] off Limestone - NAPAP : DC

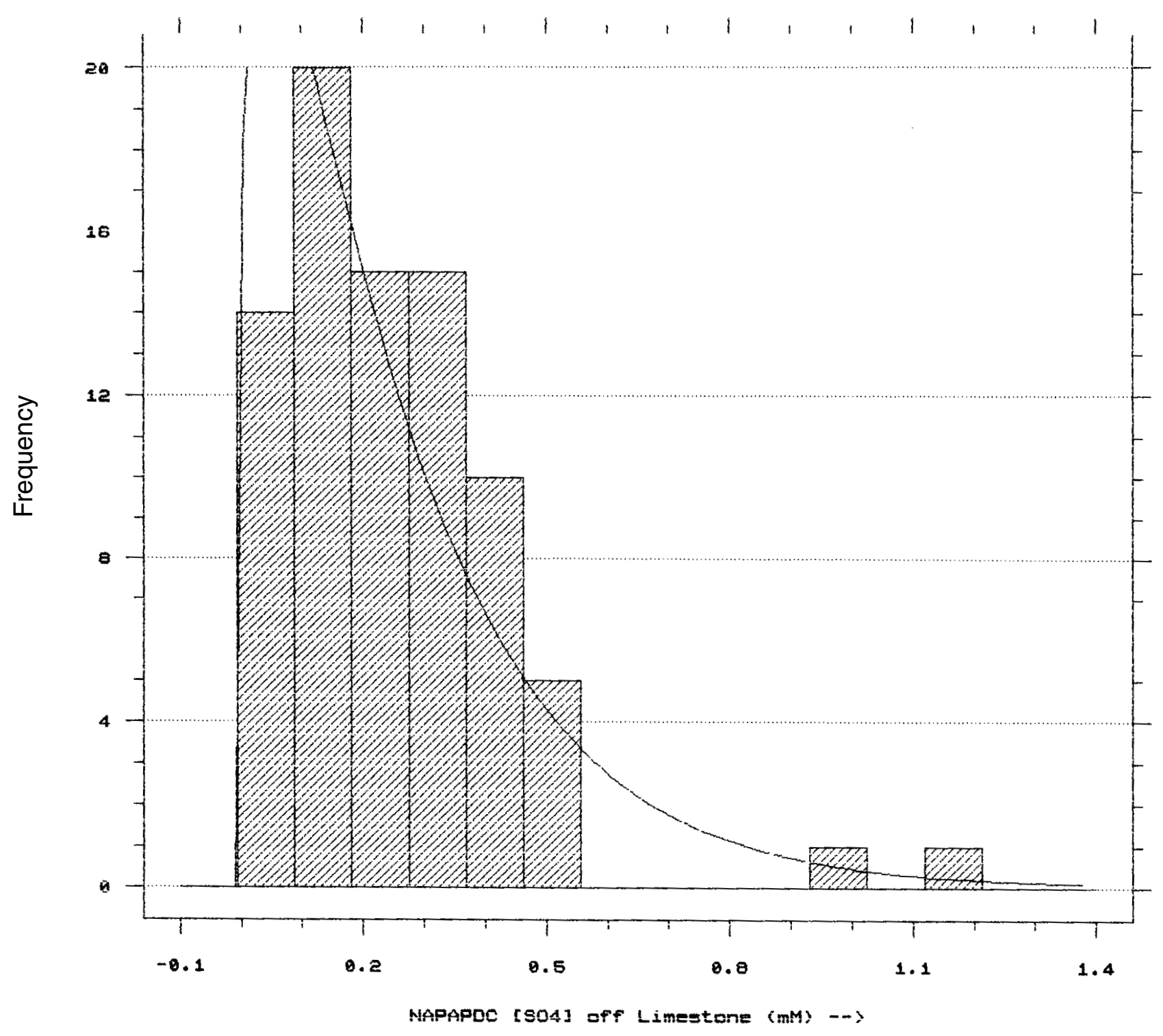

Chisquare Tiest

\begin{tabular}{|c|c|c|c|c|c|}
\hline & $\begin{array}{l}\text { Lower } \\
\text { Limit }\end{array}$ & $\begin{array}{l}\text { Upper } \\
\text { Iimit }\end{array}$ & $\begin{array}{l}\text { Observed } \\
\text { Frequency }\end{array}$ & $\begin{array}{l}\text { Expected } \\
\text { Frequency }\end{array}$ & Chisquare \\
\hline above & $\begin{array}{r}\text { below } \\
.100 \\
.200 \\
.300 \\
.400 \\
.500\end{array}$ & $\begin{array}{l}.100 \\
.200 \\
.300 \\
.400 \\
.500\end{array}$ & $\begin{array}{r}18 \\
23 \\
16 \\
10 \\
10 \\
4\end{array}$ & $\begin{array}{r}23.5 \\
19.3 \\
13.3 \\
8.8 \\
5.8 \\
10.3\end{array}$ & $\begin{array}{r}1.302 \\
.713 \\
.544 \\
.152 \\
3.106 \\
3.815\end{array}$ \\
\hline
\end{tabular}

Chisquare $=9.63162$ with 3 d. I. Sig. levei $=0.0219716$

FIGURE 36.-A, Histograms and model with goodness-of-fit statistics. (Variable: $\mathrm{SO}_{4}{ }^{2-}$; material: limestone; site: NAPAP-DC.) B, Histograms and model with goodness-of-fit statistics. (Variable: $\mathrm{SO}_{4}{ }^{2-}$; material: marble; site: NAPAP-DC.) 
B EOY4] off Marble - MAPAP : DC

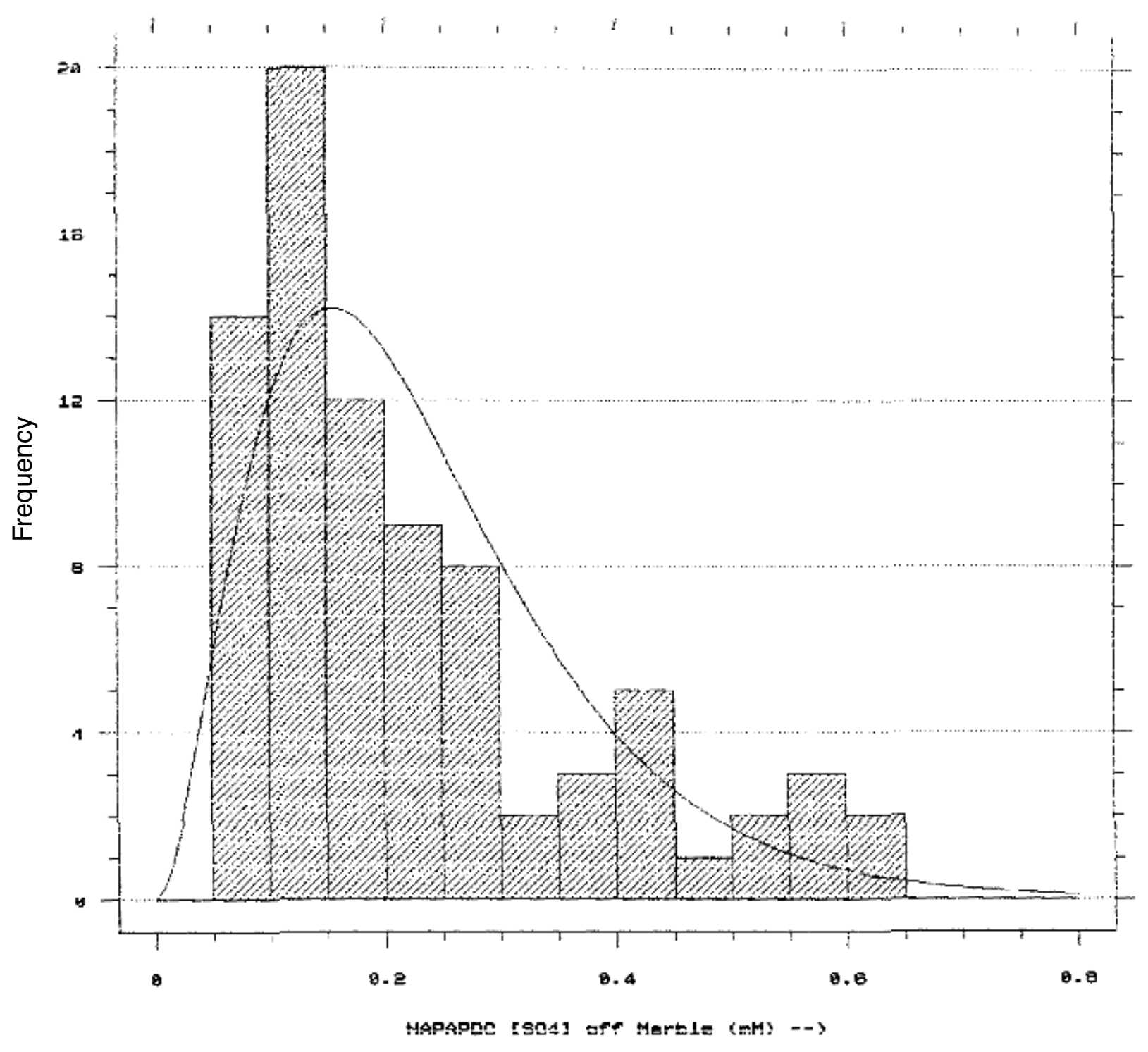

Chisquare Test

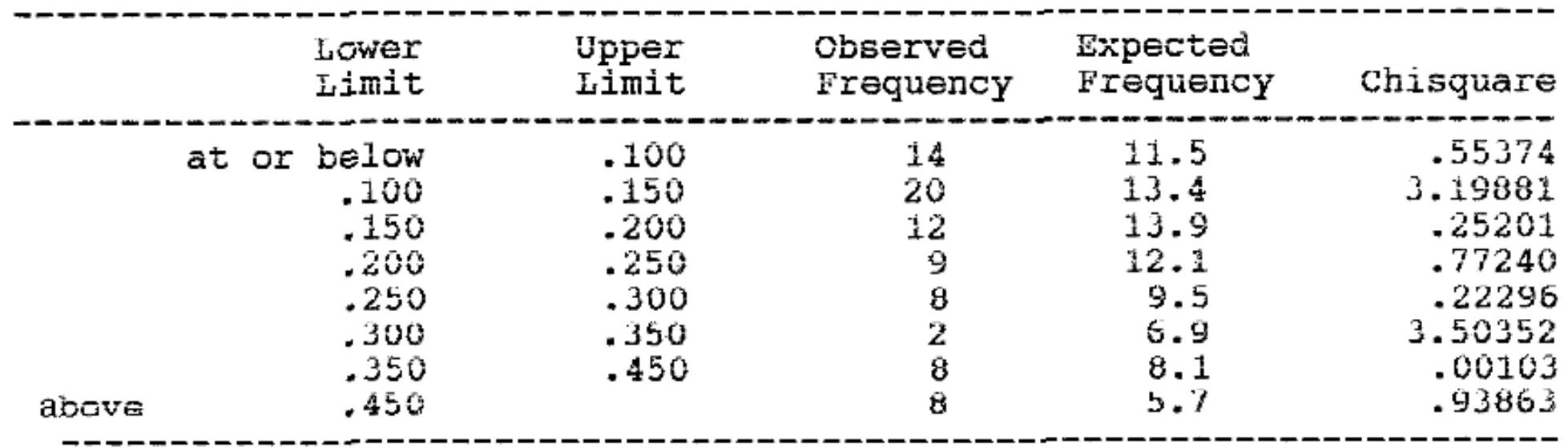

Chisquare $=9.4431$ with 5. a.f. Sig. level $=0.0926429$ 


\section{[S04] Off Limestone - NAPAP : NY}

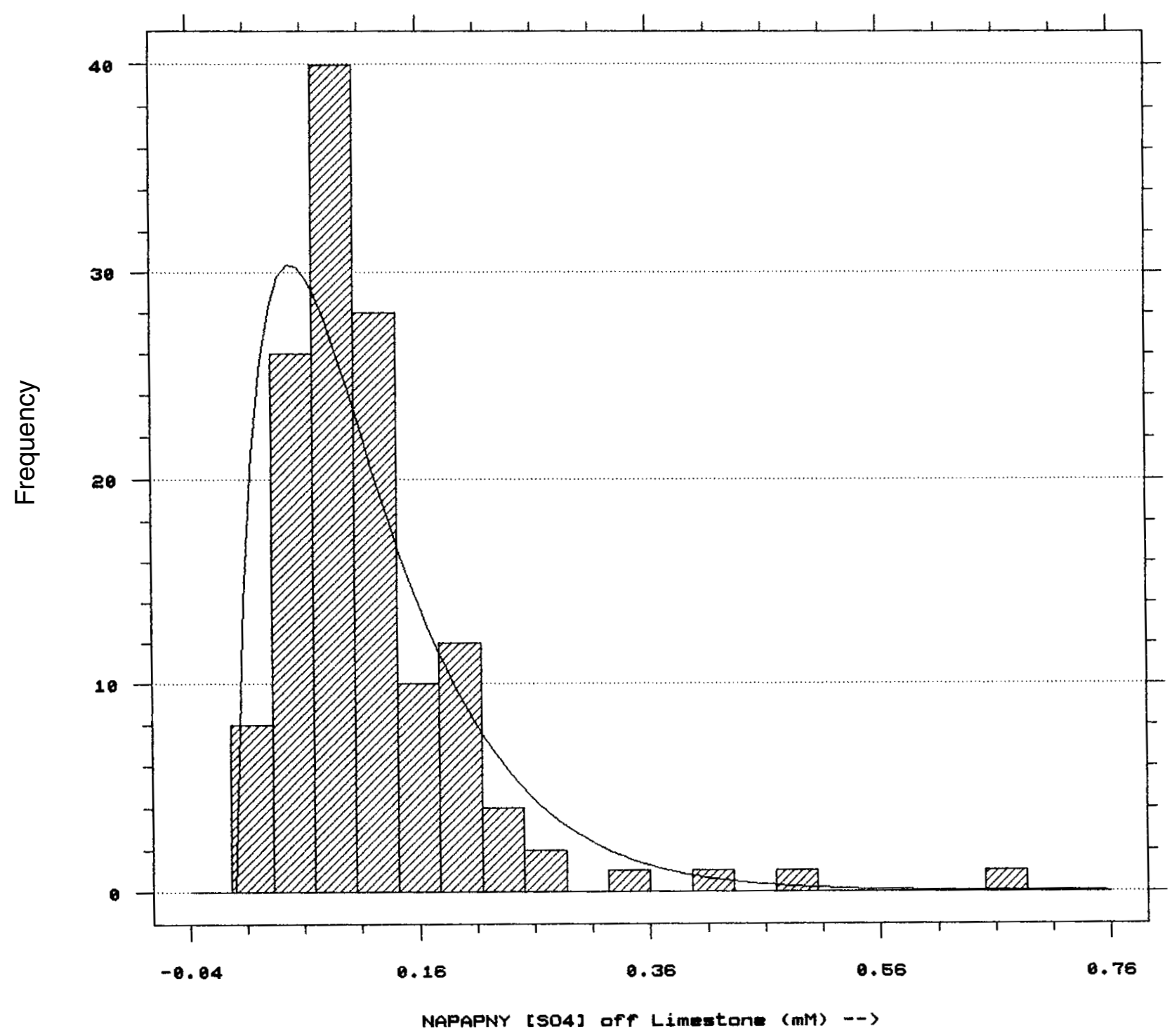

Chisquare Test

\begin{tabular}{rrrrr}
$\begin{array}{c}\text { Lower } \\
\text { Limit }\end{array}$ & $\begin{array}{l}\text { Upper } \\
\text { Limit }\end{array}$ & $\begin{array}{l}\text { Observed } \\
\text { Frequency }\end{array}$ & $\begin{array}{l}\text { Expected } \\
\text { Frequency }\end{array}$ & Chisquare \\
\hline at or below & .0327 & 8 & 17.5 & 5.157 \\
.0327 & .0691 & 26 & 29.8 & .496 \\
.0691 & .1055 & 40 & 26.3 & 7.079 \\
.1055 & .1418 & 28 & 19.9 & 3.280 \\
.1418 & .1782 & 10 & 14.0 & 1.150 \\
.1782 & .2145 & 12 & 9.5 & .683 \\
.2145 & .2509 & 4 & 6.2 & .787 \\
.2509 & & 6 & 10.7 & 2.068
\end{tabular}

Chisquare $=20.6998$ with 5 d.f. Sig. level $=9.2296 \mathrm{E}-4$

FIGURE 37.-A, Histograms and model with goodness-of-fit statistics. (Variable: $\mathrm{SO}_{4}{ }^{2-}$; material: limestone; site: NAPAP-NY.) B, Histograms and model with goodness-of-fit statistics. (Variable: $\mathrm{SO}_{4}{ }^{2-}$; material: marble; site: NAPAP-NY.) 


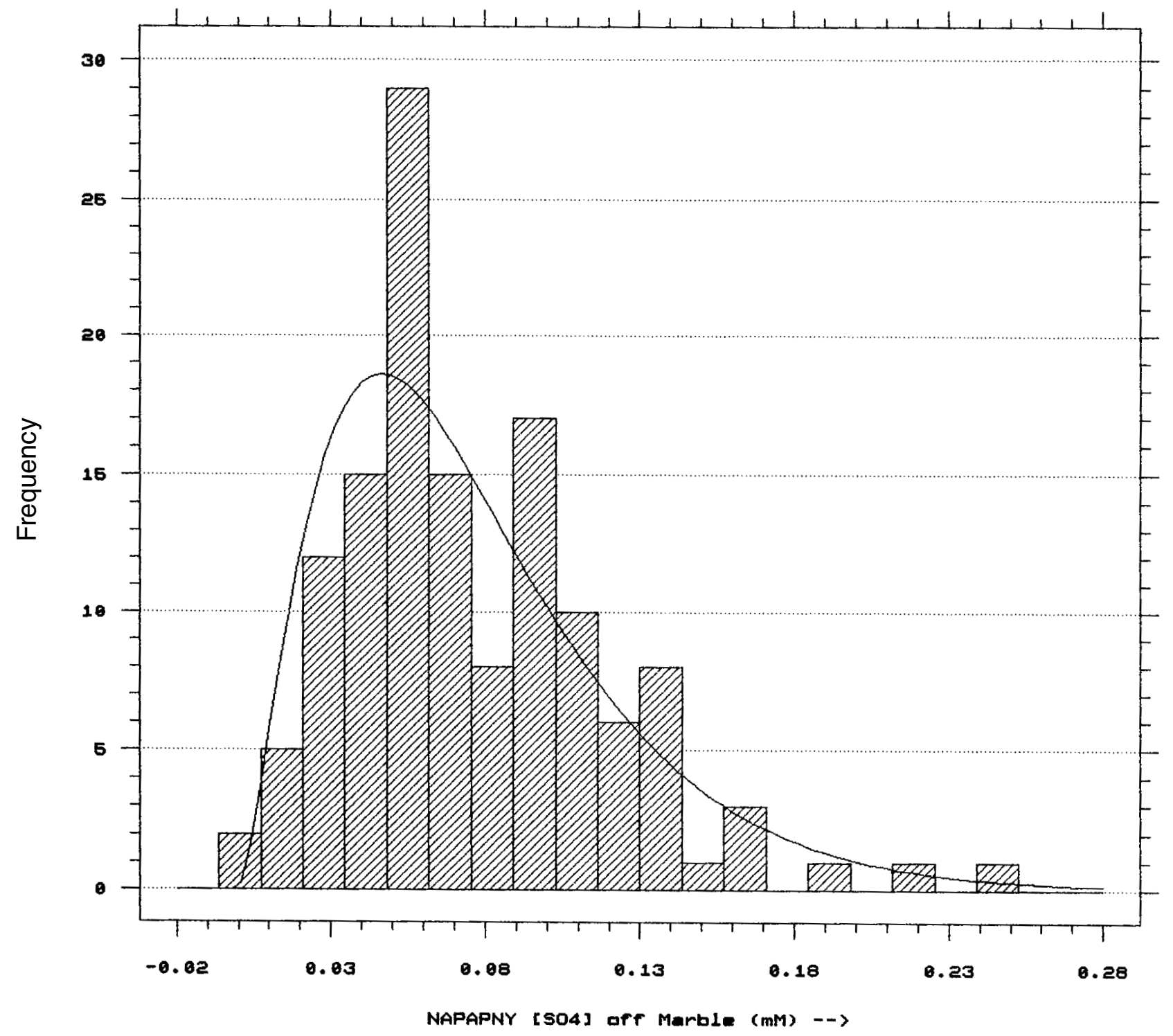

Chisquare Test

\begin{tabular}{|c|c|c|c|c|c|}
\hline & $\begin{array}{l}\text { Lower } \\
\text { Limit }\end{array}$ & $\begin{array}{l}\text { Upper } \\
\text { Limit }\end{array}$ & $\begin{array}{l}\text { Observed } \\
\text { Frequency }\end{array}$ & $\begin{array}{l}\text { Expected } \\
\text { Frequency }\end{array}$ & Chisquare \\
\hline above & $\begin{array}{l}\text { below } \\
.0209 \\
.0345 \\
.0482 \\
.0618 \\
.0755 \\
.0891 \\
.1027 \\
.1164 \\
.1300 \\
.1573\end{array}$ & $\begin{array}{l}.0209 \\
.0345 \\
.0482 \\
.0618 \\
.0755 \\
.0891 \\
.1027 \\
.1164 \\
.1300 \\
.1573\end{array}$ & $\begin{array}{r}7 \\
12 \\
15 \\
29 \\
15 \\
8 \\
17 \\
10 \\
6 \\
9 \\
6\end{array}$ & $\begin{array}{r}9.3 \\
15.4 \\
18.3 \\
18.1 \\
16.2 \\
13.6 \\
11.0 \\
8.5 \\
6.5 \\
8.4 \\
8.7\end{array}$ & $\begin{array}{r}.5655 \\
.7468 \\
.5842 \\
6.5845 \\
.0894 \\
2.3213 \\
3.3250 \\
.2487 \\
.0377 \\
.0430 \\
.8578\end{array}$ \\
\hline
\end{tabular}

Chisquare $=15.404$ with 8 d.f. Sig. level $=0.0517499$ 


\section{$A$ \\ [504] off Limestone - NAPAP : NJ}

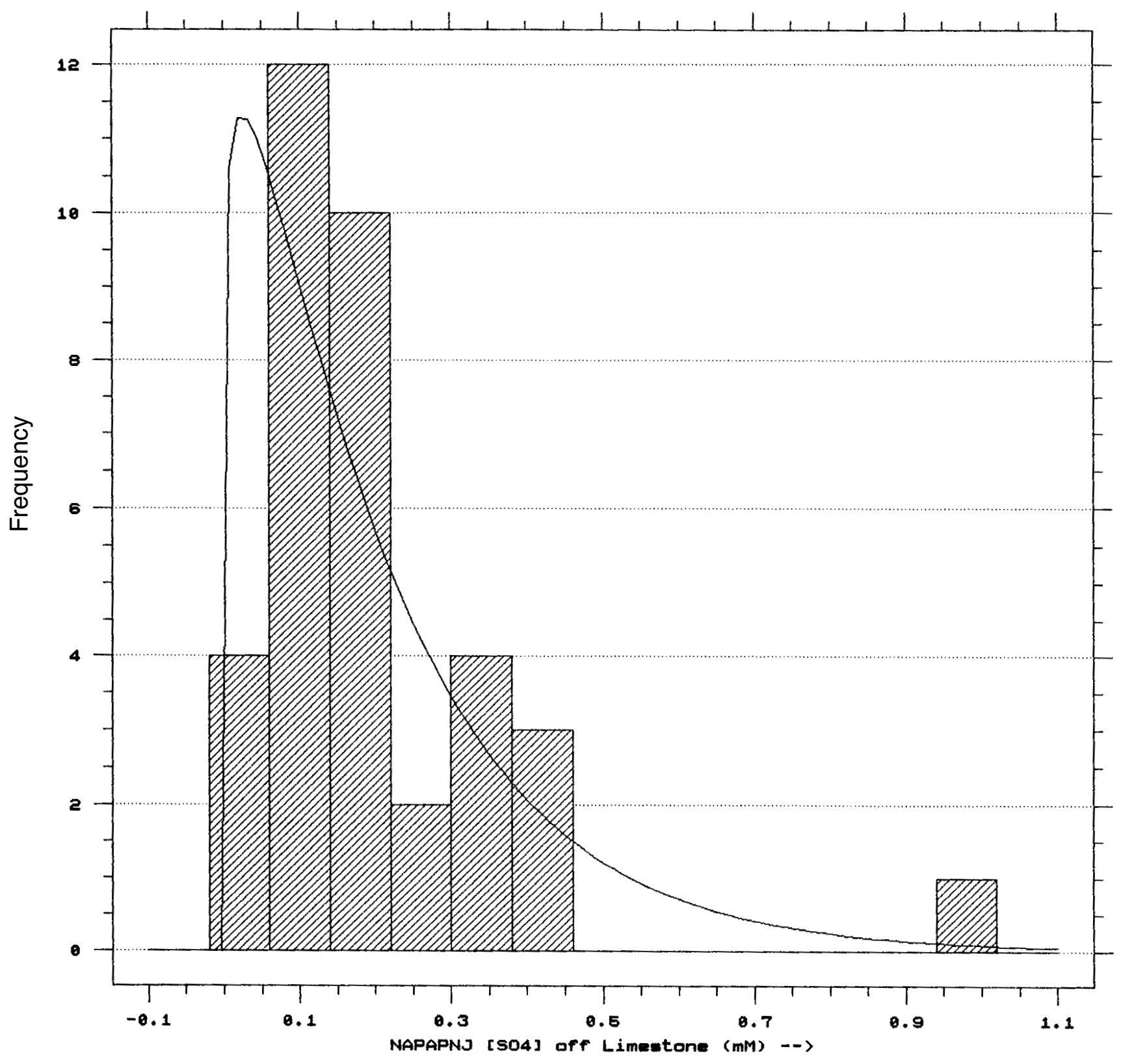

Chisquare Test

\begin{tabular}{|c|c|c|c|c|c|}
\hline & $\begin{array}{l}\text { Lower } \\
\text { Limit }\end{array}$ & $\begin{array}{l}\text { Upper } \\
\text { Limit }\end{array}$ & $\begin{array}{l}\text { Observed } \\
\text { Frequency }\end{array}$ & $\begin{array}{l}\text { Expected } \\
\text { Frequency }\end{array}$ & Chisquare \\
\hline above & $\begin{array}{l}\text { below } \\
.0600 \\
.1400 \\
.2200 \\
.3800\end{array}$ & $\begin{array}{l}.0600 \\
.1400 \\
.2200 \\
.3800\end{array}$ & $\begin{array}{r}4 \\
12 \\
10 \\
6 \\
4\end{array}$ & $\begin{array}{l}8.1 \\
9.0 \\
6.3 \\
7.1 \\
5.4\end{array}$ & $\begin{array}{r}2.094 \\
.965 \\
2.145 \\
.172 \\
.365\end{array}$ \\
\hline
\end{tabular}

Chisquare $=5.74086$ with 2 d.f. Sig. level $=0.0566746$

FIGURE 38.-A, Histograms and model with goodness-of-fit statistics. (Variable: $\mathrm{SO}_{4}{ }^{2-}$; material: limestone; site: NAPAP-NJ.) B, Histograms and model with goodness-of-fit statistics. (Variable: $\mathrm{SO}_{4}{ }^{2-}$; material: marble; site: NAPAP-NJ.) 


\section{$B$ [S04] off Marble - NAPAP : NJ}

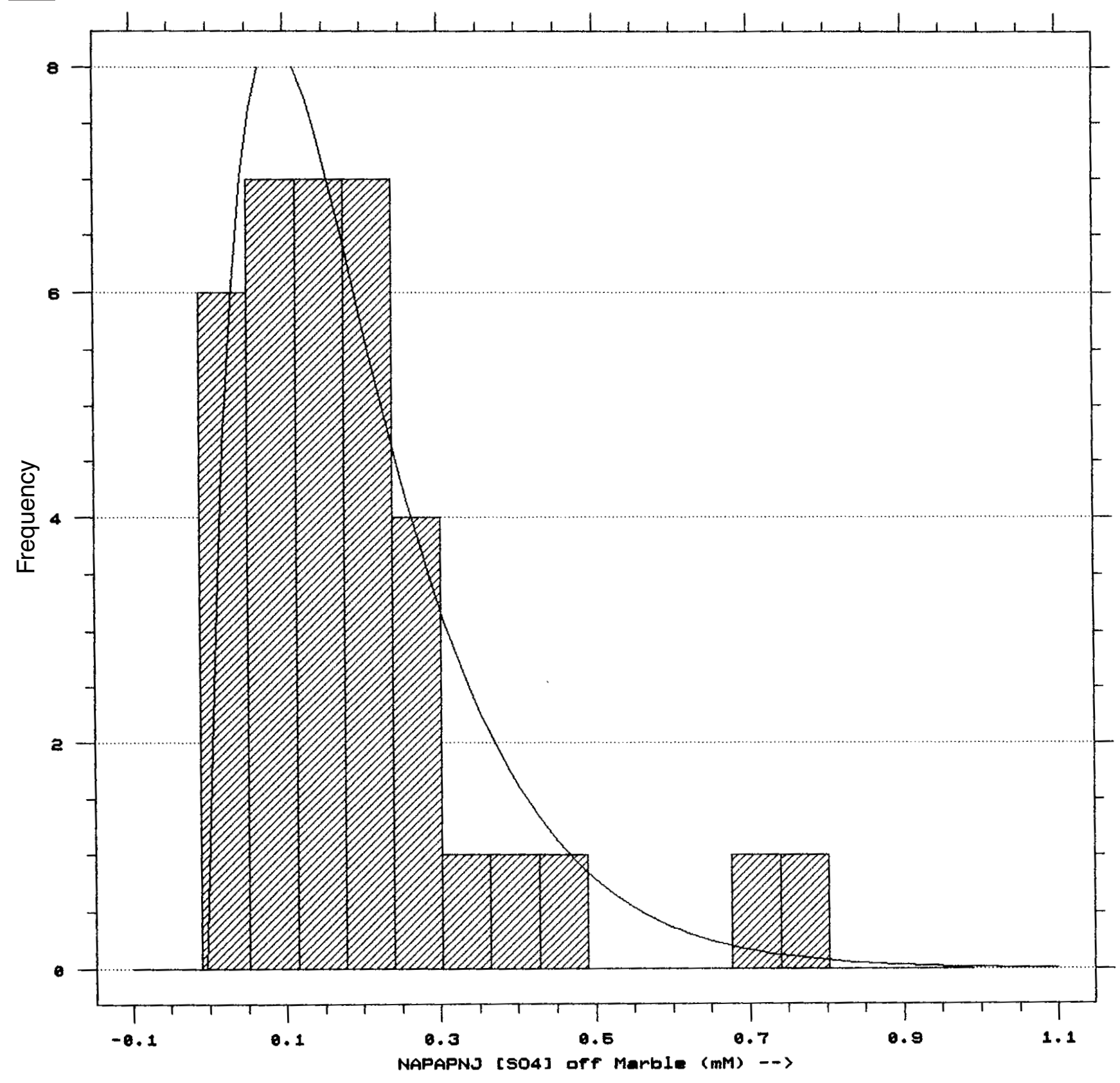

Chisquare Test

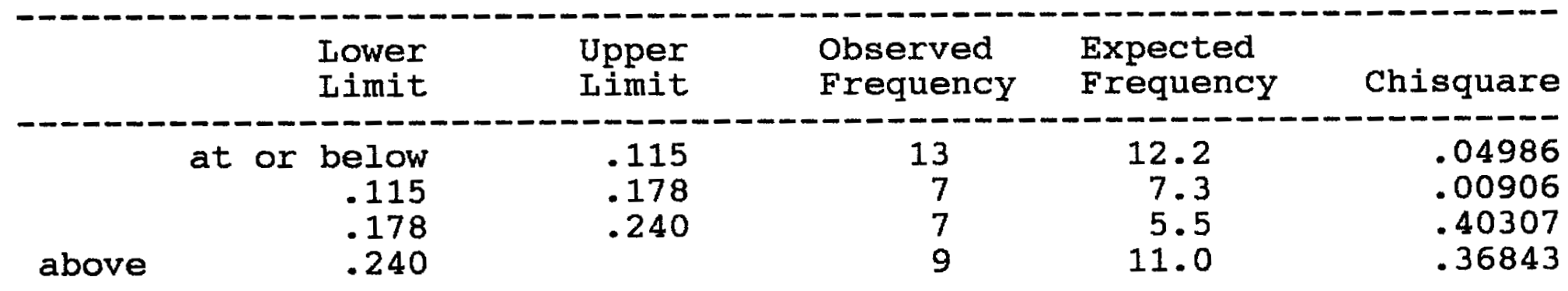

Chisquare $=0.830425$ with 1 d.f. Sig. level $=0.36215$ 
A [SO4] off Limestone - NAPAP : NC

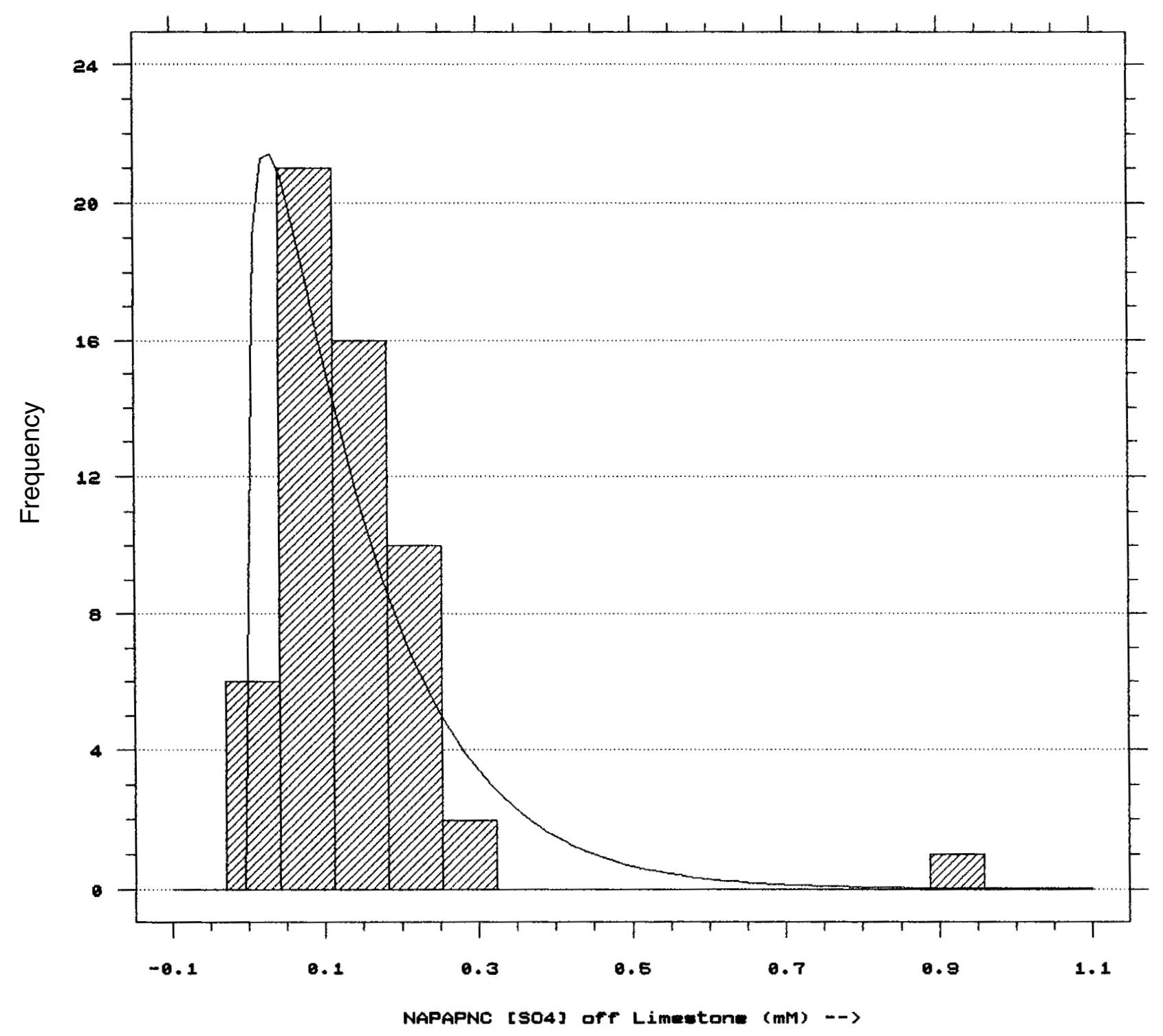

Chisquare Test

\begin{tabular}{|c|c|c|c|c|c|}
\hline & $\begin{array}{l}\text { Lower } \\
\text { Limit }\end{array}$ & $\begin{array}{l}\text { Upper } \\
\text { Iimit }\end{array}$ & $\begin{array}{l}\text { Observed } \\
\text { Frequency }\end{array}$ & $\begin{array}{l}\text { Expected } \\
\text { Frequency }\end{array}$ & Chisquare \\
\hline at or & $\begin{array}{l}\text { below } \\
.0412 \\
.1118 \\
.1824 \\
.2529\end{array}$ & $\begin{array}{r}.0412 \\
.1118 \\
.1824 \\
.2529\end{array}$ & $\begin{array}{r}6 \\
21 \\
16 \\
10 \\
3\end{array}$ & $\begin{array}{r}11.7 \\
17.7 \\
11.2 \\
6.6 \\
8.7\end{array}$ & $\begin{array}{r}2.762 \\
.607 \\
2.019 \\
1.692 \\
3.748\end{array}$ \\
\hline
\end{tabular}

Chisquare $=10.8281$ with 2 d.f. Sig. level $=4.45357 \mathrm{E}-3$

FIGURE 39.-A, Histograms and model with goodness-of-fit statistics. (Variable: $\mathrm{SO}_{4}{ }^{2-} ;$ material: limestone; site: NAPAP-NC.) B, Histograms and model with goodness-of-fit statistics. (Variable: $\mathrm{SO}_{4}{ }^{2-}$; material: marble; site: NAPAP-NC.) 
B [SO4] off Marble - NAPAP : NC

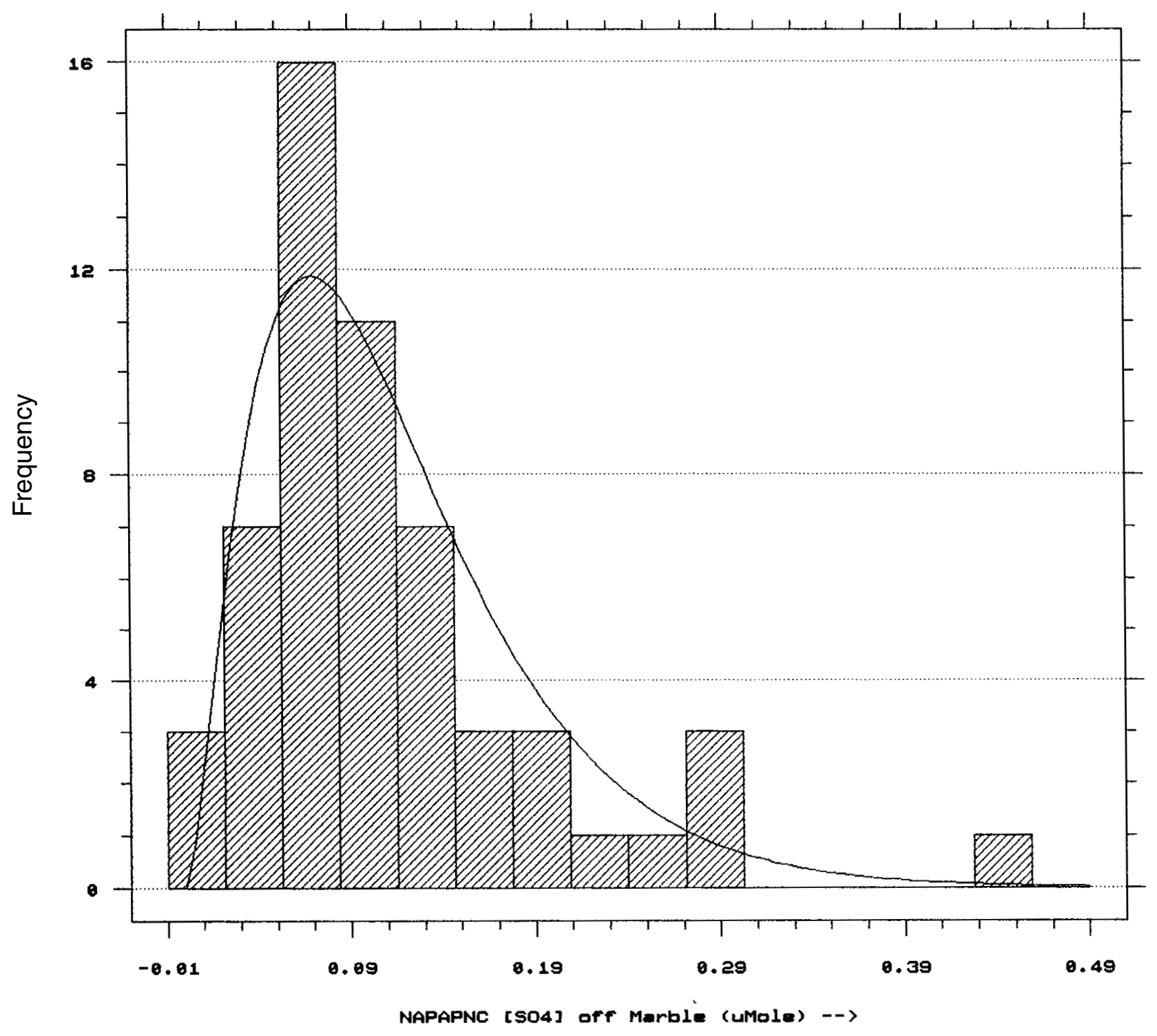

Chisquare Test

\begin{tabular}{|c|c|c|c|c|c|}
\hline & $\begin{array}{l}\text { Lower } \\
\text { Limit }\end{array}$ & $\begin{array}{l}\text { Upper } \\
\text { Limit }\end{array}$ & $\begin{array}{l}\text { Observed } \\
\text { Frequency }\end{array}$ & $\begin{array}{l}\text { Expected } \\
\text { Frequency }\end{array}$ & Chisquare \\
\hline at or & $\begin{array}{l}\text { below } \\
.0525 \\
.0838 \\
.1150 \\
.1463 \\
.1775\end{array}$ & $\begin{array}{l}.0525 \\
.0838 \\
.1150 \\
.1463 \\
.1775\end{array}$ & $\begin{array}{r}10 \\
16 \\
11 \\
7 \\
3 \\
9\end{array}$ & $\begin{array}{r}10.7 \\
11.7 \\
10.5 \\
8.1 \\
5.6 \\
9.4\end{array}$ & $\begin{array}{r}.0448 \\
1.5726 \\
.0200 \\
.1377 \\
1.2127 \\
.0168\end{array}$ \\
\hline
\end{tabular}

Chisquare $=3.00453$ with 3 d.f. Sig. level $=0.390927$ 
A [SO4] off Limestone - NAPAP : OH

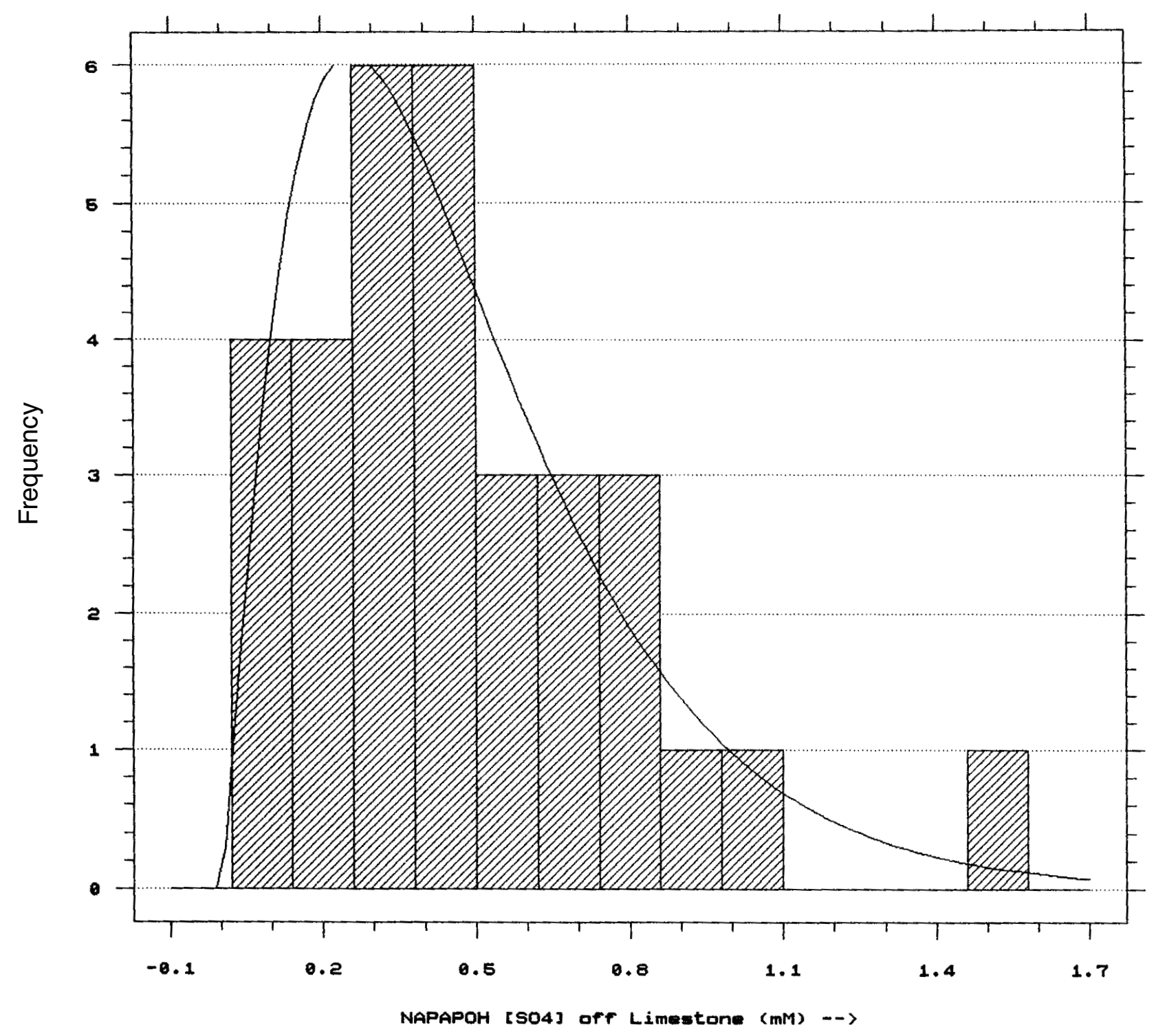

Chisquare Test

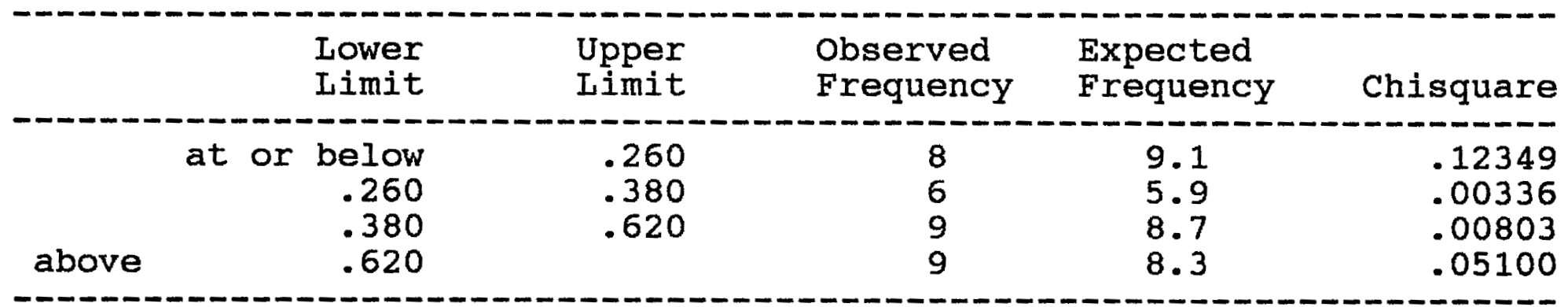

Chisquare $=0.185877$ with 1 d.f. Sig. level $=0.66637$

FIGURE 40.-A, Histograms and model with goodness-of-fit statistics. (Variable: $\mathrm{SO}_{4}{ }^{2-}$; material: limestone; site: NAPAP-OH.) B, Histograms and model with goodness-of-fit statistics. (Variable: $\mathrm{SO}_{4}{ }^{2-}$; material: marble; site: NAPAP-OH.) 


\section{[504] Off Marble - NAPAP : OH}

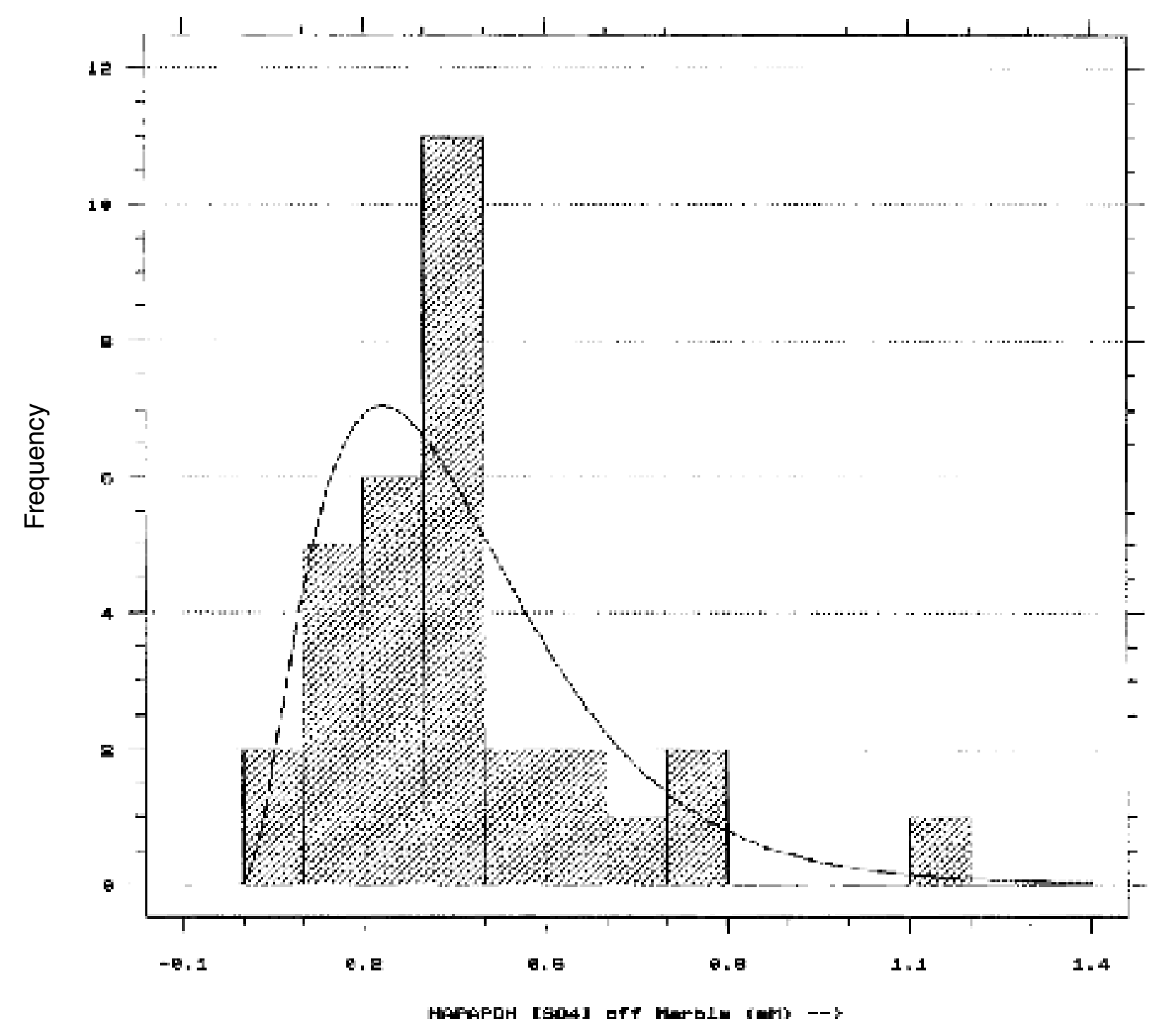

Chlequare Tes:

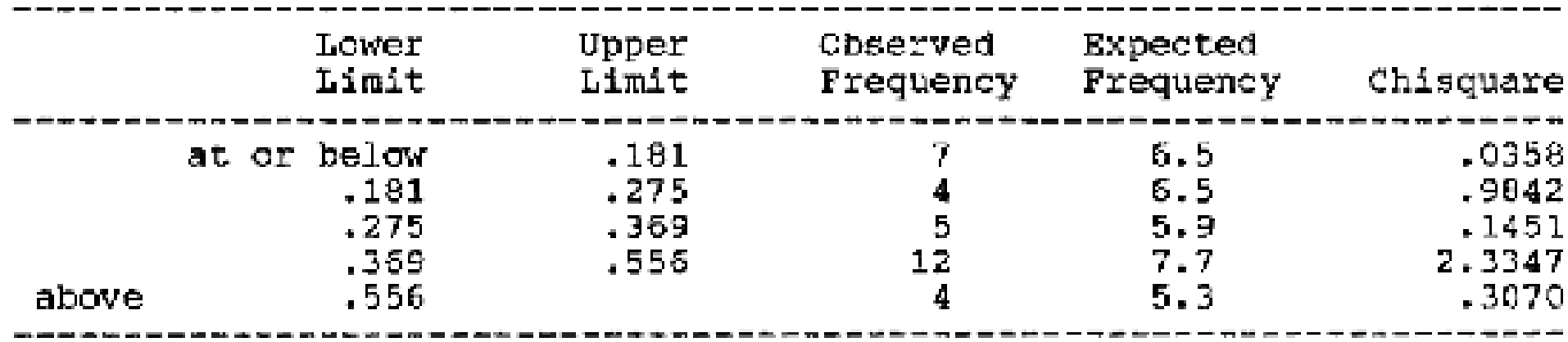

Chisquaro $=3.80675$ with 2 d.f. Sig. level $=0.149065$ 


\section{Averages of NAPAP Gypsum Limestone and Marble}

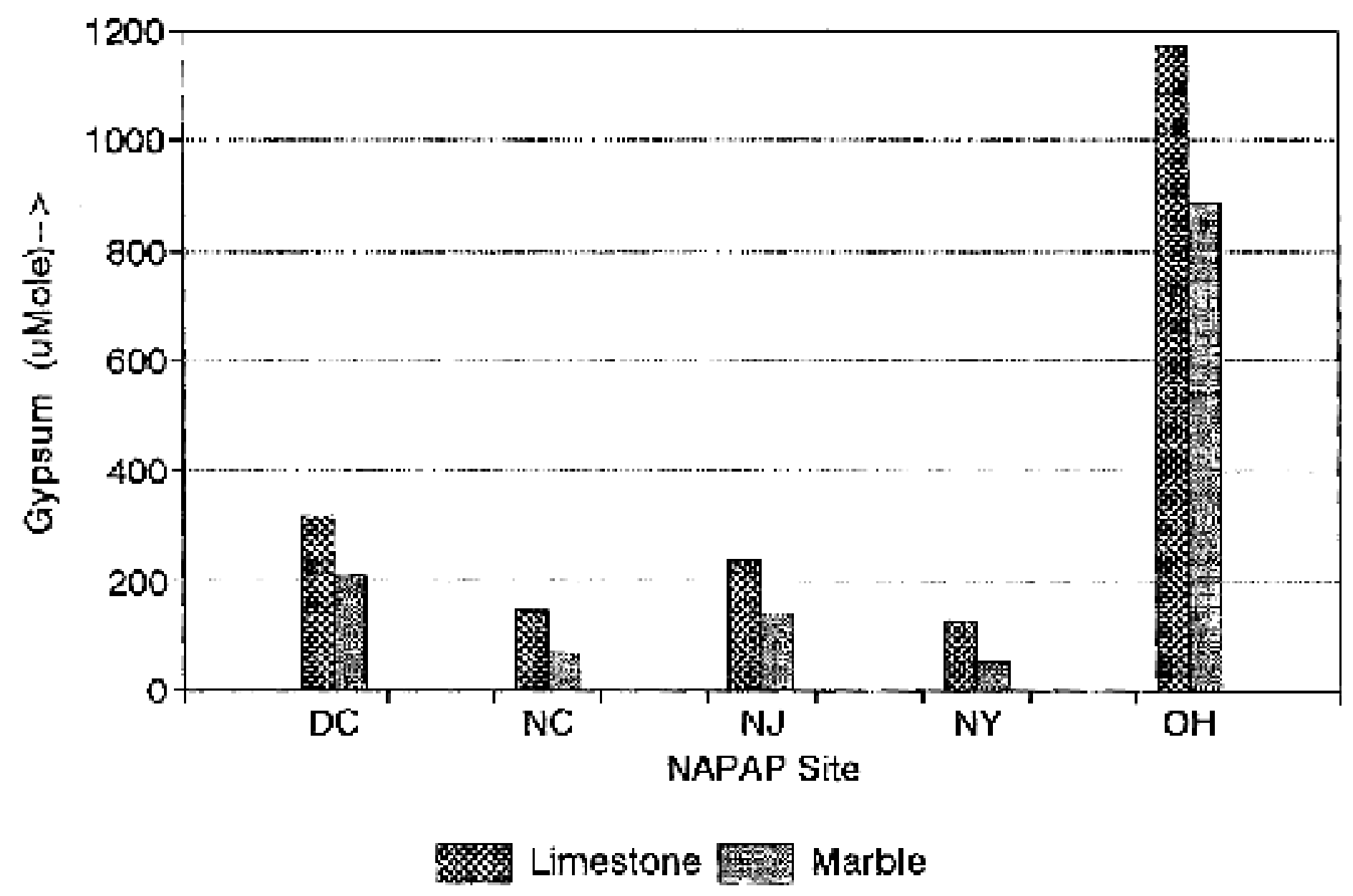

FIGURE 41(avg).-Average $\mathrm{SO}_{4}{ }^{2-}$ mass loss. (Variable: $\mathrm{SO}_{4}{ }^{2-}$ mass; material: limestone and marble; site: NAPAP-all sites.) 


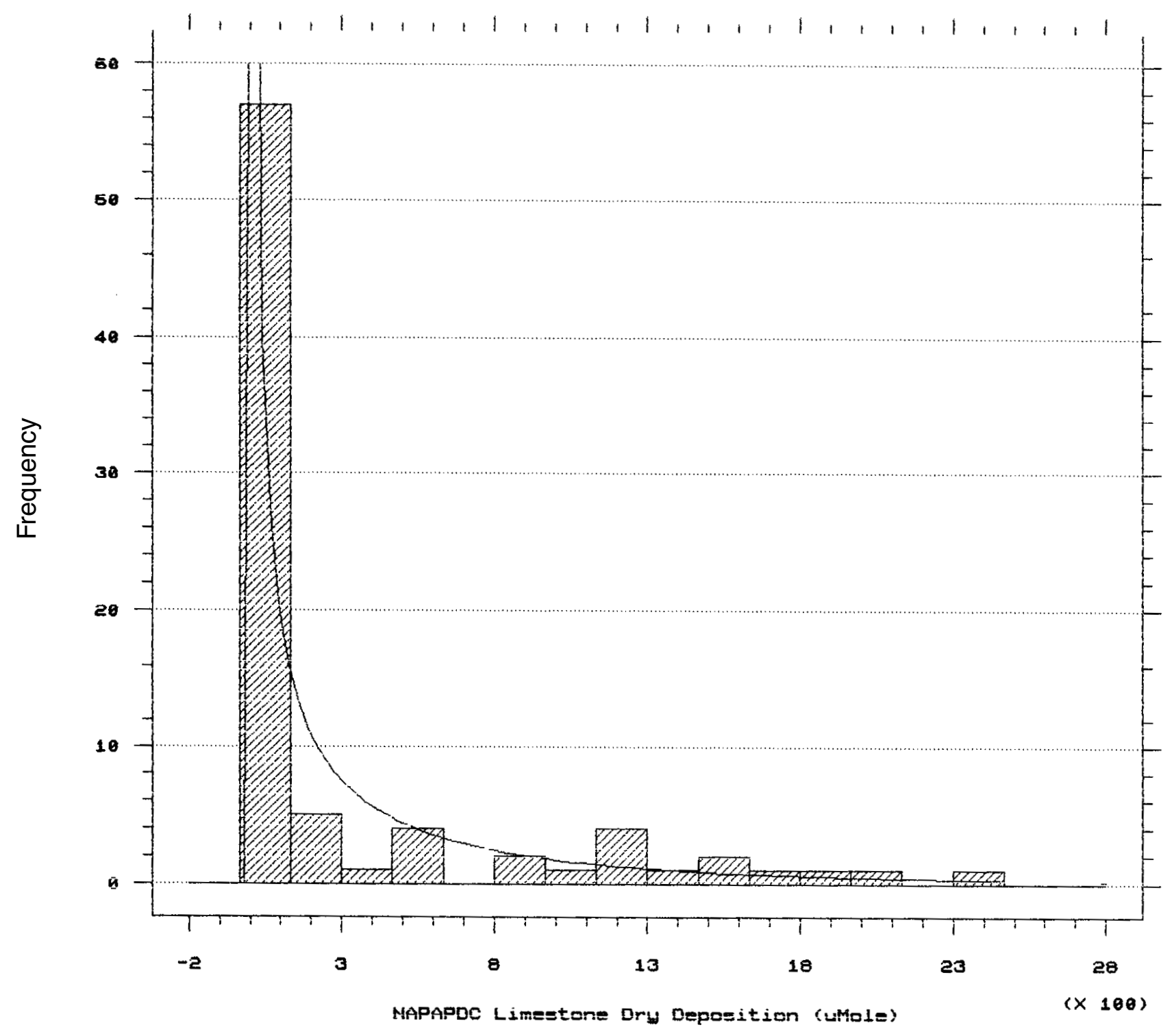

Chisquare Test

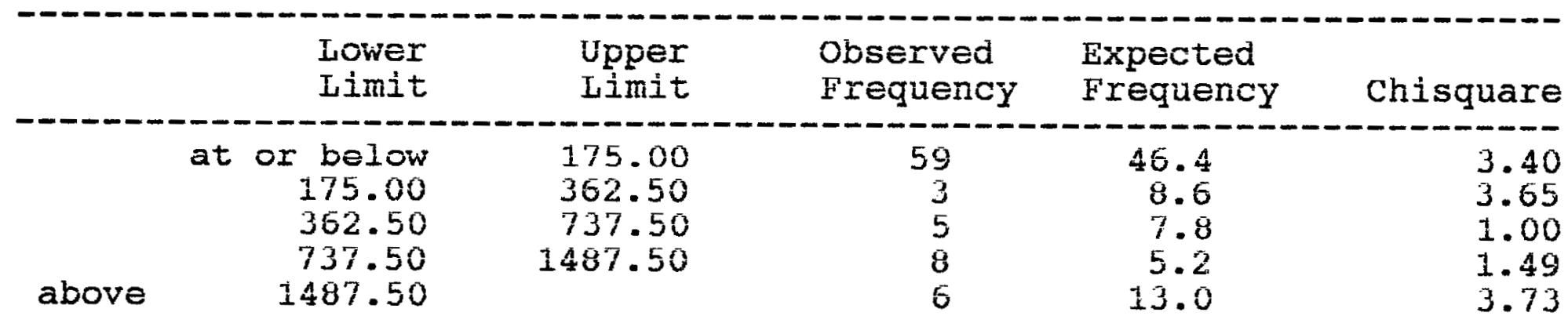

Chisquare $=13.2692$ with 2 d.f. Sig. Ievel $=1.31411 \mathrm{E}-3$

FIGURE 41.-A, Histograms and model with goodness-of-fit statistics. (Variable: gypsum load; material: limestone; site: NAPAP-DC.) B, Histograms and model with goodness-of-fit statistics. (Variable: gypsum load; material: marble; site: NAPAP-DC.) 


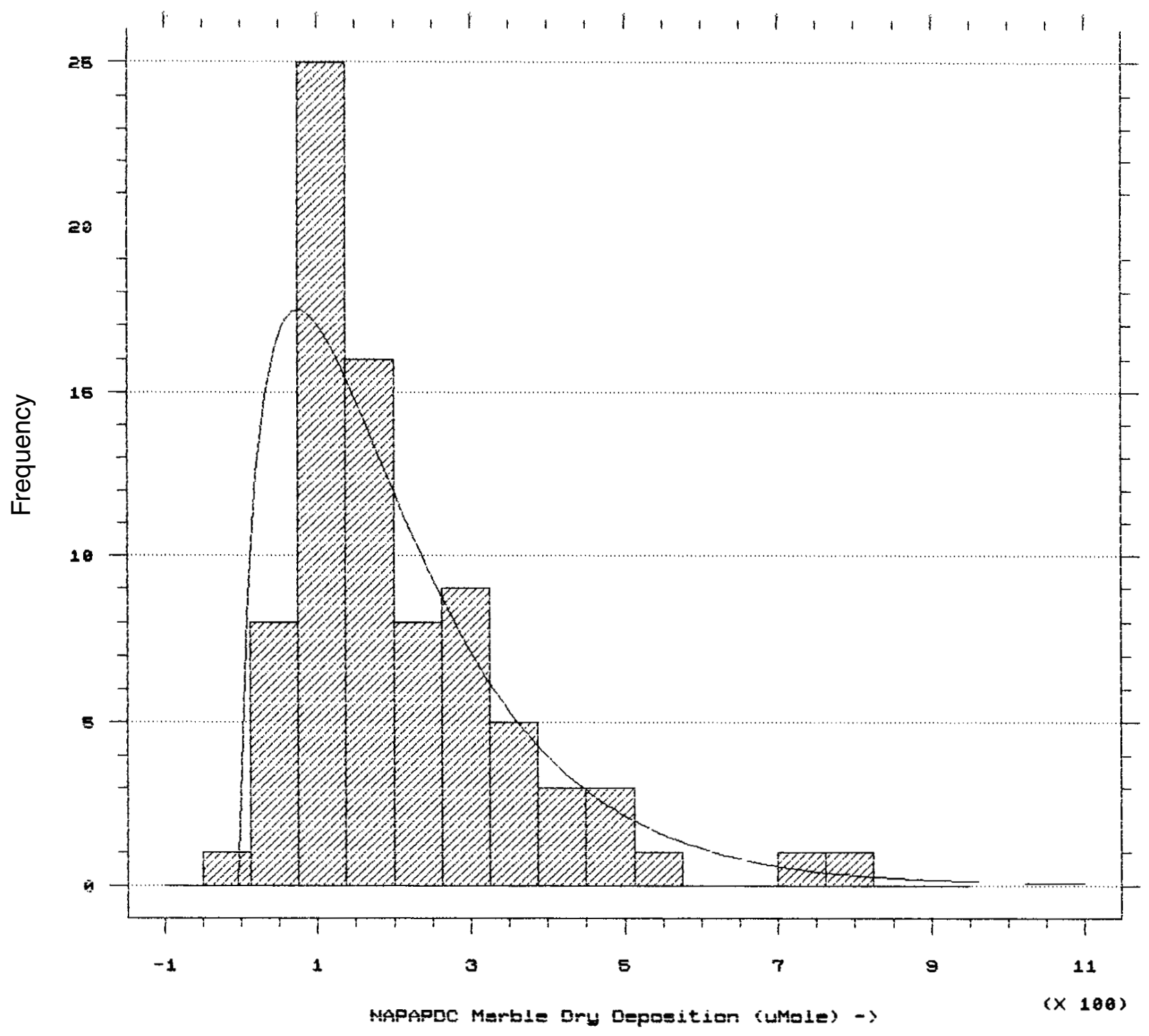

Chisquare Test:

\begin{tabular}{|c|c|c|c|c|c|}
\hline & $\begin{array}{l}\text { Lower } \\
\text { Limit }\end{array}$ & $\begin{array}{l}\text { Upper } \\
\text { Iimit }\end{array}$ & $\begin{array}{l}\text { Observed } \\
\text { Frequency }\end{array}$ & $\begin{array}{l}\text { Expected } \\
\text { Frequency }\end{array}$ & Chisquare \\
\hline above & $\begin{array}{r}\text { at or below } \\
75.00 \\
137.50 \\
200.00 \\
262.50 \\
325.00 \\
387.50\end{array}$ & $\begin{array}{r}75.00 \\
137.50 \\
200.00 \\
262.50 \\
325.00 \\
387.50\end{array}$ & $\begin{array}{r}9 \\
25 \\
16 \\
8 \\
9 \\
5 \\
9\end{array}$ & $\begin{array}{r}16.9 \\
16.7 \\
13.7 \\
10.3 \\
7.4 \\
5.2 \\
10.8\end{array}$ & $\begin{array}{r}3.57578 \\
4.12157 \\
.38738 \\
.51208 \\
.34217 \\
.00697 \\
.30928\end{array}$ \\
\hline
\end{tabular}

Chisquare $=9.35524$ with 4 d.f. Sig. level $=0.0528083$ 
A Limestone Dry Deposition - NAPAP : NY

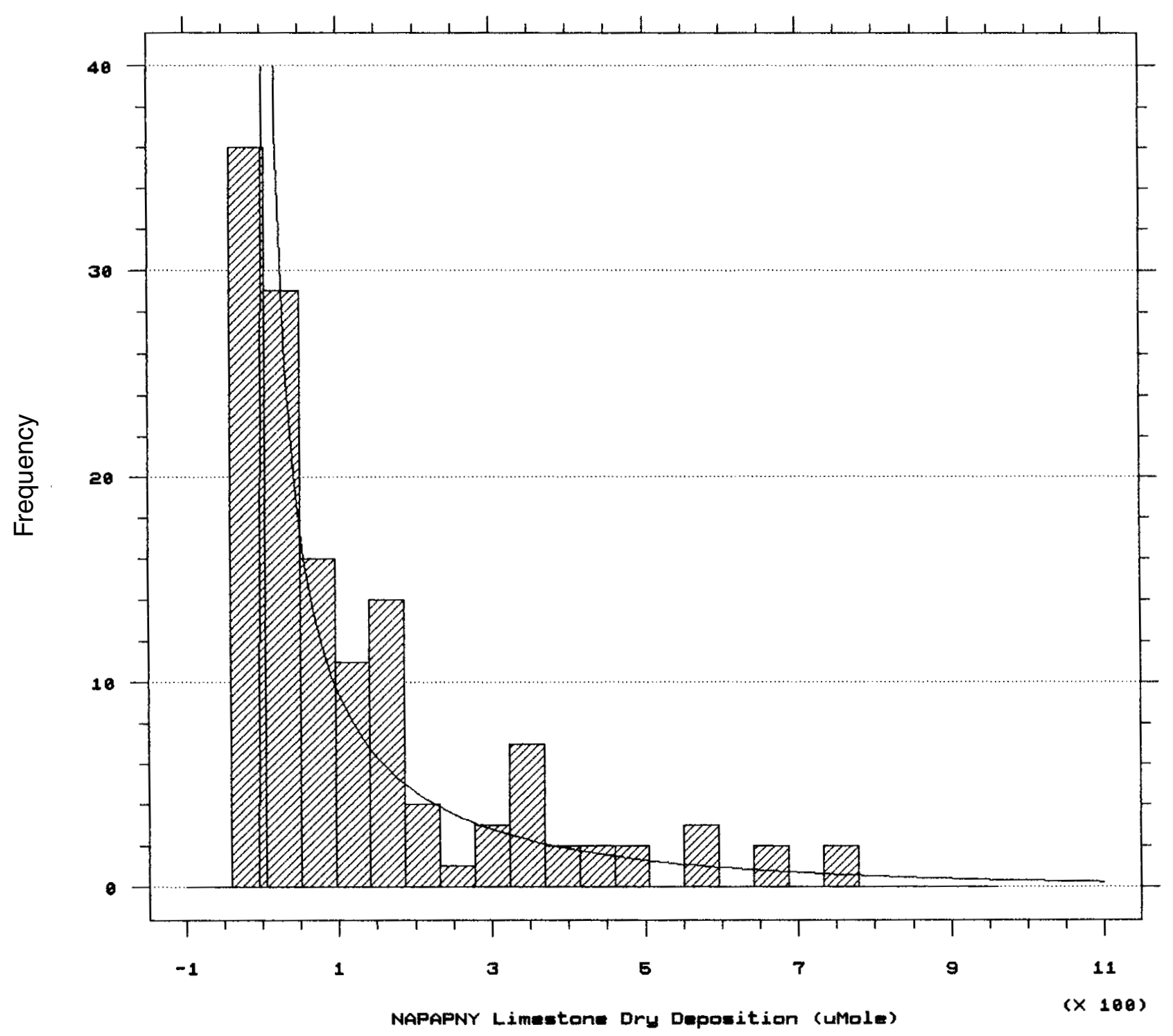

Chisquare Test

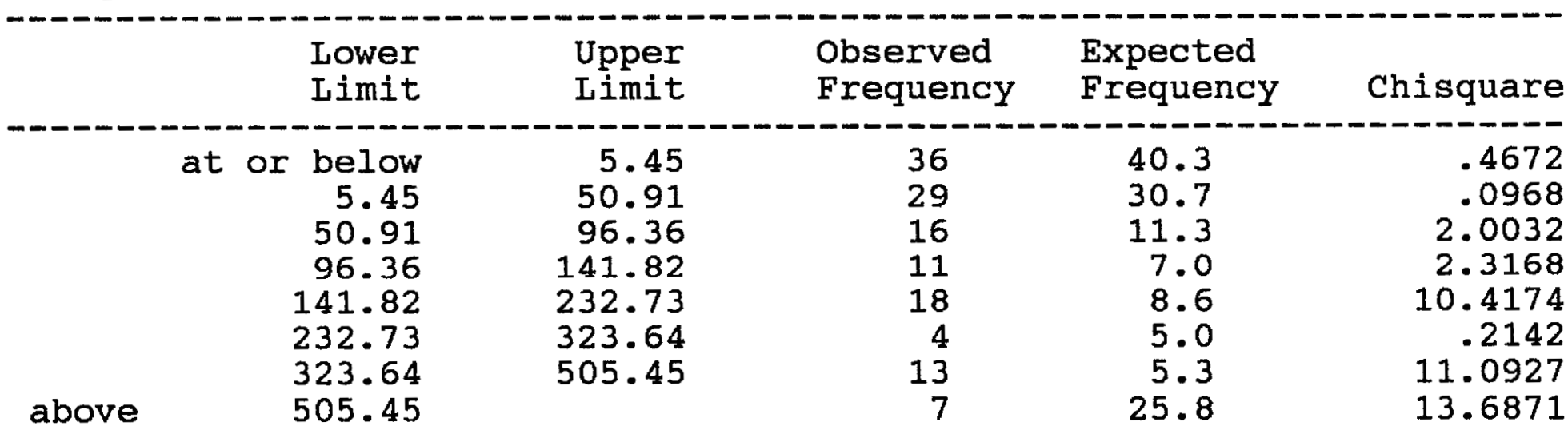

Chisquare $=40.2954$ with 5 d.f. Sig. level $=1.30189 \mathrm{E}-7$

FIGURE 42.-A, Histograms and model with goodness-of-fit statistics. (Variable: gypsum load; material: limestone; site: NAPAP-NY.) B, Histograms and model with goodness-of-fit statistics. (Variable: gypsum load; material: marble; site: NAPAP-NY.) 
B Marble Dry Deposition - NAPAP : NY

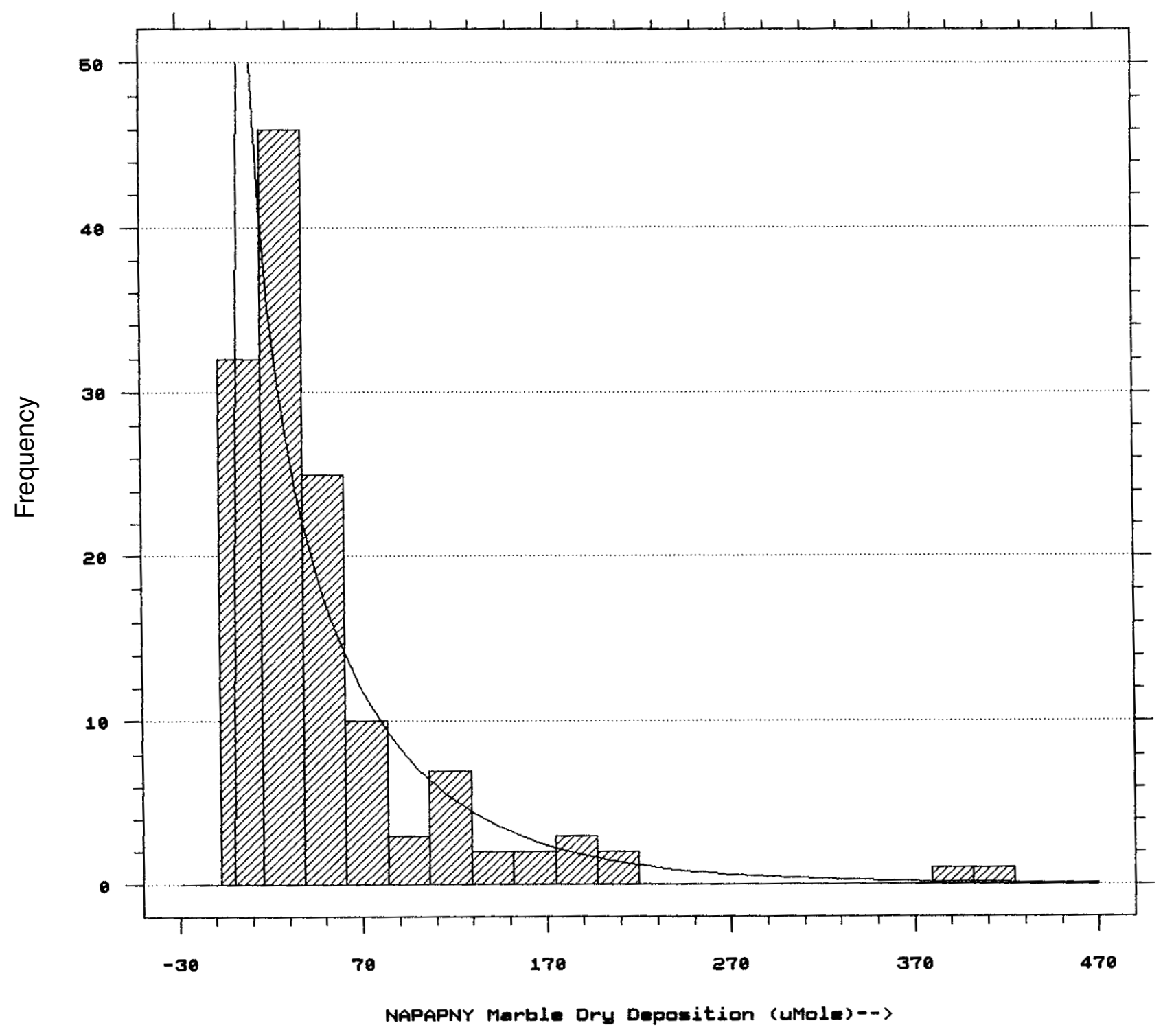

Chisquare Test

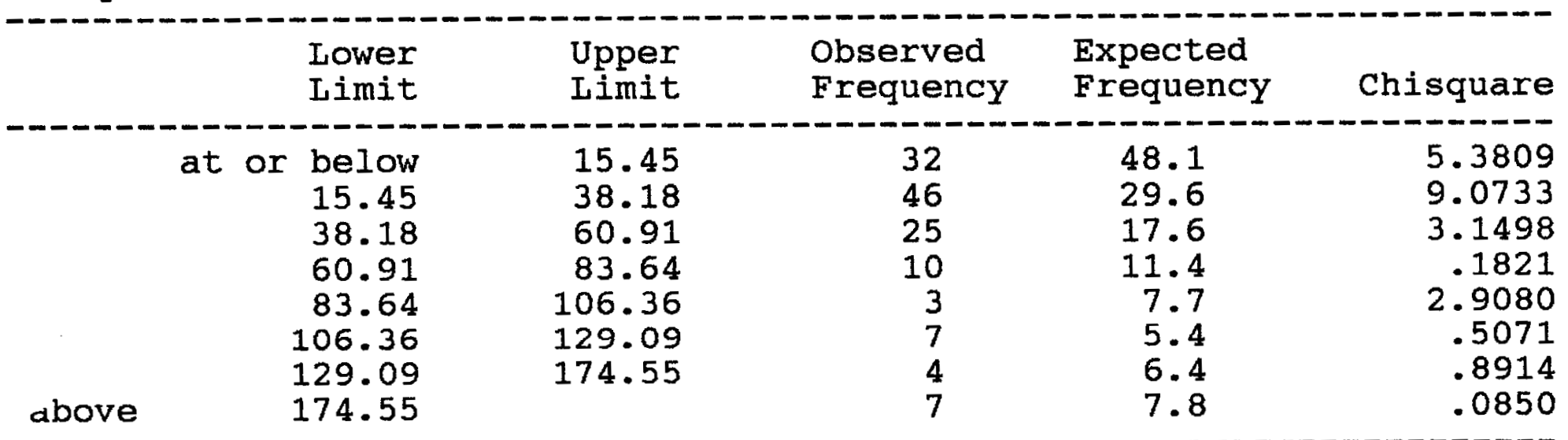

Chisquare $=22.1776$ with 5 d.f. Sig. level $=4.84428 \mathrm{E}-4$ 


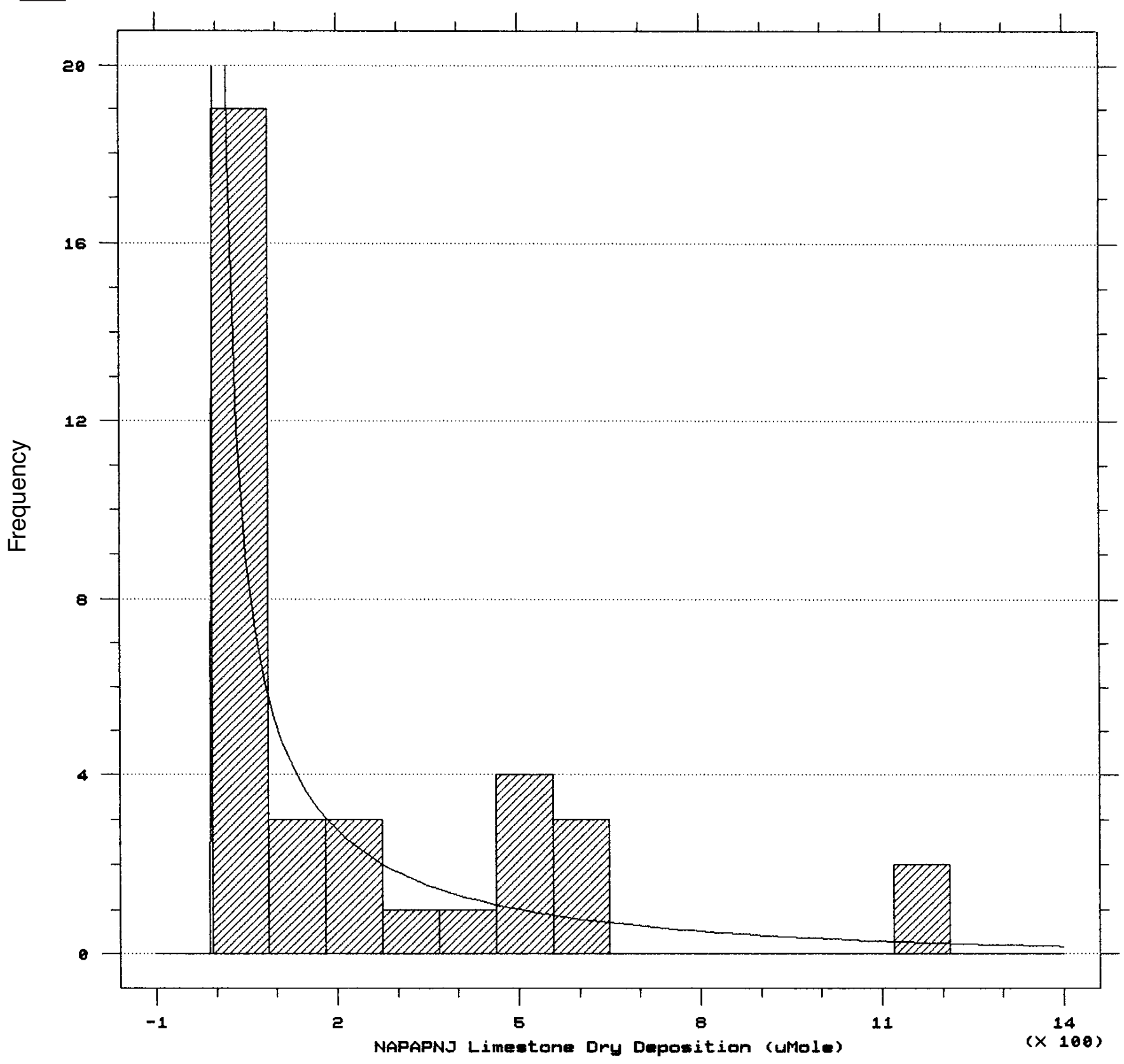

Chisquare Test

\begin{tabular}{|c|c|c|c|c|c|}
\hline & $\begin{array}{l}\text { Lower } \\
\text { Limit }\end{array}$ & $\begin{array}{l}\text { Upper } \\
\text { Limit }\end{array}$ & $\begin{array}{l}\text { Observed } \\
\text { Frequency }\end{array}$ & $\begin{array}{l}\text { Expected } \\
\text { Frequency }\end{array}$ & Chisquare \\
\hline above & 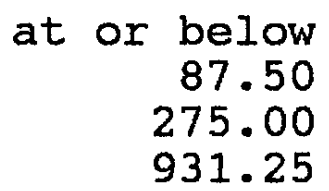 & $\begin{array}{r}87.50 \\
275.00 \\
931.25\end{array}$ & $\begin{array}{r}19 \\
6 \\
9 \\
2\end{array}$ & $\begin{array}{r}18.7 \\
5.8 \\
5.2 \\
6.4\end{array}$ & $\begin{array}{r}.00610 \\
.00665 \\
2.84475 \\
2.99577\end{array}$ \\
\hline
\end{tabular}

Chisquare $=5.85327$ with 1 d.f. Sig. level $=0.0155482$

FIGURE 43.-A, Histograms and model with goodness-of-fit statistics. (Variable: gypsum load; material: I imestone; site: NAPAP-NJ.) B, Histograms and model with goodness-of-fit statistics. (Variable: gypsum load; material: marble; site: NAPAP-NJ.) 
B Marble Dry Deposition - NAPAP : NJ

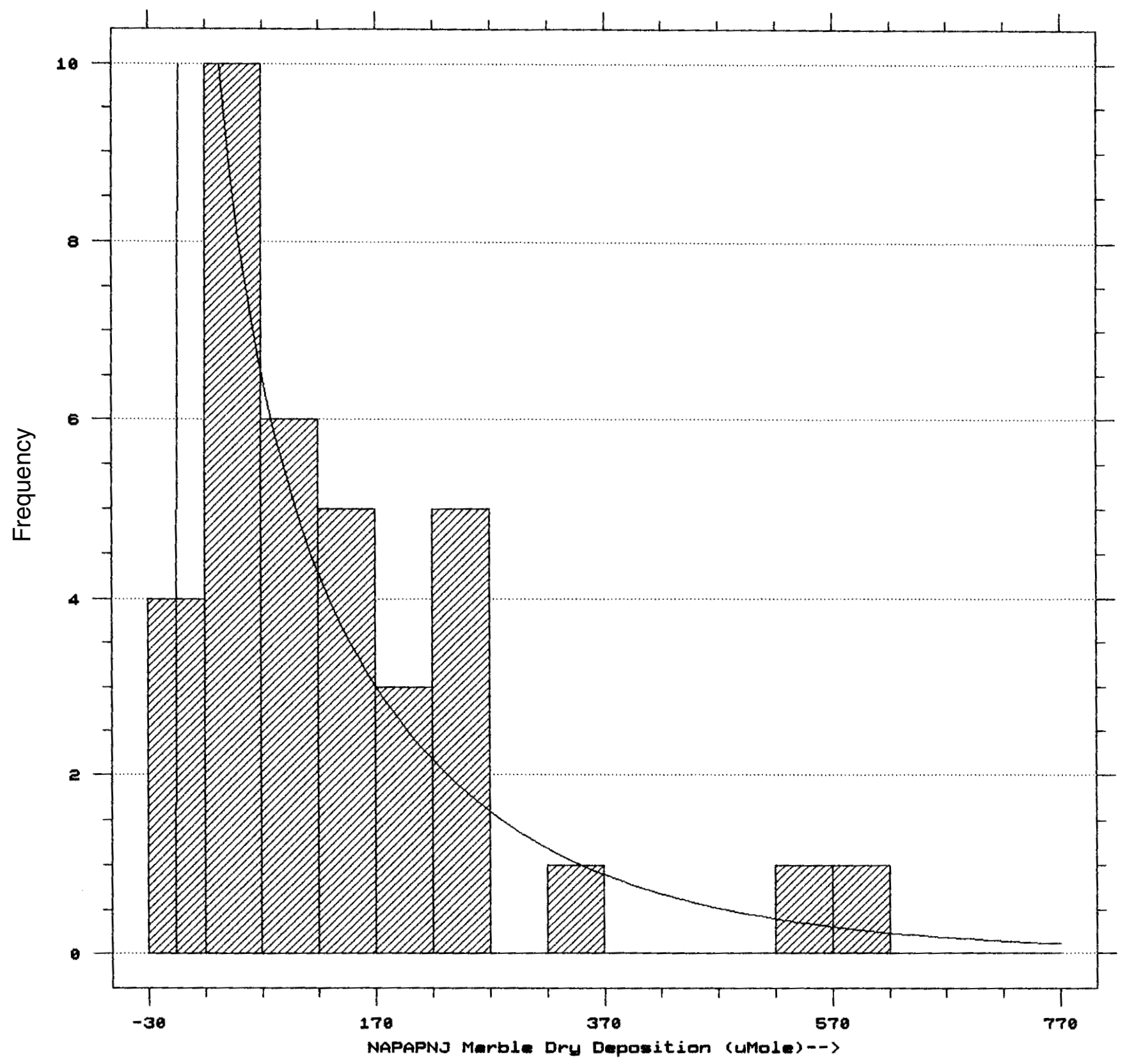

Chisquare Test

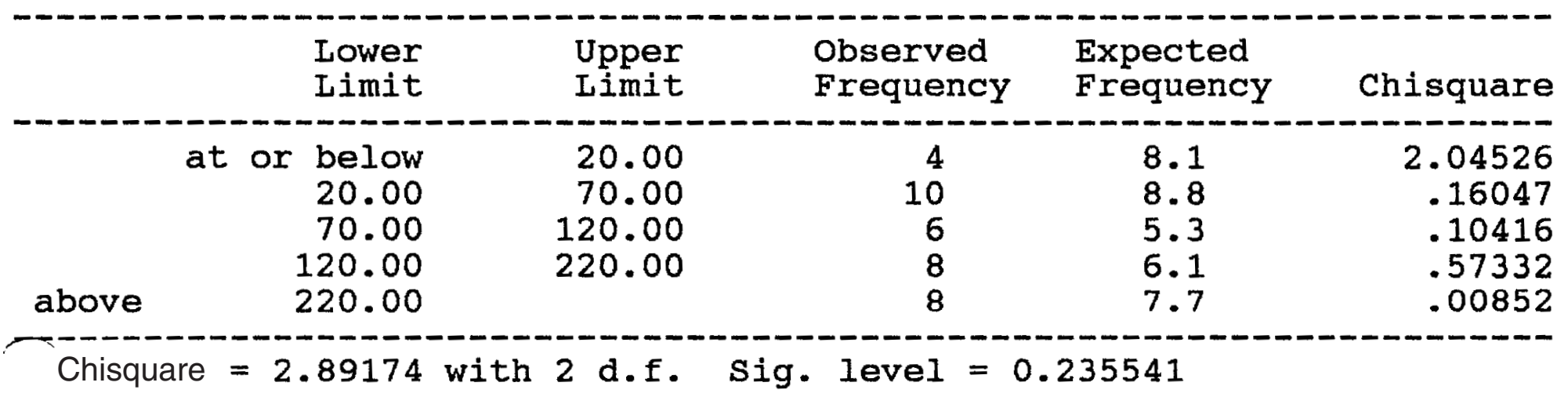


A Limestone Dry Deposition - NAPAP : NC

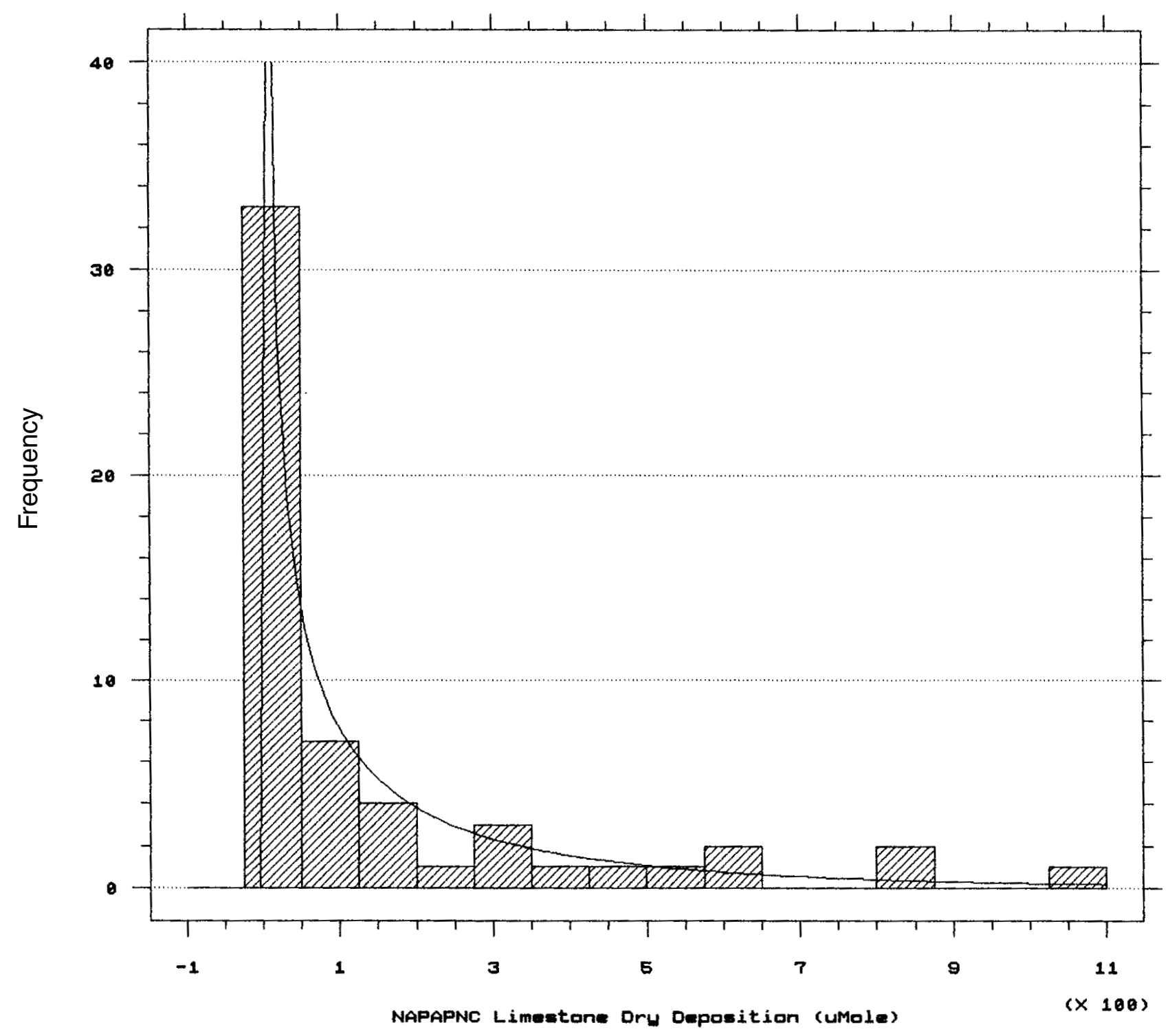

Chisquare Test

\begin{tabular}{rrrrrr} 
& $\begin{array}{l}\text { Lower } \\
\text { Limit }\end{array}$ & $\begin{array}{l}\text { Upper } \\
\text { Limit }\end{array}$ & $\begin{array}{l}\text { Observed } \\
\text { Frequency }\end{array}$ & $\begin{array}{l}\text { Expected } \\
\text { Frequency }\end{array}$ & Chisquare \\
\hline & at or below & 50.00 & 33 & 27.8 & .982 \\
& 50.00 & 125.00 & 7 & 8.3 & .202 \\
above & 125.00 & 275.00 & 5 & 7.2 & .687 \\
& 275.00 & 575.00 & 6 & 5.0 & .194 \\
& 575.00 & & 5 & 7.7 & .940
\end{tabular}

Chisquare $=3.0063$ with 2 d.f. Sig. level $=0.222429$

FIGURE 44.-A, Histograms and model with goodness-of-fit statistics. (Variable: gypsum load; material: limestone; site: NAPAP-NC.) B, Histograms and model with goodness-of-fit statistics. (Variable: gypsum load; material: marble; site: NAPAP-NC.) 
B Marble Dry Deposition - NAPAP : NC

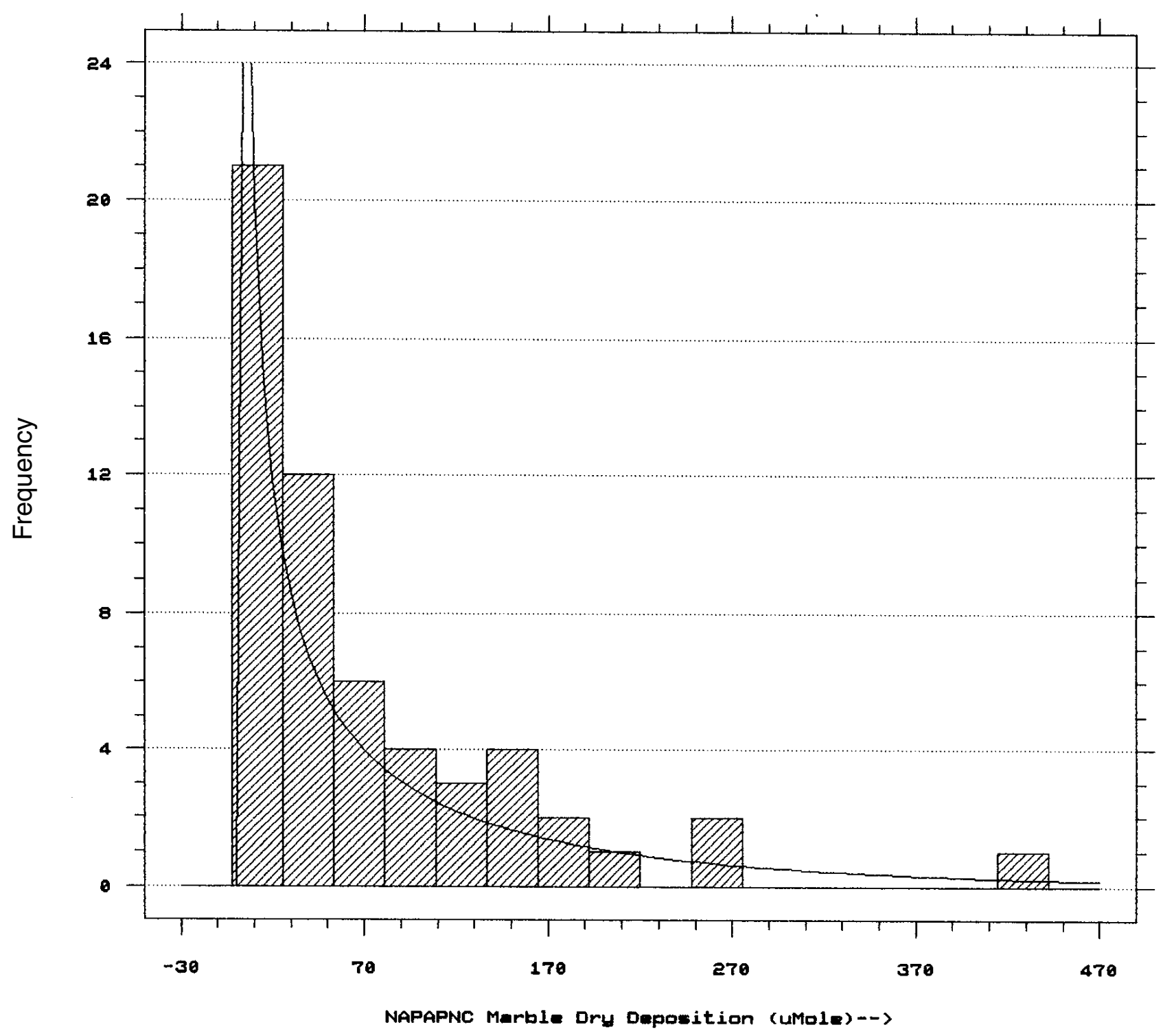

Chisquare Test

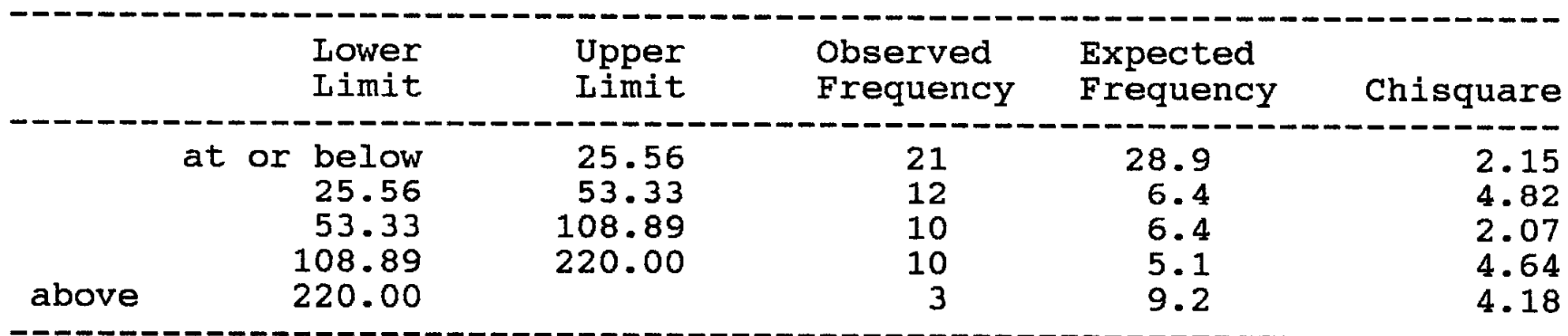

Chisquare $=17.8448$ with 2 d.f. Sig. level $=1.33369 \mathrm{E}-4$ 
A Limestone Dry Deposition - NAPAP : OH

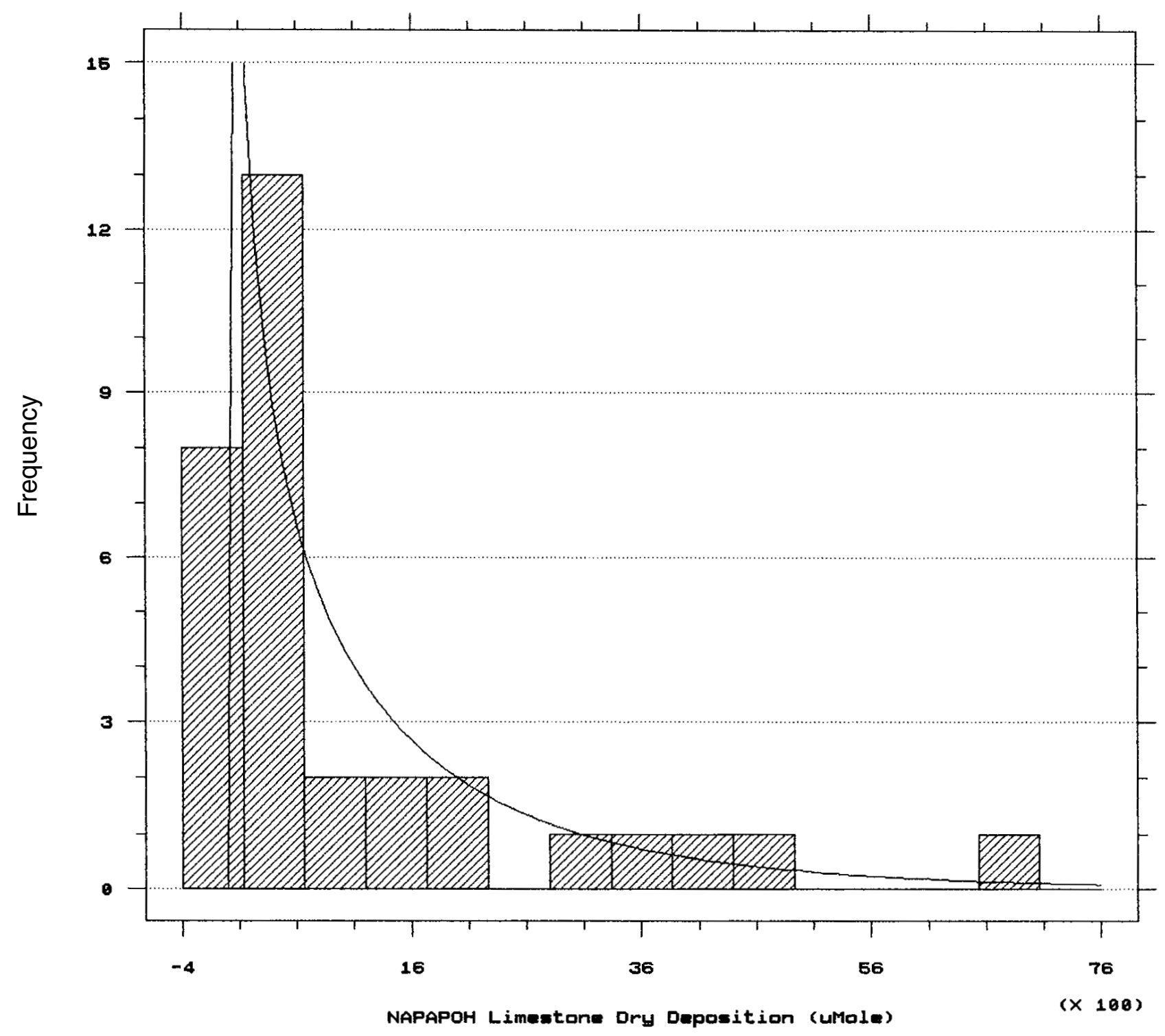

Chisquare Test

\begin{tabular}{|c|c|c|c|c|c|}
\hline & $\begin{array}{l}\text { Lower } \\
\text { Limit }\end{array}$ & $\begin{array}{l}\text { Upper } \\
\text { Limit }\end{array}$ & $\begin{array}{l}\text { Observed } \\
\text { Frequency }\end{array}$ & $\begin{array}{l}\text { Expected } \\
\text { Frequency }\end{array}$ & Chisquare \\
\hline above & $\begin{array}{r}\text { at or below } \\
100.00 \\
600.00 \\
1600.00\end{array}$ & $\begin{array}{r}100.00 \\
600.00 \\
1600.00\end{array}$ & $\begin{array}{r}4 \\
16 \\
5 \\
7\end{array}$ & $\begin{array}{l}6.5 \\
9.6 \\
7.8 \\
8.1\end{array}$ & $\begin{array}{r}.9 \\
4.2 \\
.9 \\
.1\end{array}$ \\
\hline
\end{tabular}

Chisquare $=6.30749$ with 1 d.f. Sig. level $=0.0120229$

FIGURE 45.-A, Histograms and model with goodness-of-fit statistics. (Variable: gypsum load; material: limestone; site: NAPAP-OH.) B, Histograms and model with goodness-of-fit statistics. (Variable: gypsum load; material: marble; site: NAPAP-OH.) 
B Marble Dry Deposition - NAPAP : OH

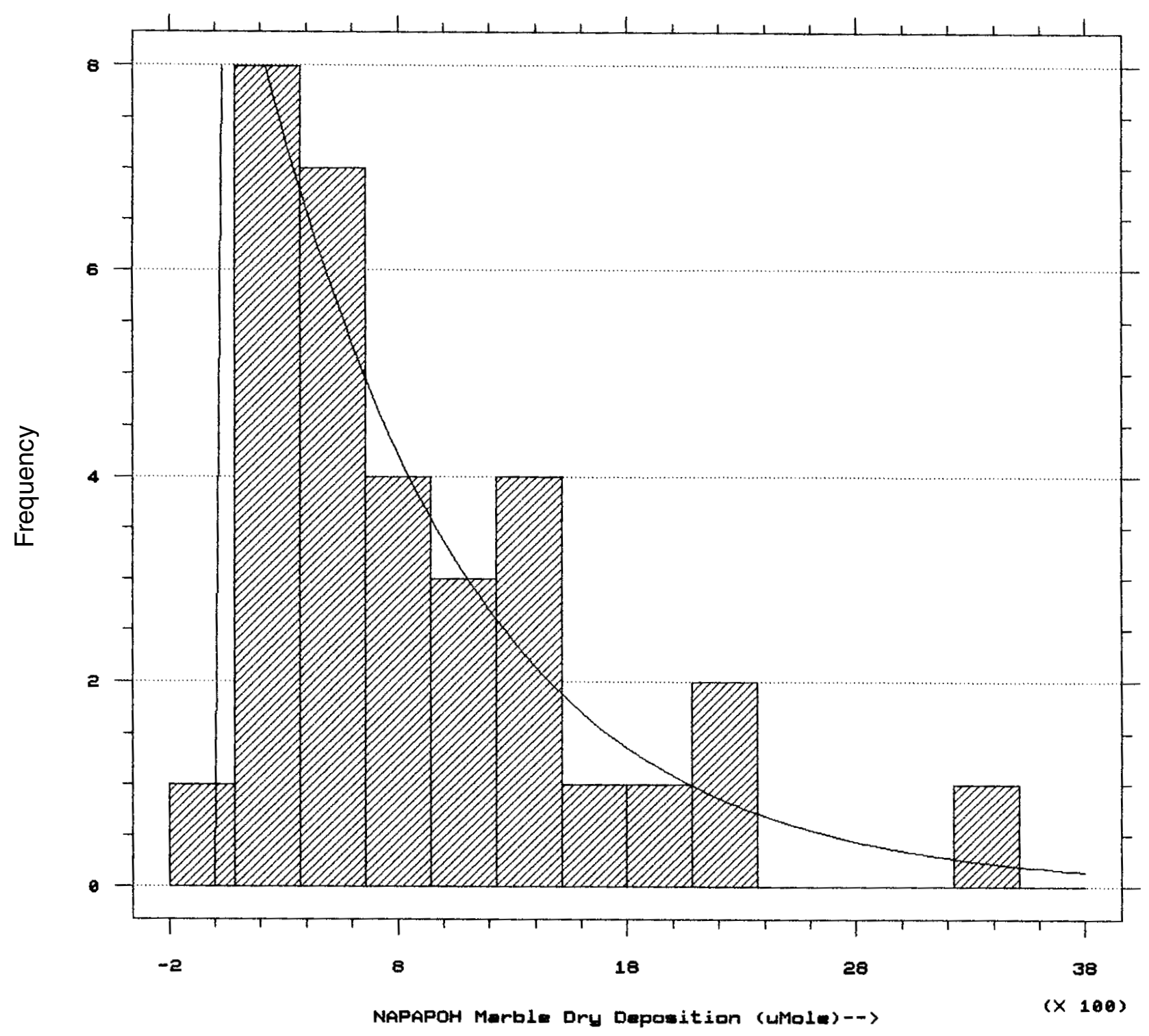

Chisquare Test

\begin{tabular}{|c|c|c|c|c|c|}
\hline & $\begin{array}{l}\text { Lower } \\
\text { Limit }\end{array}$ & $\begin{array}{l}\text { Upper } \\
\text { Limit }\end{array}$ & $\begin{array}{l}\text { Observed } \\
\text { Frequency }\end{array}$ & $\begin{array}{l}\text { Expected } \\
\text { Frequency }\end{array}$ & Chisquare \\
\hline above & $\begin{array}{r}\text { at or below } \\
300.00 \\
550.00 \\
1050.00\end{array}$ & $\begin{array}{r}300.00 \\
550.00 \\
1050.00\end{array}$ & $\begin{array}{r}5 \\
8 \\
9 \\
10\end{array}$ & $\begin{array}{l}9.0 \\
5.6 \\
7.5 \\
9.9\end{array}$ & $\begin{array}{r}1.79639 \\
1.00049 \\
.30505 \\
.00207\end{array}$ \\
\hline
\end{tabular}

Chisquare $=3.104$ with 1 d.f. Sig. level $=0.0781003$ 


\section{A Fen Marble llad - Naman : vL}

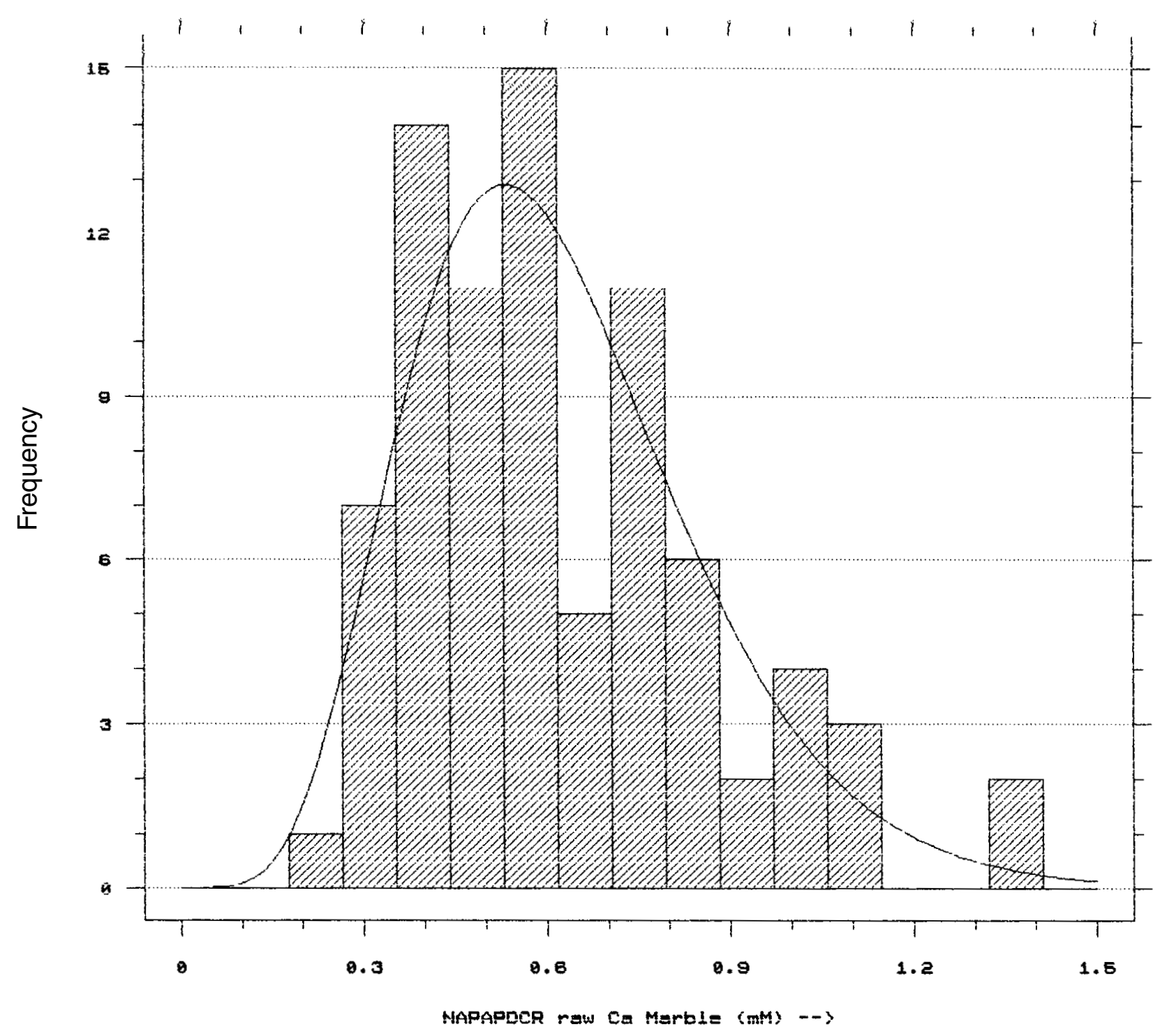

Chisguare Test

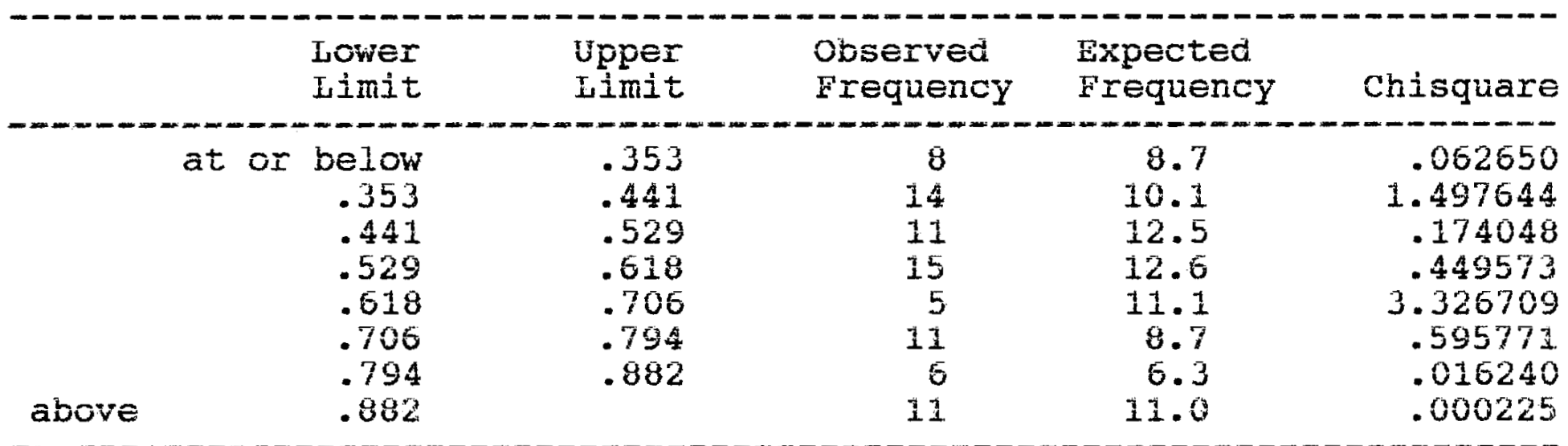

Chisquare $=5.12286$ with 5 d.f. Sig. Ievel $=0.294447$

FIGURE 46.-A, Histograms and model with goodness-of-fit statistics. (Variable: $\mathrm{Ca}^{2+}$ uncor concentration; material: limestone; site: NAPAP-DC.) B, Histograms and model with goodness-of-fit statistics. (Variable: $\mathrm{Ca}^{2+}{ }_{\text {uncor }}$ concentration; material: marble; site: NAPAP-DC.) 


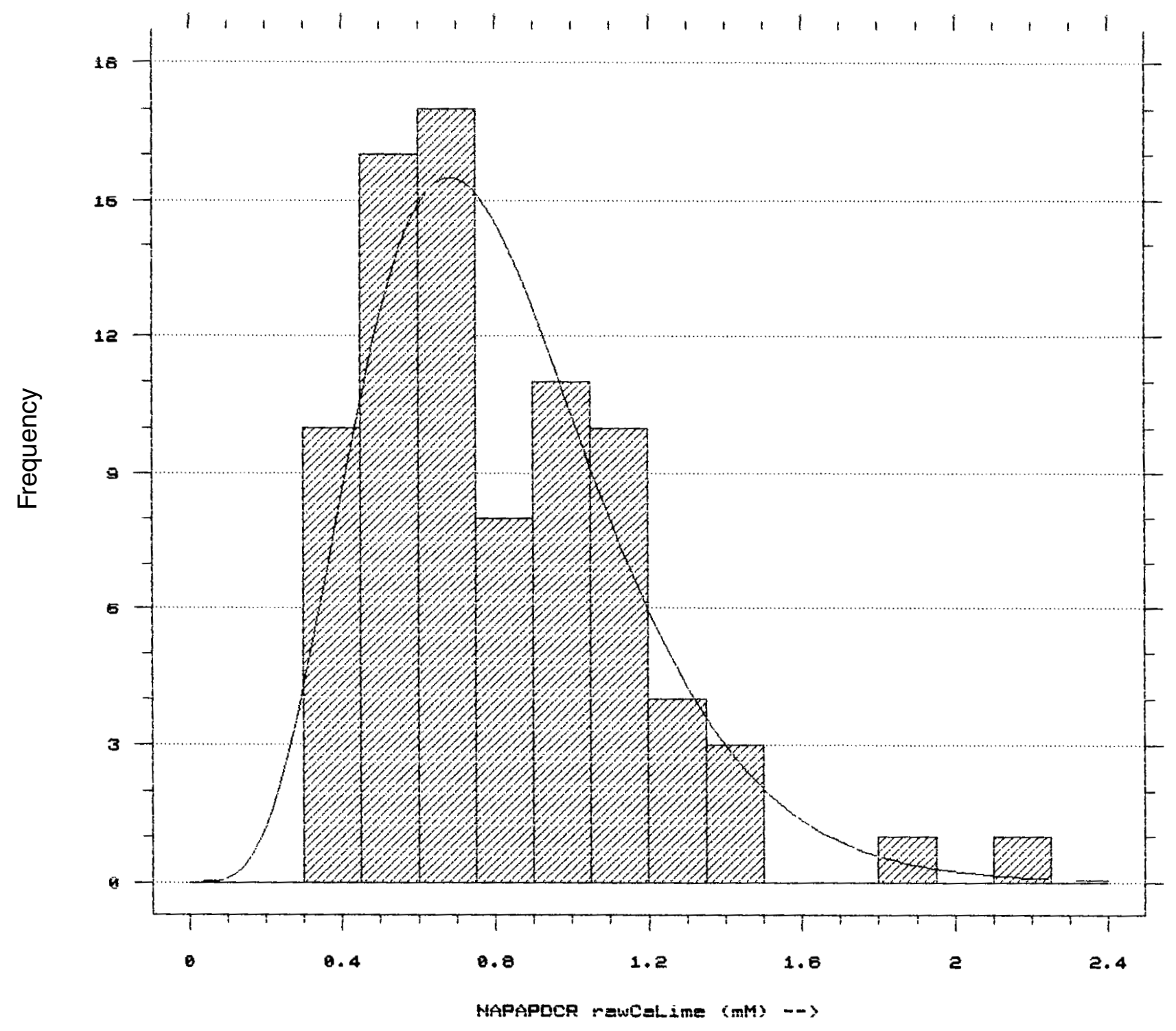

Chisquare Test:

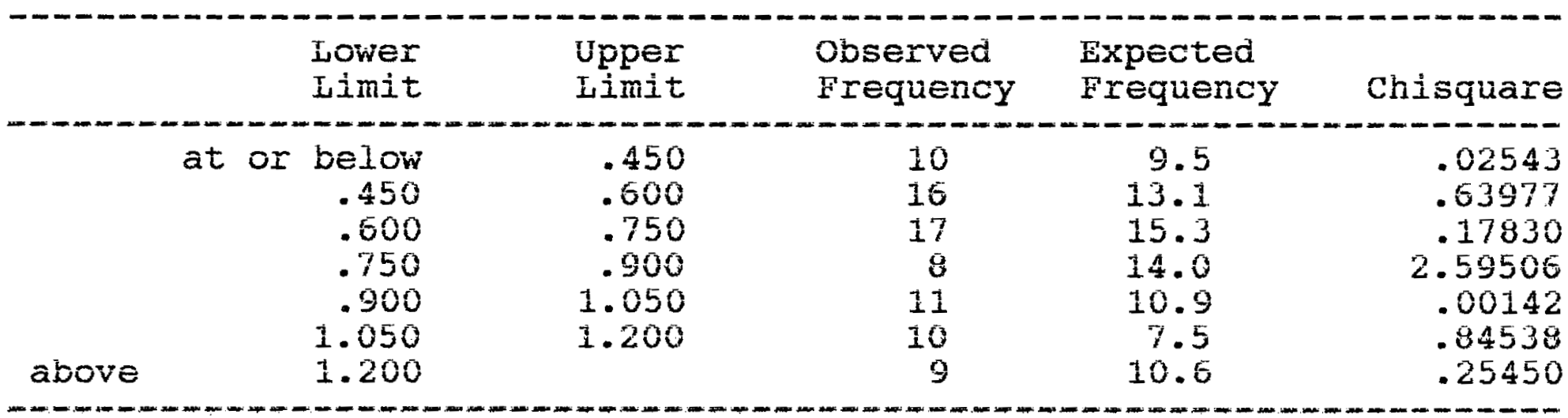

Chisquare $=4.53986$ with 4 d.f. Sig. level $=0.337847$ 


\section{$A$ \\ Limestone Raw [Ca] - NAPAP : NY}

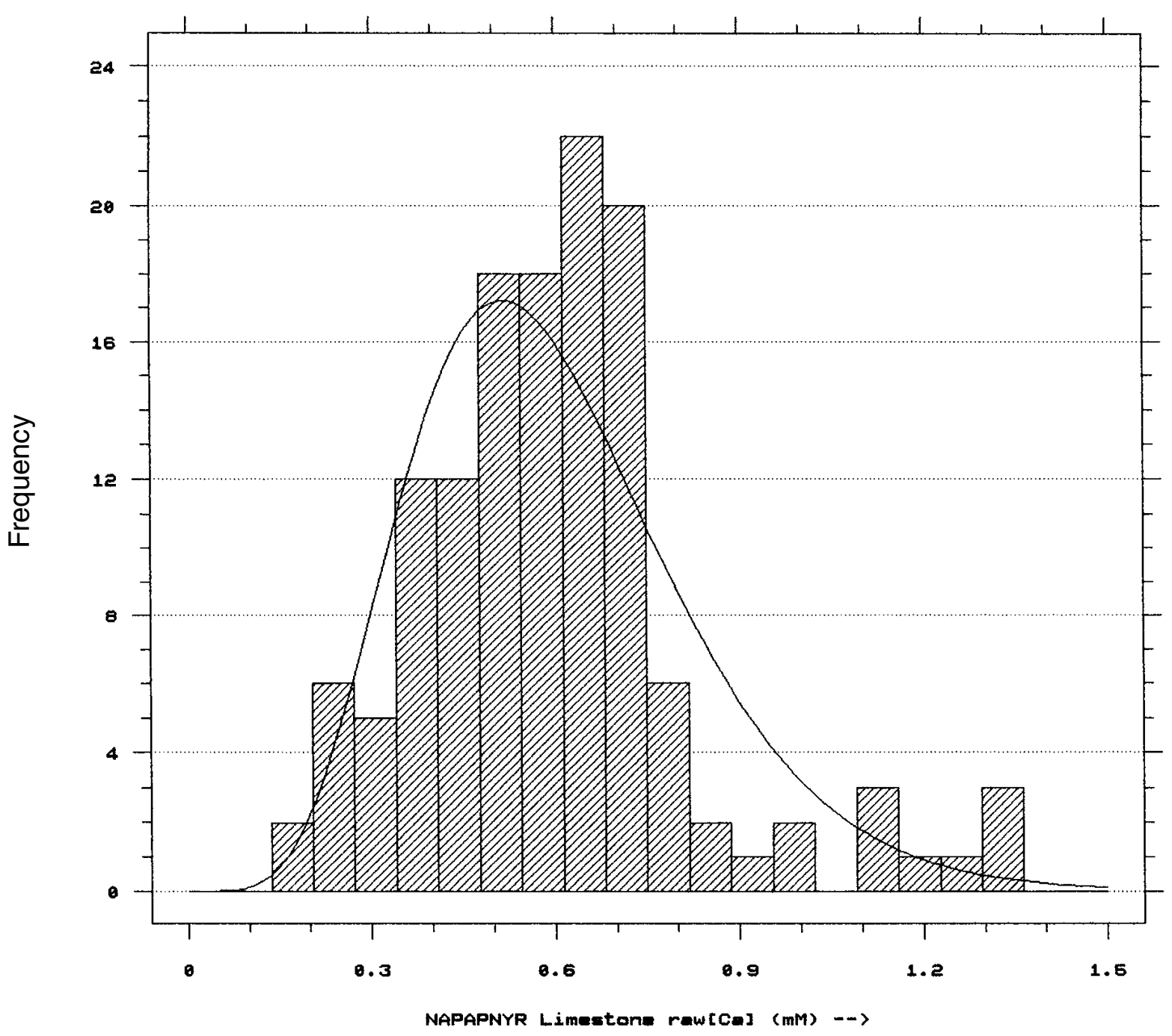

Chisquare Test

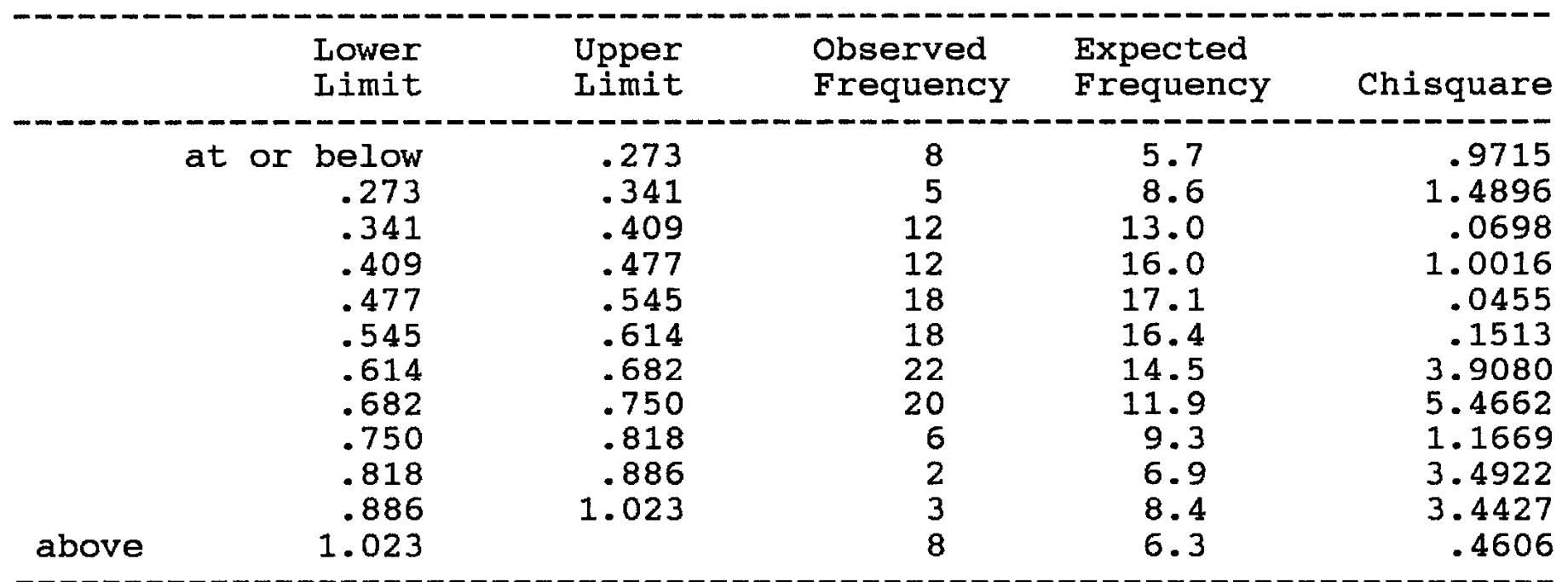

Chisquare $=21.666$ with 9 d.f. Sig. level $=9.99981 \mathrm{E}-3$

FIGURE 47.-A, Histograms and model with goodness-of-fit statistics. (Variable: $\mathrm{Ca}^{2+}$ uncor concentration; material: limestone; site: NAPAP-NY.) B, Histograms and model with goodness-of-fit statistics. (Variable: $\mathrm{Ca}^{2+}{ }_{\text {uncor }}$ concentration; material: marble; site: NAPAP-NY.) 
B Marble Raw [Ca] - NAPAP : NY

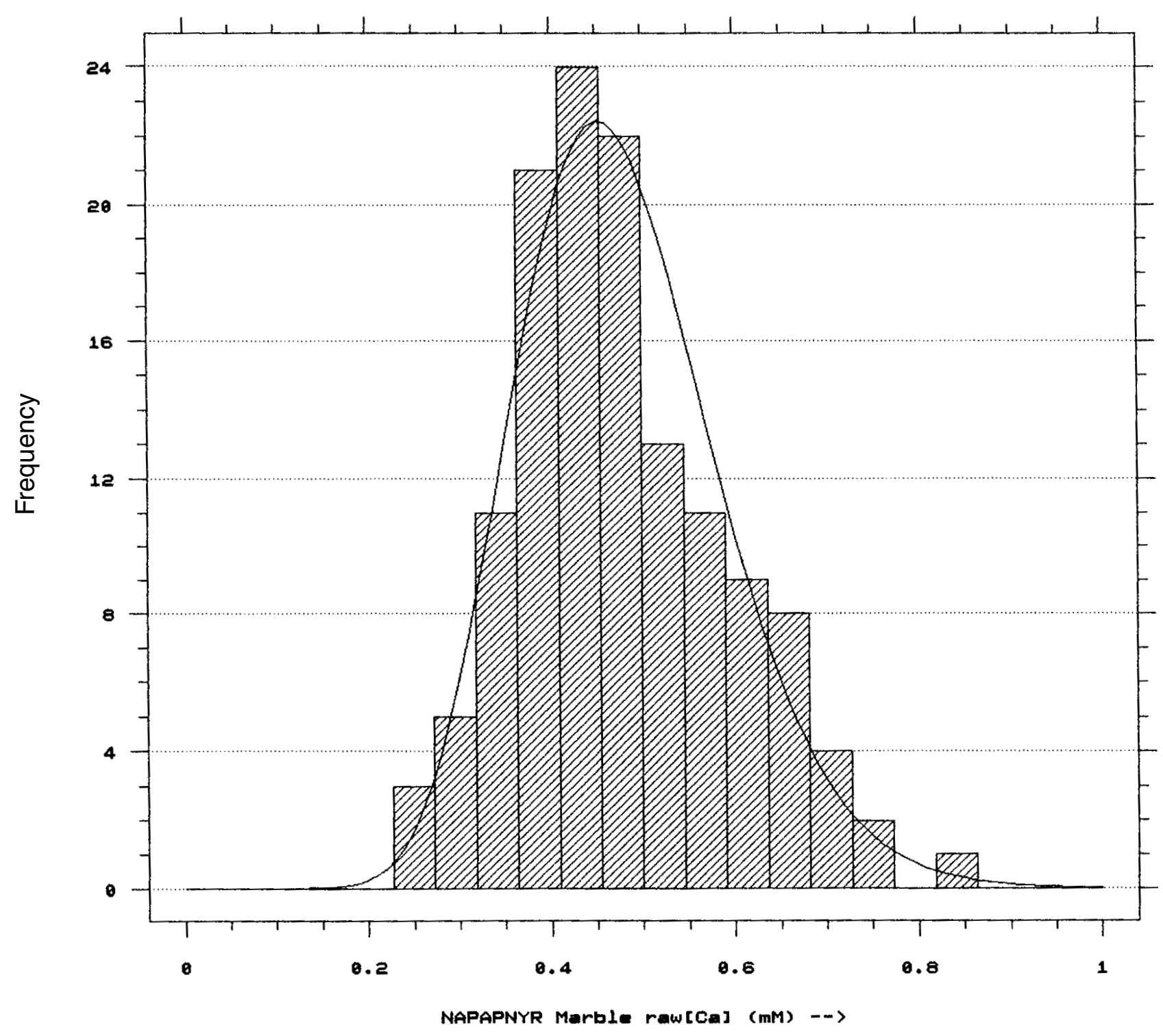

Chisquare Test

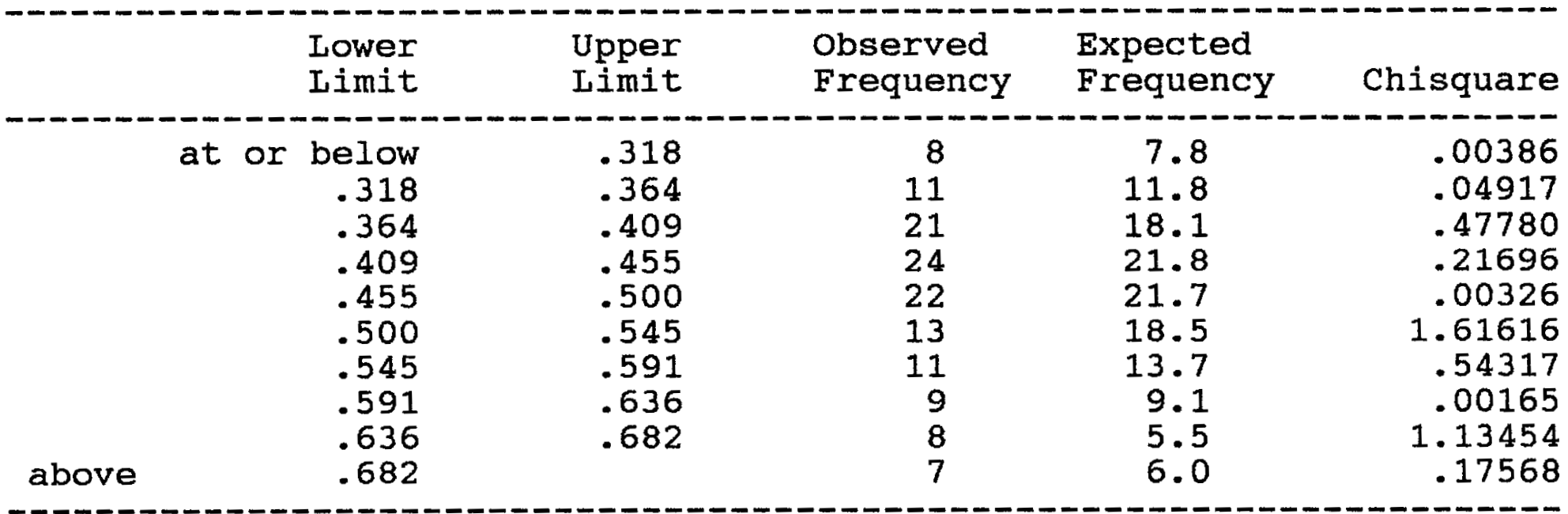

Chisquare $=4.22225$ with 7 d.f. Sig. level $=0.753853$ 


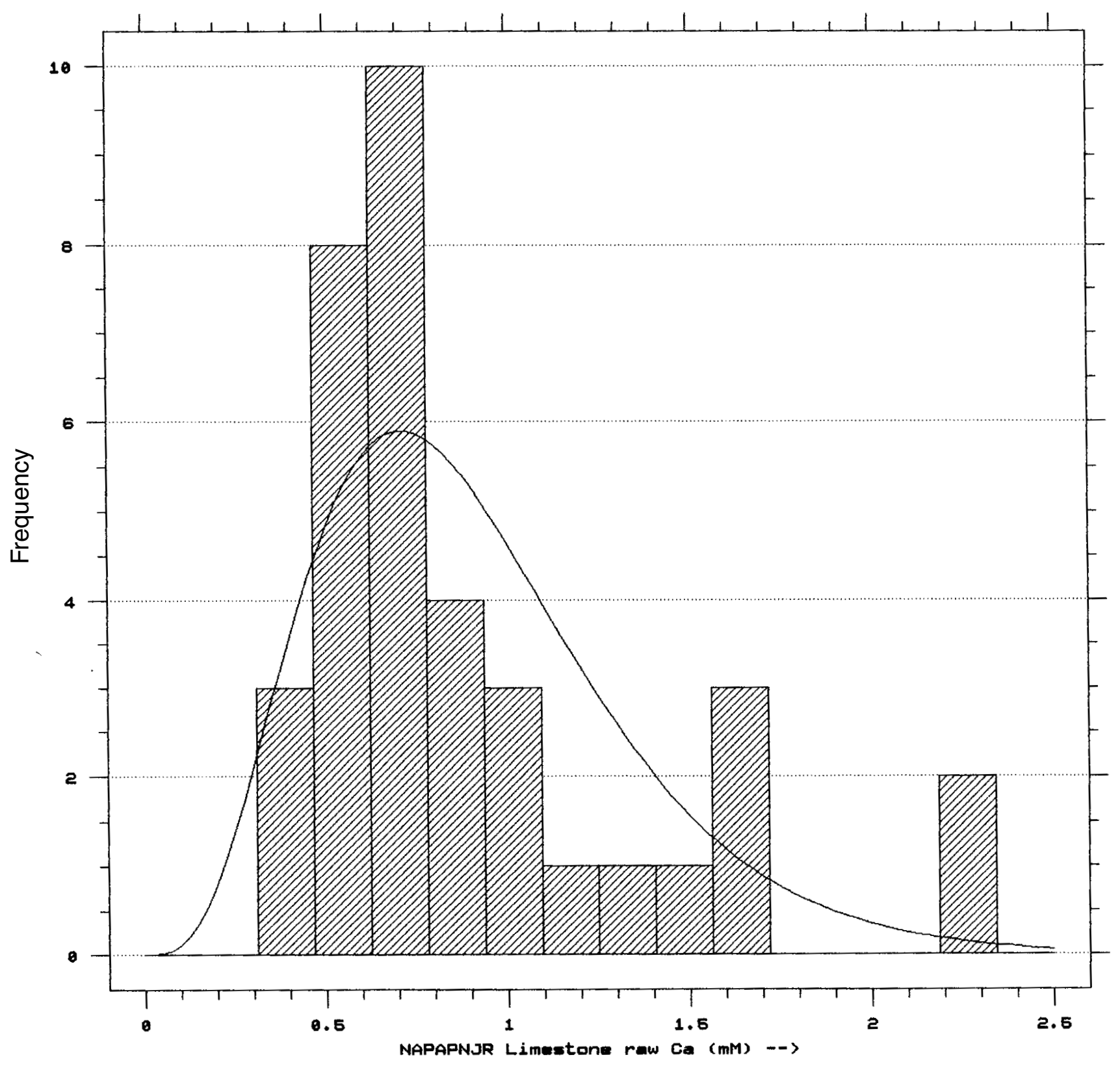

Chisquare Test

\begin{tabular}{|c|c|c|c|c|c|}
\hline & $\begin{array}{l}\text { Lower } \\
\text { Limit }\end{array}$ & $\begin{array}{l}\text { Upper } \\
\text { Iimit }\end{array}$ & $\begin{array}{l}\text { Observed } \\
\text { Frequency }\end{array}$ & $\begin{array}{l}\text { Expected } \\
\text { Frequency }\end{array}$ & Chisquare \\
\hline above & $\begin{array}{r}\text { below } \\
.625 \\
.781 \\
.938 \\
1.250\end{array}$ & $\begin{array}{r}.625 \\
.781 \\
.938 \\
1.250\end{array}$ & $\begin{array}{r}11 \\
10 \\
4 \\
4 \\
7\end{array}$ & $\begin{array}{l}9.9 \\
5.9 \\
5.5 \\
8.0 \\
6.8\end{array}$ & $\begin{array}{r}.11329 \\
2.94212 \\
.39780 \\
1.97393 \\
.00788\end{array}$ \\
\hline
\end{tabular}

Chisquare $=5.43503$ with 2 d.f. Sig. level $=0.0660388$

FIGURE 48.-A, Histograms and model with goodness-of-fit statistics. (Variable: $\mathrm{Ca}^{2+}{ }_{\text {uncor }}$ concentration; material: limestone; site: NAPAP-NJ.) B, Histograms and model with goodness-of-fit statistics. (Variable: $\mathrm{Ca}^{2+}{ }_{\text {uncor }}$ concentration; material: marble; site: NAPAP-NJ.) 


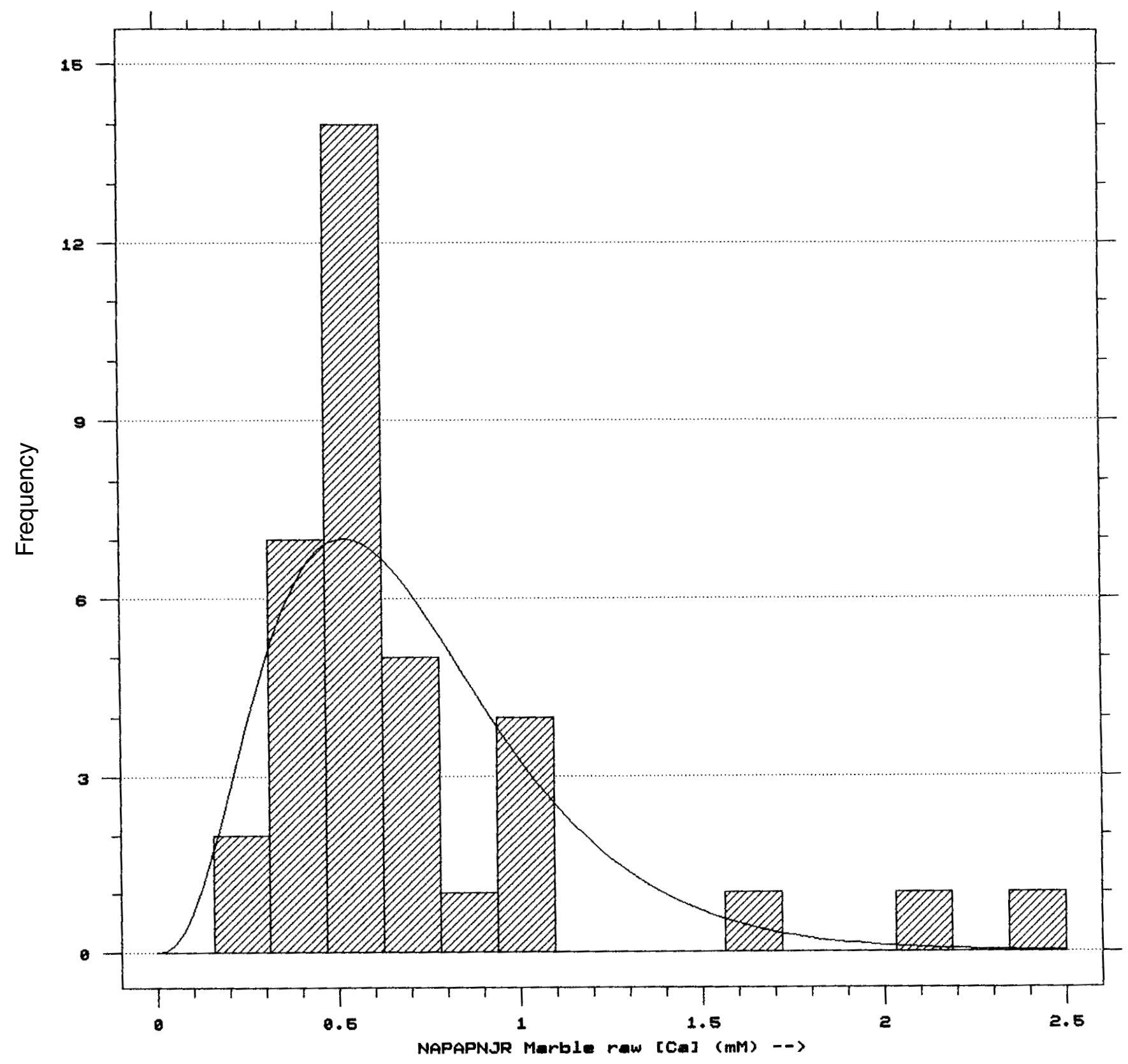

Chisquare Test

\begin{tabular}{|c|c|c|c|c|c|}
\hline & $\begin{array}{l}\text { Lower } \\
\text { Limit }\end{array}$ & $\begin{array}{l}\text { Upper } \\
\text { Iimit }\end{array}$ & $\begin{array}{l}\text { Observed } \\
\text { Frequency }\end{array}$ & $\begin{array}{l}\text { Expected } \\
\text { Frequency }\end{array}$ & Chisquare \\
\hline at or & $\begin{array}{r}\text { below } \\
.469 \\
.625 \\
.781\end{array}$ & $\begin{array}{l}.469 \\
.625 \\
.781\end{array}$ & $\begin{array}{r}9 \\
14 \\
5 \\
8\end{array}$ & $\begin{array}{r}10.3 \\
6.9 \\
6.1 \\
12.7\end{array}$ & $\begin{array}{r}.161 \\
7.208 \\
.186 \\
1.750\end{array}$ \\
\hline
\end{tabular}

Chisquare $=9.30595$ with 1 d.f. Sig. level $=2.28411 \mathrm{E}-3$ 
A Raw Limestone [Ca] - NAPAP : NC

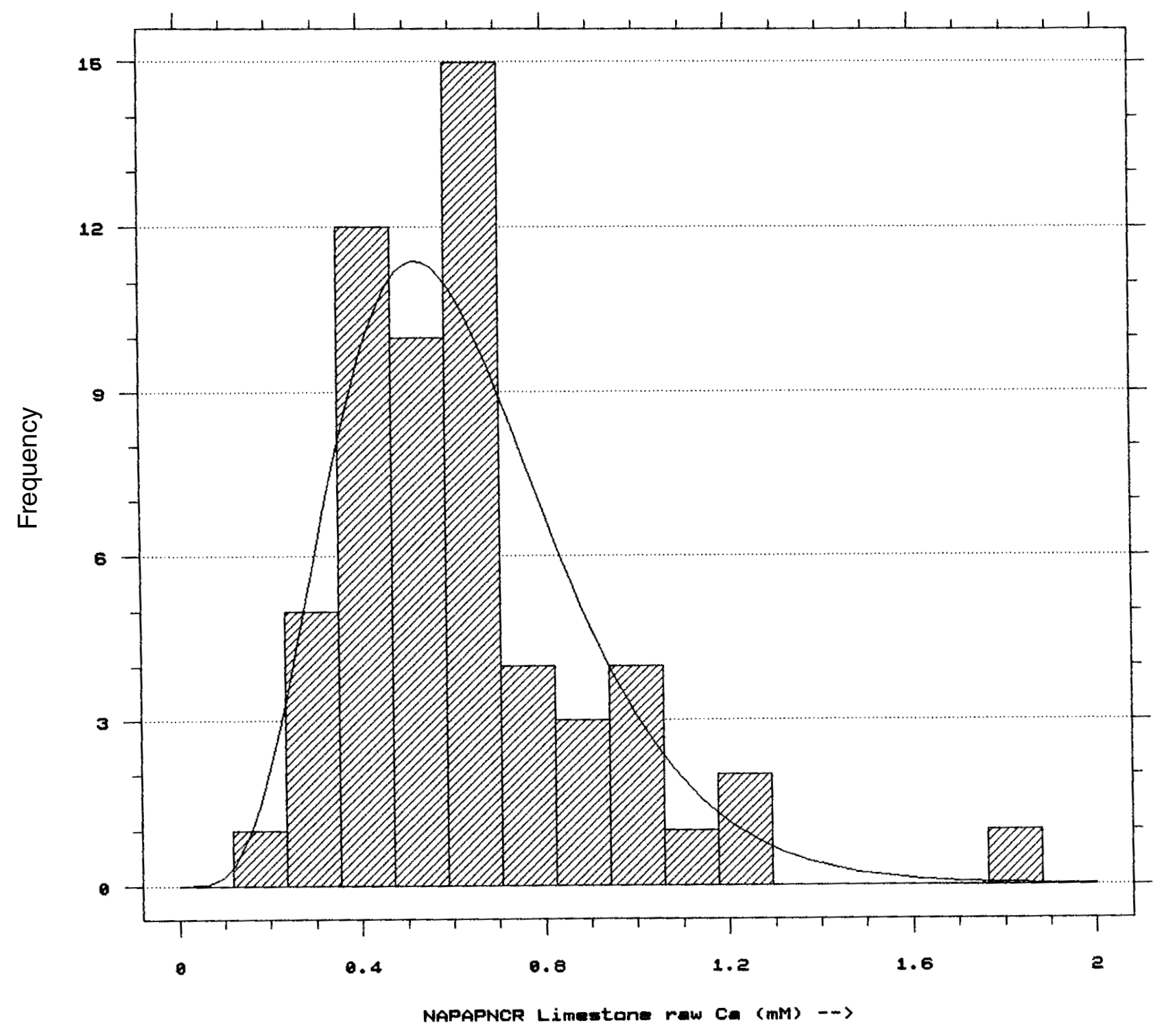

Chisquare Test

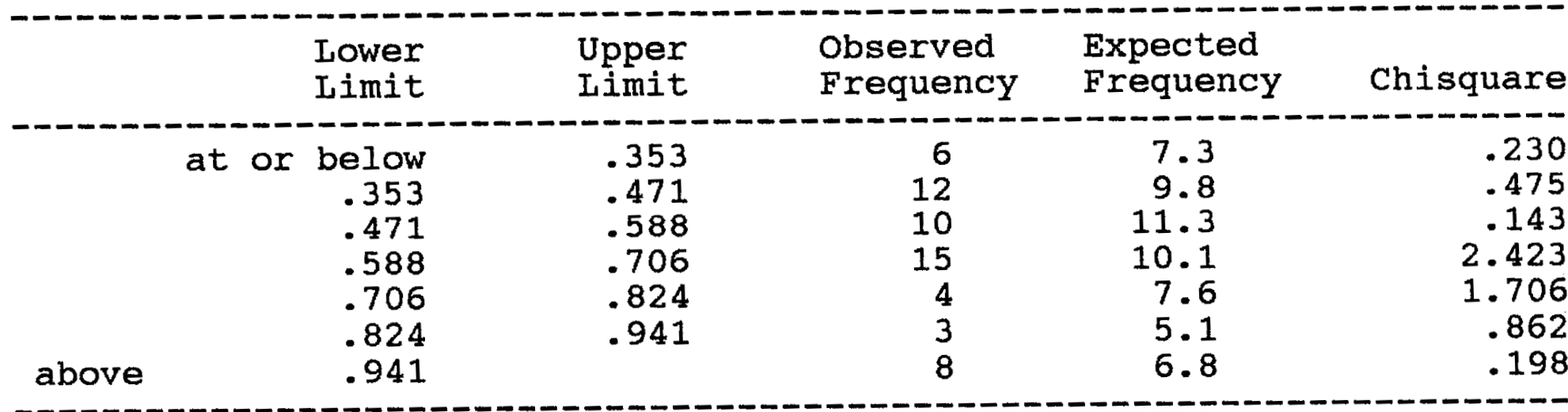

Chisquare $=6.03722$ with 4 d.f. Sig. level $=0.196386$

FIGURE 49.-A, Histograms and model with goodness-of-fit statistics. (Variable: $\mathrm{Ca}^{2+}{ }_{\text {uncor }}$ concentration; material: limestone; site: NAPAP-NC.) B, Histograms and model with goodness-of-fit statistics. (Variable: $\mathrm{Ca}^{2+}{ }_{\text {uncor }}$ concentration; material: marble; site: NAPAP-NC.) 
B Raw Marble [Ca] - NAPAP : NC

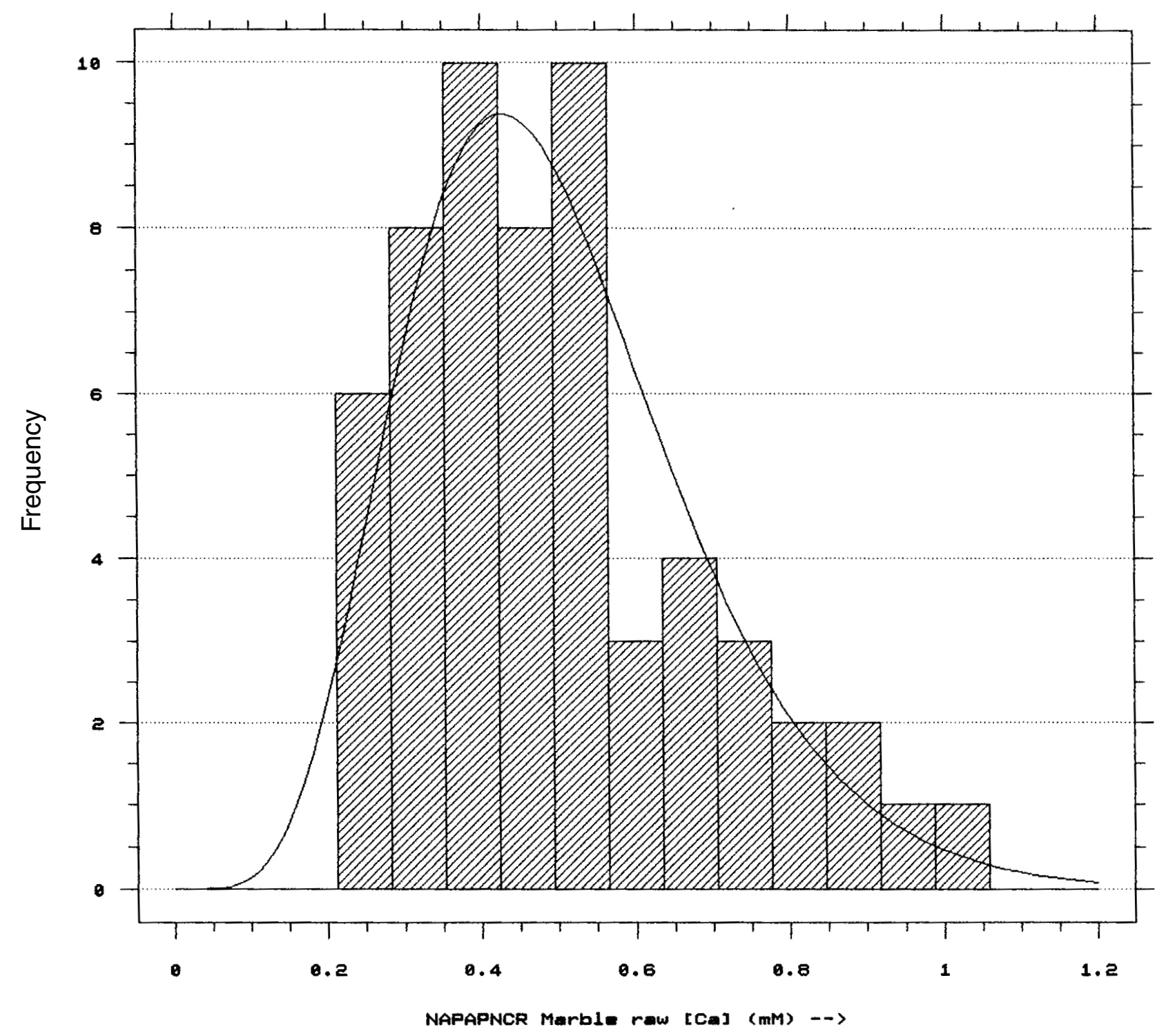

Chisquare Test

\begin{tabular}{|c|c|c|c|c|c|}
\hline & $\begin{array}{l}\text { Lower } \\
\text { Limit }\end{array}$ & $\begin{array}{l}\text { Upper } \\
\text { Limit }\end{array}$ & $\begin{array}{l}\text { Observed } \\
\text { Frequency }\end{array}$ & $\begin{array}{l}\text { Expected } \\
\text { Frequency }\end{array}$ & Chisquare \\
\hline at or & $\begin{array}{r}\text { below } \\
.282 \\
.353 \\
.424 \\
.494 \\
.565 \\
.635\end{array}$ & $\begin{array}{l}.282 \\
.353 \\
.424 \\
.494 \\
.565 \\
.635\end{array}$ & $\begin{array}{r}6 \\
8 \\
10 \\
8 \\
10 \\
3 \\
13\end{array}$ & $\begin{array}{r}6.1 \\
7.3 \\
9.0 \\
9.2 \\
8.0 \\
6.3 \\
12.1\end{array}$ & $\begin{array}{r}.000736 \\
.077351 \\
.102411 \\
.150158 \\
.480960 \\
1.726460 \\
.061074\end{array}$ \\
\hline
\end{tabular}

Chisquare $=2.59915$ with 4 d.f. Sig. level $=0.626974$ 
A LImestone Raw [Ca] - NAPAP : OH

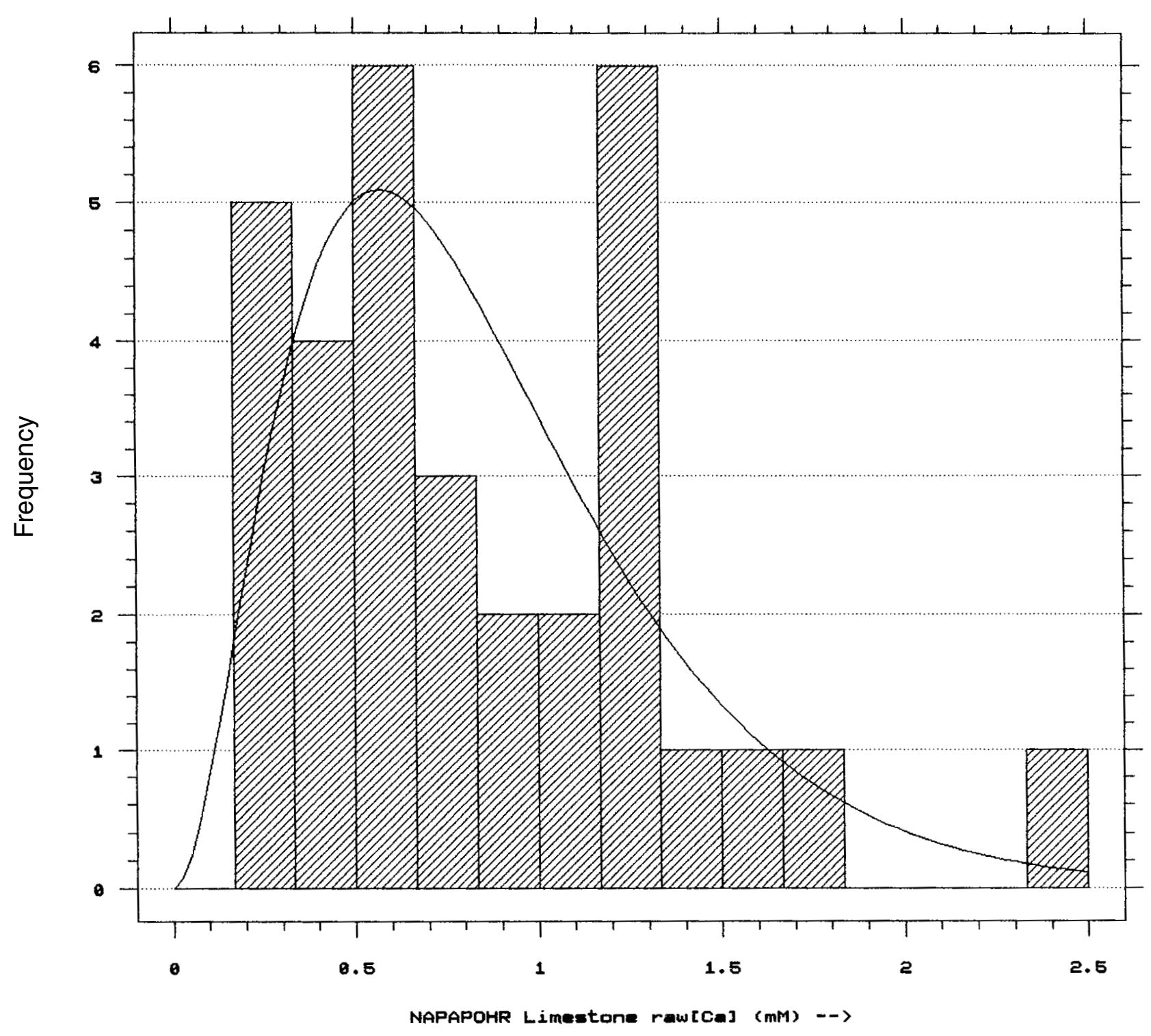

\section{Chisquare Test}

\begin{tabular}{|c|c|c|c|c|c|}
\hline & $\begin{array}{l}\text { Lower } \\
\text { Limit }\end{array}$ & $\begin{array}{l}\text { Upper } \\
\text { Limit }\end{array}$ & $\begin{array}{l}\text { Observed } \\
\text { Frequency }\end{array}$ & $\begin{array}{l}\text { Expected } \\
\text { Frequency }\end{array}$ & Chisquare \\
\hline above & $\begin{array}{r}\text { below } \\
.500 \\
.667 \\
1.000\end{array}$ & $\begin{array}{r}.500 \\
.667 \\
1.000\end{array}$ & $\begin{array}{r}9 \\
6 \\
5 \\
12\end{array}$ & $\begin{array}{r}8.3 \\
5.1 \\
8.5 \\
10.1\end{array}$ & $\begin{array}{r}.0673 \\
.1785 \\
1.4727 \\
.3384\end{array}$ \\
\hline
\end{tabular}

Chisquare $=2.05688$ with 1 d.f. Sig. level $=0.15152$

FIGURE 50.-A, Histograms and model with goodness-of-fit statistics. (Variable: $\mathrm{Ca}^{2+}{ }_{\text {uncor }}$ concentration; material: limestone; site: NAPAP-OH.) B, Histograms and model with goodness-of-fit statistics. (Variable: $\mathrm{Ca}^{2+}{ }_{\text {uncor }}$ concentration; material: marble; site: NAPAP-OH.) 
B Marble Raw [Ca] - NAPAP : OH

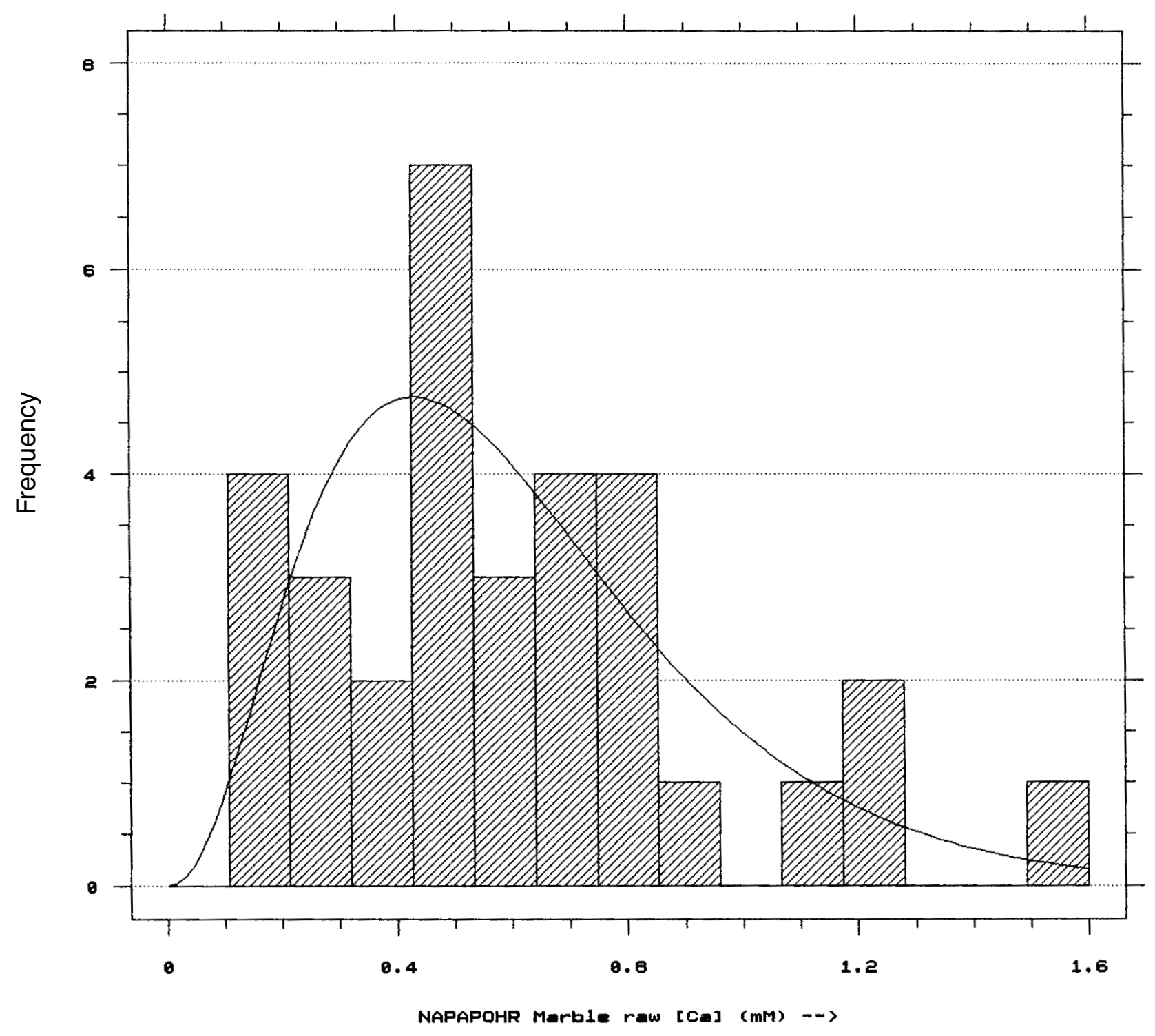

Chisquare Test

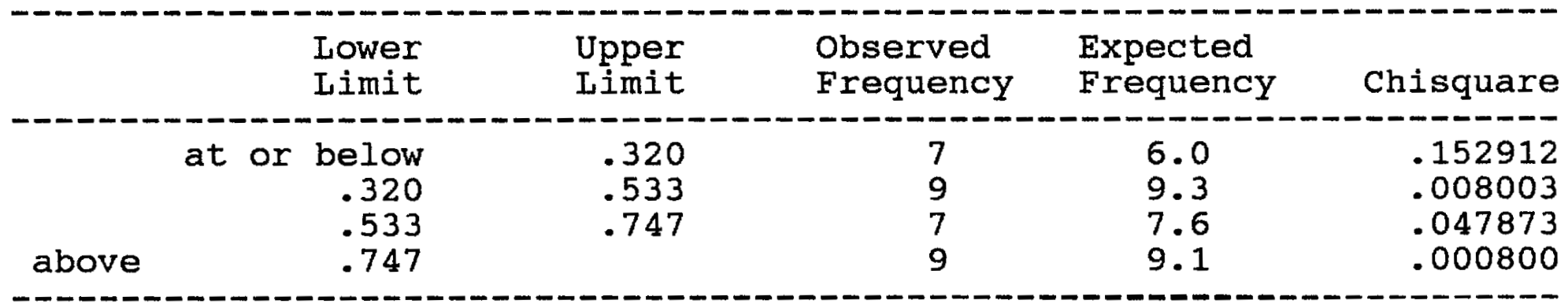

Shisquare $=0.209587$ with 1 d.f. Sig. level $=0.647092$ 
Limestone Excess [Ca] - NAPAP : NY

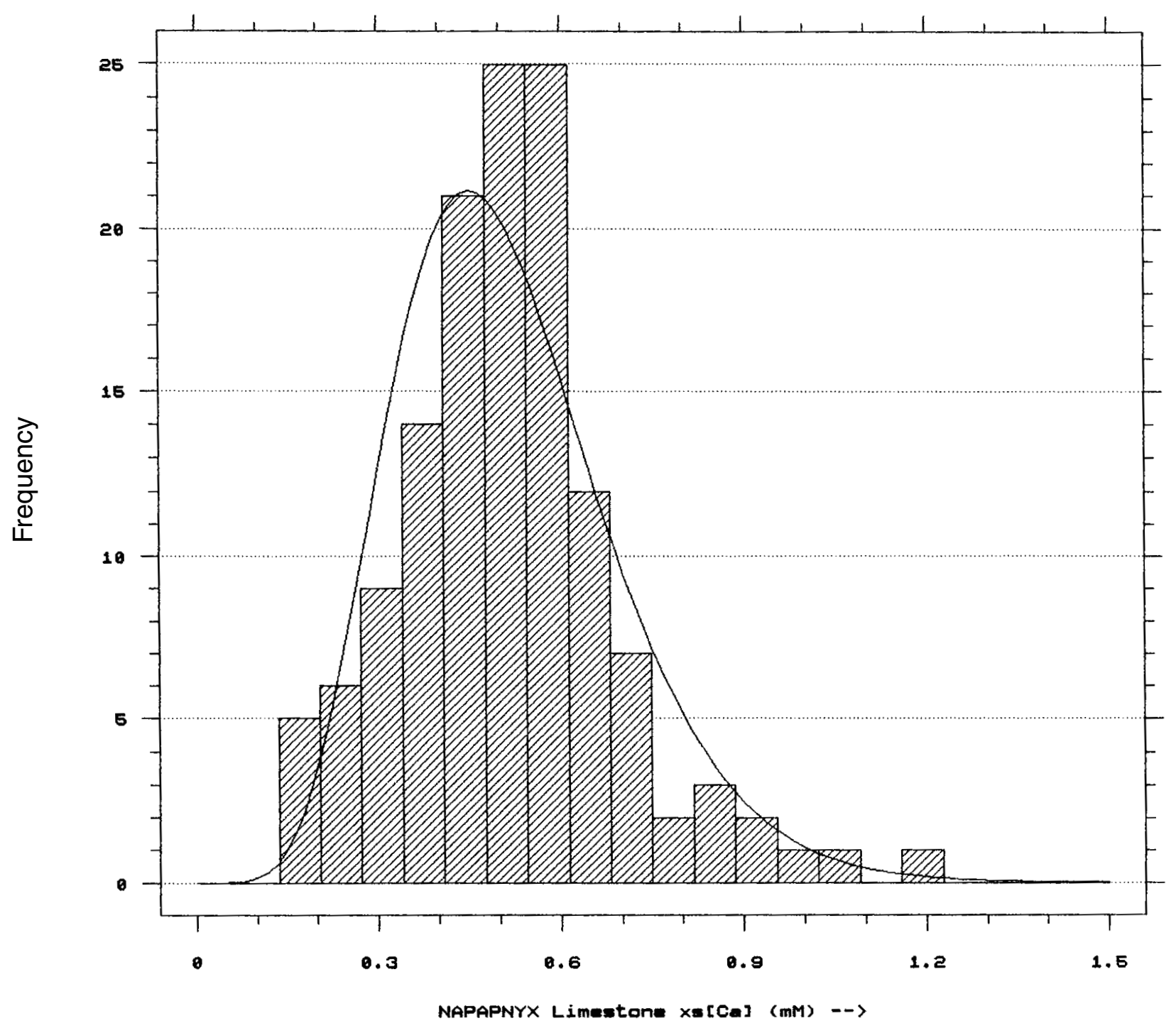

Chisquare Test

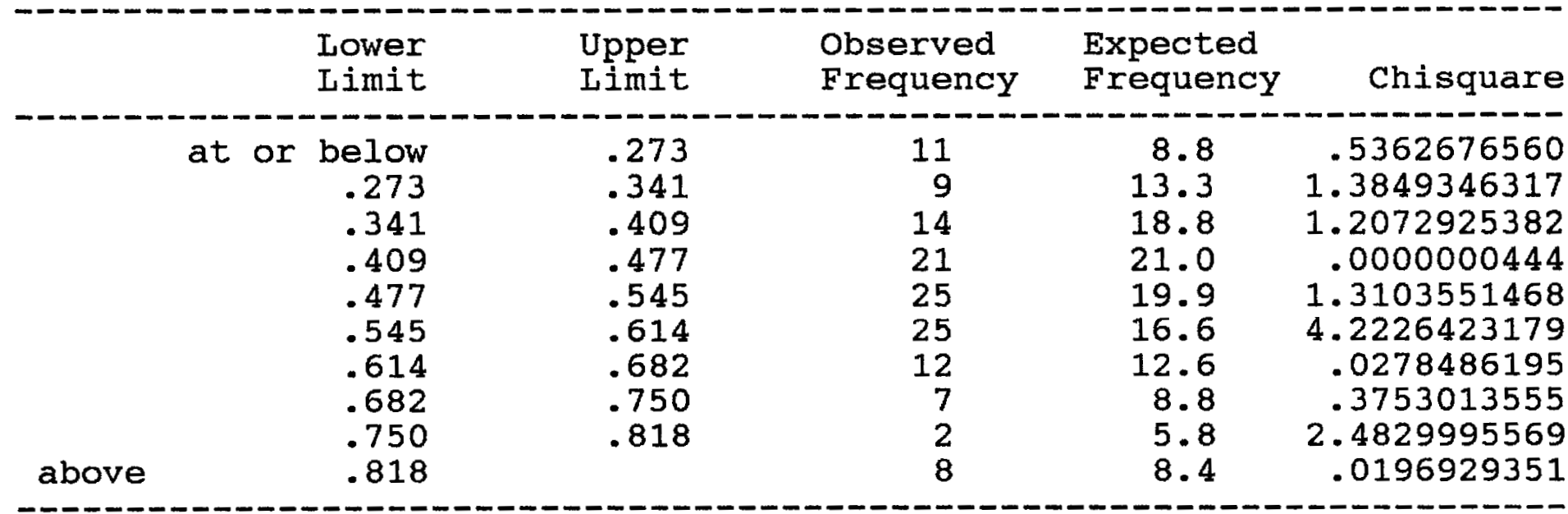

Chisquare $=11.5673$ with 7 d.f. Sig. level $=0.115715$

FIGURE 51.-A, Histograms and model with goodness-of-fit statistics. (Variable: $\mathrm{Ca}^{2+}{ }_{\mathrm{xs}}$ concentration; material: limestone; site: NAPAP-DC.) B, Histograms and model with goodness-of-fit statistics. (Variable: $\mathrm{Ca}^{2+}{ }_{x s}$ concentration; material: marble; site: NAPAP-DC.) 
B Marble Excess [Ca] - NAPAP : NY

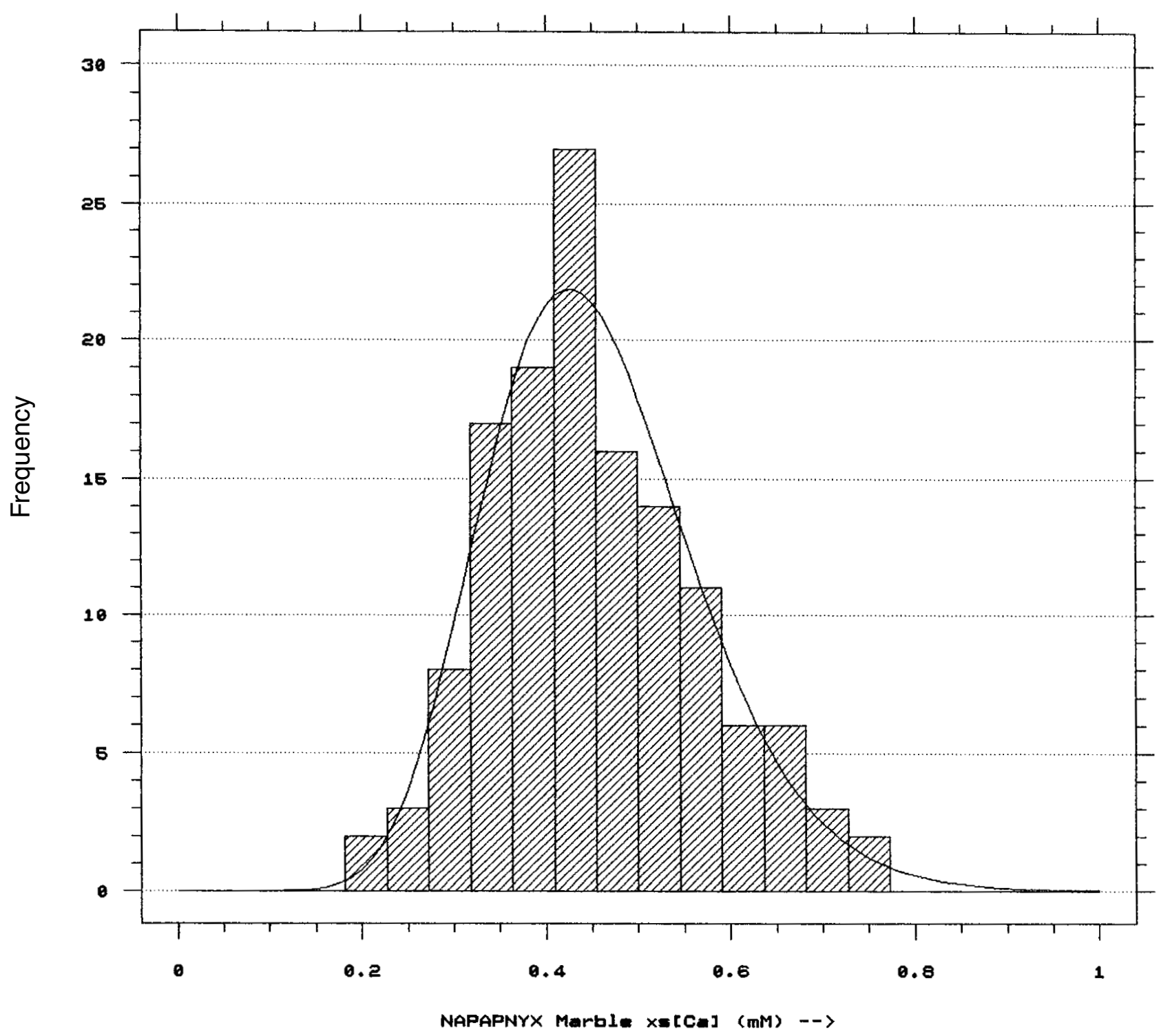

Chisquare Test

\begin{tabular}{|c|c|c|c|c|c|}
\hline & $\begin{array}{l}\text { Lower } \\
\text { Limit }\end{array}$ & $\begin{array}{l}\text { Upper } \\
\text { Limit }\end{array}$ & $\begin{array}{l}\text { Observed } \\
\text { Frequency }\end{array}$ & $\begin{array}{l}\text { Expected } \\
\text { Frequency }\end{array}$ & Chisquare \\
\hline above & $\begin{array}{r}\text { below } \\
.318 \\
.364 \\
.409 \\
.455 \\
.500 \\
.545 \\
.591 \\
.636\end{array}$ & $\begin{array}{l}.318 \\
.364 \\
.409 \\
.455 \\
.500 \\
.545 \\
.591 \\
.636\end{array}$ & $\begin{array}{r}13 \\
17 \\
19 \\
27 \\
16 \\
14 \\
11 \\
6 \\
11\end{array}$ & $\begin{array}{r}14.1 \\
15.5 \\
20.3 \\
21.7 \\
19.7 \\
15.6 \\
11.1 \\
7.2 \\
9.0\end{array}$ & $\begin{array}{r}.080684 \\
.153816 \\
.078064 \\
1.312136 \\
.688914 \\
.170551 \\
.000884 \\
.189502 \\
.458508\end{array}$ \\
\hline
\end{tabular}

Chisquare $=3.13306$ with 6 d.f. Sig. level $=0.791971$ 
A Limestone Excess [Ca] - NAPAP : NJ

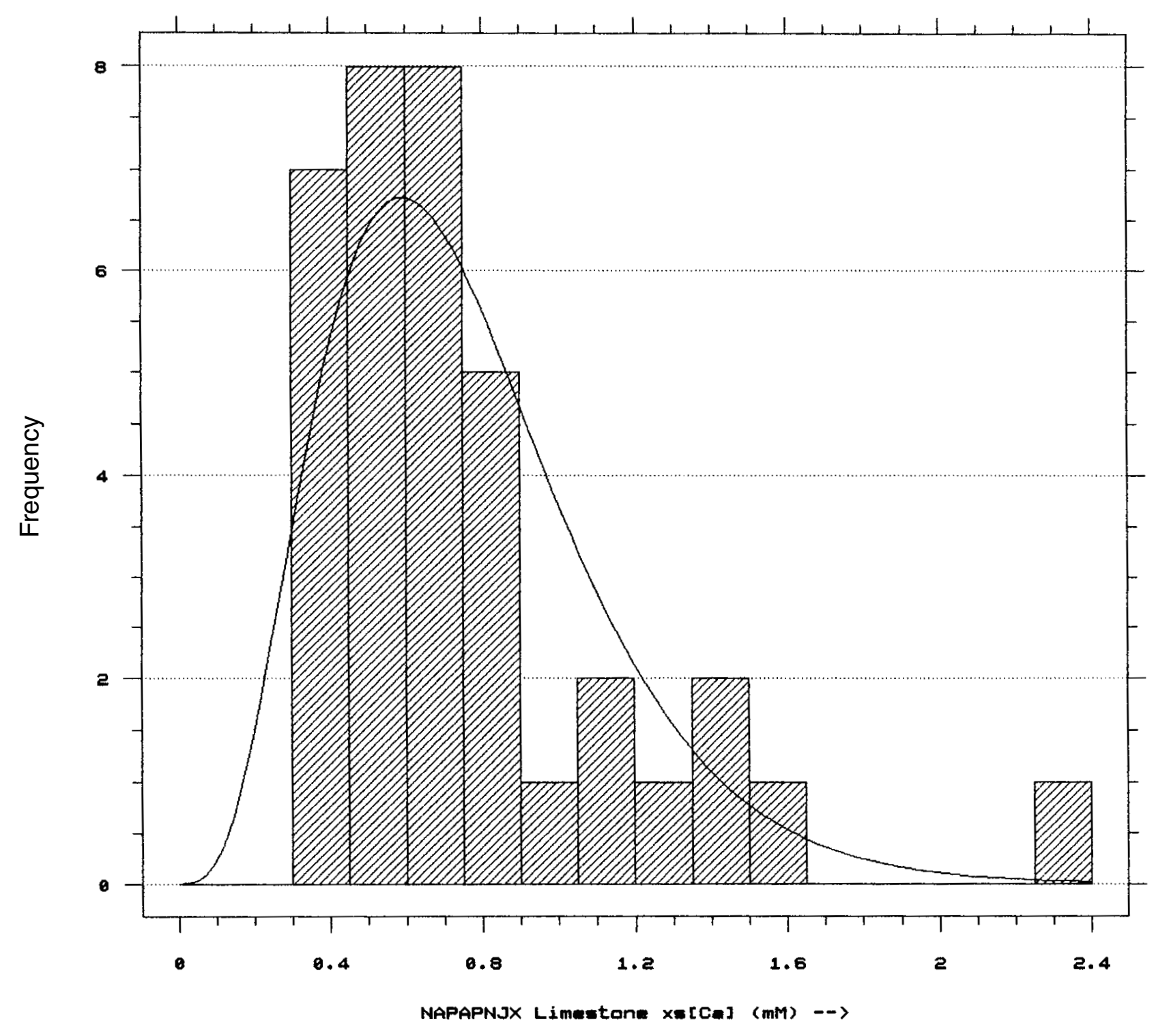

Chisquare Test

\begin{tabular}{rrrrr} 
Lower & Upper & Observed & Expected & \\
Limit & Limit & Frequency & Frequency & Chisquare \\
\hline at or below & .450 & 7 & 7.0 & .00000211 \\
.450 & .600 & 8 & 6.5 & .35049811 \\
.600 & .750 & 8 & 6.5 & .36221679 \\
.750 & .900 & 8 & 5.4 & .02662173 \\
.900 & & 8 & 10.7 & .66241551
\end{tabular}

Chisquare $=1.40175$ with 2 d.f. Sig. level $=0.49615$

FIGURE 52.-A, Histograms and model with goodness-of-fit statistics. (Variable: $\mathrm{Ca}^{2+}{ }_{x s}$ concentration; material: limestone; site: NAPAP-NY.) B, Histograms and model with goodness-of-fit statistics. (Variable: $\mathrm{Ca}^{2+}{ }_{x s}$ concentration; material: marble; site: NAPAP-NY.) 
B Marble Excess [Ca] - NAPAP : NJ

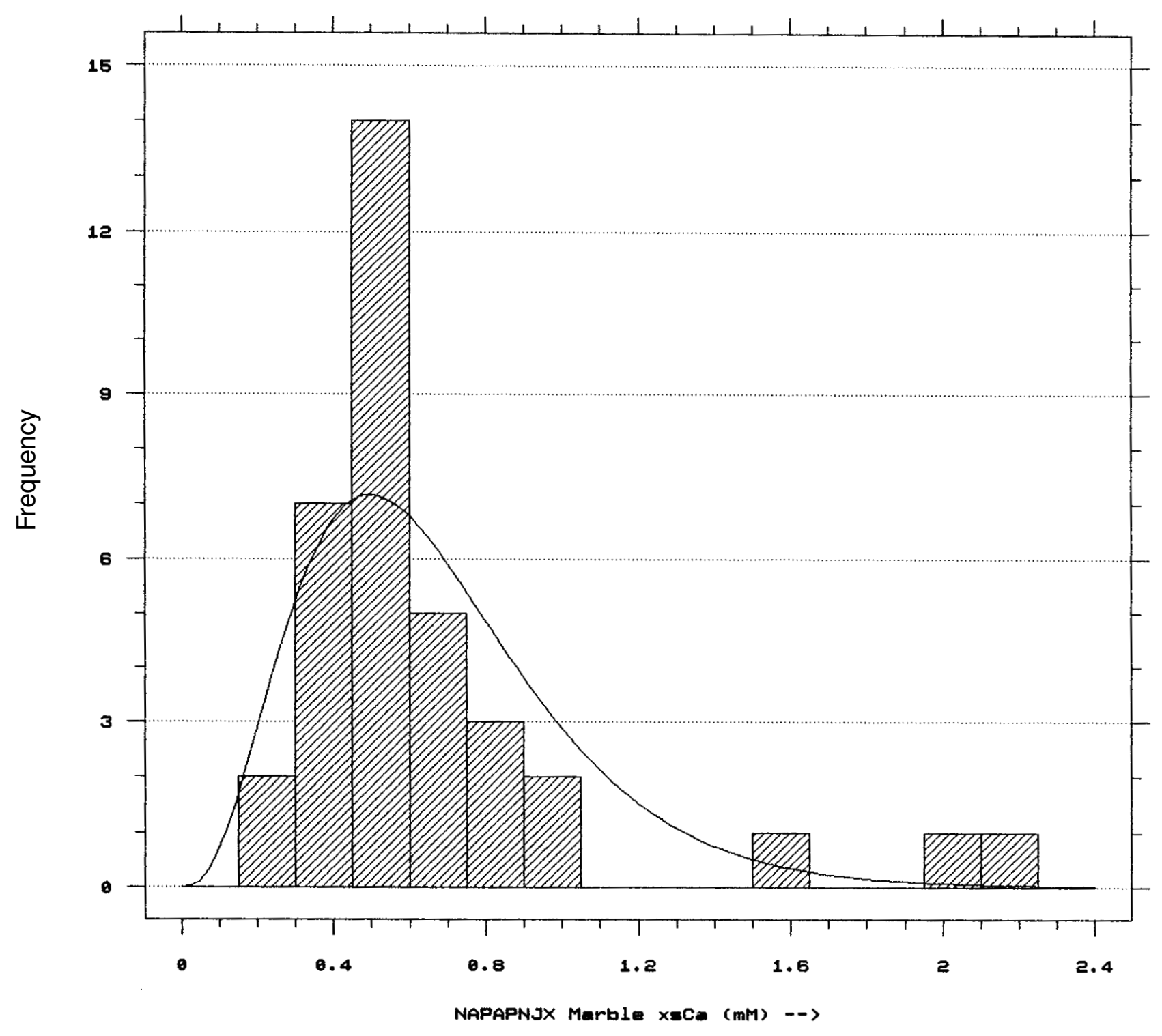

Chisquare Test

\begin{tabular}{|c|c|c|c|c|c|}
\hline & $\begin{array}{l}\text { Lower } \\
\text { Limit }\end{array}$ & $\begin{array}{l}\text { Upper } \\
\text { Limit }\end{array}$ & $\begin{array}{l}\text { Observed } \\
\text { Frequency }\end{array}$ & $\begin{array}{l}\text { Expected } \\
\text { Frequency }\end{array}$ & Chisquare \\
\hline at or & $\begin{array}{r}\text { below } \\
.450 \\
.600 \\
.750\end{array}$ & $\begin{array}{l}.450 \\
.600 \\
.750\end{array}$ & $\begin{array}{r}9 \\
14 \\
5 \\
8\end{array}$ & $\begin{array}{r}10.4 \\
7.1 \\
6.1 \\
12.4\end{array}$ & $\begin{array}{r}.185 \\
6.811 \\
.211 \\
1.568\end{array}$ \\
\hline
\end{tabular}

Chisquare $=8.77487$ with 1 d.f. Sig. level $=3.05408 \mathrm{E}-3$ 
A Limestone Excess [Ca] - NAPAP : NC

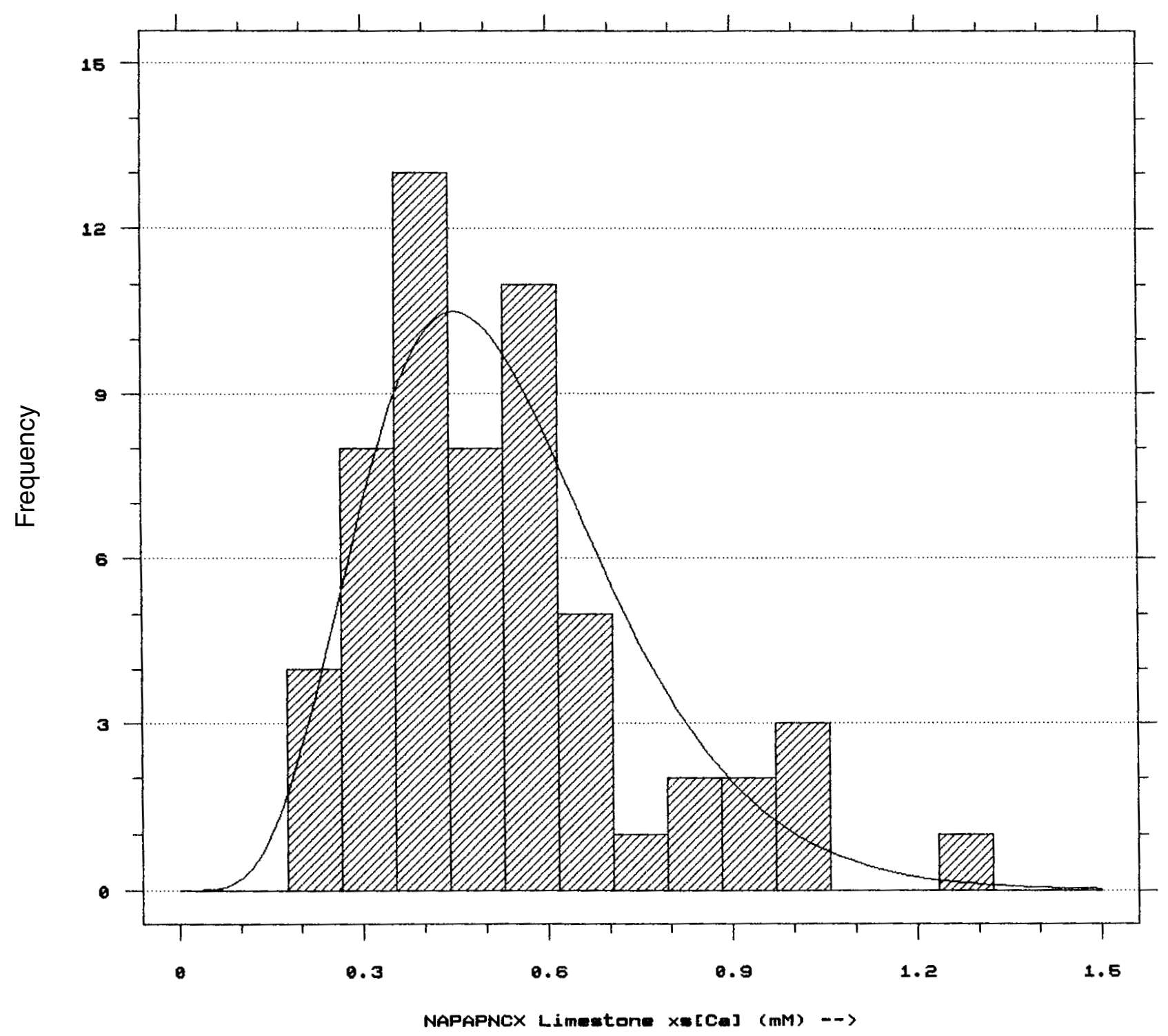

Chisquare Test

\begin{tabular}{|c|c|c|c|c|c|}
\hline & $\begin{array}{l}\text { Lower } \\
\text { Limit }\end{array}$ & $\begin{array}{l}\text { Upper } \\
\text { Limit }\end{array}$ & $\begin{array}{l}\text { Observed } \\
\text { Frequency }\end{array}$ & $\begin{array}{l}\text { Expected } \\
\text { Frequency }\end{array}$ & Chisquare \\
\hline above & $\begin{array}{r}\text { below } \\
.353 \\
.441 \\
.529 \\
.618 \\
.706\end{array}$ & $\begin{array}{l}.353 \\
.441 \\
.529 \\
.618 \\
.706\end{array}$ & $\begin{array}{r}12 \\
13 \\
8 \\
11 \\
5 \\
9\end{array}$ & $\begin{array}{r}11.5 \\
10.0 \\
10.3 \\
8.8 \\
6.6 \\
10.9\end{array}$ & $\begin{array}{r}.0216 \\
.9260 \\
.5010 \\
.5539 \\
.3850 \\
.3252\end{array}$ \\
\hline
\end{tabular}

Chisquare $=2.71262$ with 3 d.f. Sig. level $=0.438087$

FIGURE 53.-A, Histograms and model with goodness-of-fit statistics. (Variable: $\mathrm{Ca}^{2+}{ }_{x s}$ concentration; material: limestone; site: NAPAP-NJ.) B, Histograms and model with goodness-of-fit statistics. (Variable: $\mathrm{Ca}^{2+}{ }_{x s}$ concentration; material: marble; site: NAPAP-NJ.) 
B Marble Excess [Ca] - NAPAP : NC

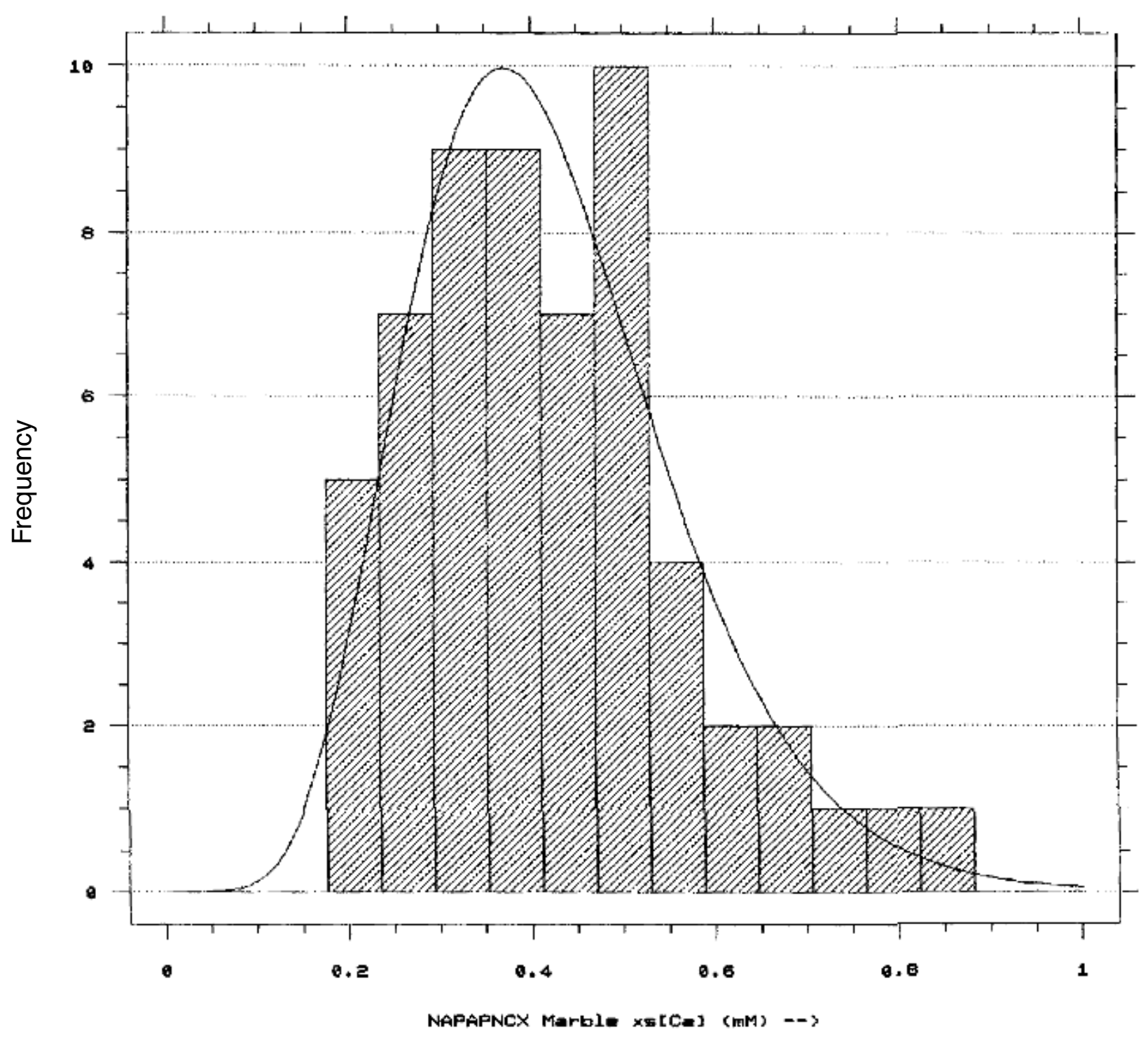

Chisquare Test

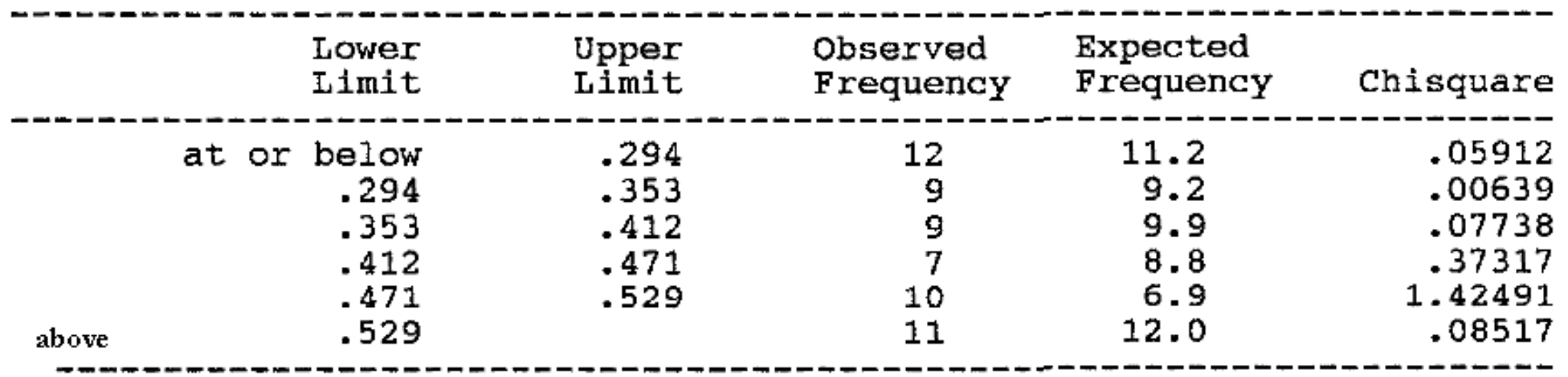

Chisquare $=2.02615$ with 3 d.f. Sig. level $=0.566997$ 


\section{A Limestone Excess [Ca] - NAPAP : OH}

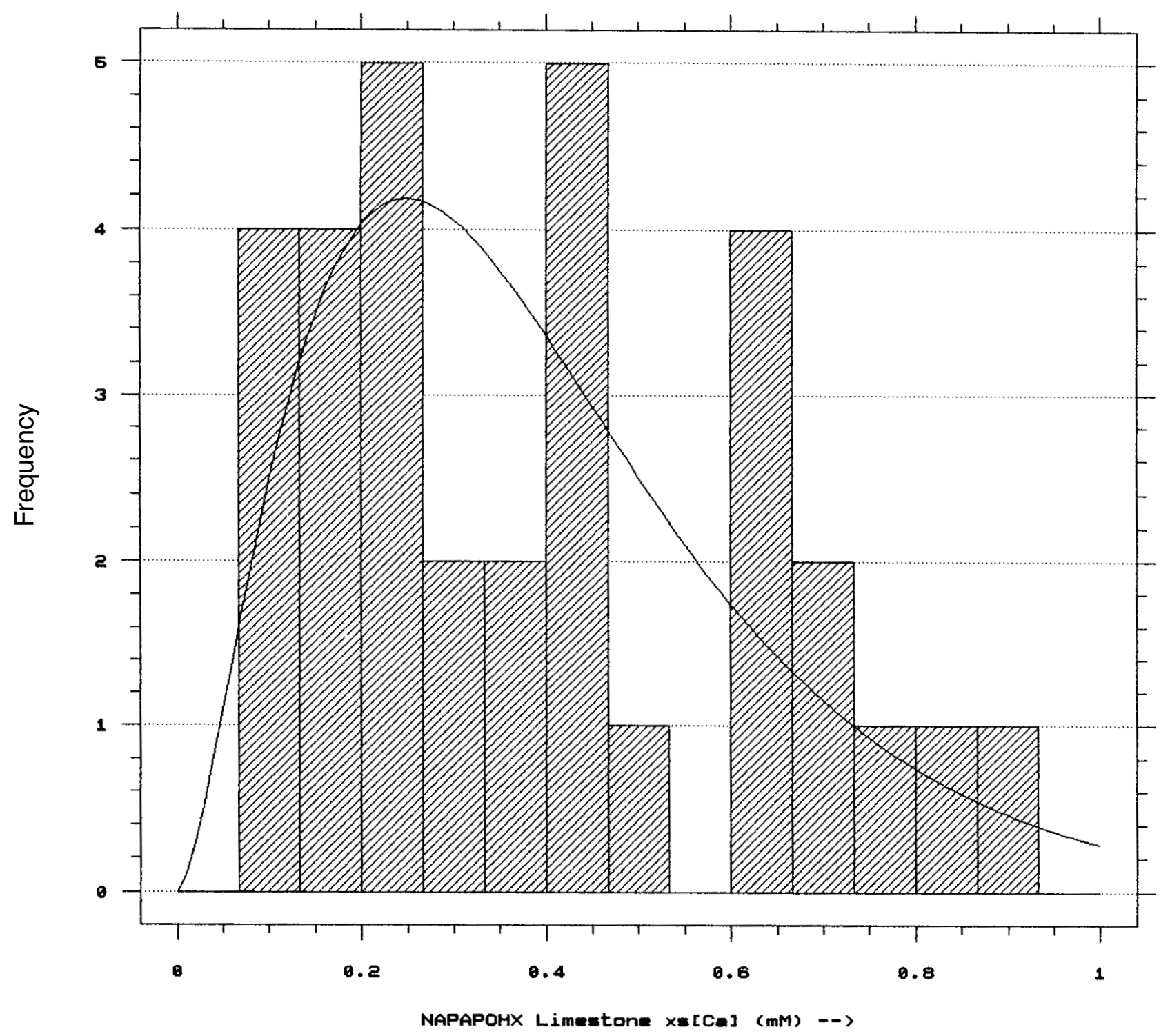

Chisquare Test

\begin{tabular}{rrrrr} 
Lower & Upper & Observed & Expected & \\
Limit & Limit & Frequency & Frequency & Chisquare \\
\hline at or below & .200 & 8 & 6.8 & .20684 \\
.200 & .333 & 7 & 8.2 & .17337 \\
.333 & .467 & 7 & 6.7 & .01310 \\
.467 & & 10 & 10.3 & .00827
\end{tabular}

Chisquare $=0.401585$ with 1 d.f. Sig. level $=0.526272$

FIGURE 54.-A, Histograms and model with goodness-of-fit statistics. (Variable: $\mathrm{Ca}^{2+}{ }_{\mathrm{xs}}$ concentration; material: limestone; site: NAPAP-NC.) B, Histograms and model with goodness-of-fit statistics. (Variable: $\mathrm{Ca}^{2+}{ }_{x s}$ concentration; material: marble; site: NAPAP-NC.) 


\section{B Marble Excess [Ca] - NaPAP : $\mathrm{OH}$}

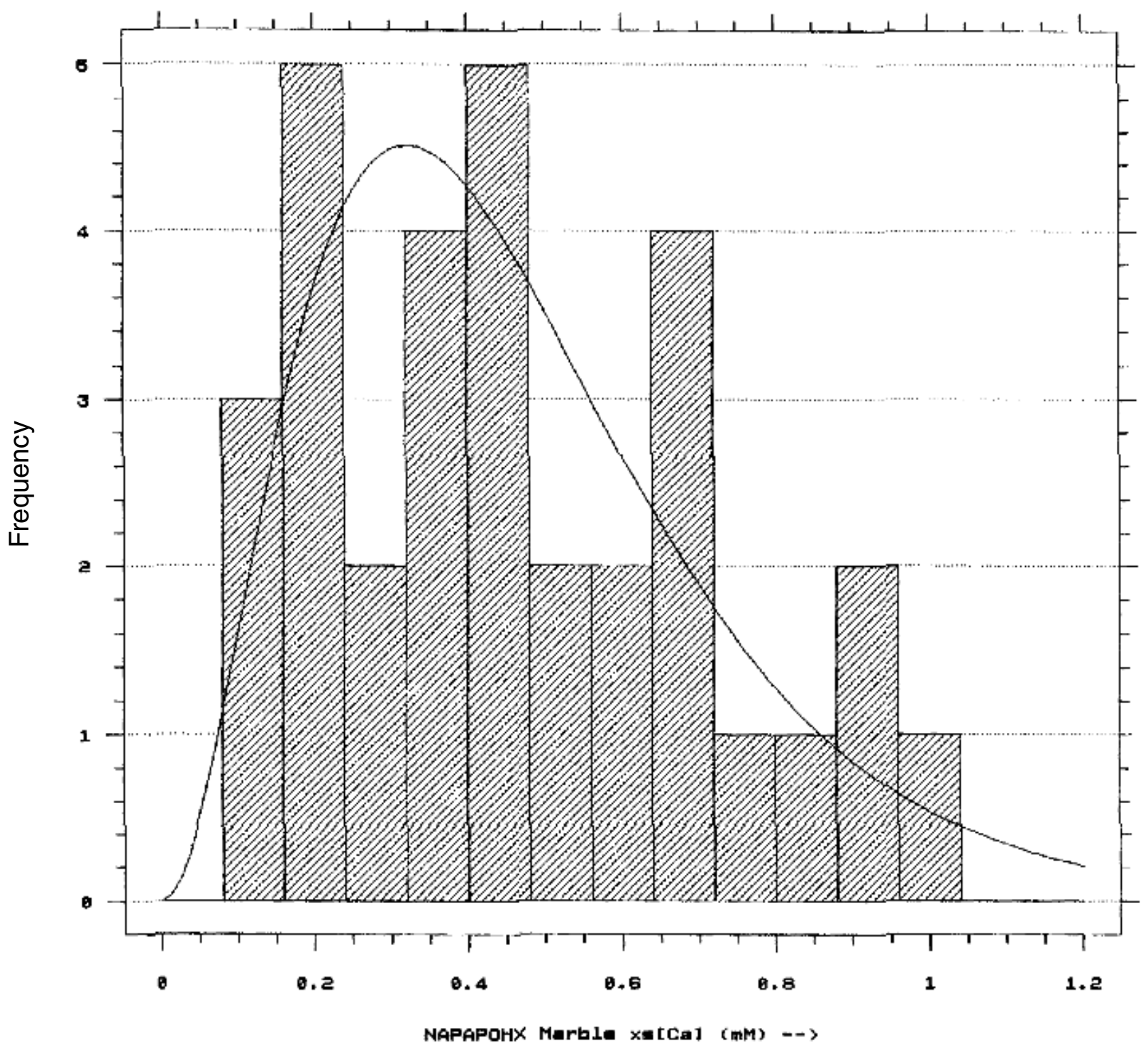

Chisquare Test

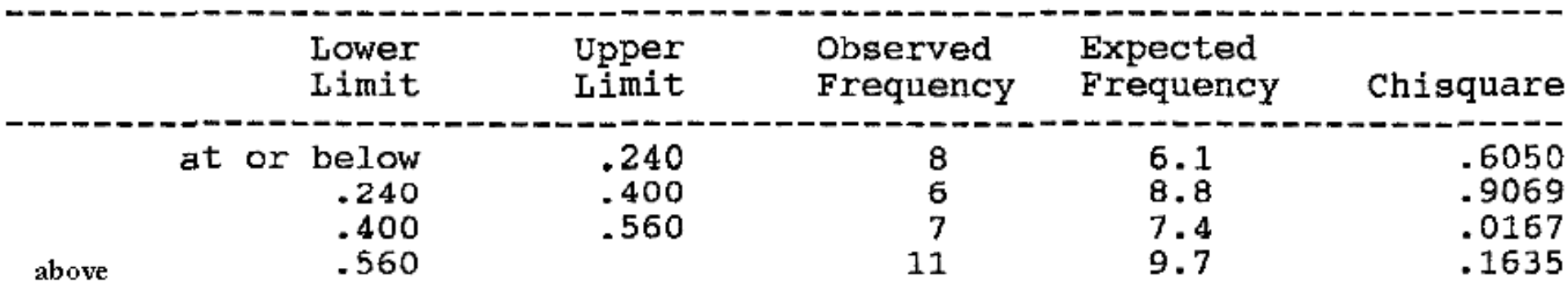

Chisquare $=1.69202$ with 1 d.f. Sig. level $=0.193335$ 


\section{A Limestone Excess [Ca] - NAPAP DC}

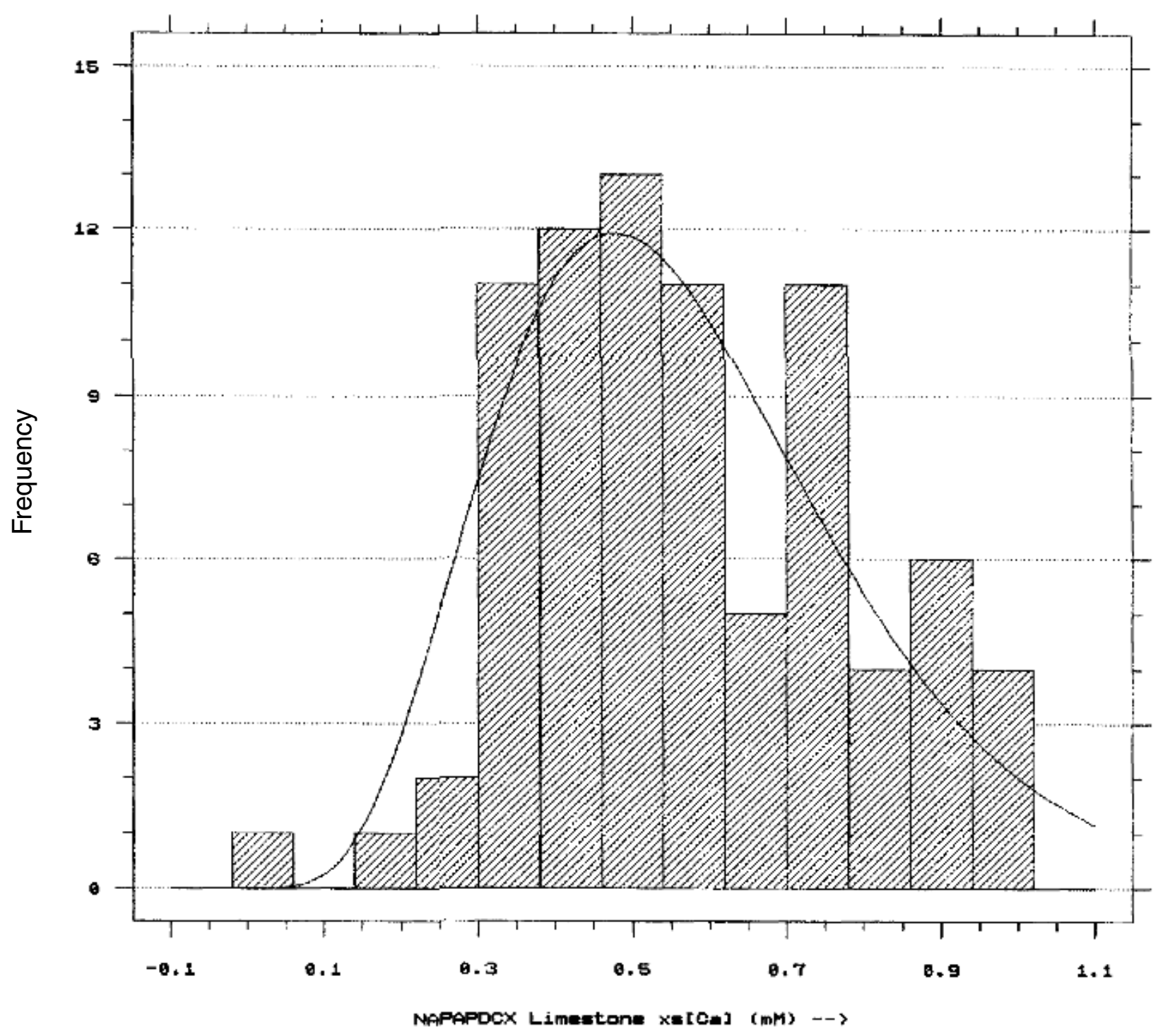

Chisquare Test

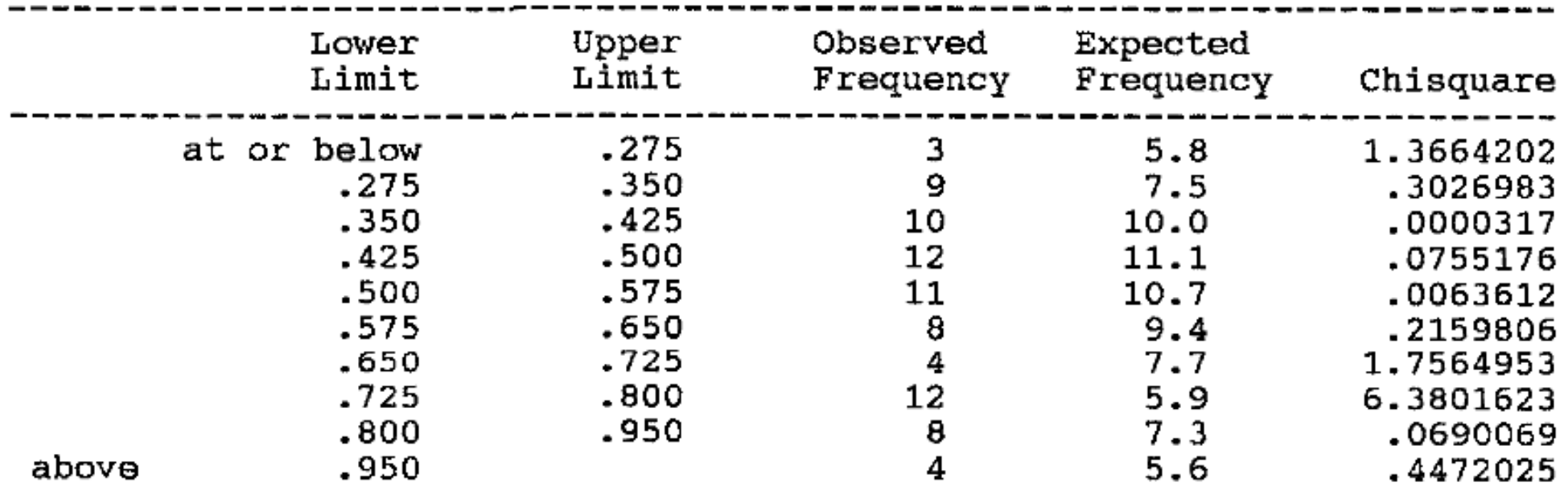

Chisquare $=10.6199$ with 7 d.f. Sig. level $=0.156081$

FIGURE 55.-A, Histograms and model with goodness-of-fit statistics. (Variable: $\mathrm{Ca}^{2+}{ }_{\mathrm{xs}}$ concentration; material: limestone; site: NAPAP-OH.) B, Histograms and model with goodness-of-fit statistics. (Variable: $\mathrm{Ca}^{2+}{ }_{x s}$ concentration; material: marble; site: NAPAP-OH.) 


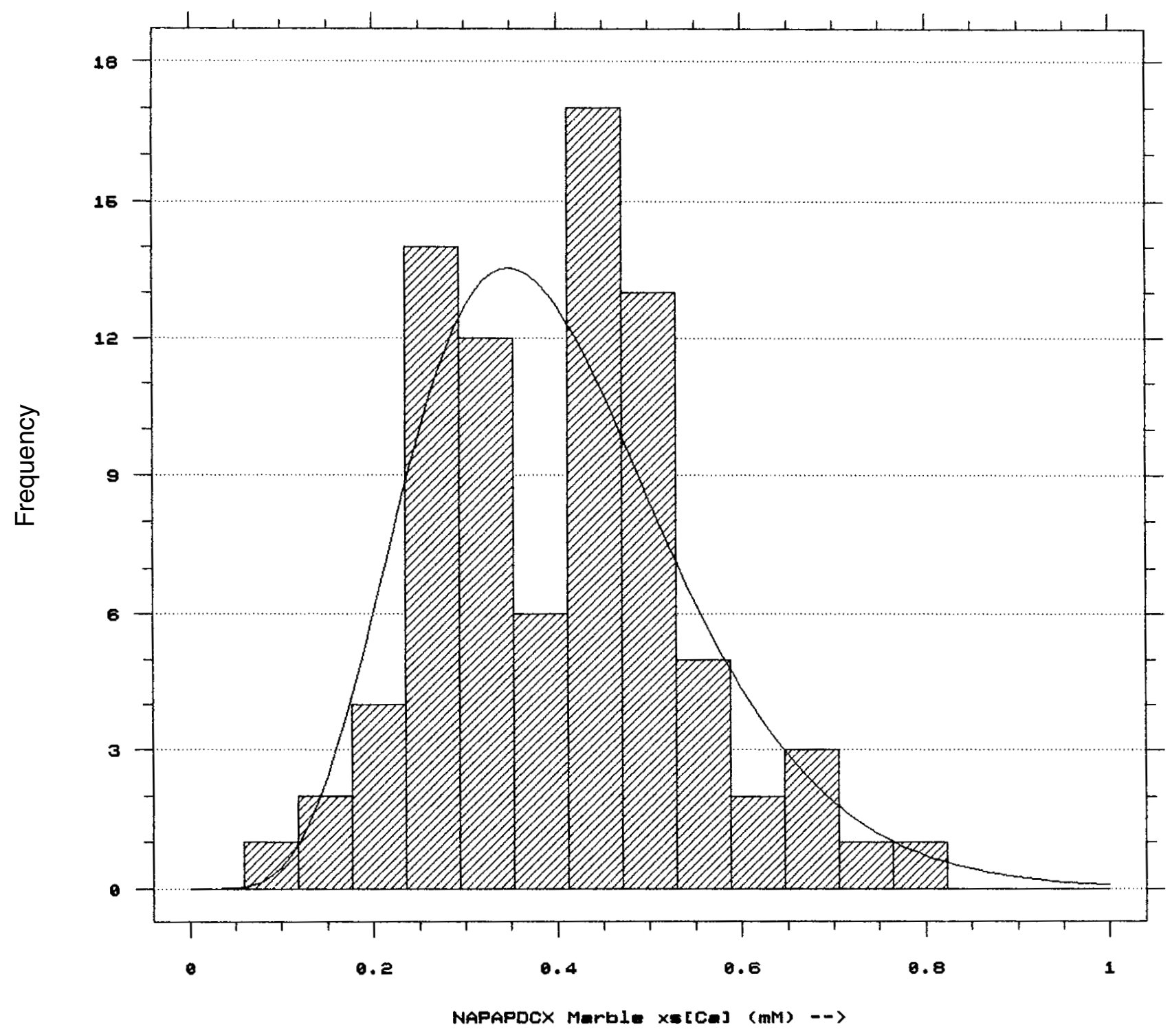

Chisquare Test

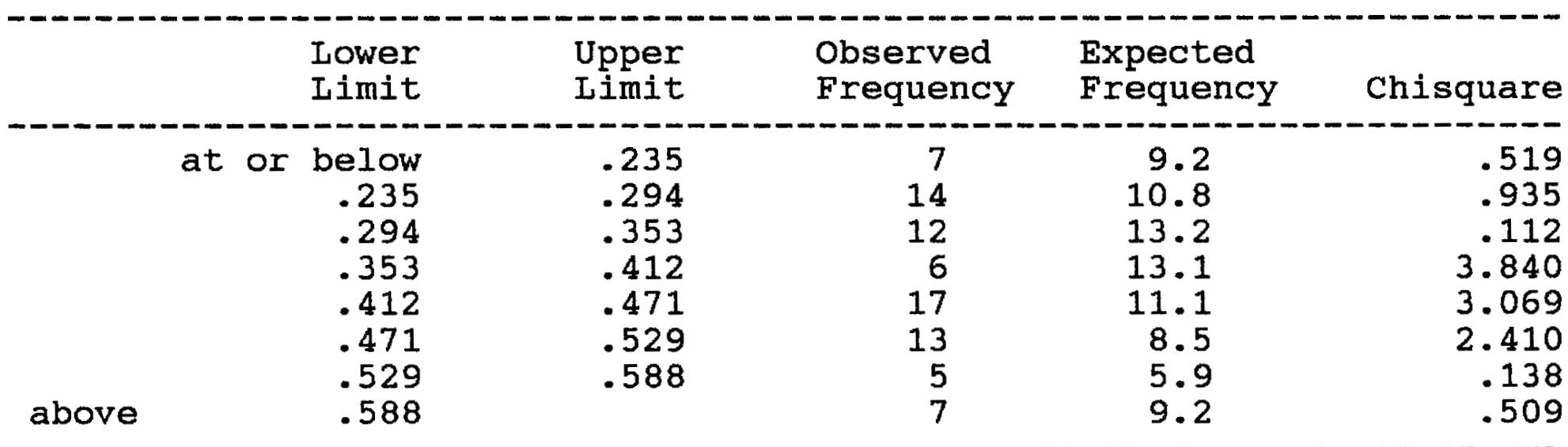

Chisquare $=11.5314$ with 5 d.f. sig. level $=0.0418051$ 
A Limestone Ca Mass Loss - NAPAP DC

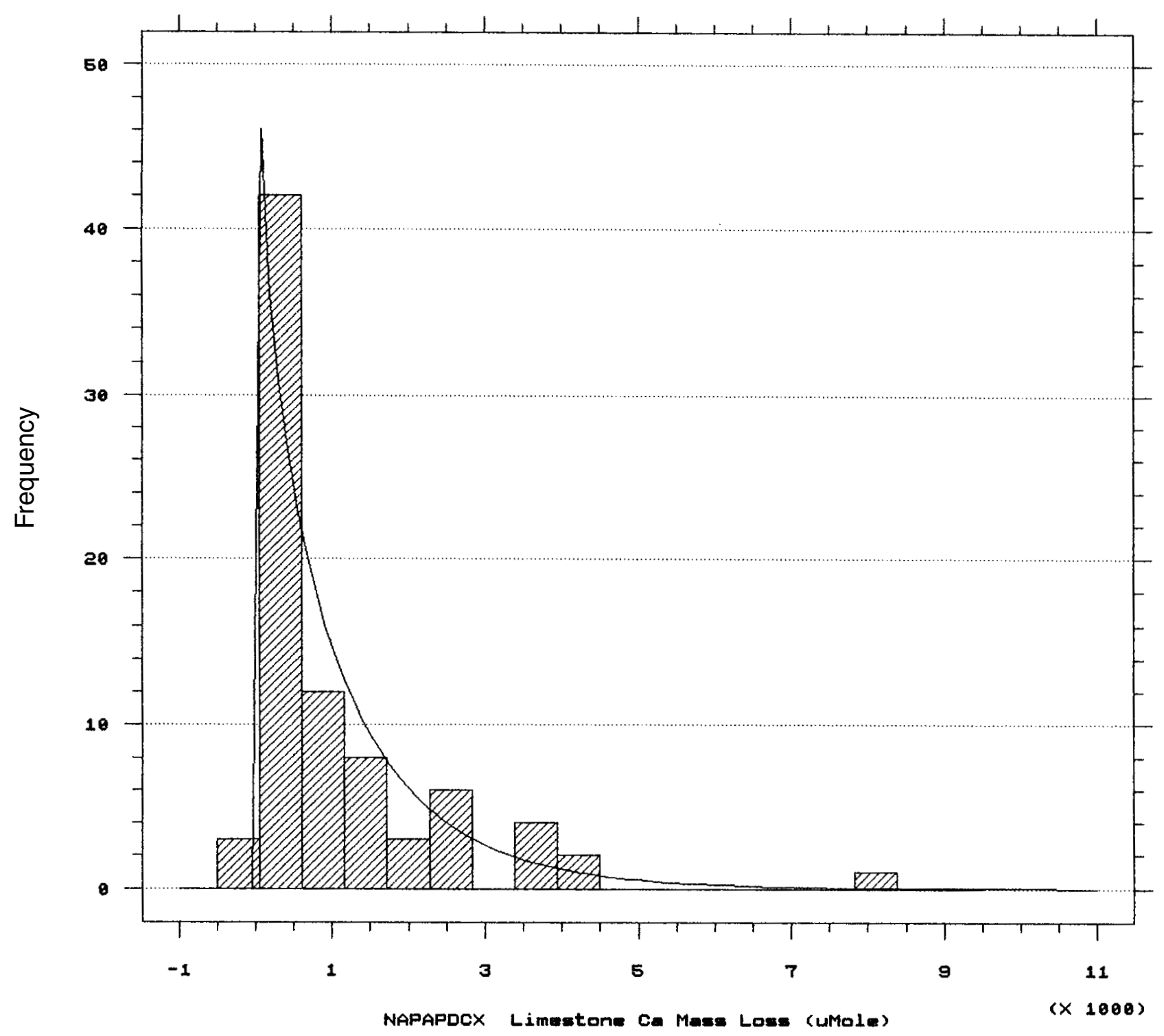

Chisquare Test

\begin{tabular}{|c|c|c|c|c|c|}
\hline & $\begin{array}{l}\text { Lower } \\
\text { Limit }\end{array}$ & $\begin{array}{l}\text { Upper } \\
\text { Limit }\end{array}$ & $\begin{array}{l}\text { Observed } \\
\text { Frequency }\end{array}$ & $\begin{array}{l}\text { Expected } \\
\text { Frequency }\end{array}$ & Chisqua \\
\hline above & $\begin{array}{r}\text { at or below } \\
55.56 \\
611.11 \\
1166.67 \\
1722.22 \\
2277.78\end{array}$ & $\begin{array}{r}55.56 \\
611.11 \\
1166.67 \\
1722.22 \\
2277.78\end{array}$ & $\begin{array}{r}3 \\
42 \\
12 \\
8 \\
3 \\
13\end{array}$ & $\begin{array}{r}6.1 \\
31.4 \\
16.7 \\
10.0 \\
6.2 \\
10.6\end{array}$ & $\begin{array}{l}1 . \\
3 . \\
1 . \\
1 .\end{array}$ \\
\hline
\end{tabular}

Chisquare $=9.09408$ with 3 d.f. Sig. level $=0.0280658$

FIGURE 56.-A, Histograms and model with goodness-of-fit statistics. (Variable: $\mathrm{Ca}^{2+}{ }_{\text {uncor }}$ mass loss; material: limestone; site: NAPAP-DC.) B, Histograms and model with goodness-of-fit statistics. (Variable: $\mathrm{Ca}^{2+}{ }_{\text {uncor }}$ mass loss; material: marble; site: NAPAP-DC.) 
B Marble Ca Mass Loss - NAPAP DC

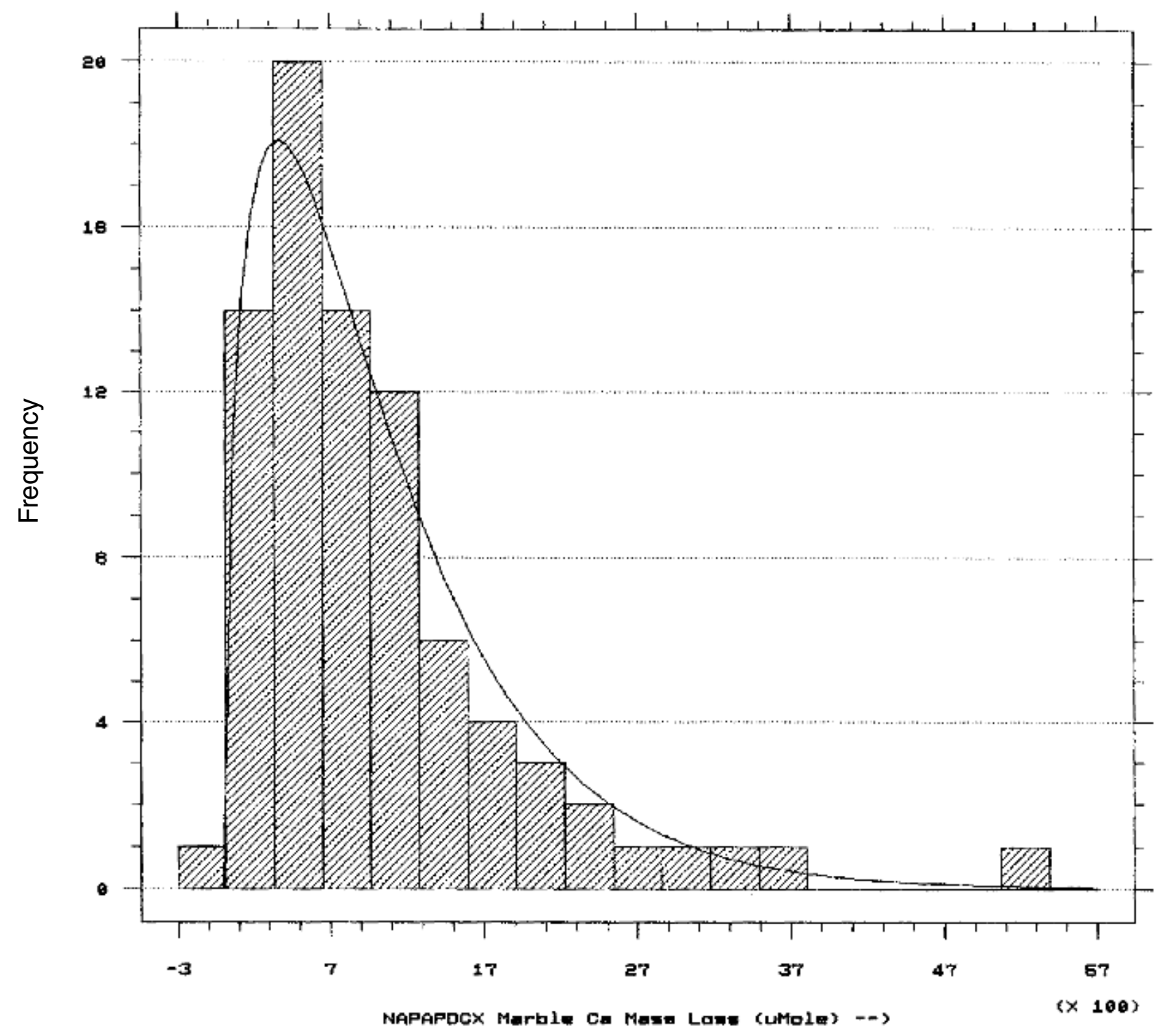

Chisquare Test

\begin{tabular}{|c|c|c|c|c|c|}
\hline & $\begin{array}{l}\text { Lower } \\
\text { Limit }\end{array}$ & $\begin{array}{l}\text { Upper } \\
\text { Limit }\end{array}$ & $\begin{array}{l}\text { Observed } \\
\text { Frequency }\end{array}$ & $\begin{array}{l}\text { Expected } \\
\text { Frequency }\end{array}$ & Chisquare \\
\hline above & $\begin{array}{r}\text { at or below } \\
331.58 \\
647.37 \\
963.16 \\
1278.95 \\
1594.74 \\
1910.53\end{array}$ & $\begin{array}{r}331.58 \\
647.37 \\
963.16 \\
1278.95 \\
1594.74 \\
1910.53\end{array}$ & $\begin{array}{r}15 \\
20 \\
14 \\
12 \\
6 \\
4 \\
10\end{array}$ & $\begin{array}{r}15.0 \\
17.4 \\
14.3 \\
10.7 \\
7.6 \\
5.3 \\
10.6\end{array}$ & $\begin{array}{l}.000158 \\
.378433 \\
.007354 \\
.160753 \\
.341610 \\
.307569 \\
.036168\end{array}$ \\
\hline
\end{tabular}

Chisquare $=1.23205$ with 4 d.f. Sig. level $=0.872795$ 


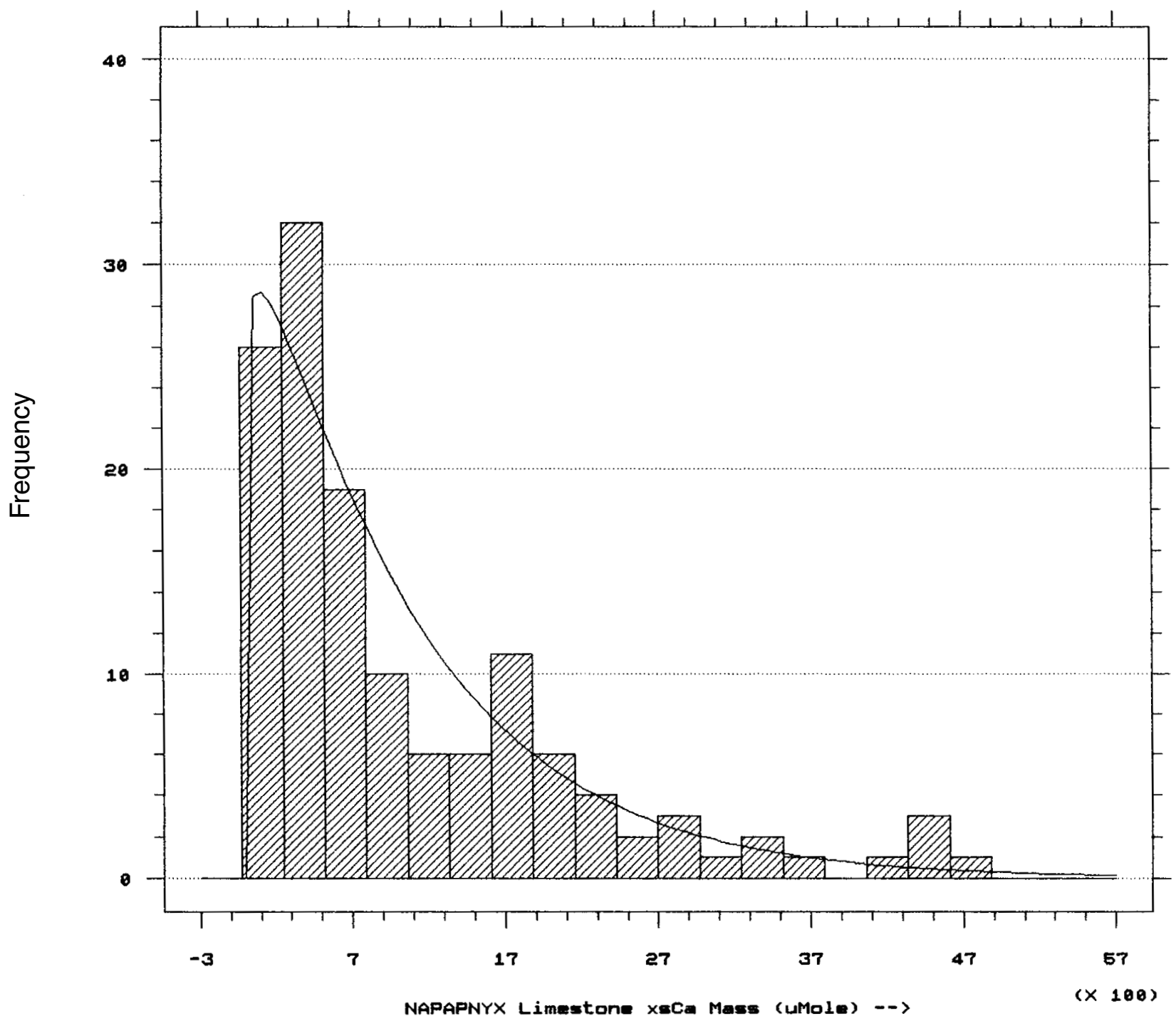

Chisquare Test

\begin{tabular}{|c|c|c|c|c|c|}
\hline & $\begin{array}{l}\text { Lower } \\
\text { Limit }\end{array}$ & $\begin{array}{l}\text { Upper } \\
\text { Limit }\end{array}$ & $\begin{array}{l}\text { Observed } \\
\text { Frequency }\end{array}$ & $\begin{array}{l}\text { Expected } \\
\text { Frequency }\end{array}$ & Chisquare \\
\hline above & $\begin{array}{r}\text { at or below } \\
245.45 \\
518.18 \\
790.91 \\
1063.64 \\
1336.36 \\
1609.09 \\
1881.82 \\
2154.55 \\
2700.00\end{array}$ & $\begin{array}{r}245.45 \\
518.18 \\
790.91 \\
1063.64 \\
1336.36 \\
1609.09 \\
1881.82 \\
2154.55 \\
2700.00\end{array}$ & $\begin{array}{r}26 \\
32 \\
19 \\
10 \\
6 \\
6 \\
11 \\
6 \\
6 \\
12\end{array}$ & $\begin{array}{r}25.0 \\
24.5 \\
19.5 \\
15.2 \\
11.8 \\
9.0 \\
6.9 \\
5.3 \\
7.1 \\
9.6\end{array}$ & $\begin{array}{r}.0365 \\
2.2792 \\
.0140 \\
1.7927 \\
2.8211 \\
1.0190 \\
2.4126 \\
.0981 \\
.1667 \\
.5957\end{array}$ \\
\hline
\end{tabular}

FIGURE 57.-A, Histograms and model with goodness-of-fit statistics. (Variable: $\mathrm{Ca}^{2+}{ }_{\text {uncor }}$ mass loss; material: limestone; site: NAPAP-NY.) B, Histograms and model with goodness-of-fit statistics. (Variable: $\mathrm{Ca}^{2+}{ }_{\text {uncor }}$ mass loss; material: marble; site: NAPAP-NY.) 
B Marble xsCa Mass Loss - NAPAP : NY

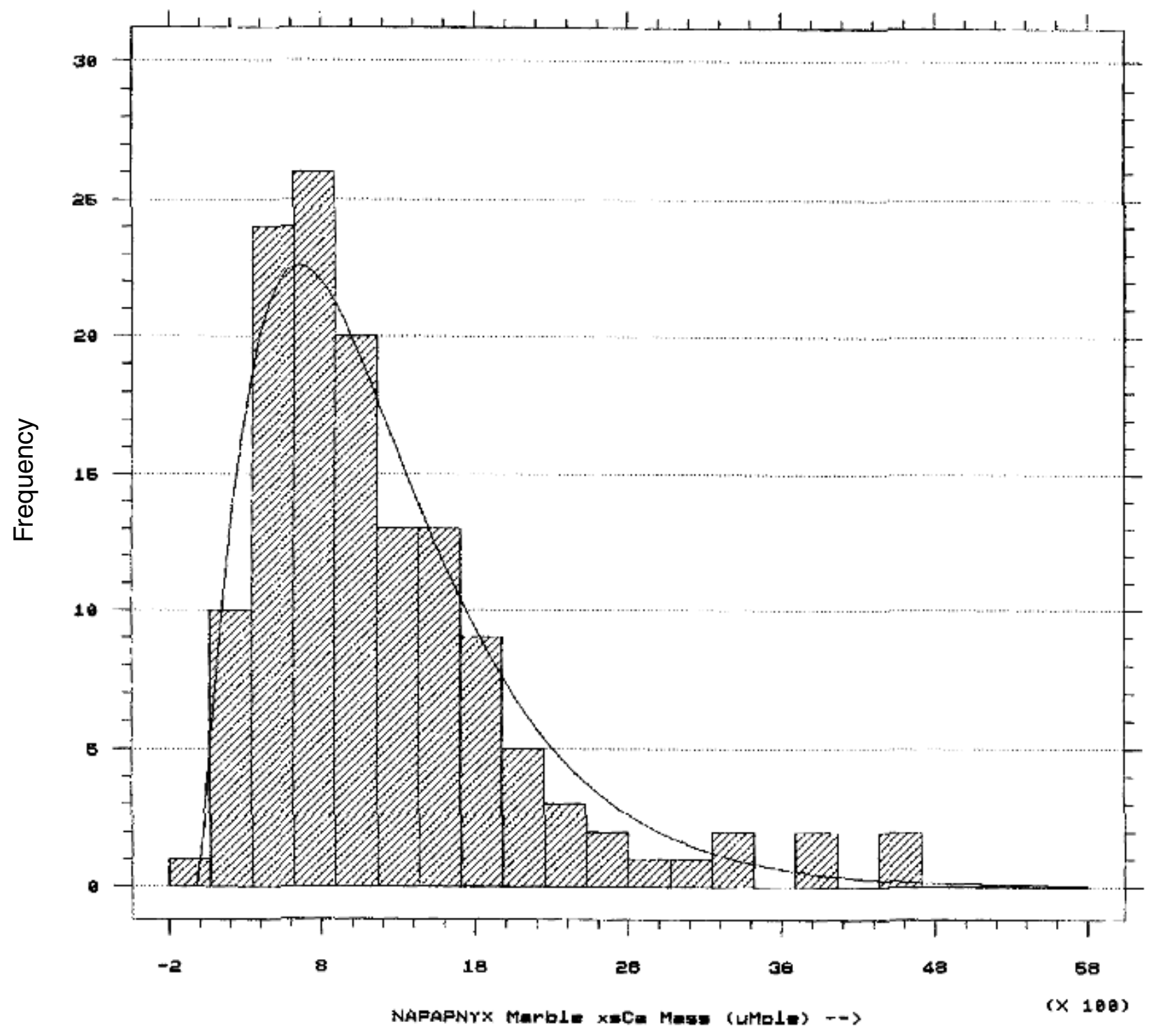

Chisquare Test

\begin{tabular}{|c|c|c|c|c|c|}
\hline & $\begin{array}{l}\text { Lower } \\
\text { Limit }\end{array}$ & $\begin{array}{l}\text { Upper } \\
\text { Limit }\end{array}$ & $\begin{array}{l}\text { Observed } \\
\text { Frequency }\end{array}$ & $\begin{array}{l}\text { Expected } \\
\text { Frequency }\end{array}$ & Chisquare \\
\hline above & $\begin{array}{r}\text { at or below } \\
345.45 \\
618.18 \\
890.91 \\
1163.64 \\
1436.36 \\
1709.09 \\
1981.82 \\
2254.55 \\
2800.00\end{array}$ & $\begin{array}{r}345.45 \\
618.18 \\
890.91 \\
1163.64 \\
1435.36 \\
1709.09 \\
1981.82 \\
2254.55 \\
2800.00\end{array}$ & $\begin{array}{r}11 \\
24 \\
26 \\
20 \\
13 \\
13 \\
9 \\
5 \\
5 \\
8\end{array}$ & $\begin{array}{r}13.4 \\
21.2 \\
22.1 \\
19.5 \\
15.8 \\
12.1 \\
9.0 \\
6.5 \\
7.7 \\
6.6\end{array}$ & $\begin{array}{l}.425202 \\
.362900 \\
.669692 \\
.010686 \\
.498115 \\
.064130 \\
.000167 \\
.328393 \\
.965407 \\
.285835\end{array}$ \\
\hline
\end{tabular}

Chisquare $=3.61053$ with 7 d.f. Sig. level $=0.823384$ 


\section{A Limestone Excess Ca Mass - NAPAP : NJ}

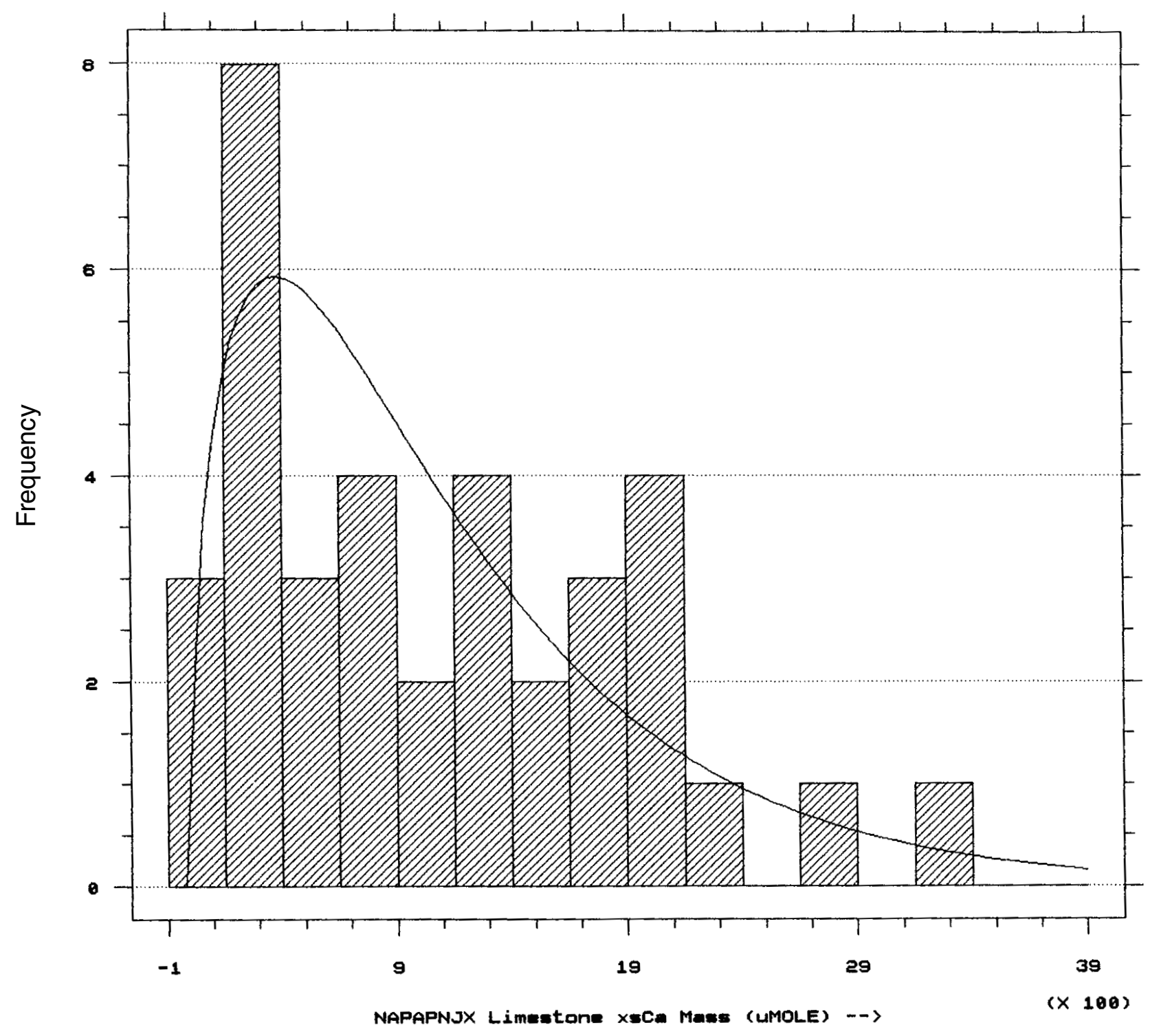

Chisquare Test

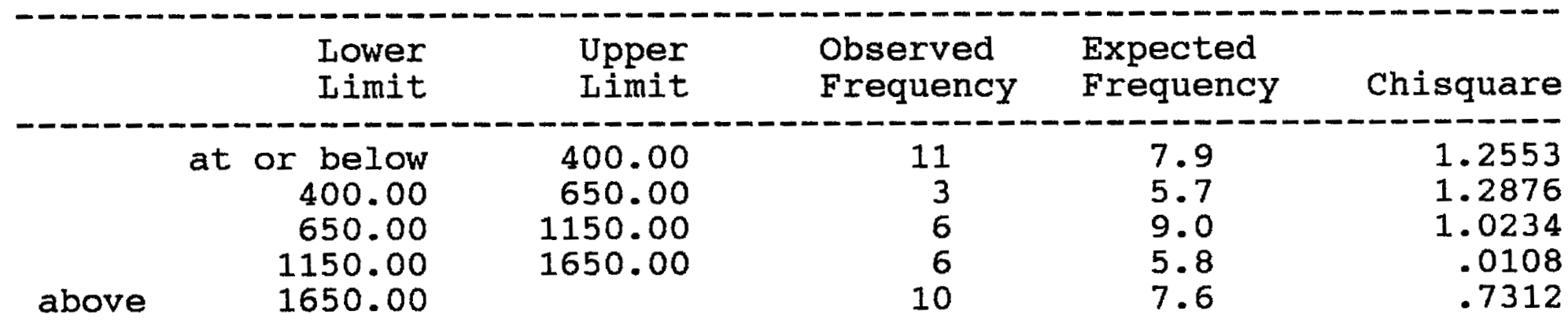

Chisquare $=4.30833$ with 2 d.f. Sig. level $=0.116$

FIGURE 58.-A, Histograms and model with goodness-of-fit statistics. (Variable: $\mathrm{Ca}^{2+}{ }_{\text {uncor }}$ mass loss; material: limestone; site: NAPAP-NJ.) B, Histograms and model with goodness-of-fit statistics. (Variable: $\mathrm{Ca}^{2+}{ }_{\text {uncor }}$ mass loss; material: marble; site: NAPAP-NJ.) 
B Marble Excess Ca Mass Loss - NAPAP : NJ

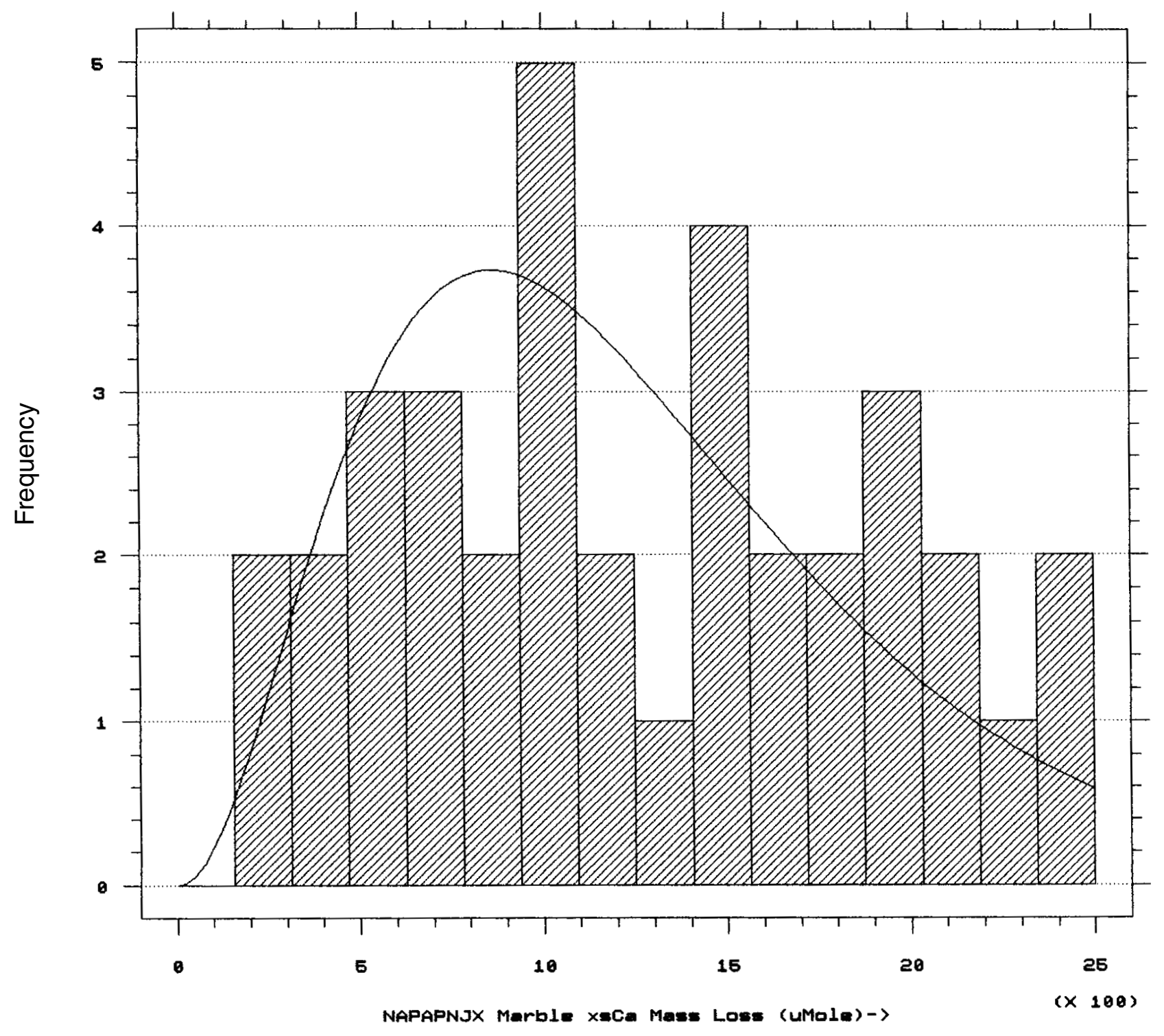

Chisquare Test

\begin{tabular}{|c|c|c|c|c|c|}
\hline & $\begin{array}{l}\text { Lower } \\
\text { Limit }\end{array}$ & $\begin{array}{l}\text { Upper } \\
\text { Limit }\end{array}$ & $\begin{array}{l}\text { Observed } \\
\text { Frequency }\end{array}$ & $\begin{array}{l}\text { Expected } \\
\text { Frequency }\end{array}$ & Chisquare \\
\hline above & $\begin{array}{r}\text { at or below } \\
625.00 \\
937.50 \\
1250.00 \\
1562.50\end{array}$ & $\begin{array}{r}625.00 \\
937.50 \\
1250.00 \\
1562.50\end{array}$ & $\begin{array}{r}7 \\
5 \\
7 \\
5 \\
12\end{array}$ & $\begin{array}{l}6.4 \\
7.3 \\
6.9 \\
5.4 \\
9.9\end{array}$ & $\begin{array}{l}.049257 \\
.710707 \\
.000861 \\
.036439 \\
.435581\end{array}$ \\
\hline
\end{tabular}

Chisquare $=1.23285$ with 2 d.f. Sig. level $=0.539872$ 


\section{A Limestone xsCa Mass Loss - NAPAP : NC}

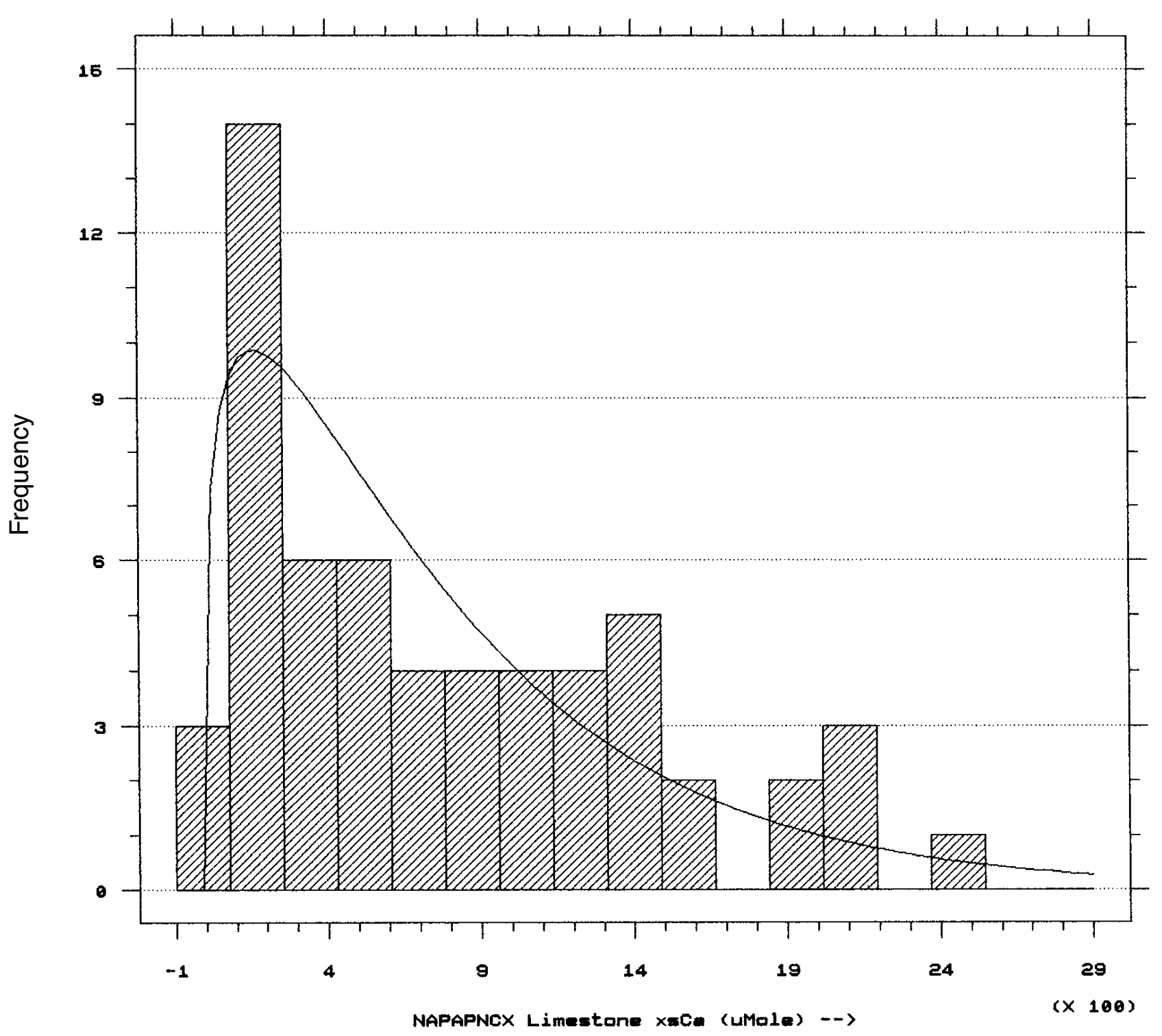

Chisquare Test

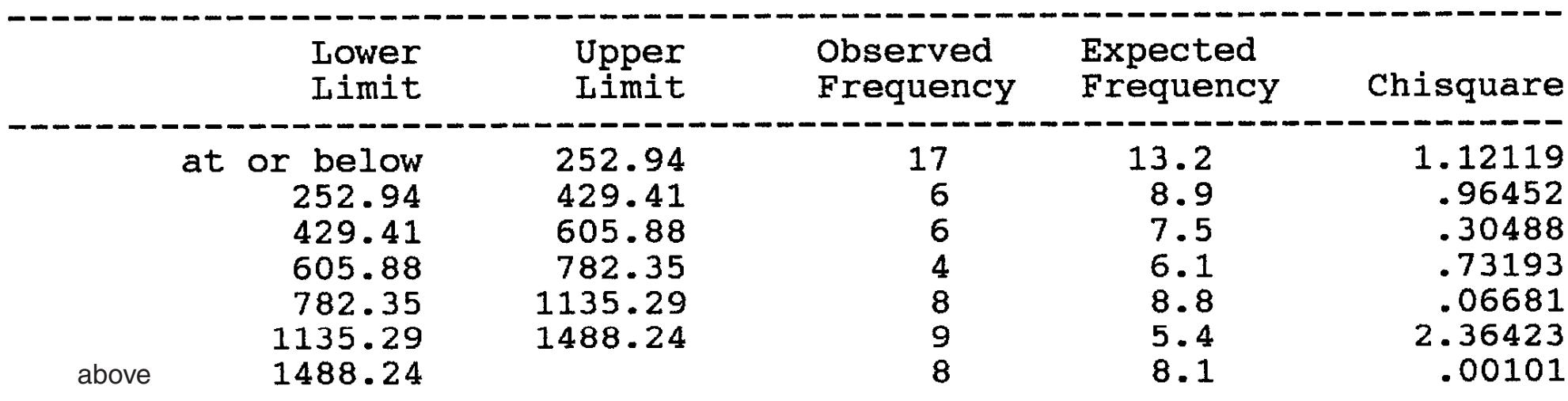

Chisquare $=5.55456$ with 4 d.f. Sig. level $=0.234975$

FIGURE 59.-A, Histograms and model with goodness-of-fit statistics. (Variable: $\mathrm{Ca}^{2+}{ }_{\text {uncor }}$ mass loss; material: limestone; site: NAPAP-NC.) B, Histograms and model with goodness-of-fit statistics. (Variable: $\mathrm{Ca}^{2+}{ }_{\text {uncor }}$ mass loss; material: marble; site: NAPAP-NC.) 
B Marble Excess Ca Mass Loss - NAPAP : NC

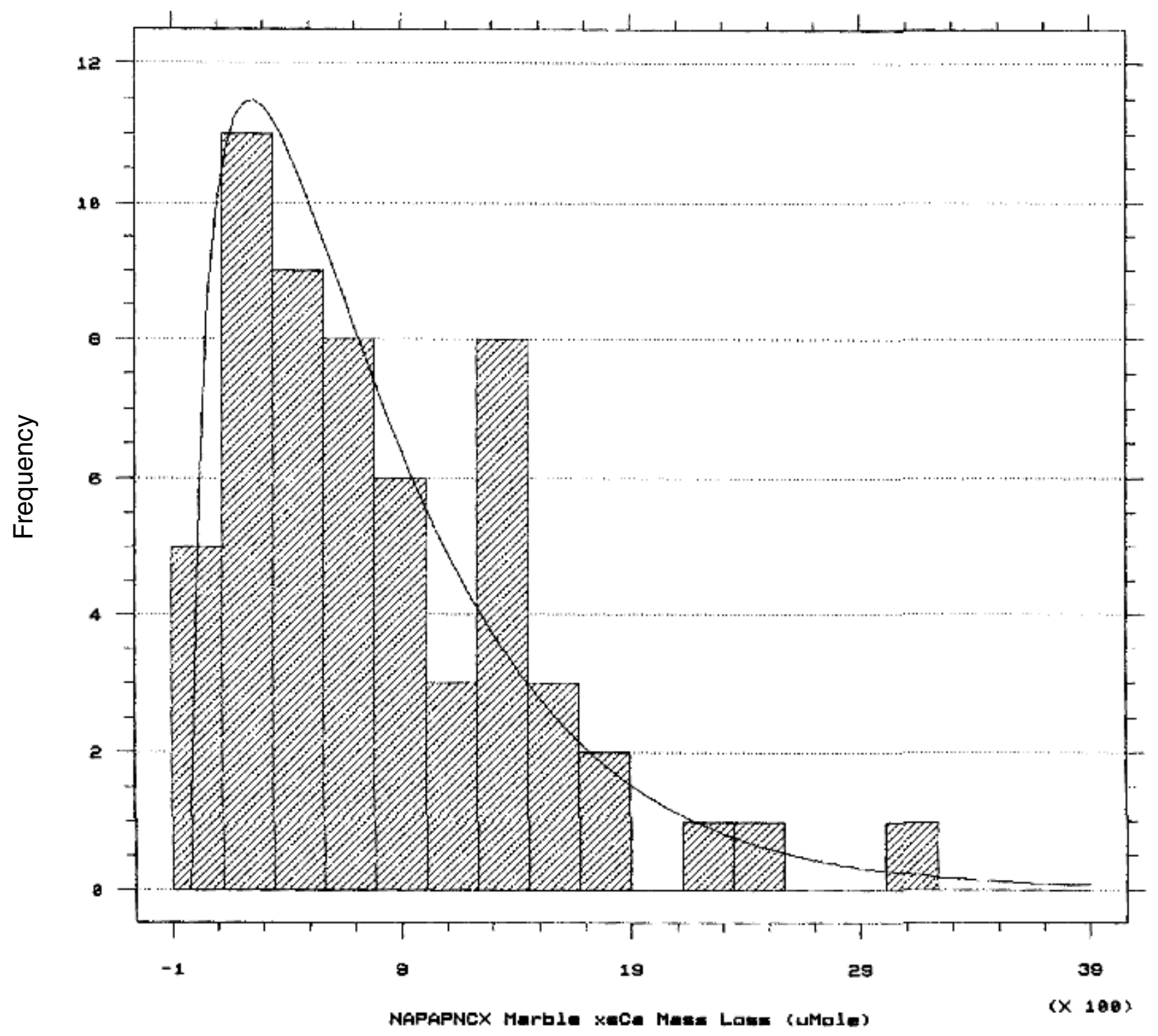

Chisquare Test

\begin{tabular}{|c|c|c|c|c|c|}
\hline & $\begin{array}{l}\text { Lower } \\
\text { Limit }\end{array}$ & $\begin{array}{l}\text { Upper } \\
\text { Limit }\end{array}$ & $\begin{array}{l}\text { Observed } \\
\text { Frequency }\end{array}$ & $\begin{array}{l}\text { Expected } \\
\text { Frequency }\end{array}$ & Chisquare \\
\hline above & 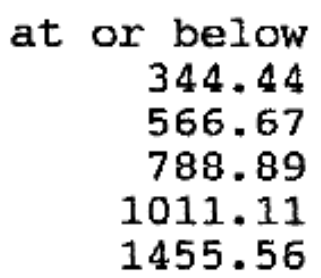 & $\begin{array}{r}344.44 \\
566.67 \\
788.89 \\
1011.11 \\
1455.56\end{array}$ & $\begin{array}{r}16 \\
9 \\
8 \\
6 \\
11 \\
8\end{array}$ & $\begin{array}{r}15.7 \\
10.4 \\
8.4 \\
6.4 \\
8.3 \\
8.8\end{array}$ & $\begin{array}{l}.00698 \\
.18171 \\
.01790 \\
.03009 \\
.85365 \\
.07223\end{array}$ \\
\hline
\end{tabular}

Chisquare $=1.16256$ with 3 d.f. Sig. level $=0.761997$ 
A Limestone xs Ca Mass Loss - NAPAP : OH

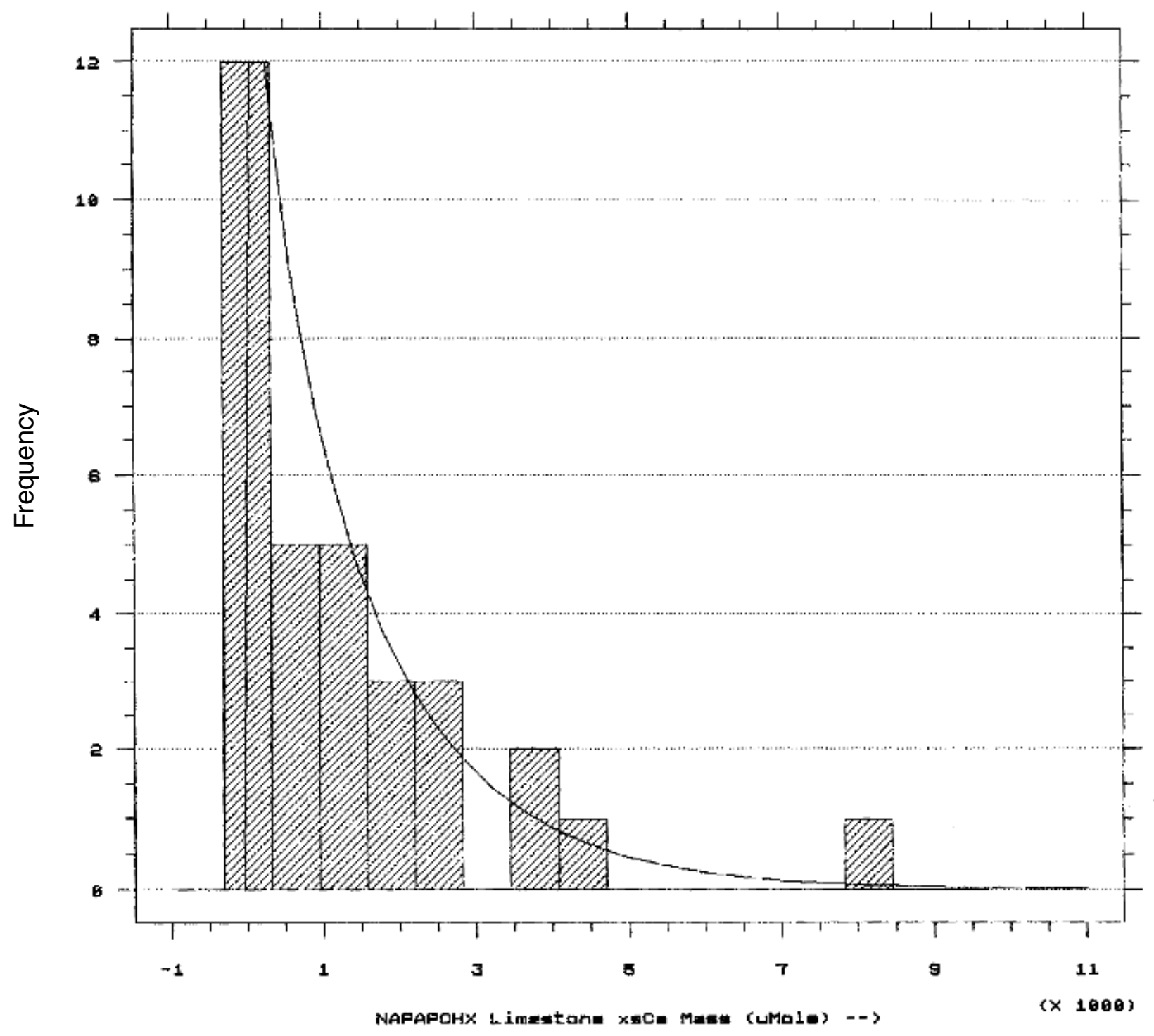

Chisquare Test

\begin{tabular}{rrrrrr} 
& $\begin{array}{l}\text { Lower } \\
\text { Limit }\end{array}$ & $\begin{array}{c}\text { Upper } \\
\text { Limit }\end{array}$ & $\begin{array}{c}\text { Observed } \\
\text { Frequency }\end{array}$ & $\begin{array}{l}\text { Expected } \\
\text { Frequency }\end{array}$ & Chisquare \\
\hline & at or below & 325.00 & 12 & 7.4 & 2.8626 \\
325.00 & 950.00 & 5 & 8.7 & 1.5845 \\
above & 950.00 & 1575.00 & 5 & 5.4 & .0344 \\
& 1575.00 & & 10 & 10.5 & .0196
\end{tabular}

Chisquare $=4.50111$ with 1 d.f. Sig. level $=0.0338729$

FIGURE 60.-A, Histograms and model with goodness-of-fit statistics. (Variable: $\mathrm{Ca}^{2+}{ }_{\text {uncor }}$ mass loss; material: limestone; site: NAPAP-OH.) B, Histograms and model with goodness-of-fit statistics. (Variable: $\mathrm{Ca}^{2+}{ }_{\text {uncor }}$ mass loss; material: marble; site: NAPAP-OH.) 
B Marble xsCa Mass Loss - NAPAP : OH

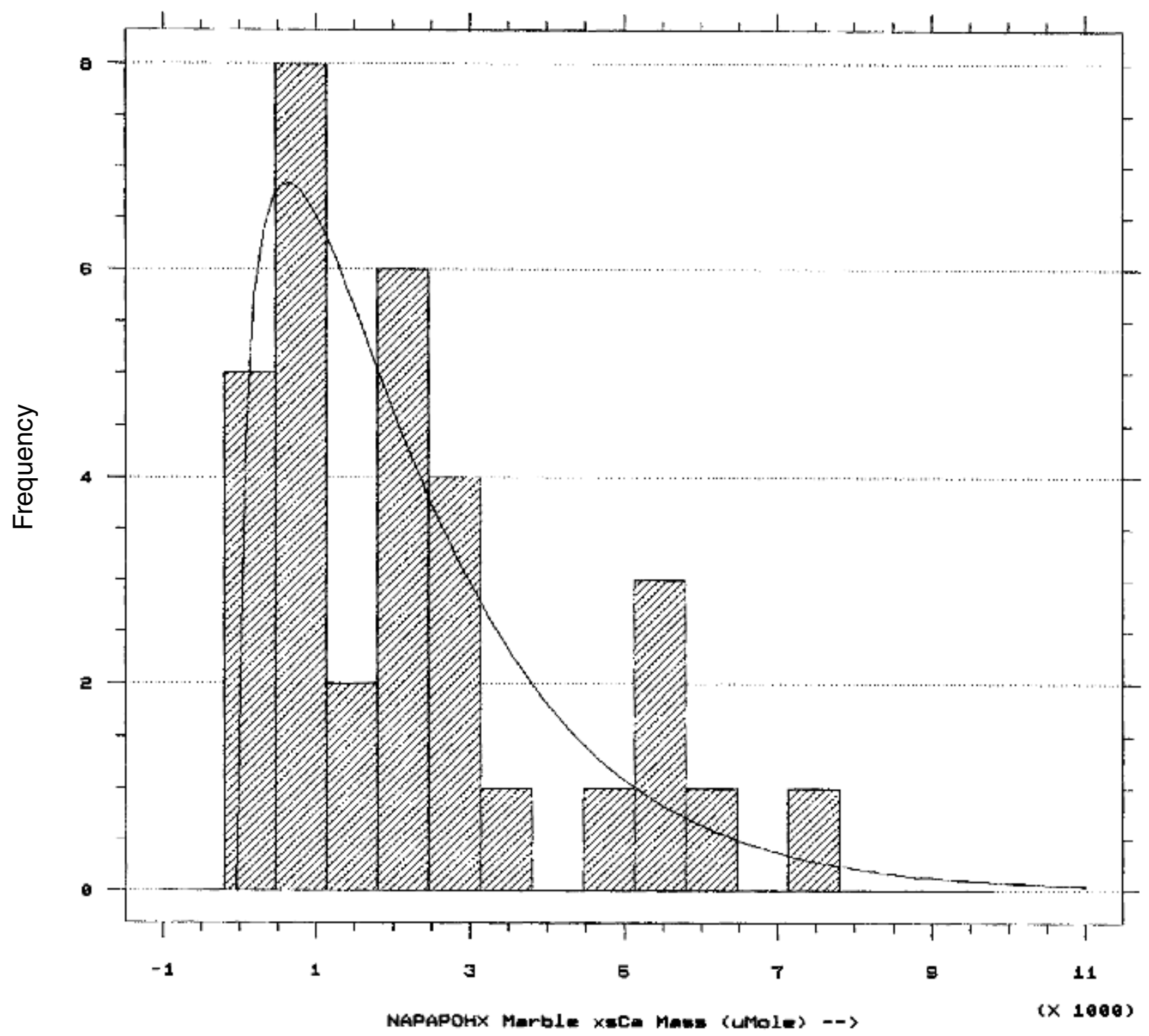

Chisquare Test

\begin{tabular}{|c|c|c|c|c|c|}
\hline & $\begin{array}{l}\text { Lower } \\
\text { Limit }\end{array}$ & $\begin{array}{l}\text { Upper } \\
\text { Limit }\end{array}$ & $\begin{array}{l}\text { Observed } \\
\text { Frequency }\end{array}$ & $\begin{array}{l}\text { Expected } \\
\text { Frequency }\end{array}$ & Chisquare \\
\hline above & $\begin{array}{r}\text { at or below } \\
1133.33 \\
1800.00 \\
3133.33\end{array}$ & $\begin{array}{l}1133.33 \\
1800.00 \\
3133.33\end{array}$ & $\begin{array}{r}13 \\
2 \\
10 \\
7\end{array}$ & $\begin{array}{r}10.6 \\
5.7 \\
7.7 \\
8.1\end{array}$ & $\begin{array}{r}.565 \\
2.394 \\
.702 \\
.142\end{array}$ \\
\hline
\end{tabular}

Chisquare $=3.80362$ with 1 d.f. Sig. level $=0.0511419$ 
A Pew Limestone CA Mass - NAPAP : DC

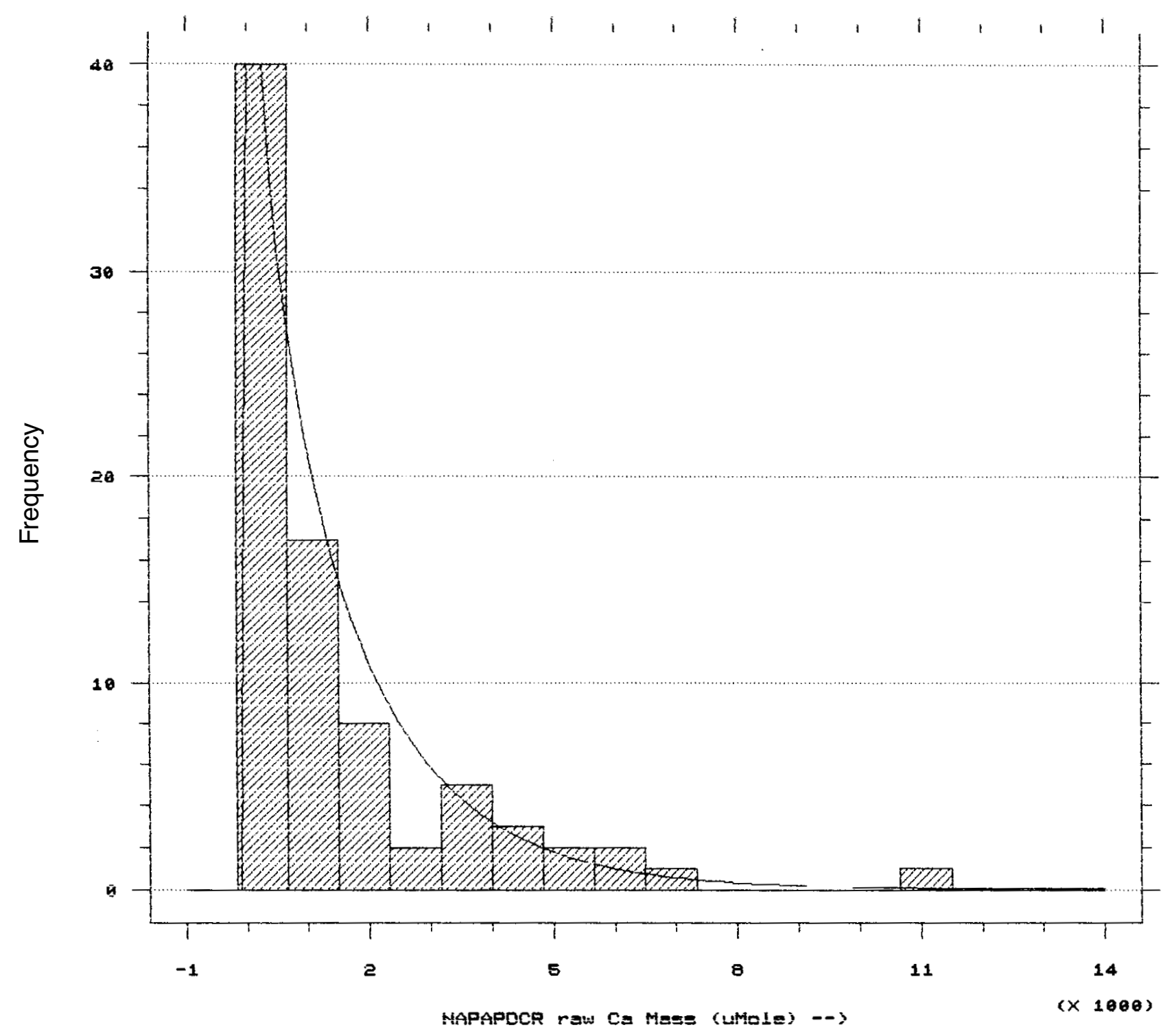

Chisquare liest

\begin{tabular}{|c|c|c|c|c|c|}
\hline & $\begin{array}{l}\text { Lower } \\
\text { Limit }\end{array}$ & $\begin{array}{l}\text { Upper } \\
\text { Limit }\end{array}$ & $\begin{array}{l}\text { Observed } \\
\text { Frequency }\end{array}$ & $\begin{array}{l}\text { Expected } \\
\text { Frequency }\end{array}$ & Chisqual \\
\hline above & $\begin{array}{r}\text { at below } \\
666.67 \\
1500.00 \\
2333.33 \\
3166.67\end{array}$ & $\begin{array}{r}566.67 \\
1500.00 \\
2333.33 \\
3166.57\end{array}$ & $\begin{array}{r}40 \\
17 \\
8 \\
2 \\
14\end{array}$ & $\begin{array}{r}31.4 \\
20.3 \\
11.6 \\
6.9 \\
10.8\end{array}$ & $\begin{array}{r}2.352 \\
.541 \\
1.134 \\
3.478 \\
.982\end{array}$ \\
\hline
\end{tabular}

Chisquare $=9.48642$ with 2 d.f. Sig. level $=0.0143614$

FIGURE 61.-A, Histograms and model with goodness-of-fit statistics. (Variable: $\mathrm{Ca}^{2+}{ }_{x s}$ mass loss; material: limestone; site: NAPAP-DC.) B, Histograms and model with goodness-of-fit statistics. (Variable: $\mathrm{Ca}^{2+}{ }_{\mathrm{xs}}$ mass loss; material: marble; site: NAPAP-DC.) 
B Marble Raw Ca Mass Loss - NAPAP : DC

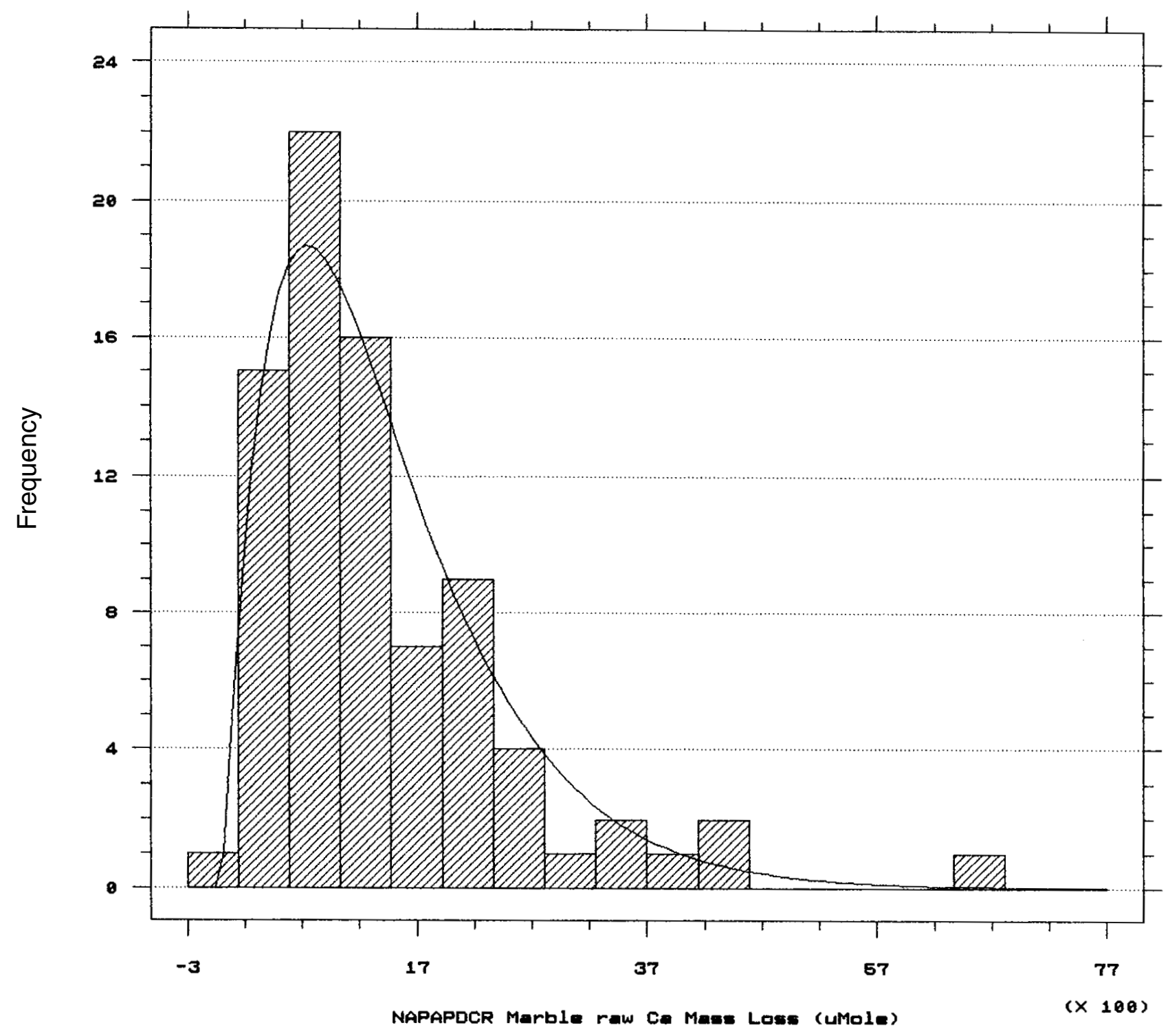

Chisquare Test

\begin{tabular}{|c|c|c|c|c|c|}
\hline & $\begin{array}{l}\text { Lower } \\
\text { Limit }\end{array}$ & $\begin{array}{l}\text { Upper } \\
\text { Limit }\end{array}$ & $\begin{array}{l}\text { Observed } \\
\text { Frequency }\end{array}$ & $\begin{array}{l}\text { Expected } \\
\text { Frequency }\end{array}$ & Chisquare \\
\hline & $\begin{array}{r}\text { at or below } \\
588.89 \\
1033.33 \\
1477.78 \\
1922.22 \\
2366.67\end{array}$ & $\begin{array}{r}588.89 \\
1033.33 \\
1477.78 \\
1922.22 \\
2366.67\end{array}$ & $\begin{array}{r}16 \\
22 \\
16 \\
7 \\
9 \\
11\end{array}$ & $\begin{array}{r}15.5 \\
18.4 \\
15.6 \\
11.4 \\
7.7 \\
12.4\end{array}$ & $\begin{array}{r}.0135 \\
.7178 \\
.0103 \\
1.6869 \\
.2309 \\
.1664\end{array}$ \\
\hline
\end{tabular}

Chisquare $=2.82579$ with 3 d.f. Sig. level $=0.419271$ 


\section{A Limestone Raw Ca Mass Loss - NAPAP : NY}

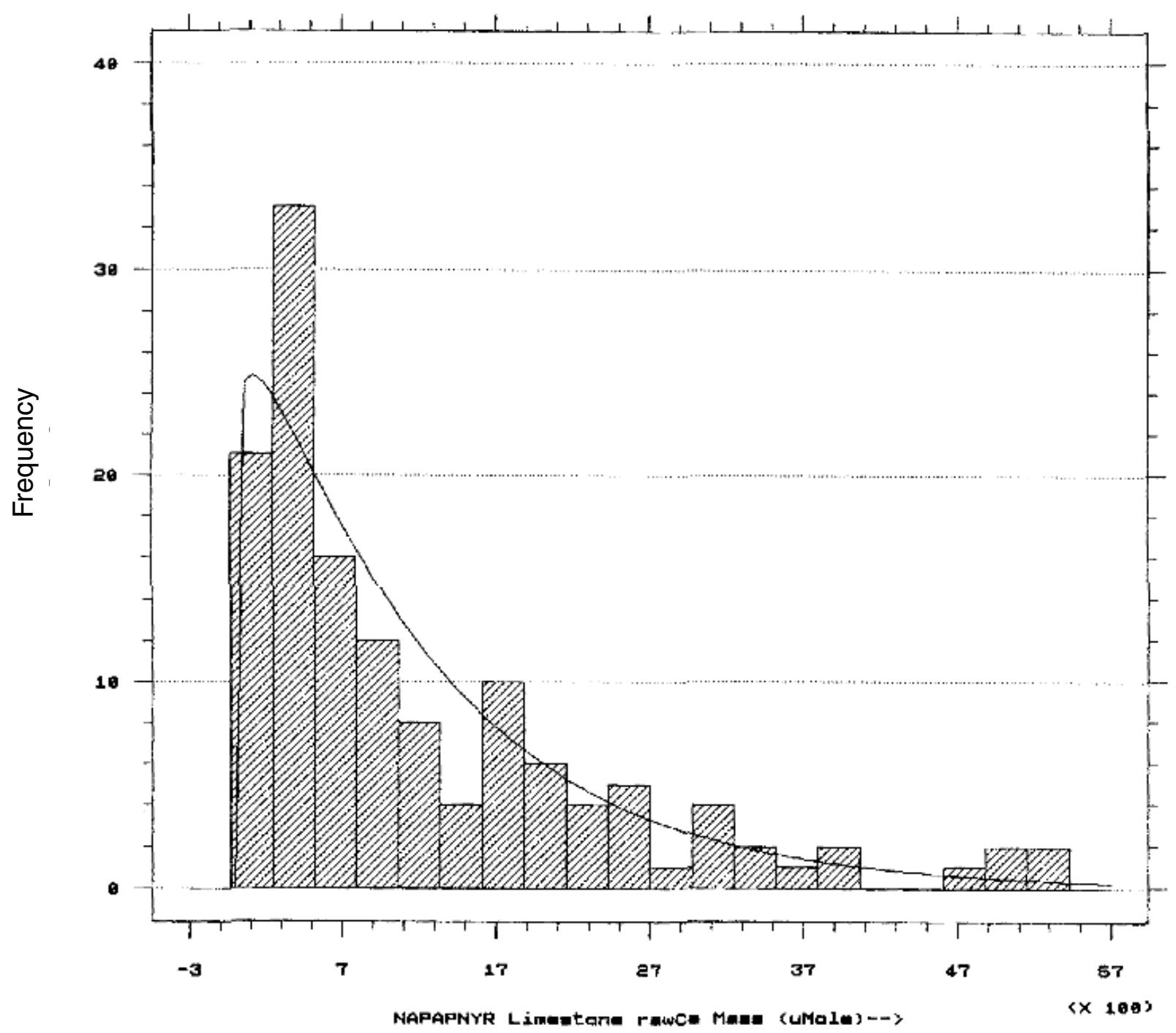

Chisquare Test

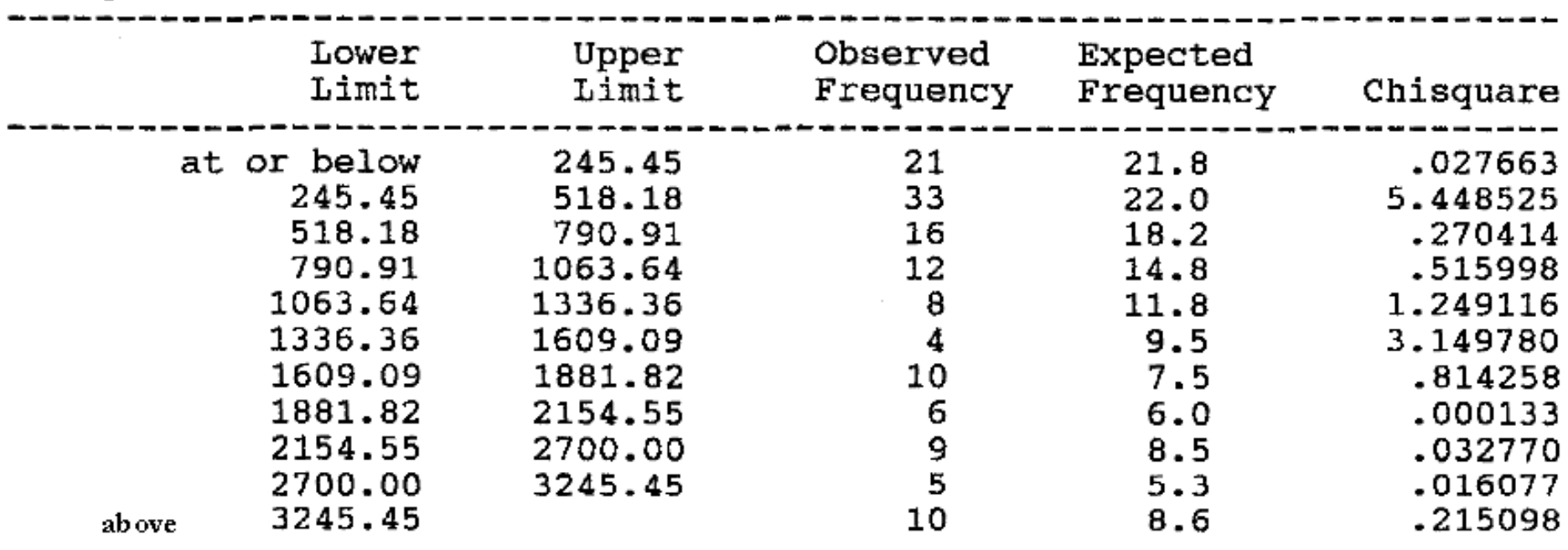

Chisquare $=11.7398$ with 8 d.f. $\mathrm{Sig}$. level $=0.163195$

FIGURE 62.-A, Histograms and model with goodness-of-fit statistics. (Variable: $\mathrm{Ca}^{2+}{ }_{\mathrm{xs}}$ mass loss; material: limestone; site: NAPAP-NY.) B, Histograms and model with goodness-of-fit statistics. (Variable: $\mathrm{Ca}^{2+}{ }_{\mathrm{xs}}$ mass loss; material: marble; site: NAPAP-NY.) 
B Marble Raw Ca Mass Loss - NAPAP : NY

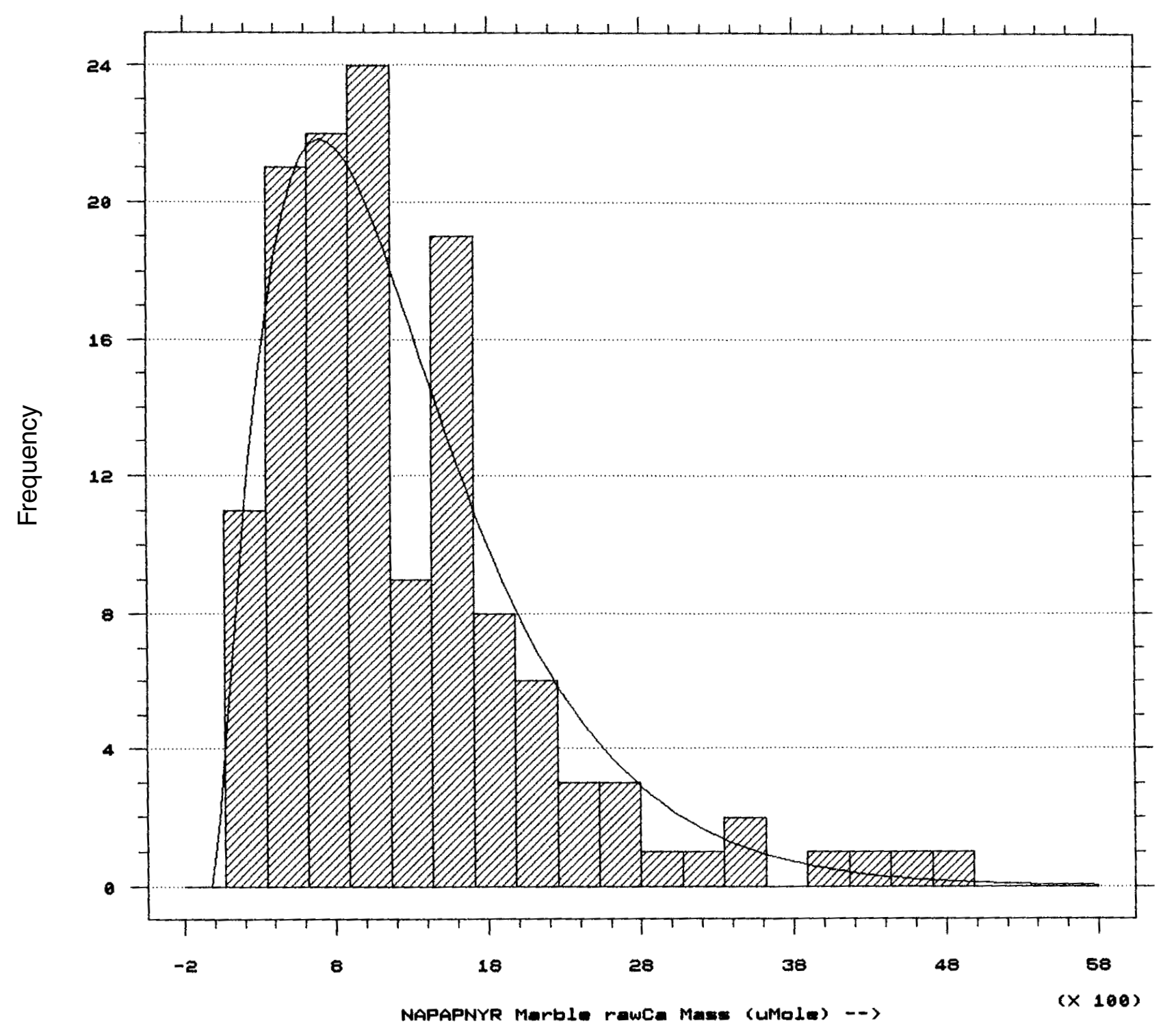

Chisquare Test

\begin{tabular}{|c|c|c|c|c|c|}
\hline & $\begin{array}{l}\text { Lower } \\
\text { Iimit }\end{array}$ & $\begin{array}{l}\text { Upper } \\
\text { Iimit }\end{array}$ & $\begin{array}{l}\text { Observed } \\
\text { Frequency }\end{array}$ & $\begin{array}{l}\text { Expected } \\
\text { Frequency }\end{array}$ & Chisquare \\
\hline above & $\begin{array}{r}\text { at or below } \\
345.45 \\
618.18 \\
890.91 \\
1163.64 \\
1436.36 \\
1709.09 \\
1981.82 \\
2254.55 \\
2800.00\end{array}$ & $\begin{array}{r}345.45 \\
618.18 \\
890.91 \\
1163.64 \\
1436.36 \\
1709.09 \\
1981.82 \\
2254.55 \\
2800.00\end{array}$ & $\begin{array}{r}11 \\
21 \\
22 \\
24 \\
9 \\
19 \\
8 \\
6 \\
6 \\
8\end{array}$ & $\begin{array}{r}11.5 \\
19.8 \\
21.6 \\
19.7 \\
16.3 \\
12.7 \\
9.5 \\
7.0 \\
8.5 \\
7.5\end{array}$ & $\begin{array}{r}.01918 \\
.07140 \\
.00682 \\
.95561 \\
3.25272 \\
3.11111 \\
.25003 \\
.13411 \\
.72180 \\
.03801\end{array}$ \\
\hline
\end{tabular}

Chisquare $=8.5608$ with 7 d.f. Sig. level $=0.285744$ 
A Limestone Raw Ca Mass Loss - NAPAP : NJ

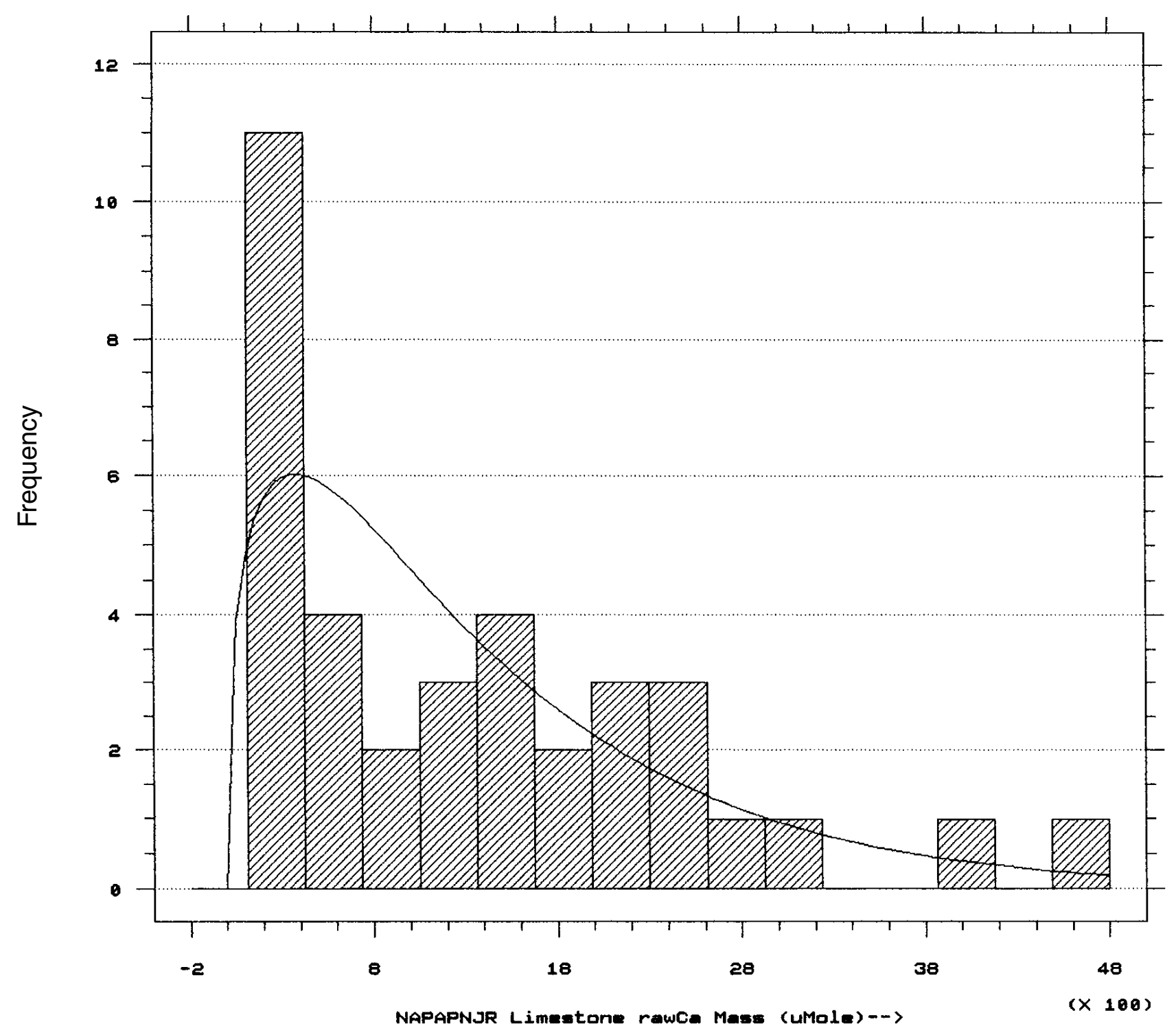

Chisquare Test

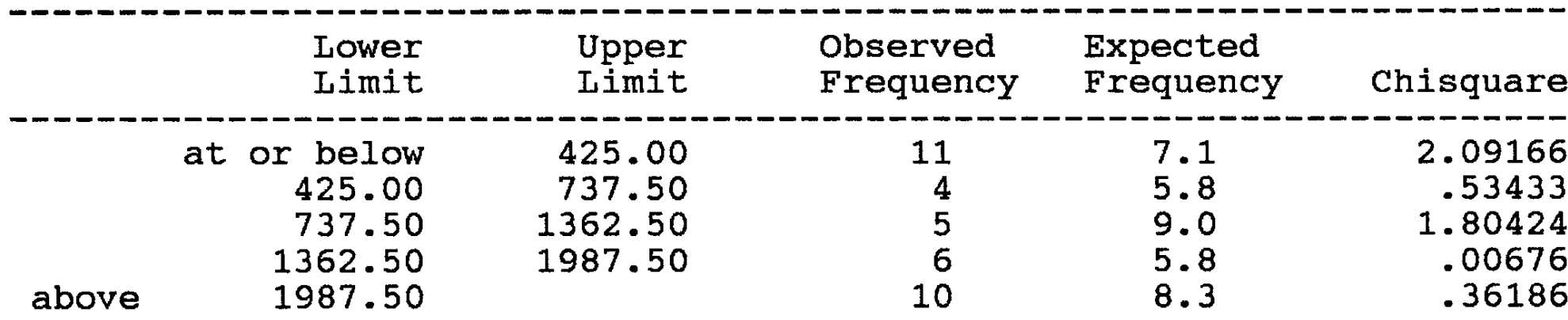

Chisquare $=4.79884$ with 2 d.f. Sig. level $=0.0907704$

FIGURE 63.-A, Histograms and model with goodness-of-fit statistics. (Variable: $\mathrm{Ca}^{2+}{ }_{x s}$ mass loss; material: limestone; site: NAPAP-NJ.) B, Histograms and model with goodness-of-fit statistics. (Variable: $\mathrm{Ca}^{2+}{ }_{\mathrm{xs}}$ mass loss; material: marble; site: NAPAP-NJ.) 


\section{B Marble Raw Ca Mass Loss - NAPAP : NJ}

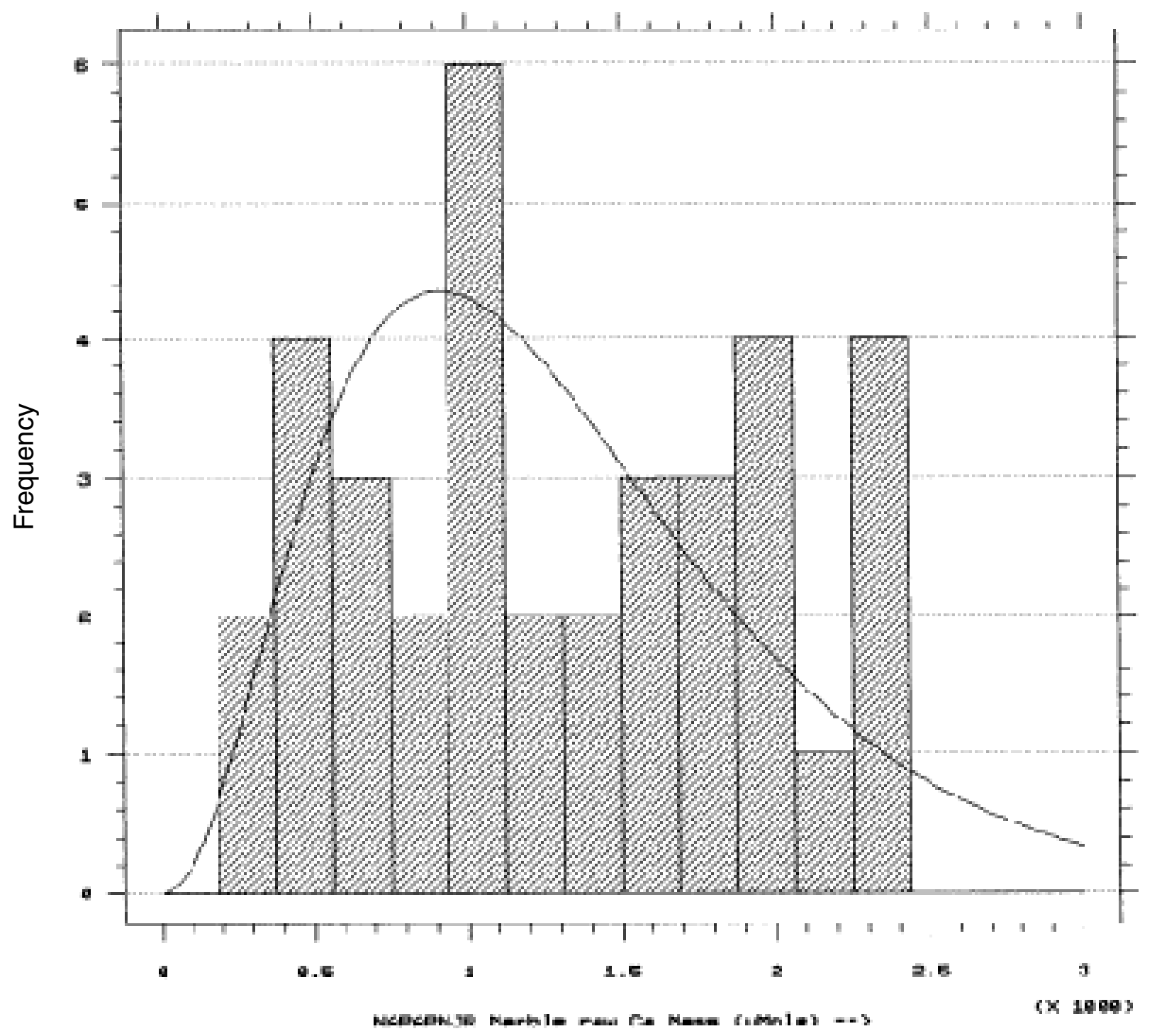

Ch1square Tes:

\begin{tabular}{|c|c|c|c|c|c|}
\hline & $\begin{array}{l}\text { Tirwar } \\
\text { Iimit }\end{array}$ & $\begin{array}{l}\text { Upper } \\
\text { Iimit }\end{array}$ & $\begin{array}{l}\text { Observed } \\
\text { Frequency }\end{array}$ & $\begin{array}{l}\text { Expected } \\
\text { Froquency }\end{array}$ & Chisquare \\
\hline abcve & $\begin{array}{r}\text { at or below } \\
750.00 \\
1125.00 \\
1500.00 \\
1375.00\end{array}$ & $\begin{array}{r}750.00 \\
1125.00 \\
1500.00 \\
1975.00\end{array}$ & $\begin{array}{l}9 \\
8 \\
4 \\
6 \\
9\end{array}$ & $\begin{array}{l}8.3 \\
8.6 \\
7.3 \\
5.2 \\
6.8\end{array}$ & $\begin{array}{r}.0596 \\
.0357 \\
1.4836 \\
+1730 \\
.719\end{array}$ \\
\hline
\end{tabular}




\section{A Raw Limestone Ca Mass Loss - NAPAP : NC}

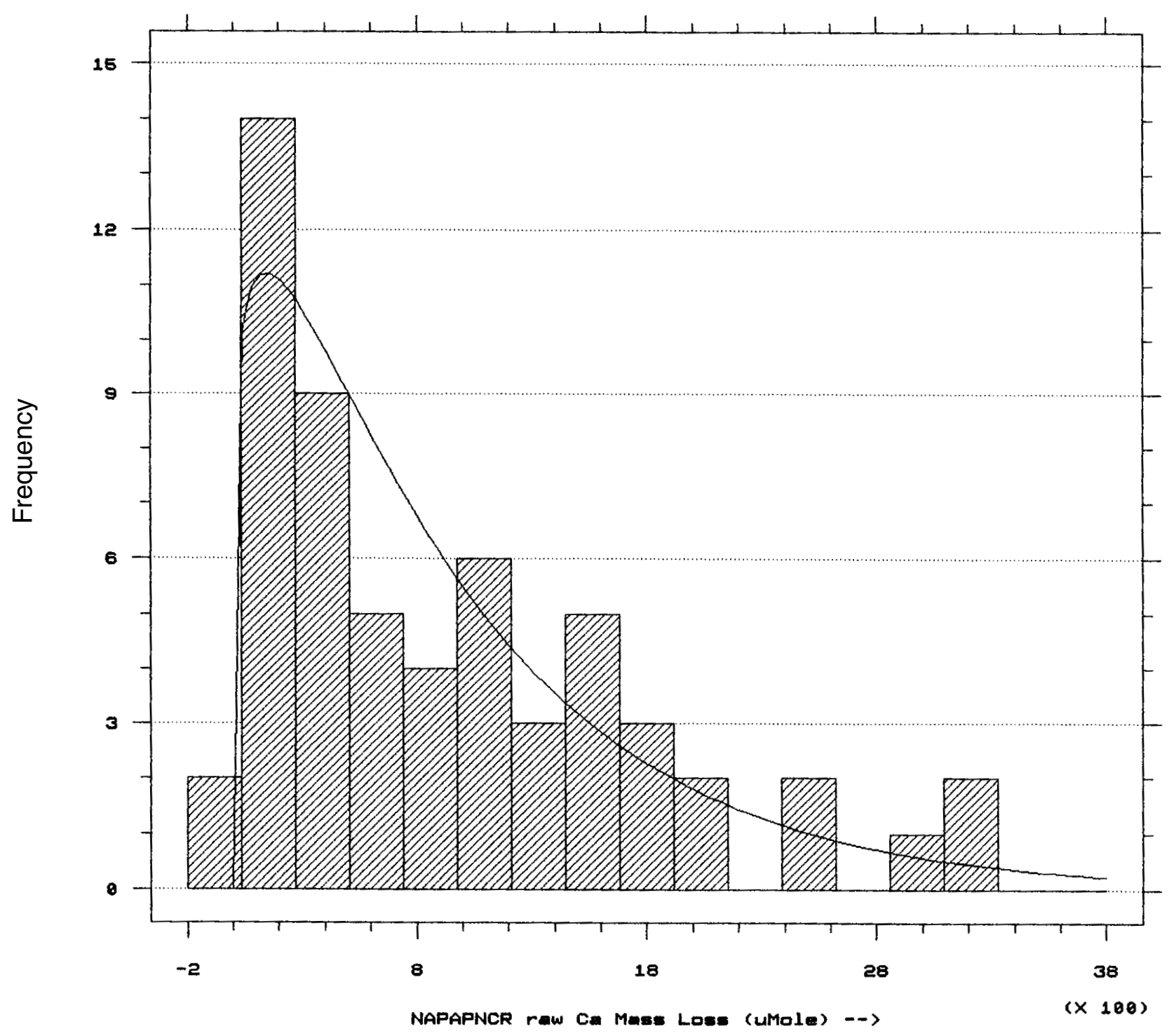

Chisquare Test

\begin{tabular}{|c|c|c|c|c|c|}
\hline & $\begin{array}{l}\text { Lower } \\
\text { Limit }\end{array}$ & $\begin{array}{l}\text { Upper } \\
\text { Iimit }\end{array}$ & $\begin{array}{l}\text { Observed } \\
\text { Frequency }\end{array}$ & $\begin{array}{l}\text { Expected } \\
\text { Frequency }\end{array}$ & Chisquare \\
\hline above & $\begin{array}{r}\text { or below } \\
270.59 \\
505.88 \\
741.18 \\
976.47 \\
1447.06 \\
1917.65\end{array}$ & $\begin{array}{r}270.59 \\
505.88 \\
741.18 \\
976.47 \\
1447.06 \\
1917.65\end{array}$ & $\begin{array}{r}16 \\
9 \\
5 \\
4 \\
9 \\
8 \\
7\end{array}$ & $\begin{array}{r}12.3 \\
9.9 \\
8.1 \\
6.4 \\
8.9 \\
5.3 \\
7.2\end{array}$ & $\begin{array}{r}1.13085 \\
.08162 \\
1.17064 \\
.89824 \\
.00211 \\
1.42902 \\
.00753\end{array}$ \\
\hline
\end{tabular}

Chisquare $=4.72002$ with 4 d.f. Sig. level $=0.31725$

FIGURE 64.-A, Histograms and model with goodness-of-fit statistics. (Variable: $\mathrm{Ca}^{2+}{ }_{\mathrm{xs}}$ mass loss; material: limestone; site: NAPAP-NC.) B, Histograms and model with goodness-of-fit statistics. (Variable: $\mathrm{Ca}^{2+}{ }_{x s}$ mass loss; material: marble; site: NAPAP-NC.) 
B Marble Raw Ca Mass Loss - NAPAP : NC

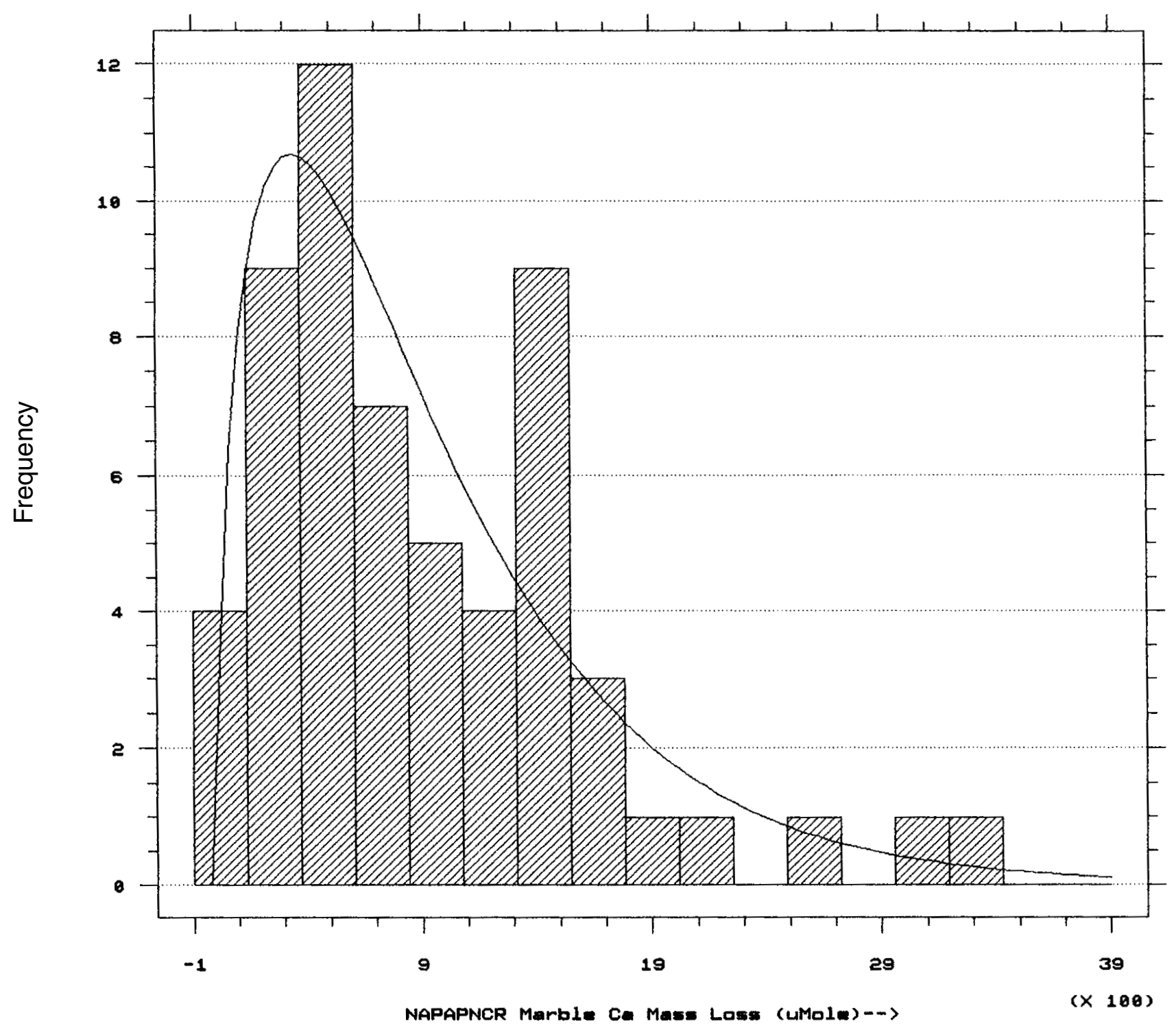

Chisquare Test

\begin{tabular}{|c|c|c|c|c|c|}
\hline & $\begin{array}{l}\text { Lower } \\
\text { Limit }\end{array}$ & $\begin{array}{l}\text { Upper } \\
\text { Limit }\end{array}$ & $\begin{array}{l}\text { Observed } \\
\text { Frequency }\end{array}$ & $\begin{array}{l}\text { Expected } \\
\text { Frequency }\end{array}$ & Chisquare \\
\hline above & $\begin{array}{r}\text { at or below } \\
370.59 \\
605.88 \\
841.18 \\
1076.47 \\
1311.76 \\
1782.35\end{array}$ & $\begin{array}{r}370.59 \\
605.88 \\
841.18 \\
1076.47 \\
1311.76 \\
1782.35\end{array}$ & $\begin{array}{r}13 \\
12 \\
7 \\
5 \\
4 \\
12 \\
5\end{array}$ & $\begin{array}{r}13.8 \\
10.2 \\
8.6 \\
6.8 \\
5.1 \\
6.6 \\
6.9\end{array}$ & $\begin{array}{r}.0488 \\
.3306 \\
.2879 \\
.4587 \\
.2538 \\
4.3782 \\
.5330\end{array}$ \\
\hline
\end{tabular}

Chisquare $=6.29084$ with 4 d.f. Sig. level $=0.178456$ 
A Limestone Raw Ca Mass Loss - NAPAP : OH

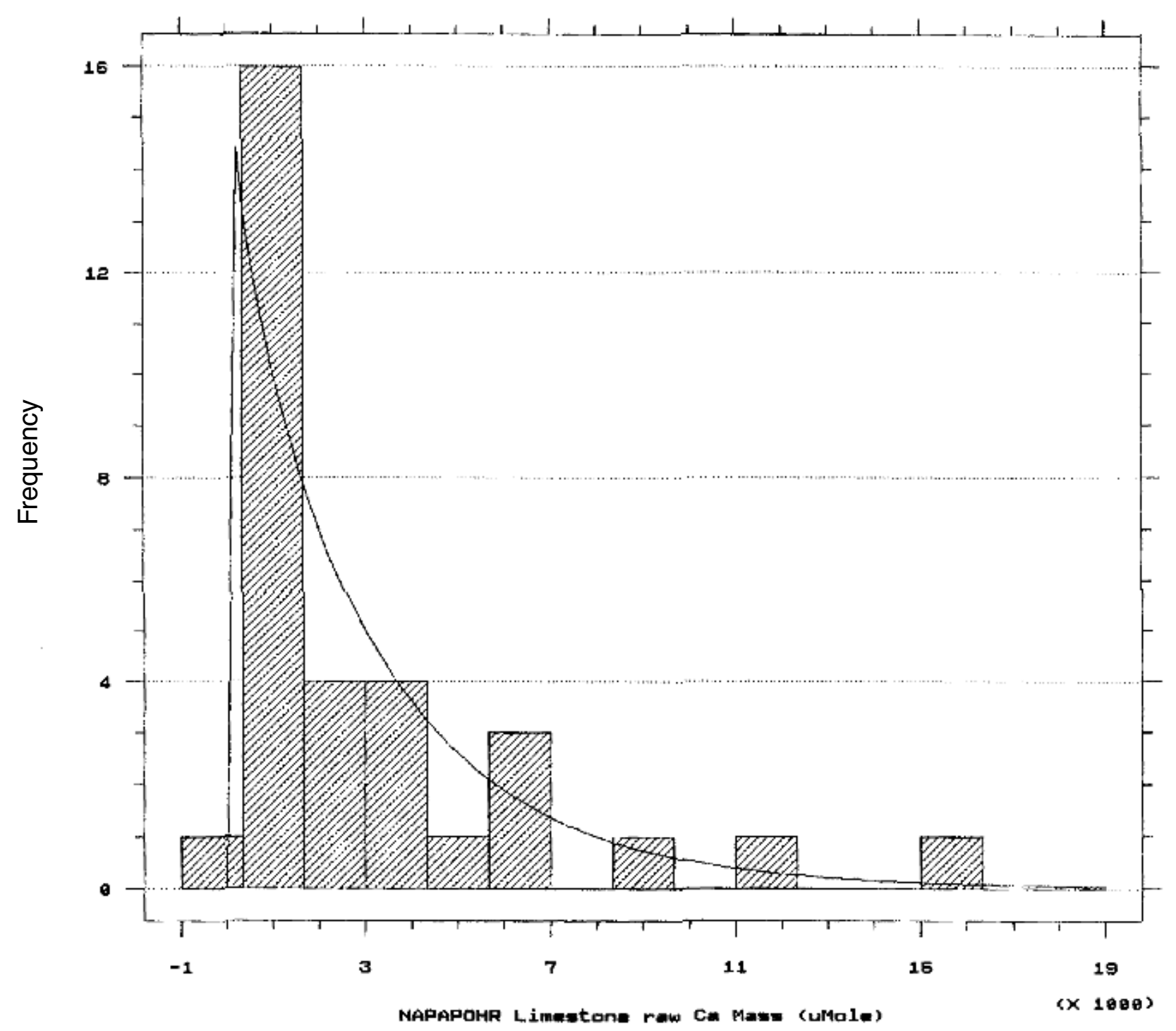

Chisquare Test

\begin{tabular}{|c|c|c|c|c|c|}
\hline & $\begin{array}{l}\text { Lower } \\
\text { Limit }\end{array}$ & $\begin{array}{l}\text { Upper } \\
\text { Limit }\end{array}$ & $\begin{array}{l}\text { Observed } \\
\text { Frequency }\end{array}$ & $\begin{array}{l}\text { Expected } \\
\text { Frequency }\end{array}$ & Chisquare \\
\hline above & $\begin{array}{r}\text { at or below } \\
1500.00 \\
2750.00 \\
5250.00\end{array}$ & $\begin{array}{l}1500.00 \\
2750.00 \\
5250.00\end{array}$ & $\begin{array}{r}17 \\
4 \\
5 \\
6\end{array}$ & $\begin{array}{r}13.0 \\
6.4 \\
7.0 \\
5.7\end{array}$ & $\begin{array}{r}1.2330 \\
.8802 \\
.5533 \\
.0188\end{array}$ \\
\hline
\end{tabular}

Chisquare $=2.68535$ with 1 d.f. Sig. level $=0.101275$

FIGURE 65.-A, Histograms and model with goodness-of-fit statistics. (Variable: $\mathrm{Ca}^{2+}{ }_{x s}$ mass loss; material: limestone; site: NAPAP-OH.) B, Histograms and model with goodness-of-fit statistics. (Variable: $\mathrm{Ca}^{2+}{ }_{\mathrm{xs}}$ mass loss; material: marble; site: NAPAP-OH.) 
B Marble Raw Ca Mass Loss - NAPAP : OH

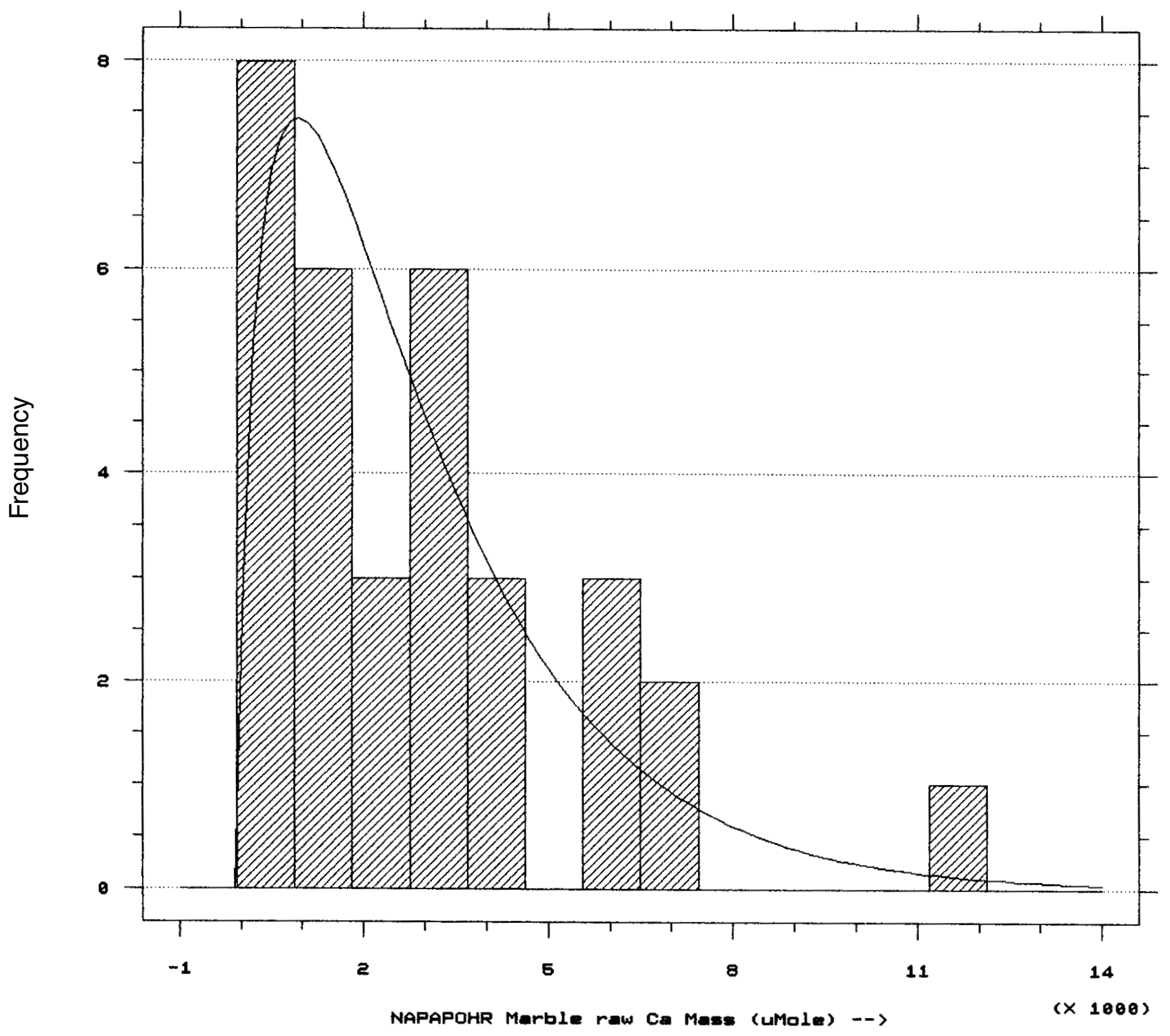

Chisquare Test

\begin{tabular}{ccccc}
$\begin{array}{c}\text { Lower } \\
\text { Limit }\end{array}$ & $\begin{array}{c}\text { Upper } \\
\text { Limit }\end{array}$ & $\begin{array}{c}\text { Observed } \\
\text { Frequency }\end{array}$ & $\begin{array}{c}\text { Expected } \\
\text { Frequency }\end{array}$ & Chisquare \\
\hline at or below & 875.00 & 8 & 5.7 & .91537 \\
875.00 & 1812.50 & 6 & 7.1 & .17497 \\
1812.50 & 2750.00 & 3 & 5.7 & 1.31070 \\
2750.00 & 4625.00 & 9 & 7.2 & .43667 \\
4625.00 & & 6 & 6.2 & .00666
\end{tabular}

Chisquare $=2.84438$ with 2 d.f. Sig. level $=0.241185$ 


\section{NAPAP-DATA (All Sites)}

\section{Excess Ca vs Ho}

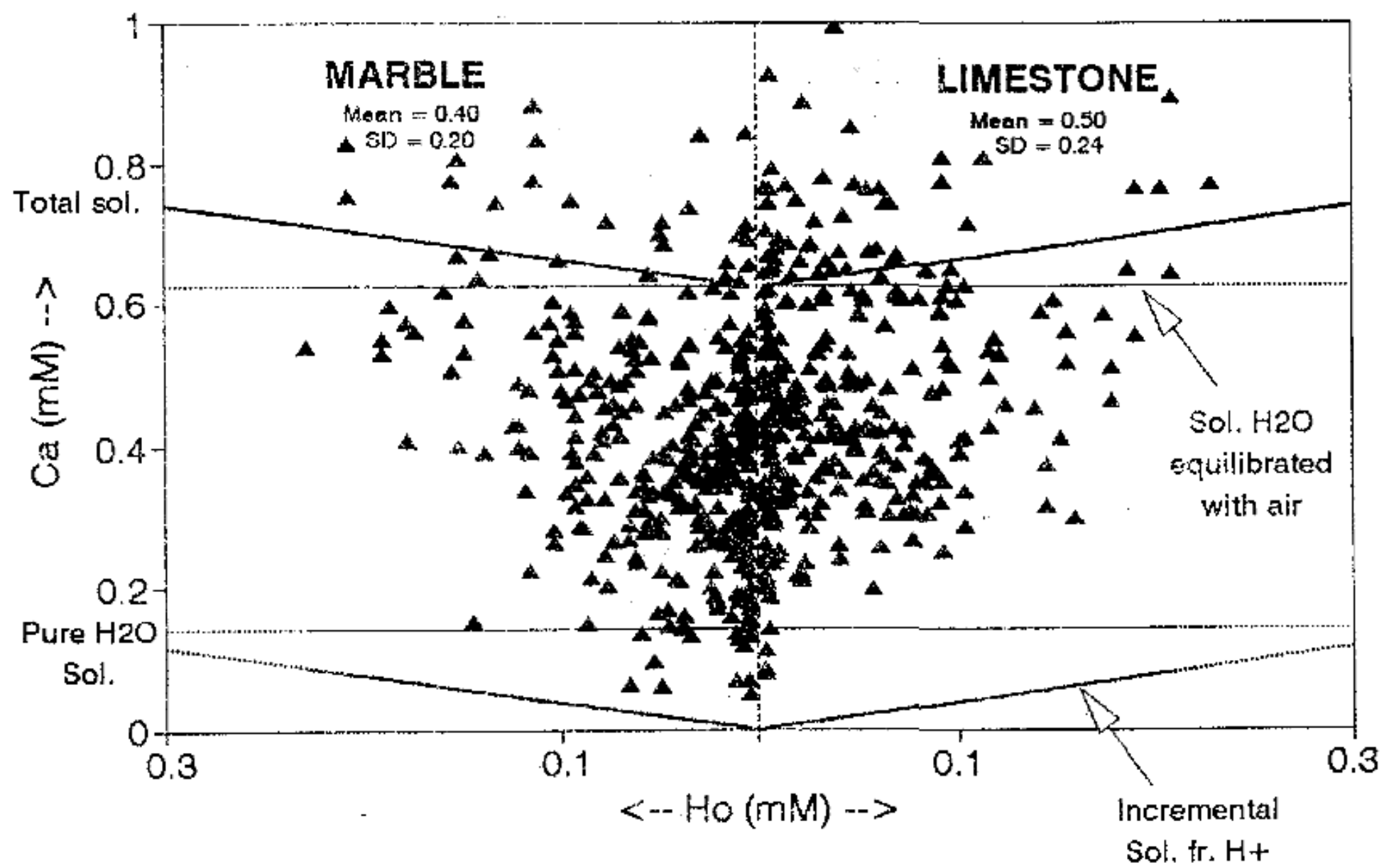

FIGURE 66.-Back-to-back scatter plots of excess $\left[\mathrm{Ca}^{2+}\right]$ versus incident $\left[\mathrm{H}^{+}\right]$for marble and limestone for all NAPAP sites. 


\section{Delta [Ca] vs Delta U \\ NAPAP Data - DC Site - Limestone}

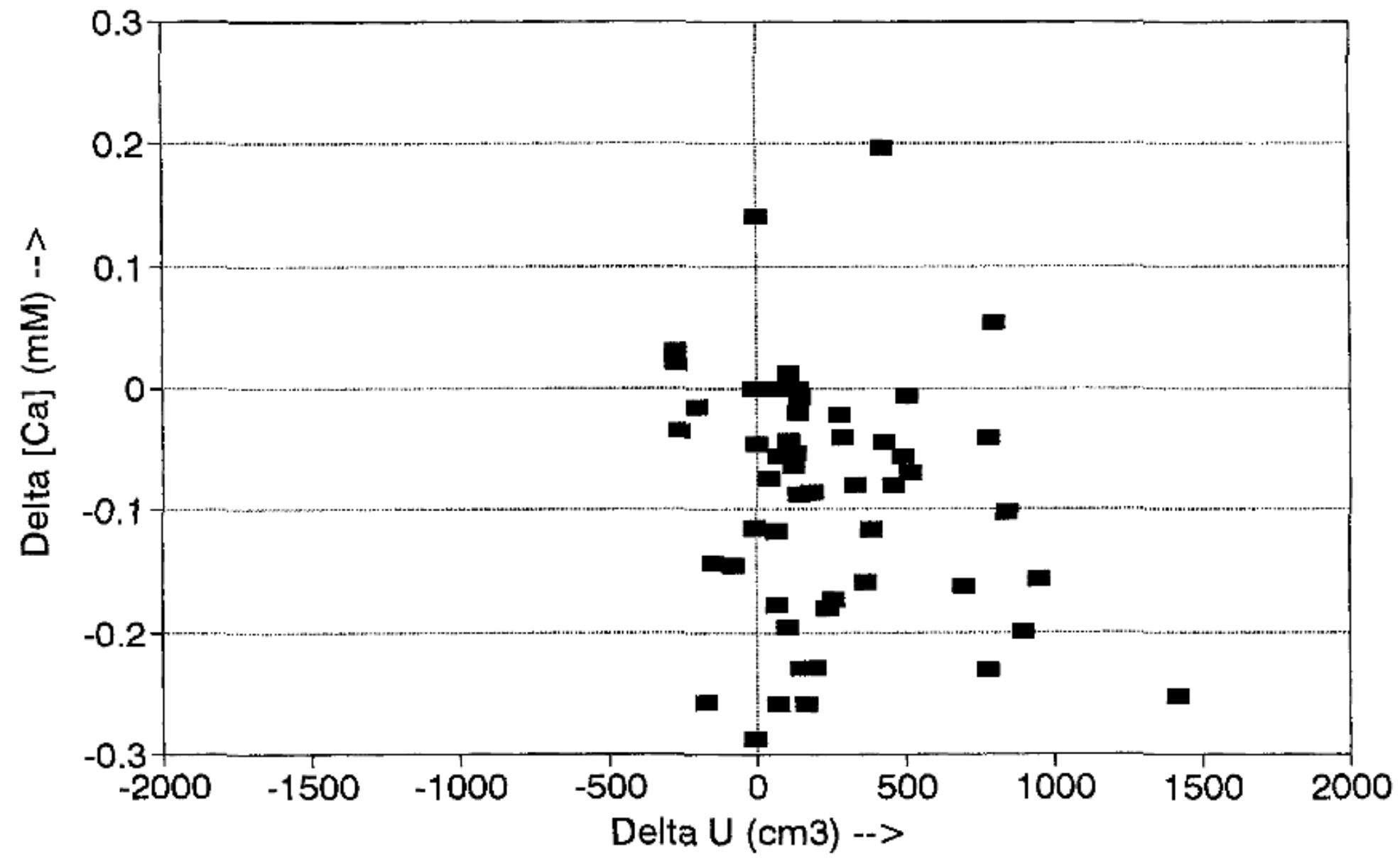

FIGURE 67.-Variability of chemistry from slab to slab. (Variables: $\Delta\left[\mathrm{Ca}^{2+}\right]_{\text {uncor }}$ vs. $\Delta U$; material: limestone; site: NAPAP-DC.) 


\section{Delta [Ca] vs Delta U \\ NAPAP Data - DC Site - Marble}

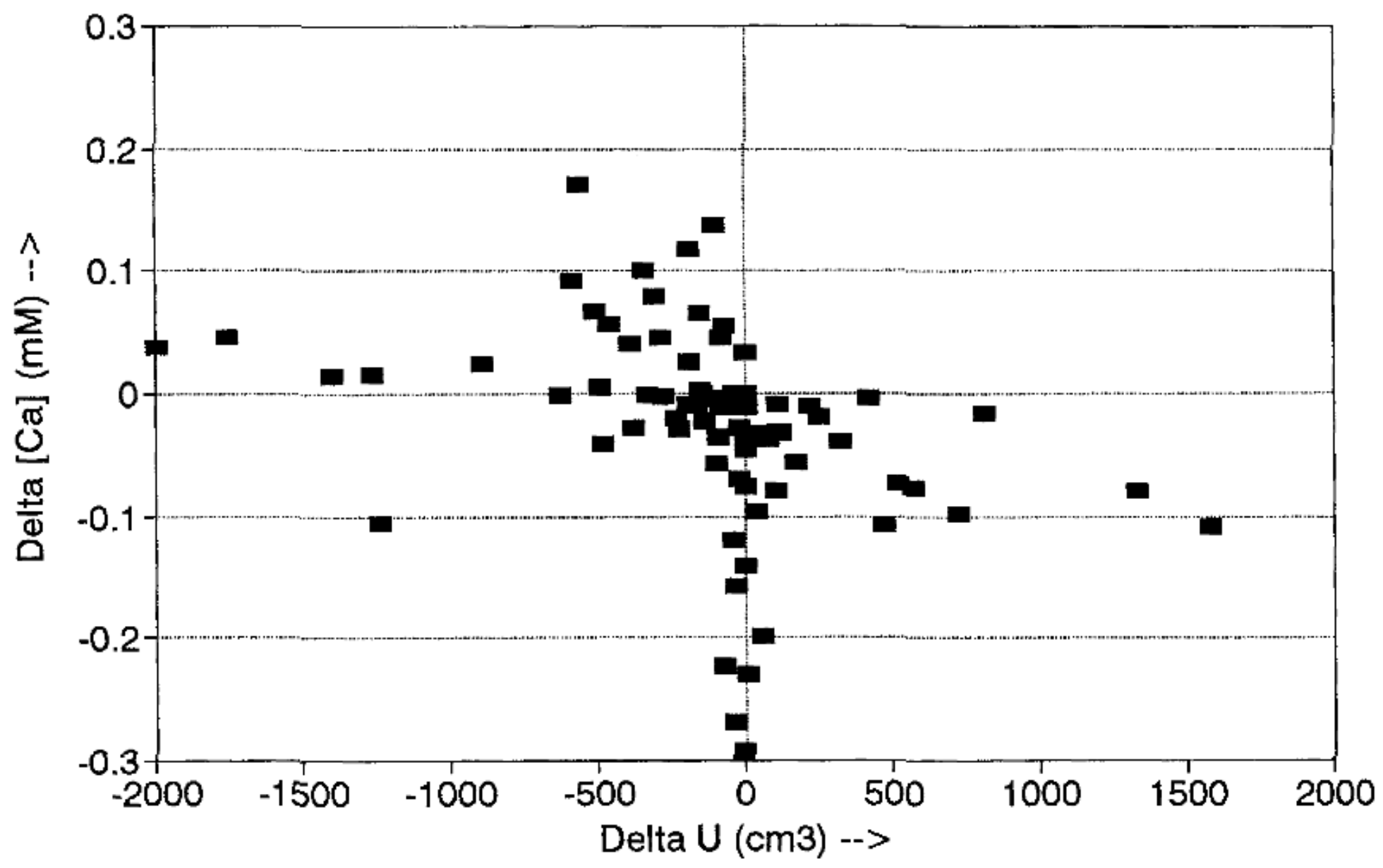

FIGURE 68.-Variability of chemistry from slab-to-slab. (Variables: $\Delta\left[\mathrm{Ca}^{2+}\right]_{\text {uncor }}$ vs. $\Delta U$; material: marble; site: NAPAP-DC.) 


\section{Delta Ca Mass vs Delta U NAPAP Data - DC Site - Limestone}

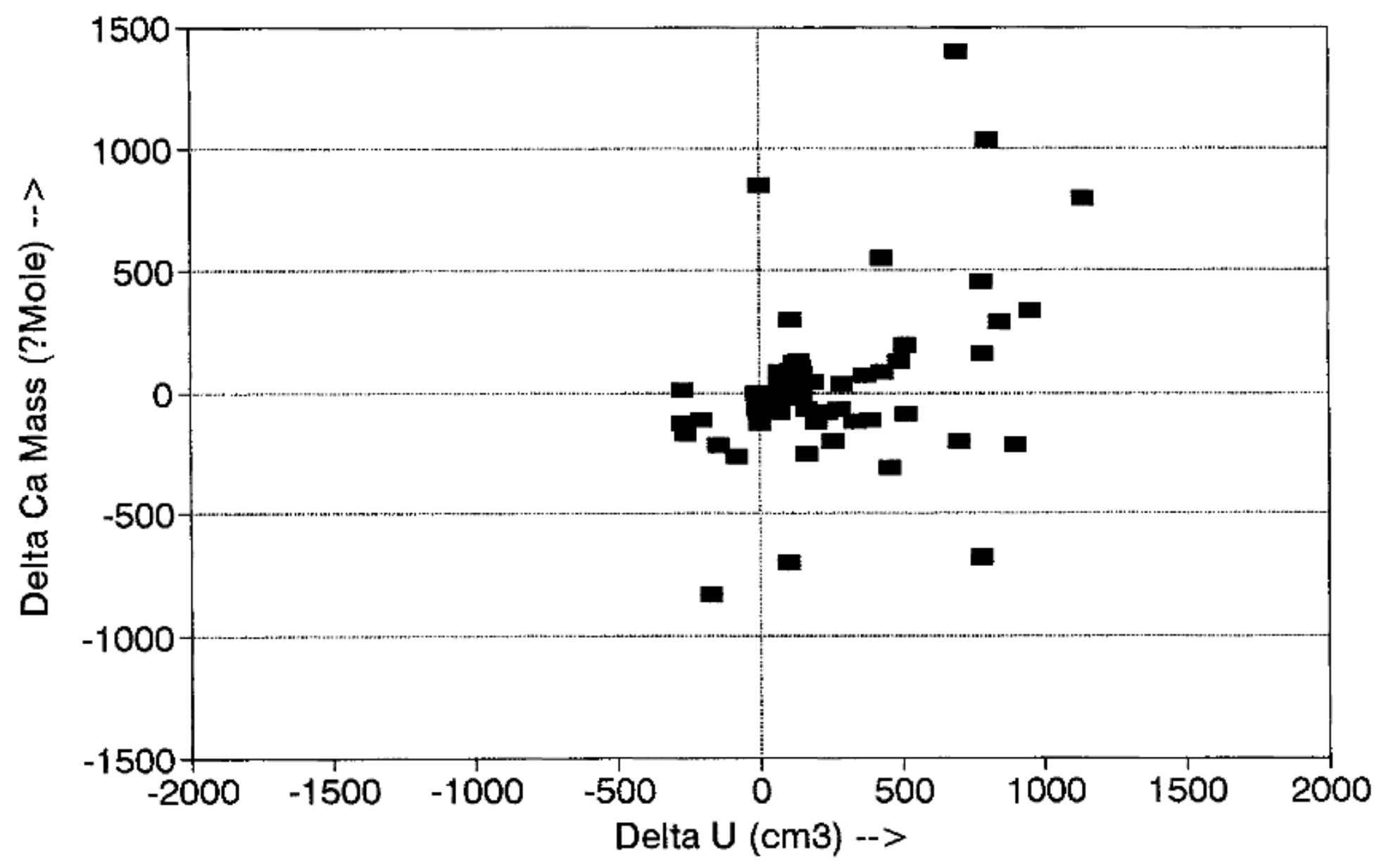

FIGURE 69.-Variability of chemistry from slab-to-slab. (Variables: $\Delta M_{t}$ uncor vs. $\Delta U$; material: limestone; site: NAPAP-DC.) 


\section{Delta Ca Mass vs Delta U \\ NAPAP Data - DC Site - Marble}

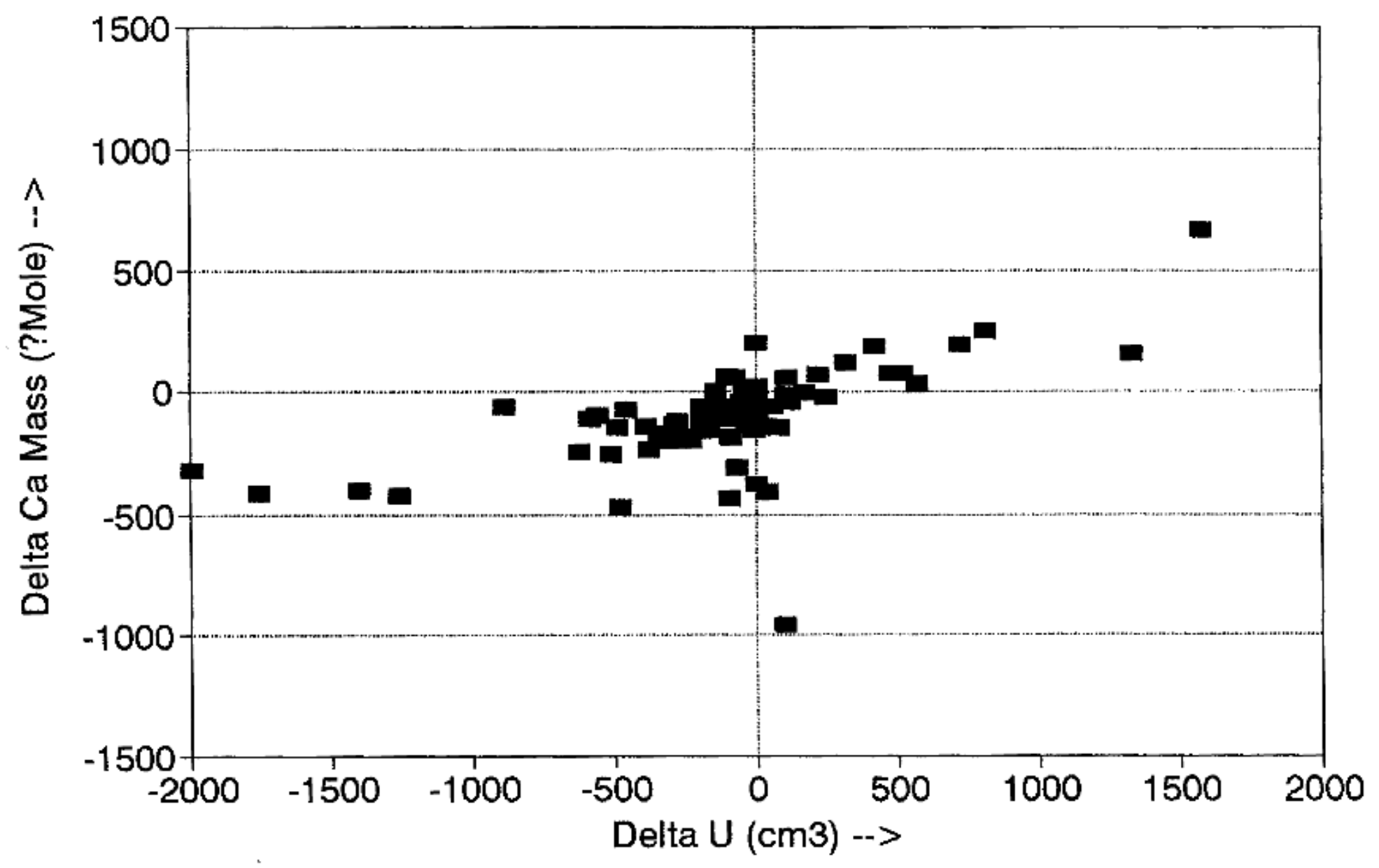

FIGURE 70.-Variability of chemistry from slab to slab. (Variables: $\Delta M_{t}$ uncor vs. $\Delta U$; material: marble; site: NAPAP-DC.) 


\section{Delta [SO4] vs Delta U NAPAP Data - DC Site}

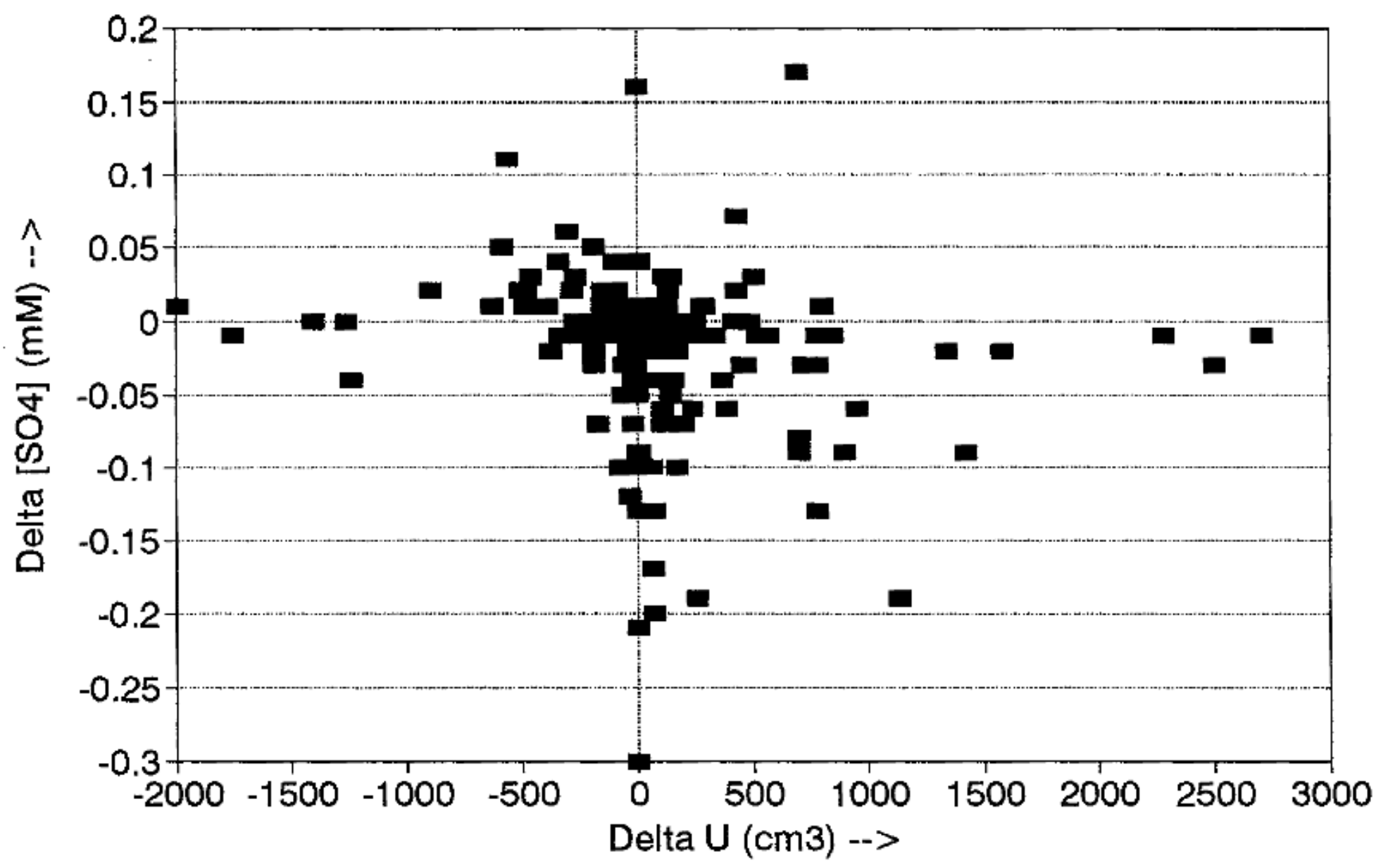

FIGURE 71.-Variability of chemistry from slab to slab. (Variables: $\Delta\left[\mathrm{SO}_{4}{ }^{2-}\right]$ vs. $\Delta U$; material: limestone and marble; site: NAPAP-DC.) 


\section{Delta Gypsum Mass vs Delta U NAPAP Data - DC Site}

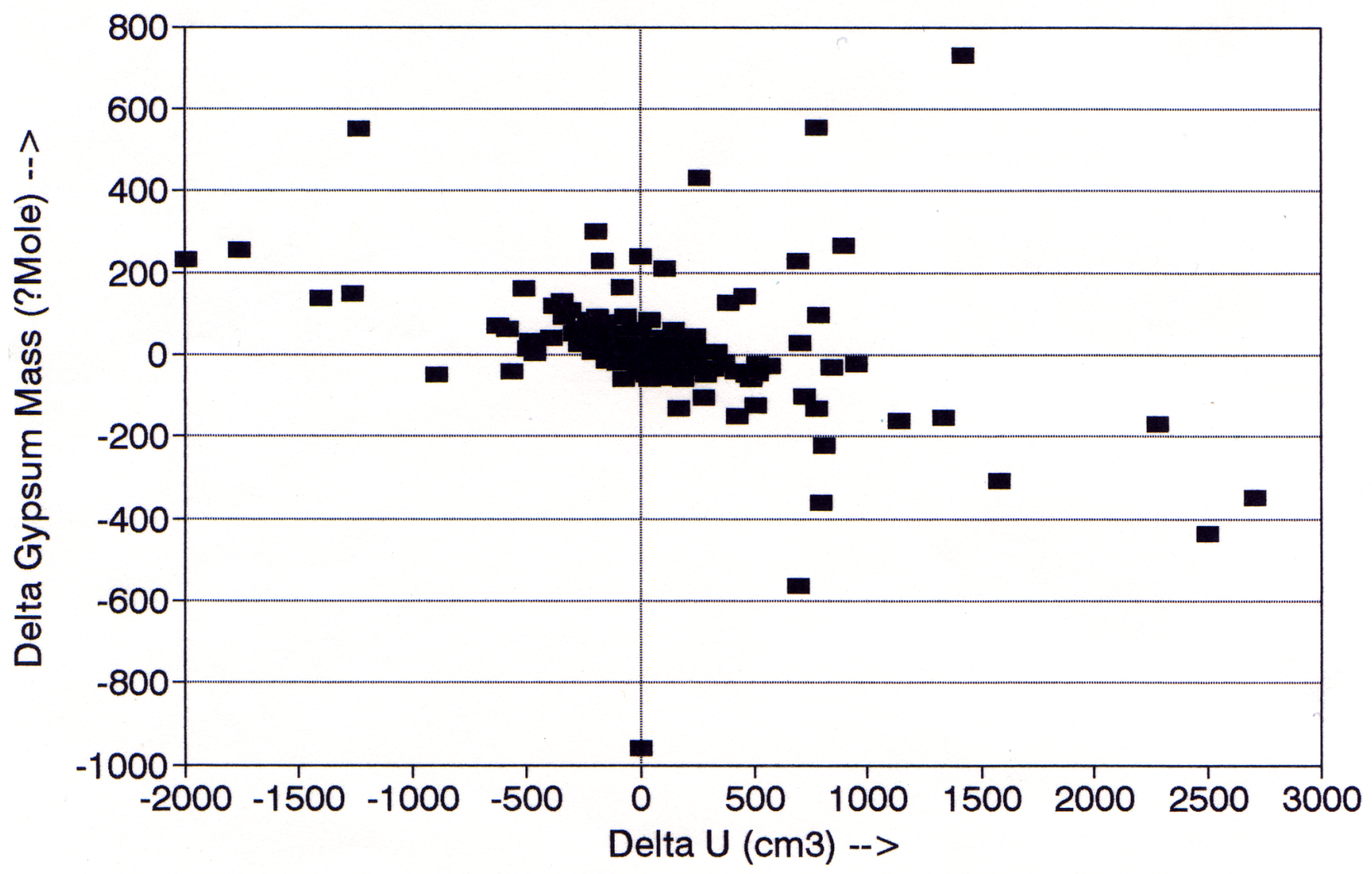

FIGURE 72.-Variability of chemistry from slab to slab. (Variables: $\Delta M_{\mathrm{SO}_{4}{ }^{2-}}$ vs. $\Delta U$; material: limestone and marble; site: NAPAP-DC.) 


\section{Subevent Volume \\ Event 14}

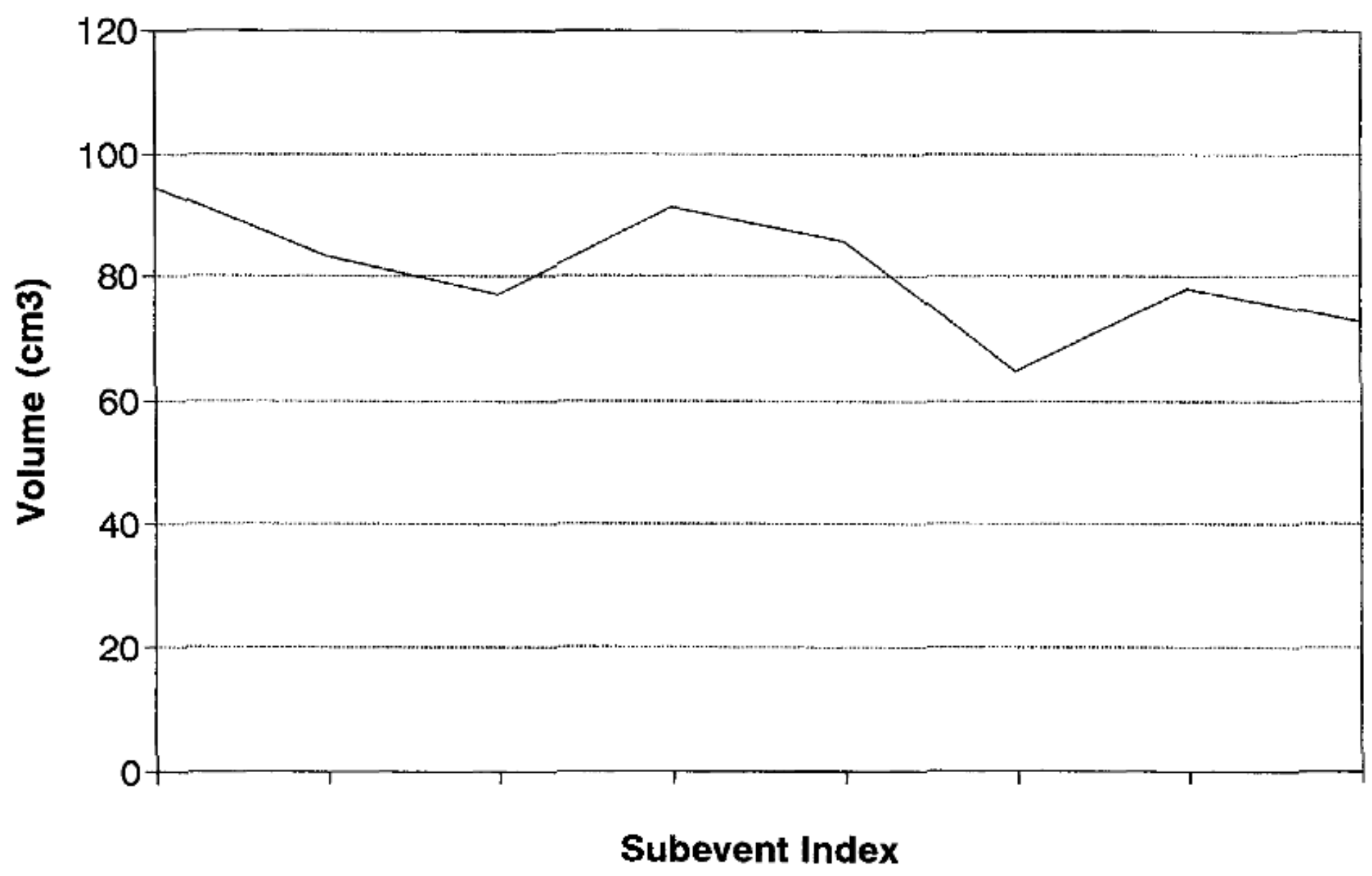

FIGURE 73.-Event 14: $U_{\text {subevent }}$ vs. index subevent $_{\text {. }}$ (Variables: subevent volume; material: volume; site: NAPAP-NY.) 


\section{Subevent Volume \\ Event 15}

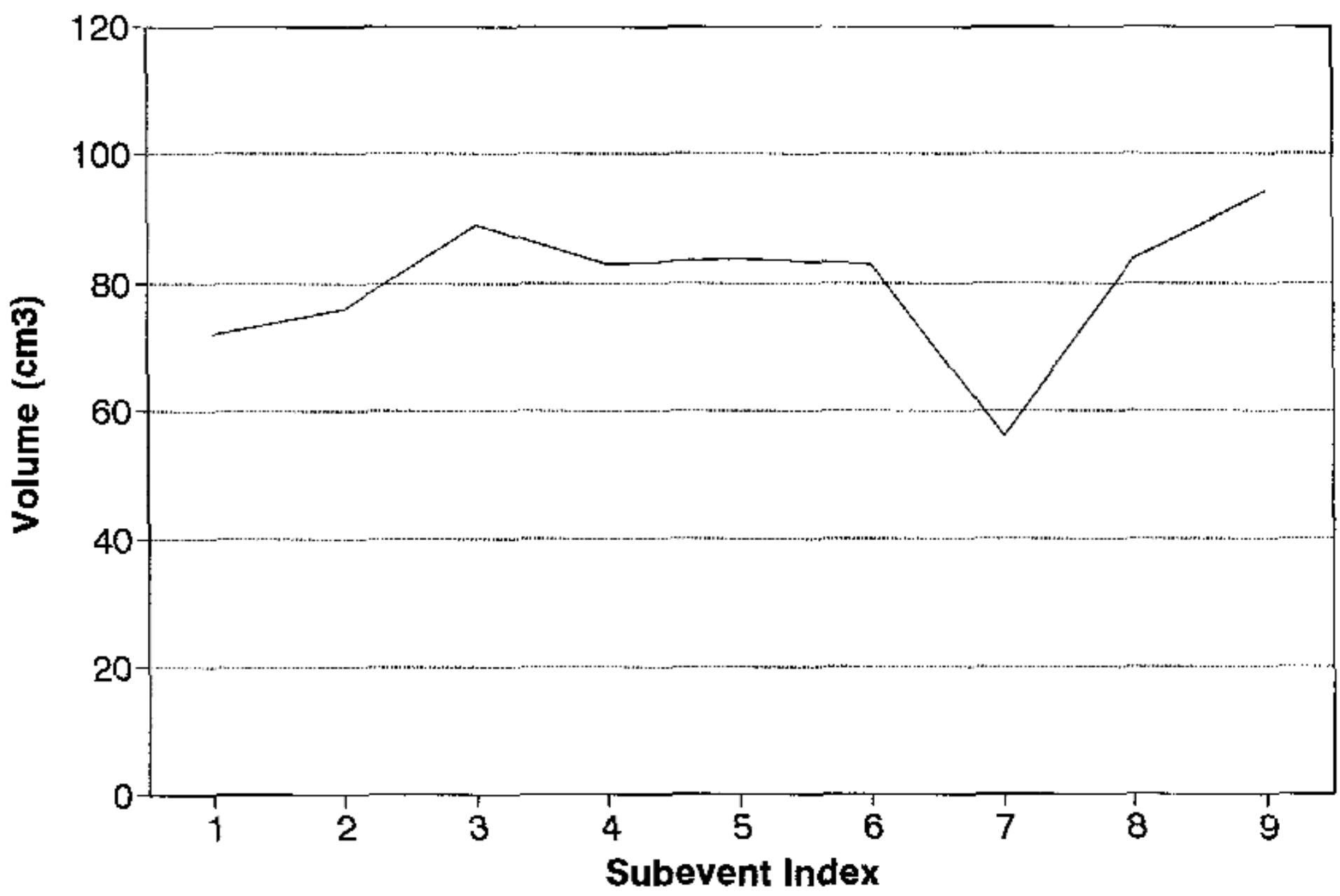

FIGURE 74.-Event 15: $U_{\text {subevent }}$ vs. index ${ }_{\text {subevent. }}$ (Variables: subevent volume; material: volume; site: NAPAP-NY.) 


\section{Subevent Volume \\ Event 16}

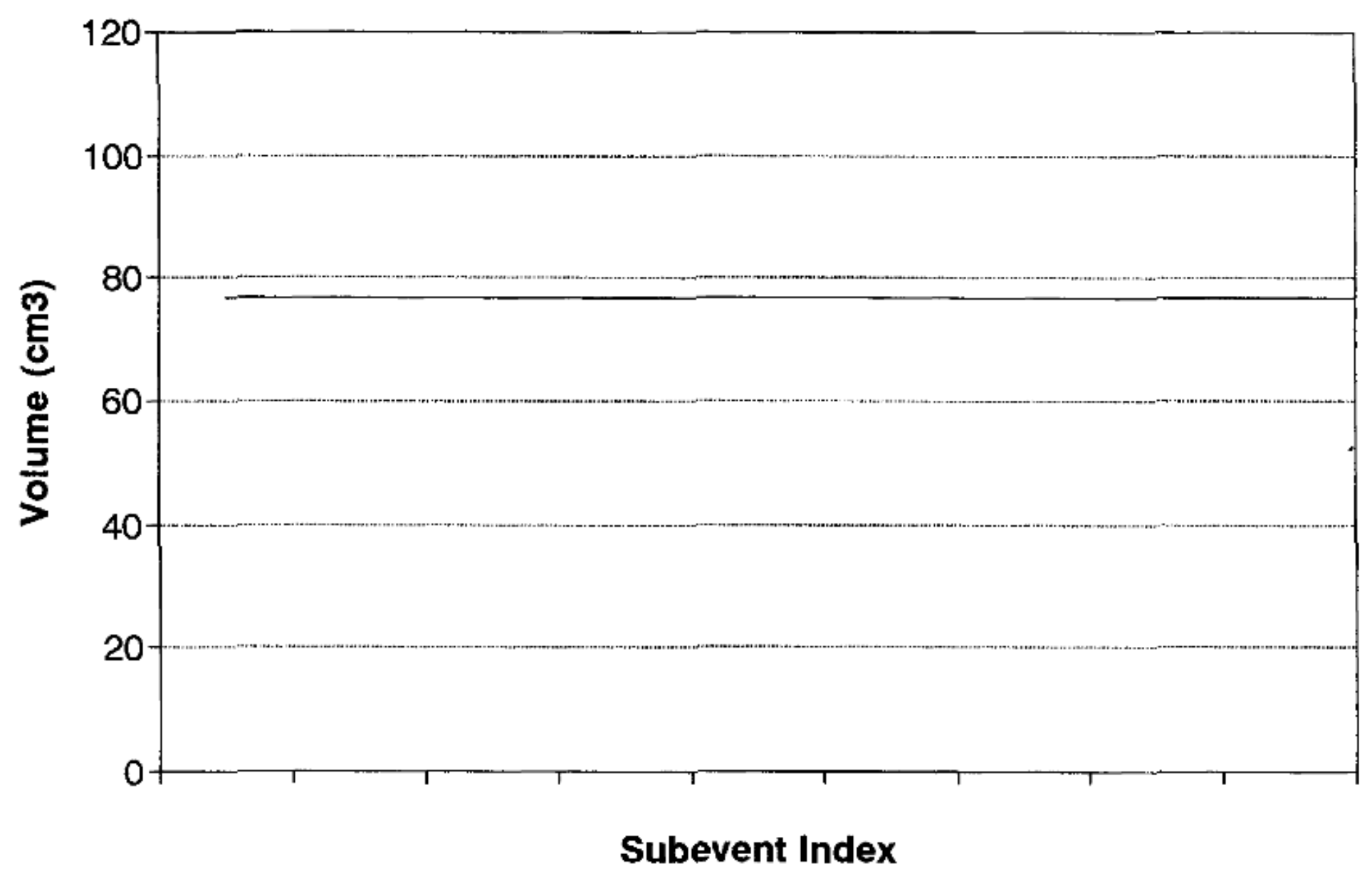

FIGURE 75.-Event 16: $U_{\text {subevent }}$ vs. index subevent (Variables: subevent volume; material: volume; site: NAPAP-NY.) 


\section{Subevent Volume}

Event 17

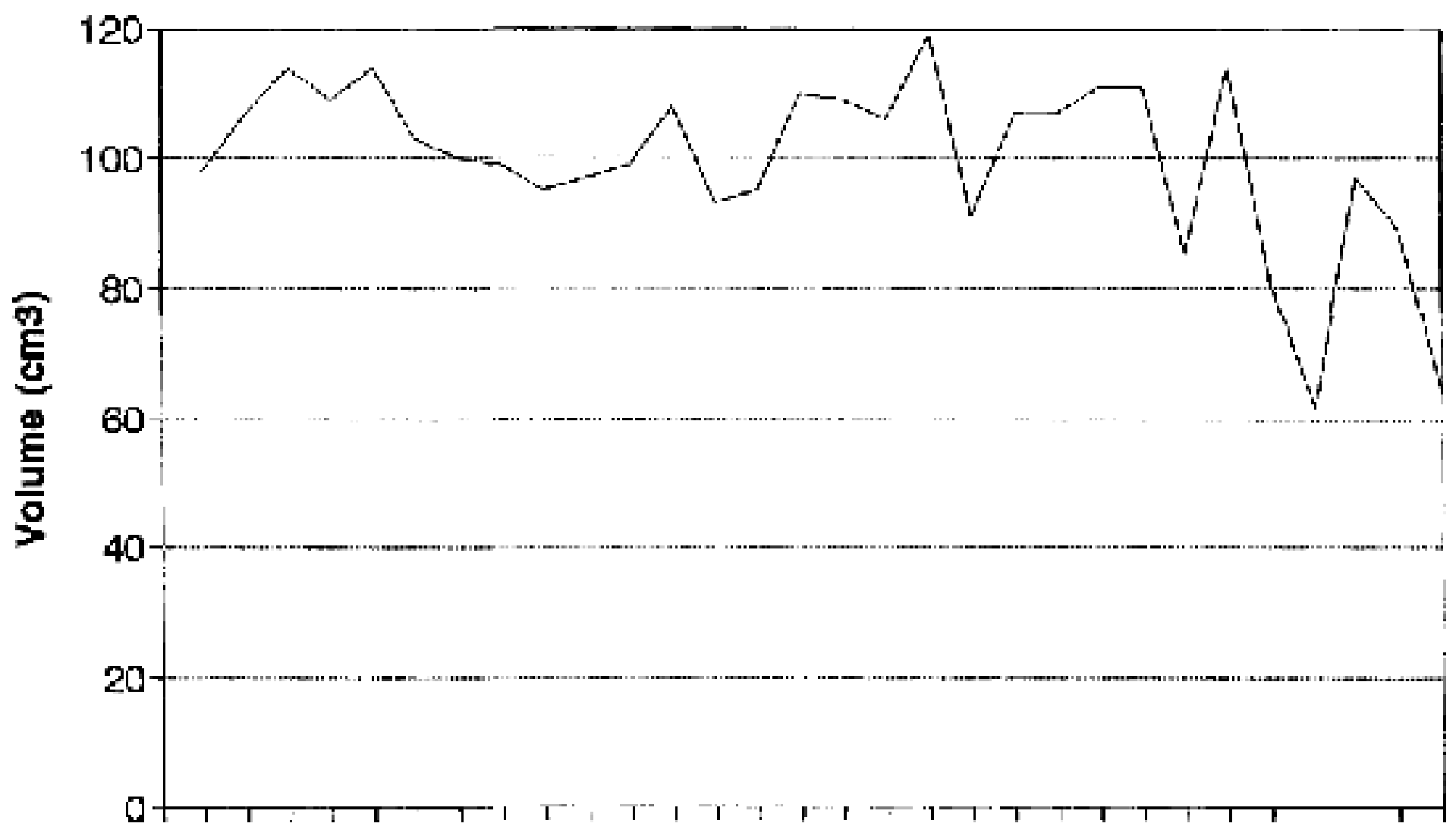

\section{Subevent Index}

FIGURE 76.-Event 17: $U_{\text {subevent }}$ vs. index ${ }_{\text {subevent }}$ (Variables: subevent volume; material: volume; site: NAPAP-NY.) 


\section{Subevent Volume Event 21}

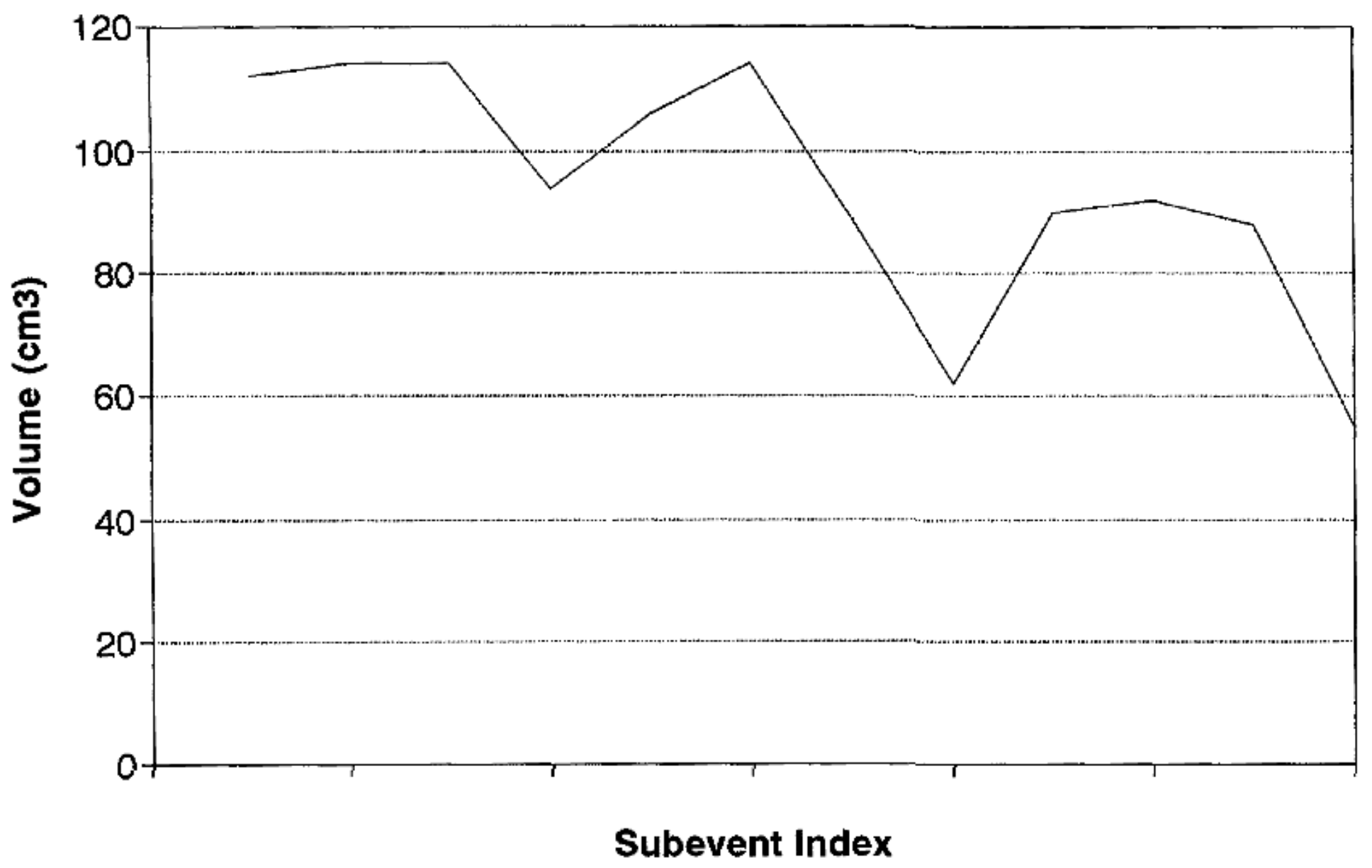

FIGURE 77.-Event 21: $U_{\text {subevent }}$ vs. index ${ }_{\text {subevent }}$ (Variables: subevent volume; material: volume; site: NAPAP-NY.) 


\section{Subevent Volume \\ Event 23}

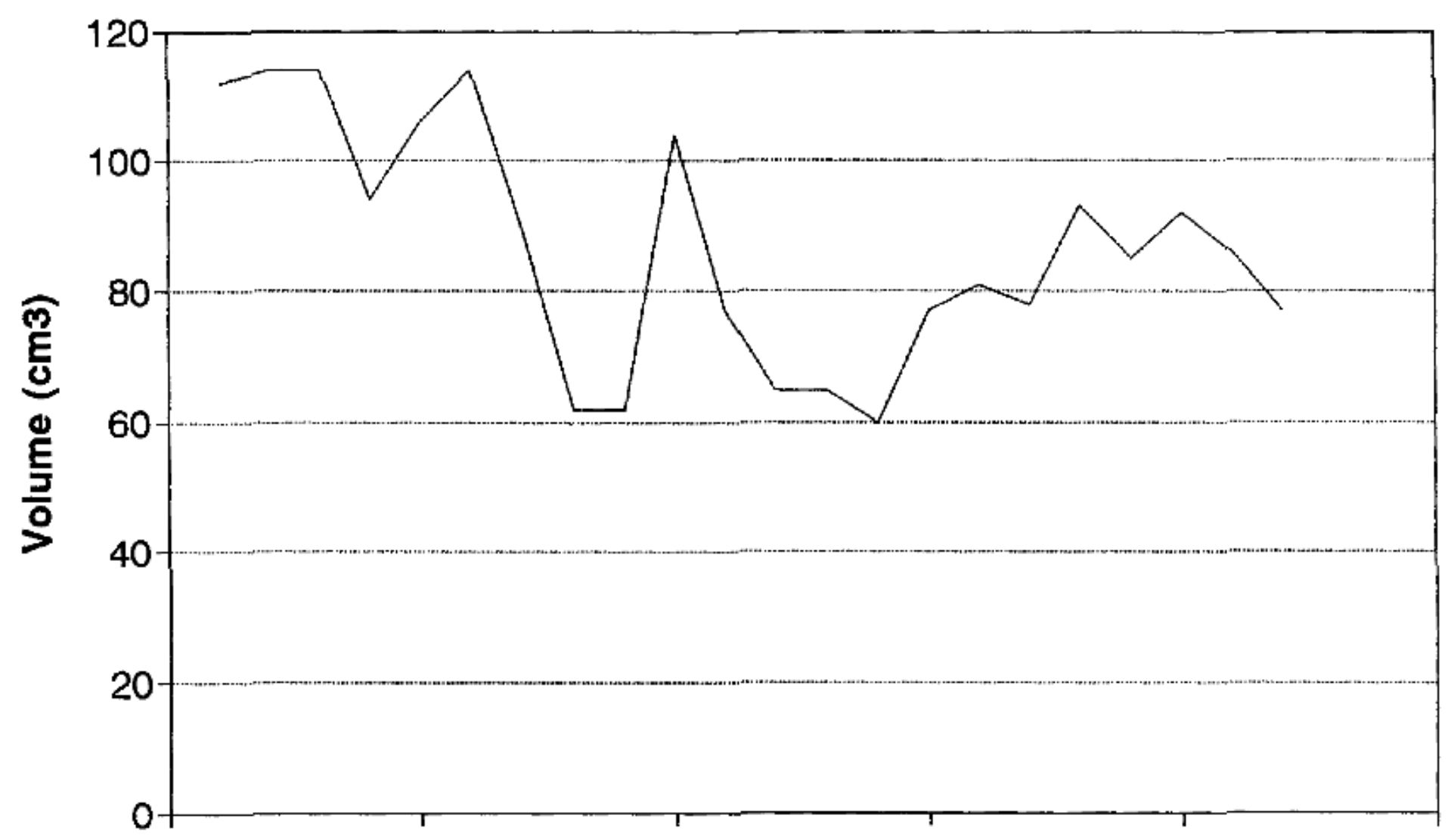

\section{Subevent Index}

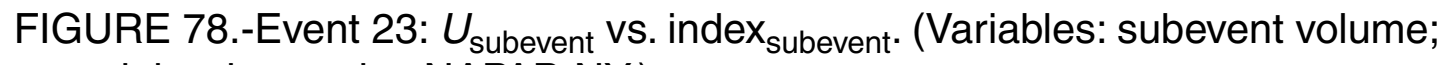
material: volume; site: NAPAP-NY.) 


\section{Subevent Volume \\ Event 25}

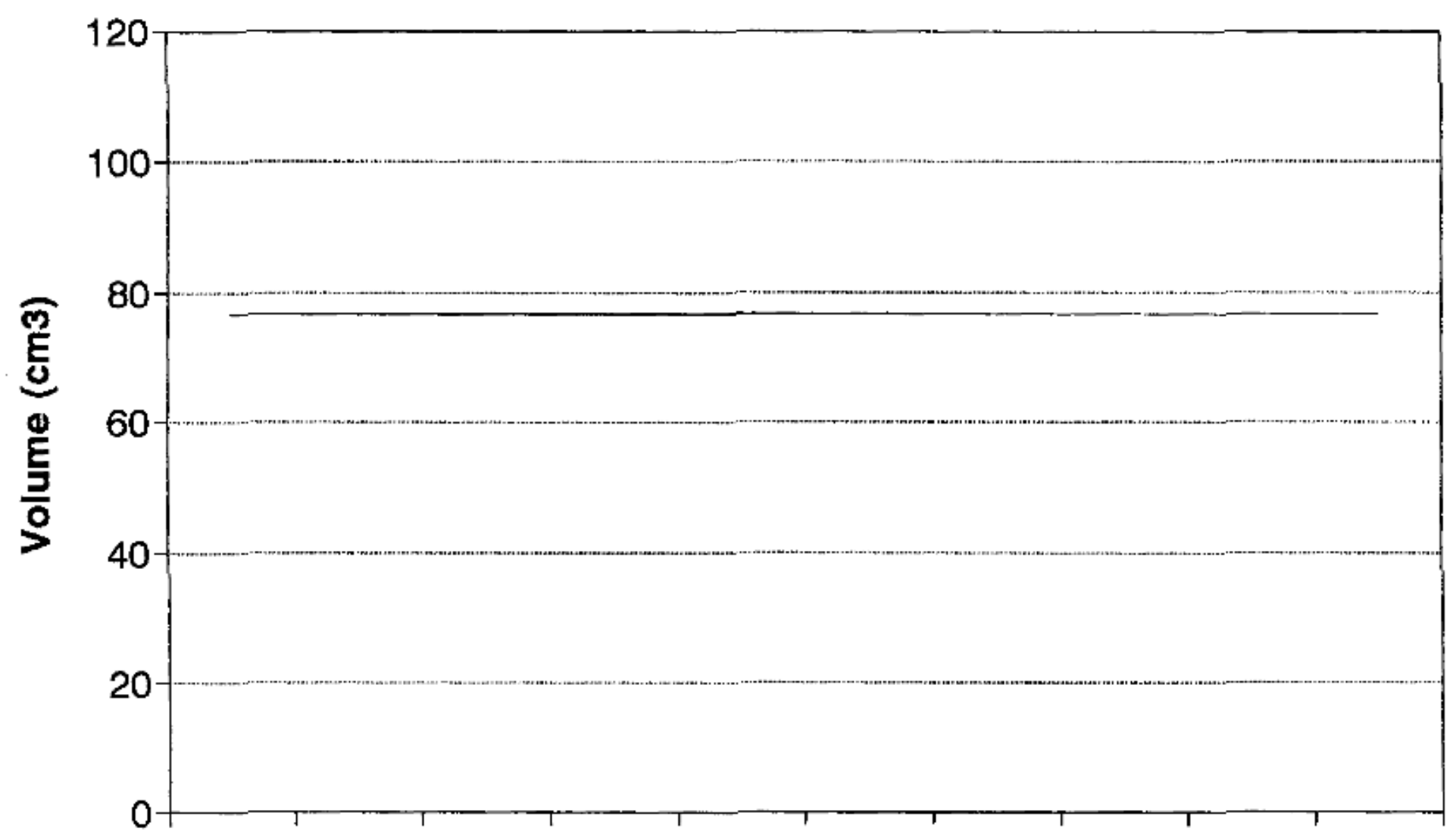

\section{Subevent Index}

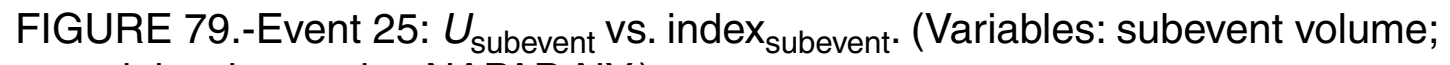
material: volume; site: NAPAP-NY.) 


\section{Subevent Flowrates \\ Fixed Volume Mean \& Average Flowrate}

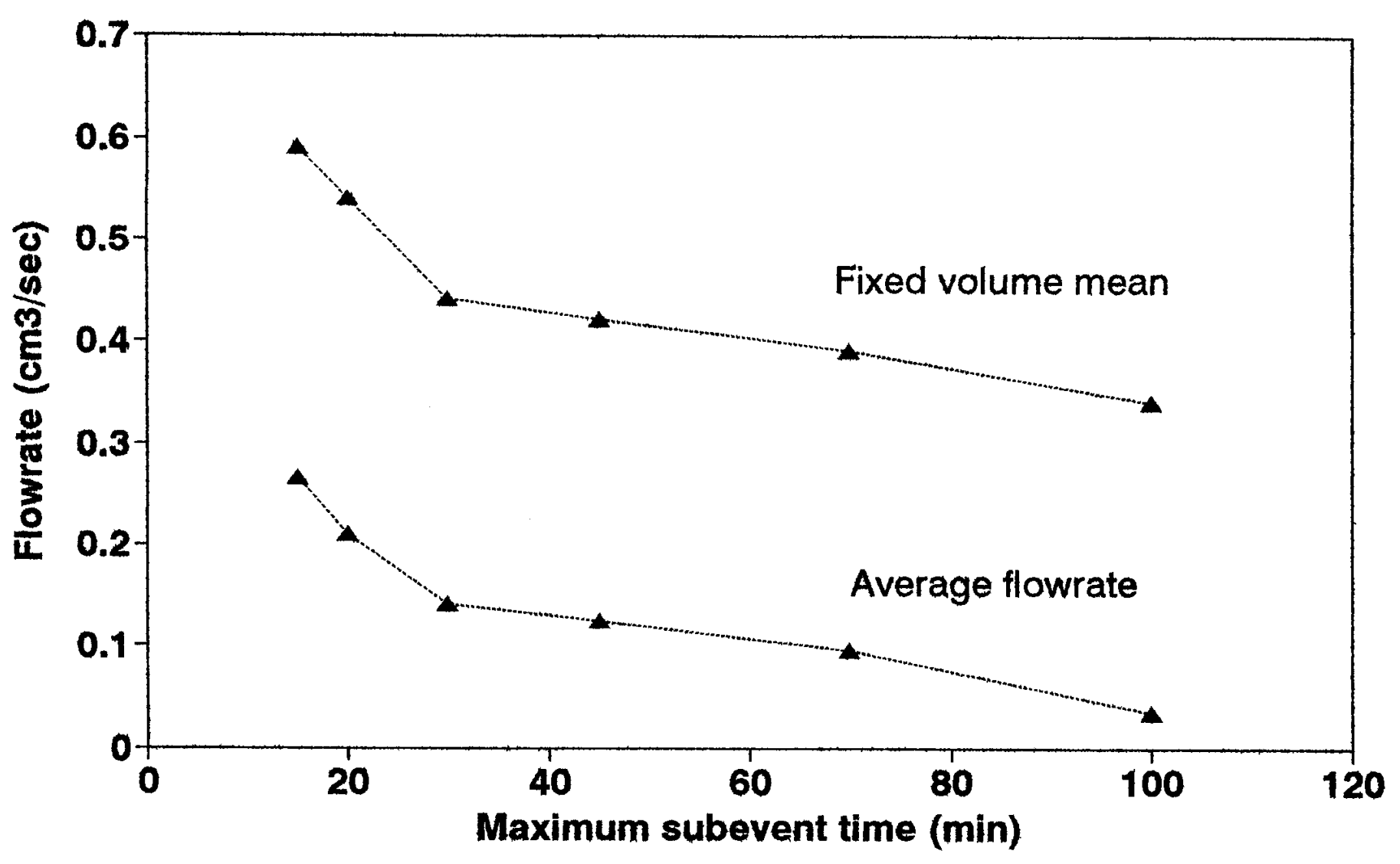

FIGURE 80.-Subevent flowrates: fixed volume mean flowrate and mean flowrate vs. $T_{\text {max }}$ (Variables: $\mu_{\phi, \text { fixed volume }} ; \mu_{\phi} ; T_{\text {max }}$; material: marble; site: NAPAP-NY.) 


\section{Marble Volume vs Blank Volume Subevents $14,21,23$}

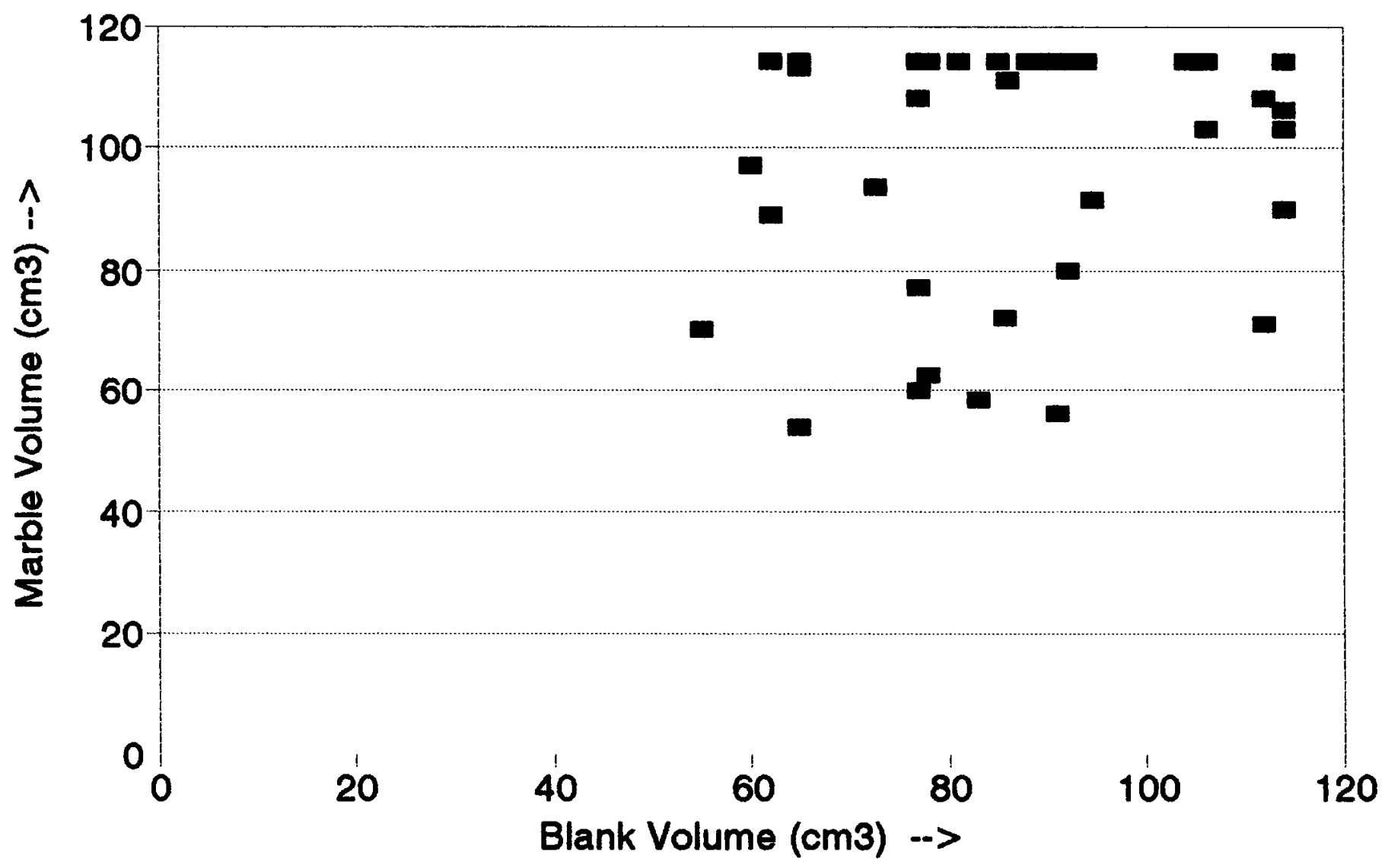

FIGURE 81.-Subevent volume (all events) vs. blank runoff volume. (Variables: volume; material: marble; site: NAPAP-NY.) 


\section{Sequential Data of [Ca],[Ho] and flow}

Event 15

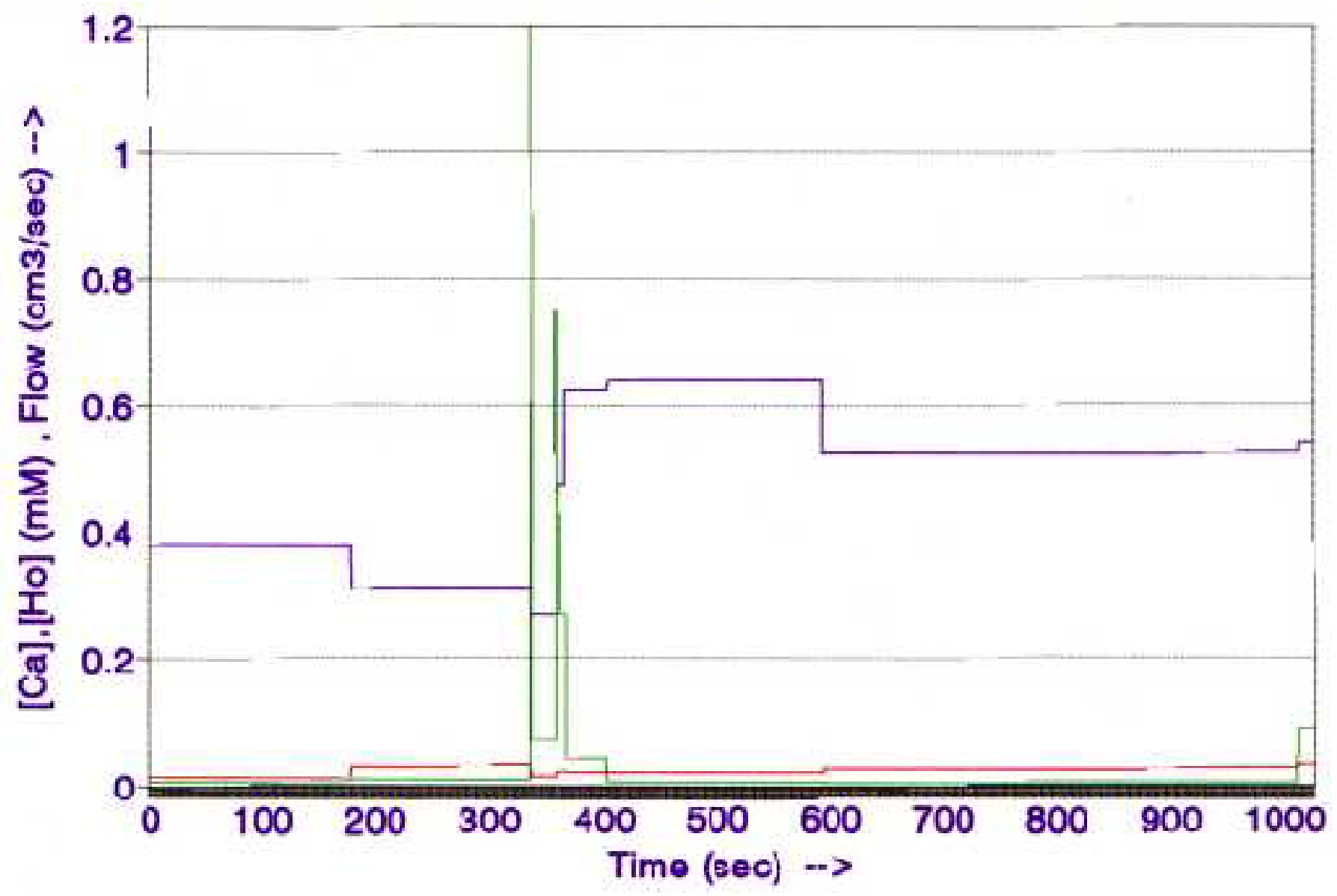

FIGURE 82.-Event 14: variables vs. cumulative event time. (Variables: purple: $\left[\mathrm{Ca}^{2+}\right]_{\mathrm{xs}}$, green: $\phi$; red: $\left[\mathrm{H}^{+}\right]^{\circ}$; material: marble; site: NAPAP-NY.) 


\section{Sequential Data of [Ca],[Ho] and flow}

Event 14

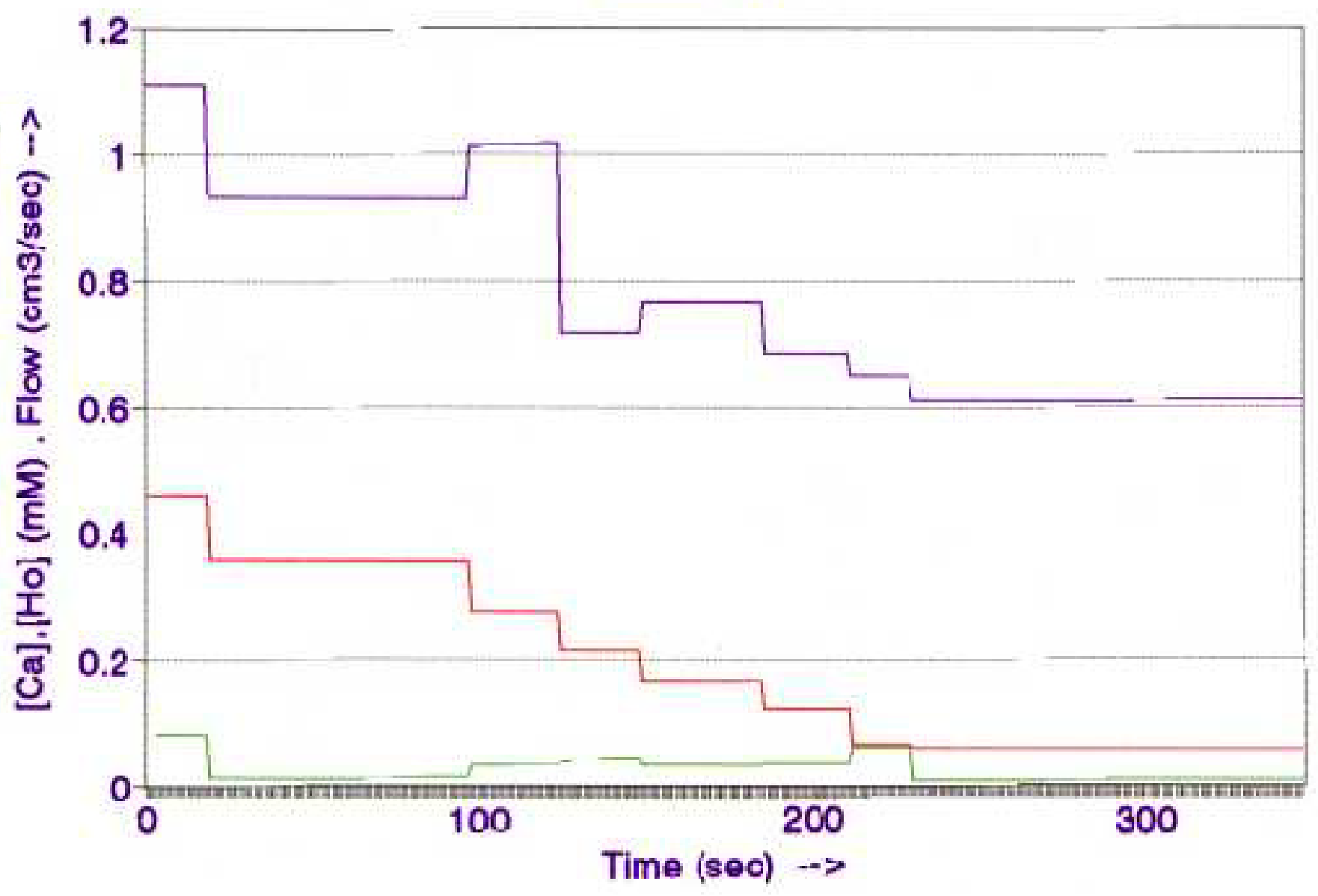

FIGURE 83.-Event 15: variables vs. cumulative event time. (Variables: purple: $\left[\mathrm{Ca}^{2+}\right]_{\mathrm{xs}}$, green: $\phi$; red: $\left[\mathrm{H}^{+}\right]^{\circ}$; material: marble; site: NAPAP-NY.) 


\section{Sequential Data of [Ca],[Ho] and flow}

Event 16

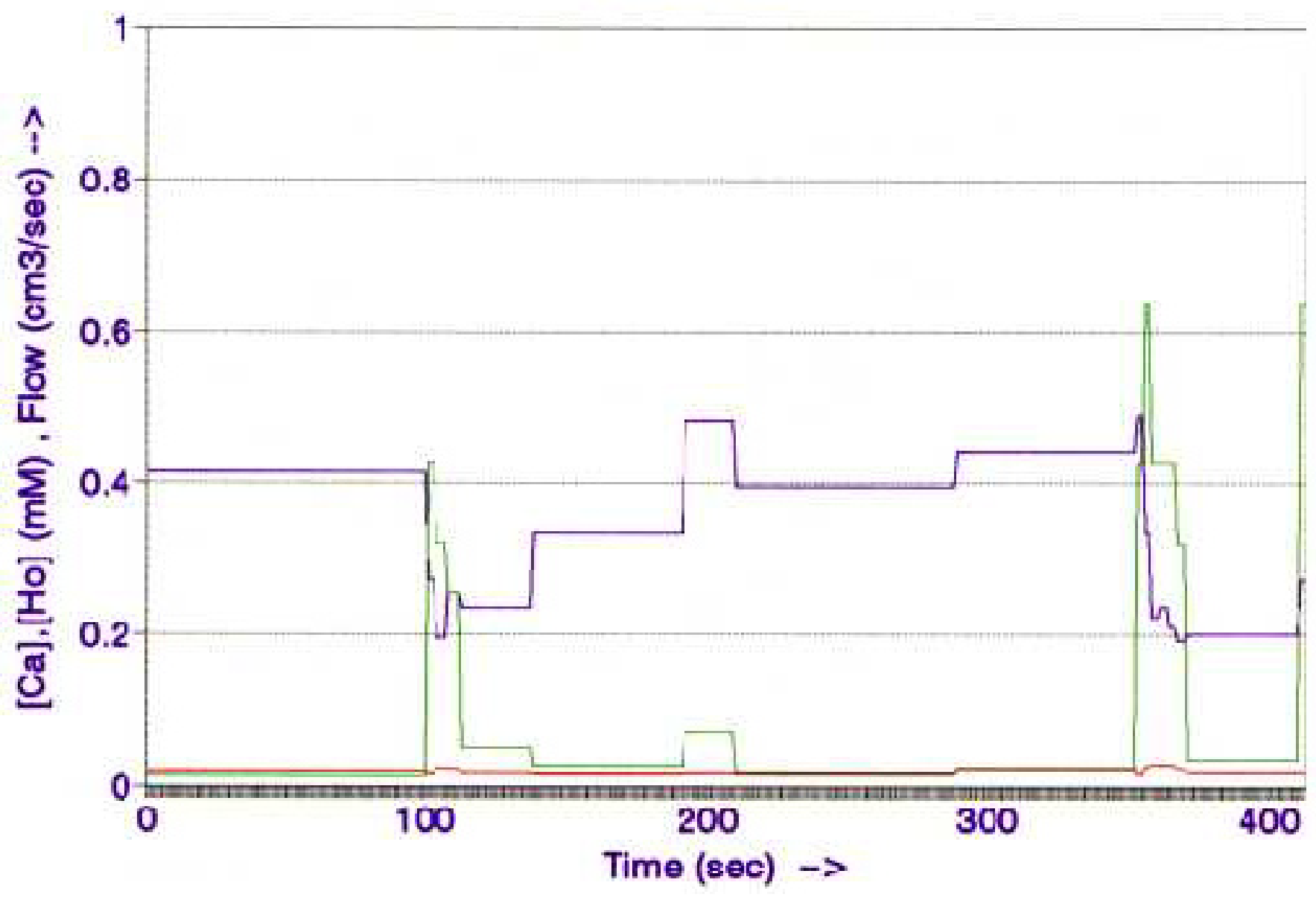

FIGURE 84.-Event 16: variables vs. cumulative event time. (Variables: purple: $\left[\mathrm{Ca}^{2+}\right]_{\mathrm{xs}}$, green: $\phi$; red: $\left[\mathrm{H}^{+}\right]^{\circ}$; material: marble; site: NAPAP-NY.) 


\section{Sequential Data of [Ca],[Ho] and flow}

Event 17

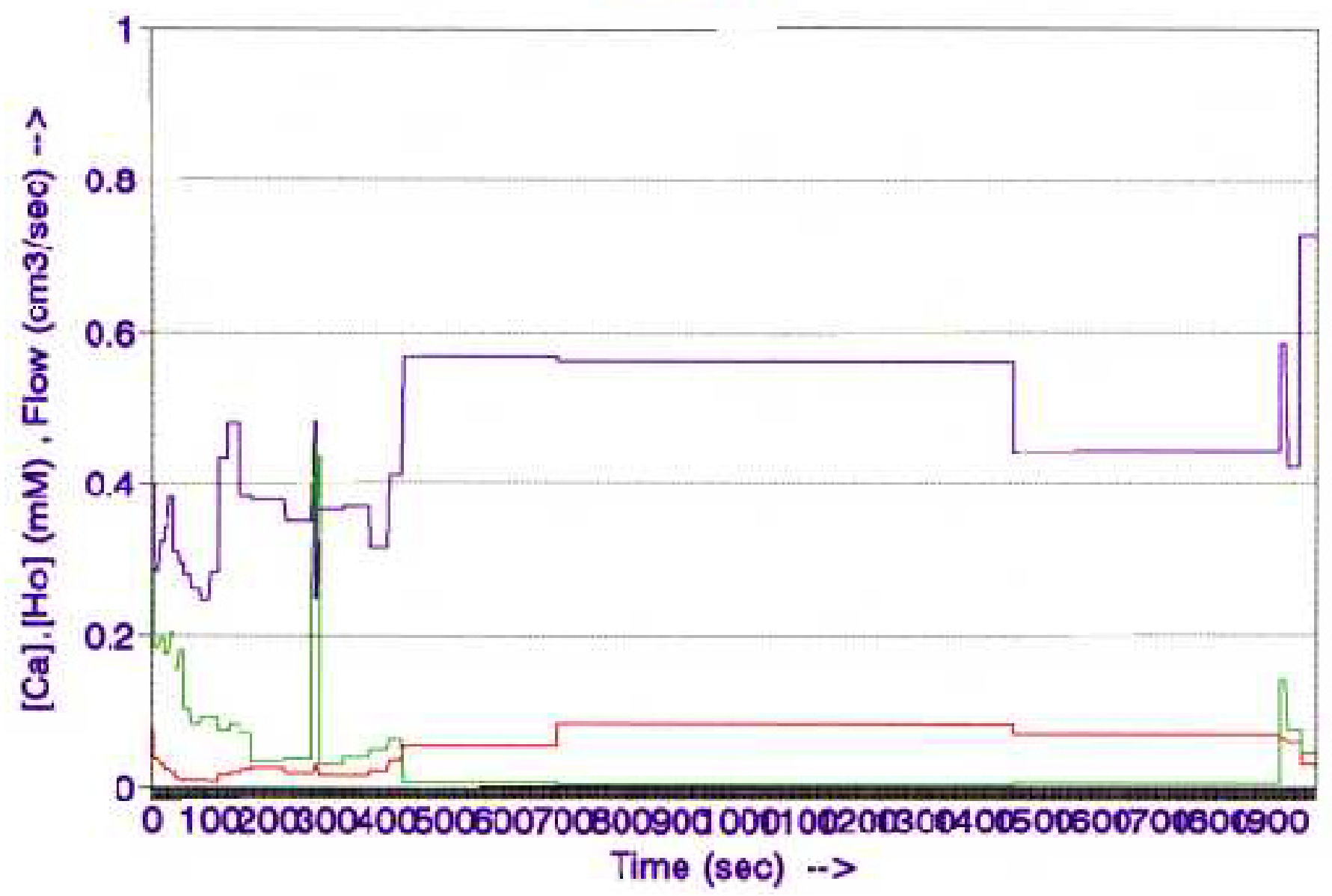

FIGURE 85.-Event 17: variables vs. cumulative event time. (Variables: purple: $\left[\mathrm{Ca}^{2+}\right]_{\mathrm{xs}}$, green: $\phi$; red: $\left[\mathrm{H}^{+}\right]^{\circ}$; material: marble; site: NAPAP-NY.) 


\section{Sequential Data of [Ca], $[\mathrm{Ho}]$ and flow}

Event 21

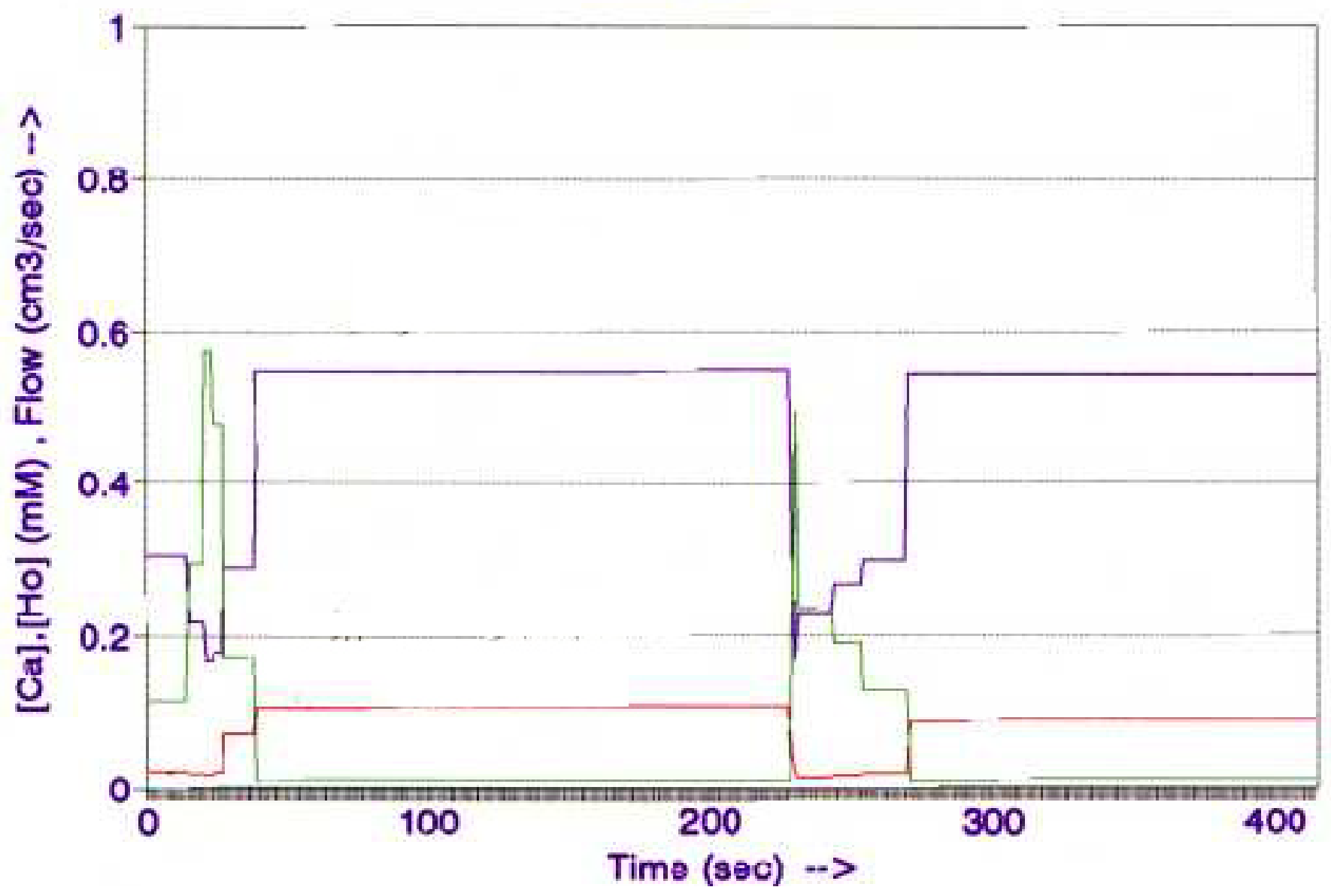

FIGURE 86.-Event 21: variables vs. cumulative event time. (Variables: purple: $\left[\mathrm{Ca}^{2+}\right]_{\mathrm{xs}}$, green: $\phi$; red: $\left[\mathrm{H}^{+}\right]^{\circ}$; material: marble; site: NAPAP-NY.) 


\section{Sequential Data of [Ca],[Ho] and flow}

Event 23

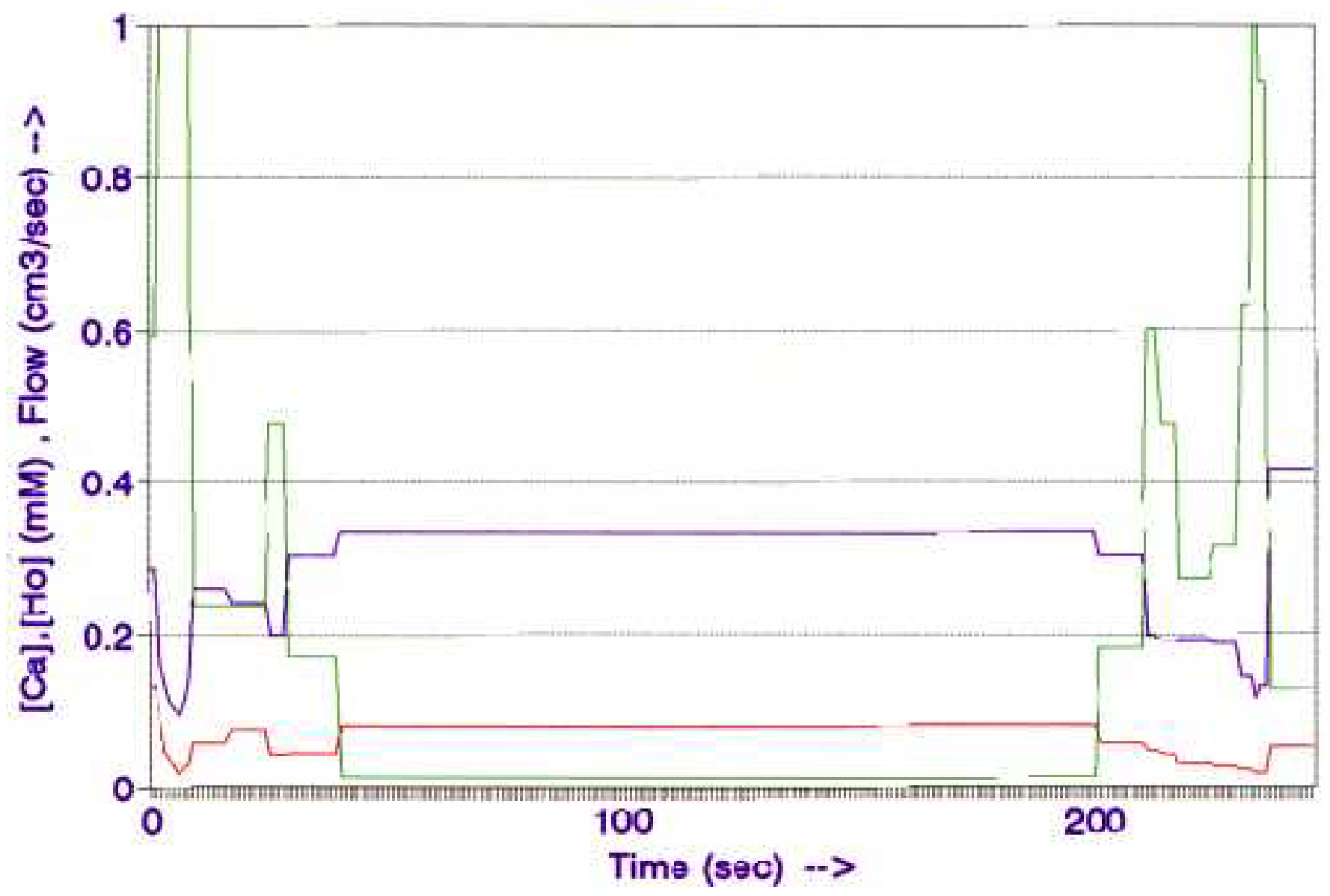

FIGURE 87.-Event 23: variables vs. cumulative event time. (Variables: purple: $\left[\mathrm{Ca}^{2+}\right]_{\mathrm{xs}}$, green: $\phi$; red: $\left[\mathrm{H}^{+}\right]^{\circ}$; material: marble; site: NAPAP-NY.) 


\section{Sequential Data of [Ca],[Ho] and flow Event 25}

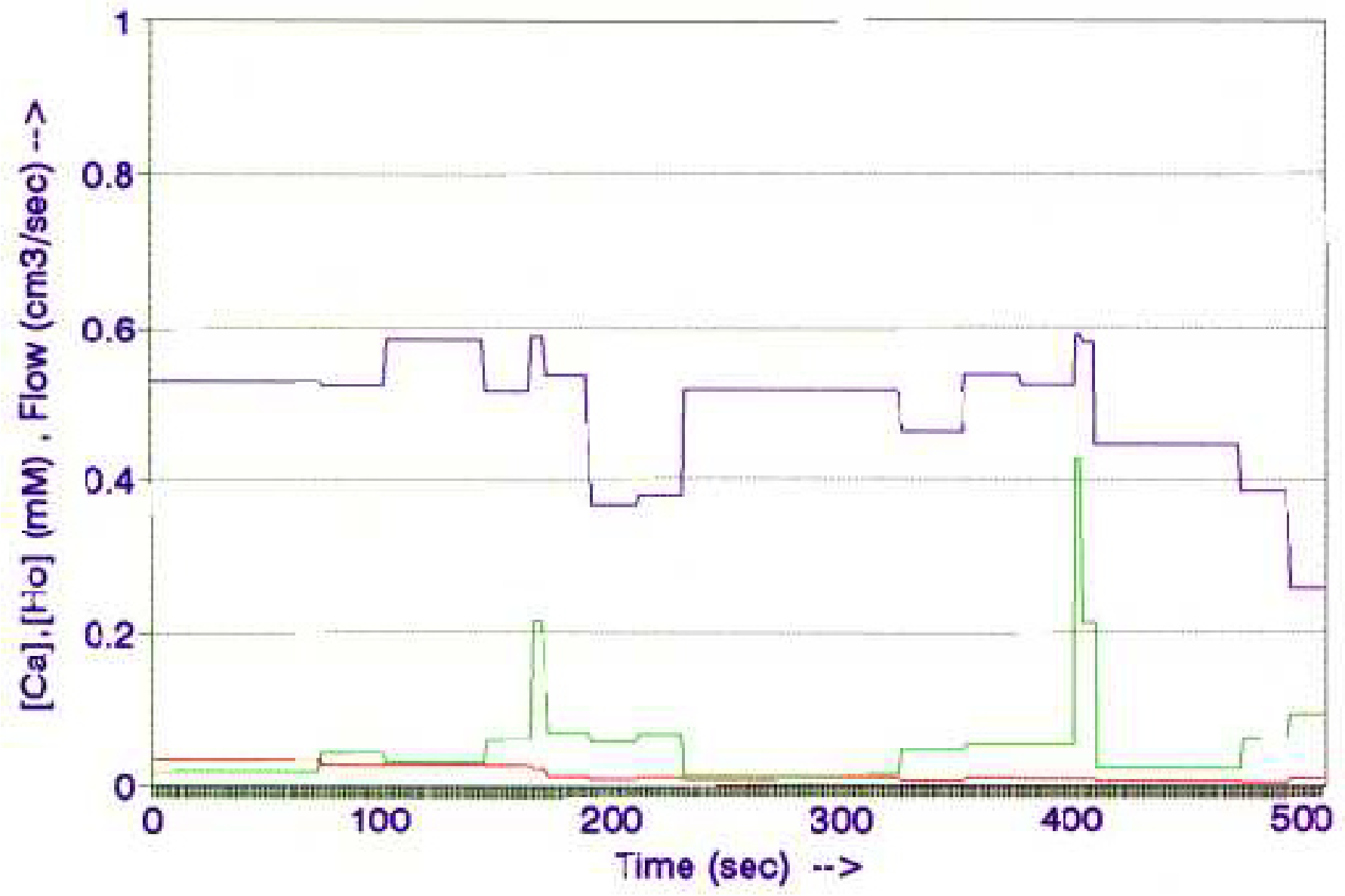

FIGURE 88.-Event 25: variables vs. cumulative event time. (Variables: purple: $\left[\mathrm{Ca}^{2+}\right]_{\mathrm{xs}}$, green: $\phi$; red: $\left[\mathrm{H}^{+}\right]^{\circ}$; material: marble; site: NAPAP-NY.) 


\section{Subevent [Ca] vs Flow \\ Event 14}

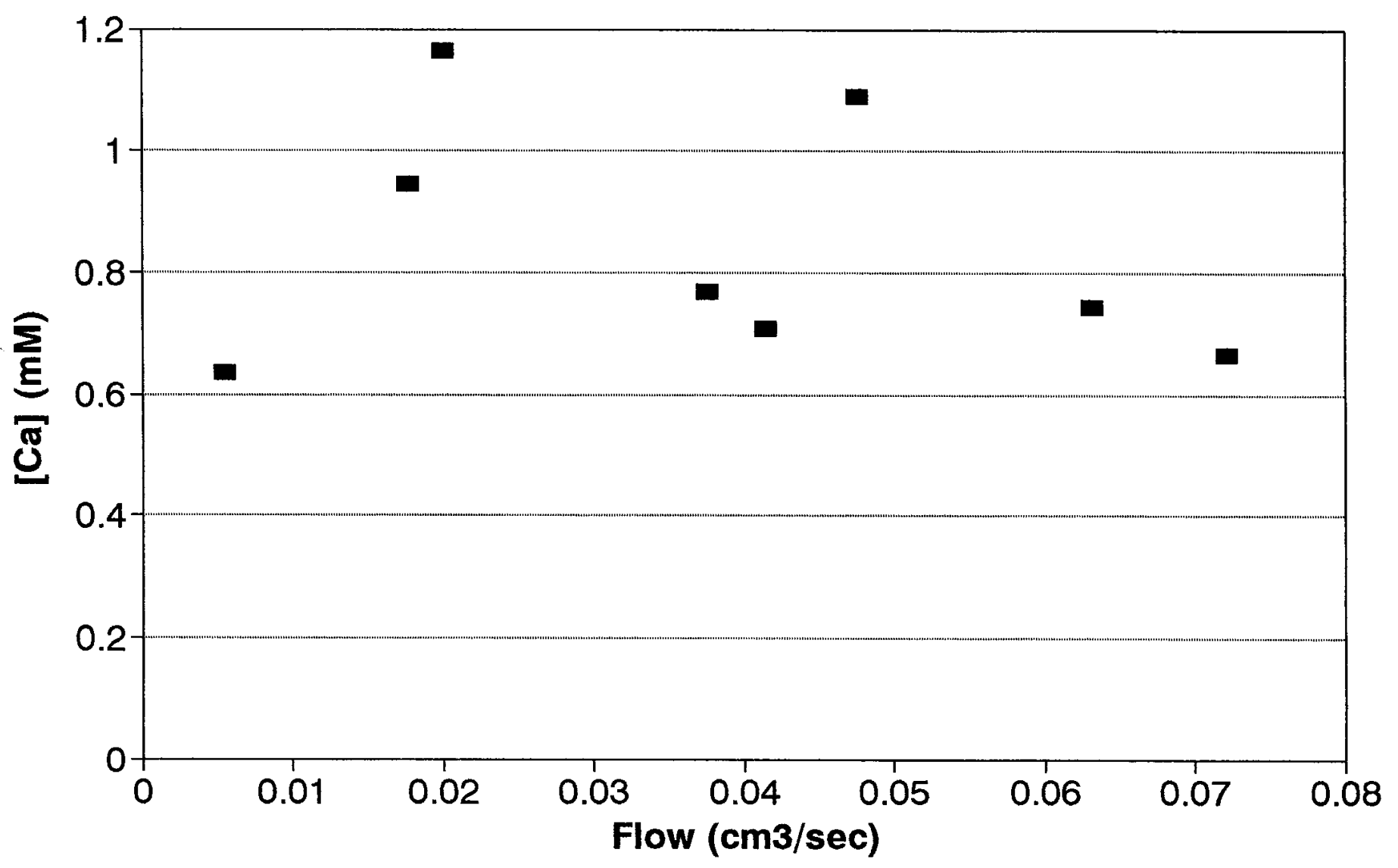

FIGURE 89.-Event 14: $\left[\mathrm{Ca}^{2+}\right]_{\mathrm{Xs}}$ vs. subevent flowrate. (Variables: $\left[\mathrm{Ca}^{2+}\right]_{\mathrm{XS}} ;$ material: marble; site: NAPAP-NY.) 


\section{Subevent [Ca] vs Flow Event 15}

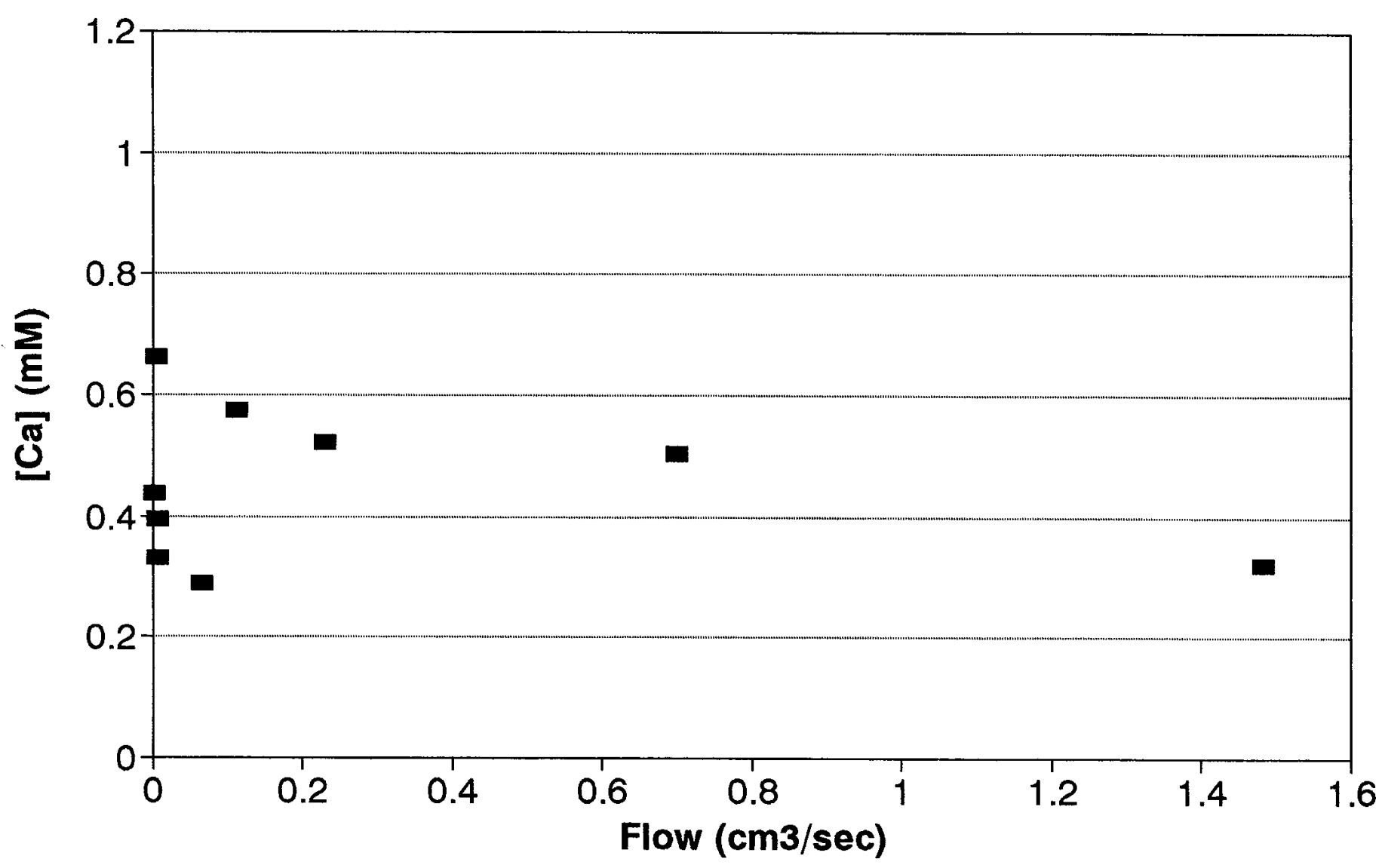

FIGURE 90.-Event 15: $\left[\mathrm{Ca}^{2+}\right]_{\mathrm{xS}}$ vs. subevent flowrate. (Variables: $\left[\mathrm{Ca}^{2+}\right]_{\mathrm{xs}}$; material: marble; site: NAPAP-NY.) 


\section{Subevent [Ca] vs Flow \\ Event 16}

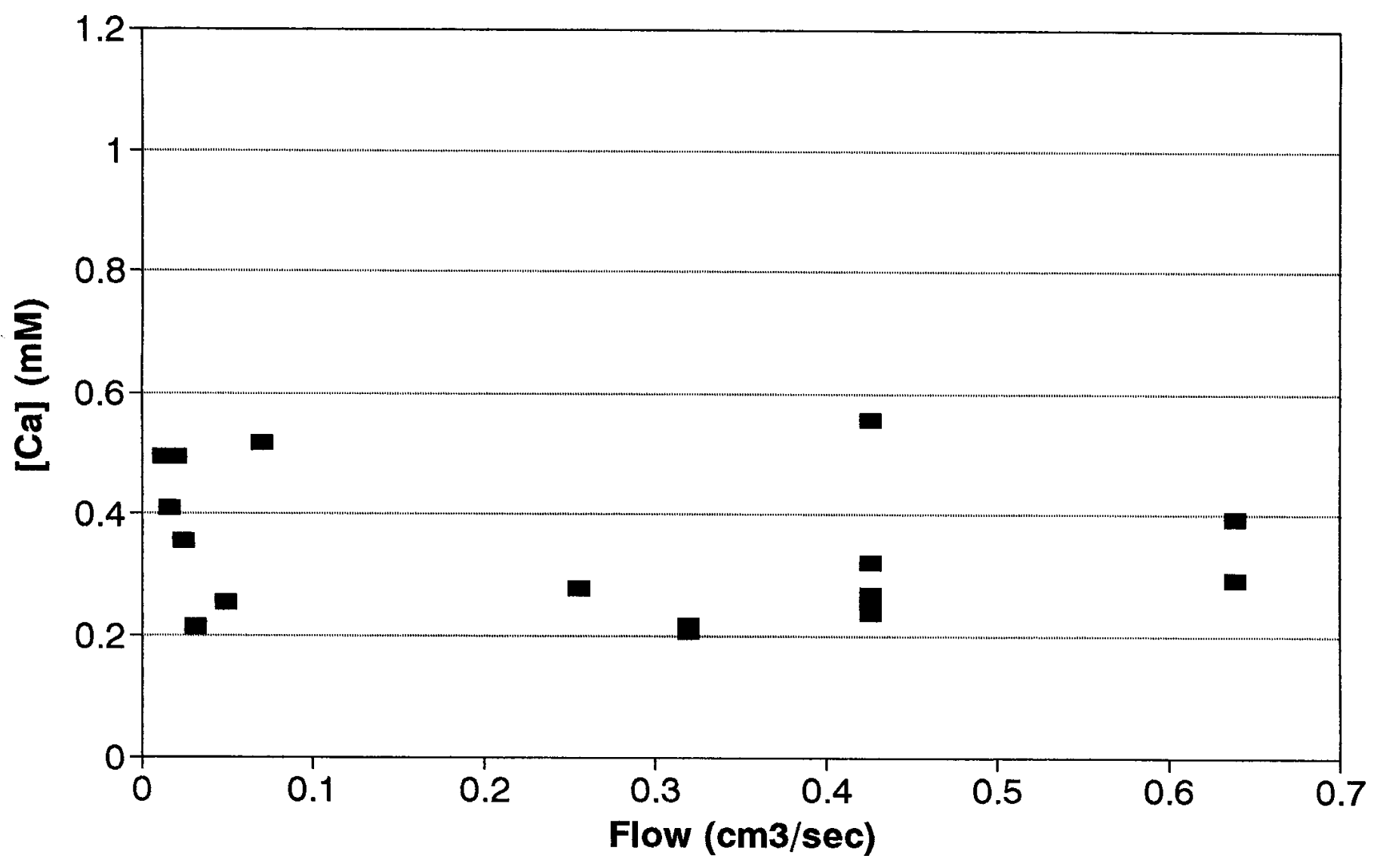

FIGURE 91.-Event 16: $\left[\mathrm{Ca}^{2+}\right]_{\mathrm{xs}}$ vs. subevent flowrate. (Variables: $\left[\mathrm{Ca}^{2+}\right]_{\mathrm{xs}}$; material: marble; site: NAPAP-NY.) 


\section{Subevent [Ca] vs Flow Event 17}

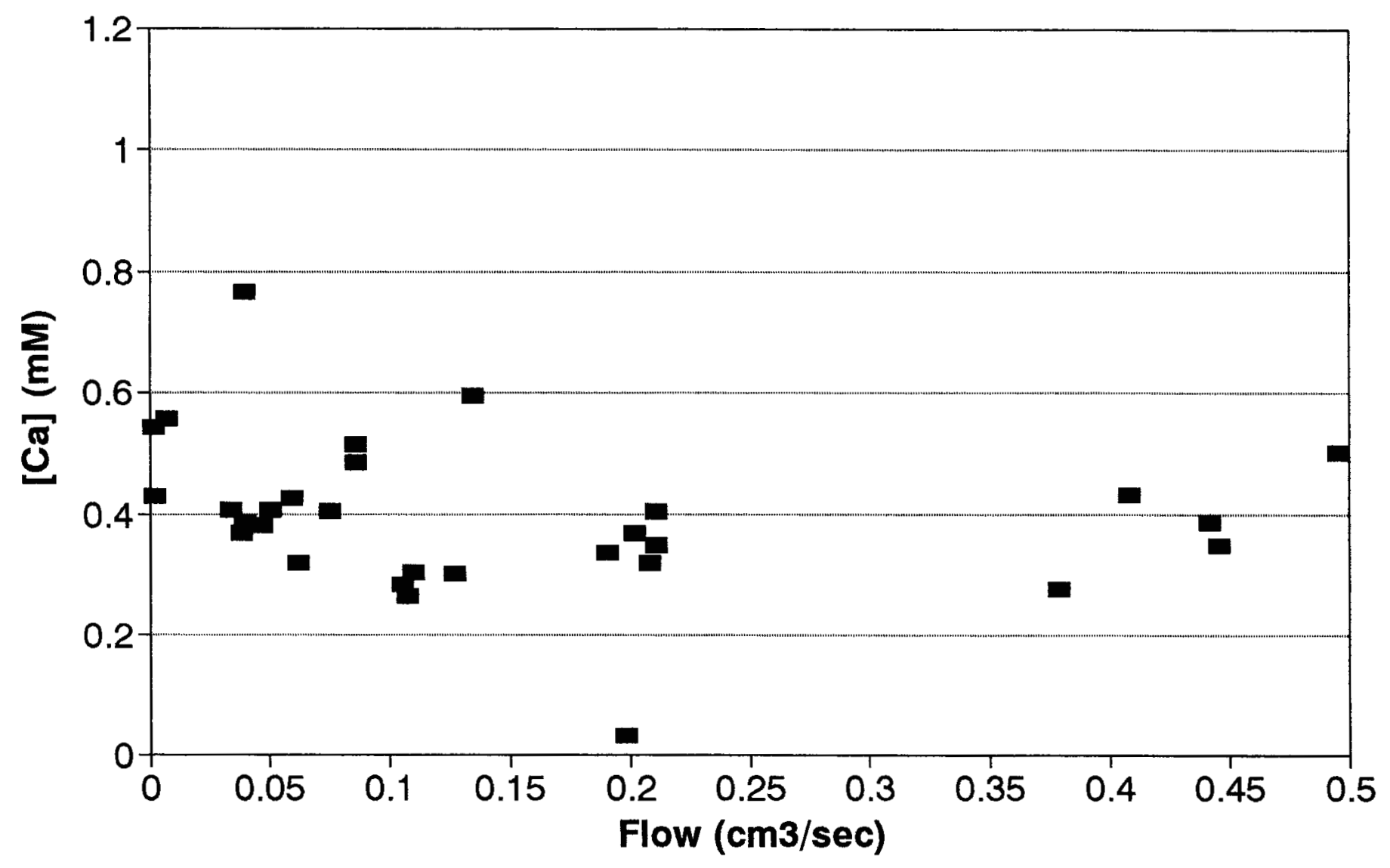

FIGURE 92.-Event 17: $\left[\mathrm{Ca}^{2+}\right]_{\mathrm{XS}}$ vs. subevent flowrate. (Variables: $\left[\mathrm{Ca}^{2+}\right]_{\mathrm{Xs}}$; material: marble; site: NAPAP-NY.) 


\section{Subevent [Ca] vs Flow}

Event 21

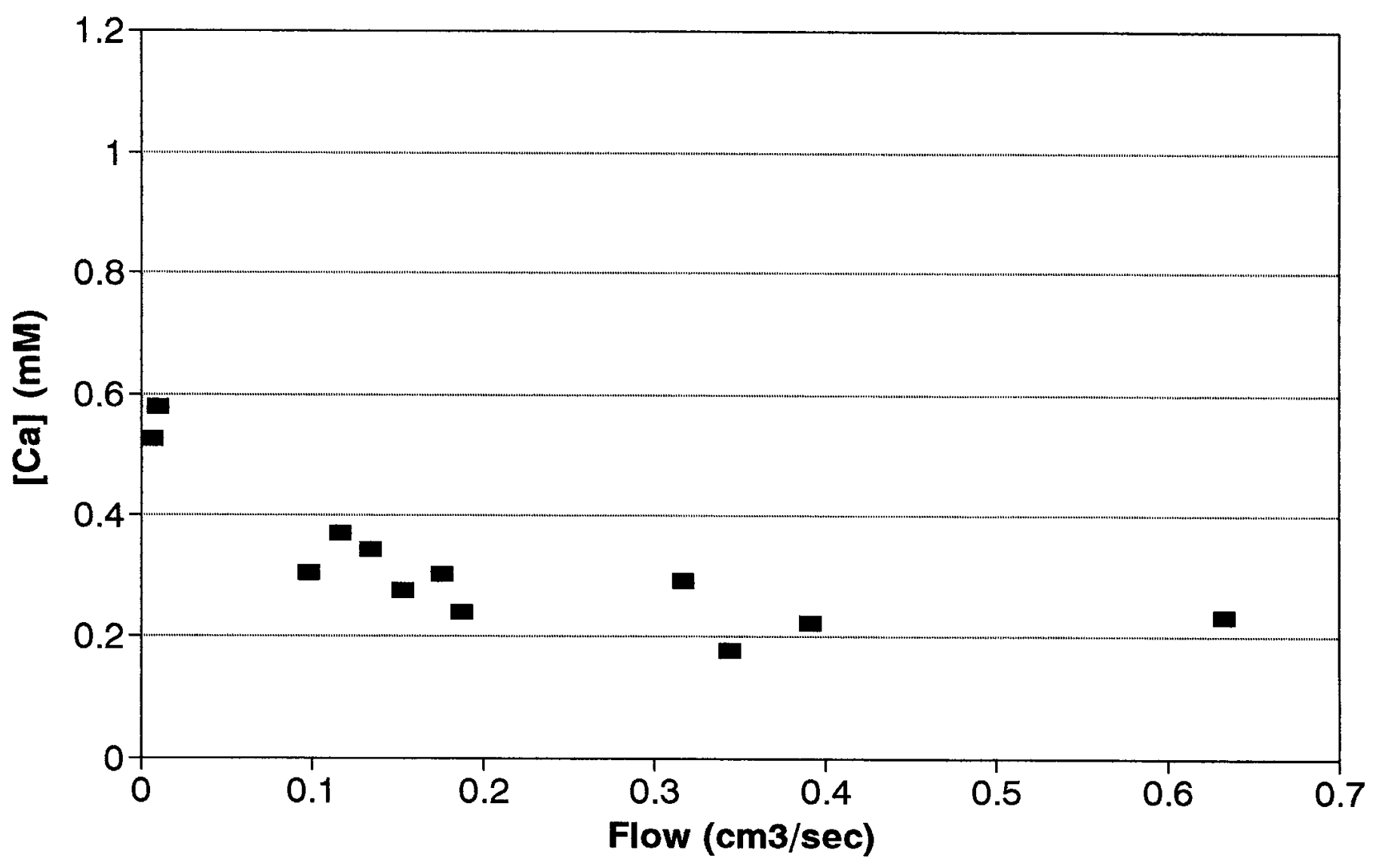

FIGURE 93.-Event 21: $\left[\mathrm{Ca}^{2+}\right]_{\mathrm{Xs}}$ vs. subevent flowrate. (Variables: $\left[\mathrm{Ca}^{2+}\right]_{\mathrm{Xs}}$; material: marble; site: NAPAP-NY.) 


\section{Subevent [Ca] vs Flow \\ Event 23}

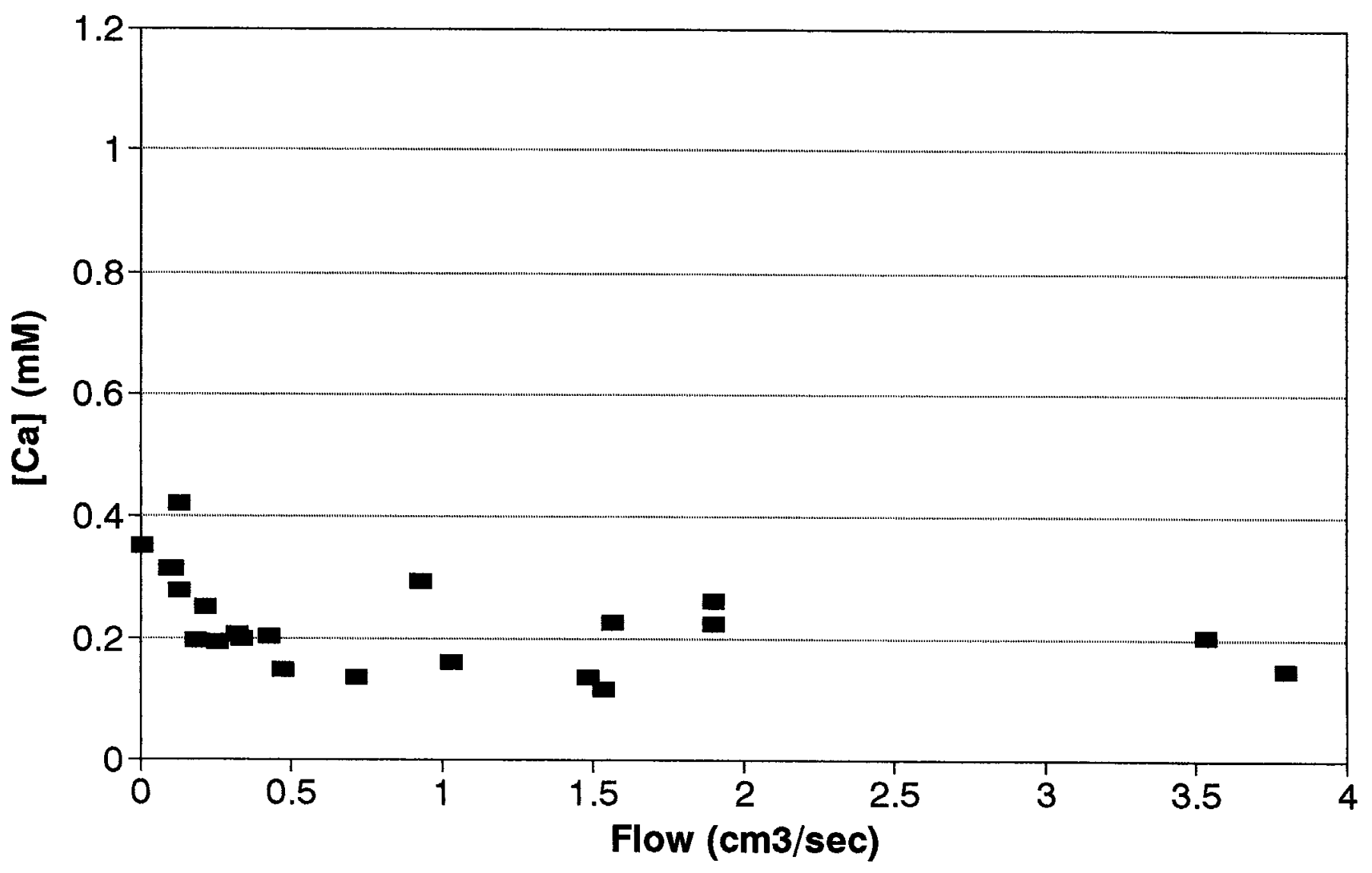

FIGURE 94.-Event 23: $\left[\mathrm{Ca}^{2+}\right]_{\mathrm{XS}}$ vs. subevent flowrate. (Variables: $\left[\mathrm{Ca}^{2+}\right]_{\mathrm{Xs}}$; material: marble; site: NAPAP-NY.) 


\section{Subevent [Ca] vs Flow}

Event 25

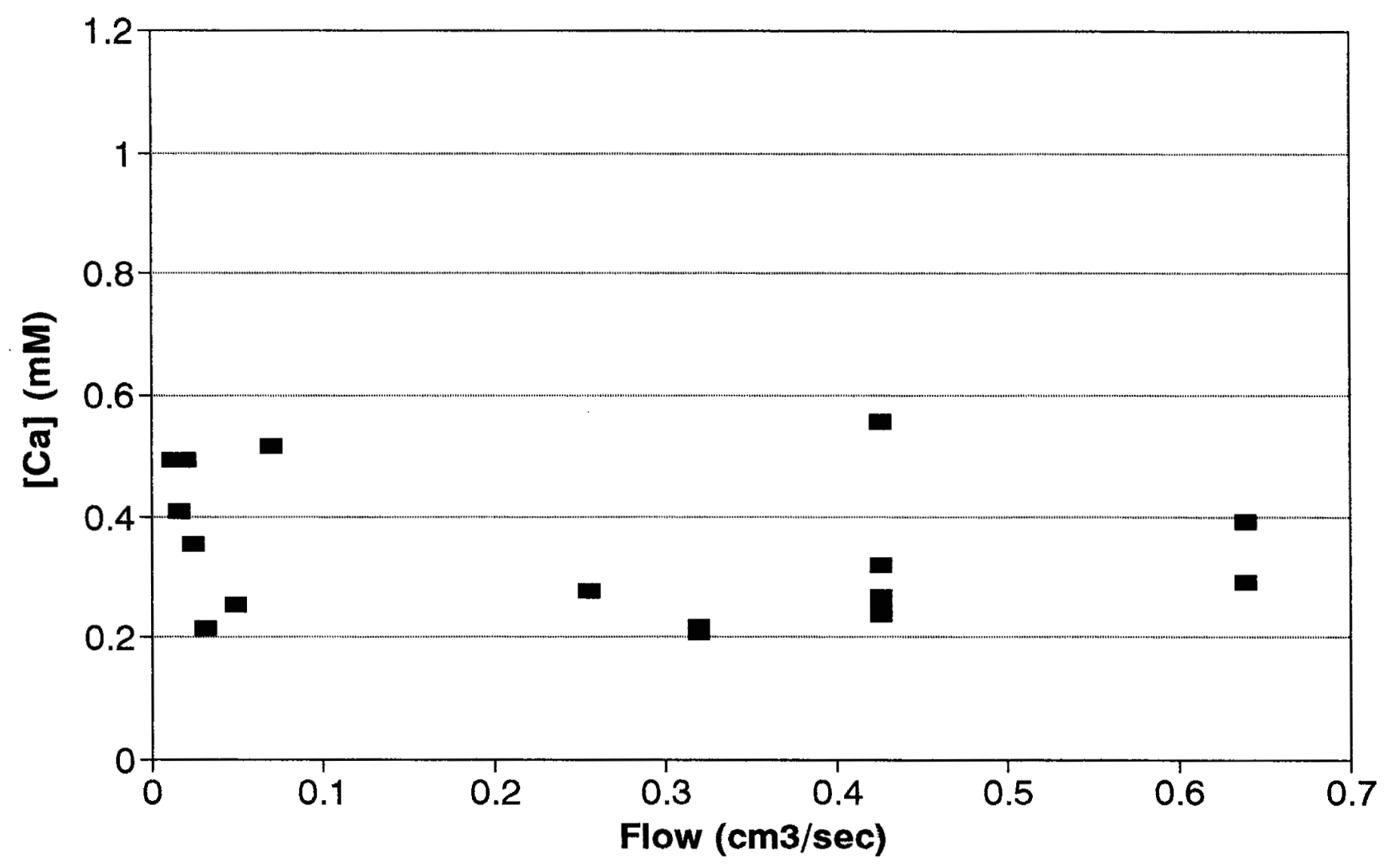

FIGURE 95.-Event 25: $\left[\mathrm{Ca}^{2+}\right]_{\mathrm{XS}}$ vs. subevent flowrate. (Variables: $\left[\mathrm{Ca}^{2+}\right]_{\mathrm{Xs}}$; material: marble; site: NAPAP-NY.) 


\section{Field [Ca] vs [Ho] \\ Event 14}

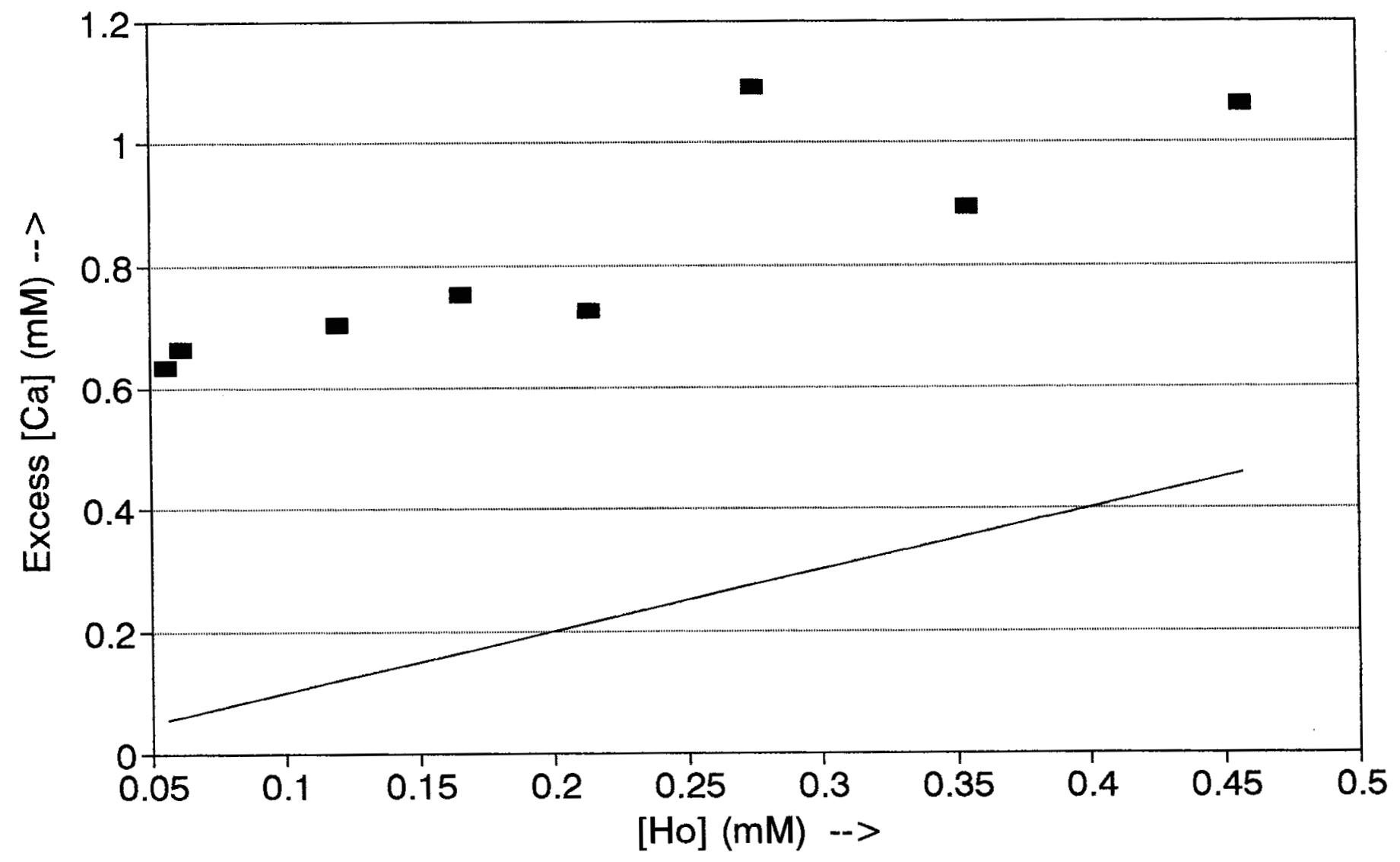

FIGURE 96.-Event 14: $\left[\mathrm{Ca}^{2+}\right]_{\mathrm{xs}}$ vs. subevent $\left[\mathrm{H}^{+}\right]^{\circ}$. (Variables: $\left[\mathrm{Ca}^{2+}\right]_{\mathrm{xs}}$; material: marble; site: NAPAP-NY.) 
Field [Ca] vs [Ho]

Event 15

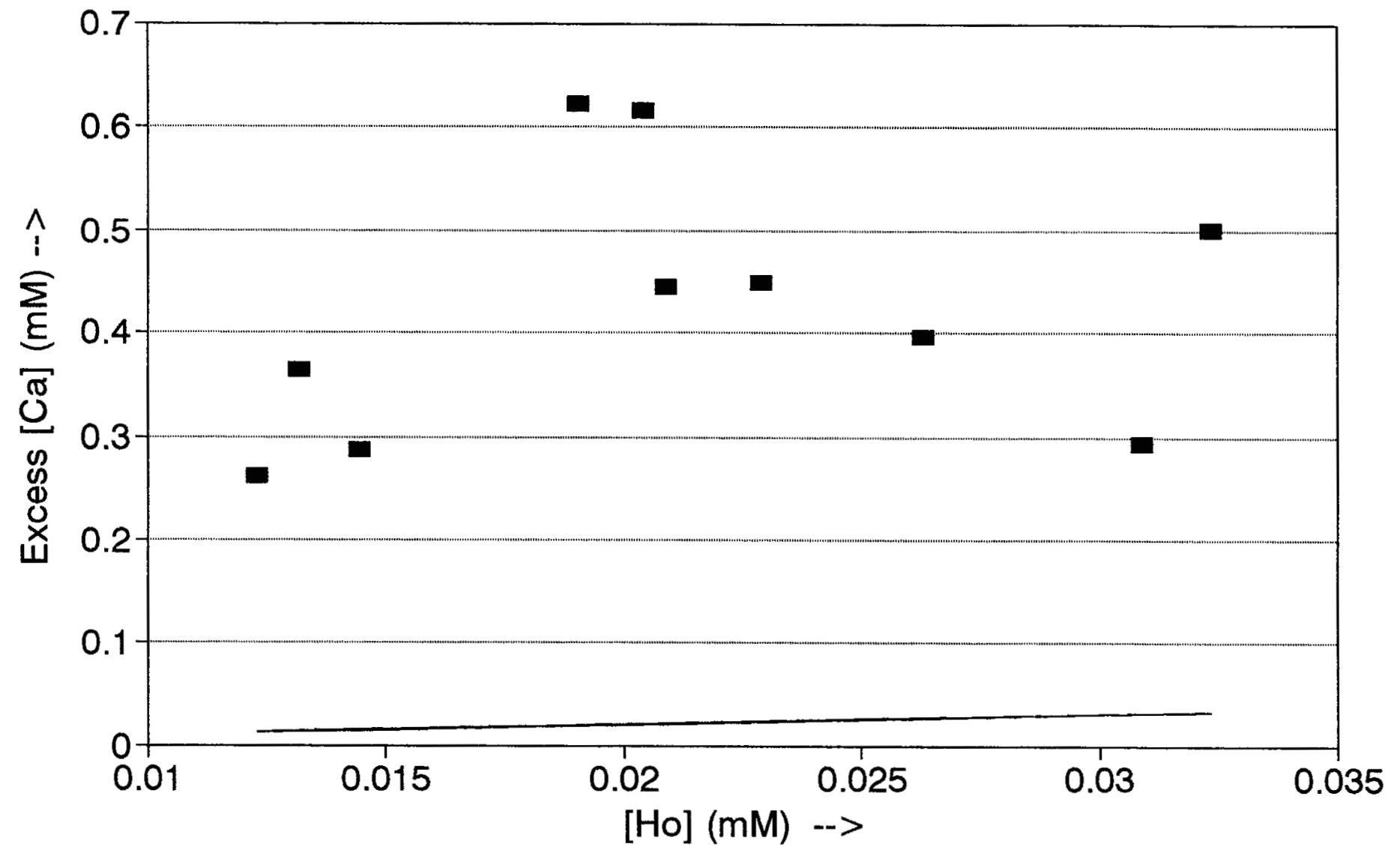

FIGURE 97.-Event 15: $\left[\mathrm{Ca}^{2+}\right]_{\mathrm{Xs}}$ vs. subevent $\left[\mathrm{H}^{+}\right]^{\circ}$. (Variables: $\left[\mathrm{Ca}^{2+}\right]_{\mathrm{Xs}}$; material: marble; site: NAPAP-NY.) 


\section{Field $[\mathrm{Ca}]$ vs $[\mathrm{Ho}]$}

Event 16

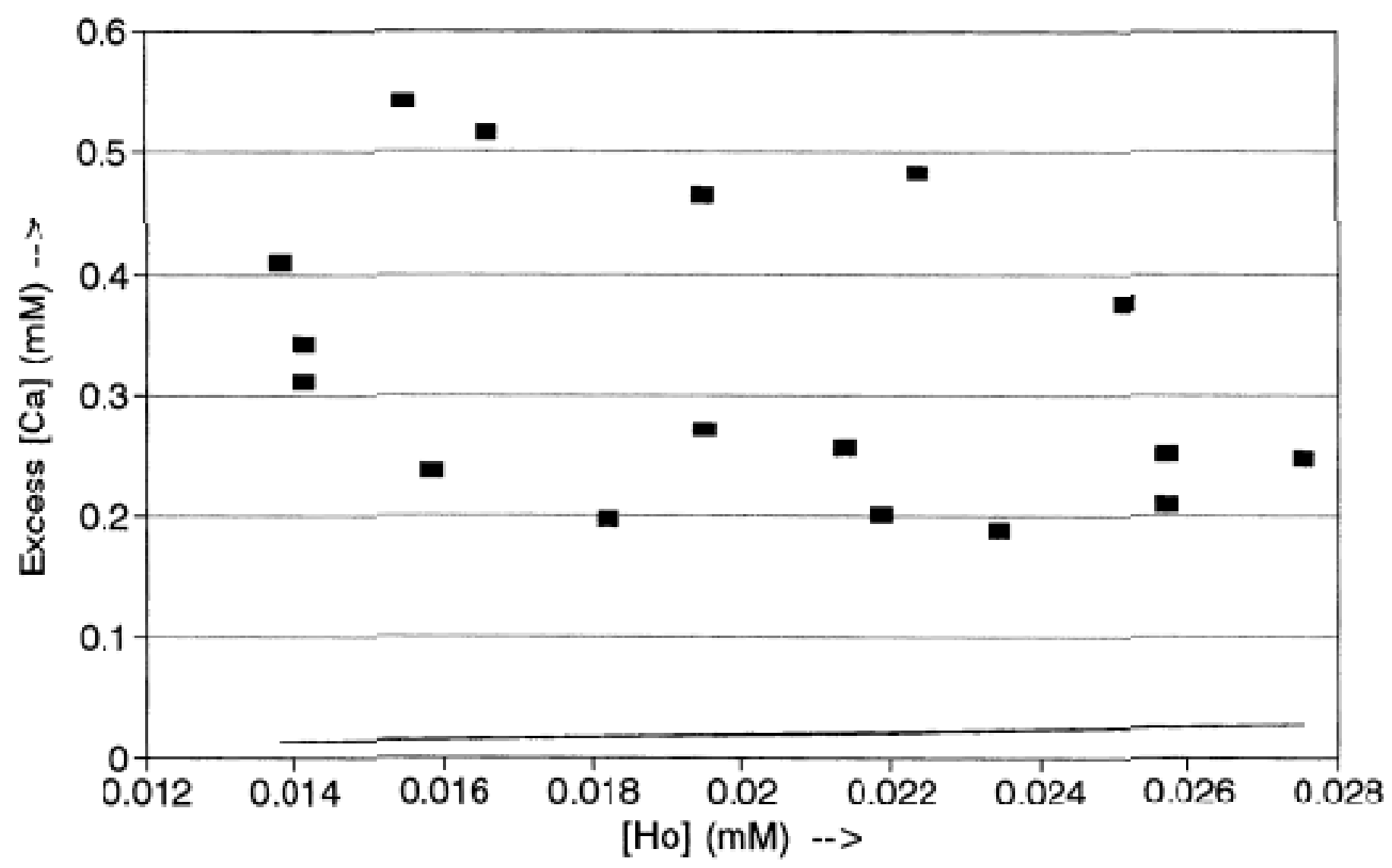

FIGURE 98.-Event 16: $\left[\mathrm{Ca}^{2+}\right]_{\mathrm{Xs}}$ vs. subevent $\left[\mathrm{H}^{+}\right]^{\circ}$. (Variables: $\left[\mathrm{Ca}^{2+}\right]_{\mathrm{Xs}}$; material: marble; site: NAPAP-NY.) 


\section{Field [Ca] vs [Ho]}

Event?

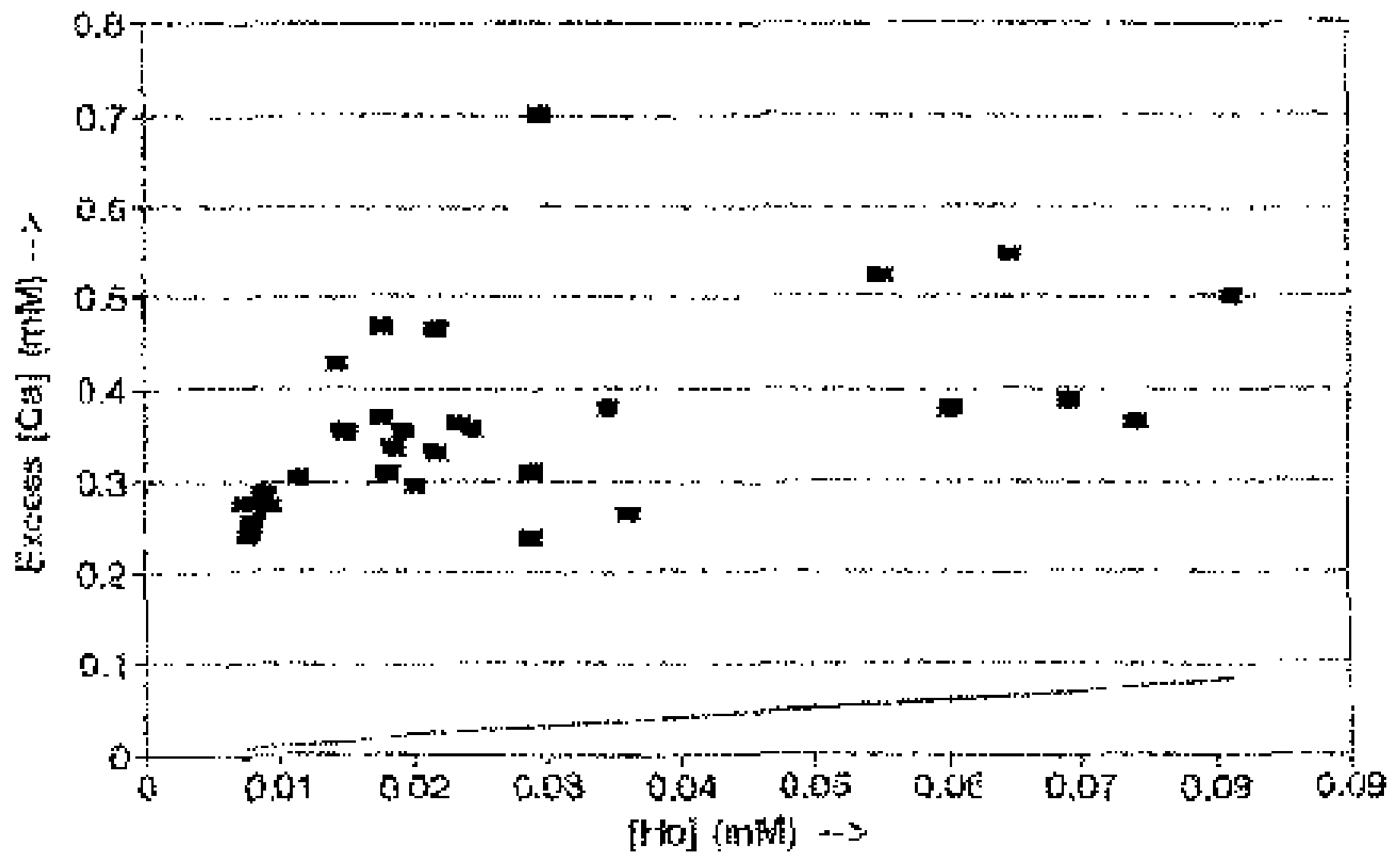

FIGURE 99.-Event 17: $\left[\mathrm{Ca}^{2+}\right]_{\mathrm{xs}}$ vs. subevent $\left[\mathrm{H}^{+}\right]^{\circ}$. (Variables: $\left[\mathrm{Ca}^{2+}\right]_{\mathrm{Xs}}$; material: marble; site: NAPAP-NY.) 


\section{Field [Ca] vs [Ho] \\ Event 21}

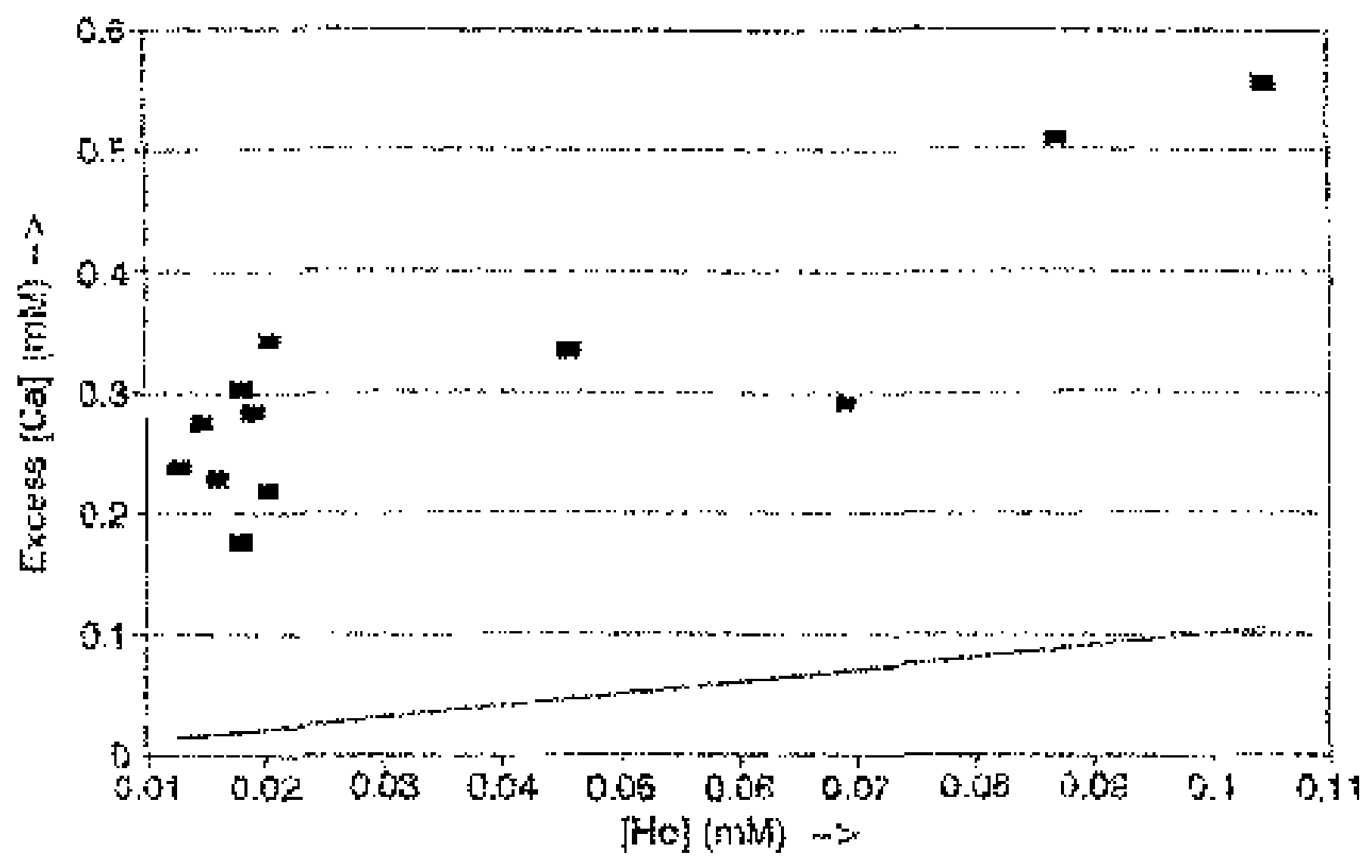

FIGURE 100.-Event 21: $\left[\mathrm{Ca}^{2+}\right]_{\mathrm{xS}}$ vs. subevent $\left[\mathrm{H}^{+}\right]^{\circ}$. (Variables: $\left[\mathrm{Ca}^{2+}\right]_{\mathrm{XS}}$; material: marble; site: NAPAP-NY.) 


\section{Field [Ca] vs $[\mathrm{Ho}]$}

Event 23

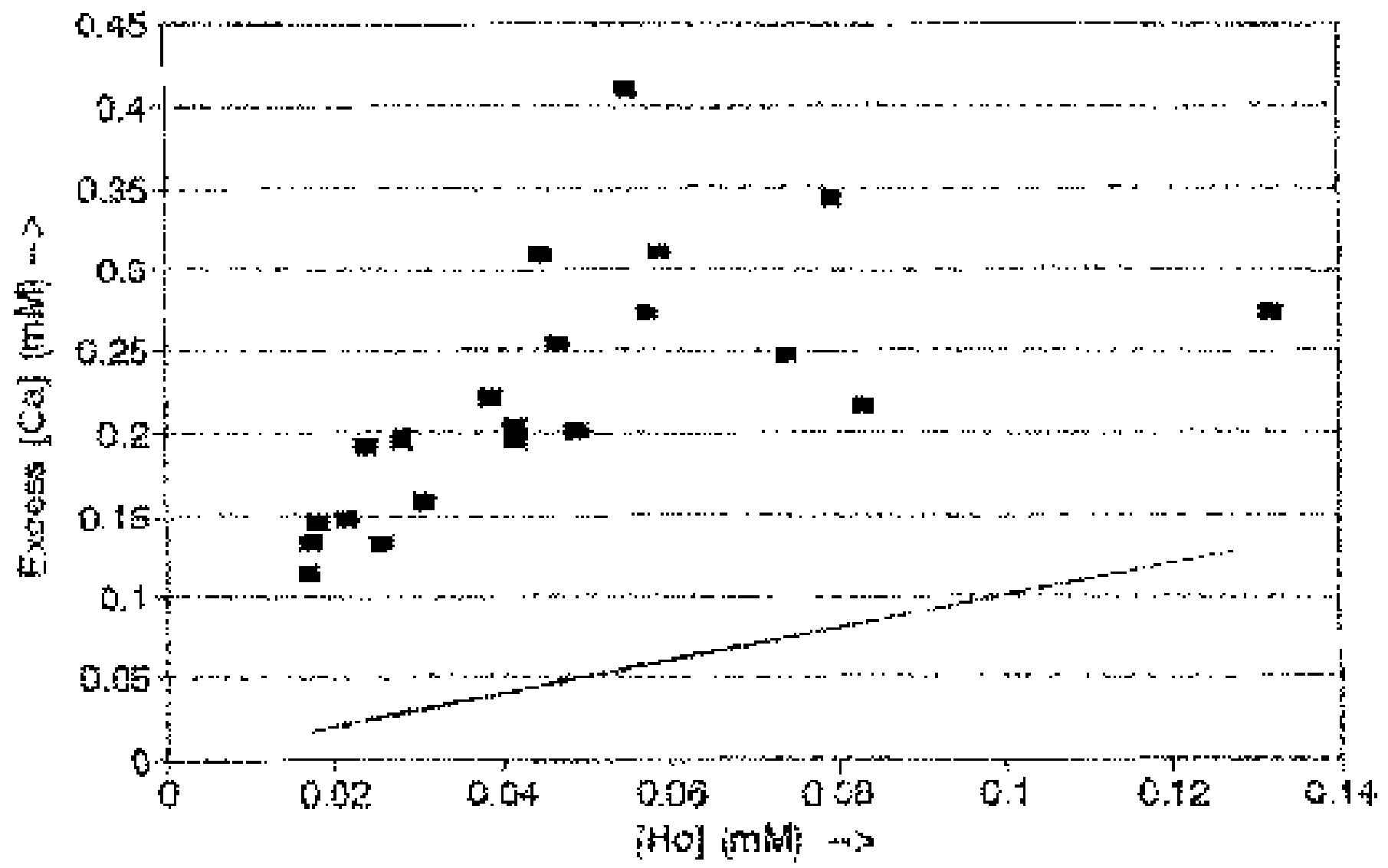

FIGURE 101.-Event 23: $\left[\mathrm{Ca}^{2+}\right]_{\mathrm{XS}}$ vs. subevent $\left[\mathrm{H}^{+}\right]^{\circ}$. (Variables: $\left[\mathrm{Ca}^{2+}\right]_{\mathrm{Xs}}$; material: marble; site: NAPAP-NY.) 


\section{Field [Ca] vs [Ho]}

Evert 25

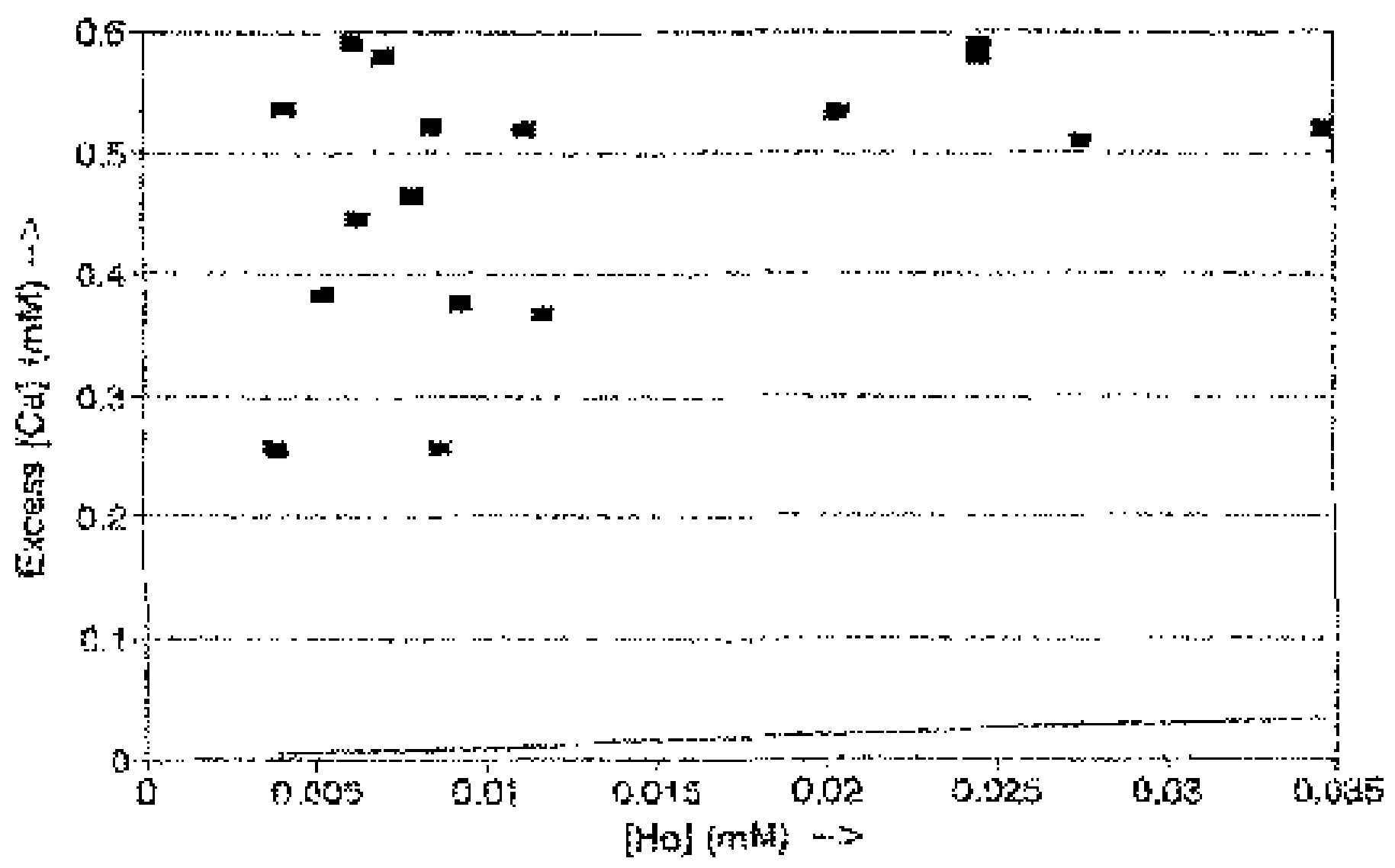

FIGURE 102.-Event $25:\left[\mathrm{Ca}^{2+}\right]_{\mathrm{XS}}$ vs. subevent $\left[\mathrm{H}^{+}\right]^{\circ}$. (Variables: $\left[\mathrm{Ca}^{2+}\right]_{\mathrm{XS}}$; material: marble; site: NAPAP-NY.) 


\section{Runoff xs[Ca] - Gettysburg Data}

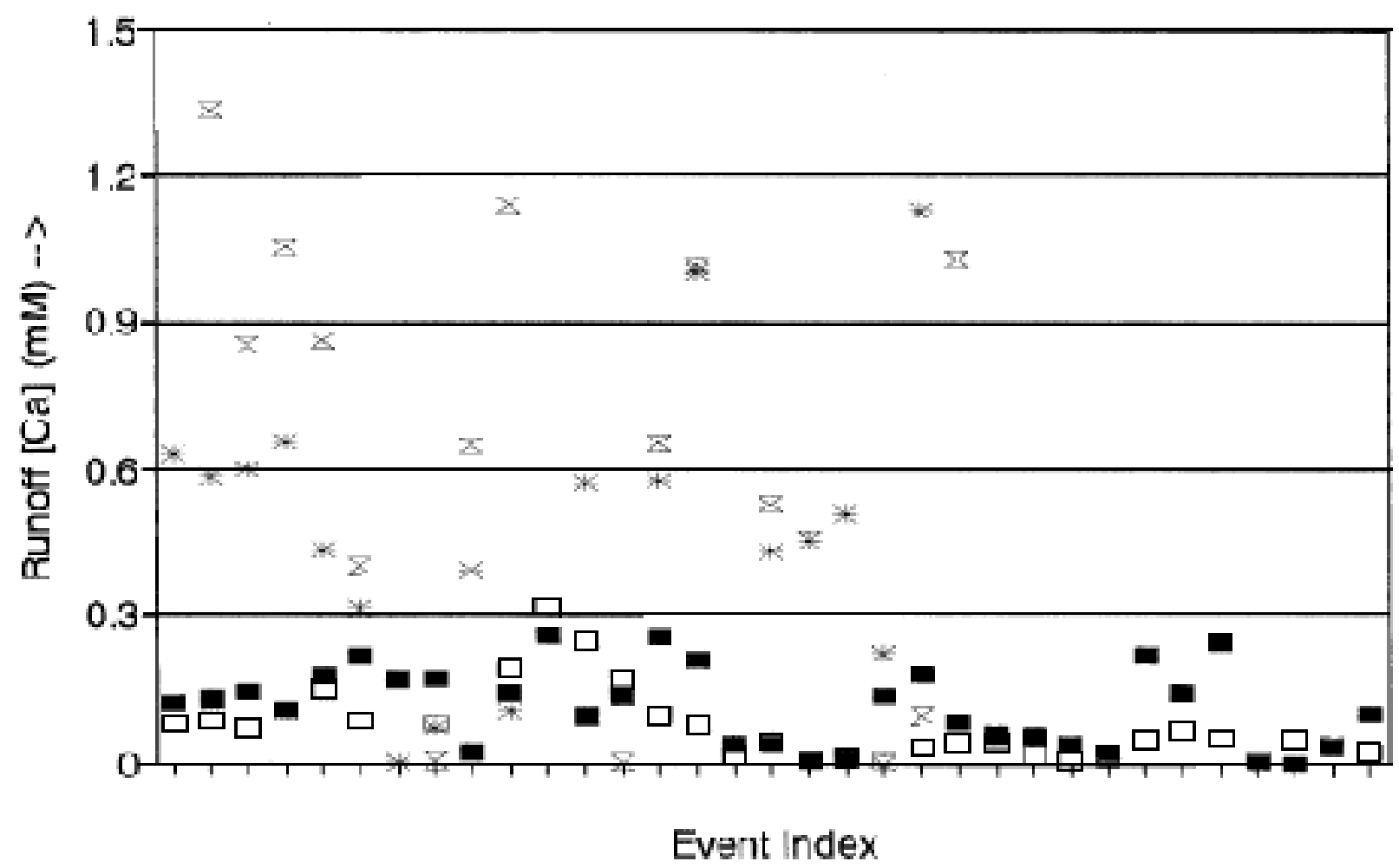

FIGURE 103.-Gettysburg in situ runoff solution chemistry. (Variables: $\left[\mathrm{Ca}^{2+}\right]_{\mathrm{xS}}$ vs. event index for statues and obelisks; material: limestone and marble.) 


\section{[Ca] vs [Ho] \\ Gettysburg Data : Statues}

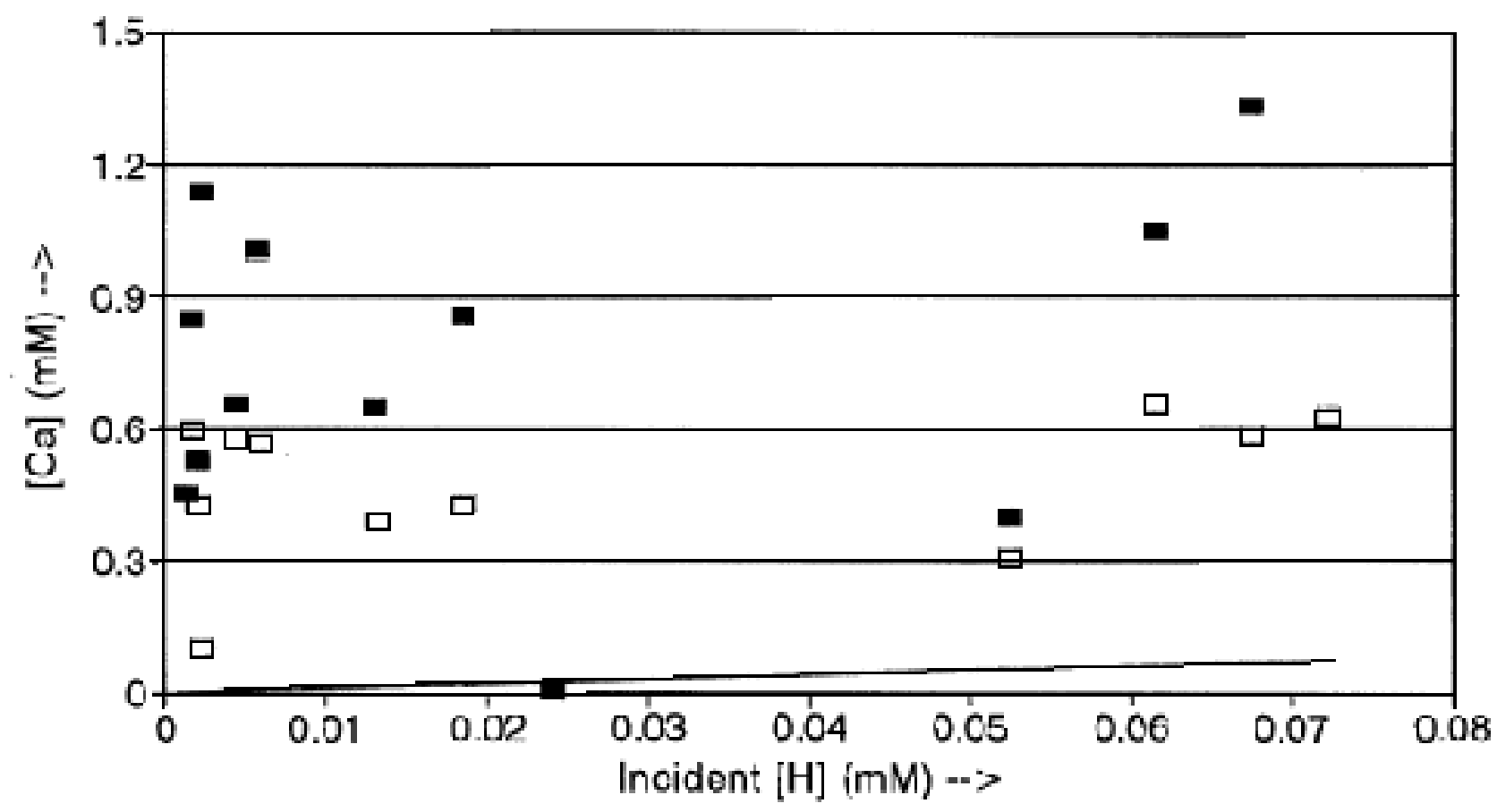

- WAR $\square$ HISTORY

FIGURE 104.-Gettysburg in situ runoff solution chemistry. (Variables: $\left[\mathrm{Ca}^{2+}\right]_{\mathrm{XS}}$ vs. $\left[\mathrm{H}^{+}\right]^{\circ}$ for statues; material: marble.) 


\section{[Ca] vs $[\mathrm{Ho}]$ \\ Gettysburg Data : Obelisks}

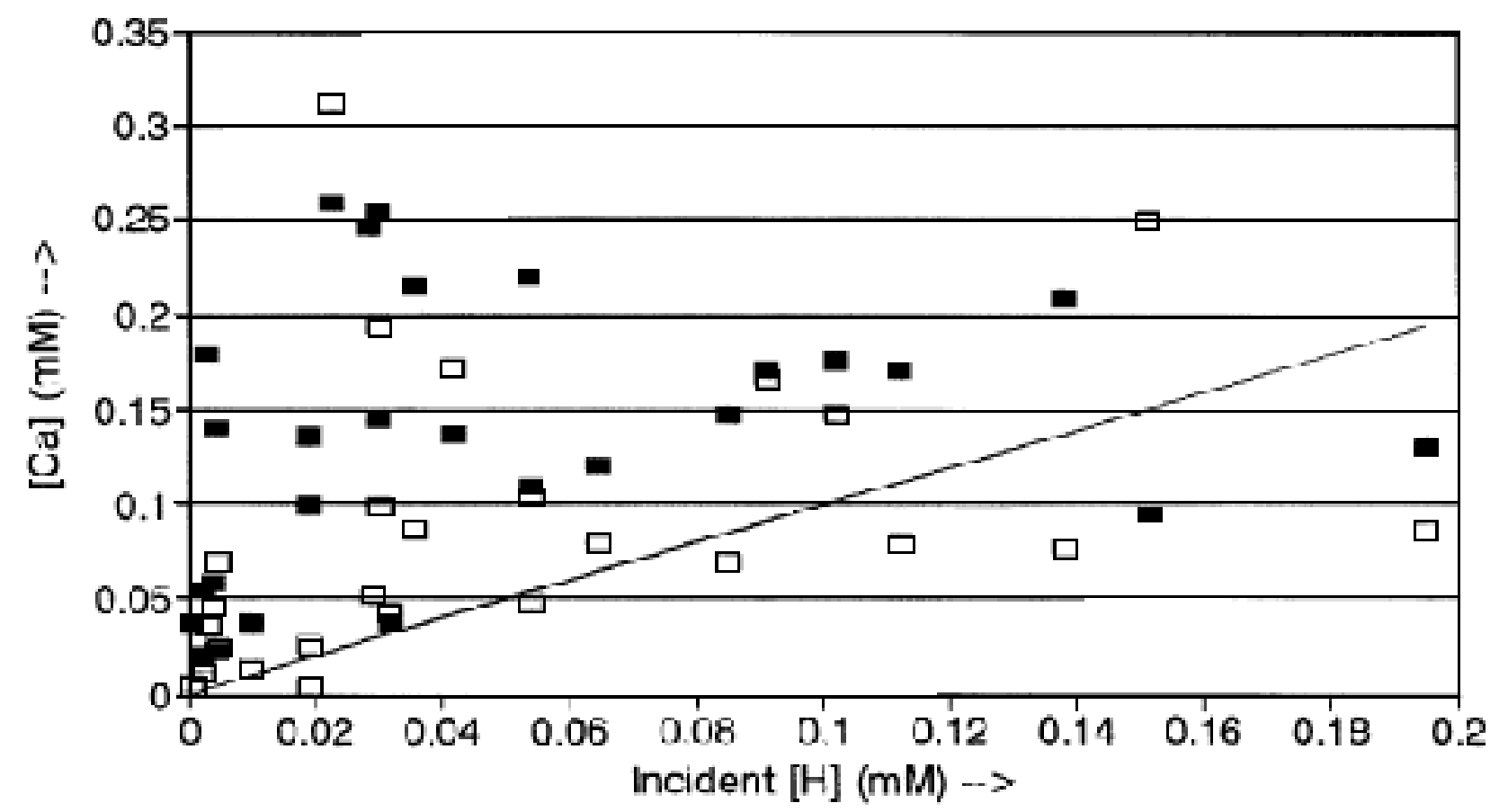

- 68PV $\square$ ZOOK

FIGURE 105.-Gettysburg in situ runoff solution chemistry. (Variables: $\left[\mathrm{Ca}^{2+}\right]_{\mathrm{xs}}$ vs. $\left[\mathrm{H}^{+}\right]^{\circ}$ index for obelisks; material: limestone and marble.) 


\section{Ca Mass Loss vs PSU Time Gettysburg Data : Statues}

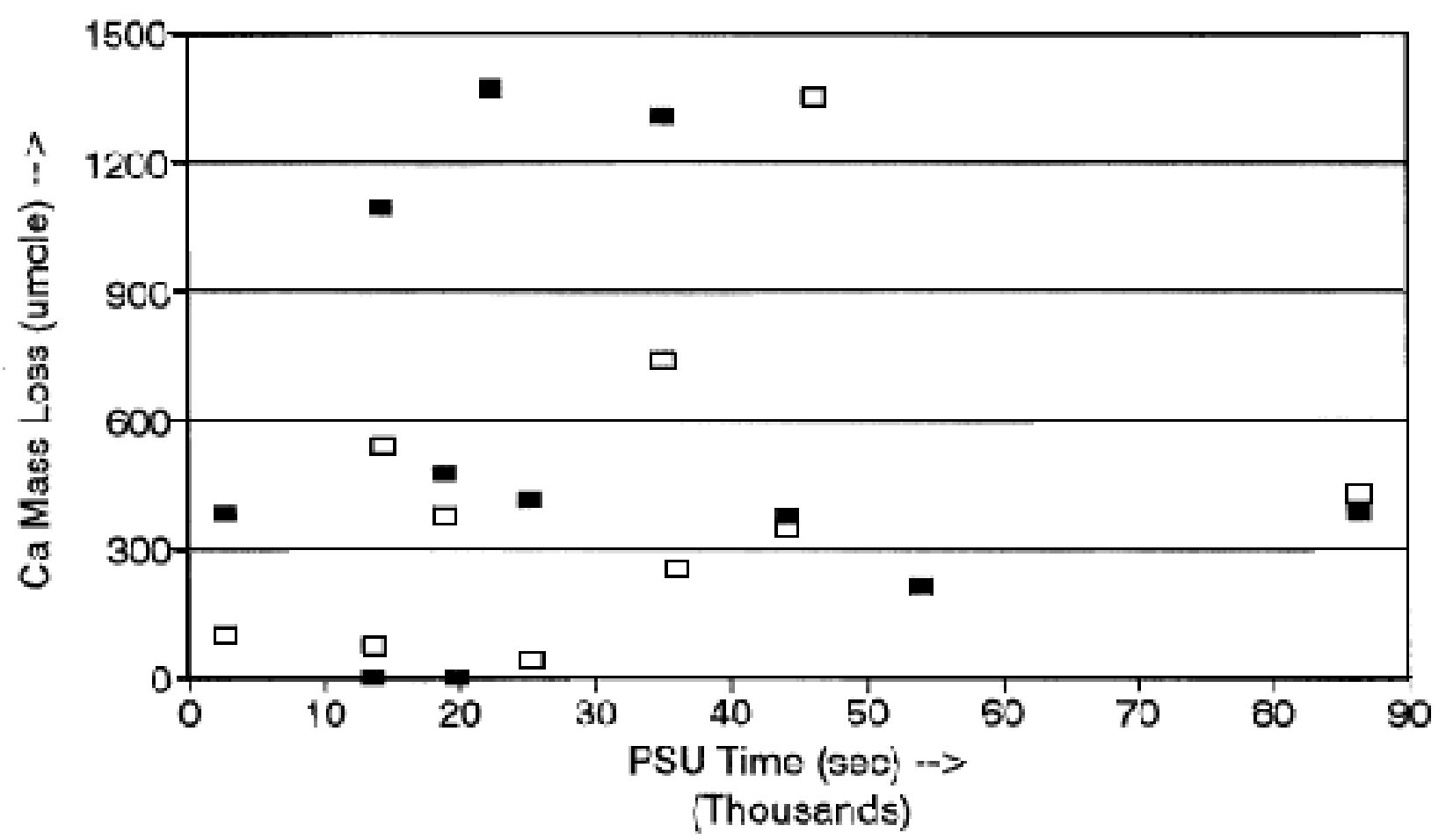

- WAR $\square$ HISTORY

FIGURE 106.-Gettysburg in situ runoff solution chemistry. (Variables: $\left[\mathrm{Ca}^{2+}\right]$ mass loss vs. event time for statues; material: marble.) 


\section{Ca Mass Loss vs PSU Time Gettysburg Data : Obelisks}

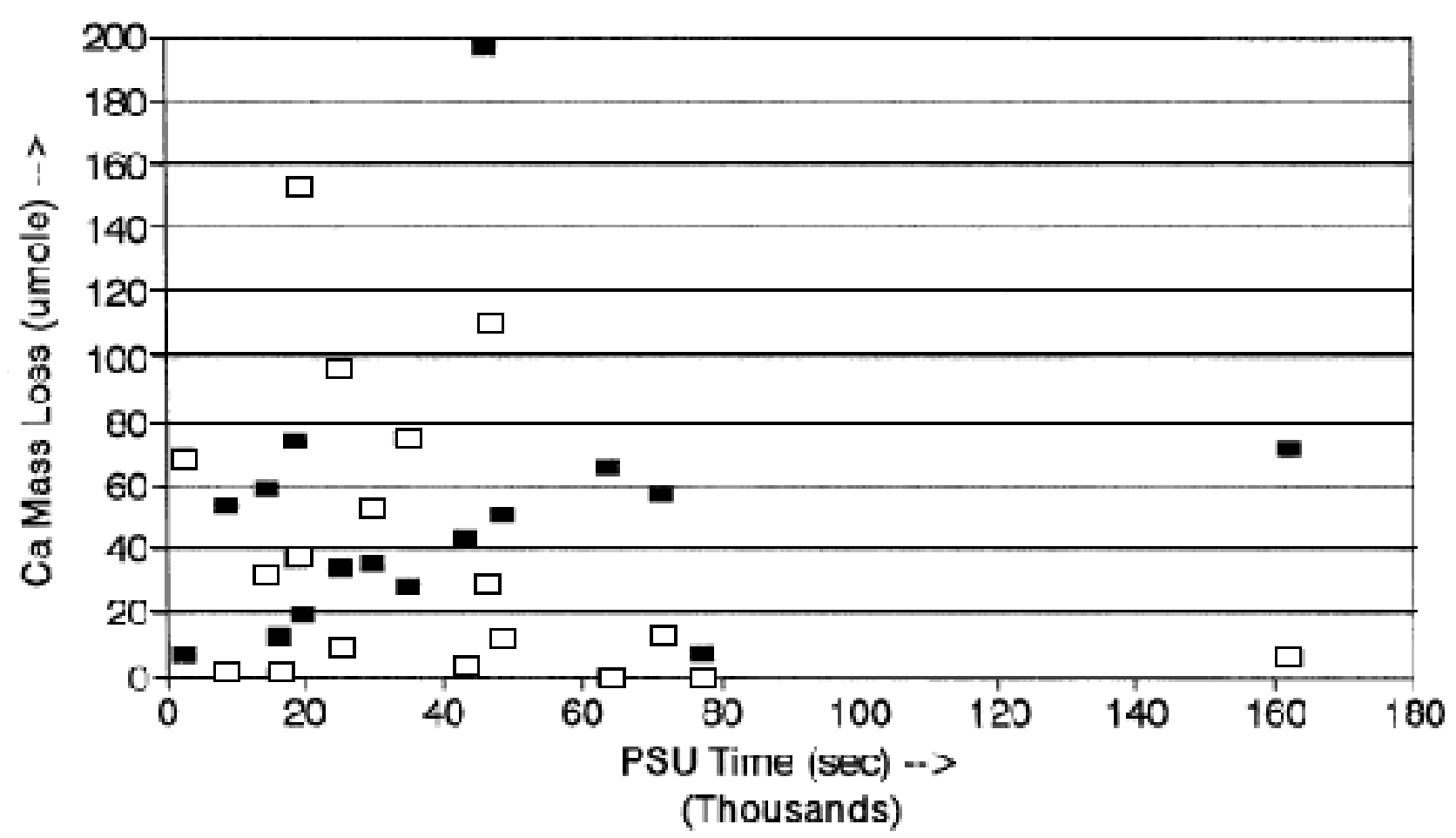

\section{- $68 \mathrm{PV} \square \mathrm{ZOOK}$}

FIGURE 107.-Gettysburg in situ runoff solution chemistry. (Variables: $\left[\mathrm{Ca}^{2+}\right]$ mass loss vs. event time for obelisks; material: limestone and marble.) 


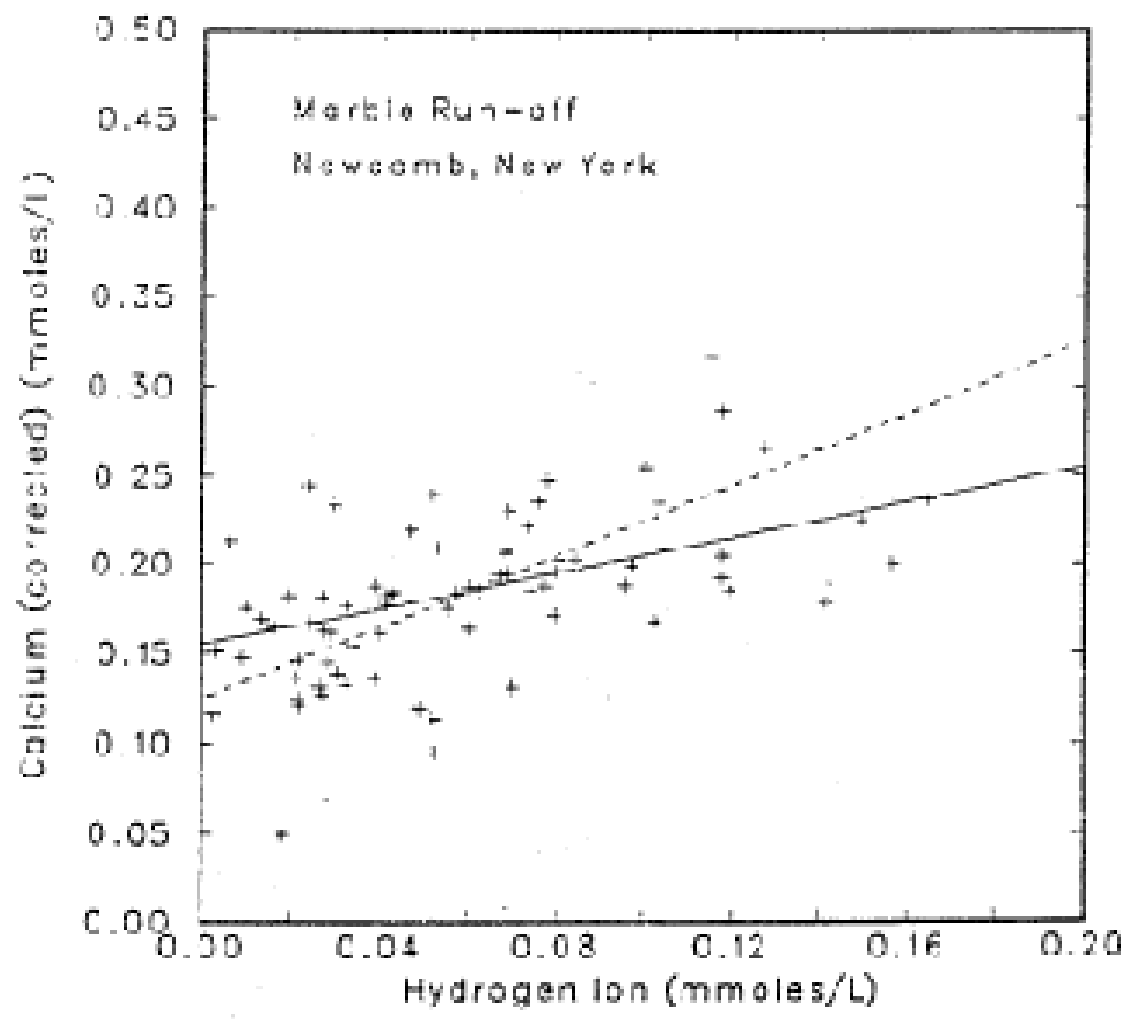

Scatter piot of "excess" calcium (blank corrected) concentration in marble rua-cfj from the Newcomb. NY exposure site against hydrogen ion concentration in the incident rain as measured by the run-off biank. The calcium concentrations have been corrected for dry depasition effects and temperature. The ines represent reaction of the stone with hydrogen ion to produce bicarbonate (maximum slope) and carbon dioxide (open system) (iower slopel.

FIGURE 108.-Baedecker laboratory simulation: spray applied to full surface of slab. (Variables: $\left[\mathrm{Ca}^{2+}\right]_{\mathrm{xs}}$ vs. $\left[\mathrm{H}^{+}\right]^{\circ}$; material: limestone and marble.) (Reproduced from Baedecker, 1990, p. 19-112, figure 19-50.) 


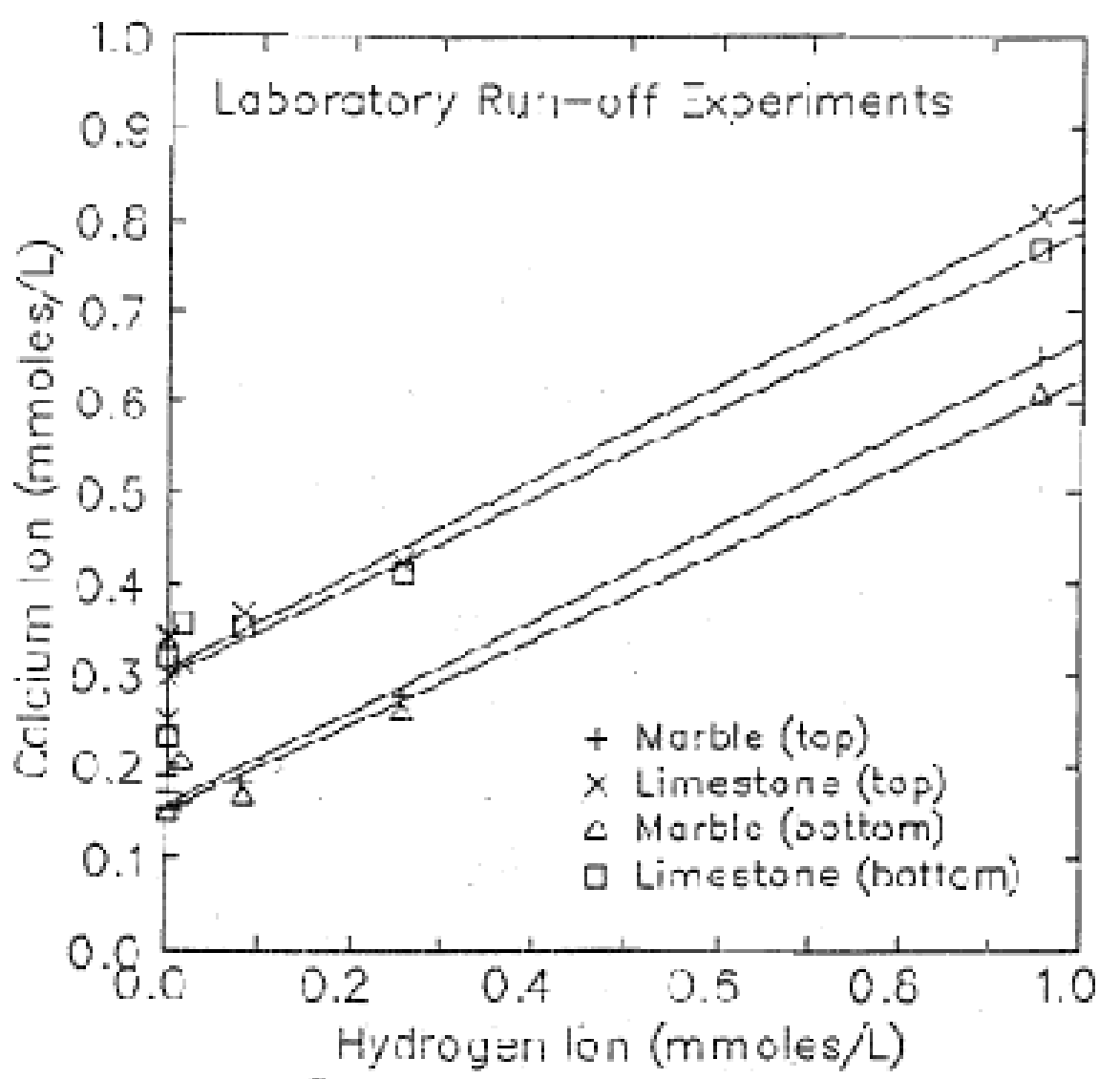

Scatter plot of calcium concentration in marble and limestone run-off from laboratory experiments aguinst hydrogen ion concentration in the incident spray. The spray solutions were deionized water acidified with sulfuric acid. The lines are least squares regression lines through the data. The spray was restricted to either the top or bottom half of the inclined stone slabs in separate experiments to test for possible effects of droplet residence time.

FIGURE 109.-Baedecker laboratory simulation: spray applied to either the top or the bottom half of the test slab. (Variables: $\left[\mathrm{Ca}^{2+}\right]_{\mathrm{xs}}$ vs. $\left[\mathrm{H}^{+}\right]^{\circ}$; material: limestone and marble.) (Reproduced from Baedecker, 1990, p. 19-111, figure 19-51.) 


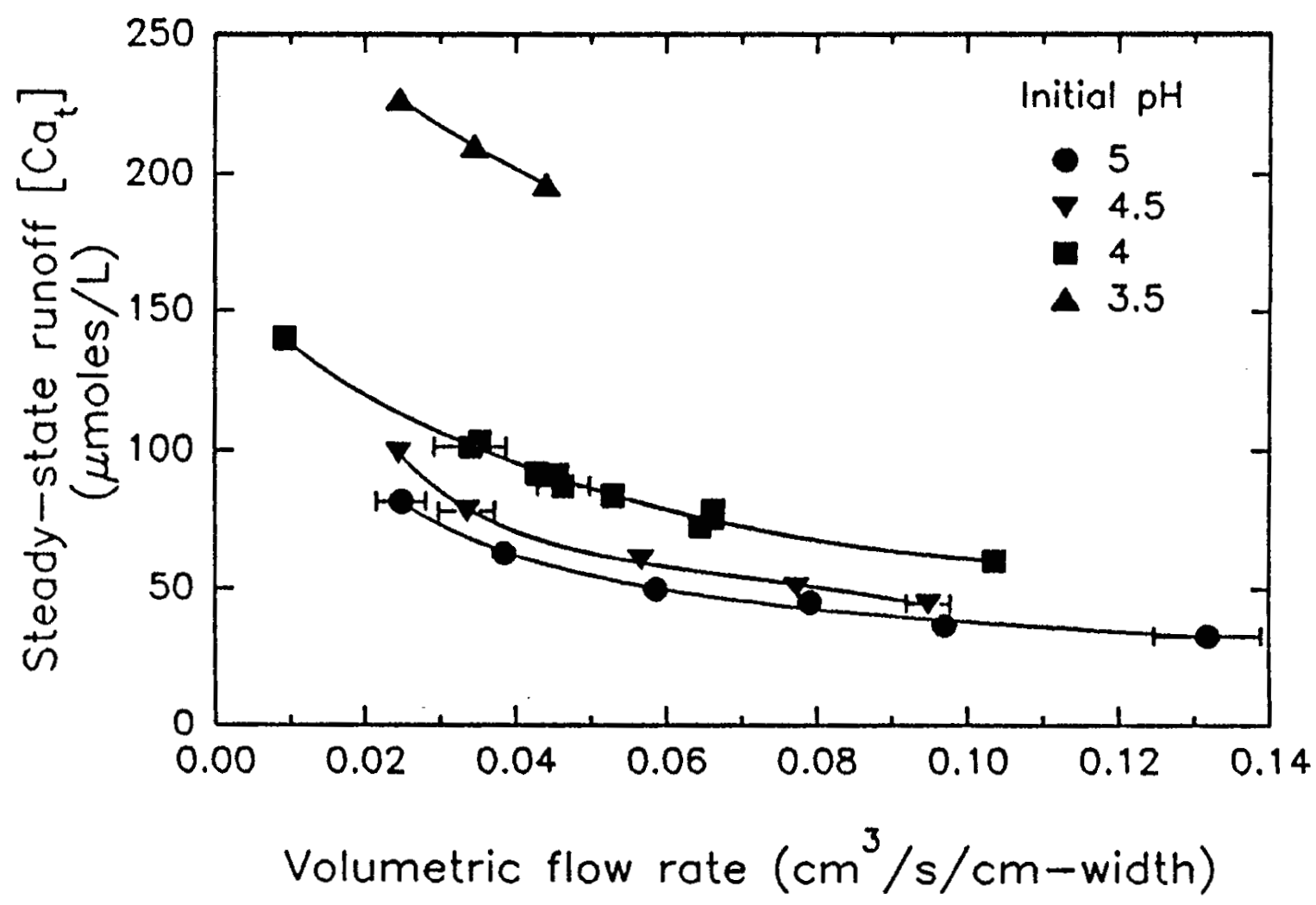

Figure 5:4 steady-state runoff total calcium concentration as a function of volumetric flow rate for various initial solution $\mathrm{pH}$ 's. Data for $\mathrm{pH} 5,4.5$ and 4 collected from $15 \mathrm{~cm}$ Salem limestone slabs while $\mathrm{pH} 3.5$ data obtained from $15 \mathrm{~cm}$ Shelburne marble slabs. Initial solution $\mathrm{pH}^{\prime} \mathrm{s}$ are nominal (see Appendix B for actual values). Error bars $( \pm 1$ standard deviation) are shown only when larger than the corresponding
symbol.

\begin{tabular}{|c|c|}
\hline \multicolumn{2}{|c|}{ SUMMARY OF EXPERIMENTAL CONDITIONS FOR FIGURE 5.4} \\
\hline STONE TYPE/LENGTH (cm) & $\begin{array}{l}\text { Salem limestone and } \\
\text { Shelburne marble / } 15\end{array}$ \\
\hline INITIAL $\mathrm{pH}$ (nominal) & $5,4.5,4,3.5$ \\
\hline $\begin{array}{c}\text { SLAB INCLINATION } \\
(0 \mathrm{fm} \text {. horiz.) }\end{array}$ & 30 \\
\hline TEMPERATURE $\left({ }^{\circ} \mathrm{C}\right)$ & 25 \\
\hline RUNS USED IN PLOT & 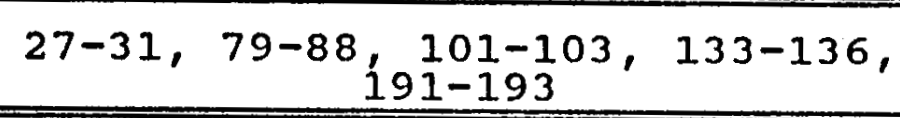 \\
\hline
\end{tabular}

FIGURE 110.-Schmiermund laboratory simulation: spray applied only to top edge of test slab. (Variables: $\left[\mathrm{Ca}^{2+}\right]$ vs. $\phi @$ pHs; material: limestone and marble; system temperature: $25^{\circ} \mathrm{C}$.) (Reproduced from Schmiermund, 1991, p. 130.) 


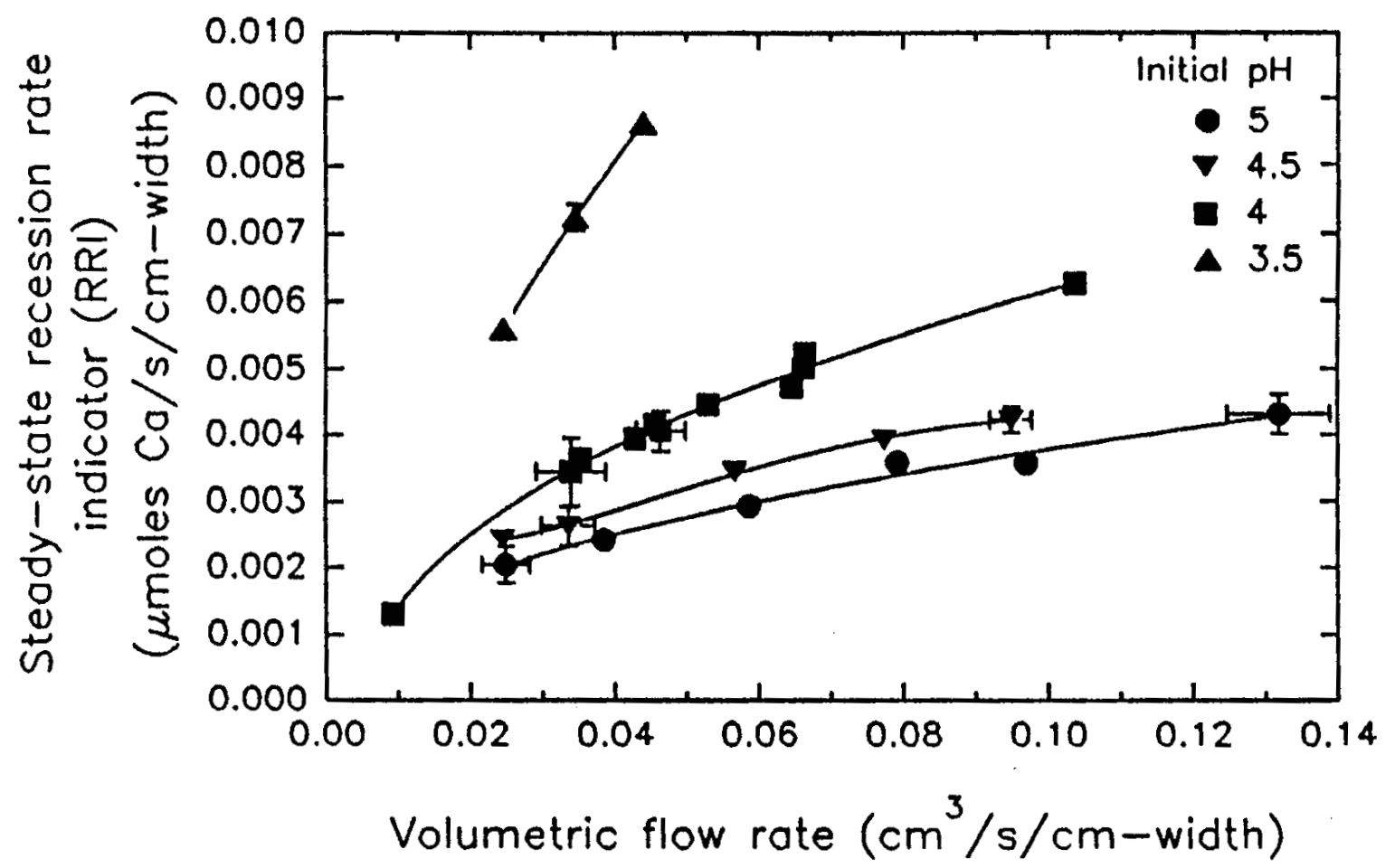

Figure 5.5. Steady-state recession rate indicator (RRI) as a function of volumetric flow rate for various initial solution pH's. Data for $\mathrm{pH} 5,4.5$ and 4 collected from $15 \mathrm{~cm}$ Salem limestone slabs while $\mathrm{pH} 3.5$ data obtained from $15 \mathrm{~cm}$ Shelburne marble slabs. Initial solution pH's are nominal (see Appendix B for actual values). Error bars ( \pm 1 standard deviation) are shown only when larger than the corresponding symbol.

\begin{tabular}{|c|c|}
\hline \multicolumn{2}{|c|}{ SUMMARY OF EXPERIMENTAL CONDITIONS FOR FIGURE 5.5} \\
\hline STONE TYPE/LENGTH (cm) & $\begin{array}{l}\text { Salem limestone and } \\
\text { Shelburne marble } / 15\end{array}$ \\
\hline INITIAL $\mathrm{pH}$ (nominal) & $5,4.5,4,3.5$ \\
\hline $\begin{array}{c}\text { SLAB INCLINATION } \\
(\mathrm{fm} . \text { horiz.) }\end{array}$ & 30 \\
\hline TEMPERATURE $\left({ }^{\circ} \mathrm{C}\right)$ & 25 \\
\hline RUNS USED IN PLOT & $27-31,79-88, \frac{101-103,133-136,}{191-193}$ \\
\hline
\end{tabular}

FIGURE 111.-Schmiermund laboratory simulation: spray applied only to top edge of test slab. (Variables: mass $\mathrm{Ca}^{2+}$ rate vs. $\phi$ @ pHs; material: limestone and marble; system temperature: $25^{\circ} \mathrm{C}$.) (Reproduced from Schmiermund, 1991, p. 130.) 
FIGURE 112.-Schmiermund laboratory simulation: spray applied only to top edge of test slab. (Variables: mass rate vs. $\phi$ (temps); material: limestone $(A)$ and marble (B); system temperature: $25^{\circ} \mathrm{C}$.) (Reproduced from Schmiermund, 1991, p. 141, 146.)

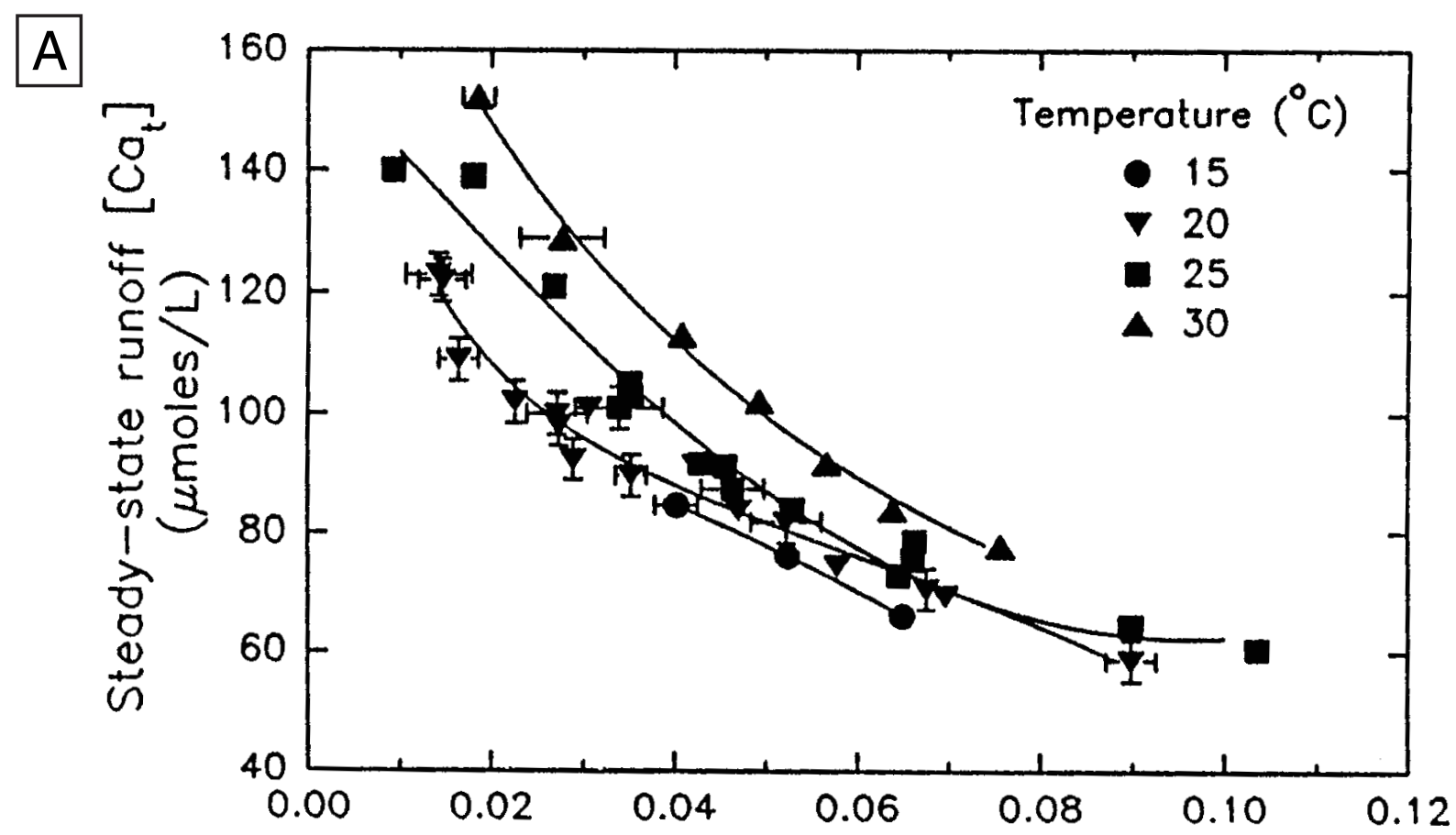

Volumetric flow rate $\left(\mathrm{cm}^{3} / \mathrm{s} / \mathrm{cm}\right.$-width)

Figure 5.9. Steady-state runoff total calcium concentration from Salem limestone as a function of volumetric flow rate for various temperatures. Error bars ( \pm 1 standard deviation) are shown only when larger than symbol.

\begin{tabular}{|c|c|}
\hline \multicolumn{2}{|c|}{ SUMMARY OF EXPERIMENTAL CONDITIONS FOR FIGURE 5.9 } \\
\hline STONE TYPE/LENGTH $x(\mathrm{~cm})$ & Salem limestone/15 \\
\hline INITIAL PH (nOMinal) & 4 \\
\hline SLAB INCLIN. ${ }^{0}$ fm. hoIIZ $)$ & 30 \\
\hline TEMPERATURE $\left({ }^{\circ} \mathrm{C}\right)$ & $15,20,25,30$ \\
\hline RUNS USED IN PLOT & $85-103,116-136,154-157$ \\
\hline
\end{tabular}




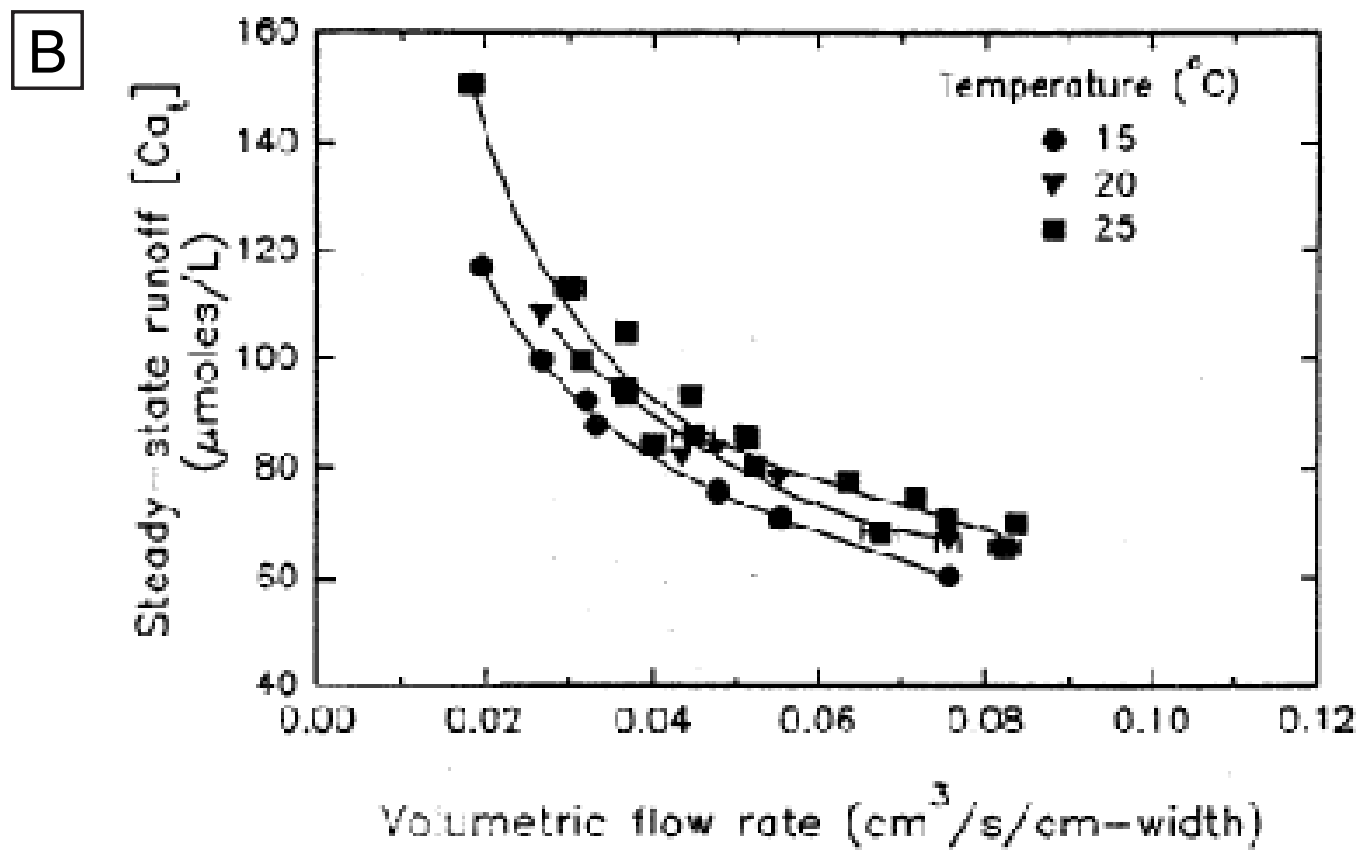

Figure 5.13. Steady-state runorf total calcium concentration from shelturne narble as a function of volunetric flow rate for varlous temperatures. Error bars ( 1 standard deviation) are shown only when larger than Eymol.

\begin{tabular}{|c|c|}
\hline \multicolumn{2}{|c|}{ STMOARY OT EXFERIMENTAL CONDITIONS FOR FIGURE 5.13} \\
\hline STONE TYPE/LENGTH $\mid \times(\mathrm{cm})$ & Shelburne marble/15 \\
\hline INITIAL $\mathrm{pH}$ (ncminal) & 4 \\
\hline SLRB INCLIN, $Q$ en. horiz.) & 30 \\
\hline TENPERATURE $\left.{ }^{n} \mathrm{C}\right)$ & $15,20,25$ \\
\hline RUNS USED IN PLOT & $185-165, \quad 167-193$ \\
\hline
\end{tabular}


FIGURE 113.-Schmiermund laboratory simulation: spray applied only to top edge of test slab. (Variables: $\left[\mathrm{Ca}^{2+}\right]$ vs. $\phi$ @ temps; material: limestone (A) and marble (B); system temperature: $25^{\circ} \mathrm{C}$.) (Reproduced from Schmiermund, 1991, p. 140, 145.)

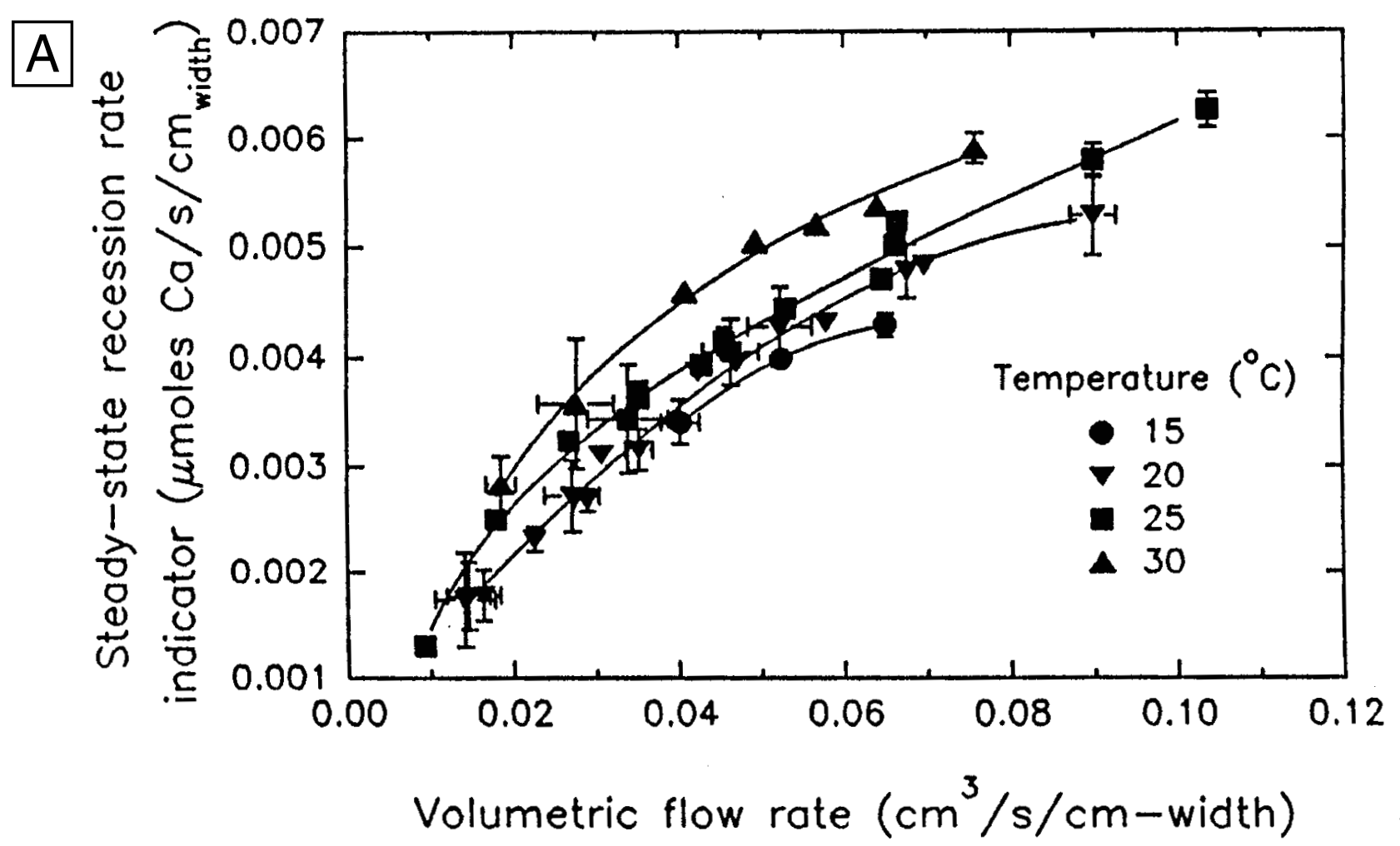

Figure 5.10. Steady-state recession rate indicator for salem limestone as a function of volumetric flow rate for various temperatures. Error bars ( \pm 1 standard deviation) are shown only when larger than symbol.

\begin{tabular}{|c|c|}
\hline \multicolumn{2}{|c|}{ SUMMARY OF EXPERIMENTAL CONDITIONS FOR FIGURE 5.10} \\
\hline STONE TYPE/LENGTH $\| \times(\mathrm{cm})$ & Salem Iimestone/15 \\
\hline INITIAL PH (nOminal) & 4 \\
\hline SLAB INCLIN. $\left({ }^{0}\right.$ fm. horiz.) & 30 \\
\hline TEMPERATURE $\left({ }^{\circ} \mathrm{C}\right)$ & $15,20,25,30$ \\
\hline RUNS USED IN PLOT & $85-103,116-136,154-157$ \\
\hline
\end{tabular}




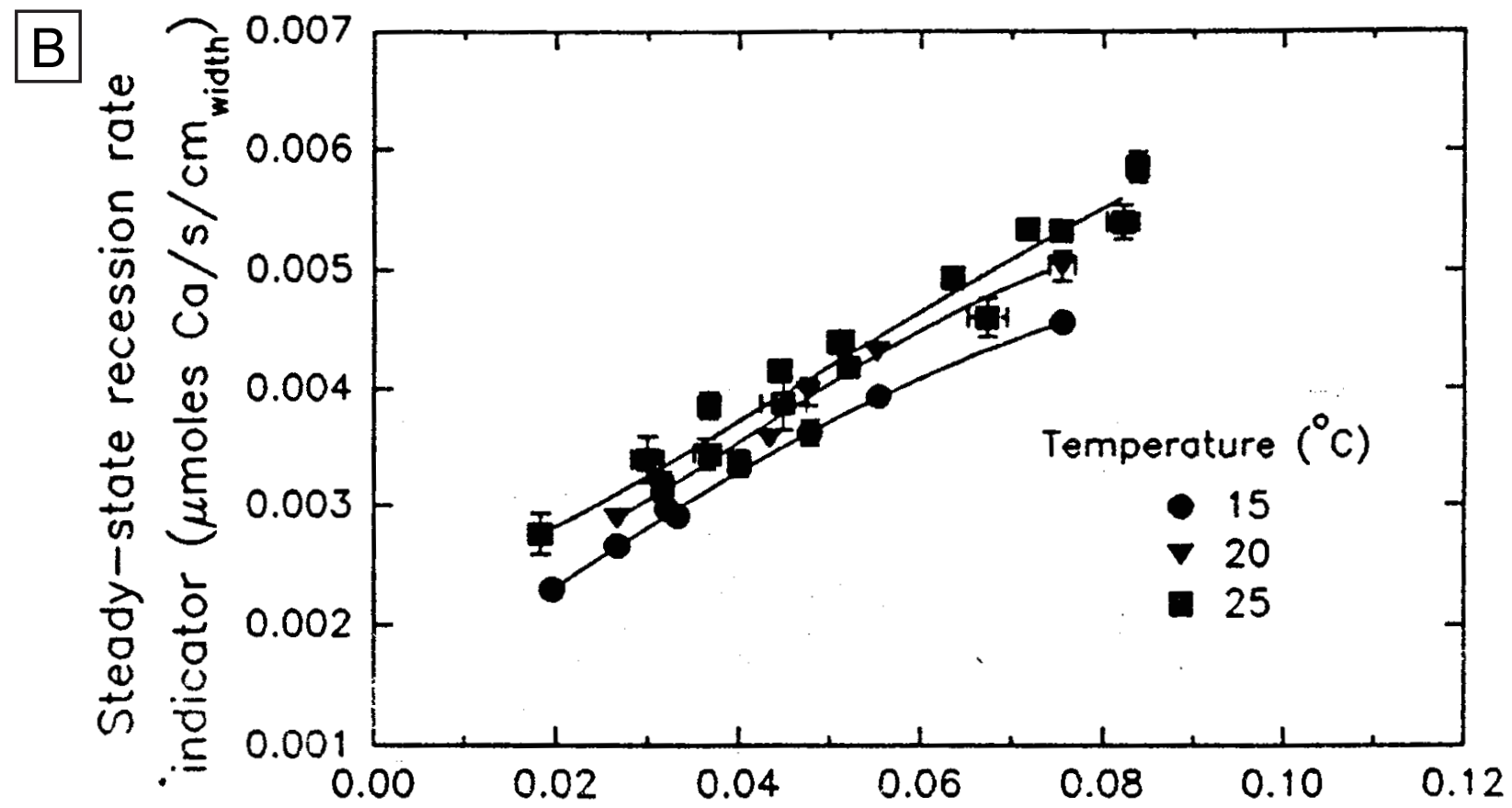

Volumetric flow rate $\left(\mathrm{cm}^{3} / \mathrm{s} / \mathrm{cm}\right.$-width)

Figure 5.14 Steady-state recession rate indicator for Shelburne marble as a function of volumetric flow rate for various temperatures. Error bars ( \pm 1 standard deviation) are shown only when larger than symbol.

\begin{tabular}{|c|c|}
\hline \multicolumn{2}{|c|}{ SUMMARY OF EXPERIMENTAL CONDITIONS FOR FIGURE 5.14} \\
\hline \hline STONE TYPE/LENGTH $\|(\mathrm{cm})$ & SheIburne marble/15 \\
\hline INITIAL PH (nOminal) & 4 \\
\hline SLAB INCLIN. $\left(^{\circ}\right.$ fm. hOTiz.) & 30 \\
\hline TEMPERATURE $\left.{ }^{\circ} \mathrm{C}\right)$ & $15,20,25$ \\
\hline RUNS USED IN PLOT & $185-165,167-193$ \\
\hline
\end{tabular}




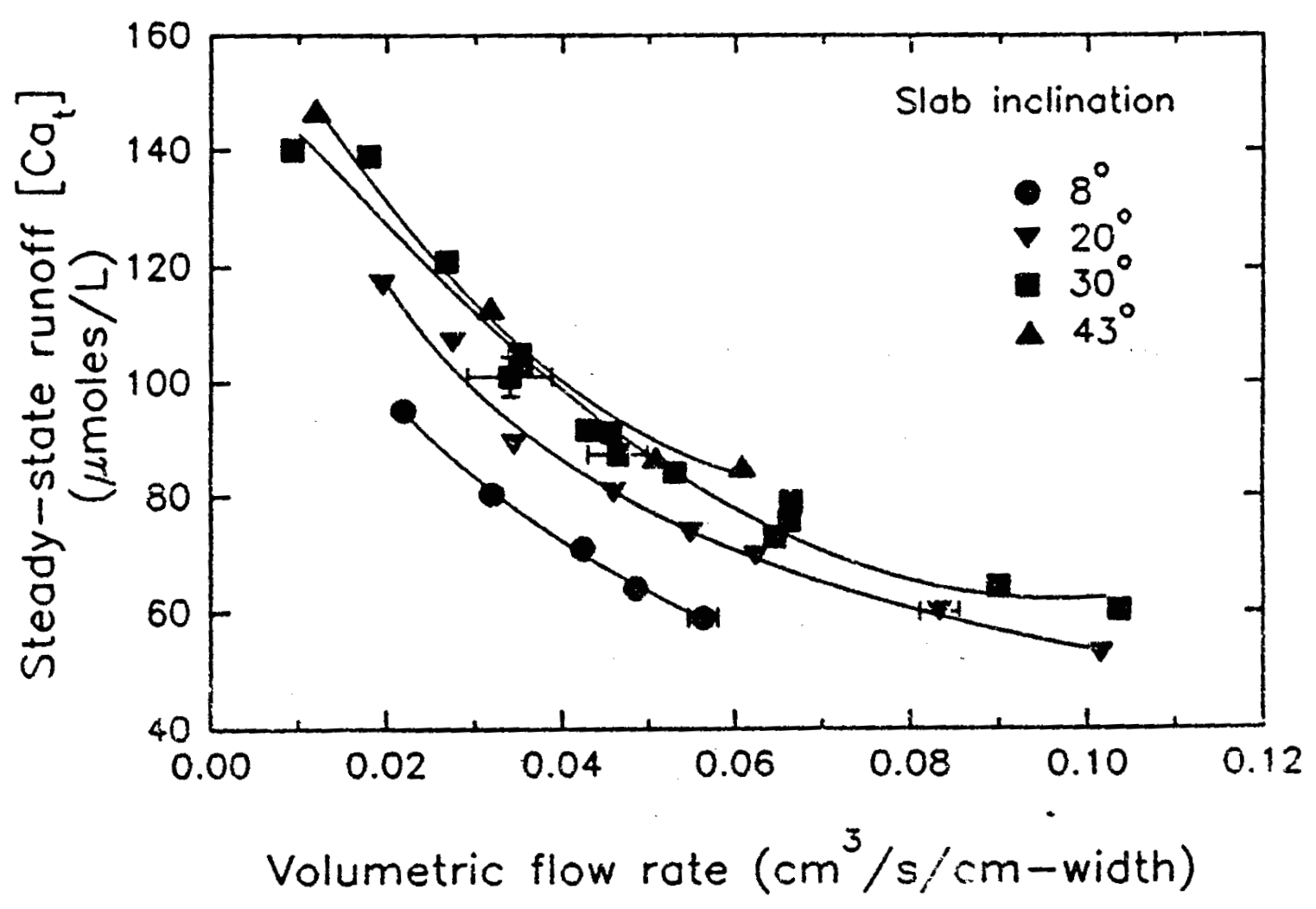

Figure 5.17. Steady-state runoff total calcium concentration as a function of volumetric flow rate and slab inclination. Error bars ( \pm 1 standard deviation) are shown only when larger than the corresponding symbol.

\begin{tabular}{|c|c|}
\hline \multicolumn{1}{|c|}{ SUMMARY OF EXPERIMENTAL CONDITIONS FOR FIGURE 5.17} \\
\hline STONE TYPE/LENGTH $\|(\mathrm{cm})$ & Salem limestone/15 \\
\hline INITIAL PH (nOminal) & 4 \\
\hline SIAB INCLIN. ${ }^{\circ}$ fm. horiz.) & $8,20,30,43$ \\
\hline TEMPERATURE ( $\left.{ }^{\circ} \mathrm{C}\right)$ & 25 \\
\hline RUNS USED IN PLOT & B5-88 $101-103,133-157$ \\
\hline
\end{tabular}

FIGURE 114.-Schmiermund laboratory simulation: spray applied only to top edge of test slab. (Variables: mass rate vs. $\phi @$ angle; material: limestone; system temperature: $25^{\circ} \mathrm{C}$.) (Reproduced from Schmiermund, 1991, p. 150.) 


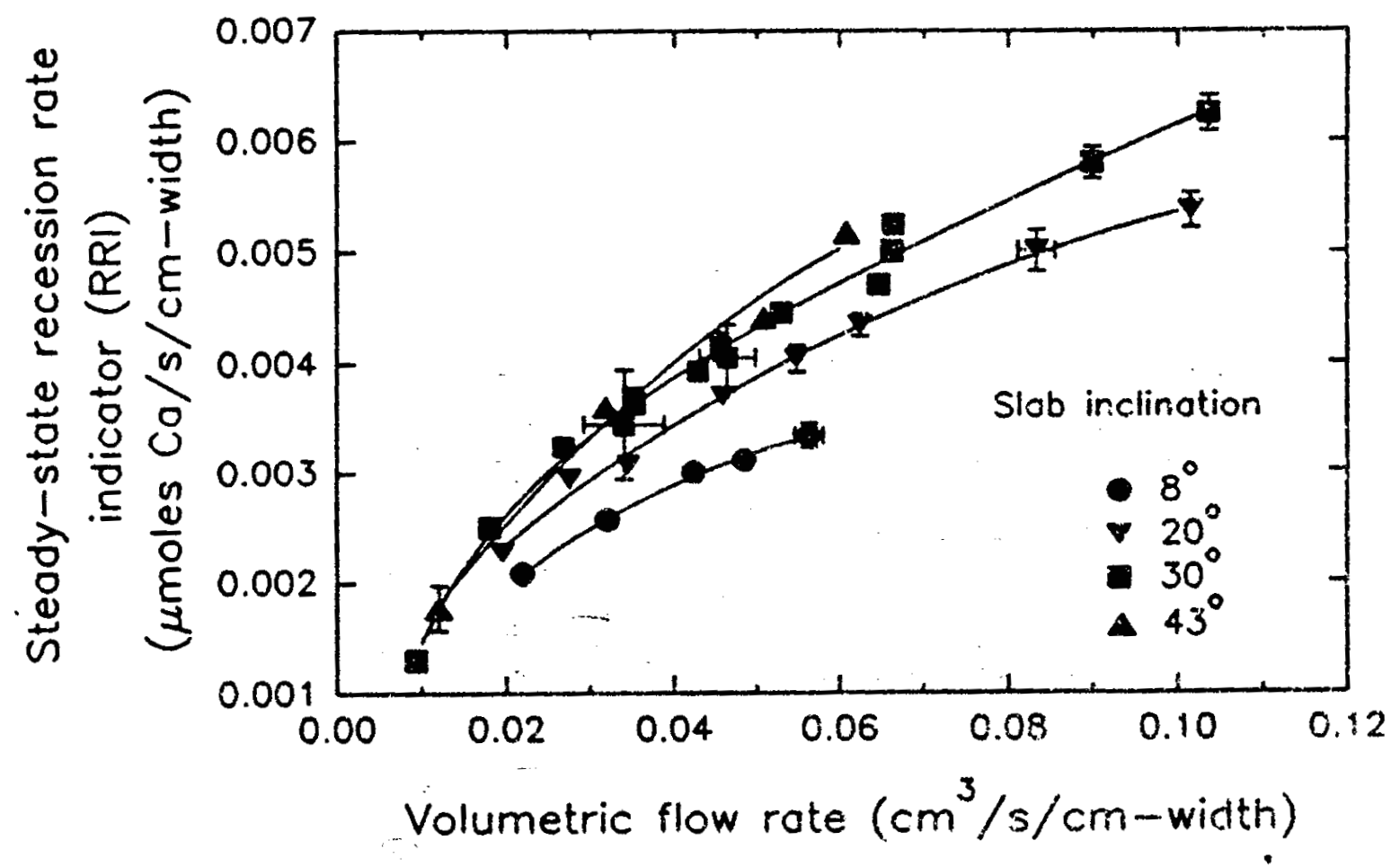

Figure 5.18. Steady-state recession rate indicator (RRI) as a function of volumetric flow rate and siab inclination. Error bars ( $t 1$ standard deviation) are shown only when larger than the corresponding symbol.

\begin{tabular}{|c|c|}
\hline \multicolumn{2}{|c|}{ SUMMARY OF EXPERIMENTAI CONDITIONS FOR FIGURE 5.18} \\
\hline STONE TYPE/LENGTH $\| \times(\mathrm{cm})$ & Salem Iimestone $/ 15$ \\
\hline INITIAL $\mathrm{pH}$ (nominal) & 4 \\
\hline SLAB INCLIN. $(0 \mathrm{fm}$. horiz.) & $8,20,30,43$ \\
\hline TEMPERATURE $\left({ }^{\circ} \mathrm{C}\right)$ & 25 \\
\hline RUNS USED IN PLOT & $85-88 \quad 101-103,133-157$ \\
\hline
\end{tabular}

FIGURE 115.-Schmiermund laboratory simulation: spray applied only to top edge of test slab. (Variables: [Ca $\left.{ }^{2+}\right]$ vs. $\phi @$ angle; material: limestone; system temperature: $25^{\circ}$ C.) (Reproduced from Schmiermund, 1991, p. 149.) 


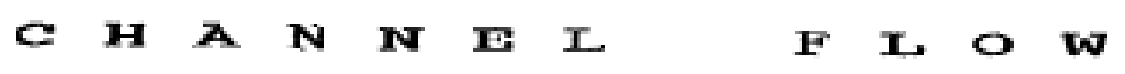
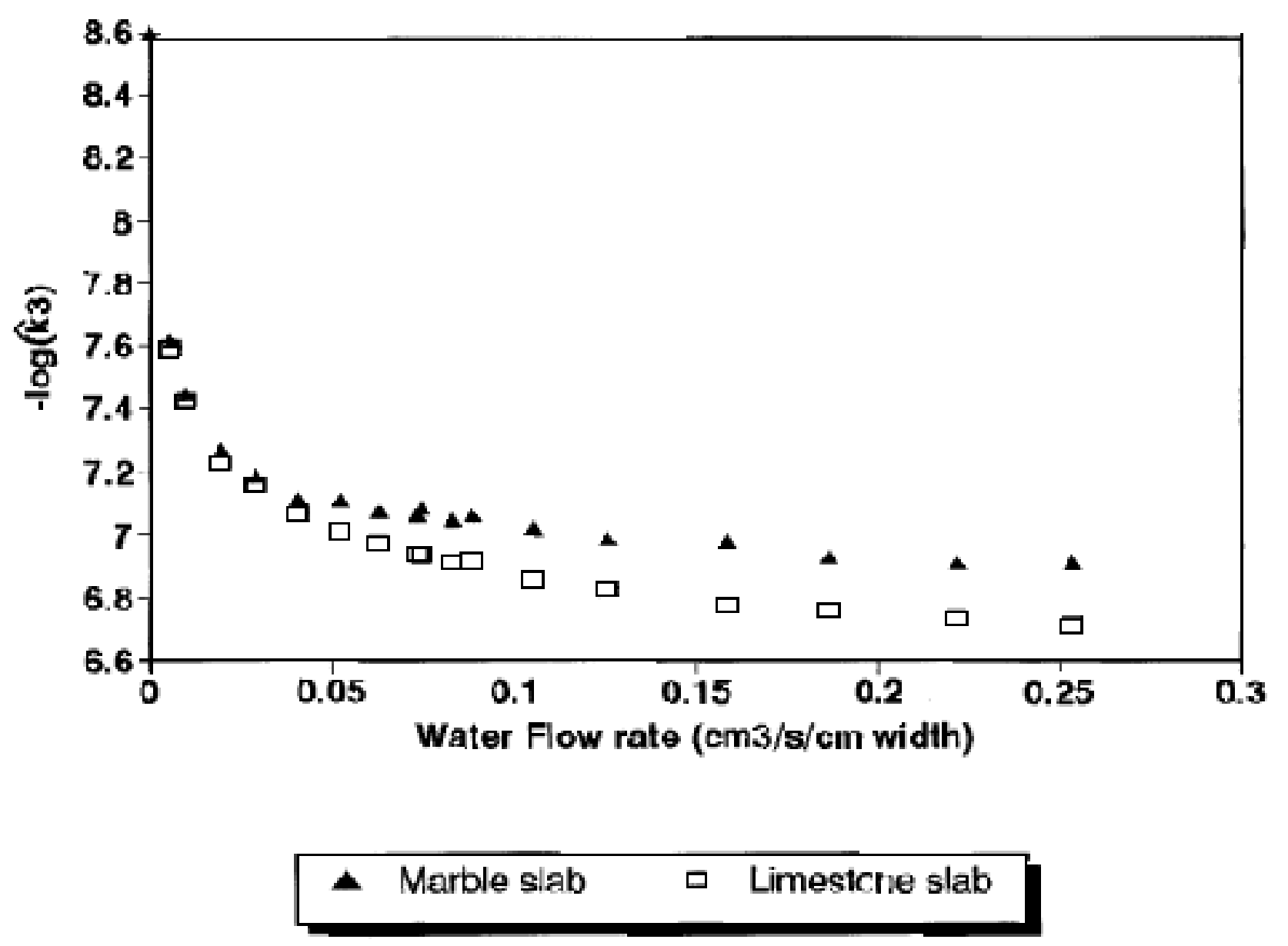

FIGURE 116.-Fries/Mossotti $\mathrm{Ca}^{2+}$ release rate: solution only applied to top edge of channel. (Variables: mass rate vs. $\phi$; material: marble; system temperature: $25^{\circ} \mathrm{C}$.) 


\section{$\begin{array}{llllllllllllllll}\text { A } & \mathbf{P} & \mathbf{P} & \mathbf{E} & \mathbf{N} & \mathbf{D} & \mathbf{I} & \mathbf{X}\end{array}$}

SUMMARY OF DATA FROM ONSITE AND LABORATORY ANALYSES OF PRECIPITATION

RUNOFF FROM CARBONATE-STONE SURFACES, NATIONAL ACID PRECIPITATION

ASSESSMENT PROGRAM, JUNE 1984 TO NOVEMBER 1987

By Michael M. Keddy, Paul F. Schuster, and James J. Harte

U.S. GEOLOGICAL. SURVEY

Open-File Report 89-246

Prepared in cooperation with the

NATIONAL PARK SERVICE 
Abstract-1-

Introduction-- 1

Data file-na 2

Summary-0.-. 3

References cited-1 3

\section{TABLES}

Table 1. Variable names and codes for source of samples and sample types-..... 4

2. Variable names and codes for sample collection and precipitation type-1 5

3. Variable names for onsite- and laboratory-measured parameters-..... 6

4-9. Summary statistics for:

4. Blank samples- 7

5. Glass samples- 8

6. Limestone samples-a

7. Marble samples-a... 10

8. Distilled-water reference samples-.... 11

9. M-82 standard reference water samples-a. 12

10. Analytical results for standard reference water sample M-82-1.

11. Summary statistics for $M-4$ standard reference water samples-.... 14

12. Analytical results for standard reference water sample M-4-15

13. Summary statistics for samples collected using the recording precipitation monitor-a. 16

14. Detection limits for laboratory analyses (1984-86) -

15. Detection limits for laboratory analyses (1987)

16-18. Sample data set of:

16. DATAT.A- 18

17. DATAT.B- 19

18. DATAT.C- 19 


\section{CONVERSION FACTORS}

Metric units (International System) in this report may be converted to inch-pound units by using the following conversion factors:

Multiply metric units

liter (L)

milliliter $(\mathrm{mL})$

millimeter $(\mathrm{mm})$

Hydrogen ion, microequivalent per 1iter ( $\mu$ eq/L) 0.001

Alkalinity (as carbonate), milliequivalent per liter (meq/L) $\quad 50.045$

Calcium ion, milliequivalent per liter (meq/I) 20.04

Magnesium ion, milliequivalent per liter (meq/L) 12.153

Sodium ion, milliequivalent per liter (meq/L) 22.9898

Ammonium ion, milliequivalent per liter (meq/L) 18.0383

Potassium ion, milliequivalent per liter (meq/L) 39.0983

Sulfate ion, milliequivalent per liter (meq $/ \mathrm{L}$ ) 48.0288

Nitrate ion, milliequivalent per liter (meq/L) 62.0049 Chloride ion, milliequivalent per liter (meq/L) 35.453
To obtain inch-pound units

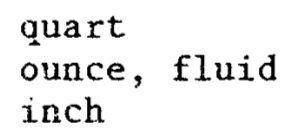

part per million $\mathrm{H}^{+}$

part per million Alkalinity (as carbonate)

part per million $\mathrm{Ca}^{2+}$

part per million $\mathrm{Mg}^{2+}$

part per million $\mathrm{Na}^{+}$

part per million $\mathrm{NH}_{4}^{+}$

part per million $\mathrm{K}^{+}$

part per million $\mathrm{SO}_{4}^{2-}$

part per million $\mathrm{NO}_{3}^{-}$

part per million $\mathrm{Cl}^{-}$

The following term and abbreviation also are used in this report:

microsiemens per centimeter at 25 degrees Celsius $(\mu \mathrm{S} / \mathrm{cm})$. 


\author{
SUMMARY OF DATA FROM ONSITE AND LABORATORY ANALYSES OF \\ PRECIPITATION RUNOFF FROM CARBONATE-STONE SURFACES, \\ NATIONAL ACID PRECIPITATION ASSESSMENT PROGRAM, \\ JUNE 1984 TO NOVEMBER 1987
}

By Michael M. Reddy, Paul F. Schuster, and James J. Harte

\begin{abstract}
This report presents a summary of data collected from June 1984 to November 1987 as part of an experimental research program to quantify the interaction of acid precipitation with a carbonate-stone surface. The work was done in conjunction with the National Acid Precipitation Assessment Program. Precipitation-runoff samples were collected from polypropylene receptacles (blank samples), glass plates, and flat surfaces of two types of carbonate stone: Salem Limestone (from Indiana) and Shelburne Marble (from Vermont). The summary is based on onsite and laboratory measurements for. 1,973 samples that are available in a computer-data file. The data file contains sample description and analytical data for precipitation and runoff samples collected at five sites, which are representative of 318 rain events, distilled-water reference samples, and standard reference water samples.
\end{abstract}

\title{
INTRODUCTION
}

The National Acid Precipitation Assessment Program, Task Group VII Materials and Cultural Resources Effects--was organized, in part, as a 10-year program to measure, document, and quantify acid-precipitation effects on two types of carbonate stone: Salem Limestone (from Indiana) and Shelburne Marble (from Vermont). In 1984, four onsite-research locations were established in the eastern United States at Newcomb, N.Y.; Chester, N.J.; Washington, D.C.; and Research Triangle Park, N.C. In 1986, Steubenvilie, Ohio replaced Chester, N.J. as an operational site. Precipitation-runoff samples from polypropylene receptacles (blank samples), glass plates, and stone surfaces were analyzed. Details of the onsite and laboratory procedures are described in other reports (Sherwood, 1984; Reddy and others, 1985; Reddy and Werner, 1985). Sample preparation, analytical procedures, and laboratory quality-control protocols used by the U.S. Geological Survey laboratory are described by Fishman and Friedman (1985). 
This work has been done as part of the National Acid Precipitation Assessment Program and was funded in part by the National Park Service. The purpose of this report is to update a report authored by See and Reddy (1987); the update includes data collected in 1987. Data and statistics presented in this report do not necessarily indicate the views of the National Acid Precipitation Assessment Program or the National Park Service.

\section{DATA FILE}

Precipitation-runoff analysis data are available for samples collected and analyzed from June 1984 to November 1987. Five types of samples were collected from 318 rain events during this period. To evaluate onsitesampling variability, replicate samples were collected from adjacent stones of the same type. The duplicate samples were submitted to the laboratory to identify variability caused by sample processing and handling. Additional distilled-water reference samples and standard reference water samples (SRWS) ${ }^{1}$ were submitted to the laboratory with the onsite samples. Both types of reference samples were processed using the same procedures as the onsite samples. During the indicated period, 1,973 samples were processed; analytical results are available in the data file which is summarized in tables 1 through 18.

The data file is available in ASCII format on a $3 \frac{2}{2}$ inch diskette. It has been divided into three subfiles. The first subfile (DATAT.A) contains descriptive information and onsite measurements of $\mathrm{pH}$ and specific conductance. The second subfile (DATAT.B) repeats some descriptive information and contains laboratory measurements of $\mathrm{pH}$, specific conductance, alkalinity, and major anions. The thixd subfile (DAIAT.C) also repeats some descriptive information and contains laboratory measurements of major cations. For further information about the availability or use of the diskette, call Michael M. Reddy, Paul F. Schuster, or James J. Harte at (303) 236-3617 or FTS 776-3617 or contact the Chief, Branch of Regional Research, Water Resources Division, Room H-2822, B1dg. 53 (mailing address: Box 25046, mail stop 418, Denver Federal Center, Denver, Co. 80225-0046).

The data file consists of 29 variables. Variable names and codes established for source of samples and sample types are listed in table 1. Variable names and codes established for sample collection and precipitation type are listed in table 2. Variable names for parameters measured onsite and in the laboratory are listed in table 3.

All data has been proofed to eliminate keypunching errors. An additional check on the quality of the data was provided by a verification of summary statistics for the data, sorted by sample type. Samples that have exceptionally large or small values were examined and reanalyzed to determine if the values were accurate or erroneous. The summary statistics for each

\footnotetext{
${ }^{1}$ SRWS - Standard reference water samples are prepared and used by the U.S. Geological Survey's quality assurance program to ensure that the laboratory is producing analytical data for inorganic constituents that are of acceptable reliability (Schroder and others, 1980).
} 
sample type are listed in tables 4 through 9, 11, and 13. Analytical results, obtained from the U.S. Geological Survey, Quality Assurance Laboratory, for standard reference water samples $M-82$ and $M-4$ are given in tables 10 and 12 .

The summary statistics are not intended for use in evaluating the effect of acid precipitation on stone samples. The statistical calculations include all entries in the data file including overflow, duplicate, and replicate samples from all of the sites. Tables 4 through 9,11 , and 13 are strictly statistical descriptions of the data file.

Samples that had analytical results less than the detection limits of the selected methods are indicated in the data set by double dashes (-) . The detection limits of quantification are listed in tables 14 and 15 . Sample parts of the data file are included in tables 16 through 18.

\section{SUMMARY}

A total of 1,973 samples from 318 rain events have been analyzed using a protocol designed to minimize errors from handling procedures, laboratory analyses, and data-entry operations. Duplicate samples and standard reference water samples are included in this sample set. Further additions will be made to the data file as sample collection continues, and as laboratory analyses are completed.

\section{REFERENCES CITED}

Fishman, M.J., and Friedman, L.C., eds., 1985, Methods for determination of inorganic substances in water and fluvial sediments: U.S. Geological Survey Open-File Report 85-495, $709 \mathrm{p}$.

Reddy, M.M., Sherwood, S.I., and Doe, B.R., 1985, Modeling limestone dissolution by acid rain, in General Proceedings of Research and Design, 85, Los Angeles, 1985: Washington, D.C. The American Institute of Architects Foundation, p. 383-388.

Reddy, M.M. and Werner, M.G., 1985, Composition of rainfall runoff from limestone and marble at Research Triangle Park, North Carolina: U.S. Geological Survey Open-File Report 85-630, 6 p.

Schroder, L.J., Fishman, M.J., Friedman, L.C., and Darlington, G.W., 1980, The use of standard reference water samples by the U.S. Geological

Survey: U.S. Geological Survey Open-File Report 80-738, 11 p.

See, R.B. and Reddy, M.M., 1987, Summary of data for onsite and laboratory analyses of precipitation runoff from carbonate-rock surfaces, National

Acid Precipitation Assessment Program, June 1984 to September, 1986:

U.S. Geological Survey Open-File Report 87-461, 14 p.

Sherwood, S.I., 1984, The National Park Service program on the effects of air pollution on cultural properties: Annual Air Pollution Control

Association Meeting, 77th, San Francisco, 1984, Preprint, p. 1-16. 
Table 1.--Variable names and codes for source

of samples and sample types

\begin{tabular}{|c|c|c|c|}
\hline Variable name & $\begin{array}{l}\text { Abbreviated } \\
\text { variable name } \\
\text { in data file }\end{array}$ & Code & Definition \\
\hline \multirow[t]{5}{*}{ Source of samples } & SITE & $\begin{array}{l}\text { DC } \\
\text { LB }\end{array}$ & $\begin{array}{l}\text { Washington, D.C. } \\
\text { Standard reference water samples } \\
\text { from U.S. Geological Survey } \\
\text { laboratory, Denver, Colo. }\end{array}$ \\
\hline & & $\mathrm{NJ}$ & Chester, N.J. \\
\hline & & NC & Research Triangle Park, N.C. \\
\hline & & $\mathrm{NY}$ & Newcomb, N.Y. \\
\hline & & $\mathrm{OH}$ & Steubenville, Ohio \\
\hline \multirow[t]{11}{*}{ Sample type } & TYPE & $\mathrm{B}$ & Blank (empty receptacle) rack \\
\hline & & G & Glass \\
\hline & & $L$ & Limestone \\
\hline & & $\mathbf{M}$ & Marble \\
\hline & & $\mathrm{D}$ & Distilled-water reference sample \\
\hline & & $\begin{array}{l}M-82 \\
M-4\end{array}$ & $\begin{array}{l}\text { M-82 standard reference water sample } \\
\text { M-4 standard reference water sample }\end{array}$ \\
\hline & & $S R-74$ & SR-74 standard reference water sample \\
\hline & & $S R-70$ & SR-70 standard reference water sample \\
\hline & & $S R-74 D$ & SR-74D standard reference water sample \\
\hline & & P-5 & P-5 standard reference water sample \\
\hline & & $\mathrm{P}$ & Recording precipitation monitor \\
\hline
\end{tabular}


Table 2.-Variable names and codes for sample collection and precipitation type

\begin{tabular}{|c|c|c|c|}
\hline Variable name & $\begin{array}{l}\text { Abbreviated } \\
\text { variable name } \\
\text { in data file }\end{array}$ & Code & Definition \\
\hline $\begin{array}{l}\text { Year } \\
\text { Event } \\
\text { Side }\end{array}$ & $\begin{array}{l}\text { YEAR } \\
\text { EVENT } \\
\text { SIDE }\end{array}$ & $\begin{array}{l}\text { Two-digit code } \\
\text { Two-digit code } \\
\text { Two-digit code }\end{array}$ & $\begin{array}{l}\text { Year of collection } \\
\text { Sample-collection sequence } \\
\text { Position of blanks, glass, and } \\
\text { stones in racks }\end{array}$ \\
\hline Duplicate & DUP & $\begin{array}{l}1 \\
2\end{array}$ & $\begin{array}{l}\text { Original sample } \\
\text { Split of original sample }\end{array}$ \\
\hline $\begin{array}{l}\text { Julian day on } \\
\text { Julian day off }\end{array}$ & $\begin{array}{ll}\text { JD } & \text { ON } \\
\text { JD } & \text { OFF }\end{array}$ & $\begin{array}{r}1-365 \\
1-365\end{array}$ & $\begin{array}{l}\text { Date sample collector was installed } \\
\text { Date sample collector was removed }\end{array}$ \\
\hline Overflow & OVERFLOW & $\begin{array}{l}\mathrm{Y} \\
\mathrm{N} \\
\mathrm{F}\end{array}$ & $\begin{array}{l}\text { Collector bottle overflowed } \\
\text { Collector bottle did } \\
\text { not overflow } \\
\text { Known problews with } \\
\text { sample collection }\end{array}$ \\
\hline Precipitation type & PRECIP TYPE & $\begin{array}{l}\text { RN } \\
\text { SN } \\
\text { SL } \\
\text { SR }\end{array}$ & $\begin{array}{l}\text { Rain } \\
\text { Snow } \\
\text { Sleet } \\
\text { Snow and rain mixed }\end{array}$ \\
\hline Filtered volume & FILT VOL & Integer & $\begin{array}{l}\text { Volume of filtered sample sent } \\
\text { to laboratory for analysis }\end{array}$ \\
\hline Unfiltered volume & UNFILT VOL & Integer & $\begin{array}{l}\text { Volume of unfiltered sample } \\
\text { sent to laboratory }\end{array}$ \\
\hline Degree & DEGREE & $0-90^{\circ}$ & $\begin{array}{l}\text { Degree at which blank, glass, } \\
\text { or stone is set with respect } \\
\text { to horizontal }\end{array}$ \\
\hline
\end{tabular}


Table 3.--Variable names for onsite- and laboratory-measured parameters

\begin{tabular}{|c|c|c|}
\hline Variable name & $\begin{array}{l}\text { Abbreviated } \\
\text { variable name } \\
\text { in data file }\end{array}$ & Units \\
\hline Volume & VOLUME & Sample volume (milliliters) \\
\hline & RAIN IN & Depth (inches) \\
\hline Precipitation & RAIN MM & Depth (millimeters) \\
\hline $\begin{array}{l}\text { Specific conductance } \\
\text { (onsite) }\end{array}$ & CON FLD & Microsiemens per centimeter \\
\hline $\begin{array}{l}\text { Specific conductance } \\
\text { (laboratory) }\end{array}$ & CON LAB & Microsiemens per centimeter \\
\hline $\mathrm{pH}$ (onsite) & PH ELD & Standard units \\
\hline $\mathrm{pH}$ (laboratory) & $\mathrm{PH}$ LAB & Standard units \\
\hline Alkalinity (laboratory) & ALK MEQ & Milliequivalents per liter \\
\hline Calcium ion (laboratory) & $\mathrm{CA} \mathrm{MEQ}$ & Milliequivalents per liter \\
\hline Magnesium ion (1aboratory) & MG MEQ & Milliequivalents per liter \\
\hline Sodium ion (laboratory) & NA MEQ & Milliequivalents per liter \\
\hline Ammonium ion (laboratory) & NH4 MEQ & Milliequivalents per liter \\
\hline Potassium ion (laboratory) & $\mathrm{K} M \mathrm{MEQ}$ & Milliequivalents per liter \\
\hline Sulfate ion (laboratory) & S04 MEQ & Milliequivalents per liter \\
\hline Nitrate ion (laboratory) & No3 MEQ & Milliequivalents per liter \\
\hline Chloride ion (laboratory) & CL $M E Q$ & Milliequivalents per liter \\
\hline
\end{tabular}


Table 4.--Summary statistics for blank samples

$[\mathrm{mL}$, milliliters; mm, millimeters; $\mu \mathrm{S} / \mathrm{cm}$, microsiemens per centimeter at 25 degrees Celsius; $\mu \mathrm{eq} / \mathrm{L}$, microequivalents per liter; meq/L, milliequivalents per liter; --, indicates that results were less than detection limits for the selected analytical procedures; missing, data unavailable; less than detection, number of samples having results that were less than detection limits for the selected analytical procedures; measured, number of samples having results that were greater than detection limits]

\begin{tabular}{|c|c|c|c|c|c|c|c|}
\hline \multirow[b]{3}{*}{ Parameter } & \multirow[b]{3}{*}{ Mean } & \multirow[b]{3}{*}{$\begin{array}{l}\text { Standard } \\
\text { deviation }\end{array}$} & \multirow{2}{*}{\multicolumn{2}{|c|}{ Range }} & \multicolumn{3}{|c|}{ Number of samples } \\
\hline & & & & & \multirow[b]{2}{*}{ Missing } & \multirow{2}{*}{$\begin{array}{l}\text { Less } \\
\text { than } \\
\text { detec- } \\
\text { tion }\end{array}$} & \multirow[b]{2}{*}{ Measured } \\
\hline & & & $\begin{array}{l}\text { Mini- } \\
\text { mum }\end{array}$ & $\begin{array}{c}\text { Maxi- } \\
\text { mum }\end{array}$ & & & \\
\hline Volume $(\mathrm{mL})$ & 1,342 & 1,260 & 11 & 4,240 & 5 & 0 & 204 \\
\hline $\begin{array}{l}\text { Precipitation (mm) } \\
\text { Specific }\end{array}$ & 15.7 & 16.8 & 0.25 & 127 & 42 & 0 & 167 \\
\hline $\begin{array}{l}\text { conductance } \\
\text { (onsite, } \mu \mathrm{S} / \mathrm{cm} \text { ) }\end{array}$ & 39.5 & 36.7 & 3.0 & 244.1 & 81 & 0 & 128 \\
\hline \multicolumn{8}{|l|}{ Specific } \\
\hline $\begin{array}{l}\text { conductance } \\
\text { (laboratory, } \\
\mu S / \mathrm{cm})\end{array}$ & 35.5 & 29.7 & 3.3 & 270.0 & 39 & 0 & 170 \\
\hline $\begin{array}{l}\mathrm{pH} \text { (onsite, } \\
\text { standard units) }\end{array}$ & 4.61 & 0.79 & 3.39 & 7.14 & 81 & 0 & 128 \\
\hline $\begin{array}{l}\text { Hydrogen ion } \\
\text { (onsite, } \mu e q / L)\end{array}$ & 60.1 & 73.4 & 0.072 & $40 ?$ & 81 & 0 & 128 \\
\hline $\begin{array}{l}\text { pH (laboratory, } \\
\text { standard units) }\end{array}$ & 4.90 & 0.98 & 3.13 & 7.70 & 40 & 0 & 169 \\
\hline Hydrogen ion & & & & & & & \\
\hline $\begin{array}{l}\text { (laboratory, } \\
\mu \mathrm{eq} / \mathrm{L})\end{array}$ & 44.94 & 69.37 & 0.020 & 741.3 & 40 & 0 & 169 \\
\hline \multicolumn{8}{|l|}{ Alkalinity } \\
\hline $\begin{array}{l}(\mathrm{meq} / \mathrm{L}, \text { as } \\
\text { carbonate })\end{array}$ & 0.028 & 0.063 & 0 & 0.520 & 22 & 0 & 187 \\
\hline $\begin{array}{l}\text { alcium ion } \\
\quad(\text { meq/L) }\end{array}$ & 0.079 & 0.177 & 0.002 & 1.951 & 34 & 1 & 174 \\
\hline $\begin{array}{l}\text { Yagnesium ion } \\
\text { (meq/L) }\end{array}$ & 0.013 & 0.024 & 0.001 & 0.253 & 36 & 4 & 169 \\
\hline $\begin{array}{l}\text { Jodium ion } \\
\text { (meq/L) }\end{array}$ & 0.028 & 0.049 & -- & 0.327 & 36 & 17 & 156 \\
\hline \multicolumn{8}{|l|}{ Immonium ion } \\
\hline $\begin{array}{l}\text { (meq/L, as } \\
\text { nitrogen) }\end{array}$ & 0.018 & 0.014 & 0.001 & 0.044 & 197 & 0 & 12 \\
\hline $\begin{array}{l}\text { Potassium ion } \\
\quad(\mathrm{meq} / \mathrm{L})\end{array}$ & 0.004 & 0.004 & -- & 0.026 & 113 & 1 & 95 \\
\hline $\begin{array}{l}\text { sulfate ion } \\
\text { (meq/L, as } \\
\text { sulfate) }\end{array}$ & 0.098 & 0.105 & 0.005 & 1.155 & 40 & 0 & 169 \\
\hline $\begin{array}{l}\text { Jitrate ion } \\
\text { (meq/I, as } \\
\text { nitrate) }\end{array}$ & 0.050 & 0.061 & 0.004 & 0.656 & 38 & 1 & 170 \\
\hline $\begin{array}{l}\text { Shloride ion } \\
\text { (meq/L) }\end{array}$ & 0.022 & 0.046 & -- & 0.352 & 103 & 4 & 102 \\
\hline
\end{tabular}


[mL, milliliters; mm, millimeters; $\mu \mathrm{S} / \mathrm{cm}$, microsiemens per centimeter at 25 degrees Celsius; $\mu$ eq/L, microequivalents per liter; meq/L, milliequivalents per liter; -- indicates that results were less than detection limits for the selected analytical procedures; missing, data unavailable; less than detection, number of samples having results that were less than detection limits for the selected analytical procedures; measured, number of samples having results that were greater than detection limits]

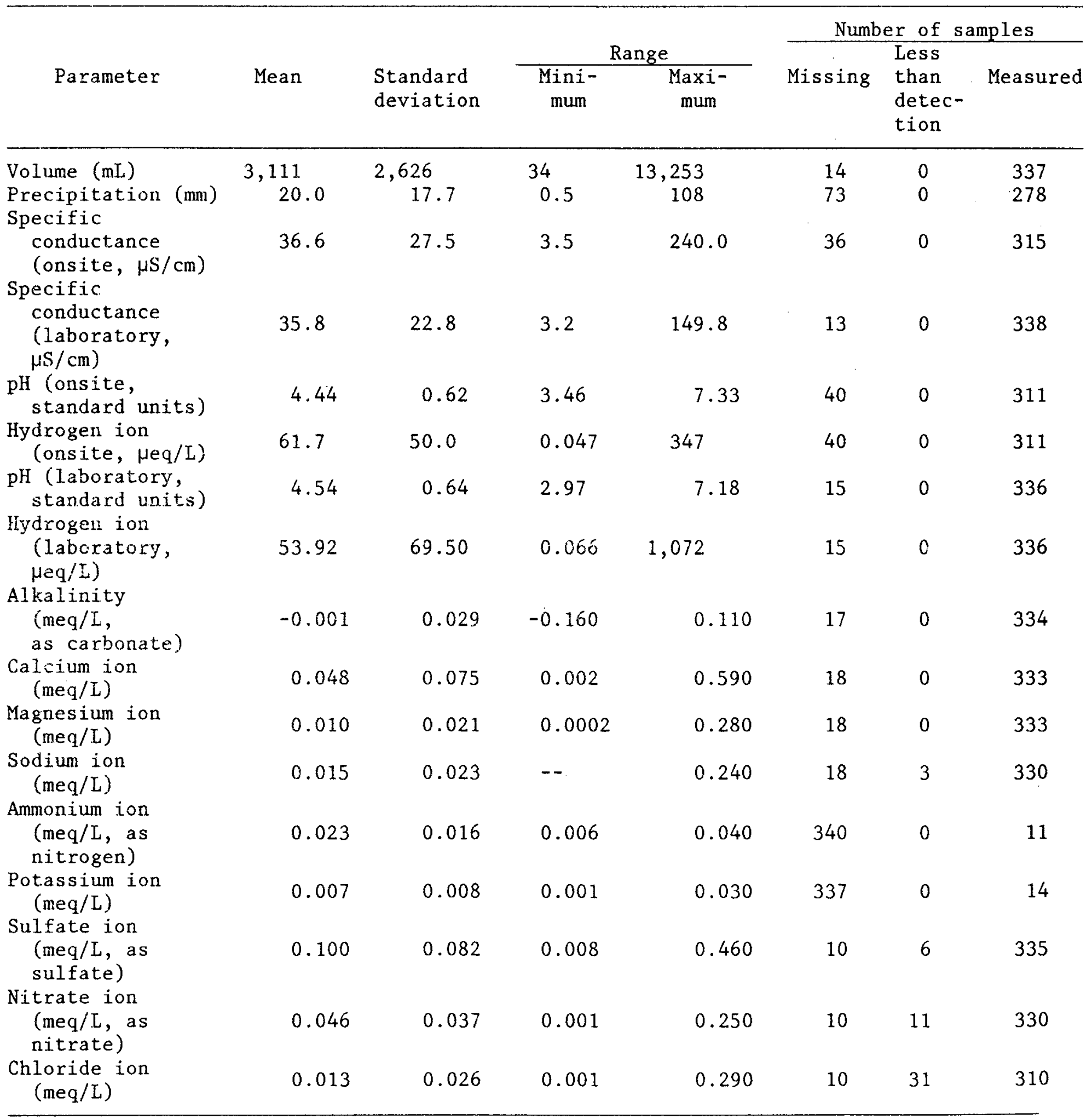


Table 6.--Summary statistics for limestone samples

[mL, milliliters; $\mathrm{mm}$, millimeters; $\mu \mathrm{S} / \mathrm{cm}$, microsiemens per centimeter at 25 degrees Celsius; $\mu \mathrm{eq} / \mathrm{L}$, microequivalents per liter; meq/L, milliequivalents per liter; --, indicates that results were less than detection limits for the selected analytical procedures; missing, data unavailable; less than detection, number of samples having results that were less than detection limits for the selected analytical procedures; measured, number of samples having results that were greater than detection limits]

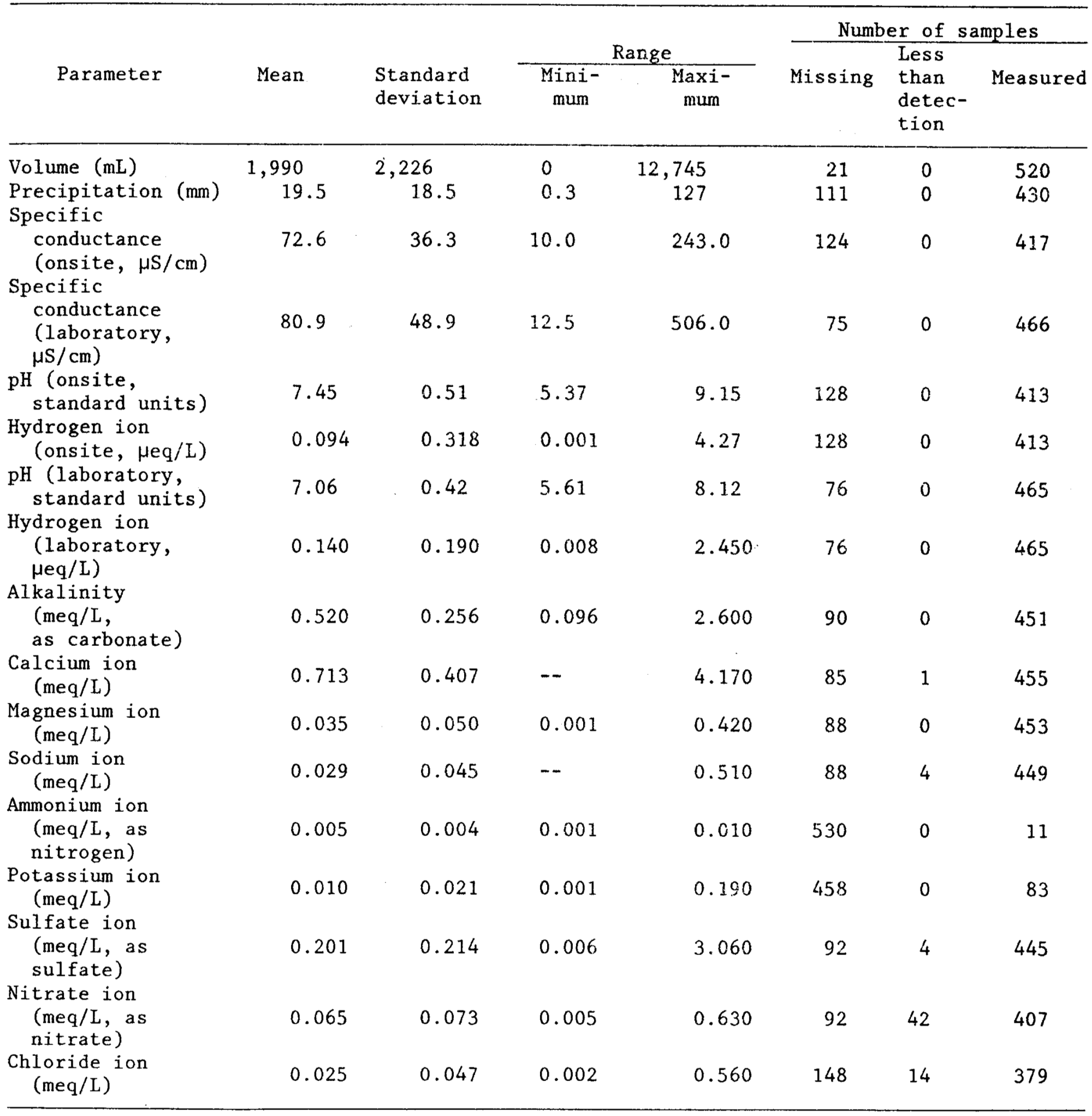


$[\mathrm{mL}$, milliliters; mm, millimeters; $\mu \mathrm{S} / \mathrm{cm}$, microsiemens per centimeter at 25 degrees Celsius; $\mu e q / L$, microequivalents per liter; meq/L, milliequivalents per liter; - , indicates that results were less than detection limits for the selected analytical procedures; missing, data unavailable; less than detection, number of samples having results that were less than detection limits for the selected analytical procedures; measured, number of samples having results that were greater than detection limits]

\begin{tabular}{|c|c|c|c|c|c|c|c|}
\hline \multirow[b]{3}{*}{ Parameter } & \multirow[b]{3}{*}{ Mean } & \multirow[b]{3}{*}{$\begin{array}{l}\text { Standard } \\
\text { deviation }\end{array}$} & \multirow{2}{*}{\multicolumn{2}{|c|}{ Range }} & \multicolumn{3}{|c|}{ Number of samples } \\
\hline & & & & & & Less & \\
\hline & & & $\begin{array}{c}\text { Mini- } \\
\text { mum }\end{array}$ & $\begin{array}{l}\text { Maxi- } \\
\text { mum }\end{array}$ & Missing & $\begin{array}{l}\text { than } \\
\text { detec- } \\
\text { tion }\end{array}$ & Measured \\
\hline Jolume (mL) & 2,541 & 2,305 & 0 & 12,756 & 19 & 0 & 558 \\
\hline $\begin{array}{l}\text { Precipitation (mm) } \\
\text { pecific }\end{array}$ & 18.8 & 18.3 & 0.25 & 127 & 112 & 0 & 465 \\
\hline $\begin{array}{l}\text { conductance } \\
\text { (onsite, } \mu S / \mathrm{cm} \text { ) } \\
\text { Specific }\end{array}$ & 62.3 & 38.2 & 14.0 & 425.0 & 104 & 0 & 473 \\
\hline $\begin{array}{l}\text { conductance } \\
\text { (laboratory, } \\
\mu \mathrm{S} / \mathrm{cm})\end{array}$ & 65.0 & 35.4 & 17.2 & 341.0 & 45 & 0 & 532 \\
\hline $\begin{array}{l}\text { H (onsite, } \\
\text { standard units) }\end{array}$ & 7.31 & 0.42 & 5.49 & 8.97 & 106 & 0 & 471 \\
\hline $\begin{array}{l}\text { lydrogen ion } \\
\text { (onsite, } \mu e q / L)\end{array}$ & 0.098 & 0.250 & 0.001 & 3.24 & 106 & 0 & 471 \\
\hline $\begin{array}{l}\text { H (laboratory, } \\
\text { standard units) } \\
\text { Iydrogen ion }\end{array}$ & 7.02 & 0.37 & 5.32 & 8.00 & 47 & 0 & 530 \\
\hline $\begin{array}{l}\text { (laboratory, } \\
\mu e q / I)\end{array}$ & 0.151 & 0.307 & 0.010 & 4.820 & 47 & 0 & 530 \\
\hline $\begin{array}{l}\text { Alkailinity } \\
\text { (meq/L, } \\
\text { as carbonate) }\end{array}$ & 0.412 & 0.174 & 0.012 & 1.480 & 61 & 0 & 516 \\
\hline $\begin{array}{l}\text { alcium ion } \\
(\text { meq/L) }\end{array}$ & 0.574 & 0.304 & 0.154 & 3.150 & 52 & 1 & 524 \\
\hline $\begin{array}{l}\text { lagnesium ion } \\
(\text { meq/L) }\end{array}$ & 0.023 & 0.023 & 0.002 & 0.310 & 54 & 0 & 523 \\
\hline $\begin{array}{l}\text { (nedium ion } \\
\text { (neq) }\end{array}$ & 0.016 & 0.031 & -- & 0.440 & 58 & 16 & 503 \\
\hline $\begin{array}{l}\text { Immonium ion } \\
\text { (meq/L, as } \\
\text { nitrogen) }\end{array}$ & 0.007 & 0.005 & 0.0004 & 0.020 & 565 & 0 & 12 \\
\hline $\begin{array}{l}\text { Potassium ion } \\
\text { (meq/L) }\end{array}$ & 0.016 & 0.095 & 0.001 & 0.920 & 480 & 2 & 95 \\
\hline $\begin{array}{l}\text { Sulfate ion } \\
\text { (meq/L, as } \\
\text { sulfate) }\end{array}$ & 0.163 & 0.158 & 0.014 & 1.710 & 50 & 1 & 526 \\
\hline $\begin{array}{l}\text { Jitrate ion } \\
\text { (meq/L, as } \\
\text { nitrate) }\end{array}$ & 0.055 & 0.046 & 0.002 & 0.560 & 50 & 12 & 515 \\
\hline $\begin{array}{l}\text { Chloride ion } \\
\text { (meq/L) }\end{array}$ & 0.016 & 0.022 & -- & 0.220 & 126 & 21 & 430 \\
\hline
\end{tabular}


$[\mu \mathrm{S} / \mathrm{cm}$, microsiemens per centimeter at 25 degrees Celsius; $\mu$ eq/L, microequivalents per liter; meq/L, milliequivalents per liter; --, indicates that results were less than detection limits for the selected analytical procedure; -, indicates that analytical results are not available; missing, data unavailable; less than detection, number of samples having results that were less than detection limits for the selected analytical procedures; measured, number of samples having results that were greater than detection limits]

\begin{tabular}{|c|c|c|c|c|c|c|c|}
\hline \multirow[b]{3}{*}{ Parameter } & \multirow[b]{3}{*}{ Mean } & \multirow[b]{3}{*}{$\begin{array}{l}\text { Standard } \\
\text { deviation }\end{array}$} & \multirow{2}{*}{\multicolumn{2}{|c|}{ Range }} & \multicolumn{3}{|c|}{ Number of samples } \\
\hline & & & & & \multirow[b]{2}{*}{ Missing } & \multirow{2}{*}{$\begin{array}{l}\text { Less } \\
\text { than } \\
\text { detec- } \\
\text { tion }\end{array}$} & \multirow[b]{2}{*}{ Measured } \\
\hline & & & $\begin{array}{l}\text { Mini- } \\
\text { mum }\end{array}$ & $\begin{array}{l}\text { Maxi- } \\
\text { mum }\end{array}$ & & & \\
\hline \multicolumn{8}{|l|}{ Specific } \\
\hline $\begin{array}{l}\text { conductance } \\
\text { (onsite, } \mu \mathrm{S} / \mathrm{cm} \text { ) }\end{array}$ & 2.8 & 4.3 & 0.9 & 17.0 & 22 & 0 & 13 \\
\hline \multicolumn{8}{|l|}{ Specific } \\
\hline $\begin{array}{l}\text { conductance } \\
\text { (laboratory, } \\
\mu \mathrm{S} / \mathrm{cm} \text { ) }\end{array}$ & 2.3 & 1.3 & 0.9 & 5.0 & 8 & 0 & 27 \\
\hline $\begin{array}{l}\text { pH (onsite, } \\
\text { standard units) }\end{array}$ & 6.10 & 0.70 & 5.50 & 7.56 & 21 & 0 & 14 \\
\hline $\begin{array}{l}\text { Hydrogen ion } \\
\quad(\text { onsite, } \mu \mathrm{eq} / \mathrm{L})\end{array}$ & 1.58 & 1.17 & 0.028 & 3.16 & 21 & 0 & 14 \\
\hline $\begin{array}{l}\text { pH (laboratory, } \\
\text { standard units) }\end{array}$ & 6.71 & 1.41 & 4.55 & 8.40 & 10 & 0 & 25 \\
\hline \multicolumn{8}{|l|}{ Hydrogen ion } \\
\hline 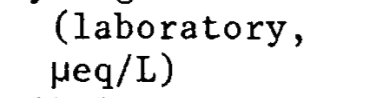 & 2.144 & 5.622 & 0.004 & 28.25 & 10 & 0 & 25 \\
\hline \multicolumn{8}{|l|}{ Alkalinity } \\
\hline $\begin{array}{l}\text { (meq/L, } \\
\text { as carbonate) }\end{array}$ & 0.042 & 0.033 & -0.003 & 0.110 & 12 & 0 & 23 \\
\hline $\begin{array}{l}\text { Calcium ion } \\
\text { (meq/L) }\end{array}$ & 0.005 & 0.006 & -- & 0.020 & 12 & 10 & 13 \\
\hline $\begin{array}{l}\text { Magnesium ion } \\
(\mathrm{meq} / \mathrm{L})\end{array}$ & 0.001 & 0.002 & -- & 0.005 & 9 & 15 & 11 \\
\hline $\begin{array}{l}\text { Sodium ion } \\
\text { (meq/L) }\end{array}$ & 0.011 & 0.010 & 0.002 & 0.034 & 9 & 13 & 13 \\
\hline \multicolumn{8}{|l|}{ Ammonium ion } \\
\hline $\begin{array}{l}\text { (meq/L, as } \\
\text { nitrogen) }\end{array}$ & - & - & - & - & 35 & 0 & 0 \\
\hline $\begin{array}{l}\text { Potassium ion } \\
(\text { meq/L) }\end{array}$ & 0.003 & 0.005 & -- & 0.010 & 25 & 3 & 7 \\
\hline \multicolumn{8}{|l|}{ Sulfate ion } \\
\hline $\begin{array}{l}\text { (meq/L, as } \\
\text { sulfate) }\end{array}$ & 0.007 & 0.004 & 0.001 & 0.011 & 6 & 23 & 6 \\
\hline \multicolumn{8}{|l|}{ Nitrate ion } \\
\hline $\begin{array}{l}(\mathrm{meq} / \mathrm{L}, \text { as } \\
\text { nitrate) }\end{array}$ & 0.005 & 0.004 & 0.002 & 0.008 & 6 & 27 & 2 \\
\hline $\begin{array}{l}\text { Chloride ion } \\
\text { (meq/L) }\end{array}$ & 0.005 & 0.002 & 0.003 & 0.010 & 15 & 11 & 9 \\
\hline
\end{tabular}


Table 9.--summary statistics for M-82 standard reference water samples

$[\mu \mathrm{S} / \mathrm{cm}$, microsiemens per centimeter at 25 degrees Celsius; $\mu$ eq/L, microequivalents per liter; meq/L, milliequivalents per liter; --, indicates that results were less than detection limits for the selected analytical procedure; -, indicates that analytical results are not available; missing, data unavailable; less than detection, number of samples having results that were less than detection limits for the selected analytical procedures; measured, number of samples having results that were greater than detecion limits]

\begin{tabular}{|c|c|c|c|}
\hline & & & Range \\
\hline Parameter & Mean & $\begin{array}{l}\text { Standard } \\
\text { deviation }\end{array}$ & $\begin{array}{l}\text { Mini- } \\
\text { mum }\end{array}$ \\
\hline
\end{tabular}

Number of samples

$\begin{array}{ll}\text { Missing } & \begin{array}{l}\text { Less } \\ \text { than Measured } \\ \text { detec- } \\ \text { tion }\end{array}\end{array}$

Specific

conductance

130.7

5.3

122.1

140.0

16

9

(onsite, $\mu S / \mathrm{cm}$ )

Specific

conductance

(laboratory,

139.6

4.9

133.5

148.0

8

17

$\mu \mathrm{S} / \mathrm{cm}$ )

$\mathrm{pH}$ (onsite, standard units)

7.54

0.16

7.21

7.72

15

0.062

15

8.00

11

6.28

0.010

0.525

11

14

Heq/I)

0.090

0.136

0.615

0.171

0.596

0.740

9

16

as carbonate)

Calcium ion

(meq/I)

0.725

0.020

0.698

0.764

9

16

0.287

0.010

0.270

0.313

6

19

0.276

0.017

0.230

0.301

6

19

(megil $)$

Ammonium ion

(meq/L, as

nitrogen)

Potassium ion

(meq/L)

0.052

0.003

0.049

0.056

19

0

6

Sulfate ion

(meq/L, as

0.582

0.027

0.549

0.668

6

19

Nitrate ion

(meq/L, as

0.016

0.033

0.075

7

11

18

Chloride ion

(meq/L)

0.071

0.014

0.025

0.084

11

14 
Table 10.--Analytical results for standard reference water sample M-82 (obtained from the U.S. Geological

Survey, Quality Assurance Laboratory, Denver, Colorado)

$[\mu \mathrm{S} / \mathrm{cm}$, microsiemens per centimeter at 25 degrees Celsius; meq/L, milliequivalents per liter]

\begin{tabular}{lllc}
\hline \multicolumn{1}{c}{ Parameter } & Mean & $\begin{array}{c}\text { Standard } \\
\text { deviation }\end{array}$ & $\begin{array}{c}\text { Total number } \\
\text { of anaiyses }\end{array}$ \\
\hline Specific conductance ( $\mu \mathrm{S} / \mathrm{cm})$ & 138.3 & 8.6 & 43 \\
pH (standard units) & 6.9 & 0.39 & 42 \\
Alkalinity (meq/L as carbonate) & 0.6614 & 0.0420 & 37 \\
Calcium ion (meq/L) & 0.6891 & 0.0349 & 43 \\
Magnesium ion (meq/L) & & & 44 \\
Sodium ion (meq/L) & 0.2954 & 0.0189 & 41 \\
Sulfate ion (meq/L) & 0.2749 & 0.0135 & 39 \\
Chloride ion (meq/L) & 0.5836 & 0.0373 & 42 \\
\hline
\end{tabular}


Table 11.--Summary statistics for $M-4$ standard reference water samples

$[\mu \mathrm{S} / \mathrm{cm}$, microsiemens per centimeter at 25 degrees Calsius; $\mu \mathrm{eq} / \mathrm{L}$, microequivalents per liter; meq/L, milliequivalents per liter; missing, data unavailable; less than detection, number of samples having results that were less than detection limits for the selected analytical procedures; measured, number of samples having results that were greater than detection limits]

\begin{tabular}{|c|c|c|c|c|c|c|c|}
\hline \multirow[b]{3}{*}{ Parameter } & \multirow[b]{3}{*}{ Mean } & \multirow[b]{3}{*}{$\begin{array}{l}\text { Standard } \\
\text { deviation }\end{array}$} & \multirow{2}{*}{\multicolumn{2}{|c|}{ Range }} & \multirow{2}{*}{\multicolumn{3}{|c|}{ Less }} \\
\hline & & & & & & & \\
\hline & & & $\begin{array}{l}\text { Mini- } \\
\text { mum }\end{array}$ & $\begin{array}{c}\text { Maxi- } \\
\text { mum }\end{array}$ & Missing & $\begin{array}{l}\text { than } \\
\text { detec- } \\
\text { tion }\end{array}$ & Measured \\
\hline
\end{tabular}

\begin{tabular}{|c|c|c|c|c|c|c|c|}
\hline \\
\hline $\begin{array}{l}\text { Specific } \\
\text { conductance } \\
\text { (onsite, } \mu S / \mathrm{cm} \text { ) }\end{array}$ & 101.9 & 6.8 & 97.6 & 112.0 & 70 & 0 & 4 \\
\hline \multicolumn{8}{|l|}{ Specific } \\
\hline $\begin{array}{l}\text { conductance } \\
\text { (laboratory, } \\
\mu \mathrm{S} / \mathrm{cm})\end{array}$ & 109.6 & 9.8 & 42.7 & 115.5 & 23 & 0 & 51 \\
\hline $\begin{array}{l}\mathrm{pH} \text { (onsite, } \\
\text { standard units) }\end{array}$ & 7.64 & 0.05 & 7.60 & 7.70 & 70 & 0 & 4 \\
\hline $\begin{array}{l}\text { Hydrogen ion } \\
\text { (onsite, } \mu \text { eq/L) }\end{array}$ & 0.023 & 0.002 & 0.020 & 0.025 & 70 & 0 & 4 \\
\hline $\begin{array}{l}\text { pH (laboratory, } \\
\text { standard units) }\end{array}$ & 7.32 & 0.23 & 6.54 & 7.91 & 26 & 0 & 48 \\
\hline \multicolumn{8}{|l|}{ Hydrogen ion } \\
\hline $\begin{array}{l}\text { (laboratory, } \\
\mu \mathrm{eq} / \mathrm{L} \text { ) }\end{array}$ & 0.055 & 0.040 & 0.012 & 0.288 & 26 & 0 & 48 \\
\hline \multicolumn{8}{|l|}{ Alkalinity } \\
\hline $\begin{array}{l}\text { (meq/L, } \\
\text { as carbonate) }\end{array}$ & 0.535 & 0.014 & 0.501 & 0.566 & 11 & 0 & 63 \\
\hline $\begin{array}{l}\text { Calcium ion } \\
(\text { meq/L) }\end{array}$ & 0.513 & 0.060 & 0.322 & 0.624 & 9 & 0 & 65 \\
\hline $\begin{array}{l}\text { Magnesium ion } \\
\text { (meq/L) }\end{array}$ & 0.222 & 0.019 & 0.162 & 0.261 & 9 & 0 & 65 \\
\hline $\begin{array}{l}\text { Sodium ion } \\
\quad(\text { meq/L })\end{array}$ & 0.186 & 0.032 & 0.102 & 0.221 & 9 & 0 & 65 \\
\hline \multicolumn{8}{|l|}{ Sulfate ion } \\
\hline $\begin{array}{l}\text { (meq/L, as } \\
\text { sulfate) }\end{array}$ & 0.423 & 0.037 & 0.360 & $0.4 / 5$ & 10 & 0 & 04 \\
\hline \multicolumn{8}{|l|}{ Nitrate ion } \\
\hline $\begin{array}{l}\text { (meq } / \mathrm{L}, \text { as } \\
\text { nitrate) }\end{array}$ & 0.012 & 0.001 & 0.010 & 0.015 & 10 & 3 & 61 \\
\hline $\begin{array}{l}\text { Chloride ion } \\
(\text { meq/L) }\end{array}$ & 0.082 & 0.009 & 0.073 & 0.113 & 10 & 2 & 62 \\
\hline
\end{tabular}


Table 12.--Analytical results for standard reference water sample M-4 (obtained from the U.S. Geological Survey, Quality Assurance Laboratory, Denver, Colorado)

$[\mu \mathrm{S} / \mathrm{cm}$, microsiemens per centimeter at 25 degrees Celsius; meq/L, milliequivalents per liter]

\begin{tabular}{lccc}
\hline \multicolumn{1}{c}{ Parameter } & Mean & $\begin{array}{l}\text { Standard } \\
\text { deviation }\end{array}$ & $\begin{array}{c}\text { Total number } \\
\text { of analyses }\end{array}$ \\
\hline Specific conductance ( $\mu \mathrm{S} / \mathrm{cm})$ & 111.0 & 5.0 & 55 \\
pH (standard units) & 7.58 & 0.22 & 56 \\
Alkalinity (meq/L as carbonate) & 0.540 & 0.022 & 48 \\
Calcium ion (meq/L) & 0.569 & 0.040 & 57 \\
Magnesium ion (meq/L) & 0.247 & 0.021 & 56 \\
Sodium ion (meq/L) & 0.200 & 0.013 & 54 \\
Sulfate ion (meq/L) & 0.412 & 0.052 & 53 \\
Nitrate ion (meq/L) & 0.014 & 0.003 & 50 \\
Chloride ion (meq/L) & 0.079 & 0.014 & 51 \\
\hline
\end{tabular}


Table 13.--Summary statistics for samples collected using the recording precipitation monitor

$[\mathrm{mL}, \operatorname{milliliters} ; \mathrm{mm}, \mathrm{millimeters;} \mu \mathrm{S} / \mathrm{cm}$, microsiemens per centimeter at 25 degrees Celcius; $\mu \mathrm{eq} / \mathrm{L}$, microequivalents per liter; milliequivalents per liter; --, indicates that results were less than detection limits for the selected analytical procedure; -, indicates that analytical results are not available; missing, data unavailable; less than detection, results that were less than detection limits for the selected analytical procedures; measured, number of samples having results that were greater than detection limits]

\begin{tabular}{|c|c|c|c|c|c|c|c|}
\hline & & & & & Numb & er of $\mathrm{se}$ & mples \\
\hline & & & & nge & & Less & \\
\hline Parameter & Mean & $\begin{array}{l}\text { Standard } \\
\text { deviation }\end{array}$ & $\underset{\text { mum }}{\text { Mini- }}$ & $\begin{array}{c}\text { Maxi- } \\
\text { mum }\end{array}$ & Missing & $\begin{array}{l}\text { than } \\
\text { detec- } \\
\text { tion }\end{array}$ & Measured \\
\hline Volume (mL) & 982 & 913 & 0 & 4,000 & 2 & 0 & 151 \\
\hline $\begin{array}{l}\text { Precipitation }(\mathrm{mm}) \\
\text { Specific }\end{array}$ & 19.9 & 18.6 & 0.5 & 127 & 22 & 0 & 131 \\
\hline $\begin{array}{l}\text { conductance } \\
\text { (onsite, } \mu S / \mathrm{cm} \text { ) } \\
\text { Specific }\end{array}$ & 530.8 & 888.5 & 10.7 & 6,000 & 40 & 0 & 113 \\
\hline $\begin{array}{l}\text { conductance } \\
\text { (laboratory, } \\
\mu S / \mathrm{cm})\end{array}$ & 385.6 & 805.4 & 1.7 & 6,960 & 40 & 0 & 113 \\
\hline $\begin{array}{l}\mathrm{pH} \text { (onsite, } \\
\text { standard units) }\end{array}$ & 4.54 & 0.73 & 3.31 & 6.87 & 41 & 0 & 112 \\
\hline $\begin{array}{l}\text { Hydrogen ion } \\
\text { onsite, Heq/L) }\end{array}$ & 57.0 & 59.0 & 0.135 & 490 & 41 & 0 & 112 \\
\hline $\begin{array}{l}\text { pH (laboratory, } \\
\text { standard units) } \\
\text { Hydrogen ion }\end{array}$ & 5.07 & 0.96 & 3.47 & 7.20 & 41 & 0 & 112 \\
\hline $\begin{array}{l}\text { (laboratory } \\
\mu \mathrm{eq} / \mathrm{L})\end{array}$ & 33.35 & 45.48 & 0.063 & 340.4 & 41 & 0 & 112 \\
\hline Alkalinity & & & & & & & \\
\hline $\begin{array}{l}\text { (meq/L, } \\
\text { as carbonate) }\end{array}$ & 0.024 & 0.075 & -0.157 & 0.454 & 42 & 0 & 111 \\
\hline $\begin{array}{l}\text { Calcium ion } \\
(\text { meq/L) }\end{array}$ & 0.041 & 0.169 & 0.001 & 1.497 & 47 & 0 & 106 \\
\hline $\begin{array}{l}\text { Magnesium ion } \\
\text { (meq/L) }\end{array}$ & 0.005 & 0.009 & -- & 0.074 & 47 & 3 & 103 \\
\hline $\begin{array}{l}\text { Sodium ion } \\
\quad(\operatorname{meq} / L)\end{array}$ & 0.047 & 0.110 & 0.001 & 0.795 & 47 & 11 & 95 \\
\hline $\begin{array}{c}\text { Ammonium ion } \\
\text { (meq/L, as } \\
\text { nitrogen) }\end{array}$ & - & - & - & - & 153 & 0 & 0 \\
\hline $\begin{array}{l}\text { Potassium ion } \\
\text { (meq/L) } \\
\text { Sulfate ion }\end{array}$ & 1.578 & 3.410 & 0.010 & 18.42 & 117 & 0 & 36 \\
\hline $\begin{array}{l}\text { (meq/L, as } \\
\text { sulfate) }\end{array}$ & 0.051 & 0.034 & 0.004 & 0.173 & 80 & 2 & 71 \\
\hline $\begin{array}{l}\text { Nitrate ion } \\
\text { (meq/L, as } \\
\text { nitrate) }\end{array}$ & 0.064 & 0.129 & 0.001 & 0.657 & 81 & 6 & 66 \\
\hline $\begin{array}{l}\text { Chloride ion } \\
\text { (meq/L) }\end{array}$ & 0.241 & 0.098 & 0.025 & 0.480 & 120 & 2 & 31 \\
\hline
\end{tabular}


Table 14.--Detection Iimits for Iaboratory analyses (1984-86)

$$
\text { [meq/I, milliequivalents per liter] }
$$

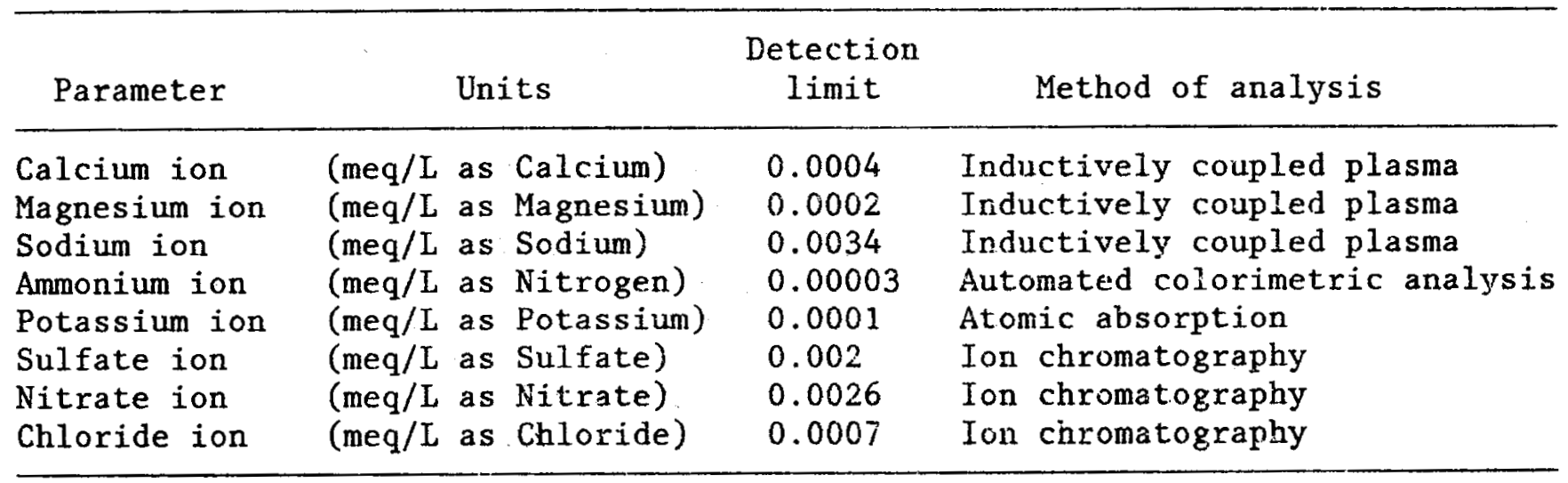

Table 15.--Detection limits for laboratory analyses (1987)

$$
\text { [meq/L, milliequivalents per Iiter] }
$$

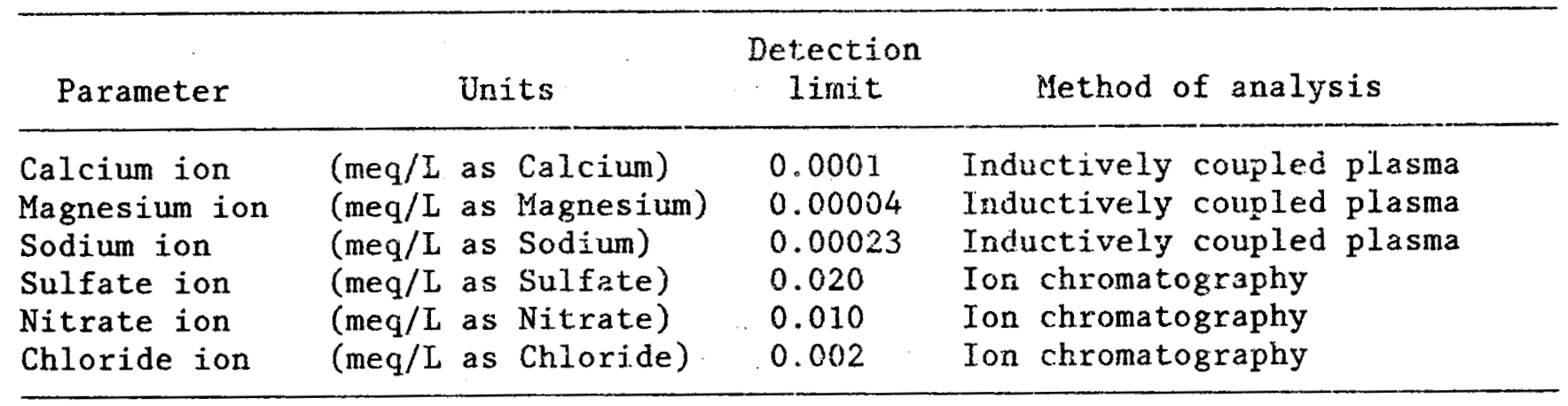


Table 16.--Sample data set of DATAT.A

[See tables 1 through 3 for definition of abbreviations;

-, indicates results not availablel

\begin{tabular}{|c|c|c|c|c|c|c|c|c|c|c|c|c|c|c|c|c|c|}
\hline SITE & TYPE & YEAR & EVENT & SIDE & DUP & $\begin{array}{l}\text { JD } \\
\mathrm{ON}\end{array}$ & $\begin{array}{l}\mathrm{JD} \\
\mathrm{OFF}\end{array}$ & VOLUME & $\begin{array}{l}\text { OVER } \\
\text { FLOW }\end{array}$ & RAIN IN & RAIN MM & $\begin{array}{c}\text { PRECIP } \\
\text { TYPE }\end{array}$ & PH FLD & CON FLD & $\begin{array}{l}\text { FILT } \\
\text { VOL }\end{array}$ & $\begin{array}{l}\text { UNFILT } \\
\text { VOL }\end{array}$ & $\begin{array}{l}\text { DEG- } \\
\text { REE }\end{array}$ \\
\hline DC & L & 84 & 4 & 4 & 1 & 290 & 299 & 830 & $N$ & - & - & - & 7.520 & 88.00 & - & - & 30 \\
\hline DC & $M$ & 87 & 11 & 7 & 1 & 239 & 240 & 2,035 & $N$ & - & - & RN & 6.640 & 47.90 & 250 & 250 & 30 \\
\hline LB & D & 85 & 0 & 0 & 1 & - & - & - & - & - & - & - & - & - & - & - & - \\
\hline NC & B & 84 & 16 & 1 & 1 & 208 & 212 & 3,943 & $\mathbf{N}$ & 2.150 & 54.610 & - & 4.490 & 18.50 & - & - & 30 \\
\hline NC & $\mathrm{L}$ & 85 & 21 & 3 & 1 & 207 & 210 & 575 & $N$ & 0.400 & 10.160 & - & 6.230 & 71.00 & - & - & 30 \\
\hline NC & $\mathrm{L}$ & 85 & 21 & 3 & 2 & 207 & 210 & - & $\mathrm{N}$ & - & - & - & - & - & - & - & 30 \\
\hline $\mathbf{N J}$ & G & 86 & 7 & 6 & 1 & 191 & 196 & 3,700 & $\mathrm{~N}$ & 0.700 & 17.780 & RN & - & - & - & 999 & 30 \\
\hline NJ & M & 85 & 6 & 7 & 1 & 91 & 102 & 290 & $\mathrm{~N}$ & - & - & - & - & - & - & - & 30 \\
\hline OH & $M$ & 86 & 2 & 6 & 1 & 288 & 301 & 2,4990 & $\mathrm{~N}$ & 0.640 & 16.256 & $\mathrm{RN}$ & 7.200 & 136.50 & 250 & 250 & 30 \\
\hline OH & L & 87 & 2 & 10 & 1 & 235 & 242 & 1,940 & $\mathrm{~N}$ & 1.160 & 29.464 & RN & 8.640 & 50.20 & 250 & 250 & 30 \\
\hline OH & $M$ & 87 & 3 & 7 & 1 & 242 & 256 & 4,620 & $\mathrm{~N}$ & 1.290 & 32.766 & RN & 7.500 & 104.70 & 250 & 250 & 30 \\
\hline LB & $M-4$ & 87 & 1 & 0 & 1 & - & - & - & - & - & - & - & - & - & - & - & - \\
\hline $\mathbf{N Y}$ & L & 86 & 10 & 3 & 1 & 171 & 174 & 862 & N & 0.360 & 9.144 & $R N$ & 7.840 & 40.00 & 250 & 250 & 30 \\
\hline $\mathbf{N Y}$ & G & 85 & 9 & 6 & 1 & 280 & 284 & 650 & $H$ & 0.070 & 1.778 & - & 3.650 & 66.00 & - & - & 30 \\
\hline $\mathbf{N Y}$ & $\mathrm{P}$ & 85 & 12 & 0 & 1 & 295 & 301 & 440 & $\mathbf{N}$ & 0.350 & 8.890 & - & 4.570 & 75.00 & - & - & 30 \\
\hline $\mathrm{NY}$ & $M$ & 87 & 32 & 8 & 1 & 279 & 282 & 720 & N & 0.420 & 10.668 & $\mathrm{SR}$ & 7.640 & 36.70 & 250 & 250 & 30 \\
\hline
\end{tabular}


Table 17.--Sample data set of DATAT.B

[See tables 1 through 3 for definition of abbreviations; -, indicates results not available; --, indicates results were less than detection limits for selected analytical. procedures]

\begin{tabular}{|c|c|c|c|c|c|c|c|c|c|c|c|}
\hline SITE & TYPE & YEAR & EVENT & SIDE & DUP & PH LAB & CON LAB & AIK MEQ & CI. MEQ & NO3 MEQ & SO4 MEQ \\
\hline $\mathrm{DC}$ & $\mathbf{L}$ & 84 & 4 & 4 & 1 & 7.422 & 92.50 & 0.72000 & - & 0.044000 & 0.229000 \\
\hline$D C$ & $M$ & 87 & 11 & 7 & 1 & 6.900 & 50.90 & 0.15210 & 0.01608 & 0.069010 & 0.237990 \\
\hline LB & D & 85 & 0 & 0 & 1 & 8.000 & 4.00 & 0 & 0.00400 & $=$ & 0.001000 \\
\hline NC & B & 84 & 16 & 1 & 1 & 4.583 & 15.75 & 0 & - & 0.047100 & 0.047890 \\
\hline NC & L & 85 & 21 & 3 & 1 & 6.829 & 76.50 & 0.59200 & 0.02652 & 0.057440 & 0.173890 \\
\hline NC & L & 85 & 21 & 3 & 2 & - & - & - & - & - & - \\
\hline $\mathrm{NJ}$ & G & 86 & 7 & 6 & 1 & 3.730 & 88.50 & 0 & 0.01633 & 0.100380 & 0.189890 \\
\hline NJ & M & 85 & 6 & 7 & 1 & 6.730 & 217.00 & 1.18000 & 0.06502 & 0.174090 & 0.733380 \\
\hline $\mathrm{OH}$ & $M$ & 86 & 2 & 6 & 1 & 6.820 & 140.00 & 0.38600 & 0.02930 & 0.093700 & 0.721200 \\
\hline $\mathrm{OH}$ & I & 87 & 2 & 10 & 1 & 7.060 & 42.10 & 0.22160 & 0.00284 & -- & 0.194900 \\
\hline $\mathrm{OH}$ & $M$ & 87 & 3 & 7 & 1 & 6.980 & 76.60 & 0.29710 & 0.01109 & 0.05272 .0 & 0.378070 \\
\hline$L B$ & $M-4$ & 87 & 1 & 0 & 1 & - & - & 0.55500 & 0.08487 & 0.015170 & 0.429800 \\
\hline NY & $\mathcal{L}$ & 86 & 10 & 3 & 1 & 6.930 & 42.50 & 0.33800 & - & 0.011920 & 0.046390 \\
\hline NY & G & 85 & 9 & 6 & 1 & - & 59.60 & 0 & 0.01117 & 0.081110 & 0.124030 \\
\hline $\mathrm{NY}$ & $\mathbf{P}$ & 85 & 12 & 0 & 1 & 5.900 & - & 0. & - & 0.040000 & 0.016000 \\
\hline $\mathrm{NY}$ & $M$ & 87 & 32 & 8 & 1 & 6.800 & 44.60 & 0.37240 & 0.00472 & 0.017740 & 0.044120 \\
\hline
\end{tabular}

Table 18. - Sample data set of DATAT.C

[See tables 1 through 3 for definition of abbreviations; -, indicates results not available; -- indicates results were less than detection limits for selected aualytical procedures]

\begin{tabular}{|c|c|c|c|c|c|c|c|c|c|c|}
\hline SITE & TYPE & YEAR & EVENT & SIDE & DUP & CA MEQ & MG MEQ & NA MEQ & NH4 MEQ & $K$ adQ \\
\hline DC & I & 84 & 4 & 4 & 1 & 0.89800000 & 0.0280000 & 0.01900000 & - & 0.0060000 \\
\hline $\mathrm{DC}$ & $\mathbf{M}$ & 87 & 11 & 7 & 1 & 0.72854000 & 0.0205100 & 0.00818000 & - & - \\
\hline LB & D & 85 & 0 & 0 & 1 & - & 0.0020000 & $\sim$ & - & 0.0010000 \\
\hline $\mathrm{NC}$ & B & 84 & 16 & 1 & 1 & 0.00416000 & 0.0006000 & - & - & 0.0033300 \\
\hline NC & $\mathbf{L}$ & 85 & $2 !$ & 3 & 1 & 0.69610000 & 0.0361400 & 0.04747000 & -. & - \\
\hline NC & I & 85 & 21 & 3 & 2 & 0.69960000 & 0.0362200 & 0.02734000 & - & - \\
\hline NJ & G & 86 & 7 & 6 & 1 & 0.02552 .000 & 0.0058800 & 0.02624000 & - & - \\
\hline NJ & $M$ & 85 & 6 & 7 & 1 & 2.06885000 & 0.0495100 & 0.03977000 & - & - \\
\hline $\mathrm{OH}$ & $\mathbf{M}$ & 86 & 2 & 6 & 1 & 1. 20658200 & 0.0653880 & 0.01001805 & - & - \\
\hline $\mathrm{OH}$ & $\mathbf{L}$ & 87 & 2 & 10 & 1 & 0.37862000 & 0.0059100 & 0.01596000 & - & - \\
\hline $\mathrm{OH}$ & $M$ & 87 & 3 & 7 & 1 & 0.66170000 & 0.0362200 & 0.02131000 & - & - \\
\hline LB & $M-4$ & 87 & 1 & $\mathrm{G}$ & 1 & 0.55788000 & 0.2368300 & 0.20341000 & - & - \\
\hline NY & I & 86 & 10 & 3 & 1 & 0.37290000 & 0.0055600 & 0.00271000 & - & - \\
\hline NY & G & 85 & 9 & 6 & 1 & 0.02197000 & 0.0048800 & 0.01679000 & 0.04100 & 0.0054230 \\
\hline NY & $\mathrm{P}$ & 85 & 12 & 0 & 1 & 0.01185000 & 0.0029600 & 0.04989000 & - & - \\
\hline NY & M & 87 & 32 & 8 & 1 & 0.44225000 & 0.0146200 & 0.00314000 & - & - \\
\hline
\end{tabular}

